UNIVERSIDADE DE SÃO PAULO

FACULDADE DE FILOSOFIA, LETRAS E CIÊNCIAS HUMANAS DEPARTAMENTO DE FILOSOFIA

PROGRAMA DE PÓS-GRADUAÇÃO EM FILOSOFIA

Roberto Carlos Pignatari

A ASCENSÃO DO CONHECIMENTO HUMANO NO
DE LIBERO ARBITRIO DE AGOSTINHO DE HIPONA

São Paulo

2014 
Roberto Carlos Pignatari

\title{
A ASCENSÃO DO CONHECIMENTO HUMANO NO \\ DE LIBERO ARBITRIO DE AGOSTINHO DE HIPONA
}

\begin{abstract}
Dissertação apresentada ao Programa de Pós-Graduação do Departamento de Filosofia da Faculdade de Filosofia, Letras e Ciências Humanas da Universidade de São Paulo, para obtenção do título de Mestre em Filosofia sob a orientação do Prof. Dr. Lorenzo Mammì.
\end{abstract}

São Paulo

2014 
Autorizo a reprodução e divulgação total ou parcial deste trabalho, por qualquer meio convencional ou eletrônico, para fins de estudo e pesquisa, desde que citada a fonte.

\section{Catalogação na Publicação}

Serviço de Biblioteca e Documentação

Faculdade de Filosofia, Letras e Ciências Humanas da Universidade de São Paulo

Pignatari, Roberto Carlos

A ascensão do conhecimento humano no De libero arbitrio de Agostinho de Hipona / Roberto Carlos Pignatari ; orientador Lorenzo Mammì. - São Paulo, 2014.

$279 \mathrm{f}$.

Dissertação (Mestrado)- Faculdade de Filosofia, Letras e Ciências Humanas da Universidade de São Paulo. Departamento de Filosofia. Área de concentração: Filosofia. 1. Filosofia Medieval. 2. Ontologia. 3. Teoria do Conhecimento. 4. Patrística. 5. Antiguidade Tardia. I. Mammì, Lorenzo, orient. II. Título. 


\section{Folha de Aprovação}

PIGNATARI, R.C. A ascensão do conhecimento humano no De libero arbitrio de Agostinho de Hipona. 280 f. Dissertação (Mestrado) - Faculdade de Filosofia, Letras e Ciências Humans. Departamento de Filosofia, Universidade de São Paulo, 2014.

\section{PROF. DR. LORENZO MAMMÌ}

Orientador

PROF. DR. MOACYR AYRES NOVAES FILHO

$1^{\circ}$. Titular

PROF. DR. PEDRO CALIXTO FERREIRA FILHO

$2^{\circ}$. Titular 
Ao meu pai, Miguel Pignatari, e à minha mãe, Maria Aparecida dos Santos Pignatari [in memoriam], cuja piedade e a caritas de sua devoção mariana sempre foram, ao meu coração protestante, o exemplo maior da interioridade que se dispõe ao fiat mihi segundo omnia verba que o Senhor permite conferre in corde suo $(L c$ 1,38 e 2,19). 


\section{Agradecimentos}

Em primeiro lugar ao meu orientador, Prof. Dr. Lorenzo Mammì, por me aceitar entre seus orientandos, por acreditar sempre e confiar na possibilidade de desenvolvimento do meu projeto inicial, pela orientação segura e serena, pela firmeza com que me ensina, pela paciência e rigor com que me corrige, pela argúcia com que me aconselha, pela generosidade com que me atende, pela sensibilidade no direcionamento e consecução da minha pesquisa, pela troca de ideias, intuições e discussões, pelas aulas ministradas nos vários cursos deste período, enfim, por todos os momentos de escuta, de atenção constante e de conversação (além, é claro, da inspiração única e preciosa advinda do lapidar STILLAE TEMPORIS). A Lorenzo eu devo mais que a oportunidade que me concedeu de orientar-me na pesquisa de mestrado da FFLCH-USP (como se fosse pouco!...); devo, principalmente, a ressurgência(!) e a realização máxima de minha vida acadêmica. A você, Lorenzo, minha (agostiniana) eterna gratidão.

Aos Profs. Drs. Moacyr Ayres Novaes Filho e Roberto Bolzani Filho, que participaram do exame de qualificação de minha pesquisa, pelas observações, correções e sugestões que me auxiliaram no desenvolvimento de partes do texto, bem como em sua finalização. Ao Prof. Moacyr, igualmente, pelo aprendizado nas aulas do curso Ontologia e moral em Agostinho (disciplina de HFM - $1^{\circ}$ semestre de 2011); também pela atenção diligente na elucidação de dúvidas e conceituações (ainda que tenham sido poucas as oportunidades). E também pela inspiração ofertada na aula ministrada em 31 de março de 2011 (a memorável "O itinerário do conhecimento, em Agostinho, é muito mais assunção que ascensão"), além, evidentemente, das páginas fundamentais de Interioridade na cosmologia agostiniana. Ao Prof. Bolzani, de igual modo, pela abordagem e avaliação positiva, embora com reservas, acerca de meu texto (mesmo em suas asseverações quanto à impossibilidade de certos desenvolvimentos por mim tentados, no texto da qualificação).

Ao Prof. Dr. Carlos Arthur Ribeiro do Nascimento, pela generosidade e solicitude ímpares, com que sempre me atendeu, ensinou e orientou; pelo inestimável apoio e pelo incentivo, em momentos cruciais; pela experiência com que permanentemente exerceu sua compreensão em relação aos meus trabalhos; bem como, ainda, pelas inúmeras trocas de ideias sobre agostinianismo e neoplatonismo; Anselmo e Boaventura; Maréchal, Pe. Vaz e tomismo transcendental, etc. 
Ao Prof. Dr. Marcelo Perine, pela prontidão com que se dispôs a ler e avaliar a primeira versão do esboço desta dissertação, pela alegria e o entusiasmo constantemente transmitidos, pela disponibilidade às conversas de estudo e pelo incentivo constante à pesquisa avançada (e também pelos bons descontos nos livros da Loyola!);

Aos professores do período de graduação no UNIFAI: Prof. Dr. Roque Frangiotti, por aceitar meu pedido para orientação no TCC (do qual nasceu a ideia inicial da presente pesquisa), bem como para participar de seu grupo de estudos em Filosofia Medieval, pela perseverança no ensino das aulas de Patrística, pelo apoio à pesquisa e ao aprofundamento do pensamento agostiniano, constantes nas orientações com que me conduziu nos trabalhos, sobretudo pelo empenho em nossos encontros de leituras; Prof. Dr. José Maurício Mazzucco, pela clareza na percepção das áreas afins ao nosso estudo no seu grupo de Linguagem $e$ Expressão Religiosa, pelo incentivo e aprendizado (e pelas longas conversas!) durante nosso convívio e amizade; e Prof. Dr. Joel Gracioso, pelo apoio e estímulo, pela dedicação aos estudos sobre a obra agostiniana, pela paixão contagiante que nutre pelo Medievo, e por me convidar a ingressar no seu grupo de estudos em Filosofia Medieval, logo no primeiro ano do curso no UNIFAI, sugerindo temas e possibilidades para pesquisas, a partir das quais pude me direcionar para o TCC.

Aos que comigo fizeram parte do grupo de orientandos do Prof. Lorenzo no biênio 2011-2012: Fabrício Klain Cristofoletti, Giovanna Mendonça Usai, Daniel Fujisaka e Antonio Mateucci, pelo aprendizado nas exposições de partes de nossos projetos, pela troca de ideias, pelo incentivo nas leituras e discussões de temas relativos ao pensamento agostiniano.

Às funcionárias da Secretaria do Departamento de Filosofia da FFLCH-USP: Maria Helena, Luciana, Mariê, Geni, e todas as pessoas que lá trabalham, pela ajuda, compreensão e prestatividade inestimáveis.

Por fim, quero deixar registrado o agradecimento, de todo meu coração e vida, a duas pessoas preciosas por demais, referências maiores na minha existência e que, embora sem o saber e por motivos diversos, foram diretamente responsáveis por todo o percurso que resultou neste trabalho, mas que já não estão mais aqui, e com as quais, infelizmente, não poderei partilhar da alegria de um trabalho realizado, que jamais teria conseguido alcançar sem a presença de ambas em minha história: Milton Schwantes, falecido em março de 2012, pastor da Igreja Evangélica de Confissão Luterana no Brasil, biblista maior e professor de teologia do AT, mestre e conselheiro, que me acolheu (mesmo eu sendo presbiteriano) em sua igreja em Guarulhos, cujos anos de permanência foram uma verdadeira faculdade para mim, de onde saíamos para a teologia e espiritualidade encarnadas na realidade viva das comunidades em 
Mairiporã, Arujá, Cabuçu... E minha mãe, Maria Aparecida dos Santos Pignatari, falecida em agosto do ano passado, a quem dedico esta pesquisa. A dor, a melancolia e a saudade se tornaram companheiras constantes, e teriam mesmo me impedido de prosseguir neste trabalho, não fosse a herança de dedicação, amor e confiança que dela recebi, a força e o carinho com que ela me sustentava, e ainda me incentivava aos estudos, mesmo ali no leito do hospital, nas noites e madrugadas de acompanhamento, nas quais várias leituras e trechos desta pesquisa foram feitos. Ela me deu a concreta lição de viver, até o fim e mesmo diante do nada iminente e prestes a lhe tragar deste mundo, na fé, esperança e caridade, no sentido pleno do (agostiniano e calvinista) cor meum tibi offero, Domine, prompte et sincere, na serenidade santa às portas da eternidade. Sua ausência me consome ainda, sei que levará tempo para poder dizer: "ego autem iam sanato corde ab illo uulnere, [...] fundo tibi, deus noster, pro illa famula tua longe aliud lacrimarum genus,..." (Confessiones IX, xiii, 34), mas a graça - da qual ela me foi exemplo único - me levanta, sustenta e me põe a caminhar no itinerário da mente, da alma e do coração... avante...

\section{Lux lucet in tenebris $(\mathrm{Jo} 1,5)$}

\section{Soli Deo Gloria}


"Essa verdade, de que há muito tempo estamos a discorrer, e na qual [sendo una] vemos tantas coisas, pensas ser mais excelente que nossa mente, igual ou inferior? Se fosse inferior, não julgaríamos segundo ela, mas sim a julgaríamos, como julgamos os corpos, que são inferiores [à razão ...] E julgamos acerca destas realidades, segundo aquelas normas interiores de verdade que nos são comuns, sem que, a seu respeito, jamais venhamos a emitir juízo algum. Nesse sentido, quando alguém diz que as coisas eternas são superiores às temporais, ou que sete e três são dez, ninguém afirma que assim deve ser, ao contrário: limitando-se a constatar que de fato é assim, não se arvora a corrigir como um censor, mas, antes, alegra-se como um descobridor."

[De libero arbitrio II, xii, 33-34] ${ }^{1}$

\footnotetext{
1 “... ueritatem de qua iam diu loquiimur et in qua tam multa conspicimus, excellentiorem putas esse quam mens nostra est na aequalem mentibus nostris na etiam inferiorem? Sed si esset inferior, non secundum illam, sed de illa iudicaremus, sicut iudicamus de corporibus quia infra sunt [...] Et iudicamus haec secundum illas interiores regulas veritatis quas communiter cernimus, de ipsis uero nullo modo quis iudicat. Cum enim quis dixerit aeterna temporalibus esse potiora aut septem et tria decem esse, nemo dicit ita esse debuuisse, sed tantum ita esse congnoscens non examinator corrigit, sed tantum laetatur inuentor."
} 


\section{RESUMO}

PIGNATARI, R.C. A ascensão do conhecimento humano no De libero arbitrio de Agostinho de Hipona. 279 f. Dissertação (Mestrado) - Faculdade de Filosofia, Letras e Ciências Humans. Departamento de Filosofia, Universidade de São Paulo, 2014.

A pesquisa intenta verificar como se dá o itinerário de ascensão do conhecimento da verdade e das ciências, conforme a descrição apresentada no De libero arbítrio, com apoio nos paralelos constantes dos diálogos De ordine e De quantitate animae, compostos por Agostinho no período Cassicíaco-Roma (386-396 d.C). Tomando como referência a ascensão intelectual apresentada no livro II do De libero arbitrio, e tendo por base as noções de condução/guia e julgamento/instituição aplicadas à razão, verificamos como o itinerário da alma no conhecimento probatório da realidade divina apresenta, para além da escalada em "subida hierarquizante" do sensível até Deus, o conhecimento como o movimento de perfazimento da realidade conhecida em eternidade, dado que a razão assenta e está fundamentada na verdade eterna e imutável, e todo ato cognitivo é por ela conduzido/orientado e adjudicado/instituído, o que, em última instância, equivale a afirmar que a eternidade se perfaz na realidade conhecida, precisamente no átimo temporal do instante em que se reconhece qualquer conhecimento como verdadeiro. Para tanto, trata-se de verificar como, em cada nível do conhecimento em ascensão, o passo seguinte está suposto - na verdade o contém e perfaz, fundamentando-o - no anterior, de maneira que a etapa posterior, necessária e permanentemente, ratifica e adjudica a etapa anterior. E, assim como o instante, ao instituir a totalidade temporal, é figuração da eternidade ${ }^{2}$, o conhecimento em ascensão perfaz e figura a absolutidade na veracidade, através da percepção imediata - e perenemente simultânea ao seu perfazimento - da totalidade da ordenação harmoniosa e universal dos seres (De ordine); da funcionalidade do ato imaginativo presente na simultaneidade verificada entre as percepções sensível/concreta e interior/espiritual (De quantitate animae); bem como nos sobreditos atos de condução e julgamento efetuados no perfazimento do conhecimento universal (De líbero arbitrio).

Palavras-chave: Eternidade, ser, instante, ascensão, simultaneidade.

\footnotetext{
2 "Mas todo instante, como ato de uma vontade livre, inicia uma série temporal sem ter uma causa anterior necessária (cf. o Livro II do De libero arbitrio). E todo instante, enquanto união do presente da memória, presente da atenção e presente da esperança, contém em si o tempo como um todo, e é portanto uma figura da eternidade." - MAMMI, Lorenzo STILLAE TEMPORIS - Interpretação de uma passagem das Confissões, XI, 2 in PALACIOS, Pelayo M. (org.) Tempo e Razãa - 1.600 anos das Confissões de Agostinho, São Paulo: Loyola, 2002, p. 61.
} 


\begin{abstract}
PIGNATARI, R.C. The ascension of human knowledge in the Augustin of Hippo's De libero arbitrio. 280 f. Thesis (Master Degree) - Faculdade de Filosofia, Letras e Ciências Humans. Departamento de Filosofia, Universidade de São Paulo, 2014.

This dissertation intends see the occurrence of the itinerary of soul's ascension in the knowledge of truth and science, according to the description given in De libero arbitrio, with suport in the parallels lectures presents in the dialogues De ordine and De quantitate animae, composed in the Augustine's Cassissiacum - Rome period (386-396 AD). Referring to intelectual ascension exposted in Book II of De libero arbitrio, and based on the notions of driving/guide and judgment/institution, in the rational way, we verified like the itinerary of the soul in probatory knowledge of divine reality shows, in addition to climbing "hierarchical elevation" of a sensibility to God, the knowledge of how the movement of factoring of reality known in eternity, as the reason rests and is founded on the eternal and unchangeable truth, and every cognitive act is driven/oriented and award/established by reason, which, ultimately, is equivalent to saying that eternity is known totals in this reality, precisely in the temporal instant that one recognizes any knowledge as true. For this purpose, it is to see how, at each level of knowledge on the rise, the next step is supposed to - actually contains and makes up reasons it - the previous, so that the subsequent necessary step and permanently, ratifies and awards the previous step. And just like the instant, by introducing the temporal totality, is like a previous or figuration of eternity, also knowledge and totals rising figure the absoluteness truthfulness through the immediate perception - and its perennially simultaneous factoring - the totality of universal and harmonious ordering of beings (De ordine); the functionality of the imaginative act in this concomitance observed between sensitives perceptions and interiority (De quantitate animae); as well as the aforesaid acts of conduct and judgment made in making of universal knowledge (De libero abitrio).
\end{abstract}

Key Words: Eternity, being, instant, ascension, simultanity. 


\section{SUMÁRIO}

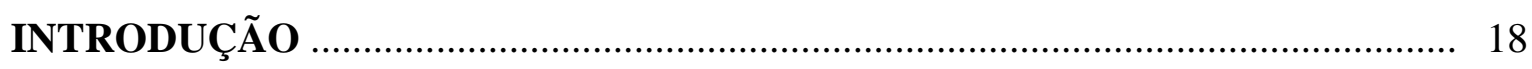

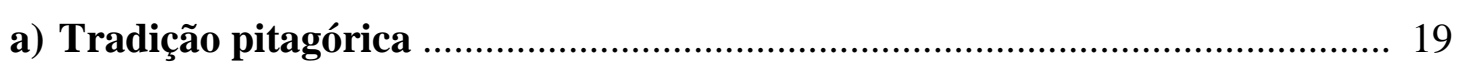

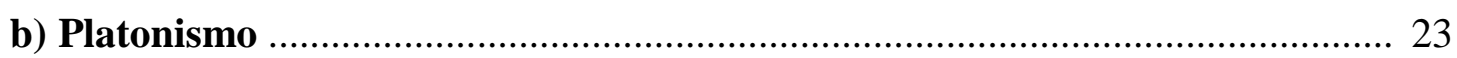

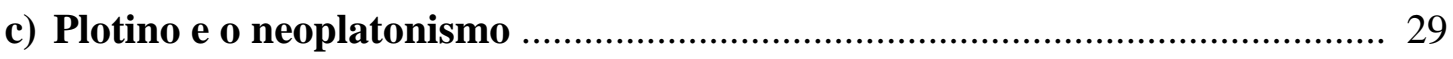

1 - ANÁLISE PREPARATÓRIA: CRER E INTELIGIR (lib. arb. II, i,1 - ii,6)

1.1) Introdução ........................................................................................ 40

1.1.1) Período de Cassicíaco/Roma: diálogos de início ............................... 41

1.1.2) Relação corpo/alma e neoplatonismo no período inicial ..................... 46

1.2) A vontade e o livre juízo .............................................................................. 49

1.2.1) Centralidade divina argumentativa (lib arb II, i, 1 - ii, 4) .................. 52

1.3) Exaurição da quaestio: suspensão do juízo cognitivo e articulação da relação crer-inteligir

1.3.1) Suspensão cognitivo-judicativa de Evódio ........................................... 65

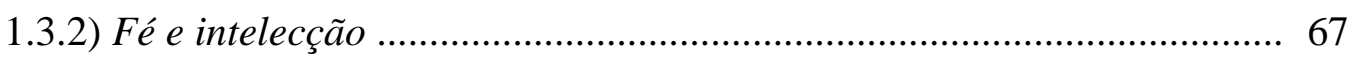

2 - A ASCENSÃO DA MENTE A DEUS (lib. arb. II, iii, 7 - v, 12)

2.1) Ser - Viver - Inteligir ........................................................................ 71

2.1.1) Ordo cognoscendi/ordo rerum ....................................................... 71

2.1.2) Esse-uiuere-intellegere ................................................................... 72

2.1.3) Excelência/Excedência - Ascendência .................................................. 75

2.1.4) Ascendência e dinamismo intelectual: análise de Moacyr Novaes $F^{o} \ldots 78$

2.1.5) Existência, intelecção e verdade .......................................................... 81

2.1.6) Ser e exauriência .......................................................................... 87

2.1.7) Stillae Temporis: instante, eternidade e temporalidade na elucidação de Lorenzo Mammi .............................................................................. 88

2.1.8) Ser, totalidade e atemporalidade .................................................... 92

2.2) O conceito de ser nos diálogos de Cassicíaco/Milão/Roma .......................... 95

2.2.1) As tríades conceituais no período inicial ............................................. 98

2.2.2) Amplitude do uso de esse nos diálogos agostinianos (análises) ........... 101

1) Paul Gilbert - Jean-Luc Marion .......................................................... 101

2) Étienne Gilson ...................................................................... 105

3) Werner Beierwaltes ...................................................................... 111 
2.3) A feitura inteleccional da realidade ................................................... 112

2.3.1) Sentidos exteriores e sentido interior ............................................... 113
a) Exterioridade
b) Interioridade …............................................................... 115
c) Racionalidade …............................................................... 116

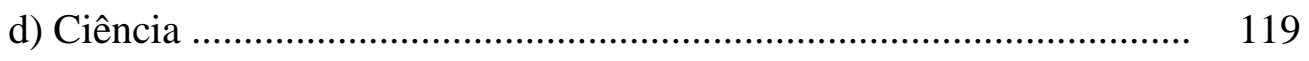
e) Referência/Comunicação ........................................................... 120

\section{3 - RAZÃO COMO GUIA E JUIZ: PONTO DE PARTIDA INSTITUINTE E}

PERFAZIMENTO DO TODO (lib. arb. II, vi, 13 - vii, 19)

3.1) Interioridade e temporalidade

3.1.1) Sentido interior enquanto âmbito da temporalidade

3.1.2) Interioridade como instância primeira de afirmação do ser .............. 126

3.1.3) Interioridade e consciência ........................................................... 127

3.1.4) Senso interior e moderação-juízo ................................................... 129

3.1.5) Recuo e avanço atemporal (prae-ponentia/potentia): busca interior e leitura inquiridora (intus-rogans/legens) ...................................... 130

3.2) Adjudicação-afirmação da realidade: a feituração no dizer e instituir a realidade

3.2.1) Pares conceituais e relações binomiais ............................................. 132

3.2.2) Feiturar e afirmar: cronometrar-contemplar (dizer-instituir) ........... 132

3.2.3) Hierarquização e feituração inteligível da realidade ......................... 134

3.2.4) Sentido interior e julgamento-moderação ......................................... 135

3.3) Ratio: instância suprema de juízo e moderação da realidade conhecida .. 139

3.4) A pergunta por Deus enquanto fundamentação prévia da argumentação probatória

3.4.1) “Aquele a quem nada é superior”: definição (de Deus) como antecipação probatória

3.4.2) “... per se ipsam cernit, ... simul et se ipsam oportet fateatur”-Presença divina na atuação racional ......................................................... 151

3.5) Singularidade e o aspecto público nas sensações ..................................... 156

3.6) Identidade e imutabilidade pontuadas no conhecimento sensível ............. 160

4 - DEUS: VERDADE ETERNA E ABSOLUTA (lib. arb. II, viii, 20 - xii, 34)

4.1) Numeralidade e razão

4.1.1) Ratio et Veritas ........................................................................ 166

4.1.2) Iluminação e ratificação .................................................................. 167 
4.1.3) Numeralidade e imutabilidade ...................................................... 173

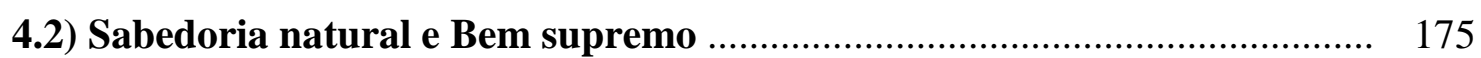

4.2.1) Sabedoria e busca por felicidade ................................................. 175

4.2.2) Eudaimonismo e sapiência (empenho vital) .................................... 178

4.2.3) Notio impressa ......................................................................... 182

4.3) Sapientia et uoluntas: aspectos volitivo e deliberativo do saber humano ... 184

4.3.1) Vontade e juízo deliberativo ........................................................... 191

4.4) Sabedoria e universalidade ............................................................ 193

4.5) Sabedoria e imutabilidade ............................................................. 201

4.6) Ascendência e transcendência ….......................................................... 204

4.7) Verdade: una, imutável, superior, excelsa e eterna .............................. 206

4.8) Paralelo: De vera religione .................................................................... 209

\section{5 - ITINERÁRIO ASCENSIONAL NOS DIÁLOGOS PARALELOS}

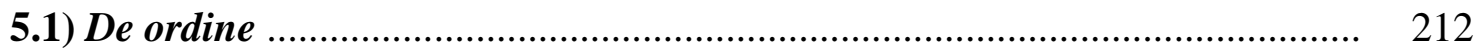

5.2) De quantitate animae .............................................................................. 240

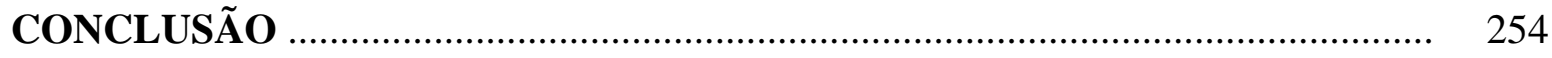

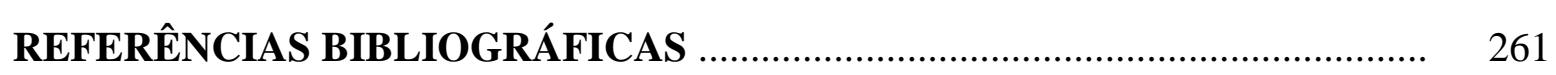




\section{Lista de abreviações}

\section{1) Textos agostinianos}

As obras de Agostinho são abreviadas segundo a lista constante no Augustinus-Lexikon, editado por Cornelius Mayer, Vol. 3, Basel: Schwabe Verlag, 2004-2010, p. XI-XXV [www.augustinus.de/lexikon/WerkeverzeichnisAL3.pdf]:

\begin{tabular}{|c|c|c|}
\hline Acad. & De Academicis libri tres & CCL 29,3-61 [2] \\
\hline an. et or. & De anima et eius origine libri quattuor & CSEL 60,303-419 [8] \\
\hline an. quant. & De animae quantitate liber unus & CSEL 89,131-231 [9] \\
\hline beata $u$. & De beata uita liber unus & CCL 29,65-85 [11] \\
\hline ciu. & De ciuitate dei libri uiginti duo & CCL 47,1-314; 48,321-866 \\
\hline conf. & Confessionum libri tredecim & CCL 27,1-273 [18] \\
\hline dial. & De dialectica & G 83-120 [27] \\
\hline diu. qu. & $\begin{array}{r}\text { De diuersis quaestionibus octoginta tribos } \\
\text { liber unus }\end{array}$ & CCL 44A, 11-249 [29] \\
\hline doctr. chr. & De doctrina christiana libri quattuor & SIMONETTI 6-362 [31] \\
\hline en. Ps. & Enarrationes in Psalmos & CCL 38,1-616; 39,623- \\
\hline & & $1417 ; 40,1425-2196[37]$ \\
\hline ench. & De fide spe et caritate liber unus & CCL 46,49-114 [44] \\
\hline ep. Rm. inch. & $\begin{array}{r}\text { Epistulae ad Romanos inchoate expositio } \\
\text { liber unus }\end{array}$ & CSEL 84,145-181 [143] \\
\hline c. Faust. & $\begin{array}{r}\text { Contra Faustum Manicheum libri triginta } \\
\text { tres }\end{array}$ & CSEL 25,1,251-797 [148] \\
\hline f. et op. & De fide et operibus liber unus & CSEL 41,35-97 \\
\hline f. et symb. & De fide et symbol liber unus & CSEL 41,3-32 [150] \\
\hline Gn. litt. inp. & De Genesi ad litteram libri duodecim & CSEL 28,1,459-503 [158] \\
\hline gr. et lib.arb. & De gratia et libero arbitrio liber unus & PL 44,881-912 \\
\hline imm. an. & De immortalitate animae liber unus & CSEL 89,101-128 [164] \\
\hline lib. arb. & De libero arbitrio libri tres & CSEL 74,3-154 [172] \\
\hline mag. & De magistro liber unus & CCL 29,157-203 [176] \\
\hline mus. & De musica libri sex & PL 32,1081-1194 [181] \\
\hline nat. $b$. & De natura boni liber unus & CSEL 25,2,855-889 [183] \\
\hline nat. et gr. & De natura et gratia liber unus & CSEL 60,233-299 [184] \\
\hline ord. & De ordine libri duo & CSEL 63,121-185 [187] \\
\hline orig. an. & De origine animae (=ep. 166) & CSEL 44,545-585 \\
\hline retr. & Retractationum libri duo & CCL 57,(1-)5-143 [200] \\
\hline
\end{tabular}


sol. Soliloquiorum libri duo

trin. De trinitate libri quindecim

uera rel. De uera religione liber unus

util. cred. De utilitate credendi liber unus
CSEL 89,3-98 [9] [334]

CCL 50,(3-)25-380;

50A,381-535 [338]

CCL 32,187-260 [340]

CSEL 25,1,3-48 [345]

Para as citações em vernáculo dos textos agostinianos, tomamos por base as traduções nos seguintes idiomas: a) português, indicadas pelas epígrafes e siglas referentes às editoras brasileiras Paulus [coleção Patrística] e Vozes [coleção Pensamento Humano]; e à editora portuguesa $\boldsymbol{C M}$ - Casa da Moeda; b) espanhol: BAC [referente à edição das Obras Completas de Agostinho pela Biblioteca de Autores Cristianos, 41 volumes, em castelhano, versões impressa (5 . ed, Madrid, 2008/2013) e eletrônica: www.augustinus.it/spagnolo]; e c) italiano: NBA [Nuova Biblioteca Agostiniana, editada pela Città Nuova Editrice, versão eletrônica: www.augustinus.it/italiano]. Tais versões encontam-se referenciadas de modo completo na bibliografia listada ao final de nossa pesquisa. Indicamos de maneira explicitada a ocorrência de adaptações que se fizeram necessárias em trechos citados, quer pela substituição de termos, quer pela alteração em sua conjugação e sintaxe, quer ainda por significativa mudança no construto frasal. As citações sem indicação de versão compõem tentativas de vertência por nós efetivadas, sempre à luz das versões ora elencadas.

\section{2) Textos bíblicos}

As citações de trechos bíblicos, textuais ou alusivas, seguem as abreviações e o padrão de referência versicular adotados pela $\boldsymbol{T E} \boldsymbol{B}$ - Tradução Ecumênica da Bíblia, nova edição revista e corrigida, São Paulo: Loyola/Paulinas, 1995 (que mantém inalterado o Índice Alfabético dos Livros Bíblicos constante da $1^{a}$. edição de 1994). A título de exemplo, a citação de $R m$ 1, 20.23-25 refere-se ao trecho constante na Epístola aos Romanos, capítulo um, versículos vinte e do vinte e três ao vinte e cinco. Além da $T E B$, as traduções e versões bíblicas utilizadas em nossa pesquisa são identificadas, no corpo textual e notações, pelas seguintes abreviações: $\boldsymbol{B J}$ - Bíblia de Jerusalém, nova edição revista e ampliada, São Paulo: Paulus, 2002; BP - Bíblia do Peregrino, São Paulo: Paulus, 2002; ARC - Almeida Revista e Corrigida, $4^{\mathrm{a}}$. ed, Barueri: Sociedade Bíblica do Brasil, 2009.

Para as referências e citações da Vulgata Latina de Jerônimo, utilizamos a edição crítica dos monges beneditinos digitalizada: BSV - Biblia Sacra iuxta Vulgatam versionem - Editio quinta (editada por Robert Weber e Roger Gryson), Stuttgart: Deutsche Bibelgesellschaft, 2007 [www.bibelwissenschaft.de/online-bibeln/biblia-sacra-vulgata/lesen-im-bibeltext] e impressa 
[Vierte Auflage (4a ${ }^{\mathrm{a}}$ ed.), Stuttgart: DB, 1994]; e a versão sixto-clementina: $\boldsymbol{V C}$ - Biblia Sacra juxta Vulgatam Clementinam - Editio Electronica, Londres, 2005 [www.vulsearch.sourceforge.net; pdf: www.wilbourhall.org/pdfs/vulgate.pdf; impressa: Nova editio ornata a Alberto Colunga et Laurentio Turrado, duodecima editio, Madrid: B.A.C., 2005]; bem como as seguintes traduções da Vulgata em português: Fig - Versão do Pe. Antonio Pereira de Figueiredo, São Paulo: Didática, 2006; MS - Versão do Pe. Matos Soares, São Paulo: Edições Paulinas, 1978; e Zioni - Versão do NT de Dom Vicente Zioni, São Paulo: Ed. Paulinas, 1970.

Para referências aos textos e manuscritos da Vetus Latina - VL, utilizamos a versão disponibilizada em pdf da Vetus Itala inclusa no BSL - Bibliorum Sacrorum latinae versiones antiguae, edição constante da Princeton Thelogical Seminary Library [www.archive.org/details/bibliorumsacroru01saba], além dos dados constantes no projeto $\boldsymbol{V V \boldsymbol { L }}$ - Vulgate + Vetus Latina - St. Jerome's Vulgate \& Old Latin Bible: The Internet Edition With Critical Apparatus, desenvolvido pelo Forum Vulgate \& Vetus Latina mantido pelo sítio eletrônico da Livraria Amazon, período 2012-2014 [www.vulgate.net].

Para as citações referentes à Versão dos Setenta: $\mathbf{L X X}$ - Septuaginta - Editio altera (versão crítica editada por Alfred Rahlfs e Robert Hanhart), Stuttgart: Deutsche Bibelgesellschaft, 2006 [www.bibelwissenschaft.de/de/online-bibeln/septuaginta-lxx/lesen-imbibeltext], além da versão impressa editada unicamente por Rahlfs: Septuaginta - Id est Vetus Testamentum Graece iuxta LXX interpretes (Duo volumina in uno), Stuttgart: Deutsche Bibelgesellschaft, 1979. 


\section{INTRODUÇÃO}

Na percepção e intelecção dos sinais presentes no caminho da busca pelo absoluto, efetuadas pelos pensadores, fieis e místicos de todas as eras, temos que a intuição de início é imediata e primordial. Mas dado que não haveria percurso sem o dado fundante, este delineia e direciona o percurso a ser seguido. $\mathrm{O}$ caminho assumirá a feição do dado fundante. Têm-se o caminho ante o início, cuja identidade revela, em verdade, o próprio telos ou meta à qual conduz o que se almeja e visualiza na própria colocação, ou no próprio dar-se do início, da verdade que é fundamento e ser em plenitude, posto que 1) anterior ao tempo de percurso; 2) antepõe a meta a ser alcançada; 3 ) mostra-se e revela a identidade de ambos (princípio e fim) como única, o que move a querer e buscar o tempo entre ambos, bem como perfaz e delineia o percurso a ser seguido.

Nossa tentativa caminha na busca do esclarecimento desta relação entre o dado primordial ou fundante, e o percurso por ele delineado, à luz dos itinerários de ascensão intelectual que Agostinho de Hipona expõe nos diálogos filosóficos do período inicial de sua carreira de pensador cristão, transcorridos durante sua estadia em Cassicíaco/Milão/Roma. Mas, nesse sentido, um dos caminhos mais estudados pelos pesquisadores e especialistas em seu pensamento vem a ser o delineado no De libero arbitrio, relato signo e ícone maior da apresentação agostiniana do percurso do conhecimento humano até o absoluto e eterno.

O itinerário da mente a Deus figura, nos diálogos do período inicial e como exposição autônoma e em escopo próprio, no imediato seguimento da adesão adulta (ou retorno) de Agostinho à fé cristã. Este contexto tem feito prevalecer, em significativo número dos estudos dedicados ao período, o entendimento de que as apresentações acerca da ascensão intelectual reproduzem, grande medida, o tópico paralelo na tradição platônica, então já sedimentado e perfeitamente reconhecido como um de seus mais característicos acentos. De fato, os sucessivos movimentos que se incorporaram à constituição do pensamento de corte platônico tornaram a ascensão do conhecimento vértice doutrinário de sua apresentação, desde os seus escritos originários, os diálogos platônicos - dentre os quais o Banquete e a República oferecem expressivas descrições - até os escritos tardios do neoplatonismo, já no século III d.C. Contudo, partimos do entendimento de que, não obstante a inequívoca presença, em seus desenvolvimentos, de traços de tais descrições oriundas de seu histórico intelectual como tributário da tradição platônica, os diálogos de Agostinho apresentam a ascensão intelectual em feitura e propósito distintos, que o tornam relatos de itinerários de ascensão próprios do 
pensamento agostiniano deste período, cujo assentamento de bases - na devida retenção, dentro da filosofia grega, daquilo que se lhe afigura como necessário, mas no interior de sua decisiva superação em seu escopo amplo - irá caminhar, evidentemente, para as grandes obras do período intermediário e para os grandes tratados da maturidade.

Nesse sentido, buscamos entrever, dentro de apresentação introdutória das correntes gregas que se situam no entorno da tradição platônica, a constituição de uma conceituação axial referente à ascensão da mente em relação ao mundo sensível, para se situar no puramente inteligível e formal, compondo elevação do plano material para o que se convencionou intitular, dentro das mesmas correntes, de espiritual ou noético. Assim, intentamos nesta introdução inserir uma sumarização relativa a tais tópicos, para ilustrar o contexto da herança traditiva na qual se move Agostinho, quando da descrição do itinerário em seus diálogos, iniciando pela tradição pitagórica - matriz ocidental da ideia de ascenção espiritual em relação ao sensível - para situarmos, em seguida, seu conteúdo herdado e rematizado, em ampliação decisiva, pela tradição platônica originária, e terminarmos com o escopo neoplatônico da processão e retorno das almas ao Uno.

\section{a) Tradição Pitagórica}

$\mathrm{Na}$ tradição filosófica do pitagorismo, a multiplicidade fundamenta-se a partir da numeralidade, instância ontológica primordial de toda a realidade. Enquanto essência universal, o número presentifica a singularidade que se manifesta no caráter relacional de todo ente, vindo a compor a tessitura ordenada do mundo em relação numérica, a qual, por sua vez, engendra toda a materialidade e os seres na amplitude da multiplicidade sensível. Nesse sentido, a numeralidade configura ${ }^{3}$, de maneira uniforme dentro da tradição pitagórica em seus vários momentos históricos ${ }^{4}$, o fundamento relacional originário do universo, no qual a

\footnotetext{
${ }^{3}$ Apoiando-se nos testemunhos da doxografia do século IV (em paralelo aos posteriores textos de Aristóteles), Walter Burkert esboça a configuração mathematikoi e akousmatikoi como central no quadro do movimento do pitagorismo primitivo, remontando a doutrina da numeralidade à tradição primeva [BURKERT, 1972: 15-16, 2122, e 197-202]; cf. BAZÁN, F.G. La concepción pitagórica del número y sus proyecciones, Buenos Aires: Editorial Biblos, 2005, p. 23-29. Em dissonância à virtualmente unânime atribuição à tradição pitagórica primeva, da numeralidade enquanto doutrina estabelecida, Gerald Bechtle coloca: "ela (doutrina dos números) nem pode ser comprovada para Pitágoras e os primeiros pitagóricos, embora [...] seja muito provável que tenha existido uma cosmogonia antiga influenciada por Anaximandro [...] dualista: ilimitado e limite eram provavelmente os archai dos quais tudo surgia" - BECHTLE, G. Pitágoras: entre ciência e vida in Erler, M. e Graeser, A. (orgs) Filósofos da Antiguidade - Dos primórdios ao período clássico, São Leopoldo, Editora Unisinos, 2002, p. 71-72. ${ }^{4}$ Com relação à identificação dos diversos períodos no desenvolvimento histórico da tradição pitagórica, Burkert detém-se no "pitagorismo antigo", visualizado a partir dos pitagóricos do século IV a.C., e não estabelecendo distinção rigorosa entre tradição originária e correntes posteriores deste século [BURKERT, 1972: 97-103], no que é seguido por Christoph Riedweg [2005: 98-119]. Charles Kahn prefere trabalhar com pitagorismo ou filosofia pitagórica, abrangendo o período do século VI a III a.C., e o neopitagorismo referente aos séculos I a.C. a III d.C. [KAHN, 2007: 15-19 e 115-123]. A tese de Gabriele Cornelli procura reconstituir, no quadro hodierno da pesquisa historiográfica, o pitagorismo enquanto corpus doutrinário identificável desde suas tradições
} 
unidade e a multiplicidade expõem-se na harmonia de princípios da composição cósmica, e cuja presença, perpassante de todo o tecido real, condiciona seu conhecimento - e sua consequente experimentação e compreensão - à racionalidade que lhe é inerente, e mesmo a perfaz. Em decorrência, a numeralidade relacional se conceitua, no interior da tradição pitagórica, como a instância ontológica da existência em suas expressões cosmológica e epistêmica, evidenciando-se muito mais como o saber unitário essencial das esferas do ser, do que como uma estratificação tripartite da realidade baseada em tal instância e suas expressões.

Certamente que o pitagorismo, tal como as especulações que se iniciavam na Jônia e em Mileto, intenta a busca pelo princípio unificador e esclarecedor da multiplicidade imponente da realidade cósmica. Mas a dissonância de suas respostas em relação a estas correntes condiciona o comparativo de soluções. A despeito da proximidade, quanto a termos e temas, em relação aos demais centros de especulação ${ }^{5}$, a tradição pitagórica ostenta especificidade quanto à impostação da relação numérica e cosmológica em harmonia, enquanto visualizadas na essência atuante do Uno. As físicas milésia e jônia buscam a localização de um princípio material como fundamento instituinte da realidade, ao passo que o movimento pitagórico postula um ente relacional, ou mesmo a relação numérica, como instância ontológica principial. Em decorrência deste contraste de origem quanto à investigação cosmológica, a pergunta dos físicos milésios/jônios se revestirá do caráter inquiridor próprio do questionamento epistêmico, ao passo que a interrogação pitagórica assume o caráter contemplativo da busca pela visualização do todo em harmonia. O múltiplo se dá em contraposição à unidade, vale dizer: a delimitação dos seres, tanto em seu aspecto formal quanto material, constitui-se no vir-a-ser da multiplicidade e da diferença, que ocorrem em relação à perenidade e unidade do ser, a partir deste e em proporção racionalmente estruturada e estratificada. Tal delimitação, estabelecida e assentada em relação de numeralidade, e constituinte da relação fundamental uno/múltiplo (já ensejada e refletida nas escolas eleática e efésia), configura um dos eixos axiomáticos do pensamento pitagórico em suas diversas etapas, possivelmente seu traço identitário característico e perene, dentro da receptividade que a tradição conheceu na posteridade filosófica. Por seu turno, este eixo dará origem e sustentação à possibilidade de se pensar o conhecimento enquanto superação da dicotomização

primevas, embora estabelecido plurisecularmente de modo coeso, ainda que heterogêneo ["poliédrico" CORNELLI, 2010: 18-20].

5 Vários estudiosos têm buscado a aproximação, e mesmo o inserimento, da tradição pitagórica junto ao âmbito da especulação associada aos jônios. Kahn [2007: 34-35] procura situar o surgimento do pitagorismo a par da tradição naturalista jônia e milésia, tomando as noções de apeiron e peras - já presentes em Anaximandro e na cosmogonia efésia - como principiais para a cosmovisão visualizada em relação numérica, no que foi antecedido por Burkert [1972: 89-90, no espectro da interpretação platônica do pitagorismo], e seguido, moderadamente, por Riedweg [2005: 44-45]. 
uno/múltiplo na totalidade do conhecido pela alma, em sua atividade racional de numerar e estratificar hierarquicamente a realidade conhecida, vale dizer: compor a itinerância intelectual de ascensão cognitiva da realidade múltipla sensível, em direção à superior unidade espiritual universal. Instanciar ou estabelecer a numeralidade como substancial à tessitura do universo fará impostar, por seu turno, a noção do princípio anímico no ser humano em decorrência da estrutura cosmológica e epistêmica inerente a tal instância. Com efeito, o acesso a esta estruturação da realidade é fornecido unicamente pela racionalidade operante na alma $(\text { psique })^{6}$, por sua vez limitada ao corpo físico por ela animado. O cognir a trama relacional através da numeralidade do universo, atesta que a racionalidade anímica perfaz atividade de suplantação dos limites da multiplicidade ôntica, para alçar-se à relação de identificação com a ilimitação essencial permeante do fundamento numérico-matemático. A delimitação essencial à multiplicidade oriunda do vir-a-ser não compõe antagonismo à unidade do ser, mas estabelece a geração e o todo em relação de harmonias e proporções ${ }^{7}$. A percepção e o entendimento de que a multiplicidade, a delimitação e mesmo a identidade dos seres dão-se na própria relação numérica, estabelecida a partir da unidade ilimitada imaterial, irão compor o fundamento para a antropologia do pitagorismo tornada referencial à filosofia platônica, que a cristaliza em seu aspecto doutrinário, bem como para toda sua posterior tradição neoplatônica, com evidente reflexo no pensamento patrístico que a tomou por inspiração, epitomizado em Agostinho.

Ora, a finitude e a fugacidade, congêneres à multiplicidade, caracterizam a limitação e consequente inferioridade do sensível e material face ao inteligível e incorpóreo. É possível afirmar que, desde o início em suas tradições ${ }^{8}$, o pitagorismo estabelece a alma como oriunda do inteligível, vale dizer: ilimitada, eterna e bela (harmoniosa). A atividade anímica consistirá

\footnotetext{
${ }^{6}$ A respeito do conceito de alma no pensamento grego anterior ao pitagorismo, vide Werner JAEGER, 1952: 7787; REALE, 2002: 70-111; BREMMER, J. The early greek concept of the soul, Princeton University Press, 1987, p. 13ss; LESKY, A. Historia de la literatura griega, I - De los comienzos a la polis griega, p. 275-281. Acerca da conceituação da função anímica ou vital, envolvendo a ideia de alma corpórea, em culturas contemporâneas não-gregas e sua possível influência no pitagorismo primevo (especificamente a egípcia), cf. HINTERHUBER, Hartmann Die Seele: Natur und Kulturgeschichte von Psyche, Geist und Bewusstsein, Wien: Springer Verlag, 2001, p . 15ss e 31-34 (tradição pitagórica: $35 \mathrm{ss}$ ).

${ }^{7}$ Assim o interpreta Nietzsche em $\underline{O}$ nascimento da filosofia na época da tragédia grega, apud $\boldsymbol{O}$ s PréSocráticos: fragmentos, doxografia e comentários, São Paulo: Abril Cultural, 1973, p. 61-63 (coleção Os Pensadores).

${ }^{8}$ Temática reconhecidamente axial dentro da doxografia relativa à figura de Pitágoras [KAHN, 2001: 73ss], a imortalidade da alma remetente à inteligibilidade do cosmos, terminando por se constituir num dos fundamentos de toda a antropologia do pitagorismo antigo - cf. JAEGER, 1952: 87-88 (apesar da reserva anterior exposta em Paideia, 1957: 164). Vide ainda REALE, 2002: 118-119.
} 
em apreender a inteligibilidade fundamentadora da ordenação do cosmos, através da qual ascenderá do dado sensível como efeito, para a causa inteligível que o fundamenta ${ }^{9}$.

Se o conduto da tradição pitagórica em relação à filosofia platônica resulta, afinal, clarificado assertivamente nos textos dos diálogos socráticos, dispondo de amplo testemunho contemporâneo e posterior, o reflorescimento da tradição pitagórica por volta do século I a.C., abrangendo os séculos I a III d.C., torna-se a referência seminal para a reconstituição do fio histórico da tradição pitagórica até então perfilhada, terminando por compor o quadro referencial de conceitos da escola, remissivo às suas várias manifestações e ressignificações. Inobstante o que foi qualificado por Kahn [2007: 83] como "traços de sobrevivência" dentro de um período de recesso por toda a época helenística, a tradição pitagórica evidenciará sinais de revivescência no século I a.C, caracterizando-se como início de uma retomada que, inicialmente de forma lenta, terminará por se revelar como abrangente e, sobretudo, de inserção em movimentos que compunham tentativas de unição das grandes escolas filosóficas em sínteses traditivas. Nesse sentido, o reflorescimento do pitagorismo tardio ocorre no seio de um movimento amplo e de sinergia com relação aos seus dados plurifontais, no qual a retomada da tradição pitagórica é assumida sob o signo de sua ampliação e sistematização, já operadas pela filosofia platônica, compondo o conhecido movimento da tipologia arquetípica seqüencial de culminância e de sumarização de suas figuras epigonais: a figura do sábio neopitagórico-platônico é cristalizada e "encarnada" em Plotino, cuja tipificação culmina as prefigurações anteriormente desenvolvidos nas tradições platônica (arquétipo socrático), e pitagórica (arquétipo do sábio universal). De fato, na consecução doutrinal levada a efeito no neoplatonismo, a figura de Plotino assume o arquétipo pitagórico já reconceituado pelo pitagorismo, ressignificado nos diálogos socráticos e, finalmente, tornado ponto de convergência às sistematizações neoplatônicas posteriores ${ }^{10}$. Nesse sentido, o pitagorismo tardio afigura-se o elemento fundante e originário de uma tradição histórica que culmina, em realização de plenificação, na metafísica neoplatônica do Uno e sua antropologia da processão/retorno da alma humana. É nesta precisa acepção que Dominic O’Meara apresenta a revivescência da tradição pitagórica dentro da Antiguidade Tardia e, especificamente, no interior do movimento sinérgico do neoplatonismo e filosofias gregas tardias, mormente

\footnotetext{
9 A apreensão da causalidade orgânica do universo, substrutural e lhe configurando como cosmos, atesta a presença, no pitagorismo, do espírito grego animador das demais correntes pré-socráticas, ainda que a arché resultante - a numeralidade relacional - seja essencialmente distinta da postulada pela física milésia.

${ }^{10}$ Nesse sentido, as figuras arquetípicas personificam a sabedoria ministrada nas escolas iniciáticas, e é sintomático que, na culminância acima descrita, Porfírio seja autor das biografias de Pitágoras e Plotino, respectivamente princípio e culminância da sabedoria universal cristalizada na sistematização neopitagóricoplatônica.
} 
através da filosofia de Jâmblico, pontuando que sua revivescência da tradição pitagórica constitui-se em fator epicêntrico de sua visão própria da síntese neoplatônica, recolhendo as principais reflexões dos pitagóricos posteriores que, desde o século I d.C., procuram retomar o vigor da especulação que o movimento conheceu nos tempos pré-acadêmicos ${ }^{11}$. Kahn [2007: 117-118] lembra-nos que, a partir dos "traços de sobrevivência" dos séculos III e II a.C., é possível afirmar que "até certo ponto, o pitagorismo sempre esteve em voga em Roma", fortalecendo-se enquanto corrente traditiva cuja "voga continua no século I a.C., quando encontramos Varrão e Cícero demonstrando interesse especial por coisas pitagóricas", ainda que tal interesse não signifique, de fato, o esposar as doutrinas da escola ${ }^{12}$.

\section{b) Platonismo}

A via ascensional do conhecimento humano compõe um dos traços fundamentais da tradição platônica em todas as suas manifestações históricas - se não a sua iconicidade suprema, vertida no relato da alegoria da caverna, imagem antonomásica da filosofia de Platão enquanto cristalização do ideal ético soteriológico ancorado em epistemologia de esclarecimento (libertação das trevas da ignorância para o saber elevado e supremo). De fato, a tradição platônica ostentará, ao longo de sua constituição pelos vários períodos históricos que se sucederam a partir da escrita dos diálogos, sua estrutura nuclear calcada no eixo da dialética processual e ascendente, entre os vários níveis do conhecimento intelectual; e precisamente tal elevação vem a se tornar, desde os seus primórdios, o próprio leitmotiv do pensamento platônico, de maneira a condicionar não somente sua feitura, mas até mesmo sua apresentação e compreensão, quando não sua vivência pelo filósofo - assim procurou demonstrar-nos Pierre

\footnotetext{
11 "Porphyry's edition could give his contemporaries every reason to feel confident in the strength and promise of their ancient philosophical culture: Plotinus had brought together with considerable success the many philosophical tendencies of preceding centuries into a whole that came astonishingly close to Plato, if not always in doctrine, certainly in emotional and spiritual power, in intellectual depth, and in the promise of a comprehensive understanding of reality. [...] This last, exremely dynamic and fruitful period in the history of Greek philosophy has in recent years been receveing the attention it deserves. The philosophical and scientific interest of the ideas of Iamblichus, Philoponus, Simplicius, and others has been stressed [...] Both the later Neoplatonists and modern research agree that Iamblichus was largely responsible for changing Plotinus' philosophy so that it would take the form in has later, for example, in Proclus. [...] However, much remains unclear about the precise ways in which Iamblichus altered the course of Neoplatonic philosophy. [...] Besides playing a pivotal role in later Neoplatonism we also know that Iamblichus attempted to revive Pythagoreanism (in some sense) as a philosophy." - O'MEARA, 1989: 1-3

${ }^{12} \mathrm{O}$ próprio Kahn se apressa em afastar possíveis ambiguidades a partir de tais simpatias e interesses: “... Varrão não era formalmente um pitagórico [...] Têm-se a impressão [...] de que a veneração de Cícero por Pitágoras reflete antes sua admiração por um grande homem do passado [...] do que sua divida para com um mestre filosófico." [KAHN, 2007: 118]
} 
Hadot - enquanto exercício espiritual de sabedoria libertadora e realizadora de sua humanidade ${ }^{13}$.

Parte considerável das caracterizações gerais da filosofia platônica pontua a ascensão do conhecimento humano no escopo das exposições, ao longo dos diálogos de maturidade, sobre a dialética processual do intelecto ${ }^{14}$. Na introdução que preparou à tradução francesa dos escritos platônicos por ele próprio dirigida, Luc Brisson assim delineia o traço essencial da epistemologia platônica:

Como sua constituição ontológica a fez uma realidade intermediária entre o sensível e o inteligível, a alma é toda ela voltada/condicionada, naturalmente, a se deslocar entre os níveis de realidade, ou seja, entre o sensível e o intelígivel, a "viagem" sendo necessariamente mais longa para aquela que mais distante se encontra do inteligível. (...) No fim das contas, as formas inteligíveis levam, seguramente, aos processos do conhecimento intelectual. (...) Não se pode conhecer os fenômenos sensíveis, tampouco falar a respeito, se estes não apresentarem certa estabilidade, que lhes assegure sua participação no inteligível. ${ }^{15}$

Igualmente, e ainda no contexto de tais exposições gerais, a ascensão intelectual é situada no interior da doutrina geral da $\alpha v \alpha \mu \nu \varepsilon \sigma \iota \varsigma$ - anamnésis $^{16}$. E, seguindo a identificação efetuada por Platão entre as ordens do ser e do conhecer, visualiza-se a hierarquização das ciências como substrato ontológico da ascensão cognitiva, postulando a classificação dos saberes como gradual e, portanto, ascensional ${ }^{17}$. Têm-se assim uma como que subordinação da consideração gradual e ascensional do conhecimento humano ao aspecto metodológico, ou

\footnotetext{
${ }^{13}$ Vide adiante, quando da exposição efetuada por Dominique Doucet [2004: 39], com relação aos diálogos agostinianos do período inicial, valendo-se da acepção de Hadot quanto à prática da filosofia como exercício espiritual/racional.

${ }_{14}$ Monique Dixsaut faz culminar, em sua exposição introdutória acerca do saber na filosofia platônica, os estatutos graduacionais da opinião, da estratificação das ciências, e das matemáticas e dialéticas, no pano-defundo hierarquizante da classificação geral dos saberes, sumarizada na - e pontificada pela - dialética DIXSAUT, 2003: 66-82.

15 "Comme sa constitution ontologique en fait une réalité intermédiaire entre le sensible et l'intelligible, l'ame est tout naturellement amenée à se déplacer entre les niveaux de réalité, c'est-à-dire entre le sensible et l'intelligible, le 'voyage' étant nécessairement plus long pour l'ame que se trouve plus loin de l'intelligible. [...] Certes, les formes intelligibles rendent compte des processus de la connaissance intellectuelle. [...] On ne peut connaître ces phénomènes sensibles, on ne peut en parler que s'ils présentent une certaine stabilité, celle que leur assure leur participation à l'intelligible." - BRISSON, L. Platon pour notre temps in Platon - Oeuvres Complètes, Paris: Flammarion, 2008, p. XX (grifos nossos).

${ }^{16}$ Cf. SPINELLI, 2006: 173-183; ALBERT, 2011: 31-42. Gadamer chega a tipificar a dialética platônica tomando

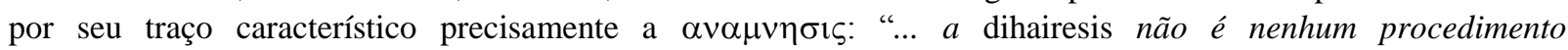
demonstrativo. Ela repousa sobre a anamnesis. [...] A dialética platônica da dihairesis não me parece [...] ter tanto por meta uma ciência universal, mas muito mais o caminho da verdade do diálogo, cujo modo de realização sempre tem algo em comum com anamnesis..." [GADAMER, 2009: 292-293].

${ }^{17}$ Nesse sentido, Elisabetta Cattanei alude à classificação platônica das ciências em geral, em consonância à estratificação ontológica da realidade, atentando para a intermediação das ciências matemáticas entre a dialética e o conhecimento sensível - CATTANEI, E. Entes matemáticos e metafísica, São Paulo: Loyola, 2005, p. 351-352.
} 
mesmo instrumental, da sistematização de suas vias de acesso $^{18}$. Nesse sentido, Monique Dixsaut precisa que

\begin{abstract}
Naquilo em que se constituem numa disposição de conversão (percurso), reconduzindo a alma do sensível para o inteligível, as cinco ciências matemáticas analisadas no livro VII, 522b-531c da República - aritmética, geometria plana, geometria dos sólidos ou estereometria (que começava a se desenvolver graças a Teeteto e Eudóxio), astronomia, harmonia - são focadas não tanto pelo seu potencial de conhecimento, quanto por sua função propedêutica. ${ }^{19}$
\end{abstract}

Assim ocorre, por exemplo, na definição do amor erótico no Banquete, em que o próprio objeto deste transmuta-se numa redefinição fundamental e decisiva para o proceder da alma em sua aspiração ao bem supremo. Tal aspiração não mais se situa nos polos delimitantes da realidade, mas passa a condicionar e significar a própria atitude da alma aspirante à elevação espiritual, da qual a filosofia constitui o exercício próprio através da dialética. Nesse sentido, a filosofia - e, em consequência, o exercício dialético pelo qual se ascende intelectualmente do sensível ao inteligível - é definida a partir desta acepção de eros. E é nesta acepção que Pierre Hadot inicia sua exposição acerca do que classifica como a redefinição dos termos filósofo e filosofia, efetuada por Platão no interior de sua filosofia: "com o Banquete, $a$ etimologia da palavra philosophia, 'o amor, o desejo da sabedoria', torna-se o programa da filosofia." [1999: 79]. Hadot nota que, a partir do que intitula oposição de contradição colocada por Diotima no decorrer do diálogo, desenvolvem-se esquemas lógicos que "tiveram importância muito grande na escola de Platão." [1999: 78], podendo-se supor que, a partir das oposições ou das polaridades invariavelmente instauradas nos diálogos socráticos, a necessidade de gradação viesse a surgir como alternativa às aporias ${ }^{20}$ que se desenhavam como

\footnotetext{
18 “... o platonismo é antes um método que uma doutrina, ou mais exatamente, a pesquisa incansável de uma doutrina que se crê e se sabe fundada imutavelmente na realidade, mas que nos é sempre antes 'proposta' que 'dada', e que não nos cabe fixar. É assim que cada diálogo acabado chega ao 'princípio suficiente', e entretanto 'a medida' dos colóquios dialéticos é a 'vida inteira' [Rep., V, 450b fim]. A ascensão para o Bem e a visão que a coroa são 'suficientes', em cada caso, para fazer-nos resolver o problema particular, de ordem teórica ou prática, donde partimos." - GOLDSCHMIDT, 1963: 51; "Essa 'ascensão' deve ser posta imediatamente em relação com o conceito [platônico] de 'filosofia' [...]: se o Amor [no discurso de Diotima] do qual agora fala Platão é 'filósofo' ou deseja a ciência, então a 'iniciação' nas coisas do amor [...] é, em sentido próprio, uma disciplina cientifica, um 'método' para obter a ciência." - VAZ, 2012: 187. Vide ainda PAVIANI, 2001: 45-49.

19 "En ce qu'elles ont un pouvoir de conversion, détournent l'âme du sensible vers l'intelligible, les cinq sciences mathématiques analysées au livre VII (522b-531c) - arithmétique, géométrie plane, géométrie des solides ou stéréométrie (qui commençait à se développer grâce à Théétète et Eudoxe), astronomie, harmonie - ne sont pas tant envisagées du point de vue de leur puissance de connaitre que de celui de leur utilité propédeutique." [DIXSAUT, 2003: 79]

${ }^{20}$ No âmbito estrito da fala de Diotima a Sócrates no Banquete, Goldschmidt assevera-nos precisamente nesse sentido: "Visto que Eros não é belo, tomemos o sentido oposto e digamos que ele é fio. [...] As duas hipóteses sendo contrárias uma à outra, são falsas. Diotima [...] explica aqui como dois termos extremos admitem um intermediário." - GOLDSCHMIDT, 2002: 211.
} 
inevitáveis desfechos no decurso do diálogo ${ }^{21}$. Tais polaridades partem, invariavelmente, da oposição originária entre a realidade inteligível e seu registro sensível, e a ascensão dialética terá por base precisamente o estatuto ocupado pelo sensível enquanto estratificação inferiorizada, no quadro geral do conhecimento. Nesse sentido, o papel do sensível e sua funcionalidade, no quadro ascensional, é entrevisto em sua fugacidade e mutabilidade, que o tornam sem atrativo face ao aperfeiçoamento crescente que se verifica nos degraus superiores, mais próximos dos níveis de perfeição da imortalidade e imutabilidade. A evanescência exclui a si própria, exatamente por sua brevidade e perecimento. O sensível, à vista do grau superior que se lhe defronta pelo amante da sabedoria, de per si leva à sua própria expiração, uma vez cumprida sua função: apontar para seu oposto, o ser. Os graus são elencados e superpostos em função de sua aproximação da universalidade e perenidade. O que o registro sensível indica (exatamente seu oposto), impõe o abandono deste, face à ampliação crescente que supera a fugacidade individual: a beleza do incorpóreo supera a limitação e transitoriedade do corporal. A superioridade advém da subtração da beleza à ação da temporalidade e limitação espacial: a beleza do discurso legiferante e jurisprudente, bem como as ciências diversas a respeito da natureza, não são destruídas pela ação do tempo, tampouco se limitam pelas alterações e fluências das coisas sensíveis.

O percurso cognitivo, no quadro geral platônico, corresponde aos níveis de elevação epistemológica da realidade, vertidos por sua vez na estratificação das ciências, através da qual a alma gradua-se no itinerário de ascensão do universo, percorrendo as etapas gradativas do

\footnotetext{
${ }^{21}$ Hadot inclusive, no espírito mesmo do discurso parenético de Diotima no Banquete, parece sinalizar nessa direção ao sublinhar, em continuidade, que "o sábio ou o que é bom são absolutos [...] Mas o que é intermediário, o que não é 'nem bom nem mau', ou o 'filósofo', é suscetivel de mais ou menos: o filósofo jamais atingirá a sabedoria, mas pode progredir em sua direção." [HADOT, 1999: 78] Ressalte-se que, em tese ao menos, a ascensão gradual e dialética dos diálogos da maturidade contempla a possibilidade de grau máximo e absoluto. Em precisa contrapartida, Karl Albert, no bojo de uma ampla exposição acerca da noção de filosofia presente no período intermédio dos diálogos, e com base nas alusões à ascensionalidade dialética presentes no Banquete, no Fedro e na República, afirma que "o conceito platônico de filosofia pressupõe haver [...] uma contemplação suprema e, precisamente por isso, uma recordação do sagrado." [ALBERT, 2011: 40]. Por seu turno, o posicionamento ofertado por Henrique de Lima Vaz traduz uma possibilidade de se abranger a gradação mediadora enquanto solução à aporética dos diálogos iniciais (Hadot, acima), junto ao elemento polar contemplativo propriamente (Albert): “... a ascensão 'erótica' termina na posse do Belo pelo conhecimento. Conhecimento que [...] será o exercício daquela phronesis, aquela faculdade de atingir as Ideias que será descrita no Fédon. [...] Mas, obtida enfim a ciência, cessa o desejo [...]; o Amor como 'filosofia', como desejo da ciência, cessa como que no limiar da própria ciência. [...] Dadas essas premissas, podemos [...] determinar a significação que tem aquela 'iniciação perfeita' na contemplação do Belo, ..." [VAZ, 2012: 186-187]. Noutro ensaio, Lima Vaz acentua que "... a possessão da ciência é, segundo o realismo platônico fundamental, uma possessão do seu objeto, ou seja, a beleza da ciência vem do belo que ela contempla..." - VAZ, H.L. A ascensão dialética no Banquete de Platão in ID. Escritos de Filosofia VIII - Platonica, São Paulo: Loyola, 2011, p. 56 (grifos nossos).
} 
sensível (doxa) rumo ao inteligível (epistéme) ${ }^{22}$. Assim, a graduação ascensional corresponde, e mesmo delineia e conduz ao mapeamento ontológico do universo, no qual: 1) as instâncias ônticas ordenam-se em níveis (ou topos) ontológicos correspondentes à relação participativa mantida, em cada um deles, com o princípio supremo da realidade; o qual, embora originário e essencial às diversas regiões ontológicas, insta-se gradualmente e, sobretudo, hierarquicamente a estas, enquanto seu nível tópico ontológico manifestamente superior ${ }^{23}$, tornando-se sua medida de realidade ontológica, ao mesmo tempo (e em decorrência) que lhes estabelece a respectiva graduação dentro da economia ontológica interna universal; e 2) sua percorrência, decorrente da estratificação hierárquica, é realizada unicamente no movimento de ascensão condicionado pela graduação do real, cuja verticalidade ontológica configura, processual e temporalmente, a vetorialidade única e irretorquível da elevação cognitiva da alma. Nesta acepção, o conhecimento ostenta, no quadro amplo da antropologia platônica, função eminentemente realista, enquanto movimento anímico essencial de reestabelecimento ontológico, qual seja, do reencontro da alma com sua origem noética e racional, reflexo cognitivo do mapeamento ontológico da realidade.

Assim, a dialética do conhecimento, ensejada pela própria dialogicidade socrática ${ }^{24}$, é instanciada nos diálogos de maturidade, enquanto método fundante e primordial, tendo os polos instaurativos sensível-inteligível herdados dos diálogos iniciais, como ilustrativos da estratificação em que se situa o conhecimento humano, remetendo sua atividade à percorrência da decorrente gradação em que está disposto o ser e a verdade das coisas e do mundo ${ }^{25}$. Tal

\footnotetext{
${ }^{22}$ Dixsaut ressalta a "natureza intermediária da opinião", atentando para sua positividade de dado primordial de conhecimento, no qual "todas as suas determinações são negativas", posto que "a opinião é desprovida da inteligência de si mesma e de seus objetos" [DIXSAUT, 2003: 73-74].

${ }^{23}$ Cf. DIXSAUT, 2003: 81-82.

24 “... o seu método (socrático) também era exercido ao modo dialético, porque fazia do questionamento e do diálogo uma prática <téchne> enquanto exercício de investigação e de promoção do saber. A bem da verdade, ele adotou, nesse sentido, a técnica do interrogatório dialético praticado por Protágoras." [SPINELLI, 2006: 173, que cita, em corroboração, D.L. IX, 51 e 53 = DK 80 A1, ressaltando entretanto sua distinção para com a "dialética sofística", conquanto "pressupõe critérios racionais de verdade": p. 174]; "Le lien entre dialectique et dialogue est donc tout sauf extérieur et contingent: en um sens, la dialectique est la condition de possibilite de tout dialogue véritable, pour autant que celui-ci ne se réduise pas à une confrontation d'opinions, cést-à-dire de monologues." - DELCOMMINETTE, S. Devenir de la dialectique in DIXSAUT, M., CASTELBOUCHOUCHI, A. e KÉVORKIAN, G. Lectures de Platon, Paris: Ellipses Édition M., 2013, p. 44. Cf. ainda BRISSON et PRADEAU, op.cit., verbete Dialectique, p. 45.

${ }_{25}$ Assim ilustra inicialmente a epistemologia platônica Yvon Lafrance, sublinhando a herança socrática da "refutação das opiniões falsas numa busca da definição", e após igualmente ressaltar que, no oposto das correntes anteriores - em particular a eleática e a atomista, as quais instanciavam-se ceticamente num dos polos da referida oposição - Platão intenta a constituição de bases sólidas para o conhecimento humano justamente ao estabelecer uma mediação de graduação entre a polaridade composta por $\delta o \xi \alpha$ e $\varepsilon \pi 1 \sigma \tau \varepsilon \mu \varepsilon$ : "A opinião e a ciência constituem os dois polos em torno dos quais vai desenvolver-se a reflexão platônica sobre o conhecimento" - LAFRANCE, Y. O conhecimento: ciência e opinião in BRISSON, L.; FRONTEROTTA, F. (orgs.) Platão: Leituras, São Paulo: Loyola, 2011, p. 150-151. É de se observar que, inobstante a virtual consensualidade de tal caracterização, o conduto assertivo da tradição pitagórica e seu respectivo influxo permitem - como já o notamos a respeito do
} 
atividade de percorrência gradual enseja um abandono da lógica anterior de cunho parmenidiano, na qual o pensar detém-se na oposição polar ontológica (ainda que herdando os polos instaurativos referidos), em favor de uma ciência que atue nas mediações correspondentes às instâncias intermediárias ônticas, através das quais a realidade natural (physis) apresenta-se como plurívoca (e não unívoca), composta (e não imposta como única), e dialogal (e não monológica), qual seja: estratificada em camadas, etapas e diferenças que compõem a multiplicidade e mutabilidade do universo, cabendo pois ao conhecimento situar-se nas mediações articuladas e manifestas a partir da instância ontológica suprema, para igualmente compor e articular, pela ciência dos múltiplos e diferentes, sua relação interna (entre si), bem como a relação externa (para com o ser supremo), dando conta assim da intermediação ontológica (instância da mutabilidade e plurivocidade) entre os polos do sensível e do inteligível. Nesse sentido, a dialética platônica tem por origem o influxo da reflexão efésia acerca da mutabilidade e instabilidade ôntica, no interior da lógica polar herdada do pensamento eleata, consistindo precisamente na tentativa de situar a mutabilidade intermédia física dentro da ontologia parmenidiana.

No que permite definir-se enquanto processo de conhecimento, a dialética pode ser dita a arte de mapear e articular o real. Trata-se da ciência da realidade enquanto tal. Ao passo que as diversas ciências não tomam senão partes do real, a dialética alcança a estratificação em si do universo, permitindo à hierarquia, em sua totalidade ontológica, o seu dar-se à racionalidade. No desenvolvimento da conceituação platônica nos diálogos tardios, a dialética é trabalhada como a ciência das intermediações componentes do universo estratificado, possibilitando conhecer o real e o ser em seus vários níveis ontológicos. Mas ela também possibilita, sobretudo, a realização ontológica através do conhecimento que se eleva e/ou ascende do não-ser ao ser, mediante o qual se avança da limitação e restrição à ilimitação e infinitude. Trata-se de um processo de libertação, através do qual o conhecimento se torna o meio de remissão da alma junto à sua origem e essência. Nesse sentido, a dialética pode ser caracterizada, por um lado, como ciência soteriológica e ética, procedendo ao resgate e à libertação para com o ethos primordial da vivência anímica ${ }^{26}$. Noutro viés, ela é o

pitagorismo e suas tradições - situar a epistemologia de Platão como catálise de ambas as pesquisas, à qual a impostação epistemico-antropológica do pitagorismo se presentifica como vetor de possibilidade e fundamentação. Por fim, relembramos que, traditivamente, a recepção a vários influxos deu margem, como nota Brisson ao atentar para o testemunho de Diógenes Laércio, à visualização da síntese platônica como plagiária, o que evidentemente atesta, em leitura reversa, a riqueza de matizes presente na teoria do conhecimento platônica D.L. VIII, 8 - apud BRISSON, 2003: 43.

26 “'On voit toute la distance qui sépare la dialectique platonicienne d'une simple 'méthode' au sens d'instrument de la science: pour Platon, la dialectique est la science, une science que n'est aucunement coupée d'implications éthiques, mais est em même temps la vertu véritable. Plus précisément, afin de ne pás préjuger des distinctions 
conhecimento que alcança o fundamento superior infinito e imutável, do dado inferior limitado e inconstante. Numa palavra: a ciência da hierarquia universal, estrutura ensejante da ascensão intelectual/espiritual da alma rumo às Formas da realidade.

\section{c) Plotino e o neoplatonismo}

$\mathrm{Na}$ tentativa de melhor caracterizar o sentido da ascensão intelectual dentro do pensamento plotiniano, deve-se ressaltar, primeiramente, que sua finalidade precípua reside na experiência de contemplação do Uno, afigurando-se em realidade como uma componente da vida ascética e contemplativa, evocada em uníssono pelo círculo neoplatônico reunido em torno dos ensinamentos plotinianos, na convergência das máximas proclamadas a respeito pelas escolas neopitagóricas. Nesse aspecto, aliás, o neoplatonismo parece fazer convergir (ou talvez se pudesse afirmar: revivescer) seu núcleo estritamente platônico com as escolas neopitagóricas então em voga, fazendo com que, em realidade, a demarcação entre ambas as tradições terminasse rarefeita ou mesmo inexistente. A caracterização do itinerário ascensional do conhecimento ocorre, pois, no contexto da herança da ampla tradição do conduto pitagórico-platônico $^{27}$, relativa ao modo ou trajetória - ou ainda ao método - de superação da(s) inferioridade(s). Da realidade inferior sensível para a superior inteligível; da corporalidade para a espiritualidade; da multiplicidade para a unidade, compondo mediação de cunho intelectual ascensional, que se reflete em rígida disciplina pessoal de caráter moral, mas de natureza essencialmente espiritual ${ }^{28}$. A trajetória ascendente é traçada em verticalidade inexorável e, pode-se dizer, excludente, dado que se trata de superação das inferioridades numa perspectiva de retorno (e não de consumação). Nessa perspectiva, a descrição de Hadot [1999: 227-231; e 235-239] nos faz ver que a ascensão intelectual constitui-se, em Plotino, como ideário a ser viabilizado pela ascese espiritual, dado que o espírito é a parte superior da alma, e esta ruma para seu retorno através de disciplinas práticas resultantes em exercícios espirituais

entre parties de la philosophie que seront introduites par Aristote, on peut dire que'il s'agit d'une science agathologique (de agathon = 'bien'); ce qui revient tout simplement à dire que la dialectique s'identifie em définitive à la philosophie elle-même.” - DELCOMMINETTE, S. Devenir de la dialectique, op.cit., p. 52.

${ }_{27}$ Vide o primeiro item de nossa introdução, versando sobre o pitagorismo primitivo e seus influxos na tradição platônica. Em relação a Plotino, cf. Porfírio, Vitae Plotinae, 21. Outrossim, deve-se lembrar da presença forte do estoicismo no autor das Enéadas: "Plotino busca, de fato, realizar uma síntese entre o platonismo, que lhe permite articular a universalidade e os seres individuais, ou seja: o Um, o Ser e a Alma; e o vitalismo estoico, o qual afirma que o universo é estruturado em uma série indefinida de ciclos, por uma energia interna." BRISSON, L. Logos et logoi chez Plotin - Leur nature et leur role in Les Cahiers Philosophiques de Strasbourg - Tome 8: Plotin, 1999, p. 87. Cf. PIGLER, A. La réception plotinienne de la notion stoïcienne de la sympathie universelle in Revue de Philosophie Ancienne, Tome XIX/no 21, Bruxelles: 2001, p. 77-78.

28 "Plotin, on l'a dit, accorde à l'âme humaine un statut ontologique tout à fait à part: sa conversion nécessite une sorte de médiation d'ordre éthique. Il s'agit de préférer sciemment le Bien au mal, l'unité à la multiplicité, la concentration à la dispersion, l'esprit à la matière." - PANERO, 2005: 56.; Cf. ULLMANN, 2008: (todo o capítulo trata da ética plotiniana, e a ascese espiritual como um de seus desdobramentos). 
de afastamento e superação das camadas inferiores (paixões, afeições e desejos aviltantes). Neste quadro, o itinerário aponta para o refluxo e o desfazimento das atenções voltadas à realidade sensível ${ }^{29}$.

Nas apresentações de cunho sistemático da obra plotiniana, a ascensão intelectual é caracterizada, por vezes, em conjugação ao movimento processional das emanações do Uno, compondo uma polaridade dinâmica entre a processão das almas individuais, por um lado; e seu retorno ao seio essencial e originário da Inteligência e, enfim, do Uno, noutro polo. Ao tratar deste dinamismo polar, Agnès Pigler sumariza que o binômio Processão/Conversão (proodos/epistrophe) termina por compor

... os dois movimentos do mesmo processo de constituição das realidades derivadas
do Uno. Com efeito, a plenitude do Princípio absoluto procede, por superabundância,
uma energia derivada, que se constitui em realidade definida, marcando uma trajetória
na sua ligação com sua fonte, e se torna pois seu gerador. [...] com efeito, a própria
Inteligência também excede, e a energia que então é derivada se torna pois seu
gerador, para se autorealizar. ${ }^{30}$

O itinerário de ascensão intelectual em Plotino pode ser melhor compreendido, atentando-se à sua funcionalidade dentro da concepção do universo como realidade estratificada pelos diversos níveis de ser e verdade. Da multiplicidade verificada no universo material, o conhecimento sensível se avulta como primeiro nível de tomada de contato com a realidade emanada do Uno, porém fragmentado, efêmero e limitado. De tal nível primário é a alma impulsionada a conhecer a realidade permanente e única, não sujeita a mudanças e à transitoriedade características da materialidade. Afirma Plotino o desejo da alma de conhecer o que o nível sensível material meramente vislumbra: as substâncias verdadeiras dos seres materiais. Anseia a alma por inteligir tais essências, acessando a inteligibilidade da qual o mundo sensível é mera expressão figurativa, além de - e sobretudo - imperfeita ${ }^{31}$.

\footnotetext{
29 “ $O$ discurso filosófico pode esforçar-se para pensar a alma 'considerando-a no estado puro, porque toda adição a uma coisa é um obstáculo ao conhecimento da coisa' (Enéada IV, 7, 10,27ss). Mas somente a ascese permite ao eu conhecer-se efetivamente como alma separada do que não é ela, isto é, tornar-se concreta e conscientemente o que ela foi sem o saber" - HADOT, 1999: 236-237.

30 "La procession et la conversion sont les deux mouvements du même processus de constitution des réalités dérivées de l'Un. En effet, de la plénitude du Principe absolu procède, par surabondance, une énergie dérivée qui se constitue en réalité achevée lorsqu'elle marque un arrêt dans son éloignement d'avec sa source et se tourne vers son générateur. [...] en effet, l'Intelligence elle aussi surabonde, et l'énergie qui en dérive se tourne vers son générateur pour s'auto-réaliser." - PIGLER, A. Le vocabulaire de Plotin, Paris: Ellipses, 2003, p. 40.

31 "Il est très fréquent que, dans les Ennéades, Plotin présente la hiérarchie ontologique comme une hiérarchie des niveaux de la vie, et, de même, qu'il utilise, pour distinguer les termes de cette hiérarchie, l'analogie de la lumière plus ou moins intense." - CHIARADONNA, R. Connaissance des intelligibles et degrés de la substance - Plotin et Aristote in Études Platoniciennes III - L'âme amphibie: études sur l'âme selon Plotin, Paris: Les Belles Lettres, 2006, p. 80; “... a realidade deste mundo também é boa, por depender, em última análise, do Bem primeiro - o prôton agathón -, representando, porém, apensas uma pálida imagem deste, mas harmonicamente constituída." - ULLMANN, 2008: 136.
} 
A intelecção supõe anseio, ou desejo expresso, por parte da alma em adentrar na essência da realidade que tange sua vivência corporal ${ }^{32}$. Neste aspecto, o sensível ou a corporalidade fornece à alma a alteridade a partir da qual irá ela (alma) se sentir tocada e desejosa de alçar-se à sua essência, pois sua condição atual - ou "situação humana" - a impede de ver-se enquanto tal, embora lhe possibilite, ainda que indiretamente (devido à sua limitação e mutabilidade), a experiência de ultrapassagem de seu nível para ascender intelectualmente rumo às Ideias (platonismo acadêmico) e ao Uno ${ }^{33}$.

No interior de nossa exposição acerca da ascensão intelectual em Plotino, convém iniciar pelo delineamento de dois aspectos basilares, em torno dos quais é composta a funcionalidade do itinerário ascensional. $\mathrm{O}$ primeiro diz respeito à relação intra-hipostática entre o Intelecto (ou Inteligência) Universal e a Alma do Mundo; o segundo concerne à congenitalidade entre as almas individuais e a segunda hipóstase. Tais aspectos como que fornecem o fundamento para a necessidade anímica de retomada de sua identidade essencial, congênere às duas hipóstases em questão. No plano de sua inserção na tradição platônica, temse feito notar que a filosofia plotiniana, a par de sua herança do eixo sensível-inteligível (matizado pelo neopitagorismo que lhe é contemporâneo, comportando a hierarquização ontológica e estratificação de intermediações entre os polos deste eixo, com a decorrente necessidade de se transitar entre os níveis intermediários, numa palavra: a própria itinerância ascensional do conhecimento humano) - a par de tal herança, verifica-se na filosofia plotiniana, igualmente, a ocorrência de diferenças na concepção do itinerário intelectual, tais que justificariam visualizar, no trabalho de Plotino, a constituição de uma ontologia geral essencialmente distinta de sua tradição matricial, quanto ao núcleo relativo à concepção do Uno, e sua relação para com o múltiplo e o sensível; bem como em relação ao retorno destes para aquele. Com efeito, a anagogé e a epistrophé possuiriam estatutos diversificados, respectivamente no platonismo originário e no neoplatonismo, notadamente quanto ao estatuto da alteridade no plano geral do retorno das almas ao Uno, e sobretudo quanto à presença de uma autêntica conversão destas para o caminho de retorno àquele. Dentre outros, Alain Panero

\footnotetext{
32 "Em VI, 7, 34, Plotino declara que é o amor e o desejo intenso pelo Um que dá o impulso para que a alma percorra todo o caminho de supressão da alteridade [...] Em VI, 9, 9, o amor ao Um é apresentado como inato à alma, pois ela necessariamente deve amar aquele que é sua origem [...]Finalizando seu discurso sobre o amor na Enéada VI, 9, Plotino pede ao leitor que compare os dois tipos de amor, para que perceba a superioridade do amor ao Um e, assim, odeie os ultrajes daqui e se purifique. O amor ao Um, segundo ele, é melhor que o dirigido ao mundo sensível porque não se volta para as coisas passageiras e pode alcançar uma maior plenitude: se amamos o Um, podemos nos unir realmente a ele e não apenas o abraçar com o nosso corpo, como fazem os amantes daqui" - BRANDÃO, Bernardo Guadalupe S.L. A contemplação mística do Um em Plotino in Sapere Aude, Revista de Filosofia da PUC-MG, Belo Horizonte, I/2, setembro/2010, p. 9-10.

${ }^{33}$ Enéada II, 1.
} 
procura apresentar tais constrastes entre Platão e Plotino, empreendendo tentativa de ler toda a obra plotiniana através da noção de conversão:

\begin{abstract}
Assim, se a noção de conversão - a qual implica, por seu turno, a imagem de um retorno, bem como a ideia de uma ruptura decisiva - afigura-se como ideal para uma abordagem sistemática das Enéadas, tal se dá, sobretudo, por ela ser uma categoria chave da metafísica plotiniana. A conversão pode ser definida como a fase de substancialização dos diferentes níveis de realidade a partir do Uno. ${ }^{34}$.
\end{abstract}

A alma deseja unificar-se, ou vivenciar sua essência no mundo inteligível, vale dizer: deseja reintegrar-se ao Uno, via Inteligência. Já a visualização de tal meta remete a uma aspiração de identificação com a realidade unificadora inteligível e verdadeira, por um lado; e ao desejo de superação e libertação, por parte da alma, da materialidade sensível. Desta forma, a ascensão rumo ao inteligível configura um ideário de afastamento, via superação (mas não abandono imediato), de tudo que implique em limite e dualidade, ou ainda possua caráter ôntico determinado, com forma e ato, ou seja, limite e tempo ${ }^{35}$. Ao reconhecer-se como desejosa de reintegração ao Uno, a alma igualmente percebe-se como aspirante a um determinado resgate, por parte da inteligibilidade, de sua condição de estranha ou limitada ao mundo dos objetos e formas, limites e fugacidades. E, reconhecendo-se necessitada de tal resgate, anseia a alma pelo mesmo como libertação de sua condição de atrelamento ao sensível e material, para ser resgatada ao Uno, sua fonte e origem. Trata-se de um resgate para reintegração, retorno, retomada identitária. Ora, precisamente em torno desta libertação intelectual, na qual podemos visualizar uma teoria soteriológica desenvolvida e maturada, temse anotado importantes diferenças entre os desenvolvimentos platônicos registrados nos diálogos de maturidade (cf. O Banquete; Fedro, etc.), e os textos análogos das Enéadas, nos quais se verifica que a libertação contempla, como dito acima, verdadeiro anseio explicitado que atua como mote inspirador do trabalho de ascensão da alma rumo à sua libertação. Nesse preciso sentido que, segundo Panero [2005: 14], a acepção de retorno ao Uno comporta a noção de conversão (metanoia), sendo que, nas Enéadas, tal noção "é definida, antes de tudo, com base em duas outras noções fundamentais, quais sejam: processão e purificação." ${ }^{\text {. }}$.

\footnotetext{
34 "Cela dit, si la notion de conversion, que implique à la fois l'ímage d'un retornement et l'idée d'une rupture décisive, est idéale pour aborder l'etude des Ennéades, c'est surtout parce qu'elle est une catégorie clef de la métaphisique plotinienne. La conversion peut être défine comme la phase de substantialisation des différents niveaux de réalité à partir de l'Un" - PANERO, 2005: 16. O autor teve o cuidado propedêutico de ressaltar, face ao uso milenar que foi feito de metanoia no matiz religioso de conversão pela fé, ou iluminação religiosa, que a noção plotiniana, a exemplo do já trabalhado por Platão, não comporta este traço de religiosidade: "Or, ni Platon ni Plotin n'en appellent à la foi. Tel est leur point commun." [2005: 14].

${ }^{35}$ Cf. CASTELLAN, A. Plotin: l'ascension intérieure, Paris: Michel Houdiard Éditeur, 2007, p. 51.

36 "Dans les Ennéades, la notion plotinienne de conversion est avant tout définie par rapport à deux notions fondamentales, celles de procession et de purification."
} 
Ressaltamos anteriormente que o motivo precípuo para se traçar uma pedagogia ou método de retorno-em-ascensão da alma, através do conhecimento espiritual e rumo à identificação com a Alma Universal (e à contemplação do Uno), reside na identidade congênere entre ambas. Com efeito, a alma individual se reconhece na harmonia e na perfeição da imutabilidade, próprias à inteligibilidade característica da Alma permeante do universo, pelo que, igualmente e em decorrência, termina por: a) reconhecer sua identidade essencial para com ela, bem como sua necessidade de retornar ao seio da realidade/igualdade noética superior, já que a limitação corporal a retém na realidade sensível inferior ${ }^{37}$; e b) condicionarse, enfim, na propensão ao exercício contemplativo do Uno, ponto máximo de sua ascese espiritual. Grande parte dos estudos dedicados ao pensamento plotiniano visualizou este sumário da relação entre as duas hipóstases noéticas decorrentes na psicologia plotiniana Alma Universal e individualidade anímica - precisamente dentro da alteridade ontológica entre $\operatorname{ambas}^{38}$. A explícita distinção hipostática não permite dúvida quanto à efetiva distinção entre a universalidade do Nous e a particularidade da alma encerrada num corpo. Mas como se processa, em termos ontológicos, a relação entre as duas hipóstases, quando da identificação entre ambas, dentro do processo de retorno da individualidade anímica para a inteligibilidade universal? Novamente, número considerável dos estudos acerca das Enéadas mantém que a totalidade da alma individual encontra-se restrita ao corpo físico e, portanto, atrelada à realidade inferior ${ }^{39}$. A questão acerca do modo como se dá a relação de reconhecimento intrahipostática, bem como a conscienciosidade envolvida em seu entorno, oferece-nos ocasião para o equacionamento de um problema que nos permitirá abordar temática fundamental para traçarmos contraste de base entre o movimento de retorno plotiniano da alma ao Uno, e o itinerário ascensional de perfazimento do conhecimento agostiniano, a saber: a simultaneidade

\footnotetext{
${ }^{37}$ Enéada V, 1ss; "A relação do esquema cósmico de Plotino com ânsia de salvação funda-se em que, pela descrição metódica das hipóstases do ser, torna-se manifesta à alma a necessidade de retornar à pátria perdida. Para percorrer o caminho de regresso ao Uno [...] é mister à alma fazer abstração do mundo sensível." ULLMANN, 2008: 163. A retomada plotiniana do tema platônico do regresso da alma à sua realidade de origem (vide o item b) de nossa introdução), comporta uma estratificação ontológica originária da alma individual, através da qual a relação Alma universal inteligível/alma individual, assentada na metexis cósmica no sistema platônico, assume agora uma conotação de alteridade face à identidade de origem hipóstatica, pela qual a realidade sensível e sua temporalidade inerente, compõem estágios de impedimento a ser superados.

${ }^{38}$ HADOT, 1997: 23-38; LACROSSE, 2003: 15-160; PHILONENKO, 2003: 218-224; FATTAL, 1998: 23-27; PANERO, 2005: GUITTON, 1971: 131; ULLMANN, 2008: 28-29; D'ANCONA, C. Plotin in GOULET, R. (dir.) Dictionnaire des Philosophes Antiques, Volume V-a, Paris: CNRS Editons, 2012, p. 997-998 e 1011-1012 (Le problème de l'âme humaine). Vide ainda BRISSON, L. Logos et logoi chez Plotin..., op.cit., p. 90;

39 "Car même si Plotin insiste sur l'unité de l'âme, l'âme du monde et celles des individus ne sont pas des parties da l'Âme que se situent au-dessus d'elles; elles en sont des reflets. L'Âme du monde diffère de l'âme de l'individu dans la mesure où le corps qu'elle produit et qu'elle anime est meilleur que le corps humain, et surtout parce qu'elle ne souffre pas et n'est pas affectée par les problèmes qui viennent troubler l'âme des hommes et même celle des animaux." - BRISSON, L. Logos et logoi chez Plotin..., op.cit., p. 90.
} 
e a imediaticidade percorrentes e fundamentadoras de ambos os trajetos ${ }^{40}$. A esse respeito, Michel Fattal afirma:

Esta valorização da imediaticidade característica da alma intelectual humana, bem como do ato criador de Deus; esta superioridade da intuição sobre a discursividade; da unidade e da identidade sobre a multiplicidade e a diferença, são verdadeiramente tomadas de empréstimo por Agostinho junto à Plotino. Ainda que não seja o caso, em Plotino, de uma decorrência da criação ex nihilo, mas sim de um engendramento, de produção ou de processão dos seres e coisas a partir do Um e da Alma, nem por isso este engendramento deixa de ser athroos, efetivado num só golpe, de modo imediato e todo em eternidade. ${ }^{41}$

Esta curta seção da análise ampla realizada por Fattal, acerca do influxo plotiniano na produção de Agostinho, nos traz dois elementos de base para avançarmos em nosso estudo sobre a imediaticidade e simultaneidade em ambos os pensamentos: 1) o uso, nas duas epistemologias, das duas noções como modus operandi ou o modo em que se dá e se perfaz o ato cognitivo, e que Fattal entende na relação de continuidade, por parte de Agostinho, dos pontos teóricos de Plotino; 2) sobretudo, situar a cosmologia como pano-de-fundo em ambas as teorias do conhecimento. De fato, a inserção do campo cosmológico, se não chega a condicionar, nas duas escolas de pensamento, o desenvolvimento dos pontos epistemológicos centrais, opera entretanto como medida e referência à composição destas. Dado que a ordenação dos seres e da realidade sensível nos leva a compreendê-los, enquanto ordenados e interrelacionados, como resultantes de atividade noética, torna-se evidente que a consideração cosmológica irá ensejar a necessidade de se compreender como se dá a constituição (ou de compreensão) de uma relação que dê conta da presença da racionalidade unificadora numa realidade múltipla, do sentido de imutabilidade e eternidade numa percepção limitada, fluida e temporal. Com matizações e conceituações evidentemente diferentes nas duas abordagens que lhe serão herdeiras, uma das mais agudas questões da tradição platônica conhecerá novos desenvolvimentos e equações.

Assim, a arquetípica e platônica relação uno/múltiplo encontrará, em Plotino, uma complexa estratificação, a partir da presença de uma nova matriz intermédia: a Alma Intelectual ou Universal ${ }^{42}$. Sendo todas as coisas feitas (emanadas) a partir desta origem

\footnotetext{
${ }^{40}$ Cf. BRISSON, L. Logos et logoi chez Plotin..., op.cit., p. 89

41 "Cette valorisation de l'immédiateté propre à l'âme intelligente de l'homme et à l'acte créateur de Dieu, cette supériorité de l'intuition sur la discursivité, de l'unité et de l'identité sur la multiplicité et la différence, sont vraisemblablement empruntées par Augustin à Plotin. Bien que chez Plotin, il ne soit pas question de création ex nihilo, mais d'engendrement, de production ou de procession des êtres et des choses à partir de l'Un et à partir de l'Âme, il n'en demeure pas moins que cet engendrement se fait athroos, d'un seul coup, d'une manière immédiate et de toute éternité" - FATTAL, M. Plotin chez Augustin et Farâbi, Paris: L'Harmattan, 2007, p. 71 (que cita como base textual os textos da Enéada II, 9,12.15-16).

${ }^{42}$ Cf. ULLMANN, R. A. Plotino - a relação entre o Uno e o Mundo in FELTES, Heloísa Pedroso M. F. e ZILLES, Urbano (orgs.) Filosofia: diálogo de horizontes - Festschrift em homenagem a Jayme Paviani, Caxias do Sul: Educs/Porto Alegre: Edipucrs, 2001, p. 289-297.
} 
ontológica (cuja postulação, ao lado da alma individual, já de per si configura uma primeira instância de solução para o problema da relação de base), e segundo sua atuação, evidencia-se que o universo de seres finitos, mutáveis e múltiplos ostenta a presença de algo que, de imediato, as supera e denega (dialética platônica). Assim, a relação uno/múltiplo em Plotino assenta-se sobre a característica (que lhe é inerentemente ontológica) de superação para recuperação e reproposição da uma relação essencial e originária. A visão, para Plotino, é a de processão em distenção ou separação, ou ainda distanciamento e perda. A percepção do todo emanado, segundo as palavras de Fattal, "num só golpe", se dá numa intuição da verticalização da ordenação ontológica, em que a disposição interna de seus elos e segmentos é dada como relação de superação causal, a partir da matriz originária. Visualiza-se, neste "único golpe", uma escada ascendente e excludente de cada degrau superado. Por seu turno, a concepção agostiniana, a partir da nota criacional e providencial [cf. lib. arb. II, i, 1 - ii, 6], faz apontar para a visão imediata de uma composição na simultaneidade, não mais restrita (ou no âmbito estrito) à Inteligência criadora, mas essente e perceptível na presença do absoluto e eterno na realidade criada em sua totalidade, na qual todas as suas partes ostentam a presença e sinal do Criador, compondo mais a visão de um mosaico em crescendo (ou feitura) horizontal, do que a visão verticalizante de uma escada. Se na filosofia plotiniana as realidades inferiores encontram-se situadas nos degraus superados e não inclusos na realidade inteligível, no pensamento agostiniano a criação em totalidade, desde seus níveis mais elementares e sensíveis até as realidades mais espirituais, consuma-se in totum e em simul [cf. an. quant. xxxiii, $70-$ xxxiv, 78; vide ainda a sumarização das disciplinas de percurso verticalizante em ord. II, xiv, 39 - xv, 42], num quadro completo e mosaicizado da atividade noética, sem exclusões, mas tudo incluso na percepção do todo. A rigor, a presença do binômio imediaticidadesimultaneidade, no polo inicial da ascensão verticalizante de Plotino, segundo Brisson ${ }^{43}$; e no transcurso intermediário ${ }^{44}$, bem como em seu polo final ${ }^{45}$, da ascensão mosaicizante de Agostinho, mais que ilustrar figurativa ou espacialmente a diferença de base, vem elucidar a funcionalidade essencial de ambas as noções, como reveladoras dos motes conducentes e sustentadores das duas epistemologias: verticalizante e excludente no neoplatonismo; abarcadora e inclusiva no pensamento agostiniano. Metaforicamente, uma escada não permite que se veja ambos os polos ao mesmo tempo, ao passo que a visão em mosaico da realidade em horizontalidade permite o simul total de imediato.

\footnotetext{
${ }^{43}$ Enéada II, 9,15-16. Cf. BRISSON, L. Logos et logoi chez Plotin..., op.cit., p. 93.

${ }^{44}$ ord. II, xiv-xv; lib. arb. II, i-ii;

${ }^{45}$ an. quant. xxxiii;
} 
Em finalização destas considerações introdutórias quanto ao equacionamento do problema a ser desenvolvido em nossa pesquisa (no preciso contraste entre ambas as escolas de pensamento), podemos indicar que, no interior mesmo de sua construção teórica, bem como no decurso da história do pensamento ocidental, as duas escolas ensejaram resultados decorrentes cuja diversidade assume nítido contraste. Se, por um lado (e em função do movimento ascensional excludente depurar, por assim dizer, toda a realidade de alteridade que lhe inere em sua processão), o retorno epistrófico em Plotino conduz necessariamente ao termo místico sua especulação teórica, por outro lado o itinerário de feitura cognitiva da realidade, na ontologia agostiniana, leva ao louvor e à restauração da história em ressurreição [cf. novamente an. quant. xxxiv,78] ${ }^{46}$. Enfim, se qualificamos, a partir da própria rematização trabalhada por Plotino (em total fidelidade à herança platônica), sua descrição da anagogè por retorno da alma individual à intelectualidade universal hipostasiada na Alma Inteligente, tal se dá unicamente por esta descrição ostentar o eixo verticalizante, na sustentação de todos os elos graduais ou níveis de ser da realidade universal, no qual invariavelmente se parte da realidade inferior, rumo à libertação da alma deste verdadeiro aprisionamento ${ }^{47}$. No paralelo em contraste das duas ascensões anímicas, é possível visualizar a descrição plotiniana, enquanto percurso de retorno à reidentificação da alma individual à sua origem e essência, como: 1) intrinsecamente libertadora de sua condição atual para sua essência perene, bem como da sua própria autoqueda e alteridade sedutora para seu monismo identitário superior [Enéada V, 1ss], numa palavra: 2) livrá-las de um eu que não é si mesma, de uma imagem que não é sua essência, resgatá-la enfim de uma temporalidade que se afigura que se afigura enquanto queda, face ao eterno $[\text { Enéada IV }, 1]^{48}$. Em consequência, a interiorização da ascensão se dará em detrimento e em exclusão da alteridade exteriorizante. Por outro lado, intentamos ilustrar que é possível visualizar as descrições (que, se não chegam a ser complementares entre si, perfazem aspectos de um esboço sistematizante quanto a uma teoria geral da ascensão ou progressão do conhecimento humano) agostinianas, construídas a partir de um pressuposto ético de cunho eudaimonístico, como em lib. arb. II (tal como em Plotino ${ }^{49}$, embora não lhe seja prevalecente o caráter eudaimonístico), mas sobretudo na simultaneidade de uma epistemologia: 1) centrada

\footnotetext{
${ }^{46}$ Cf. FABRE, I. La plume et l'envol: une analyse stylistique de la Méditation sur l'Ascension de Jean Gerson in Revue de l'histoire des religions, Tome 230 - Fascicule 4, octobre-décembre 2013, Paris: Armand Colin, p. 509-536.

${ }^{47}$ Enéada $\mathrm{V}$, 1ss.

${ }^{48}$ Cf. SCHNIEWIND, A. L'Éthique du sage chez Plotin, Paris: Vrin, 2003, p. 102-105.

${ }^{49}$ Cf. ULLMANN, 2008: 133-135; SCHNIEWIND, A. L'Éthique du sage chez Plotin, op.cit., p. 85-112. Nas descrições agostinianas, o acento ético, além do caráter eudaimonístico, encontra-se incluso na nota de providência divina no curso cosmoantropológico da realidade, desde a criação até sua consumação (cf. toda a discussão acerca da presença do mal em relação ao uso das paixões em lib. arb. I; vide ainda an. quant. xxxv).
} 
no noção de esse enquanto dado manifesto primordialmente, após a ausência de percepção judicativa advinda da supressão da cognição, e no tempo mesmo em que "confere" (fundamenta) a existência [lib. arb. II iii, 7ss); 2] no ato imaginativo da percepção enquanto primordial atividade anímica para a feitura cognitiva da realidade, na confluência entre a percepção sensível e a inteligível [an. quant. v, 9ss); e 3] na imediaticidade da percepção da realidade como totalidade em ordenação [ord. II, i, 1ss]. Ao contrário do trajeto plotiniano (o qual, na feitura interna de seus passos, privilegia a ascensão interior em detrimento do exterior sensível), as descrições agostinianas, em nossa tentativa de visualização em conjunto, ostentam a imediaticidade do dado que impulsiona a feitura cognitiva do exterior enquanto vetor para o interior, da realidade sensível enquanto sinal da inteligível, de um abarcamento em mosaico da realidade, que perfaça o todo simultaneamente à sua existência dada (como esse) em totalidade ordenada. Em suma, a descrição plotiniana aponta para uma região de exclusão interiorizante; ao passo que as descrições agostinianas caminham para a inclusão, na interioridade, do aspecto cognitivo do exterior ${ }^{50}$, para a confluência entre a ontologia e a cosmologia (a partir do dado ontológico primordial: imediaticidade do esse à simultaneidade da ordo rerum).

A finalização da apresentação relativa à ascensão intelectual em Plotino, com o breve contraste traçado em relação à exposição agostiniana do itinerário cognitivo, permite-nos a observação, a título de encerramento desta introdução, acerca de algumas referências de elucidação, em estudos e análises, que se firmaram durante a consecução de nossa pesquisa, tornando-se pontuações nodais ao nosso percurso, ora em leitura confluente, ora em contraste elucidativo. Notamos que nossa tentativa, tendo como ponto de partida a referência em caráter único ainda ostentada pela Introdução ao estudo de santo Agostinho de Étienne Gilson, e na tentativa de verificação da relação entre as noções de esse e de intellegere (e sua referência maior ao summus ens ou Vere Esse), tais quais expostas nos diálogos agostinianos (bem como o próprio esmiuçamento de ambos os conceitos, sobretudo no De libero arbitrio), terminou por se aproximar, linhas gerais, de alguns dos pressupostos presentes na pesquisa acerca da "não"ontologia agostiniana de Jean-Luc Marion, envolvendo o conceito de esse como manifestação, doação e presença, mais que substância (embora reserve espaço para essentia), e constantes

\footnotetext{
${ }^{50}$ Moacyr Novaes Filho trabalha as dimensões exteriorizante e interiorizante, verificadas nas descrições agostinianas, em termos de um "dinamismo espiritual" que lhes é necessariamente intrínseco: "Considerando mais de perto a ordem estabelecida na criação, o espírito humano pode divisar uma hierarquia mais complexa do que a dicotomia entre naturezas corporais e naturezas espirituais. No estudo desta hierarquia se adensa o sentido do dinamismo espiritual, traduzido fundamentalmente como vontade. Não se trata de negar aquela dicotomia, mas sim de examinar degraus internos que proporcionam como que apoio ao progresso do espírito. [...] A progressão da hierarquia, além de ascendente, pode ser apresentada também como interiorizante. Com efeito, sob uma linguagem espacial, opondo exterior a interior, Agostinho mostra que um degrau é tanto melhor, mais refinado, quanto mais ele corresponde ao verdadeiro ser,..." - NOVAES, 2007: 186 e 190.
} 
sobretudo do capítulo VII (em que discute o Idipsum de Agostinho e sua leitura de Ex 3, 14, conjuntamente à decorrente "metafísica do Êxodo" intepretada por Gilson) de seu Au lieu de soi, bem como de sua conferência no Colóquio Inaugural do Instituto de Estudos Medievais em 2010, do Institut Catholique de Paris $^{51}$ (embora nos mantenhamos à distância, dentro dos limites de nossa dissertação, da discussão acerca da interpretação de Marion do "Deus sem ser", ${ }^{, 52}$, bem como do "interior sem sujeito", aplicados a Agostinho); na exata proporção que os ensaios de Christoph Horn, mormente o seu Sobre a autorreferencialidade do espírito em Plotino e Agostinho, se revelaram-nos propícios à leitura divergente, mas precisamente por isso - a divergência - excelente fonte para nosso esclarecimento e discernimento próprio quanto aos rumos que adotamos em nosso estudo, amparados pelo refinamento dos auxílios exegéticos presentes na síntese introdutória de Dominique Doucet, bem como nas exposições doutrináriosistemáticas de fôlego de Anne-Isabelle Bouton-Touboulic e Paula Oliveira e Silva. Por seu turno, o ensaio de Lorenzo Mammì STILLAE TEMPORIS - Interpretação de uma passagem das Confissões, XI, 2, mostrou-se-nos, desde o início de nosso projeto, verdadeiramente seminal em sua elucidação acerca do instante e da relação entre temporalidade e conhecimento probatório da realidade divina, aplicado ao contexto do De libero arbitrio II. Do mesmo modo, as análises constantes de Interioridade na cosmologia agostiniana, ensaio de Moacyr Novaes Filho componente do capítulo 4 de seu A razão em exercício: estudos sobre a filosofia de Agostinho, tornaram-se fundamentais às nossas tentativas de captação e entendimento do sentido interno à itinerância intelectual exposto nos diálogos agostinianos, em sua relação para com a dinâmica da interiorização face ao acento cosmológico inerente às descrições ascensionais. Por fim, o recente estudo de Vincent Giraud, Augustin, les signes et la manifestation, na medida em que possibilita uma visão orgânica entre a linguagem e a realidade, manifestada no conhecimento enquanto receptividade e percepção da significação dos nomes divinos, e sua diferença para com os signos presentes e dados na realidade (capítulo VII); e, sobretudo, a relação entre antecipação, temporalidade e referência do sentido (capítulo VIII), permitiu-nos clarificar de que maneira se faz presente, já nos diálogos agostinianos,

\footnotetext{
${ }^{51}$ MARION, J.-L. Note sur l'usage de substantia par saint Augustin et sur son appartenance à l'histoire de la métaphysique in DE LIBERA, A. (ed.) Après la métaphysique: Augustin? - Actes du coloque inaugural de l'Institut d'Études Médiévales de l'Institut Catholique de Paris, 25 juin 2010, Paris: Vrin, 2013, p. 147-165.

${ }^{52} \mathrm{Na}$ obra homônima de Marion, o capítulo III é composto pelo ensaio La croisée de l'Être (cuja redação, esclarece Marion, toma por base uma conferência de 1980, que levou o sugestivo título de "A evanescência do ser e o nome de Deus"), no qual afirma, seguindo a leitura heideggeriana, ser o pensamento agostiniano ainda tributário da "constituição onto-téo-lógica da metafísica" em sua leitura de Ex 3, 14, e portanto do "ser" de Deus - MARION, J.-L. Dieu sans l'être, $3^{a}$. édition, Paris: Quadrige/Presses Universitaires de France, 2010, p. 110. Em Au lieu de soi, Marion tratará de oferecer sua interpretação própria de Agostiinho, centrada no texto das Confessiones, e já no matiz da fenomenologia da doação-presentificação, e da saturação.
} 
importante reflexão sobre o signo e a transcendência inerentes à cognição ascensional do universo.

Uma última palavra acerca da estruturação de nossa tentativa. Iniciaremos pela exposição do itinerário ascensional constante no livro II do De libero arbitrio, texto axial à nossa pesquisa, intentando clarificar como Agostinho o expõe enquanto argumentação probatória da existência do ser absoluto e transcendente à razão humana, no interior da qual são expostas as relações credere-intellegere; a ascensão intelectual a partir da tríade esseuiuere-intellegere; e a verdade enquanto realidade suprema. Após a análise de nosso texto de base, intentamos uma aproximação com as descrições do itinerário constantes no livro II do De ordine, no qual Agostinho sumariza a apresentação das disciplinas e artes liberais no escopo ascensional do conhecimento humano da realidade sensível até a divina; e no De quantitate animae, em que, a partir do ato imaginativo como o moto principial da alma em sua grandeza e potência, termina por compor o relato da ascensão anímica enquanto mosaico da feitura intelectual da realidade no qual se culmina o conhecimento na visão beatífica do ser divino. A apresentação em paralelo dos relatos permite acentuar - assim o cremos ter atingido - a peculiaridade da itinerância ascensional da mente, trabalhada por Agostinho em seus diálogos do período inicial, caracterizando sua precisa funcionalidade no escopo de seu entendimento acerca das noções de ser, razão e mundo, vale dizer: no âmbito de uma ontologia, psicologia e cosmologia já explicitadas neste período do pensamento agostiniano, e que evidentemente alcançarão sua plenitude nos textos de maturidade. 


\section{1 - ANÁLISE PREPARATÓRIA: CRER E INTELIGIR} (lib. arb. II, i,1 - ii,6)

\section{1) Introdução}

Por vezes tomada como tópico emblemático da herança da tradição platônica presente no pensamento de Agostinho, a ascensão do conhecimento humano a Deus, nos diálogos de início, frequentemente é analisada de maneira isolada, em destaque do corpo textual no qual se encontra inserida, e tendo como pano-de-fundo unicamente seus paralelos naquela tradição, sobretudo o plotiniano ${ }^{53}$. Se a evidência do arcabouço traditivo grego se impõe, até mesmo pela admissão do próprio autor, nem por isso a referida análise deveria estar circunscrita a tal herança assumida, ou mesmo restrita a uma comparação com os paralelos referidos. A ascensionalidade em Agostinho possui princípio e finalidade próprios, que lhe permitem certamente lançar mão do desenvolvimento neoplatônico já tornado corrente então, porém com o fito de compor ponto de superação da fé cristã em relação ao pensamento grego, em que este é como que realizado, em suas grandes teses e propósitos, naquela.

Tentaremos apresentar, num primeiro momento, elementos introdutórios para análise do itinerário ascensional agostiniano, tecendo breve apanhado histórico para, em seguida, tentar ilustrar o caráter decorrente da ascensão intelectual, qual seja, visualizá-la como atividade essencial e teleológica da alma, ao mesmo tempo como o resultado de sua abertura e predisposição volitiva à intelecção do dado advindo da fé. Para tanto, tomaremos por base a apresentação levada a efeito por Agostinho no Livro II do De libero arbitrio, mas igualmente levando em conta os símiles descritivos apresentados em outros diálogos do período Cassicíaco/Roma, notadamente o De quantitate animae, cuja descrição tem por ambiência fundante o ato primordial anímico da imaginação, vértice estrutural do diálogo; bem como o Livro II do De ordine, tendo ainda presente os paralelos constantes do De vera religione. Assim, após situarmos nosso texto em breve panorama cronológico e de desenvolvimento conceitual dos trabalhos de Agostinho, passaremos à discussão inicial do Livro II, na qual tentaremos exposição esquemática do que qualificamos como articulação da relação polar entre

\footnotetext{
${ }^{53}$ Mesmo estudos referenciais da bibliografia agostiniana, ainda que com reservas ou ressalvas, partilham de tal abordagem: vide BRACHTENDORF, 2008: 135-138; ou a notação de Gilson: “... Agostinho [...] leu [...] Sobre as três substâncias principais (Enéada V, 1, sobretudo caps. 1-7) [...] Esse tratado de Plotino é também um itinerário da alma para Deus através do interior, que santo Agostinho soube refazer de modo cristão, mas do qual em nada alterou o platonismo essencial." - GILSON, 2007: 47-48; e o juízo categórico de Karl Rahner: "A ascensão a Deus - por mais que se queira cristianizada - é concebida por Agostinho, também na maturidade, em estreita dependência do neoplatonismo" - RAHNER, K. e VILLER, M. Ascetica e mística nella patrística, Brescia: Queriniana, 1991, p. 250. Vide ainda OLIVEIRA E SILVA, 2007: 138.
} 
o ato de crer e a intelecção, elaborada após o "vácuo" cognitivo surgido em decorrência da suspensão judicativa efetuada por Evódio, e do qual resultará a postulação da tríade axial esseuiuere-intellegere, com o caráter primordial da afirmação do ser, conjuntamente ao emergir de sua intelecção, enquanto dado primordial do conhecimento relativo ao caráter indubitável da existência de quem questiona o existir [II, i, 1- ii, 6]; para então procedermos análise do itinerário ascensional [II, iii, 7 - vii, 19], finalizando com a exposição sumária da graduação e ratificação do conhecimento humano no absoluto e eterno, em consumação final de sua predisposição de princípio, tencionando clarificar, na consecução do percurso ascensional, suas relações de decorrência internas.

\subsection{1) Período de Cassicíaco/Roma: diálogos de início}

Uma breve rememoração acerca do trajeto agostiniano no período pós-conversão, em Cassicíaco/Milão e, mais propriamente, na estadia em Roma, além de permitir a devida inserção contextual, bem como a verificação de seu devido locus na obra geral do autor, fornecerá uma visualização adequada para uma fase da reflexão agostiniana que se revelará como sendo a de estabelecimento dos postulados axiais (ou verdades de princípio), aos quais Agostinho irá se referir e reportar de forma permanente, para seus voos intelectuais maiores e mais densos ${ }^{54}$. São os diálogos do período Cassicíaco/Roma que articulam os pontos de sustentação da visão agostiniana da realidade, em cujo centro se encontra já o vislumbre da interioridade, enquanto presença perene e atemporal da verdade a ser assentida, reconhecida e realizada $^{55}$.

A estadia em Cassicíaco deu-se de pronto após sua adesão plena (e já adulto) ao catolicismo $^{56}$, mas primordialmente no contexto imediato de culminância do trajeto intelectual de Agostinho. A adesão pontua termo ao processo de busca do conhecimento da verdade e,

\footnotetext{
${ }^{54}$ No desenvolvimento desta dissertação, teremos ocasião para aludir, termos sumários, ao denso temário referente à relação entre o período inicial em Cassicíaco-Milão e a fase de maturidade, já em Roma, na produção intelectual de Agostinho. Para análise inicial a respeito, vide HARRISON, 2006: 20-33; DUPONT, A. Continuity or Discontinuity in Augustine? in Ars Disputandi [http://ArsDisputandi.org.], volume 08 (2008), p. 67-79; cf. ainda BRACHTENDORF, 2008: 147ss; vide igualmente nos grandes ensaios biográficos: BROWN, 2012 (2000): 141-156; e LANCEL, 1999: 117-145 ; e ainda na breve biografia de VIGINI, 2012: 47-71.

${ }^{55}$ A exposição acerca do trecho final do De quantitate animae (xxxiii, 70 - xxxvi, 81), quando da perfilha do itinerário ascensional, ilustrará um dos passos iniciais, neste período dos diálogos de Cassicíaco/Roma, que culminam com a cristalização nas obras de maturidade, da conceituação da interioridade como princípio estrutural de todo o pensamento agostiniano. Vide OLIVEIRA E SILVA, 2007: 139-140; GUARDINI, R. La conversión de Aurélio Agustín, Bilbao: Desclée De Brouwer, 2013, p. 35-43; VAZ, H.C.L. A metafisica da interioridade Santo Agostinho in ID. Ontologia e História - Escritos de Filosofia VI, $2^{\text {a }}$ edição, São Paulo: Loyola, 2001, p. 84-85.

${ }^{56}$ Vale lembrar que estudiosos têm se posicionado de maneira favorável a uma trajetória pessoal, por parte de Agostinho, como efetuada desde sempre no interior da vivência cristã, sem solução de continuidade, embora pontuada ou marcada pela adesão adulta ou conversão em Milão. Claudio Moreschini cita, a respeito, a obra de Goulven Madec Saint Augustine et la philosophie: notes critiques, Paris, 1996 [MORESCHINI, 2008: 445].
} 
como tal, evoca uma retomada em síntese de todo o percurso até então efetivado. Nesse sentido, a fé cristã caracteriza o coroamento responsivo e conclusivo de um caminho que fora trilhado a partir das doutrinas maniqueístas e do ceticismo ${ }^{57}$, mas com empuxo definitivo dado pelo neoplatonismo ${ }^{58}$, no qual Agostinho identifica a composição articulada de verdades centrais que foram, afinal, vislumbradas e atingidas pelos gregos pagãos ${ }^{59}$. O trabalho referencial de Charles Boyer expôs a postura por assim dizer epitômica a respeito da evolução e possíveis sedimentações em etapas, do pensamento agostiniano, no qual aponta para a preponderância do posicionamento cristão de Agostinho desde o período de Cassicíaco, a partir do qual opera com seletividade o elenco de ideias que visualiza como concordes ao cristianismo [BOYER, 1920: 193-195]. O posicionamento de Goulven Madec, por sua vez, tem se tornado referencial, o qual postula que, desde seus escritos iniciais, Agostinho mantém um núcleo doutrinal em contínua expansão e lapidação ${ }^{60}$. Por seu turno, Johannes Brachtendorf

\footnotetext{
${ }^{57} \mathrm{Na}$ introdução que preparou à sua tradução do an. quant., Riccardo Ferri nota que ele constitui, ao lado do De moribus Ecclesiae Catholicae e do livro I do lib.arb., uma tríade "contendo uma forte carga antimaniquéia (em particular com relação a temáticas de interpretação da Escritura, da moral, da incorporeidade da alma e do mal)" - FERRI, R. Introduzione in La grandezza dell'anima - De quantitate animae, Palermo: Officina di Studi Medievale, 2004, p. 8.

${ }^{58}$ Dentro do escopo introdutório de nosso texto, relembremos o esquema histórico-temático no qual Henri Marrou condensa a obra agostiniana: a) período de 387 a 400 d.C: polêmica antimaniquéia/“filósofo da essência"; b) de 400 a 412: polêmica antidonatista/“doutor da Igreja"; c) de 412 a 430: polêmica antipelagiana/"campeão da graça" (inserindo, aqui, o "teólogo da história contra os pagãos") - MARROU, Henri-Irénée Saint Augustin et l'augustinisme, Paris: Éditions du Seuil, 2003, p. 44-45 (obra originalmente publicada em 1955). Evidentemente um esquema "extremado", nas próprias palavras de Marrou, que em seguida tratará de esmiuçá-lo e nuançá-lo mais e mais, caracterizando os primeiros diálogos de Agostinho como tendo sido escritos dentro do seu "novo ideal de neoplatonismo cristão", no qual "a polêmica [...] é dirigida contra o ceticismo da Nova Academia na mesma medida que é dirigida contra o pessimismo maniqueu" (p. 45).

59 "Suponhamos que Platão vivesse atualmente e não se recusasse às minhas perguntas [...] suponhamos que algum discípulo seu, no tempo em que ele vivia, o interrogasse sobre essa questão. Receberia a seguinte explanação: que a verdade não se capta com os olhos do corpo, mas com a mente purificada; [...] que ao conhecimento da verdade nada se opõe tanto quanto a corrupção dos costumes e as falsas imagens corpóreas [...]; que, pela mesma razão, antes de tudo deve-se cuidar da alma, para que possa contemplar o exemplar imutável dascoisas e a beleza incorruptível [...]; que, entre todos os seres existentes, só foi dado à alma racional e intelectual, o privilégio de encongtrar suas delícias na contemplação da divina eternidade [...] Suponhamos que Platão tenha persuadido seu discípulo de tais ensinamentos, e que ele lhe perguntasse: 'no caso de um hoomem excelente e divino convencer os povos dessas verdades [...] julgarias ser ele digno de honras divinas?' Penso eu que Platão teria respondido que isso não poderia ter sido feito por simples homem, mas só se a força e a sabedoria de Deus tivessem escolhido alguém [...] E quanto à resposta sobre as honras divinas que tal homem mereceria, eu julgo supérflua a pergunta, por ser fácil compreender quanta honra de fato merece a sabedoria de Deus, visto que é sua ação e governo que valeram a esse homem a verdadeira salvação do gênero humano, $e$ merecimento pessoal imenso. Ora, essas suposições já estão realizadas e são celebradas em escritos e monumentos." - uera rel. iii, 3-4 (Paulus). Cf. ainda iii, 5 - iv, 7. Vide a respeito o artigo de Gouveln MADEC $\underline{\text { Si }}$ Plato uiueret... (Augustin De uera religione, 3.3) in Néoplatonisme - Mélanges offerts à Jean Trouillard, Le Cahiers de Fontenay no. 19/22, Paris, 1981, p. 231-248.

${ }^{60}$ Cf. a discussão sumarizante a respeito em DUPONT, A. Continuity or Discontinuity in Augustine? in Ars Disputandi [http://www.ArsDisputandi.org], Volume 8 (2008), p. 67-79. Em seu artigo a respeito, Michael Foley postula com incisão que uma das principais fontes filosóficas para o período de Cassicíaco-Roma é a obra de Cícero: “..., the hunt for Plotinus' or Porphyry's footprints has all but overshadowed Augustine's indebtedness to another thinker praised in those same pages as the savior of Rome and the Latin father of philosophy: Marcus Tullius Cicero." - FOLEY, M. P. Cicero, Augustine, and the Philosophical Roots of the Cassiciacum Dialogues in Revue de Études Augustiniennes, 45 (1999), Paris, p. 51.
} 
[2008: 148] sumariza a discussão histórica a respeito da relação entre cristianismo e neoplatonismo neste período, referenciando-se na postura assumida por Pierre Courcelle em sua obra clássica sobre Agostinho, qual seja, a de relacioná-las em uma "unidade sintética". Restando evidente a impossibilidade, no âmbito de nossa presente pesquisa, do avanço e esmiuçamento no estudo das posturas dos autores, tão-somente delineamos nossa perspectiva no sentido da proximidade com a tese de Madec a respeito, no lastro do entendimento de um continuum permeante a todas as fases da filosofia agostinina, tomando a fase inicial (e portanto os diálogos compostos em tal período) como portando, para além das notas oriundas do estoicismo romano, o acento neoplatônico, entendido em sua relação de vetor à plenificação da doutrina cristã, ou mesmo como identidade de essência e de propósitos entre o neoplatonismo plotiniano/porfiriano e o cristianismo ${ }^{61}$, contendo este, entretanto, aquele em culminância de aperfeiçoamento e realização $^{62}$; após o que poderemos, afinal, situar nosso texto de base.

O traçado panorâmico do contexto que envolve a composição dos diálogos de início permite-nos trazer ao relevo uma leitura em paralelo dos três diálogos referidos, nos quais Agostinho expõe a ascensão intelectual para Deus ${ }^{63}$ já na forma esquemática e normativa quanto à atuação da ratio $^{64}$, apontando para a itinerância da alma em culminância no absoluto através dos graus de intelecção da realidade. Por sua vez, a possibilidade da sinopse permite-

\footnotetext{
${ }^{61}$ Urs Von Balthasar acentua categoricamente que "o neoplatonismo e o cristianismo apresentam-se em uníssono aos olhos de Agostinho: a forma filosófica e a doutrina cristã que ele recolheu e estruturou, justamente nesta forma filosófica. Seus primeiros escritos dão testemunho, com igual força, de uma e de outra." - VON BALTHASAR, H.U. Gloria: una estética teológica, volume 2, Madrid: Ediciones Encuentro, 1986, p. 98. Antes, Von Balthasar pontuara que "... já nos escritos de Cassicíaco se reconhece Agostinho como absolutamente cristão e crente, e, como demonstrou Courcelle, Agostinho conheceu Plotino nas pregações milanesas de Ambrósio, e em suas relações com o sacerdote Simpliciano, que era cristão neoplatônico." - Idem, ibidem.

62 "[Carol] Harrison coaduna-se à tese de Goulven Madec e outros, os quais sustentam que conceitos posteriores de Agostinho, em teologia, estavem sempre presentes, in nucleo, nos escritos iniciais." - DUPONT, A., op.cit., p. 68. Cf. HARRISON, 2008: 8-19. As grandes biografias igualmente pontuam neste sentido: "A leitura agostiniana dos livros platônicos fez uma coisa que todos puderam compreender: levou Agostinho a uma 'conversão' final e definitiva de uma carreira literária para uma vida 'na Filosofia'. [...] Mas Agostinho jamais seria outro Plotino; [...] ele recorreu, nesse momento, à busca de uma disciplina que complementasse a lúcida espiritualidade dos platônicos. Não chega realmente a surpreender que ele se tenha voltado para os escritos de São Paulo. [...] Como quer que fosse, Agostinho sempre vivera suficientemente inserido na esfera do cristinanismo para que sua imaginação fosse captada tanto por um apóstolo quanto por uma sábio pagão: para ele, ambos eram vigi magni, os 'Grandes Homens' de seu passado curiosamente misto. [...] Com efeito, era um convertido entusiástico à 'Filosofia', mas essa 'Filosofia' já deixara de ser um platonismo independente. Fora 'fortalecida', de maneira sumamente individual, pelos ensinamentos mais sombrios de São Paulo e, num nível muito mais profundo, passara a se identificar com a 'religião entranhada em nossos ossos na infância' - ou seja, com a sólida devoção católica de Mônica." - BROWN, 2012 (2000): 123-127; LANCEL, 1999: 130-132.

${ }^{63}$ Cf. KERSTING, Wolfgang "Noli Foras Ire, In Te Ipsum Rede" - Augustinus über die Seele in JÜTEMANN, Gerd; SONTAG, Michael; WULF, Christoph (Hs.) Die Seele: Ihre Geschichte im Abendland, Göttingen: Vandenhoeck \& Ruprecht GmbH \& Co., 2005, p. 59. Kersting pontua, a exemplo de vários autores, a posição deste período - sobretudo a do an. quant. - como especificamente neoplatônica (p. 61), o que, embora formalmente correto, intentamos mostrar, em nosso presente estudo, como materialmente impreciso, visto que a ascensão anímica exposta nos diálogos em questão, ostentará traço inequívoca e essencialmente distinto quanto ao aspecto teleológico do itinerário ascensional.

${ }^{64}$ ord. II, x,25-27; an. quant. xxxiii, 70 - xxxvi, 81; lib. arb. II, iii,7 - xii,34;
} 
nos a percepção de que a temática da ascensão intelectual compõe preocupação de primeira ordem no período de Cassicíaco/Milão/Roma, em que a presença da filosofia neoplatônica é, confessadamente, manifesta e poderosa ${ }^{65}$. Torna-se claro, pois, que o itinerário ascensional tópico polar do neoplatonismo plotiniano, enquanto retorno processional da alma ao Uno ${ }^{66}$ perfaz ponto de embate e superação do pensamento agostiniano para com sua herança platônica, vale dizer: assimilação depurativa da filosofia neoplatônica ${ }^{67}$.

Numa visualização necessariamente sumária, os diálogos de início apresentam como que um eixo motriz: a preocupação em afastar, pelo uso da razão, os postulados céticos e maniqueístas que intentavam divergência no que diz respeito ao cerne da fé cristã, qual seja, a relação soteriológica entre a confessionalidade interior e o Deus absoluto ${ }^{68}$, estabelecida como dialógica e racional enquanto espaço de investigação intelectiva (perceber os vestígios divinos nos graus ascensionados intelectualmente pela alma, em sua busca primordial e ratificadora do Deus conhecido pela fé $)^{69}$. Nesse sentido, o crer no dado revelado/escriturístico perfaz ato de fé em confessio, por sua vez vivenciado na relação dialógica com Deus perpassada pela ratio, estabelecida na $m e n s^{70}$. Os postulados da nova academia e do maniqueísmo contrastam de

\footnotetext{
${ }^{65}$ Cf. conf. VII. Vide ainda beata $\boldsymbol{u}$. iv. Ver a respeito: NUNES COSTA, M.R. A influência do neoplatonismo na conversão de Santo Agostinho in Cultura e Fé, Porto Alegre: IDC, vol. 124, Ano 32, Janeiro-Março 2009, p. 42-63. Vide notas 54, 59 e 61 .

${ }^{66}$ Cf. Enéadas I, 6ss; IV, 8ss; V, 1, 3-5; 9,2; etc.

${ }^{67}$ Alguns autores têm procurado situar a influência do pensamento neoplatônico sobre Agostinho para além de Plotino, ou mesmo a este excluindo, quando do debate acerca do real alcance da leitura agostiniana dos paucissimi libri plotinianos, procurando trazer ao relevo influências de outros neoplatônicos, sobretudo de Porfírio e seu Retorno da alma - vide MORESCHINI, 2008: 445.

${ }^{68}$ Cf. BROWN, 2012 (2000): 126-127.

${ }^{69}$ Acerca da relação entre a confessionalidade e o exercício da razão enquanto programa filosófico, no contexto dos escritos iniciais agostinianos, vide DOUCET, 2004: 29-32; “O caráter dialógico (das Confessiones) não anula a legitiimidade do monólogo (Soliloquia) e, por consequência, o pensamento não pode reduzir-se pura $e$ simplesmente a um 'colóquio', pelo mero fato de que Deus não é um partner finito, mas sim o pressuposto ontológico (interior inteimo meo) da atuação pessoal do pensamento" - VON BALTHASAR, H.U. Glória: una estética teológica, op.cit., p. 111.

${ }^{70}$ Gilson e Boehner observam que Agostinho trabalha com o duplo matiz de confessio: 1) expor-se enquanto alma pensante; e 2) dispor-se enquanto coração crente, ou seja: os aspectos intitulados pelos comentadores de "autobiográfico" e "teológico", respectivamente [cf. GILSON-BOEHNER, 1988: 140]. Ressalte-se que, como se pode verificar pelo desenvolvimento ratificador presente nas obras de maturidade, a confessio é manifestada e realizada na entrega conducente e na atitude ouvinte à presença de Deus: confesso porque invoco; invoco porque creio - "Que eu Vos procure, Senhor, invocando-Vos; e que Vos invoque, crendo em Vós [...] Senhor, invoca-Vos a fé que me destes" [conf. I, i; vide I, v]. A circularidade de tal atitude desvela, em verdade, o fio condutor de todo o pensamento metafísico agostiniano. De resto, é a confessio o próprio instanciar-se da interioridade enquanto locus veritas, o que, para Agostinho, equivale ao locus Dei por excelência. De seu turno, Moacyr Novaes Filho trabalha a especificidade do papel inquiridor, e contrapontual à postura platônica, da confessio em sua vivência como correlatio à uma "cosmologia interiorizante" [NOVAES, 2007: 167-172]. Mais adiante, ao tratar especificamente do sentido hierarquizante presente nas descrições dos itinerários da alma em pauta (os quais classifica como "escalonamentos"), Novaes sublinha que tal sentido obedece ao princípio de subordinação, ostentado sobretudo na relação entre o conhecimento sensível e a racionalidade, cuja superioridade, face aos sentidos externos e interno, consiste "na sua capacidade de pensar a si mesma, de voltar-se para si. [...] vetor interiorizante. A progressão da hierarquia, além de ascendente, pode ser apresentada também como
} 
modo frontal com tal base de fé, na medida em que, para a primeira, inexiste o que se possa ter e crer por verdade absoluta a superar a dispersão e a contraditoriedade do sensível; bem como, para o segundo, o dado corpóreo e sensível compõe realidade inexcedível, limite insuperável para o pensar, e postulado como princípio ontológico da realidade criatural, em contraposição ao princípio espiritual que atua em permanente oposição àquele. ${ }^{71}$

Ante tal quadro, torna-se imperativo lançar luz a respeito da 1) existência da verdade, bem como da possibilidade de se atingi-la; 2) de seu locus originário e próprio, qual seja, a mens em exercício através da ratio, atualizada no princípio anímico e consubstanciado na interioridade enquanto perenidade ontológica principial (a qual, nos diálogos em questão, mormente no De libero arbitrio, situa-se no exercitar da razão que, após a suspensão judicativa e pretensamente absoluta do conhecimento ${ }^{72}$, opera de per si, a partir do dado primordial do esse contingente, rumo ao esse absoluto ${ }^{73}$ ); e 3) do estabelecimento de seu fundamento na relação com o eterno e ilimitado, para o que afigura-se então, como propósito deliberativo e programático, o "rastreamento" da atividade intelectiva compondo como que painel de seu percurso, de modo tal que dê conta da atuação da ratio em relação ao limitado e imperfeito, evidenciando sua origem e fundamento em Deus, eterno e absoluto ${ }^{74}$. Em tal escopo, a ascensão da alma passa a ser visualizada como plenificação em consumação do universo conhecido, e na culminância ${ }^{75}$ da atividade anímico-racional, perfazendo como que um

interiorizante. [...] e ser levado ao seu criador, encontra a si mesmo como momento privilegiado desta trajetória: [...]" [2007: 189-190].

${ }^{71}$ Nossa caracterização do princípio estrutural do maniqueísmo tem por base a exposição que dele nos oferece Justo GONZALEZ em Uma História do Pensamento Cristão - volume 2: De Agostinho às vésperas da Reforma, traduzida a partir da segunda edição inglesa de 1987, São Paulo: Cultura Cristã, 2004, p. 17-20, com ampla indicação bibliográfica. Vide igualmente, para os termos sumários deste ponto de nosso estudo: GÓMEZ, Manuel Guerra Maniqueísmo in ID. Diccionario Enciclopédico de Las Sectas, Madrid: B.A.C., 1998, p. 500; CHALLAYE, Francien Maniqueísmo in SCHLESINGER, Hugo e PORTO, Humberto (orgs.) Dicionário Enciclopédico das Religiões - volume II, Petrópolis: Vozes, 1995, p. 1677-1678. Cf. ainda os sumários doutrinais a respeito, fornecidos por BROWN, 2012 (2000): 57-70; e LANCEL, 1999: 64-67.

${ }^{72}$ lib. $a r b$. II, ii,5

${ }^{73}$ lib. arb. II, iii,7.

74 "Pois, na verdade, assim como a alma é toda a vida do corpo, do mesmo modo toda vida bem-aventurada da alma é Deus. Enquanto vamos executando esse trabalho até o levarmos à sua hora de perfeita realização, estamos ainda a caminho. E já que nos é concedido gozar desses bens verdadeiros e seguros, embora sejam como espécie de lampejos em nossa viagem ainda tenebrosa, observa se não seria o que a Escritura diz sobre a Sabedoria, referindo-se à sua conduta em relação àqueles que a amam, que vêm a seu encontro e a procuram. Com efeito, está dito: 'Ela se mostrará a eles, jubilosamente, nos caminhos e irá a seu encontro, com toda a solicitude' (Sb 6,16). Efetivamente, em qualquer lugar onde olhares, a sabedoria te fala pelos vestígios que imprimiu em todas as suas obras." - lib. arb. II, xvi, 41. Cf. ainda II, xvi, 43-44.

75 "Ouviu sobre a força e o poder da alma. E num breve resumo: ainda confessando que a alma humana não é o mesmo que Deus, temos que deduzir que nada criado está mais perto de Deus. [...] Este é o único Deus que a alma deve adorar, sem dele dizer nada falso ou menos verdadeiro. Aquele que a alma adora como Deus, tem que ser necessariamente considerado por ela como superior ao espírito humano. Nem a terra imensa, nem o oceano, nem as estrelas ou a lua, nem o sol, nada absolutamente do que podemos ver ou tocar deve ser entendido como superior à alma [...] A razão nos convence de que todas estas coisas são inferiores a qualquer alma [...] Somente a Deus devemos adorar como único autor de todas as coisas, e também da alma." - an. quant. xxxiv,77-78. 
mosaico sumarizante (no sentido de um todo harmônico e esteticamente ordenado na justeza de suas partes) do real na grandeza (quantitate) da anima em sua adoração ante o Deus absoluto, compondo seu perfazimento cognitivo em cada passo julgado e moderado pelo conhecimento através da ratio, na simultaneidade advinda da dinâmica interiorizante/exteriorizante ${ }^{76}$.

\subsection{2) Relação corpo/alma e neoplatonismo no período inicial}

Se temos por certo, no pensamento agostiniano, o pano-de-fundo neoplatônico como mote para a condução da filosofia, rumo à sua concretização como exercício da razão em julgar e orientar (iudicare/moderare), bem como agir sabiamente (sapientia); e se igualmente vislumbramos o período de Cassicíaco/Milão/Roma como um "projeto de superação" (justamente enquanto concretização/consumação de seu intento) da filosofia grega pela vivência da fé cristã, resulta evidente a importância de se elucidar como a relação corpo/alma é estabelecida nos escritos iniciais. E, ainda no contexto da redação dos primeiros diálogos, observa-se que tal tópico compõe ilustração maior desta relação inicial estabelecida entre neoplatonismo e credo cristão, a qual logicamente condicionará o estabelecimento e prosseguimento dos diálogos com Evódio no livro II do De libero arbitrio (como também no De quantitate animae).

Embora constitua ponto de partida às exposições iniciais de Agostinho, acerca da atividade anímica como refutação inequívoca do ceticismo neoacadêmico e de certo materialismo maniqueísta, a antropologia de base característica da tradição platônica certamente não as condiciona no estabelecimento de seus postulados centrais, tampouco na consecução de seus propósitos e metas, nem mesmo ainda em seus desdobramentos por assim dizer apologéticos ${ }^{77}$. Enquanto postulação resoluta e unívoca acerca da superioridade do princípio anímico - congênere ao mundo inteligível e das Formas - em relação ao mundo sensível e à limitação corporal, a tradição platônica coadunou-se quase que perfeitamente ao propósito agostiniano de demonstrar a superioridade do espiritual e eterno face ao temporal limitado e fugaz ${ }^{78}$. Porém, se lhe propicia uma plataforma argumentativa inicial irretocável, os postulados do pensamento platônico não percorrem o alcance da antropologia desenvolvida nos

\footnotetext{
${ }^{76}$ an. quant. xxxiv, 77-78; lib.arb. II, ii, 2-7; ord. II, i, 2-5. Cf. NOVAES, 2007: 171.

77 "A refexão agostiniana sobre a alma representa o desatar de um nó decisivo. A sua posição, fortemente religiosa e 'ascensivel', e a identificação do pensamento com a vida do ser racional à procura de Deus põem o tema da alma no centro da sua filosofia. Porém, isso não leva Agostinho a uma elaboração diretamente antropológica da temática, e sim a uma elaboração da vida de ascensão para Deus por meio da alma, em conexão com uma reflexão sobre ela como objeto e sede de escolhas axiológicas." - VANZAGO, L. Breve história da alma, São Paulo: Loyola, 2012, p. 58-59.

${ }^{78}$ Assim é que os paralelos entre a antropologia de base contida nos diálogos socráticos, mormente no Fédon, e as argumentações expostas nas descrições dos itinerários - sobretudo no an. quant. e no lib.arb. em seus níveis iniciais de conhecimento - como que revelam a pertinência, e mesmo o uso alusivo, por estas, da primeira.
} 
estágios de culminância dos itinerários anímicos agostinianos, tendo-se em mente, sobretudo, as conclusões do De quantitate animae e De libero arbitrio.

Verifica-se que até mesmo na definição da relação corpo/alma, que ocupa posição central no pensamento de corte platônico e decisiva para o seu encaminhamento das questões epistemológicas - e, em conseqüência, do horizonte ontológico - a posição agostiniana escapa a uma clarificação simplesmente derivativa, ou mesmo condicionada, às correntes manifestamente presentes em seu pensamento. Tomemos como exemplo a posição de um dos mais autorizados mestres no estudo do pensamento medieval: Étienne Gilson.

Observa-se certa mudança no posicionamento de Gilson quanto à consideração da antropologia agostiniana na relação corpo/alma, e quanto à medida da influência nela exercida pelo matiz neoplatônico. Em 1942, na sua Introdução ao estudo de Santo Agostinho, Gilson assim se posiciona:

Ainda que ele considere o homem total como uma substância, Agostinho insiste com ênfase particular no fato de que a alma é una. Assim, por exemplo, em vez de definir a alma em função do homem, ela é descrita diretamente em si mesma (...) Essa definição do homem, em que a ênfase é colocada com muita insistência na transcendência hierárquica da alma em relação ao corpo, está de acordo com as tendências profundas do agostinianismo. [GILSON, 2006: 97-98].

Porém, alguns anos mais tarde, nas lições editadas em conjunto com Philotheus Boehner, lemos:

Não é infrequente afirmar-se que para Agostinho a essência do homem é uma alma que se utiliza de um corpo; todavia, é fora de dúvida que ele doutrina, clara e reiteradamente, que o homem se compõe de alma e corpo, graças a uma estreita união destes dois componentes, e que só o ser assim composto merece o nome de homem. [GILSON-BOEHNER, 1988: 180].

Se por um lado é evidente que Gilson não alterou de forma conceitual o seu posicionamento, contudo a mudança é clara no que tange à abordagem e exposição a respeito. Se por primeiro acentuava o matiz neoplatônico na definição de alma no pensamento agostiniano, posteriormente revelou-se mais moderado quanto ao acento desta influência. Tal mudança de nuança talvez revele o quanto a trama agostiniana na conceituação da essência anímica humana se mostra complexa e profusa, revelando-se de difícil classificação mesmo a grandes especialistas $^{79}$. A referência a Gilson deveria, em verdade, bastar para nos fazer ver quão inconsistente se mostra a usual classificação da antropologia agostiniana das relações

\footnotetext{
79 "Deve-se dizer [...] que em Agostinho coexistem várias determinações da alma e da relação corpo-alma, de acordo com a fase da evolução de seu pensamento, isso não vale apenas para a conversão do paganismo ao cristianismo, mas também depois que tal conversão aconteceu. [...] A concepção da alma de Agostinho possui aspectos de continuidade, mas também de ruptura com relação à tripartição geralmente mais difundida entre os autores gregos. Ele retoma a ideia de que a alma racional deva ser distinta da 'irracional', noção que, no entanto, unifica o que em Platão é distinto entre alma volitiva e alma desiderativa;...” - VANZAGO, L. Breve história da alma, op.cit., p. 59.
} 
corpo/alma como meramente herdeira da tradição platônica ${ }^{80}$. Em exemplificação, tomemos o texto da Enéada V,1 o tratado plotiniano Sobre as três substâncias principais. Verificamos que Plotino trata, imediatamente ao abrir seu tratado, de situar - e até mesmo mensurar - o afastamento das almas em relação à substância que lhes é congênere e essencial (o Uno) precisamente na volição própria em relação a este, mas sobretudo: na alteridade de si próprias, vale dizer: na delimitação da corporeidade identitária que lhes individualiza, separando-as da substância originária e condicionando-as teleologicamente ao processo de retorno da alma ao Uno. Por outro lado, a par da evidente diversidade de matizes presente nas descrições do itinerário ascensional anímico nos diálogos de Cassicíaco/Roma, certos eixos conducentes sobressaem com nitidez, dentre os quais a vetorialidade ascendente como perfazimento cognitivo da feitura ontológica da realidade sensível, em suas estratificações e hierarquias, as quais não compõem alteridade excludente em relação ao princípio essencial criador, mas sim, e em contraste com o matiz neoplatônico, apresentam vestígios e sinais de sua presença atuante na ordenação harmoniosa do universo, tal qual podemos verificar no De ordine; como também a corporalidade soma-se à culminância do itinerário de atuação anímica expressa pela grandeza e potência da alma, em seu conhecimento da realidade universal hierarquizada, conforme a descrição do De quantitate animae.

Os exemplos acima dão conta - assim nos parece ilustrado - da improcedência de se qualificar as posições de Agostinho como condicionadas, em seu desenvolvimento, pela tradição platônica, antepondo pois evidente cuidado de revisão ou de releitura, quanto ao entendimento do alcance das exposições acerca da atividade anímica, exercício da ratio e definição da mens levadas a efeito nos primeiros diálogos, perfazendo a atividade cognitiva da

\footnotetext{
80 “Quase sempre este tema é tomado como indicativo da 'conversão' do jovem Agostinho ao neoplatonismo, mas a noção de retorno ao mundo espiritual deriva do Hortensius de Cícero, dispensando qualquer recorrência à influência plotiniana." - NAPIER, 2010: 43. Toda a primeira parte da pesquisa doutoral de Daniel Napier procura reconstituir a trajetória de estabelecimento da antropologia agostiniana dos diálogos iniciais do período em Cassicíaco. Por várias ocasiões, são ressaltados influxos diversos na composição do pensamento antropológico deste período: p. 44-45. Ressalte-se que, como pudemos notar no capítulo anterior de nosso estudo, o contexto próprio do neoplatonismo, e mais especificamente o da obra plotiniana - que serão, afinal, as fontes imediatas de Agostinho quanto à tradição platônica - representa um âmbito de convergência intencional entre a herança do conduto pitagórico-platônico e a escola aristotélica, ao qual se soma ainda o influxo da corrente estoica: "Si l'on en croit Porphyre (Vie de Plotin, 21), Plotin cherchait à mettre en accord ce qu'il considérait être les principes des Pythagoriciens et ceux de Platon. Mais, comme Plotin vivait dans un contexte où l'influence du Stö̈cisme était largement dominante, on comprend que la synthèse qu'il proposa ait été très fortement influencée par le Stö̈cisme" - BRISSON, L. Logos et logoi chez Plotin - Leur nature et leur role in Les Cahiers Philosophiques de Strasbourg - Tome 8: Plotin, Université Marc Bloch de Strasbourg, 1999, p. 87. Por fim, vale lembrar a asseveração de Victorino Capánaga a respeito: "Quando se pretende fazer de Agostinho um platônico na concepção do homem, se esquece que, mais que platônico, [Agostinho] é cristão: não crê na preexistência das almas; nem que estas foram aprisionadas nos corpos para expiar uma culpa anterior à sua vinda a este mundo; nem que o relação do corpo e da alma é antinatural, mas sim natural, e que Deus criou o homem inteiro, alma e corpo, reunindo-os para que vivessem em pacífica convivência" - CAPÁNAGA, V. Introduccion in La dimension del alma [Obras Completas de San Agustín, volume III, B.A.C.]
} 
alma em decisiva superação dos postulados maniqueus e céticos. Tal cuidado nos previne quanto à precipitação de se entrever, ou trabalhar, os estatutos do sensível e do inteligível em uma espécie de segmentação delimitante ${ }^{81}$, ou ainda, apelando-se a certa leitura bastante corrente ao longo da história, classificá-los em "esquema dual platônico" nas suas variadas tradições. E este cuidado se impõe, sobremaneira e por evidente, na leitura do De libero arbitrio (igualmente, dos textos do De quatitate animae e do De ordine).

\section{2) A vontade e o livre juízo}

A explicitação do problema da funcionalidade exercida pelo livre-arbítrio, no quadro das relações entre o Deus criador e o ser humano, marca propositadamente o início do livro II do De Libero Arbitrio. É característico da retórica dialogal de Agostinho a máxima explicitação do questionamento (quaestio), em culminância conceitual, como pontuação instaurativa de nova etapa no desenvolvimento da discussão. Tais explicitações levam a termo a conversação conduzida até então, convergindo para a elucidação dos conceitos em jogo e instaurando novo âmbito de discussão. Estas pontuações tópicas ostentam atuações de interveniência conceitual na "costura" de um todo dialogal e estruturado, através das quais a discussão deve rumar e atingir uma meta doutrinária pressuposta (inuentio) ao início do diálogo ${ }^{82}$. Pressupomos, como perspectiva ampla de análise, que, tendo por âmbito primordial o binômio formado por a) um questionamento fundamental e de princípio, acerca de um postulado ora celebrizado por correntes filosóficas já em curso, ora aceito pela fé (quaestio); e b) uma asseveração, ou mesmo colocação assertiva, tomada por ponto indiscutível no contexto da discussão prestes a se instalar (inuentio) - questão e asserção fundamentais, a disputatio é instaurada e se desenvolve com base nas recorrências de explicitações do binômio primordial, o que, em última análise, decorre da própria concepção agostiniana das relações sabedoria humana e fé cristã, a qual parte do dado aceito e crido na fé fundante, para sua ratificação via questionamento e disputa argumentativa. A retórica agostiniana ostenta, pois, seu caráter instrumental como decorrência direta do plano doutrinário e conceitual: a instituição do binômio quaestio-inuentio instaura a disputatio como exercício do intellegere da mens em seu

\footnotetext{
81 “A alma é para Agostinho um princípio hierárquico de domínio do corpo e da sua orientação em relação às paixões. Isso significa que a alma se apresenta distinta do corpo sem ser totalmente o seu oposto. Agostinho, porém, tende a distinguir a alma como princípio vital do animus como summus gradus animae, e enquanto tal identificado com o spiritus e com a mens $e$ as suas manifestações (ratio, intellectus)."- VANZAGO, L. Breve história da alma, op.cit., p. 59.

${ }^{82}$ A sucessão tópica e, mais precisamente, o locus e o ordenamento sequencial que ocupam, no interior da composição retórica agostiniana, os elementos da quaestio, disputatio e inuentio, perfazem parte considerável do estudo de Alfonso Rincón GONZÁLEZ, Signo y lenguaje en San Agustín, Bogotá: Centro Editorial/UNC, 1992.
} 
itinerário ascensional rumo a Deus ${ }^{83}$. Assim, a problematização agudizada acerca do papel desempenhado pelo livre-arbítrio nas economias soteriológica e das relações homemcriatura/Deus, explicita a incongruência entre a vontade humana boa - havendo sido criada por Deus - e o mal desejado pela mesma vontade. Porém, a agudização não visa unicamente explicitar a discussão em curso, mas avançar até o esclarecimento da solução para um problema pressuposto em todo o diálogo: conciliar a ordem criatural boa feita por Deus, com a experiência da presença do mal nesta mesma ordem.

$\boldsymbol{E v}$. - Se possível, explica-me agora a razão pela qual Deus concedeu ao homem o livre-arbítrio da vontade, já que, caso não o houvesse recebido, o homem certamente não teria podido pecar.

Ag. - Logo, já é para ti uma certeza bem definida haver Deus concedido ao homem esse dom, o qual supões não dever ter sido dado. ${ }^{84}$

A explanação do argumento principia pela petição de explicitação, ou seja, pela extração de pressupostos implícitos e aceitos até então pela discussão ora em curso. $\mathrm{O}$ ato de peticionar é composto em dois tempos: 1) remissão do todo em jogo, e discutido até o momento (concessão, por parte de Deus, do livre-arbítrio ao homem); e 2) anteposição de seu par oposto (negação da concessão, com a hipotética consequência imediata). Assim, o pedido de Evódio intenta a extração das razões internas às pressuposições relacionais que polarizaram a discussão: Deus e homem. O elemento intermédio - livre-arbítrio - ostenta neste ponto tipologia ambivalente, ou mesmo ambígua pura e simples: não se supõe como logicamente possível a atribuição de liberdade plena - atributo próprio do Criador - à criatura. Porém, se esta o exerce de fato, evidentemente que lhe foi possibilitado somente por concessão do Criador:

Pois, se é verdade que o homem em si seja certo bem [alusão ao pressuposto discutido e estabelecido na primeira discussão - livro I], e que não poderia agir bem, a não ser querendo, seria preciso que gozasse de vontade livre, sem a qual não poderia proceder dessa maneira. Com efeito, não é pelo fato de uma pessoa poder se servir da vontade também para pecar, que é preciso supor que Deus no-la tenha concedido nessa intenção. ${ }^{85}$

Cabe ressaltar, em modo sumário, que a articulação ostentada neste ponto revela-se como proposição do fundamento de todo o decurso seguinte do diálogo. Trata-se de momento determinante para o que podemos conceituar como autêntica expositio Dei agostiniana, no

\footnotetext{
${ }^{83}$ Tal é o plano geral dos escritos agostinianos do período Cassicíaco/Milão/Roma: lib. arb. II, i, 1 - ii, 6; an. quant. iii, 3ss;

${ }^{84}$ Ev. - Iam, si fieri potest, explica mihi quare dederit Deus homini liberum voluntatis arbitrium: quaod utique si non accepisset, peccare non posset. - Aug. - Iam enim certum tibi atque cognitum est, Deum dedisse homini hoc, quod dari debuisse non putas? [lib. arb. II, i, 1-2].

${ }^{85}$ lib. arb. II, i, 3.
} 
sentido de se expor como a atuação criacional de Deus - expressa no caráter donativo da liberdade e volição humanas, através das quais o homem age e se realiza de modo próprio e único enquanto ser criado - pode ser entendida sem os pressupostos excludentes da fé, na decorrência das soluções angariadas na discussão. Tal exposição terminará por se revelar como o verdadeiro "coração" da obra em seu todo, na qual Agostinho irá explicitar como a discussão nela encontra seu transfundo, vale dizer: sua origem ontológica e sua performação teleológica, na medida em que a discussão conducente de todo o De libero arbitrio tem por mote e esteio a relação criatural Deus-homem em bases ontológicas e epistêmicas. A explicitação e ampliação conducente se dá mediante a instauração de novo âmbito no diálogo, ampliando-o mais e mais na abertura do Livro II, de maneira a permitir a postulação acerca do livre-arbítrio, por sua vez antevisto em sua função de ato executor da temporalidade anímica, na qual a atividade racional, por sua vez, irá se perfazer enquanto feitura cognitiva da realidade (ancorada, segundo lemos em De quantitate animae v, 9, na atitude primordial da imaginatio) no escopo amplo da assim chamada "prova da existência de Deus" trabalhada no Livro II do De libero arbitrio $^{86}$. Em suma, é possível visualizar a composição textual agostiniana como um duplo movimento em simetria: 1) disputatio recursiva e/ou remissiva (enquanto retomada) à quaestio até então desenvolvida (as paixões e tematização da voluntas no âmbito geral da discussão sobre a atuação divina e a livre responsabilidade humana - Livro I do De libero arbitrio), pela qual se reporta, em retroação, à atuação anímica como ponto de partida; e 2) expositio prospectiva, pela qual se lança à exposição do itinerário de ascensão do conhecimento humano a Deus, pelo perfazimento da realidade temporal no instante atuante da ratio, através dos seus momentos de iudicare e moderare o dado conhecido pela mens [lib. arb. II, iii, 7 - vii, 19]. Na intersecção do duplo movimento, a inuentio instaurativa e pressuposta por todo o diálogo.

Em suma, a análise do passo retórico perpassado na estrutura textual permite-nos a percepção de que Agostinho, dentro da tradição platônica de submissão da techne ao ta onta (da ars ao ens), faz valer a retórica como ordenamento discursivo de apresentação da ordem ontológica. Tal qual Platão nos diálogos de maturidade, onde a forma de exposição da dialética ascensional terminava por revelar a forma ontológica da realidade, assim Agostinho expõe a ontologia subjacente às relações Deus/ser humano precisamente na forma da retórica dialogal $^{87}$, na qual o passo subsequente da quaestio é remissivo ao pressuposto da inuentio

\footnotetext{
${ }^{86}$ Cf. GILSON, 2007: 46-53.

${ }^{87}$ TAURISANO [2011: 35ss] expõe uma visão antitética entre os papeis da retórica nos diálogos platônicos e no texto agostiniano, ressaltando primordialmente a "visão desencantadora da retórica" legada por Platão nos diálogos iniciais (p 35), embora ressaltando a amenização posterior de tal juízo, sobretudo a subordinação de uma verdadeira arte da eloquência à dialética (p. 37). Em nosso estudo, tentamos indicar para o que entendemos como
} 
presente por toda o diálogo: a autorictas principial ${ }^{88}$, outorgada pelo Criador, enseja, como âmbito de sua própria vivência e aceitação, o instanciar-se da racionalidade, pela qual é validada e ratificada através do próprio ato libertário (fundante) do julgamento racional, na medida em que a ratio, autônoma em seu exercício, fundamenta sua própria atuação e independência, superando todo condicionamento imposto pela realidade sensível, permitindo transpor e perfazer, cognitivamente (intellegere), toda a realidade criatural. Nesse sentido, podemos concluir que Agostinho faz valer seu aparato e preparo de mestre retórico como instrumental a serviço do conteúdo da fé cristã, terminando por estatuir papel diferenciado à arte discursiva, espécie de retórica própria, de moldagem e forma especificamente cristãs ${ }^{89}$ : não mais a persuasão pretendida é estabelecida anteriormente ao conteúdo argumentado, mas o dado da fé fundamenta e condiciona o discurso a se apresentar, tal qual exercício autonomamente ratificador do dado advindo do credere (ou da pístis bíblica), no qual a rusticidade do dado escriturístico é como que restaurada para uma nova expressão, ampliada e perfeita no discurso que se instaura a partir do inteligir a quaestio de princípio ${ }^{90}$. Vale notar, por fim, que para os efeitos de nosso presente estudo, importa-nos ainda, mais detida e internamente ao texto, observar como a agudização de abertura irá conduzir à exposição da ascensionalidade do conhecimento humano nas seções 3 a 7. Com efeito, o precisar o locus da voluntas dentro da atuação humana, conduz Agostinho ao delineamento da ordo rerum, a qual por sua vez o leva à exposição e contemplação do summus ens.

\subsection{1) Centralidade divina argumentativa (lib. arb. II, i, 1 - ii, 4)}

A pergunta de início feita por Evódio apresenta duplo movimento: petição de explicação (explica mihi); seguida pelo seu "oposto": caso não ocorresse o fato originário do qual se pede explicação (utique si), não haveria a ação ou consequência oposta à origem: o pecado. A articulação do questionamento instaurativo do Livro II assenta-se, pois, no polo binomial ação-divina/ação humana, lançando-se na explicitação de nova quaestio através da remissão implícita da discussão percorrida até então: 1) se temos por certo, após toda a discussão do Livro I, que possuímos livre-arbítrio, dom concedido pela ação de Deus, mas

convergência formal, entre os dois filósofos, com relação ao papel da retórica enquanto discurso estabelecido e estruturado de acordo com o conteúdo essencial a que se presta expor.

${ }^{88}$ Cf. TAURISANO, 2011: 45-46.

${ }^{9}$ Cf. TRAPE, A. San Agustín in DI BERARDINO, A. PATROLOGIA - vol. III: La edad de oro de la literatura patrística latina, Madrid: B.A.C., 1981 (5ª impresión: mayo de 2007), p. 488.

${ }^{90}$ MORESCHINI e NORELLI [2009: 175] notam que somente a partir do século IV, com Jerônimo e Agostinho, haverá um amadurecimento acerca do entendimento do dado escriturístico em sua tipologia literária, no qual os autores, "respeitando a verdade de seus conteúdos, sabem também utilizar as categorias retóricas empregadas pelos pagãos para ampliar a qualidade literária dos textos sagrados". 
causa formal do pecado, então 2) como explicar a ação humana resultante, possibilitada unicamente pela ação divina originária, ao mesmo tempo que contrária a ela? O desdobramento da apresentação da questão instaurativa mostra que o polo binomial condiciona a condução da discussão:

$\boldsymbol{A g}$. Também me recordo de termos chegado à evidência a respeito desse ponto. Mas, no momento, eu te pergunto o seguinte: esse dom que certamente possuímos e pelo qual pecamos, sabes que foi Deus quem no-lo concedeu?

$\boldsymbol{E} \boldsymbol{v}$. Na minha opinião, ninguém senão ele, pois é por ele que existimos. E é dele que merecemos receber o castigo ou a recompensa, ao pecar ou ao proceder bem. [lib. arb. II, i, 1] $]^{91}$

A interrogação interposta por Agostinho remete o fio condutor do questionamento, em recorrência, à origem divina da ação humana, recentralizando e instituindo o caráter teocêntrico de toda a discussão: a moralidade remonta, instância última, à origem divina e ao Ser, pelo qual somos e agimos. Mas a centralidade de Deus questionada por Agostinho remete ao dado primordial da autorictas, e visa não se deter de maneira unicamente remissiva e pontual, como que meramente aludindo à causa formal da moralidade humana - Deus - e sim "saber" o agir de Deus como fonte da conduta humana. Temos o dado do credere que aponta para a origem divina, porém Agostinho interroga não propriamente sobre a posse ou a notitia do dado ${ }^{92}$, mas acerca do saber, conhecer, experienciar esse dado: Deum nobis dedisse scias. Não se trata de um saber cujo estatuto esteja situado em contraposição ao da fé, tampouco em seu aprofundamento ou superposição (como uma sua evolução), mas sim um desejo em amplificação ratificadora ${ }^{93}$.

Tentemos precisar a funcionalidade (e o estatuto) de scire, dentro da epistemologia agostiniana exposta neste passo do texto, para além da disposição intelectiva da fé cristalizada como matiz primordial no mote celebrizado em crede ut intelligas (que Agostinho irá expor logo adiante). A utilização de scire se dá, propriamente, como o equacionamento da nova quaestio de abertura do livro II. Em certo sentido, ele traduz e elucida a nova questão, ao funcionar como meio de atuação entre os polos componentes do binômio a que nos referimos. A relação entre o agir divino e a ação humana não "costura" sua tessitura como justaposição de partes independentes entre si, mas sim como reflexo de feitura recíproca entre um e outro.

\footnotetext{
91 Aug. Ego quoque memini iam nobis id factum esse perspicuum. Sed nunc interrogavi utrum hoc quod nos habere, et quo nos peccare manifestum est, Deum nobis dedisse scias. - Ev. Nullum alium puto. Ab ipso enim sumus; et sive peccantes, sive recte facientes, ab illo poenam meremur aut praemium.

92 Cf. ANDRADE, M. P. O autoconhecimento da mens no livro X do De Trinitate de Santo Agostinho, Dissertação de Mestrado - PUC-SP, 2007, p. 21-57.

${ }^{93}$ Cf. VON BALTHASAR, H.U. Glória: una estética teológica, op.cit., p. 111 (vide nota 69, p. 43). "Também a fé tem seus olhos, com os quais de alguma forma vê que é verdade, aquilo que ainda não vê" (Epistola 120, 2,8); "intellectum valde ama" (Epistola 120, 3,13) - Vide TRAPÈ, A. San Agustín in DI BERARDINO, A. PATROLOGIA - vol. III: La edad de oro de la literatura patrística latina, Madrid: B.A.C., 1981 (5 impresión: mayo de 2007), p. 482.
} 
Há uma observação quanto ao locus ocupado por scire no contexto agostiniano, que irá permitir exploração privilegiada daquilo que pode ser considerado o fio estrutural e recorrente de toda a obra de Agostinho: a simultaneidade interposta entre credere e intellegere. Se a celebrização do mote latinizado, alusivo à versão que a Septuaginta oferece de Isaias 7,9, tornou lugar-comum a articulação entre a religião e a filosofia no interior do pensamento agostiniano, terminou entretanto por fixar, com concisão única, o sentido de sua atitude de base e princípio - crer $e$ entender - embora tenha, de certa forma, lhe empobrecido o alcance, precisamente ao determinar-lhe vetorialidade - crer para entender. O mote tem, efetivamente, a função propedêutica de balizar o direcionamento vital de sua filosofia, porém sua concisão encontra-se fundamentada na interrecorrência entre os polos do binômio anteriormente referido: ação divina e ato humano, Deus criador e atitude volitiva humana. No escopo teológico de seu ideário, Agostinho expõe o binômio criação-volição no âmbito das relações entre graça e liberdade. $\mathrm{O}$ exercício desta última, enquanto bem manifesto, só pode ter sua origem na primeira, pois "todo bem procede e é de Deus" [lib. arb. II, i,1]. Ora, precisamente este simul entre ação divina a possibilitar o ato humano, o qual por sua vez àquela remete e busca, caracteriza todo o movimento de composição e exposição da argumentação discursiva dos passos neste preciso momento de nosso texto. A presença primordial de Deus, cuja ocorrência é postulada, neste passo preciso de nosso texto, no credere enquanto dado recepcionado de per si (a autorictas presente na resposta de Evódio ${ }^{94}$, mas sub judice da ação ratificadora da mens a partir de II, ii, 7), amplifica a alma, em sua atividade racional e espiritual (noética), da sensibilidade material ao sentido interior. Scire configura, assim, o movimento próprio da simultaneidade estruturante da filosofia de Agostinho: desejo saber acerca (e confiar em) do que já tenho e me é dado, do qual já sou notificado e pelo qual sou movido a buscá-lo Nesse sentido, James Wetzel, em seu guia introdutório ao pensamento de Agostinho, explicita que "fundamentalmente, para Agostinho, não chegamos à verdade; a verdade chega a nós e nos abarca em nosso lugar de internamento corporal." [WETZEL, 2011: 89]. Mais adiante ainda, Wetzel trata de detalhar as relações entre a aspiração por sabedoria e o desejo mais profundo da alma - scire e voluntas - em termos menos qualitativos que quantitativos, com a precisa nuança que esta última acepção ocupa na antropologia anímica dos diálogos agostinianos do período inicial, notadamente no De quantitate animae: à qualificação da vontade em sua abertura essencial, deve corresponder - simultaneamente - a quantificação da sabedoria em sua infinitude: "Aberto é o que um desejo finito por sabedoria infinita tem de

\footnotetext{
94 "Ev. - Auctoritati quidem me primum de hac re credidisse confirmo." Abordaremos mais adiante, em nosso estudo, o alcance e a precisão do matiz de receptividade e datum que Agostinho associa e empresta a Autorictas.
} 
ser" [2011: 90-91], o que resulta na intimidade interior, na qual o datum da presença divina ocorre: a) inicialmente, na autorictas que preside o ato de fé; e b) em decorrência, e ensejado pelo dado de fé, ocorre igualmente na percorrência da estrutural ascensional do universo, pela ação ratificadora e judicativa da mens. Assim, temos a biunivocidade, ou mais propriamente: a simultaneidade que caracteriza e estrutura todo o pensamento agostiniano estabelecido nesta fase dos diálogos de início, em cuja utilização de scire, neste momento de nosso texto [lib. arb. II, ii, 5], permite adentrar como passo inicial, e de sinalização diretiva, à condução do percurso discursivo culminante no itinerário ascensional da alma, exposto logo adiante.

Em contínuo, a resposta de Evódio retroage a questão à sua fonte ontológica: à inquirição acerca de sua ciência sobre o caráter donativo (dedisse) do livre-arbítrio, responde com o remontar, por primeiro, a quaestio ao plano criacional/ontológico, para evidenciar a decorrência antropológica e moral da discussão acerca da voluntas. Com tal passo, a resposta de Evódio extrai, junto à teocentralidade da pergunta de Agostinho, o seu aspecto fundante, para evidenciar que a elucidação acerca da liberdade de uso do arbítrio humano advém da ilustração de seu caráter decorrente de tal teocentralidade. Observamos, pois, que a tessitura própria do diálogo, bem como sua apresentação, constituem-se segundo o movimento mesmo da simultaneidade agostiniana: a uma quaestio acerca de aspectos humanos - no caso, a liberdade do juízo e arbítrio morais - ocorrerá primeiramente um como que passo-de-volta, ou o sentido retrocessante/recorrente, para remontar a questão em seu aspecto ontológico e de princípio (espécie de arquiteologia). Para se explicar como agimos rumo ao Bem supremo, deve-se antes remontar ao próprio Bem supremo. E, analogamente, quando Agostinho devolve a quaestio repisando a inquirição de seu scire acerca da origem divina do livre-arbítrio, Evódio uma vez mais apresenta o argumento da recorrência minimum-maximum:

Ag. Mas o que eu desejo saber é se compreendes com evidência esse último ponto. Ou se, levado pelo argumento da autoridade, crês de bom grado, ainda que sem claro entendimento.

$\boldsymbol{E} \boldsymbol{v}$. Na verdade, devo afirmar que, sobre esse ponto, eu aceitei-o primeiramente dócil à autoridade. Mas o que poderia haver de mais verdadeiro do que as seguintes asserções: tudo o que é bom procede de Deus. E tudo o que é justo é bom. Ora, existe algo mais justo do que o castigo advir aos pecadores, e a recompensa aos que procedem bem? Donde a conclusão: é Deus que atribui o infortúnio aos pecadores e a felicidade aos que praticam o bem. [lib. $\boldsymbol{a r b}$. II, i, 1] $]^{95}$

\footnotetext{
95 Aug. Hoc quoque utrum liquido noueris, an auctoritate commotus libenter etiam incognitum credas, cupio scire. - Ev. Auctoritati quidem me primum de hac re credidisse confirmo. Sed quid uerius quam omne bonum ex Deo esse, et omne iustum bonum esse, et peccantibus poenam recteque facientibus praemium iustum esse? Ex quo conficitur a Deo affici, et peccantes miseria, et recte facientes beatitate.
} 
A resposta faz o mínimo remissivo ao máximo: à pergunta se há convicção, de sua parte, acerca da origem divina do livre-arbítrio enquanto dom (e bênção, por conseguinte), Evódio apresenta o argumento da autoridade baseado, por assim dizer, não em incognitum credo, mas elucidando sua vetorialidade: Deus $=$ Bem $=$ Justiça $=$ Moral, a qual por sua vez ostenta explicitamente sua instituição teo-teleológica. Ao resolver a quaestio no remontá-la a Deus, Evódio na verdade dissolve-a no imediato da postulação da origem divina do bem (ou ao caráter donativo do libre-arbítrio, como dom) enquanto datum primordial, notitia à qual a ratio exercitará sua função de moderação-condução e, sobretudo, sua adjudicação (julgamento), pela qual todo dado apresentado ao intelecto é submetido à sua ratificação. Tal postulação fora o ponto de partida, tal como ora perfaz o apontamento final. Longe de eclipsar as verdades intermédias contidas na série argumentativa, esta imediaticidade de postulado as traz ao lume, fazendo com que se revelem e se constituam como intelecção da inuentio de início. O imediato se mostra, aqui, como constituinte das possibilidades de mediações intelectuais do conteúdo doutrinário crido (imediato e instituído), sendo que não somente as mediações qualificam e inteleccionam o dado crido de início, mas são em realidade possibilitadas e impulsionadas por ele. É o postulado doutrinário (conteúdo crido) imediato que enseja (no sentido de solicitar e/ou encaminhar ao) o entendimento/mediação da razão, enquanto solícito (necessitado) de sua adjudicação via ratificação. Enfim, a imediaticidade do dado crido - a inuentio de interveniência do diálogo - apresenta-se como a própria simultaneidade agostiniana: não há prioridade ou primordialidade sobreposta de uma sobre a outra - credere e intellegere - mas em realidade instituem-se num só saber imediato, cuja discursividade no tempo constitui a intelecção ascencional do universo criado pela scientia Dei.

Precisamente a relação de decorrência imediata entre a imediata postulação e/ou remissão ao dado do conteúdo crido, por um lado; e sua mediação construída pela intelecção argumentativa que a penetra (discerne), é que impede a composição argumentativa exposta até então, de se qualificar e se estabelecer como construto puramente teológico. Credere (atitude intelectiva perante a autorictas, que enseja sua própria ratificação, ou seja: institui/instaura a racionalidade) não se impõe como involuntário, mas sim como desejado e buscado de início, imediatamente. Por sua vez, scire apresenta a busca já dada e concretizada na interioridade; porém levada a efeito, em sua discernimento e penetração, através da ratio atuando na intelecção mediada pela exterioridade ${ }^{96}$. O conteúdo crido e o ato de inteligir dão-se, pois, no

96 “A progressão da hierarquia (nos itinerários intelectuais descritos nos diálogos do período inicial), além de ascendente, pode ser apresentada também como interiorizante. [...] o espírito humano, ao investigar o mundo e ser levado ao seu criador, encontra a si mesmo como momento privilegiado desta trajetória [...] Se nele (no 
âmbito de instituição da atualidade anímica da interioridade, e de constituição da receptividade perceptiva da exterioridade - na simultaneidade do scire e da scientia na feitura cognitiva da realidade in totum. Mais adiante, na apresentação do itinerário anímico em Deus, retomaremos $\mathrm{o}$ aprofundamento desta apresentação.

O fio de continuidade de nosso diálogo é tecido como extração e consecução desta simultaneidade fundamental que estrutura o pensamento agostiniano aqui exposto. Face ao direcionamento da quaestio moral ao postulado, por parte de Evódio, da origem divina do livre exercício da voluntas, Agostinho evidencia que este posicionamento pede a colocação da quaestio em termos radicais:

$\boldsymbol{A g}$. Nada tenho a opor. Mas apresento-te esta outra questão: Como sabes que existimos por virmos de Deus? Isso de fato não é o que acabas de explicar, mas sim que dele nos vem o merecer, seja o castigo, seja a recompensa. ${ }^{97}$

A inquirição apresentada ilustra que, se a formulação de uma dada quaestio enseja, em sua própria exposição, determinada solutio (nela mesma contida enquanto inuentio de princípio), esta por sua vez enseja a radicalização da quaestio rumo à fonte da disputatio. Assim, a sequência inuentio-quaestio-solutio se dá, não de forma sucessiva ou processual/progressiva, mas sim de forma retrocessiva/recorrente: retorna-se, a cada nova exposição da quaestio (esmiuçada e radicalizada, por sua vez, a cada novo passo da disputatio), ao ponto originário que, afinal, Evódio tratara logo de supor: a origem divina da ação humana. Agostinho trata então de evidenciar que, se não há o que retorquir a tal postulado do credere origem divina - igualmente há que se avançar na quaestio até o esgotamento da inuentio nela contida: a postulação da origem divina da ação humana implica em questionar, mais amplamente - e, portanto, para além da moral - se a própria existência procede de Deus. Mostra-se, assim, que o postulado acerca da fonte divina para a moral humana contém, em si, a inuentio da ontologia fundamental que sua própria asserção acarreta: a origem divina da existência. A resposta agostiniana irá mais e mais evidenciar que a inuentio trazida por tal asserção contém e apresenta, imediata e simultaneamente, sua própria quaestio já ensejada em

conjunto da criação) está impressa a sabedoria divina, o princípio ordenador, nele se começará a busca. A partir daí, a atenção volta-se para o homem interior, lugar privilegiado do reconhecimento da presença divina. 'Reconhecimento', bem entendido, pois não se deve esperar que o homem apreenda completamente o que é Deus: as pretensões do esforço confessional são de certo modo inalcancáveis." - NOVAES, 2007: 190 (cf. ainda p. 168169); vide DOUCET, 2004: 21-22; vide ainda: RATZINGER, Joseph Originalité et tradition dans le concept augustinien de 'confessio' in CARON, M. (dir.) Les Cahiers d'Histoire de la Philosophie - Saint Augustin, Paris: Éditions du Cerf, 2009, p. 20-21; OLIVEIRA, Manfredo A. O Ocidente enquanto encontro entre a metafisica da natureza e a metafísica da liberdade: o exemplo de Agostinho in FELTES, Heloísa Pedroso M. F. e ZILLES, Urbano (orgs.) Filosofia: diálogo de horizontes, Caxias do Sul: Educs/Porto Alegre: Edipucrs, 2001, pp. 221-235.

${ }^{97}$ Aug. Nihil resisto: sed quaero illud alterum, quomodo noveris nos ab ipso esse. Neque enim hoc nunc, sed ab ipso nos vel poenam, vel praemium mereri explicasti. [lib. arb. II, i, 2] 
máxima amplitude e solutio: a existência é devida a Deus, cuja existência, por sua vez, é atestada pela realidade. Eis, maximamente ilustrada, a simultaneidade agostiniana recorrente e perene, na qual o passo seguinte é não somente suposto pelo anterior, mas é até mesmo por ele ensejado e solicitado, por assim dizer. É precisamente neste escopo da postulação da origem divina, ensejante da ontologia e cosmologia fundamentais, que se dará a descrição do itinerário ascensional levada adiante por Agostinho a partir de II, iii, 7. Antes porém, exploremos toda a solutio trazida à baila pela amplitude da quaestio movente do diálogo, ensejada pela inuentio do conteúdo assertivo crido.

Não obstante responda de forma direta, embora parcialmente, à questão de Agostinho, o responso de Evódio é composto tendo por eixo a recorrência ao dado primordial do conteúdo crido (credere), o qual afirma a procedência divina de todo bem existente. O trecho final contempla diretamente a inquirição agostiniana ao trazer que

$\boldsymbol{E} \boldsymbol{v} .[\ldots]$ todo bem procede de Deus. Isso nos faz compreender que o homem também procede de Deus. Porque o próprio homem, enquanto homem, é certo bem, pois tem a possibilidade, quando o quer, de viver retamente. [II, i, 2] ${ }^{98}$

Novamente, a recorrência ao dado primordial, através do passo argumentativo retrocedente ao fundamento divino da realidade, leva Evódio a reiterar a argumentação analógica do maximum referenciando o minimum: dado que Deus é o bem maior e origem de todo outro bem, tem-se de imediato que o ser humano, enquanto tal e "vivendo retamente", é (também ele) um bem manifesto e, portanto, procedente de Deus. Esta composição, por sua vez, engendrará a continuidade da discussão argumentativa até a exaurição do dado primordial postulado pela autoridade da fé, condicionando o desenvolvimento do diálogo às teses nele implícitas. Ora, precisamente a estruturação dialogal da questão de princípio ensejará, no ínterim do responso de Agostinho, o duplo movimento deste seu exaurir-se:

\begin{abstract}
Ag. Realmente, e se é essa a questão por ti proposta, já está claramente resolvida. Pois, se é verdade que o homem em si seja certo bem, e que não poderia agir bem, a não ser querendo, seria preciso que gozasse de vontade livre, sem a qual não poderia proceder dessa maneira. Com efeito, não é pelo fato de uma pessoa poder se servir da vontade também para pecar, que é preciso supor que Deus no-la tenha concedido nessa intenção. [II, i, 3] $]^{99}$
\end{abstract}

Equacionada desta forma, a questão de origem, segundo Agostinho, já se põe (plane si) solucionada (soluta est), visto ser evidente sua decorrência interna: sendo Deus o bem originário e fundante da realidade, tudo o mais estará resolvido neste dado, pois sua postulação

\footnotetext{
${ }^{98}$ Ev. [...], omne bonum ex deo esse, etiam hominem ex deo esse intellegi potest. Homo enim ipse in quantum homo est, aliquod bonum est quia recte uiuere cum uult potest.

${ }^{99}$ Aug. Plane si haec ita sunt, soluta quaestio est quam propossuisti. Si enim homo aliquod bonum est e t non posset, nisi cum uellet recter facere, debuit habere liberam uoluntatem, sine qua recte facere non posset. Non enim quia per illam etiam peccatur, ad hoc eam deum dedisse credendum est.
} 
de princípio implica a presença dos demais postulados: 1) a livre vontade (libera voluntas) do ser humano para querer a retitude (por conseguinte, também a justiça); e 2) precisamente a liberdade inerente à vontade e ao arbítrio, como evidência da inautoria divina de seu mau uso, pois o contrário implicaria que a vontade não é essencialmente livre, deixando de se constituir num quaerere. Mostra-se assim, pontuado neste momento e articulado de maneira concisa dentro do construto epistemológico que Agostinho leva a termo, o preciso papel da livre vontade, enquanto dom divino: motus decisório próprio e princípio de ação, votado à realização da retidão [ou do correto proceder/agir (recte facere)], cuja condição é justamente a liberdade pressuposta ao seu exercício.

Detenhamo-nos nesta precisão do locus por Agostinho reservado à vontade livre dentro da discussão em curso, por sua vez conduzida, neste momento, até a pressuposição divina do seu aspecto donativo, bem como ordenativo da ação humana deliberada. Retomemos: para se constituir num quaerere, o agir humano deve possuir, em condição prévia (sine qua), a vontade essencialmente livre (debuit habere liberam uoluntatem). Por seu turno, a ação humana (facere) jamais poderá ser qualificada como boa (recte), se não for almejada como tal (nisi cum uellet). E, instância última, a bondade é ontologicamente divina (omne bonum ex Deo esse - II, i, 2). Evidencia-se, assim, que a exaurição (e sua resolução) da quaestio através da recorrência a seu dado principial (ex Deo) deu-se, não pela imposição da autorictas (credere) de princípio (ainda que este lhe seja recorrente, à maneira de uma fonte permanente e permeante a todo o desenvolvimento da quaestio em disputa), mas sim unicamente mediante a disputatio em torno à ação humana e sua realização correta (tendo, é certo e ainda, o dado anteposto da autorictas como seu fio de percurso e recorrência: Deus existe; e todo bem vem de Deus). Unicamente no âmbito do embate racional é que ocorre a remissão da quaestio ao seu fundamento perene: a correta feitura e a boa realização, por parte do ser humano, da finalidade proposta por Deus. Neste decurso, a liberdade, explicitada no quaerere fundamental da vontade humana, instituise como uma espécie de instância executora da justiça e da bondade divinas, à medida que o bom proceder (feitura e realização) se dá tão-somente a partir da boa vontade. A deliberação humana está, assim, situada em referência à ética teleológica da ordo rerum: é pela fundamental decisão em querer proceder/feiturar, no ato livre da ratio através do intellegere, a realidade em seu propósito bom - ou por sua rejeição - que posso definir e evidenciar ser a vontade humana essencialmente livre. A liberdade da vontade revela-se como constituída pela presença inalienável da possibilidade de querer proceder à feitura/ação (facere), em 
consonância a um propósito de antemão reconhecido como bom ${ }^{100}$. Este duplo evidenciar-se bondade reconhecida; e (em consequência) pressuposta, manifestando a liberdade de querê-la e feiturá-la - será determinante para a exposição do itinerário da mens rumo ao absoluto e divino, que Agostinho irá proceder adiante [II, iii,7ss], posto que a ordo rerum manifesta a presença divina na feitura cognitiva do universo; o que, por reverso, possibilita à vontade humana, via ordo cognoscendi, a presença do espaço deliberativo para - cognitiva, moral e justamente - feiturar/proceder a realidade.

A continuidade do responso agostiniano reafirma a relação de decorrência e de interdependência entre justiça e liberdade:

$\boldsymbol{A g}$. Há, pois, uma razão suficiente para [a vontade livre] ter sido dada, já que sem ela o homem não poderia viver retamente. Ora, que ela tenha sido concedida para esse fim, pode-se compreender logo, pela única consideração que se alguém se servir dela para pecar, recairão sobre ele os castigos da parte de Deus. Ora, seria isso uma injustiça, se a vontade livre fosse dada não somente para se viver retamente, mas igualmente para se pecar. Na verdade, como poderia ser castigado, com justiça, aquele que se servisse de sua vontade para o fim mesmo para o qual ela lhe fora dada? $[\text { II, i, 3 }]^{101}$

Uma colocação se faz notar de pronto, na argumentação interposta por Agostinho: a recepção intelectual do dado justificativo é tomada por imediata (uel hinc intellegi potest). Tal justificativa ilustra que a relação de decorrência interna entre os elementos de uma disputatio argumentativa, no quadro da epistemologia agostiniana aqui exposto, apresenta-se de forma imediata e simul. As relações de decorrência não estão dispostas em estruturas sequenciais de uma ordenação que se eleva hierárquica e temporalmente construída, mas simultaneamente se dispõem a um só instante - portanto, imediatamente - ao espírito, ante o qual serão então mediatizadas na convergência à sequência temporal pela ratio $^{102}$, ainda que esta, em sua feitura

100 Cyrille Michon explana que, da mesma forma como emprestou ao termo liberdade duas fundamentais acepções (política e metafísica), Agostinho houve por bem "igualmente distinguir entre a vontade como faculdade; e como exercício desta faculdade [...] Agostinho fala do uso desta faculdade, por oposição à sua possessão." - MICHON, C. Le libre arbitre in CARON, M. (dir.) Les Cahiers d'Histoire de la Philosophie Saint Augustin, Paris: Éditions du Cerf, 2009, p. 309.

${ }^{101}$ Aug. Satis ergo causae est cur dari debuerit, quoniam sine illa homo recte non potest uiuere. Ad hoc autem datam uel hinc intellegi potest, quia si quis ea usus fuerit ad peccandum, divinitus in eum uindicatur. Quod iniuste fieret, si non solum ut recte uiuerentur, sed etiam ut peccaretur, libera esset uoluntas data. Quod enim iuste uindicaretur in eum, qui ad hanc rem usus esset uoluntate, ad quam rem data est?

${ }^{102}$ A simultaneidade das relações decorrentes - e sua imediaticidade ao espírito - parece compor traço epistêmico característico do período Cassicíaco/Milão: “Quaremimus quippe de animae potentia, et fieri potest ut haec omnia simul agat, ..." [an. quant. xxxv, 79], com a devida ressalva, no ínterim do itinerário ascensional do conhecimento, acerca da sua detenção e convergência à (inter)mediação racional: “... , sed id solum sibi agere videatur quod agit cum difficultate, aut certe cum timore. Agit enim hoc multo quam caetera attentior" (Idem); "Intuitus ergo et considerans universam creaturam, quicumque iter agit ad sapientiam, sentit sapientiam in via se sibi ostendere hilariter, et in omni providentia occurrere sibi: et tanto alacrius ardescit viam istam peragere, quanto et ipsa via per illam pulchra est, ad quam exaestuat pervenire" [lib. arb., II, xvii, 45]; cf. ainda imm. an. viii, 14. A respeito da funcionalidade de tal característica, Gilson comenta, no âmbito das descrições da itinerância anímica racional enquanto provas da existência de Deus, no interior do pensamento agostiniano: "Não se pode 
intelectiva e temporal, detenha-se passo a passo nos estágios consequentes e decorrentes do discurso argumentativo (dialético).

No prosseguimento do responso, uma vez mais Agostinho repassa a relação de decorrência entre justiça e liberdade, visto que o ato humano somente se torna meritório se praticado no âmbito do desejado livremente pela vontade. A aplicação da justiça (vindicatur) está em relação direta com a possibilidade de escolha entre usar a vontade para o bem, ou para recusá-lo. A segunda hipótese incorrerá em penalização, pressupondo-se que a voluntas não foi dada ao ser humano para tal fim, o que configura a deliberação em não querer o bem (por sua vez já conhecido). A liberdade tem por base o conhecimento do bem como dado, para sua escolha ou eventual recusa. Por conseguinte, à medida que todo agir humano decorre de ato deliberativo de sua vontade, elucida-se, a par da perenidade judicativa envolvida na atitude humana como um todo ${ }^{103}$, o dado fundamental sobre o qual se apoia a voluntas, a saber: que omne bonum ex Deo esse. A livre voluntas, pois, somente pode ser exercida humanamente sobre o escopo do dado teleológico ético e antropológico, no qual se insere, por evidência in ordo rerum, o dado teleológico cosmológico. Novamente, Agostinho enseja o quadro no qual irá tecer a itinerância racional para Deus, como decorrência da disputatio sobre o livre-arbítrio.

O termo final do responso agostiniano aponta para aspecto de grande importância, no interior das relações verificadas entre a vontade livre - e por isso, humana - e conhecimento primordial do bem: o caráter de confiabilidade e de recomendação inerente ao ato justo humano (ou à feitura/prática da justiça):

Ag. Por outro lado, se o homem carecesse do livre-arbítrio da vontade, como poderia existir esse bem, que consiste em manifestar a justiça, condenando os pecados e premiando as boas ações? [...] Ora, era preciso que a justiça estivesse presente no castigo e na recompensa, porque aí está um dos bens cuja fonte é Deus $[\mathbf{I I}, \mathbf{i}, \mathbf{3}]^{104}$.

Deus atribui a justiça (commendatur ipsa iustitia) à atitude humana, através da manifestação meritória da mesma: condenação do pecado (damnandis peccatis) e enaltecimento do reto proceder (recteque factis honorandis) nas ações humanas. Agostinho

negar que sua doutrina contenha todos os elementos necessários para uma prova deste gênero [...] Não obstante, algumas vezes [Agostinho] se exprime de tal maneira que a simples visão da ordem do mundo parece equivaler a uma prova imediata da existência de Deus. [...] De fato, sua demonstração da existência de Deus é uma longa meditação na qual cada etapa deve ser percorrida segundo a ordem e seu tempo [...]; mas uma vez que se tenha encontrado a meta, o pensamento não está obrigado a se deter nela. Ao voltar para trás, o pensamento constata que já poderia ter descoberto a meta de cada uma dessas etapas, mas que isso é descoberto depois de, tendo-as atravessado, tê-las completado." [GILSON, 2006: 47 e 49].

${ }^{103}$ Elucidaremos melhor e mais amplamente a preeminência e a perenidade da atitude judicativa humana, quando a ela voltarmos na análise da exposição do itinerário ascensional para Deus, a partir de lib. arb. II, v, 12.

${ }^{104}$ Aug. Deinde illud bonum, quo commendatur ipsa iustitia in dammandis peccatis recteque factis honorandis, quomodo esset, si homo careret líber uoluntatis arbítrio? [...] Debuit autem et in supplicio et in praemiio esse iustitia, quoniam hoc unum est bonorum quae sunt ex deo. 
acautela-se de atribuir ao ser humano, e à sua prática da justiça, um caráter elogiativo. Onde poderia talvez se valer de laudare (para ressaltar um eventual caráter de merecimento humano na conduta justa), ele prefere se referir à prática da justiça como dom atribuído, ou mesmo recomendado, enquanto ideal ético teleológico) por Deus ao ser humano, partilhado e a ele confiado para que a fizesse notar e, sobretudo, vivenciá-la. Mas que significa, no contexto de uma discussão acerca do livre-arbítrio, elucidar que a justiça é atribuída ao ser humano? A qualificação de Agostinho pode ser vista em paralelo ao caráter donativo do livre-arbítrio: tanto este, quanto a justiça, compõem datum, dádivas divinas ao agir humano, sendo que o exercício do primeiro constitui-se condição para a efetivação do segundo. O paralelo se torna claro ao intentarmos precisar sua procedência. Valendo-se de commenda, Agostinho matiza a realização da justiça como missio, tarefa cujo cumprimento é confiado ao ser humano enquanto tal, posto que somente ele pode, em sua deliberação e arbítrio, efetivá-la com vistas a se alcançar a plenificação da ação correta (recteque factis honorandis). Nesse sentido, a justiça como missão em commendatur está, no curso de nosso texto, em relação diretamente proporcional ao intento de se atingir a plenitude da feitura ativa (honor). Assim, o mérito pela realização da justiça não compõe uma laudatio em prol de uma característica própria do ser humano, senão um honorário, uma completude em virtude de se atingir o cumprimento de uma missão a ele delegada, mediante sua deliberação para fazer o bem que se lhe apresenta já de antemão conhecido, recusando por consequência a possibilidade de não fazê-lo (mal).

\title{
1.3) Exaurição da quaestio: suspensão do juízo cognitivo e articulação da relação crer- inteligir
}

Não obstante o convencimento de Evódio quanto ao caráter donativo e origem divina do livre-arbítrio, permanece nítido o dilema de base:

\begin{abstract}
Ev. Eu já admito que Deus nos concedeu a vontade livre. Mas não te parece, pergunto-te, que se ela nos foi dada para fazermos o bem, não deveria poder levar-nos a pecar. É o que acontece com a própria justiça dada ao homem para viver bem. Acaso alguém poderia viver mal, em virtude de sua retitude? Do mesmo modo, ninguém deveria poder pecar por meio de sua vontade, caso esta lhe tivesse sido dada para viver de modo honesto [II, ii, $\mathbf{4}]^{105}$.
\end{abstract}

Observa-se, no início do retorno responsivo, uma ratificação do paralelo a que aludimos no trecho anterior, acerca do caráter donativo entre a justiça e o livre-arbítrio: Evódio assente (iam concedo) que ambos são vivenciados pelo ser humano enquanto dádivas (data est) divinas

\footnotetext{
${ }^{105}$ Ev. Iam concedo eam deum dedisse. Sed nonne tibi uidentur, quaeso te, si ad recte faciendum data est, quod non debuerit ad peccandum posse conuerti, sic ut ipsa iustitia quae data est homini ad bene uiuendum? Numquid enim potest quispiam per iustitiam suam male uiuere? Sic nemo posset per uoluntatem peccare, si uoluntas data est ad recte faciendum.
} 
(eam Deum dedisse), mas pretende fazer ver (videtur) a Agostinho o que se lhe afigura contraditório por essência, no equacionamento da quaestio a partir de tal assentimento: precisamente tendo em conta o caráter donativo da vontade livre e sua deliberação; bem como da vivência da justiça e sua conduta; e sobretudo a partir da procedência de tais dons, Evódio procura evidenciar o contraste essencial entre dom divino - e portanto bom (bene vivendum... recte faciendum) - e mal ativo - e portanto voluntário (voluntatem peccare... male vivere) humano. A contradição pretendida evidente por Evódio parece almejar, igualmente, outra evidência de maior alcance, espécie de estrutura mais ampla à qual se referencia, e da qual decorre o contraste ora em questão: a ação donativa divina e a conduta reativa humana, cujo paralelismo contrastante revela-se como cuidadosamente tecido de molde a ressaltar, dentro do quadro geral das relações decorrentes dos referidos paralelos, o inalienável lugar da livre vontade. Por seu turno, o ressalto acerca da voluntas e de seu preciso locus parece ter sido interposto, neste momento da sequência cursiva da disputatio, visando encaminhar (e exaurir) a quaestio ao ponto em realidade pretendido desde o início por Agostinho: a presença permanente da ação e justiça divinas ao ser humano; e a responsabilidade deste ao datum e à commenda iustitiae que lhe são confiados pelo Criador. Do interrelacionamento entre tais polos, decorre a elucidação acerca da liberdade humana e da providência divina, e da responsabilidade em relação ao mau uso do arbítrio na efetivação da iustitia confiada por Deus ao ser humano, que em realidade Agostinho pretende situar unicamente na esfera humana. Para tanto, a correta visualização do âmbito de atuação originária de cada um dos elementos componentes torna-se fundamental, o que enseja uma recomposição das relações originárias Deus - ser humano - cosmos, no interior do propósito divino estabelecido na criação, e tornado manifesto na ordem ontológico-teleológica do universo, a qual será fundamental e se dará, a partir de II, iii, 7, em forma de feitura cognitiva da realidade criatural.

Mas o intento de Agostinho é mais amplo, visto haver uma disputatio em torno, precisamente, da negação da procedência divina da ordenação da realidade, constatada através da presença do mal nesta mesma ordem. Ora, no quadro geral da disputatio sumarizado até o momento, o elemento permanente ao entorno de toda a sequência discursiva diz respeito ao datum divino da voluntas, e de sua deliberação atuante; bem como a atribuição da iustitia ao ser humano por parte de Deus, mediante a qual a realidade é efetivada (per-feita ou per-fazida) em seu propósito originário e final. Pois bem: o que ocorre se o questionamento incidir até mesmo sobre este dado fundante? Um passo antes, porém, de exaurir a questão na inquirição acerca da existência de Deus, Agostinho apela ainda a uma última evidência, como que esgotando o conteúdo manifesto no pressuposto da presença atuante do Criador - providência 
divina - antes de atingir e fazer chegar o questionamento à própria possibilidade de ser da pressuposição:

\begin{abstract}
Ag. [...] Mas antes, dize-me um pouco, eu te peço - uma vez que tens como evidente e certo o que já te perguntei, a saber: que foi Deus que nos concedeu a vontade livre, nesse caso, poderíamos afirmar que Deus não nos deveria ter dado tal dom? Isso, já que reconhecemos ser ele mesmo que o deu a nós. Com efeito, se fosse incerto que Deus nos tenha concedido a vontade livre, nós teríamos o direito de indagar se foi bom ela nos ter sido dada. Desse modo, se descobríssemos que foi bom, igualmente, reconheceríamos o doador naquele que deu ao homem todos os bens. Ao contrário, se descobríssemos que foi mal, teríamos de compreender que o doador não é Aquele a quem não é permitido incriminar algo que seja [Idem $]^{106}$.
\end{abstract}

Agostinho trata de retorquir a oposição trabalhada por Evódio no responso anterior, mostrando que, em realidade, ela própria - e, por consequência, o questionamento que dela advém - é que compõe flagrante contradição de termos: se se admite - como de fato ocorreu no decurso da presente disputatio - que a livre vontade é dádiva de Deus, então a própria colocação do pretendido contraste decorrente do questionamento resulta impossível: a admissão - ou a pressuposição - de Deus como origem da nossa livre-vontade, elimina a possibilidade de inquirir sobre o caráter eventualmente danoso da mesma, posto que nenhum malefício pode ter autoria ou origem divinas (quem culpare nefas est). Em realidade, Agostinho trata de refinar a quaestio em termos de compreensão dos seus elementos em jogo: se falamos em origem divina das habilidades e capacitações possuídas pelo ser humano, temos então de reconhecer que: 1) são dádivas de Deus; e 2) como tais, não comportam sequer a indagação acerca de seu caráter (se foram de fato para o bem do ser humano), pois sua procedência divina o atesta inequivocamente. Assim, Agostinho pratica uma remissio quaestio à fundamentação última da inuentio de princípio: falamos da origem em Deus como instância última da conduta humana. Exaurimos a quaestio em sua pressuposição recorrente. Resta, pois, que o entendimento do livre-arbítrio do ser humano; de sua conduta em justiça e direito; bem como de sua finalidade moral, encontram-se radicadas no âmbito maior das relações antropológico-criaturais, entre Deus e o ser humano. Mas é somente na plena exaurição da quaestio humana que se pode radicá-la quanto a incidir sobre seu fundamento último: Deus existe?

\footnotetext{
${ }^{106}$ Aug. [...] Sed paulisper uolo mihi dicas, si id quod abs te quasiueram certum et cognitum tenes, deum nobis dedisse liberam uoluntatem, utrum oporteat dicere dari non debuisse quod dedisse confitemur deum. Si enim incertum est utrum dederit, recte quaerimus utrum bene sit data, ut cum inuenerimus bene datam esse, inueniatur etiam illum dedisse a quo animae data sunt omnia bona; si autem inuenerimus non bene datam esse non eum dedisse intellegamus, quem culpare nefas est.
} 


\subsection{1) Suspensão cognitivo-judicativa de Evódio}

Evódio trata, por sua vez, de responder ao esgotamento da questão, devolvendo-a através da inversão do sentido da referida pressuposição recorrente. Exaurida por Agostinho a quaestio em remissão ao dado fundante (pressuposto da dádiva divina para a decorrente ação responsiva humana), Evódio inverte os seus polos:

$\boldsymbol{E v}$. Apesar de crer em tudo isso com fé inabalável, todavia, como não possuo ainda pleno entendimento, continuemos procurando como se tudo fosse incerto. Com efeito, pelo fato de ser incerto a vontade livre nos ter sido dada, para com ela agirmos bem já que podemos também pecar -, decorre esta outra incerteza: se foi um bem ou não, ela nos ter sido dada. Porque, se é incerto ela nos ter sido dada, para agirmos corretamente, tampouco é certo que seja um bem ela nos ter sido dada. Por aí, não é igualmente certo que seja Deus o doador. Com efeito, a incerteza sobre a conveniência do dom torna incerta a origem, isto é, o fato de ser Aquele a quem não nos é permitido crer que conceda algo que não deveria ter concedido [II, ii, $\mathbf{5}]^{107}$.

Se antes a discussão teve por impulso a manifestação concreta do mal na realidade natural; e por conseguinte sua impertinência à ordem criatural boa originada em Deus, restando daí a quaestio que Agostinho tenta dissipar através da recorrência ao seu ponto de origem (dádiva divina, fim teleológico), trata-se agora de tomar por impulso precisamente o termo agostiniano da exaurição - Deus e as relações de criação estabelecidas com o ser humano - e exaurir sua inteligibilidade junto à contradição manifesta (inegável, para Evódio) entre a ordem criatural boa e a presença do mal, entre a dádiva do livre-arbítrio e seu mau uso por parte do homem.

Observamos que Evódio procede a um modo de suspensão do curso até então efetuado, dentro da disputatio: em falta de um conhecimento ainda não obtido ou realizado (quia cognitione nondum teneo - embora se disponha ou se tenha uma fé inamovível - busquemos o perfazimento do conhecimento como se nada nos fosse disponibilizado (quaeramus quasi omnia incerta sint). A medida drástica nos leva a perguntar pelo sentido da suspensão total das noções advindas ou já dadas (ainda não manifestas?). Se no decurso até então efetuado, a elucidação das contrastações resultava em recorrência à perenidade do conteúdo assentido (pela postulação da autorictas, assumindo portanto sentido retrocedente), a postulação da incerteza total incorre em sentido procedente: de posse confiante do dado autoritativo, lançome à busca de sua certificação ou legitimação. Trata-se de realizar, cognitiva e temporalmente através da intelecção da ordenação do universo, o que já se me é antecipado atemporalmente

\footnotetext{
${ }^{107}$ Ev. Quaquam haec inconcussa fide teneam, tamen quia cognitione nondum teno, ita quaeramus quase omnia incerta sunt. Video enim ex hoc quod incertum est, utrum ad recte faciendum uoluntas libera data sit, cum per illam etiam peccare possimus, fieri etiam illud incertum utrum dari debuerit. Si enim incertum est ad recte faciendum datam esse, incertum est etiam dari debuisse; ac per hoc etiam utrum eam deus dederit incertum erit, quia si incertum est dari debuisse, incertum est ab eo datam esse, quem nefas est credere dedisse aliquid quod dari non debuit.
} 
pelo dado da fé, porém em vetor racionalmente processual e excludente: unicamente através da ratio, instrumento pelo qual reporto minha cognitio da realidade à sua totalidade.

Ainda assim, cabe interrogar acerca da amplitude ${ }^{108}$ da suspensão pleiteada por Evódio: exigiria a ratio fidei uma exclusão total de sua procedência do dado in autorictate? Poderia a ratio deixar de ser fidei? Certa forma, o caráter absoluto assumido pela suspensão intelectiva evodiana deixa entrever um alcance maior, agudo: os estatutos das certezas advindas da fé e da razão diferem entre si? Ou a procedência única de ambas - em instância última: Deus - atesta que as certezas convergem, embora em sentidos e/ou decursos diferentes? Afinal: fé e conhecimento racional partilham da mesma certeza? ${ }^{109}$

A justificativa de Evódio para a busca da intelecção do dado/notitia, reconhecido e aceito como verdade pela fé, foi preparada pela digressão agostiniana acerca da necessidade de se demonstrar a veracidade do conteúdo crido, ante a ausência prévia do credere. Tal justificação aparece como elemento de transição entre a supressão de todo e qualquer conhecimento, e a explicitação das relações entre o conhecimento pela fé e o conhecimento demonstrativo racional, articuladas em torno ao binômio crer-compreender. Após levar a quaestio para incidir no âmbito fundamental e primordial do conhecimento - questionamento sobre a existência de Deus - e ante a resposta como que fugidia de Evódio (postulação inesperada e incoerente acerca da primordialidade da fé, dado que até então ele se recusara a concluir, com base unicamente no saber in credere, que o livre-arbítrio seja dom divino), Agostinho trata de ressaltar a improcedência da argumentação evodiana, diante da supressão do traço fundamental presente em todo e qualquer conhecimento adquirido pela fé. Ou seja, se tomamos por fundamento o elemento crido, nosso conhecimento rui por inteiro ante o questionamento advindo da ausência do credere. Mais, e sobremaneira importante: Agostinho faz ver, no corpo da exposição argumentativa baseada no exemplo do interlocutor não crente, que não haverá conhecimento verdadeiro se não houver dipositio de princípio verdadeira, mais

\footnotetext{
${ }^{108}$ Verifica-se que o alcance e a medida da suspensão irão corresponder, já na leitura em paralelo com o an. quant., à amplitude da feitura cognitiva da realidade através do itinerário de ascensão intelectual.

109 Aflora claramente o alvo do diálogo: para além dos postulados maniqueístas, Agostinho mira o ceticismo acadêmico na sua recusa em conceder a possibilidade de certificação a qualquer tipo ou nível de conhecimento adquirido pelo ser humano. Ao assumir metodologicamente, no ínterim de um dos seus diálogos da fase inicial (de estabelecimento da relação pensamento filosófico grego/verdade revelada em termos de consumação da primeira na segunda), procedimento consubstanciado e recorrente em uma das correntes em voga - a epoché cética Agostinha certamente intenta uma resposta cristã, mas valendo-se das próprias bases do interlocutor (no caso, o ceticismo em suas variadas escolas). Vale lembrar que a suspensão do juízo, nas correntes do ceticismo antigo, proporcionava ao sábio a correspondente ausência de perturbação - ataraxia, o que certamente não escapava a Agostinho, preocupado em estabelecer a beata uita em termos críveis e racionais. Para uma abordagem da funcionalidade da epoché cética, e sua relação com a ataraxia, vide: BOLZANI, R. A epokhé cética e seus pressupostos in Discurso n ${ }^{\circ}$ 27, Revista do Departamento de Filosofia da USP, 1996, p. 37-60 (sobretudo, para o tema em pauta, p. 42-45)
} 
especificamente: empenho sincero, ou ainda: boa disposição (bono animo). Este se mostra como basilar na argumentação de transição apresentada a esta altura, pois sua ausência invalidaria todo o prosseguimento, não somente da resposta neste momento do diálogo, mas até a este próprio enquanto desenvolvimento da disputatio inicial. O desejo bom que move a alma condiciona, em verdade, toda a articulação que Agostinho irá cristalizar na justificativa dada por Evódio: "Sim, mas é que pretendemos saber e entender aquilo em que cremos." [II, ii, $6]^{110}$. A construção da resposta evodiana é feita de modo a articular os elementos definidores em jogo até então, acerca do conhecimento humano: crer, conhecer, entender e desejar. Tal articulação resulta do momento transitivo que a justificativa evodiana ocupa no texto, e ostenta tentativa de mediar e estabelecer elo entre os polos do conhecimento pela fé e do conhecimento pela razão. O desejo de saber leva de um polo a outro, ligando-os enquanto dispositio de busca da alma por Deus. Este liame funciona como elemento de transição entre a argumentação desenvolvida à luz do dado in credere, até aquele momento da disputatio, e sua consecução como ascensão intelectual efetuada univocamente através da ratio. Tal marco transitório recebe espécie de confirmação na devolução de Agostinho:

2.6 $\boldsymbol{A g}$. Vejo que tens boa memória. Foi, na verdade, isso que decidimos no início de nosso diálogo precedente, e não o podemos negar. Com efeito, se crer não fosse uma coisa e compreender outra, e se não devêssemos, primeiramente, crer nas sublimes e divinas verdades que desejamos compreender, seria em vão que o profeta teria dito: "Se não o crerdes não entendereis" (Is 7,9, na $\mathbf{L X X})$. - II, ii, $\mathbf{6}^{111}$

\subsection{2) Fé e intelecção}

A extensão do responso agostiniano permite-nos entrever sua intenção mais ampla, concomitante - na verdade, em decorrência - à sua funcionalidade neste momento da disputatio: ante a suspensão plena da certeza do conhecimento postulada por Evódio (ita quaeramus quasi omnia incerta sint), e o passo demonstrativo da existência de Deus a ter início a partir de II, iii, 7, Agostinho interpõe a articulação explicitada entre os polos constituintes do conhecimento: credere e intellegere. A articulação é tecida de modo a se fazer ressaltar enquanto ponto nodal na continuidade do diálogo, revelando-se como transposição entre a concepção por assim dizer teologal acerca da origem do conhecimento, e a postura que prescinde do ponto de partida no dado da fé fornecido pelas Escrituras. Se até então o diálogo caminhou tendo por pressuposto recorrente o elemento discursivo baseado na autorictas divina, doravante pretende-se a exposição exclusivamente mediante o exercício da intelecção,

\footnotetext{
${ }^{110}$ Ev. Sed nos id quod credimus nosse et intellegere cupimus.

111 Aug. Recte meministi, quod etiam in exordio superioris disputationis a nobis positum esse negare non possumus. Nisi enim et aliud esse credere, aliud intellegere et primo credendum esset quod magnum et diuinum intellegere cuperemus, frusta propheta dixisset: Nisi credideritis, non intellegetis.
} 
das verdades já recepcionadas e conhecidas através do ato de fé. Nota-se, igualmente, que a exposição da articulação assume feição categórica em forma binomial, com a devida ênfase empregada por Agostinho na sua nomeação: Nisi enim et aliud esset credere, aliud intellegere. A alteridade realçada por aliud traduz o empenho em demarcar a presença independente dos polos constituintes do conhecimento humano, fazendo-se perceber o intento subreptício de ostentar, frente aos que acusavam a fé cristã de antirracionalismo, a presença real e autônoma do exercício da razão na compreensão da verdade já conhecida pelo ato de $\operatorname{crer}^{112}$; bem como o intento precípuo de realização plena do ser humano, em seu gozo da vida eterna, a qual consiste justamente em conhecer a manifestação e revelação de Deus enquanto Criador e Redentor (ii, 6: Ag. “... ut cognoscante te verum Deum, et quem misisti Iesum Christum.”), evidenciando-se nesse sentido como um empenho sistemático, onde Agostinho estabelece os campos específicos de atuação dos polos do conhecimento, com o qual pretende-se alcançar a verdade enquanto realização do ser humano. É no reconhecimento desta feição categórica, bem como do empenho sistemático agostiniano quanto ao papel de credere-compreendere, que Christian Göbel inicia seu estudo acerca da presença da relação binomial em (e seu influxo em Anselmo de Cantuária), esclarecendo-nos que “... da compreensão de fides $e$ ratio e suas implicações, decorre a temática relativa à prova de existência de Deus pelo estudo da evidência (alethológica)". ${ }^{113}$ Com efeito, é a concepção da sabedoria enquanto exercício

\footnotetext{
${ }^{112}$ Giraud inicia a segunda parte (sobre a referência) de seu ensaio sobre Agostinho precisamente pela "aporia da busca e a antecipação compreensiva do credere" (título do parágrafo 40), condensando sua verificação numa passagem de transição da primeira parte de seu estudo (sobre a diferença) à análise do sentido e da referência (vértice de sua obra) no pensamento agostiniano: "Chercher Dieu, c'est là ce à quoi doit s'efforcer toute vie humaine; mais comment, à partir de la différance qui le caractérise, l'homme, à la fois créature et pécheur, pourra-t-il se mettre em chemin vers son Créateur? Car il faut repartir de cette évidence: nous ne voyons pas Dieu. Si la connaissance est um voir [Trin, VIII, 4,6], et si d'autre part ce voir n'a pas lieu, Dieu est donc méconnu de l'homme. [...] Surgit alors cette autre question, qui renchérit sur la première: comment aimer ce qu'on ignore? [...] Nous voici donc em um cercle: il faut chercher Dieu afin de le connaître, mais il est nécessaire de le connanître afin de le chercer? [...] La tension imanente à la différance se meut dans um tel cercle aussi longtemps que ne lui est pas donnée la connaissance qui pourrait éveiller, nourrir et diriger son amour. Cette connaissance, toutefois, n'as pas besoin d'étre parfaite, ni complete. [...] Or, une telle connaissance imparfaite, mais néanmoins certaine, voilà précisément ce que a servi à definir la foi, [...] Ce pari-qui, inutile de le préciser, n'a rien de pascalien -, crédit fait à l'intelligence, voilà ce qu'est pour Augustin la foi. Croire, non contre l'intelligence, donc, mais pour ele, et em vue d'elle. La voix du croire est celle qui, au lieu de me figer dans la position de maîtrise qu'implique toute intelligence, me dit qu'il y a peut-être encore là quelque chose à comprendre, et que je ne suis pas encore à même de saisir" - GIRAUD, 2013: 237-240 (grifos nossos). "Sua postura [agostiniana] se situa entre o fideísmo e o racionalismo. [...] compreender é a conquista da fé; defende a validade deste princípio e deste método, escrevendo um livro sobre a utilidade de crer. A fé é útil a todos, também ao filósofo. [...] Esforçou-se [Agostinho] em demonstrar a credibilidade da fé e aprofundar seus ensinamentos" TRAPÈ, A. San Agustín, in DI BERARDINO, A. PATROLOGIA - vol. III: La edad de oro de la literatura patrística latina, Madrid: B.A.C., 1981 (5 $5^{\mathrm{a}}$ impresión: mayo de 2007), p. 482.

113 “...das Verhältnis von fides und ratio und seine Implikationen wie der verwandte alethologische Gottesbewiss." - GÖBEL, C. Fides und ratio bei Anselm (1033-1109) und Augustinus in FISCHER, N. (dir.) Augustinus Spuren und Spiegelungen seines Denken, Band 1: Von den Anfängen bis zur Reformation, Hamburg: Felix Meiner Verlag, 2009, p. 37. Göbel define o exercício probatório agostiniano como alethologico, valendo-se praticamente de um neologismo, na junção das raízes gregas alethes (verdade, evidência) e logos, devidamente
} 
espiritual para o encontro e gozo da verdade, que se delineia explicitada na articulação agostiniana, estrategicamente situada entre o ceticismo intelectual e a prova racional da existência de Deus. Nesta sistematização, Agostinho deixa claro o papel prioritário reservado ao ato de crer/confiar, ponto de partida para se inteleccionar as verdades nele dadas. Por sua vez, a intelecção é vista não enquanto contraste, mas como ratificação do conteúdo crido mediante o cognir humano autônomo. Assim, o ato de intelecção legitima e ratifica, por assim dizer, o ato de fé com vistas à consumação do experienciar a verdade em sua integralidade, ou do encontro e conquista do dado de fé em sua plena compreensibilidade no tocante ao ser humano em seu todo. $\mathrm{O}$ binômio credere e intellegere em Agostinho revela-se, nesse preciso sentido e a par de sua leitura própria de Is 7,9 $\boldsymbol{L} \boldsymbol{X} \boldsymbol{X}^{114}$, como espectro condicional da amplitude da alma humana em sua penetração e vivência espirituais da verdade eterna. O prosseguimento da resposta agostiniana aponta para tal direcionamento, com as citações aos ditos de Jesus acerca da vida eterna e da busca e encontro. É precisamente enquanto exercício de vivência (ou de consumação) espiritual da verdade que Dominique Doucet, seguindo a leitura das correntes clássicas gregas delineada por Pierre $\operatorname{Hadot}^{115}$, situa o desenvolvimento do método agostiniano já nos diálogos filosóficos de início:

transliteradas. Igualmente, Giraud tece detida análise do binômio credere-intellegere, afirmando que "o 'crer para compreender' é, em si mesmo, uma injunção racional. A razão precede a fé naquilo que ela apela, mas a fé a precede, por seu turno, naquilo que a faz avançar e lhe prepara." - GIRAUD, 2013: 241. Outrossim, o reflexo teológico, assaz frequente ao esforço filosófico devido à configuração da sapiência agostiniana, ajuda-nos a minuciar tal passo: "Antes de dar assentimento ao anúncio, há que se levar em conta a validade das razões que nos levam ao assentimento: 'Ninguém pode crer em algo, se previamente não pensar que tem de crer nele' (De fide rerum quae non videntur, vii,10). Comenta [R.] Aubert, a propósito do pensamento de Santo Agostinho, que a atividade da razão que precede a fé não consiste tão-somente em captar o sentido daquilo em que há de crer, mas sim em assegurar o caráter razoável e prudente da adesão." - SAYÉS, J.A. Teología de la fe, $2^{\mathrm{a}}$ edición revisada, Madrid: San Pablo, 2004, p. 46.

${ }^{114}$ Martine Dulaey oferece-nos, em seu artigo sobre a prática de exegese bíblica de Agostinho, um breve, porém precioso panorama histórico quanto ao uso latino de Isaias 7, 9, pontuando com um paralelo conceitual de grande proximidade entre Agostinho e Ambrosiaster, que nos parece confirmatório quanto à nossa tentativa, acima esboçada: "En fait, cette citation est bien connue, puisque elle figure deux fois dans l'Ad Quirinum de Cyprien, et en particulier dans un groupement de versets réunis sous le titre: 'La foi est utile à tout: plus nous croyons, plus nous sommes forts'. Le verset apparaît plusieurs fois chez Tertullien, ainsi que chez Origène, [...] Plus proche de l'utilisation augustinienne est celle de l'Ambrosiaster [...] surtout à un passage des Questions sur l'Écriture de l'Ambrosiaster qu'est apparenté le texte du De libero arbitrio [...] L'Ambrosiaster donc, plaide come Augustin pour l'intelligence de la foi, et s'oppose au fidéisme, ou foi du charbonnier, mais la foi est donnée comme un moyen d'accès à un ordre supérieur de connaissance, grâce à l'aide de l'Esprit Saint, sur la base d'Is 7,9. Il est frappant que les deux auteurs usent pareillement à ce sujet de Jn 17,3 pour affirmer que croire n'est pas la valeur ultime, mais seulement un étape nécessaire pour parvenir à la connaissance, qui est vie." - DULAEY, M. L'apprentissage de l'exégèse biblique par Augustin - Première partie: dans les années 386-389 in Revue des Études Augustiniennes, $\mathrm{n}^{\circ} 48$ (2002), p. 270-272. Por sua vez, a notação de Giraud acerca do uso agostiniano confirma a utilização em sequência da $\boldsymbol{V L}$ e da $\boldsymbol{L} \boldsymbol{X X}$ : “... Augustin lit ainsi, avec la Vetus latina, le sinemy des LXX..." - GIRAUD, 2013: 241. Acerca da leitura e exegese agostinianas dos textos bíblicos em geral, vide DE MARGERIE, B. Introduction à l'histoire de l'exégèse, tome III - Saint Augustin, Paris: Éditions du Cerf, 2009 (réimpression - $1^{\mathrm{a}}$ édition: 1983), mormente as p. 28-56; DE LUBAC, H. A Escritura na Tradição, São Paulo: Edições Paulinas, 1970, p. 24-25.

115 HADOT, 2000: 259-289; e sobretudo 290-297, fundamental para o paralelo com relação à ascensão anímica. 
"Esta dimensão da filosofia como exercício espiritual reaparece, sobremaneira, nos primeiros diálogos de Agostinho [...] O método invariavelmente tem por início um ensinamento oral tradicional (Sol., 1,4,9), demandando uma incessante disposição de transformação da alma (De ord., 2,4,11; 2,6,18; Sol., 1,15,27; 2,6,9), que busca se conhecer, ao mesmo tempo que conhece a Deus (De ord., 2,18,47; Sol., 1,2,7) ..." [DOUCET, 2004: 39] ${ }^{116}$

Neste quadro, a descrição do itinerário intelectual pelo universo, compondo elemento probatório da existência de Deus, surge e se explica a partir da escolha de intellegere como indicativo do papel primordial (ou mesmo essencial) da razão, em sua relação com o dado da fé $^{117}$ : ratificá-lo, confirmando-o com a solidez racional da construção firme e verificável que permeia o todo conhecido ${ }^{118}$.

\footnotetext{
116 "Cette dimension de la philosophie comme exercise spirituel se reencontre de manière privilégiée dans lês premiers dialogues d'Augustin [...] La méthode suivie part d'um enseignement oral traditionnel [...], elle demande une tension sans cesse renouvelée de l'âme [...] qui cherche à se connaître elle-même ainsi que Dieu..."

117 "Na antropologia filosófica agostiniana, a fé é a condição da procura que não teria guia nem direção sem ela. A fé é início e término da procura. A procura encontra o fundamento e o guia na fé e a fé encontra sua consolidação na procura." - COSTA, Marcos. R. N. Conhecimento, ciência e verdade em Santo Agostinho in DE BONI, L. A. (org.) A ciência e a organização dos saberes na Idade Média, Porto Alegre: Edipurs, 2000, p. 43.

${ }^{118}$ No contexto de sua análise acerca da "aparente circularidade" e tensão verificada entre a invocação do ato de fé em Deus, e o conhecimento divino, Moacyr Novaes indica que Agostinho soluciona a questão "convertendo a aparente circularidade em expressão de um esforço incessante", no qual se "dirige a atenção sempre para o interior, isto é, da fé ao que é dado exteriormente a teologia conduz à in-vocação e à inte-lecção", fazendo notar o uso deliberado, por parte de Agostinho, do recurso à elucidação etimológica dos termos em pauta [NOVAES, 2007: 190-191; grifo nosso]. Embora o contexto em que se dá seja o das obras de maturidade (Confessiones e De trinitate), a análise de Novaes ostenta, a nosso ver, a possibilidade de aplicação ao âmbito geral do pensamento agostiniano [“... essa trajetória da natureza ao Criador, cujo estágio mais notável é o homem, consiste no plano geral de textos importantes, como o décimo livro das Confissões, ou o conjunto dos livros Sobre a Trindade (De Trinitate)" - 2007: 191; grifo nosso], podendo-se incluir, em nosso entendimento, o período inicial dos diálogos de Cassicíaco/Milão/Roma.
} 


\section{2 - A ASCENSÃO DA ALMA A DEUS (lib. arb. II, iii, 7 - v, 12)}

\section{1) Ser - Viver - Inteligir}

\subsection{1) Ordo cognoscendi/ordo rerum}

É de especial interesse retomar que, após a suspensão de conhecimento levada a termo por Evódio culminar em sua consequência maior (inquirição sobre a existência de Deus), o prosseguimento da discussão segue em verdade novo curso, como que se reiniciando ou se recolocando em suas mesmas teses, mas com fundamentação totalmente nova, cujo eixo compõe, como visto no final do percurso anterior, a articulação polar credere-intellegere. Agostinho propõe que a investigação retome seu curso a partir de uma pré-ordenação:

Ag. [...] $1^{\circ}$ - procuremos como provar com evidência a existência de Deus; $2^{\circ}$ - se na verdade tudo o que é bem, enquanto bem, vem de Deus; $3^{\circ}$ - enfim, se será preciso contar, entre os bens, a vontade livre. [II, iii, 7] $]^{119}$

Retenhamos que a exaurição da sequência anterior deu-se no bojo de um desenvolvimento, tendo por suposto o dado da fé acerca da ação donativa divina, bem como sobre a conduta reativa humana. A pressuposição menor a respeito do caráter benéfico da deliberação volitiva no ser humano, tornava decorrente e imediato o passo retrocedente rumo ao pressuposto maior acerca de sua autoria divina, em simultaneidade à decorrência contrária, caso não se tomasse a livre vontade como um bem. As decorrências em evidência tornam-se, nesse sentido, ilustrativas de que o diálogo deve caminhar no passo de ordenações rigorosas e pressupostas, cujos postulados permitirão clarificação inequívoca, acerca dos conteúdos neles implícitos. O sentido das ordenações captadas pelas percepções sensoriais externas, e a noção de ordem enquanto tal, verificada e constatada como universal, revestem-se de especial interesse para a epistemologia agostiniana do período Cassicíaco/Milão/Roma, na medida em que, pela rigorosa aplicação lógica, permitem compreensão do todo arguido e discutido, a partir das decorrências imediatas de um pressuposto de início ${ }^{120}$.

119 Aug. [...] primum, quomodo manifestum est deum esse; deinde, utrum ab illo sint quacumque in quantrumcumque sunt bona; postremo, utrum in bonis numeranda sit uoluntas libera.

${ }^{120}$ A par da nítida construção silogística da argumentação por parte de Agostinho, procuramos clarificar, em nossa pesquisa, o delineamento estrutural do texto em seu aspecto temático e conceitual, mais que estilístico. Para uma aproximação à estilística retórica agostiniana, suas fontes e influxos diversos, bem como à catalogação de seus construtos formais (de um ponto-de-vista próximo a uma kritikform, ou mesmo de uma formgeschichte da composição textual do lib. arb.), vide a pesquisa efetuada por Ricardo TAURISANO em sua dissertação de mestrado $\boldsymbol{O}$ De libero arbítrio de Agostinho de Hipona, Departamento de Letras Clássicas, FFLCH-USP, 2007, p. 123-126 (www.teses.usp.br/teses/disponiveis; www.fflch.usp.br/df/cepame/textos/teses). O artigo de Taurisano Retórica no De Libero Arbitrio de Agostino de Hipona, publicado em Teoliterária - Revista Brasileira de Literaturas e Teologias, Associação Latino-Americana de Literatura e Teologia, volume $\mathrm{I}, \mathrm{n}^{\mathrm{o}} 2,2^{\circ}$ semestre de 2011, p. 35-67, apresenta uma sumarização de sua dissertação. 
Sobremaneira especial para sua articulação do saber cristão (crer-compreender), o sentido da ordem universal, tomado em si, permite como que uma prévia superação da dualidade uno/múltiplo, possibilitando a Agostinho situar-se perante uma das questões centrais de sua herança platônica, de forma a iniciar sua abordagem de maneira essencialmente diversa da tradição herdada, ao manifestar o todo captado na multiplicidade criatural, no imediato do instante. Numa palavra: a ordem presentifica o todo no imediato de seu sentido. Para além da função metodológica, a disposição dos elementos da disputa argumentativa em uma ordem precisamente delineada ocupa, no quadro geral do pensamento agostiniano deste período inicial, a condição irretorquível de todo e qualquer exercício espiritual na busca e na conquista da sabedoria verdadeira ${ }^{121}$. A ordem de princípio - a qual irá ensejar a feitura da ordo cognoscendi, em simul à ordo rerum - na retomada da disputatio expõe, em realidade, o mesmo elenco da sequência anterior, mas no sentido inverso: ordenam-se os elementos na procedência Deus - bem - livre-arbítrio, compondo precisa inversão da retrocedência livrearbítrio-bem-Deus. ${ }^{122}$.

\subsection{2) Esse - uiuere - intellegere}

Ag. Assim pois, para partirmos das verdades mais evidentes, eu te perguntaria, primeiramente, se existes. Ou, talvez, temas ser vítima de engano ao responder a essa questão? Todavia, não te poderias enganar de modo algum, se não existisses.

$\boldsymbol{E} \boldsymbol{v}$. É melhor passares logo adiante, às demais questões.

Ag. Então, visto ser claro que existes - e disso não poderias ter certeza tão manifesta, caso não vivesses -, é também coisa clara que vives. Compreendes bem, que há aí duas realidades muito verdadeiras?

Ev. Compreendo-o perfeitamente.

121 "Situando-se no cerne da metafísica augustiniana, a reflexão sobre a ordo rerum não é exclusiva do Hiponense. [...] A obra augustiniana obedece a esta solicitude pela ordem das coisas [...] nem a temática, nem o modo de a abordar definem a especificidade da reflexão do Hiponense sobre a noção de ordo. Todavia, no intuito de identificar o que nela há de próprio, cabe destacar dois aspectos, intensamente vividos por Agostinho: a experiência da desordem e a exigência de resposta para a questão essencial de toda a metafísica, a saber, a da relação entre o Uno e o múltiplo." - OLIVEIRA E SILVA, 2007: 15. "Or, saint Augustin est le seul dans le monde antique à avoir composé, parmi ses toutes premiéres oeuvres, un De ordine, titre hapax, que n'a pas d'équivalent dans la littérature grecque ou latine antérieure. Cet indice témoigne de son intérêt précoce pour la notion d'ordre, que tend à confirmer l'omniprésence des références à ses ouvrages dans l'article que le Thesaurus Linguae Latinae consacre à ordo." - BOUTON-TOUBOULIC, 2004: 13. Vide ainda DOUCET, 2004: 39; GILSON, 2006a: 397-398; MORESCHINI, 2008: 463-464. Na sequência imediatamente seguinte de nosso presente estudo, tentaremos um esboço de abordagem específica do itinerário ascensional da razão no De Ordine.

${ }^{122}$ Maxence Caron, em seu estudo acerca da presença e funcionalidade, no pensamento agostiniano como um todo, da noção de princípio enquanto Deus-ser, expõe a importância da "principialidade" do princípio divino (que, por evidente no plano teológico, não se problematiza neste âmbito) para o discurso filosófico como tal, perpassando-lhe estruturalmente por inteiro: “... si le Principe est bien le terme de toute recherche, il en est également l'origine. Cette constatation peut paraître évidente, mais sa conséquence méthodologique est pourtant étonnamment absente de la philosophie traditionelle, où tou se passe comme si jamais n'était déduit le corrêlat attaché à la notion même de Principe: non seulement se situer au terme de la recherche, mais également imprégner et déterminer toute opération intellectuelle ou volontaire en faveur de cette recherche." - CARON, Maxence Être, Principe et Trinité in ID. (dir.) Saint Augustin - Les Cahiers d'Histoire de la Philosophie, Paris: Éditions du Cerf, 2009, p. 593. Retornaremos ao estudo de Caron por ocasião de nossa tentativa de análise da simultaneidade essencial epistemológica, na continuidade da disputatio de nosso texto. 
Ag. Logo, é também manifesta terceira verdade, a saber, que tu entendes? Ev. É claro. [II, iii, 7] $]^{123}$

A ordem exposta e requerida por Agostinho como preliminar à retomada da discussão, tem por base a tríade ser-viver-entender, tecida de fato em torno ao conceito de ser, como tentaremos expor mais logo adiante. Pontuemos novamente que a disputa se reinicia devido ao esgotamento da sequência anterior, motivado pela suspensão do conhecimento postulada por Evódio.

Delineada a ordenação sobre a qual irá se desenvolver o reinício da investigação, Agostinho propõe, como princípio de sua consecução, que se parta de uma verdade evidente (manifestissimis), como que contemplando diretamente a suspensão judicativa de Evódio. A devolução desta suspensão por parte de Agostinho - que, relembremos uma vez mais, culminara no questionamento acerca da existência de Deus, fundamento de todo ato cognitivo até então, embora sua existência tenha se mantido exclusivamente no assentimento próprio ao ato de crer - é praticada de modo a evidenciar a inadequação, ou mesmo a impossibilidade, de uma suspensão total do juízo cognitivo. A quem eleva o questionamento acerca do ser ao âmbito essencial da existência mesma, numa espécie de renúncia ao primado da evidência ontológica e cognitiva do dado primeiro relativo ao ser, Agostinho faz ver que tal pretensão volta-se contra si mesma (utrum ipse sis), questionando a existência de quem questiona a existência em si. Se alçamos voo ao questionamento a respeito do Ser supremo, somos em verdade tragados pelo próprio voo, pois perguntar pelo Ser equivale a perguntar por si. Daí Agostinho partir, na tríade das primeiras intuições, do esse (e não do intellegere) ${ }^{124}$. $\mathrm{O}$ propósito de situar o ponto de partida da demonstração da existência de Deus, numa certeza cuja evidência a torne indisputada, torna manifesta a fundamental congruência, no interior do pensamento agostiniano, da epistemologia à ontologia. Uma notitia (ou um dado conhecido), somente se qualifica como uma certeza indisputada, à medida que se apresenta dotada de evidência inequívoca. Certificação advém, pois, da intuitio que reveste de evidência o dado conhecido. Consequentemente, o caráter principial da certeza evidente instancia-se em sua ausência de mediação, que a torna o dado primeiro sobre o qual se inicia a retomada da

\footnotetext{
${ }^{123}$ Aug. Quare prius abs te quaero, ut de manifestissimis capiamus exordium, utrum tu ipse sis. An fortasse tu metuis ne in hac interrogatione fallaris? Cum utique si non esses falli omnino non posses. - Ev. Perge potius ad cetera. - Aug. Ergo quionim manifestum est esse te nec tibi aliter manifestum esset nisi uiueres, id quoque manifestum est, uiere te. Intellegisne duo ista esse uerissima? - Ev. Prorsus intellego. - Aug. Ergo etiam hoc tertium manifestum est, hoc est intellegere te - Ev. Manifestum.

${ }^{124}$ Ao comentar este passo da disputatio, o qual intitula como preparatório à prova da existência de Deus a ser desenvolvida, Patrick Kremer relaciona a certeza primeira, ancorada no esse enquanto dado indubitável, com a capacidade da mente humana de atingir a verdade, constituindo-se no fundamento próprio para a argumentação probatória prosseguinte - cf. KREMER, P. J. The "psychological" proof for the existence of God developed by Saint Augustine, Chicago: Loyola University, 1948 [ebook (pdf) gratuito em www.ecommons.luc.edu], p. 9-10.
} 
sequência argumentativa, sendo correto afirmar que a ontologia agostiniana exposta no $D e$ libero arbitrio toma seu ponto de partida diretamente do conceito de esse, desde que ressaltada sua imediação ${ }^{125}$.

A interpelação da sequência a Evódio é feita de modo a se fazer notar o caráter de evidência manifesta (manifestissimis) de cada um de seus elementos, atestado e reconhecido através de suas três respostas. Este caráter manifesto de evidência decorre, de imediato, após a colocação da primeira das três certezas, respectiva ao esse, ao passo que as demais são decorrentes do entendimento dos graus do ser nelas contidos ${ }^{126}$. Parece-nos, neste desenvolvimento do diálogo, impor-se a observação da relação de decorrência entre o questionamento acerca da própria existência e aquele que questiona o fundamento da existência em geral; e o caráter manifesto e evidente da certeza primeira, gerada no vácuo da suspensão judicativa postulada por Evódio. A certeza postulada por Agostinho ostenta imediata evidência, tal que se mostra diretamente proporcional à suspensão judicativa praticada por Evódio, terminando em realidade por evidenciar sua impossibilidade na medida da inerência do manifestissimi ao esse, tornando-o indubitável e impassível ao questionamento e à perquirição evodianos. Não há que se duvidar do esse tomado enquanto tal, pois ao se voltar a si, o questionamento acerca do esse depara-se com seu próprio esse. Não pode haver dúvida acerca da existência de quem pretende duvidar da própria existência. As relações de decorrência que se seguirão à primeira certeza - há vida, e portanto, há inteligência em quem sabe que existe e vive - assentam-se sobre a conceituação de disponibilização imediata do dado ao intentado (intuído), qual seja: existir (esse). Em realidade, uma não leva à outra, mas todas se dispõem de pronto $^{127}$, à colocação da primeira ${ }^{128}$, simultaneidade esta que a própria "impaciência" altiva,

\footnotetext{
125 As considerações analíticas de Paul Tillich parecem-nos fundamentais, convergindo ao espírito de nossa tentativa: "Na tradição agostinista, a fonte de toda a filosofia da religião é a presença imediata de Deus na alma, ou como prefiro dizer, a experiência do incondicional, do supremo, em termos da preocupação suprema ou incondicionada. Trata-se do prius de todas as coisas. Não se discute se alguém existe ou não. Agostinho liga essa questão ao problema da certeza. Ele afirma que temos a evidência imediata de duas coisas. Em primeiro lugar, da forma lógica [...] e, em segundo lugar, da experiência sensorial imediata,..." - TILLICH, P. História do Pensamento Cristão, $4^{\text {a }}$. edição, São Paulo: Aste, 2007, p. 125.

${ }^{126}$ No contexto dos diálogos de início, Jean Pépin traz à lume a analogia do aumento/esvaziamento da massa corporal, herdada no contexto do neoplatonismo plotiniano e, sobretudo, da matização trabalhada por Porfírio; presente já em autores latinos ( ); e utilizada por Agostinho no tocante à gradação ontológica - cf. PÉPIN, J. $\underline{A}$ propos de la doctrine de la conversion: Augustin et Porphyre sur le degré d'être in KOBUSCH, Theo; ERLER, Michael (Her.) Metaphysik und Religion: zur signatur des Spätantiken Denkens, Munique/Leipzig: K.G. Saur Verlag GmbH, 2002, p. 158-164.

${ }^{127}$ Anne-Isabelle Bouton-Touboulic ressalta a funcionalidade, presente já no neoplatonismo plotiniano e assumida por Agostinho, do trinômio em seu duplo aspecto: composição hierarquizante, assaz em relação de implicação: "Le fonctionnement de la triade esse-uiuere-intellegere relève à la fois de la gradation et de l'implication, et Augustin hérite de ce double principe." [BOUTON-TOUBOULIC, 2004: 120-121]. Em nossa pesquisa, a opção por qualificar tais relações como de decorrência, mais que de implicação, visa ressaltar a simultaneidade essencial e ensejante à feitura cognitiva do universo levada a efeito pelo itinerário intelectual. Retomaremos a análise de
} 
com traço desdizente, de Evódio parece-nos confirmar, visto a imponência da imediaticidade ser de tal monta, que o leva a considerar sua investigação como pueril e indigna de consideração. Prosseguiremos na análise da tríade em questão mais adiante, seguindo-se à apresentação do movimento interno de ascendência que ora iniciamos.

\subsection{3) Excelência/Excedência-Ascendência}

Via de regra, as relações de decorrência, ou de implicação, a partir de uma evidência manifesta e de princípio, são analisadas como se estivessem dispostas em progressão, partindose do esse enquanto certeza primeira, para evidenciar o intellegere como verdade indubitável, tomando-se a argumentação agostiniana como desenvolvimento da relação de pertença ampliada entre os três termos: esse em uiuere, ambos em intellegere, concluindo-se pela prevalência deste último, precisamente por conter os dados anteriormente dispostos, o que parece confirmado pela continuidade do diálogo, sobretudo na articulada justificativa de Evódio:

$\boldsymbol{A g}$. Qual dessas três [existir, viver e entender] parece a ti a mais excelente? Ev. O entender.

Ag. Por que te parece assim?

$\boldsymbol{E} \boldsymbol{v}$. Por serem três: o ser, o viver e o entender. É verdade que a pedra existe e o animal vive. Contudo, ao que parece, a pedra não vive. Nem o animal entende. Entretanto, estou certíssimo de que o ser que entende possui também a existência e a vida. É porque não hesito em dizer: o ser que possui essas três realidades é melhor do que aquele que não possui senão uma ou duas delas. [Idem $]^{129}$.

Nota-se que é o conjunto das três realidades que funciona como sustentáculo à propositura de Evódio, no tocante à postulação de excelência reservada à inteligência. Instado por Agostinho a indicar qual, dentre as três, porventura exceda (ultrapasse enquanto manifestação - excellere) as outras duas, Evódio responde qualificando inicialmente a tríade, tomada em seu conjunto e/ou com seus elementos manifestados conjuntamente (cum tria sint), como realidade "mostrável", ou que ostenta apresentação real de per si (haec). Com efeito, a uma única verdade, isolada do conjunto, não se lhe poderia atribuir densidade ontológica que

Bouton-Touboulic, em maior amplitude, logo adiante, por ocasião da abordagem específica da tríade estruturante em questão.

${ }^{128} \mathrm{O}$ sentido de esse neste trecho do De libero arbitrio é visto, por vezes, próximo à generalidade e indeterminação máxima que irão matizar o conceito de ser ao longo da história, possibilitando, precisamente pela indeterminabilidade, que se o tomasse por fundamento a toda determinação e, portanto, a esta apresente e enseje de modo imediato. Paul Gilbert qualifica este primeiro sentido de esse como portando um "significado pobre, mínimo, até mesmo mineral. [...]" - GILBERT, P. "Eu sou aquele que serei" - Deus: da sarça ardente às aventuras da razão in MIES, Françoise (org.) Bíblia e filosofia: as luzes da razão, São Paulo: Loyola, 2012, p. 28-29. Retomaremos a análise do sentido de esse no presente passo de nosso texto, assim como a qualificação de Gilbert e de outros autores, na sequência imediata de nosso estudo.

${ }^{129} \mathbf{A g}$. Quid in his tribus tibi videtur excellere? - Ev. Intellegentia. - Ag. Cur tibi hoc videtur? - Ev. Quia cum tria sint haec, esse uiuere intellegere, et lapis est et pecus uiuit, nec tamen lapidem puto uiuere aut pecus intellegere; qui autem intellegit, eum et esse et uiuere certissimum est. Quare non dubito id excellentius iudicare cui omnia tria insunt quam id cui vel unum desit. 
perfizesse suficiência ontológica mensurável. Ao comentar a tríade em questão no seu reaparecimento em De trinitate [X, iv, 6], Emmanuel Bermon reporta-se ao contexto dos diálogos de início, com a asseveração de que a argumentação de Agostinho consiste em "passar do fato de que o espírito por inteiro conhece que sabe, que vive e, ainda, que é, ao fato que ele está, inteiramente, disposto ao saber, ao viver e ao ser, de modo que se possa concluir, nos três casos, que ele se conhece, a si mesmo, por inteiro." [BERMON, 2001: 93]. É unicamente em conjunto, ou seja: a partir de uma totalidade mensurável e internamente comparativa, que se pode falar em manifestação excedente ou ultrapassamento ontológico, tomado enquanto superação de limites de determinação da realidade sensível. Assim, verificamos que o princípio de ultrapassagem ou superação, vale dizer: o que se expõe, no surgimento de seu ser próprio, ou seja: excellere, a excelência, vem a ensejar, em sua própria postulação, a ascensio mentis como movimento de captação da densidade ontológica verificada nos diversos níveis de manifestação do ser, contidos nas verdades que, por sua vez, situam-se em mensurações (vale dizer: graus) diversas, consoante a internalidade relacional com os demais níveis, tomada (como sempre) em simul: aquela verdade (ou nível de manifestação) que puder apresentar/mostrar (hic) as demais, a estas ultrapassa na medida em que as apresenta efetivamente (manifestamente), expondo-as em seu ser (excelência). Porém, se a uma primeira vista tal constatação parece confirmar a fundamentação do responso evodiano como disposição em progressão dos níveis ontológicos, é justamente pela radicação no ser que se pode verificar como que o contrário: tanto o caráter de manifestação evidente, quanto a ultrapassagem ou expansão em conjuntura (excelência - excellere), decorrem do esse primordial às três verdades; as quais, por sua vez, somente puderam ser qualificadas por Evódio como realidades (sint $h a e c$ ), precisamente enquanto decorrências do esse fundacional. São realidades (ser insurgente, que surge: hic, ecce), ou seja, ostentam ou manifestam, ou ainda: apresentam o ser, tal que se convertem em instâncias ontológicas, ou de ocorrência e manifestação da realidade inteligível. É o esse, enquanto dado primeiro e certeza fundante, que atua no perfazimento do conjunto, à medida que confere realidade a cada uma das verdades apresentadas, as quais engendram-se justamente a partir da existência, ou do dado primeiro e manifesto do ser: a inteligência excede a vivência, posto que existe para além dela e a evidencia e mostra para além de si, o que igualmente o faz a vivência em relação à existência que abruptamente irrompera como certeza diante da suspensão judicativa da cognição, evidenciando a nuança da irruptura ou o irromper do ser no nada do juízo cognitivo.

Efetivamente, no conceito de existência primeira, enquanto conjunto ou totalidade da realidade em de níveis de ser, só poderá haver o dado imediato de sua existência. Contudo, o 
conceito ou ideia de ser engloba a todos os níveis ou realidades, perpassando-os na precisa medida em que os fundamenta: é o esse que permite a cada um dos níveis ou realidades, antecipar e conter (no sentido de engendrá-lo) o próximo, enquanto sinaliza-lhe a excedência ou ultrapassagem. De fato, a pedra aponta à sua superação, na medida em que esgota a realidade da factualidade. Por seu turno, a vivência, contendo a factualidade, aponta à sua superação na medida em que esgota a animalidade. Finalmente, a inteligência, contendo os dois níveis anteriores, foi por antecipada por ambos, na medida mesma da soma dos dois, ou seja, de um todo formado em conjunto, tal que se permitiu integrá-los e contê-los como conjunto. Porém, a própria inteligência aponta à sua superação, na medida em que traz consigo, ostentando-as no momento mesmo de seu exercício e/ou atividade, possibilidades de ser para além de si, o que, na visualização do perpassamento dos três níveis, equivale a dizer que, somente enquanto radicada e fundamentada (perpassada) pelo esse, pode a inteligência ensejar - como veremos adiante - extraindo de si e de seu conteúdo próprio (ex-cello, excelência), sua excedência/superação.

Talvez pudéssemos, no intuito da clarificação e na tentativa de penetrar nas sutilezas da conceituação de esse nos diálogos agostinianos, e de seu fino mecanismo de engendramento em superação dos níveis/graus de realidade no itinerário ascensional do conhecimento, lançar mão da noção de haurir uma realidade interna como moto central na visualização do percurso e na descrição que ora trazemos dos passos cognitivos. De fato, como teremos ocasião logo adiante em nossa pesquisa, utilizaremos o cognato exauriência para pontuar o que, por ora, intitulamos como esgotamento dos níveis ou passos de ser na gradação do percurso intelectual, apontando para a internalidade do movimento do esse de um determinado nível, que enseja sua própria superação no passo seguinte, no qual este torna manifesto o conteúdo internalizado naquele, até o momento. Nesse sentido específico, exaurir implica em sentido idêntico a ascender, ou mesmo a excellere, explicitado no texto agostiniano, apontando à acepção de esse presente no De libero arbitrio (e, veremos, também presente nos diálogos em paralelo do período inicial), pela qual o ser do passo anterior plenifica o ser do posterior, pelo que o ser itinera-se no ser, não porém tornando-se em devir (o que remeteria a uma conceituação próxima à tradição do conduto pitagórico-platônico, consumada no neoplatonismo - vide nossa Introdução, p. 24-27), mas feiturando a realidade em totalidade, cujo sentido do todo em harmonia é presentificado na percepção da ordenação harmonizante, dada ao início do percurso 
cognitivo (como veremos adiante, ao intentarmos nossa abordagem pelo De ordine; e ainda no De quantitate animae $)^{130}$.

\subsection{4) Ascendência e dinamismo intelectual: análise de Moacyr Novaes Filho}

Em diversos estudos e análises do passo textual em questão, ou de escopos maiores relacionados à temática da elevação intelectual no período inicial agostiniano, o sentido da ascendência e/ou excelência entre os níveis de conhecimento - sobretudo quanto aos elementos da tríade inicial - tem apresentado aspectos que permitem corroboração e referenciais, embora com nítidos contrastes pontuais (ou mesmo de cunho geral), quanto às nossas tentativas de visualizar o esse como elemento fontal e ensejante do itinerário intelectual, vindo a perfazer como que um trajeto em elipse no qual as pontas se encontram, posto que o termo de chegada já se afigura no início, estando em posse da intellegentia desde o começo (unicamente enquanto credere no intercurso da suspensão cognitiva, e como surgimento primordial e fundante do esse da tríade axial, referendado pelo esse absoluto do final da intelecção) com o fito de percorrer a feitura da concretude existencial, em culminância no termo final, o telos convergindo ao principium.

Assim, Moacyr Novaes Filho parte de um sentido essencialmente hierárquico em sua análise da ascensionalidade, esclarecendo que "precisamente na 'prova da existência de Deus' desenvolvida no II livro do De libero arbítrio, Agostinho expõe uma hierarquia prospectiva", na qual "retoma a escala corpo/alma/Deus, e o dinamismo ali embutido." Num primeiro momento, tal hierarquização apresenta um "exame retrospectivo", em que a "natureza espiritual, dotada de inteligência, [...] examinará as naturezas que the são inferiores. Uma vez que ela também é e vive, o fato de inteligir lhe dá superioridade e condições de abranger as demais." Já numa segunda estapa, "a análise de cada nível faz com que o espírito racional dirija sua atenção para um nível superior. A inteligência é capaz de ordenar hierarquicamente sua experiência, de forma que já nos degraus mais baixos o espírito encontra remissão a degraus superiores" [NOVAES, 2007: 187-188]. Se a apresentação deste dinamismo em seu duplo movimento não deixa dúvidas quanto ao entendimento de Novaes acerca do caráter essencialmente hierarquizante da ascensão anímica intelectual no De libero arbitrio, algumas de suas pontuações permitem-nos contato com nossa tentativa de leitura anierarquizante do itinerário ascensional, ou mais propriamente, plenificante (ou pleromarquizante) de seu perfazimento. Ao destacar o dinamismo interno à ascensão intelectual, Novaes apresenta-o em

130 "Das Böse wird von Augustin dezidiert nicht als Substanz aufgefasst, sondern in die Gesinnung des Menschen verlegt. Sein freier Wille verfügt darüber, ob er sich innerhalb der Seinordnung eher nach oben oder in sündhafter Weise nach untern orientiert." - TRELENBERG, 2004: 37-40 (grifo nosso). 
seus vetores de composição retro e prospectivos: a inteligência se debruça retrospectivamente nos degraus inferiores, tanto quanto prospectivamente nos superiores. Tal imagem permite-nos supor que início e finalização do passo ascensional são efetivados a partir do instante em que a inteligência dispõe da anterioridade, tanto quanto do posterior. Em contínuo decorrente, podemos afirmar que os sentidos retrocedente e procedente sinalizam e orientam, em realidade, uma única vetorialização autuada pela inteligência, perfazendo o dinamismo a que se refere Novaes ${ }^{131}$, bem como evidenciando o caráter de antecipação, por parte da inteligência, com relação ao próprio moto em que se dinamiza. Com efeito, a razão, na intelecção da realidade criatural e essente, encontra-se situada em antecipação à internalidade em que se efetua o movimento de ascendência que perfaz o itinerário do conhecimento humano. Por seu turno, tal dinamismo traduz a potencialidade do exercício anímico de suplantação (tanto temporal quanto espacial) da limitação do ente, exercício que se mostrará epicêntrico no De quantitate animae. A par da herança neoplatônica (a qual recolhe, por sua vez, evidentes elementos aristotélicos em sua formulação), esta potencialidade intelectual no engendramento do movimento ascensional repousa indiscutivelmente no âmbito do esse, de modo a lhe ensejar a exauriência e suplantação interna em seus passos cognitivos, os quais apontam aos graus de ser, cujo sentido hierárquico revela-se, em realidade, como gradação de manifestação ontológica, ou de participação de determinado esse em relaçao ao ser absoluto (Vere Esse).

No prosseguimento de sua análise, Novaes acentua o caráter de superioridade hierárquica entre os diversos graus de conhecimento, indicando dois aspectos fundamentais de sua configuração: 1) a "nítida subordinação entre as diferentes atividades" anímicas, como clarificam as constatações relativas aos exercícios dos sentidos externos, do sentido interno e da própria razão; e 2) "o fato de a superioridade da razão [...] consistir na sua capacidade de pensar a si mesma, de voltar-se para si”, acrescentando, pois, outro sentido à movimentação anímica: "o vetor interiorizante" [2007: 189]. A explanação prosseguinte esclarece, de modo inequívoco (e corroborando as decorrências que citamos no parágrafo anterior): “... sob uma linguagem espacial, opondo exterior a interior, Agostinho mostra que um degrau é tanto melhor, mais refinado, quanto mais ele corresponde ao verdadeiro ser, à pura identidade, ..." [2007: 190; grifos nossos]. Apontando, no que entendemos de maneira inequívoca, para a primazia do esse quanto ao engendramento do movimento ascensional da intelecção da realidade concreta e sensível, a análise de Novaes indica ainda outro aspecto de particular interesse à nossa pesquisa, que se nos afigura precioso à nossa tentativa de visualizar a

\footnotetext{
${ }^{131}$ Igualmente Doucet caracteriza o movimento enquanto dinamismo: “... il [l'exercice spiritual] se fonde sur la structure même des êtres et dans le dynamisme que les constituent." - DOUCET, 2004: 96.
} 
ascensão intelectual como exauriência ontológica de excelência entre os graus do conhecimento, bem como à tentativa de entendê-la, em seu dinamismo próprio, como surgimento ou manifestação do esse na simultaneidade de sua intelecção, em trecho densamente elucidativo e de grande agudeza:

[...] a fé dá o sentido da busca, que o intelecto preenche parcialmente: sempre mais e mais para o alto, procurando indícios daquele que criou o mundo e sua beleza, sempre mais e mais para o íntimo, procurando a imagem do criador no espírito humano. Assim, o 'material' para a busca dessa inteligência é, a princípio, o mundo das criaturas. Nele Agostinho seleciona o homem, mais precisamente, o homem interior, para então finalmente nada mais restar senão o mesmo Criador. [NOVAES, 2007: 192; grifos e negrito em itálico nossos.]

O adensamento de Novaes permite-nos, assim o entendemos, elucidações corroborantes de pontos estratégicos quanto ao sentido geral de nossa tentativa. Ao situar a dupla procura do intelecto 1) pelos indícios do criador, bem como 2) pela imagem do criador, evidencia-se que o percurso de intelecção da realidade criatural (o "material" da busca) visa unicamente o Vere Esse, que se evidencia o mesmo e único alvo do duplo movimento de busca. Ora, ostentar um mesmo alvo equivale a postular que a busca se perfaz e é efetivada na simultaneidade de seus vetores exterior (sinais ou signos da relação esse-Vere Esse) e interior. Ambos os vetores, por seu turno, sinalizam para o alvo presente desde o início e sempre, cuja presença dá o sentido arqueológico e teleológico (principial e final, fundante e culminante, bem como simultâneo ao início e fim) da ascensão intelectual: a postulação presencial do Vere Esse pela atitude do credere, que se evidencia, se assim podemos tentar numa definição em síntese conceitual, próximo a algo como credo, ergo intelligo (enquanto condicionamento recíproco e de decorrência inalienável entre ambos os atos), o que intentamos desenvolver na conclusão de nossa pesquisa. Tal evidência (nossa tentativa de credo, ergo intelligo) decorre, sobremaneira, do sentido primordial instituído pela fé (cuja circularidade evidencia a própria constituição do pensamento agostiniano: o assentimento presente na fé revela-se seu próprio inteligir), portanto presente e instituinte da meta a ser alcançada, bem como pelo meio a ser utilizado para tanto. Ambos - fim e meio - serão consubstanciados pelo esse enquanto manifestação e doação, efetivados na dinâmica da exauriência e feitura intelectual entre os passos da ascensão do conhecimento, o que nos parece ratificado pela definição de Novaes quanto à funcionalidade e atualidade do intelecto: a de preenchimento de um escopo de antemão delineado e sabido, cujo itinerário tratará de oferecer consistência e conteúdo à sua realização pela intelecção do universo criatural ${ }^{132}$.

\footnotetext{
${ }^{132}$ A definição de Novaes, em sua precisão e refinamento terminológicos, apresenta familiaridade com a imagem resgatada por Jean Pépin junto à herança neoplatônica de Agostinho, na análise a que procede dos textos do
} 


\subsection{5) Existência, intelecção e verdade}

Tema de um dos capítulos com que introduz sua monografia acerca de Agostinho, a ascensão intelectual será o ponto de partida para Étienne Gilson explanar a essencial congruência entre verdade, ser e Deus no interior da filosofia agostiniana, ostentando, portanto, sentido fundamental a todo o seu desenvolvimento. Situando-se no contexto dos diálogos de início, e tendo por escopo precisamente o texto do De libero arbitrio II, Gilson inicia [2007: 34] lembrando o âmbito peculiar no qual se insere o itinerário ascensional: a refutação ao ceticismo ante a existência de Deus (culminância, como vimos, da disputatio em torno do livre-arbítrio enquanto bem de caráter donativo divino). A remissão ao contexto de início da exposição da ascensão anímica permite a visualização inequívoca da sobredita confluência entre verdade e Deus. Assim, provar a existência da verdade equivale a provar que somos dela capazes $^{133}$, bem como identificá-la junto ao fundamento do ser (e, portanto, do conhecimento):

Agostinho estabelece a possibilidade da certeza em geral, e o faz ao apoderar-se da primeira de todas as certezas [...]: sua própria existência. [...] O remédio contra a dúvida universal é essa evidência [...]: eu sou e sei que sou. [...] Mas ele não se apreende somente como sendo, ele se sabe vivente; e como para saber que é e que vive é necessário conhecer, apreendemos com evidência três termos, e não um único, desde o início de nossa busca. [...] Assim, posto que o conhecimento implica a vida e o ser, ao passo que nem o ser nem a vida implicam o conhecimento, deve-se admitir que, dos três termos, o conhecimento é o mais elevado. [GILSON, 2007: 35-36; grifos nossos].

Não obstante postular qualificação entre os três termos enquanto superioridade interna (ou hierarquização), Gilson, inequivocamente, trabalha com premissas que apontam à primeiridade do esse e sua fundamentação à certificação do conhecimento da realidade. Ao reconhecer a primazia do ser enquanto certeza de fundamento (remédio contra a universalidade do questionamento), Gilson a expressa (“eu sou e sei que sou”) em alusão, formal e conceitual, às expressões celebrizadas quanto ao nome de Deus em Ex 3,14 (“Eu sou o que sou”) ${ }^{134}$; bem como, ainda que obliquamente, à intuição que fundamenta a postulação do cogito enquanto certeza primeira do pensamento cartesiano. Em sequência, sua asseveração a respeito do modo como se dá a tríade fundamental igualmente nos permite apontar contato corroborante para com nossa tentativa: "apreendemos com evidência três termos, e não um único, desde o início

período inicial: a da intumescência/esvaziamento - PÉPIN, J. A propos de la doctrine de la conversion ...., op.cit., p. (cf. nota 152 - p. 82 de nossa pesquisa).

${ }^{133}$ Cf. VELÁSQUEZ, Ó. La iluminación agustiniana como explicación de los contenidos de la mente: Agustín em Casiciaco in Teología y Vida, Vol. XLVIII, 2-3, Pontificia Universidad Católica de Chile, Santiago, 2007, p. 217.

${ }^{134}$ Examinaremos adiante a referência trabalhada por Gilson quanto à metafísica do Êxodo, relativa ao conceito de Deus enquanto Vere Esse, e sua importância à nossa presente pesquisa. 
de nossa busca". Gilson ressalta o imediato da evidência na apreensão da tríade em sua totalidade, e não em sequência a cada um de seus termos, sinalizando assim para a simultaneidade essencial com que trabalhamos por toda nossa leitura; bem como aponta para a presença perene (“desde o início”) da apreensão simultânea (permeante, portanto) de todo o processo ascensional. Se é certo que de tais asseverações Gilson caminha para arrematar conclusivamente que a inteligência ostenta primazia qualificativa sobre os dois outros termos, pode-se perceber sua igualdade quanto aos aspectos temporal e, por assim dizer, arqueológico (no sentido de fundamentação) no interior do trinômio fundante.

Também para Dominique Doucet, não obstante a ascensionalidade engendrada pela tríade em questão (no "entrelaçamento dos esquemas evento-presença-permanência (atividaderesultado), com aquele relativo à tripartição filosófica") apresentar "uma dimensão dinâmica e hierárquica do real e do pensamento, que Agostinho herda não somente de suas leituras filosóficas, mas que reencontra igualmente nas meditações escriturísticas", seu sentido assenta-se, de modo inequívoco, na fundamentação ontológica e primazia do esse, tal que Doucet intenta, de modo explícito, "evidenciar as implicações do esquema ser-vidapensamento junto à noção de similitudo que estrutura a hierarquia dos seres e a progressão do conhecimento" [DOUCET, 2004: 95-96] ${ }^{135}$. Valendo-se do estudo de Pierre Hadot acerca do trinômio fundamental em Plotino ${ }^{136}$, e reconhecendo de modo categórico a simultaneidade essencial interna aos termos da tríade, Doucet afirma ainda que esta é

... caracterizada igualmente pelo fato de que qualquer momento que a constitui pode ser reconhecido como 'predominante', no sentido de explicitude de sua atividade. Como explica P. Hadot, isto decorre do fato de, na substância inteligível, tudo 'se implica reciprocamente [...] É este sentido assaz peculiar que configura as relações entre o ser, a vida e o pensamento em [Marius] Victorinus [...] ser, vida e pensamento não predominam em planos diferentes da realidade, mas constituem um só ato de uma só substância interior à ela própria'. [2004: 96-97 - grifo nosso]

\footnotetext{
${ }^{135}$ Há que se ressaltar que a noção-chave tomada por Doucet guarda relação radicial com simul; bem como tal noção é trabalhada ante a tríade como um todo, conferindo a esta uma unidade que, uma vez mais, privilegia seu dado imediato nesta totalidade (sem postular a sequência qualificativa temporal que, invariavelmente, privilegia o terceiro termo do trinômio), bem como lhe fundamentando na relação de participação Vere Esse-esse, dado que a relação de similitude lhe é côngenere (em realidade, dela deriva/ou: em realidade, esta deriva daquela).

136 HADOT, P. Être, Vie, Pensée chez Plotin et avant Plotin in ID. Plotin, Porphyre - Études néoplatoniciennes, Paris: Les Belles Lettres, 2010, p. 127-157 (publicado originalmente em 1960). Ao analisar o trecho constante da Enéada V, 7 [38], 23. 18-24, Hadot afirma: "Ici, être, vie, penser apparaissent nettement comme les trois formes de l'existence, l'existence plénière et totale n'étant obtenue que par la possession simultanée des trois. Mais cette existence plénière n'est réalisée que dans la seconde hypostase: 'Le Bien doit être supérieur à la vie et à l'intelligence;' ..." (p. 138 - grifo nosso). Mais adiante, Hadot assinala categoricamente: "Une chose est certaine: depous Platon, l'idée de perfection substantielle, de plenitude d'être, est liée à la possession simultanée de ces trois formes de la réalité: l'existence, la vie et l'intelligence. [...] La hiérarchie des êtres s'établit selon la possession de ces caractéres. [...] Mais cette hiérarchie n'exclut pás l'implication réciproque des trois constituants de la réalité plénière, ..." (p. 139-140 - grifo nosso).
} 
Na continuidade de sua análise, Doucet esmiúça a relação entre a tríade fundante e o conhecimento em seu aspecto processual cognitivo, tomando por base a passagem dos Soliloquia I, vi, 12, para afirmar que a razão, personificada neste texto, "se encarrega de purificar o espírito e lhe expor a dinâmica da atividade cognitiva. Ela distingue, pois, no interior de um mesmo processo, três momentos distintios que ocorrem em uma relação recíproca." [2004: 97].

Por seu turno, Christoph Horn visualiza o sentido primordial da ascendência intelectual, bem como seu ponto de partida triádico, de modo coerente à sua postura afirmativa em relação à possibilidade de haver um cogito no pensamento agostiniano:

\begin{abstract}
Agostinho liga ao cogito, além do mais, a noção neoplatônica de que se pode, pela via do pensamento, alcançar a Deus. Em verdade, Agostinho liga ao seu cogito duas provas da existência de Deus. Em Agostinho, porém - diferentemente do que em Descartes -, é pensada uma espécie de ascensão intelectual do espírito humano a Deus. [...] a filosofia significa, para ele, imediatamente 'retorno para Deus' [...] Os temas da alma e de Deus formam, para ele, um objeto unitário - e unicamente valoroso - do conhecimento. [...] Repetidamente, o Pai da Igreja apresentou o caráter anagógico da obtenção do saber na forma de graus (especialmente em De ordine II e nas Confessiones VII 17,23). A passagem de prova mais famosa, que explana a relação entre o cogito e a 'ascensão do espírito', é a exortação presente em De vera religione $(39,72)-$ [HORN, 2008: 40]
\end{abstract}

Nota-se, de pronto, a explicitude com que Horn trata a centralidade que entende possuir o cogito agostiniano. No âmbito de sua análise, Agostinho expõe a argumentação probatória acerca da existência de Deus, referenciando-as ao cogito advindo (ou surgindo) precisamente da tríade fundante, o que faz com que as provas sejam estabelecidas no âmbito - e em decorrência - do autoconhecimento enquanto verdade primeira e certeza inquestionável. Entretanto, não tarda para que Horn apresente escopo maior em que se dá o surgimento da cogitatio na filosofia agostiniana: o exercício filosófico enquanto voltado ao ser supremo e absoluto, reconhecendo a conexão - diríamos, no espírito da tentativa de nossa presente pesquisa: a simultaneidade - entre o aspecto ontológico e o do conhecimento, bem como a relação de imbricância entre ambos ("Os temas da alma e de Deus formam [...] um objeto unitário - e unicamente valoroso - do conhecimento."). Ao sinalizar para a preeminência da passagem localizada em uera rel. xxxix, 72, Horn deixa claro a relação sequencial a que procede - uma vez mais de modo coerente à sua defesa da centralidade do cogito em Agostinho - entre a ascensão a Deus e a emergência da cogitatio, condicionando a primeira - e tornando-a mesmo uma sua decorrência - à segunda. Porém, mesmo em uma análise como a de Horn - explicitamente referenciada no cogito como ponto de partida e centro de todo o construto ontológico agostiniano, incluindo textos como o De uera religione - verifica-se que 
o sentido da ascendência ou excelência do conhecimento do esse, mesmo tendo o cogito como seu ponto de partida, encontra-se relacionado à presença e consumação no Vere Esse enquanto seu escopo teleológico. De igual modo, a referência primordial ao ser, ainda que conjugado à noção de ordenação cosmológica e sua feitura teleológica, é notada na análise de Urs Von Balthasar, igualmente centrada no cogito:

Ser, viver e compreender, os quais implicam mais que o simples ato do pensamento cartesiano, constituem no cogito agostiniano unidade e trindade primordiais. [...] Não se trata de uma identidade vazia de ser e pensamento, nem de uma "tensão" radical entre sujeito e objeto, mas sim da recuperação da ordem primordial do ser do mundo dentro do processo primordial da consciência. ${ }^{137}$

$\mathrm{Na}$ análise de Bouton-Touboulic, a estruturação de base para a ordenação da realidade criatural advém precisamente da relação de inclusão dedutiva crescente verificada, segundo a autora, na vetorialização do ser ao viver; de ambos à intelecção; e do nível hierárquico inferior no superior ${ }^{138}$. Se, por um lado, afigura-se claramente a "inclusão crescente" verificada entre os níveis de ser, é igualmente manifesto, por outro, que o trinômio axial em questão é dado, como ressaltamos anteriormente - inclusive com a notação por parte da própria BoutonTouboulic - em simultaneidade de base, presente já na tríade plotiniana (embora circunscrita à segunda hipóstase, e portanto conhecida tão-somente na ordem atemporal anterior à queda das almas - vide nota 126, p. 79]. A simultaneidade essencial ao manifestar-se da tríade, por seu turno, assenta-se sobre a preeminência do ser, que "carrega" e manifesta o viver e sua intelecção, ensejando, em decorrência deste caráter donativo conferido à relação de pertença dos dois termos posteriores ao termo primordial, sua excelência e consequente ascendência, a qual perfaz - nisto convergimos com a análise de Bouton-Touboulic - inclusão do passo anterior no posterior. Porém a inclusão resulta, em nossa tentativa, como decorrência do apontamento e manifestação oriunda do esse fundante (o qual, na análise de Bouton-Touboulic, resulta inferior em relação aos dois outros termos ${ }^{139}$ ). Em suma, a presentificação primordial possibilita a inclusão final, ao fornecer a esta o conteúdo plenificante. Não é a inclusão que supera a apresentação, mas esta é que se plenifica e leva àquela, no nada advindo da exaurição da apresentação, em cujo vácuo resultante irrompe, uma vez mais e perenemente, o passo

\footnotetext{
${ }^{137}$ VON BALTHASAR, H.U. Gloria: una estética teológica, op.cit., p. 108. Cf. DE LIBERA, A. Augustin et la question du sujet in ID. (ed.) Après la métaphysique: Augustin?, Paris, 2013, p. 13-41 (especificamente, as p. $35-41)$

138 "Le lien continu qui forge un ordre unitaire naît de cette relation d'inclusion croissante entre les trois propriétés, énumérées selon un ordre hiérarchique. La hiérarchie interne à cette triade repose précisément sur la règle de récapitulation; formellement, la propriété supérieure est définie par sa faculté à inclure les deux autres." - [BOUTON-TOUBOULIC, 2004: 122].

139 "Celle [propriété/propriedade] qui n'implique aucune des deux autres, à savoir l'être, est la moins bonne, ..." [Idem, ibidem].
} 
prosseguinte ou posterior, cuja forma ou delineamento foi dado e apresentado precisamente pela exaurição anterior. Vide nossa tentativa de exposição a respeito, logo adiante.

$\mathrm{Na}$ simultaneidade interna à tríade esse-uiuere-intelligere, temos que o instante do surgimento ou manifestação do ser, postulado após a suspensão judicativa evodiana, é o mesmo de sua intelecção. Esta, no escopo triádico fundamental à ascensão cognitiva da realidade, atua como o polo de interiorização do conhecimento, constituindo-se o esse no polo de exterioridade/alteridade. Nesse sentido, a simultaneidade do surgimento do esse primordial atesta o surgimento de sua intelecção, instante de exterioridade convergindo para o de interioridade, o que equivale a dizer, dada a primordialidade do esse no simul constituinte da tríade, que esta institui o surgimento do intellegere. Temos que, à luz da simultaneidade interna da estrutura triádica, o ato cognitivo, a par da manifestação e evidência do esse, matiza-se enquanto intellegere do esse em interioridade.

Como já notado no decorrer de nossa pesquisa até o momento, a simultaneidade intrínseca aos postulados principiais é trabalhada de forma fundamental por Agostinho, perfazendo feição estrutural e conducente em seus desenvolvimentos filosóficos, mormente do período inicial registrados nos diálogos de Cassicíaco/Milão/Roma. Nesse sentido, aduz Francisco Benjamin de Souza Netto que

\begin{abstract}
[...] já que se trata de questionar o tempo e a ordem deste, tal o implica o cogito, a certeza de que sou é a mais imediata. Mas porque ela me capta na iminência do não ser, se ela subtrai o poder que eu poderia presumir ter de negar-me, por outro lado, por si só, ela não me justifica sem a sua resolução plena, isto é, sem aquela resolução que não sendo imediata, ao menos no curso da existência presente, há de impor-se a partir desse mesmo cogito: eu penso, porque penso sei que sou, sei isto com certeza e, ao sabe-lo, sei ser o que chamo "eu", mas o porquê deste "eu", sua razão de ser, escapa-me e, com ela, escapa-me a razão de ser de tudo mais, até que possa encontrar Deus em minha origem e na de tudo. ${ }^{140}$
\end{abstract}

De igual modo, ao comentar o surgimento e o papel da interioridade no decurso da feitura intelectual da realidade, Novaes faz notar, qualificando sua presença enquanto "vetor interiorizante", que "... o espírito humano, ao investigar o mundo e ser levado ao seu criador, encontra a si mesmo como momento privilegiado desta trajetória: ao pensar a si mesmo, pensa aquele que pensa, e encontra uma imagem, ainda que imperfeita, da identidade." [NOVAES, 2007: 189-190; grifos nossos]. Para além do texto ora trabalhado como base em nosso presente estudo, vários outros trazem o simul sistematizado e decorrencial de forma, notabilizando-se alguns pela explicitude nesse sentido, mormente a passagem dos Soliloquia I, 2: “Anseio por conhecer a Deus e a alma. Nada mais do que isso? Nada mais.”. Dentre inúmeras outras

${ }^{140}$ SOUZA NETTO, F. B. Tempo e memória no pensamento de Agostinho in PALACIOS, P. M. (org.) Tempo e razão - 1.600 anos das Confissões de Agostinho, São Paulo: Loyola, 2002, p. 12. 
possibilidades, a análise gramatical primeira e simples da sentença traz, de imediato, o eixo binomial relativo ao espectro componente do telos da pesquisa filosófica, cuja forma em simul como que a epigrafa enquanto leitmotiv do período inicial do pensamento agostiniano, celebrizando a condensação de todo o seu projeto inicial. Nesse sentido, Jürgen Moltmann, ao comentar as possibilidades verificadas no âmbito da história do pensamento ocidental, quanto ao conhecimento de Deus pela via da interioridade, aduz precisamente o leitmotiv agostiniano de início, ressaltando seu aspecto pioneiro nesse sentido. Comentando acerca da postura de Agostinho no texto citado, Moltmann coloca que

\begin{abstract}
O autoconhecimento não é mais um pedaço do conhecimento do mundo, mas referese exclusivamente ao conhecimento de Deus: "Ó eterno Deus, pudera eu saber quem sou eu, e quem sois vós." (Sol. I,2) [...] O sujeito torna-se imediatamente cônscio de si. A certeza de Deus é um correlato da imediata certeza de si. Tal acesso a Deus tem fundamento bíblico: o mundo é obra de Deus; o homem, porém, é a imagem de Deus. Por isso, todo homem encontra em si mesmo o espelho através do qual pode conhecer a Deus. O conhecimento de Deus na imagem que se lhe assemelha é mais seguro do que o seu conhecimento pelas suas obras. Portanto, é em Deus que reside o verdadeiro fundamento do autoconhecimento. ${ }^{141}$
\end{abstract}

De modo similar, Henrique de Lima Vaz, ao comentar no âmbito do De uera religione - texto redigido à mesma época do livro II do De libero arbitrio (cerca de 390/391 d.C.), acerca da pressuposta noção de cogito agostiniano, a este caracteriza em termos que nos trazem proximidade à nossa tentativa:

O 'cogito' agostiniano não tem [...] a evidência estática da idéia cartesiana [...] a evidência desta intuição assume um caráter dinâmico, ela opera imediatamente a passagem à Verdade transcendente [...] Ora, a Verdade transcendente, assim descoberta no mais íntimo da razão, é Deus (...) E justamente porque Deus é presença antes de ser idéia, descobrir o Deus-Verdade é necessariamente, para Agostinho, entregar-se ao Deus-Amor", 142 .

O testemunho de Romano Guardini, enfim, confirma-nos a possibilidade de leitura, no tocante à interioridade enquanto instanciar da evidência do esse em intellegere, levando em conta ainda a já citada sentença de abertura dos Soliloquia:

A interioridade agostiniana ostenta toda a força de um incomum sentimento da própria realidade e dignidade, que se enfrenta ante o restante da realidade: pensemos na frase dos Soliloquia que diz: 'Quero conhecer a Deus e à alma, nada mais'. E, sem dúvida, essa interioridade não está atada ao eu, mas encontra-se como realidade na trama de todo o real, por ele é sustentada e, por sua vez, o determina. ${ }^{143}$

\footnotetext{
${ }^{141}$ MOlTMAnN, J. Trindade e Reino de Deus, Petrópolis: Vozes, 2000, p. 28 (grifo nosso). Retomaremos adiante o texto de Novaes, quando da análise do estatuto de esse no contexto dos diálogos de início. Vide igualmente VELÁSQUEZ, Ó. La iluminación agustiniana ..., op.cit., p. 220.

${ }_{142}$ VAZ, H.C.L. A metafisica da interioridade - Santo Agostinho in ID. Ontologia e História - Escritos de Filosofia VI, $2^{a}$ edição, São Paulo: Loyola, 2001, p. 85.

${ }^{143}$ GUARDINI, R. La conversión de Aurelio Agustín, Bilbao: Desclée de Brower, 2013, p. 35.
} 


\subsection{6) Ser e exauriência}

Antes de atuar, na ascensionalidade exposta nos diálogos, como condição de possibilidade, o ser se apresenta, na concepção exposta nos diálogos do período inicial, como exaurição de possibilidades: no passo anterior, o esse se manifesta contendo sua potencialidade, mas igualmente apresentando-as em explicitude, ensejando-as e exaurindo-se em sua própria concreção, "explodindo" uma vez mais e tornando o "vácuo" ou nada, novamente presente por sua exauriência. $\mathrm{O}$ ser exaure o ser, não em devir, mas em sua própria manifestação, pois sua excedência/excelência supera o anterior, a partir de sua plenificação, dado que o posterior não ocorreria se o anterior não se exaurisse e o ensejasse, vale dizer: o anterior possibilita e enseja o posterior, somente quando este se afigura como nova concreção ensejada pelo esgotamento daquele. A feitura do posterior, bem como sua amplitude e abarcamento do anterior, são a resolução da exaurição deste: o que (acaba e) exaure no anterior, é o que (delineia e) prefigura o posterior, ou se se quiser: a exaurição prefigura e enseja a manifestação do ser, tal qual sua intelecção. A imponência da nova manifestação no vácuo de exauriência, a esta torna evidente, ou seja, o posterior presentifica o anterior. Igualmente, não se saberia o que seria o posterior, qual sua medida e amplitude, tampouco sua posterioridade em relação ao passo presente, se este não se rompesse em exaurição e irrompesse no posterior. A irrupção deste contém e abarca o rompimento e exaurição daquele. Se o sentido desta itinerância de intelecção conduzisse um ao outro não tendo por dado primordial e fudante o esse, não haveria presença exauriente, enquanto dado primordial em surgimento, que ensejasse sua excelência e superação, a partir do nada advindo de sua concreção exauriente. A exaurição advém precisamente a partir do surgimento do ser, no vácuo e no nada advindo da exaurição anterior. É em função da excelência ensejada pelo passo anterior, que podemos lançar mão da noção de exaurição, que nos parece perfeitamente decorrente do uso que Agostinho faz de excellere no texto do De libero arbitrio II. O sentido mor da excelência/ascendência interna ao trinômio axial (e, sensu major, de todo o itinerário ascensional no percurso cognitivo da realidade criatural), resulta-nos clarificado sobremaneira, ao intentarmos verificar que o ser enseja sua própria excelência e exaurição, consumando-se em ser. Porém, não nos parece que se possa concluir que haja no passo posterior "mais" ser que no anterior, contrariando aqui, portanto, a Marion e sua leitura da verdade como fenômeno de saturação do ser que se dá e presentifica, mas sim que a irrupção do posterior presentifica e impõe a ambos, em simultaneidade à exaurição do anterior (lembremos que a tríade ostenta, em seu interior, a relação de decorrência em simultaneidade essencial). A percepção da tríade, 
na sua postulação a Evódio, e em relação de decorrência e simultaneidade essencial entre seus termos, implica a imediaticidade de sua intelecção.

2.1.7) Stillae Temporis: instante, eternidade e temporalidade na elucidação de Lorenzo Mammì.

O intellegere agostiniano corresponde ao instante de contenção do anterior pelo posterior, a partir do que irrompe no nada, e à luz do qual (do nada) intentamos qualificar a instantaneidade inteleccional, enquanto cientificação em conjunto do ser-temporalidade (ou seja: consciência), como inserido na dinâmica própria da temporalidade (nadificante) inerente à exauriência do ser. Como instante, ele é atemporal (e, portanto, voltado à eternidade), o que nos remete, nesta nossa tentativa a respeito da intelecção enquanto instante de consciência relacional da alteridade receptiva ao ser, à definição trabalhada (e exemplificada pelo livro II do De libero arbitrio) por Lorenzo Mammi em seu ensaio STILLAE TEMPORIS:

Mas todo instante, como ato de uma vontade livre, inicia uma série temporal sem ter uma causa anterior necessária (cf. o Livro II do De libero arbitrio). E todo instante, enquanto união do presente da memória, presente da atenção e presente da esperança, contém em si o tempo como um todo, e é portanto uma figura da eternidade. ${ }^{144}$

É certo que nossa proximidade com a definição ocorre, num determinado sentido, de maneira formal: ao passo que Mammi aponta à instituição da seriação temporal causada pelo ato volitivo livre e atemporal, nossa ênfase recai sobre a presentificação plena e em imediação, na instituição da intelecção no momento da manifestação, nesta, do esse que se dá e surge ante o nada. A partir da temporalidade instituída livremente (e, portanto, de modo autônomo e “irruptivo") pelo ato da vontade, cuja atuação e papel serão por nós analisados adiante, a definição lapidada por Mammi detém-se justamente no instante da conjunção dos momentos na totalidade perfazida pelo tempo (figurativa da eternidade enquanto totalidade indivisa), enquanto nossa tentativa, aqui neste passo preciso da pesquisa, detém-se justamente no momento da exaurição e surgimento simultâneos e internos aos passos anterior e posterior da intelecção da realidade, na totalidade do conhecimento perfazida atemporalmente, posto que remissiva, de forma recorrente (e portanto perene), ao ser perfeito (exaurido), e simultaneamente prospectiva (e igualmente de forma recorrente) ao ser que se perfaz em surgimento. A definição de Mammi centra-se na temporalidade figurativa da eternidade, enquanto estamos, nesse ponto de nossa pesquisa, centrados na simultaneidade cognitiva da

${ }^{144}$ MAMMI, Lorenzo STILLAE TEMPORIS - Interpretação de uma passagem das Confissões, XI, 2 in PALACIOS, Pelayo M. (org.) Tempo e Razão - 1.600 anos das Confissões de Agostinho, São Paulo: Loyola, 2002, p. 61. 
imediação atemporal (domínio este que, menor, certamente converge ao âmbito maior em questão no texto de Mammi).

A referência à definição ofertada por Mammi conduz-nos a uma breve alusão à questão da temporalidade, que será tratada mais amplamente quando da abordagem, no próximo capítulo de nossa pesquisa, do De ordine. Com efeito, a digressão que ora esboçamos pode dar a impressão de estarmos próximos do pensamento hegeliano, em sua dialética processual do conhecimento, tornada ciência da mediação do saber absoluto ${ }^{145}$. No prefácio de sua Fenomenologia do Espírito, Hegel explicita que a mesma

[...] apresenta esse devir da ciência em geral ou do saber. O saber, tal como é de início, ou o Espírito imediato, é o que é privado de espírito, a consciência sensível. Para tornar-se propriamente saber, ou para produzir o elemento da ciência que é o seu conceito puro, o saber deve percorrer trabalhosamente um longo caminho. ${ }^{146}$

Por seu turno, a Ciência da Lógica tem início com a preocupação exposta por Hegel a respeito de seu princípio, a qual se converte na questão acerca do seu objeto, mas de modo oblíquo: a resposta sobre o âmbito no qual se instaura a ciência lógica revela seu proprium, tratando por conseguinte de trazer à luz seu ponto de partida:

Lógico é o início se ele deve ser feito no elemento do pensamento existente livre por si mesmo, no saber puro. Mediado ele é desse modo pelo fato de que o saber puro é a última verdade absoluta da consciência. Foi observado na introdução que a Fenomenologia do espírito é a ciência da consciência, a exposição da mesma, que a consciência tem como resultado o conceito da ciência, isto é, o saber puro. A lógica tem, por conseguinte, como sua pressuposição a ciência do espírito que aparece, a qual contém e demonstra a necessidade e a prova da verdade do ponto de vista do que é o saber puro, assim como de sua mediação em geral. ${ }^{147}$

Em contínuo, Hegel precisa o nível ou estratificação do saber no qual se opera a imediaticidade do conhecimento: "Nessa ciência do espírito que aparece parte-se da consciência sensível, empírica e esse é o saber imediato propriamente dito;..."148 E, finalizando a qualificação dos estatutos da consciência empírica $=$ saber imediato, e consciência lógica $=$ saber puro (reflexivo e, portanto, em culminância no absoluto), Hegel

\footnotetext{
145 “[...], a Fenomenologia do Espírito descreve de modo não-psicológico o 'devir da ciência em geral' (PhE, 1 25), isto é, o caminho feito de experiências sempre retificáveis, que conduz da consciência ao saber absoluto. [...] O espírito não é uma substância (a res cogitans de Descartes, [...] mas, como a própria ideia lógica, um processus: 'O desenvolvimento total do espirito não é nada mais do que seu ato de elevar-se a si mesmo até sua verdade' (Encyclopédie, 3, 379 A, 383) [...] Mas para atingir esse resultado, correspondente ao ponto de vista do saber absoluto, é necessário todo o percurso da Fenomenologia. Ele é longo e supõe a paciência do conceito celebrado pelo 'Prefácio' " - KERVÉGAN, J-F. Hegel e o hegelianismo, São Paulo: Loyola, 2008, p. 57-58.

${ }^{146}$ HEGEL, G.W.F. Fenomonologia do Espírito (Prefácio), tradução de Henrique C. de Lima Vaz, São Paulo: Abril Cultural, 1980, p. 17 (coleção Os Pensadores)

${ }^{147}$ HEGEL, G.W.F. Ciência da Lógica, seleção de excertos e tradução por Marco Aurélio Werle, São Paulo: Barcarolla, 2011, p. 51.

${ }^{148}$ Idem.
} 
define que " a lógica é a ciência pura, isto é, o saber puro em toda a amplitude de seu desenvolvimento. Essa ideia (como saber puro), porém, determinou-se até aquele resultado como a certeza que se tornou verdade..." ${ }^{149}$. Resulta-nos evidenciado que, nas definições hegelianas expostas, a ciência lógica efetiva seu desenvolvimento enquanto mediação da consciência que se conceitualiza e consuma no saber absoluto. É na totalidade como resolução - o que traduz a recapitulação operada na $a b$-solução das determinações - que se tem a "última verdade absoluta". Em Hegel, o ser resulta do - e no - pensamento absoluto enquanto tal, ao termo da processualidade dialética da realidade ${ }^{150}$. Mas, precisamente na constituição da lógica enquanto ciência da mediação do real (no saber absoluto, o que equivale a dizer, no domínio da filosofia hegeliana: no ser), é que visualizamos sua distância para com a imediaticidade da presença do esse no construto agostiniano da itinerância inteleccional da realidade universal. A temporalidade lógica, em termos de dialética processual, afigura-se a própria constituição do saber rumo ao (ser) absoluto, ao passo que, em Agostinho, o instante da consciência, na intelecção da realidade - intellegere - dá-se não processualmente, mas em simultaneidade essencial e ensejante de uma temporalidade em decorrência da prefiguração instituinte da atemporalidade. No itinerário ascensional agostiniano, a temporalidade resulta de forma perene da excelência recorrente entre os passos anterior e posterior, de modo que não se constitui um saber que se absolutiza no ser, mas sim este é que se instaura em feitura de concreção, nos passos recorrentes e perenes de uma temporalidade que se compõe, a cada instante, na retomada da presencialidade do esse pós exaurição do passo anterior. O absoluto prefigura e institui a temporalidade, e não é resultante desta ${ }^{151}$.

\footnotetext{
${ }^{149}$ Idem. Grifos nossos, dos quais Jarczyk-Labarrièrre igualmente traduzem por "le savoir pur dans toute l'ampleur de son développement." e “..., dans ce résultat-là,...”- Science de la Logique I, Paris: Éditions Kimé, 2007 , p. 51.

150 "Hegel concebe o absoluto como sendo a identidade entre a substância e o sujeito (cf. Prefácio à Fenomenologia do Espírito), ou melhor, como sendo o percurso que conduz da substância ao sujeito, porém de tal forma que a efetuação do absoluto como sujeito exponha todo este seu movimento enquanto exposição de suas diferenças, das várias etapas mediante as quais o finito é posto, ou seja, negado, superado e conservado nesta unidade logicamente superior." - ROSENFIELD, D. L. A metafisica e o absoluto in ID. (ed.) Hegel, a moralidade e a religião, Rio de Janeiro: Jorge Zahar Editor, 2002, p. 164.

${ }^{151}$ Com relação aos paralelos entre o pensamento agostiniano e a filosofia hegeliana, Manuel Moreira da Silva, dentro de certa leitura frequente nos estudos a respeito, procura estabelecer aproximação entre ambas de modo a visualizar, no primeiro, a concretização de uma filosofia do absoluto (iniciada na tradição platônica enquanto "segunda navegação") que se consuma na segunda, em que a sabedoria divina correponde ao saber absoluto atingido pela especulação filosófica, o qual une objetividade (leitura dos sinais divinos no mundo exterior) à interioridade (espírito) - SILVA, Manuel M. O problema da fundação de uma terceira navegação em Agostinho e a suprassunção da segunda navegação platônica in Síntese, Revista de Filosofia da F.A.J.E de Belo Horizonte/MG, Vol. 32, no 102 (2005), p. 39-59. O avanço no contraponto, ou mesmo nos eventuais paralelos, entre a filosofia hegeliana e o pensamento agostiniano, escapa aos termos de nossa pesquisa. Pontuamos somente, somando às considerações acima, que o desenvolvimento da Fenomenologia do espírito (cujo subtítulo, na edição de 1807, é Sistema da ciência, traduzindo a concatenação e mediação conceitual própria do construto sistemático), que Hegel define como "viagem do sensível ao absoluto", se por um lado ostenta paralelo formal
} 
Este breve delineamento de um contraponto com a filosofia hegeliana permite-nos, por outro lado, lançar luz acerca do sentido efetivo da temporalidade interna à feitura cognitiva da realidade, a ser verificada na apresentação do itinerário ascensional que terá ocasião logo adiante. Retomemos que o movimento de exauriência/presença interno à tríade axial esseuiuere-intellegere, tem por fundamento o primeiro termo; o qual, em simultaneidade atemporal, exaure-se em sua manifestação essente, por sua vez instante recepcionada e inteligida no terceiro termo. Tal movimento constitui, em realidade, uma temporalidade alinear, ou - no intencional abuso de nossa contraposição de termos - um tempo recorrente e perene, ou perenemente recorrente, numa palavra: uma presença permanente. Com efeito, teremos ocasião de verificar, a partir da exposição dos passos do itinerário ascensional, que em cada um deles a exaurição reclama e "simultaneia" a intelecção, ou, noutros termos: o passo posterior recapitula e apresenta o anterior, que o delineara e o ensejara. Nesta recorrência permanente, a razão atua internamente à constituição da feitura cognitiva da realidade, através da intelecção do dado essente, vale dizer: institui permanentemente o tempo de exauriência na qual se dá o surgimento (do esse em novo passo), o que significa dizer que a temporalidade, enquanto momento de exaurição, inexiste, ou que o tempo da intelecção - instituída, por sua vez, pela exaurição-insurgência do esse/ser - é nada ${ }^{152}$. Enquanto tal, o instante inteleccional é a medida da juris cognitiva da realidade, ou seja, atesta e estatui a realidade através da ratio, em seu passo judicativo/cognitivo. É o que tentaremos expor no decurso prosseguinte de nosso diálogo, quando da abordagem do texto presente em lib. arb. II, iii,9ss.

Após esta digressão prospectiva de nossas tentativas na continuidade de nossa pesquisa (iremos retomá-las quando da abordagem detida do texto aludido ao final do parágrafo anterior), podemos afirmar que, em suma, a certificação que permite a fundamentação e estabelecimento de níveis de excelência (superação) na ascensão intelectual da realidade, advém e, sobretudo, sustenta-se e se perfaz no esse que mostra e a torna manifesta e certíssima, estabelecendo-se a relação de convergência, senão de identidade, entre verdade e ser.

com os itinerários expostos nos diálogos agostinianos (e também com as teorizações levadas adiante pelos agostinianos escolásticos, mormente Boaventura), guarda entretanto considerável distância em relação a estes, no que respeita ao telos movente do percurso: feitura cognitiva da realidade criatural, à luz do ser supremo criador que se conhece no princípio, e se consuma no final (Agostinho); elevação da certeza sensível ao pensamento tornado conceito no saber absoluto (Hegel). "O que a Fenomenologia do espírito pretende apresentar é caracterizado em vários momentos como a ciência da experiência da consciência. [...] $O$ movimento fenomenológico da consciência é sustentado [...] por uma necessidade que só pode tornar-se consciente ou vir a ser para a consciência no fim do caminho, quando se depara com o saber absoluto e está finalmente preparada para o sistema da ciência no elemento puro do conceito." - BECKENKAMP, J. O jovem Hegel: formação de um sistema pós-kantiano, São Paulo: Loyola, 2009, p. 271-272 - grifo nosso.

152 "Pode-se dizer que ela [a questão do tempo no pensamento de Agostinho] se inscreve no espectro que se abre à questão máxima, qual seja: a que incide sobre o ser e o não-ser." - SOUZA NETTO, F. B. Tempo e memória no pensamento de Agostinho, op.cit., p. 10-11. 


\subsection{8) Ser, totalidade e atemporalidade}

Mas por que a manifestação do esse é tomado como sustentação no perfazimento da ascensionalidade, a partir da excelência que se perfaz entre os níveis ontológicos componentes da realidade sensível e inteligível? Temos um primeiro elemento responsivo já no próprio encaminhamento da exaurição da quaestio que expusemos anteriormente: a verdade imediata e indubitável, advinda do esse primordial, contempla a suspensão do juízo cognitivo aduzida por Evódio, preenchendo o vácuo por ela gerado e fazendo surgir certeza e, portanto, verdade. Nesse sentido, e à luz da tríade exposta em seguida, calcada no princípio de excelência intragradual verificado entre os seres, é possível afirmar que, ao nada decorrente do vácuo cognitivo, Agostinho postula a totalidade ontológica, o tudo do ser ensejado no esse primordial, do qual se segue a excelência extratificadora gradual da realidade dos seres do universo. Postular o ser como certeza imediata e fundante equivale a instituir (ou principiar) a explanação do universo a partir do ser como totalidade fundamentadora, a qual, a par de seu intellegere, simultâneo ao esse, é anterior à temporalidade instaurada pela atividade decorrente da simultaneidade aludida, qual seja, a intelecção universal ascensional, advinda da exauriência intragradual entre os seres inteleccionados. Numa palavra: a totalidade fundamentadora dá-se em atemporalidade, a partir da qual o simul entre esse e intellegere institui a temporalidade própria à dinâmica de exaurição inteleccional dos seres e suas possibilidades, contrapondo-se ao nada cético ${ }^{153}$. Significa ter, mediante a inquirição que recua ao nada da incerteza; e a partir de um "grau zero" ou "vácuo" de elementos cognoscíveis, a imediatez do elemento da existência pura, simples e primordial, ou seja, identidade única, total (sem divisões ou extratificações graduais); e, enquanto instituinte de uma totalidade ensejante da alteridade, ser o primeiro quanto à organicidade desta, como que ordenando todo o ser subsequente no desenvolvimento intragradual da realidade. Se o esvaziamento da quaestio conduzira Evódio à suspensão da certeza acerca do conhecimento (ainda que com a preservação do dado aceito em auctoritas, vale dizer: mantendo-se a fé), leva-o evidentemente à incognição total, nada restando que possa ser postulado como certo, o que incorre em ausência temporal. Igualmente, a certeza a ser anteposta a tal nada deve, necessariamente, conter um todo igualmente ilimitado e atemporal, noutros termos: o totum eterno, o que irá ratificar o primum datum mantido pela fé: Deus como ser eterno e absoluto. A par desta identificação entre o esse primordial e

\footnotetext{
${ }^{153}$ Émilie Zum Brunn identifica, no pensamento agostiniano, a conceituação de ser e de nada como uma dialética em termos absolutos, qualificando-a como matriz de outras relações binomiais presentes na obra de Agostinho cf. ZUM BRUNN, E. Le dilemme de l'être et du néant chez Saint Augustin - Des premier dialogues aux 'Confessions', $2^{\mathrm{a}}$ editon avec additons de l'auteur, John Benjamins Publishing, 1984, p. 9-11. Cf. BLÁZQUEZ, 2012: $135-142$.
} 
absoluto e o ser divino - cuja cristalização irá se verificar na acepção essencialista em que o texto de Êxodo 3,14 é tomado por Agostinho, caracterizando o que, a partir de Etienne Gilson, foi definido e celebrizado como metafísica do Exxodo (a qual iremos abordar adiante) - decorre, de igual modo, o paralelo com a doutrina da criação agostiniana, sobretudo com o postulado axial da atividade criadora de Deus como ex nihilo. O ser absoluto, em sua atividade criadora, enseja e faz existir os seres, os quais, por sua vez, devem sua existência à presença no (e do) Absoluto. Existir reveste-se, pois, nesta acepção oriunda do texto agostiniano, de certeza primeira e fundamento no conhecimento da verdade, enquanto idêntica ao ser, numa palavra: Deus é a verdade. O conhecimento da realidade sensível haverá, nesse sentido, de atestar a presença do ser absoluto nos diversos momentos de ensejo e manifestação do esse primordial em sua feitura de essentia ${ }^{154}$, na excelência que fundamenta a ascendência cognitiva, em feitura ou expansão criadora, abarcando a extratificação gradual componente da totalidade criatural, por sua vez ensejada totalidade eterna e manifestíssima do esse primordial, que enseja o ser a partir do nada. Importante, nesse sentido, as observações que nos traz Francisco Benjamin de Souza Netto, as quais entendemos como concordes ao espírito de nossa tentativa, mormente por contemplar o período inicial do pensamento agostiniano:

Desde os primeiros escritos nosso doutor firma posição segundo a qual o ser, no infinitivo, em acepção estrita, enão fazendo as vezes do particípio, ente, é algo que cabe tão-somente a Deus. Aliás, Agostinho ainda pertence a uma geração que não utiliza o particípio ente que ainda não fora criado quase que a 'fórceps' no interior da língua latina. [...] Deus é em verdade, como ser, o objeto da questão maior, sem a qual não se imposta nenhuma outra questão, [...]. Sem dúvida, já que se trata de questionar o tempo e a ordem deste, tal o implica o cogito, a certeza de que sou é a mais imediata. ${ }^{155}$

\footnotetext{
${ }^{154} \mathrm{Na}$ ontologia trabalhada pelos diálogos agostinianos, nossa tentativa de leitura caminha no sentido de que o esse se amplia, semanticamente, em essentia cuja presença efetiva-se na imediação da existência. Na seção seguinte de nosso estudo, trataremos do uso e preferência de Agostinho por essentia, em relação à substantia; vide SOUZA NETTO, F. B. Augustinus - Teologia da Trindade: conceitos, imagens, analogias in DE BONI, L. A. (org.) Lógica e linguagem na Idade Média, Porto Alegre: Edipucrs, 1995, p. 26-33. Nos limites do escopo de nossa pesquisa, não podemos trabalhar o histórico traditivo de transposições e vertências latinizadas acerca dos termos gregos on e ousia, para o que seria necessário abordar, além de essentia, também o fio histórico relativo à substantia. No que diz respeito às amplitudes relativas ao esse, enquanto essentia e existentia, Gilson, em $L$ 'être et L'essence, oferece-nos um denso panorama histórico a respeito de sua origem e usos na patrística latina e período tardo-medieval [GILSON, 1951: 13-22, texto ao qual retornaremos adiante, quando de nossa alusão à interpretação de Gilson acerca do conceito de ser no pensamento agostiniano inicial]. Com relação ao histórico de vertência para substantia - e seus influxos nos construtos metafísicos "substancializantes" e/ou categoriais, na esteira das tradições aristotélicas - vide COURTINE, J-F. Les catégories de l'être: etudes de philosophie ancienne et médiévale, Paris: P.U.F, 2002, p. 15ss. Importa notar, ainda, a discussão de Marion a respeito da leitura de Gilson (aludindo também à Courtine) em Note sur l'usage de substantia par sain Augustin e t sur son appartenance à l'histoire de la métaphysique in DE LIBERA, A. (ed.) Après la métaphysique: Augustin?, Paris: Vrin, 2013, p. 147-165; como também em MARION, 2008: 412-414.

${ }^{155}$ SOUZA NETTO, F. B. Tempo e memória no pensamento de Agostinho, op.cit., p. 11-12.
} 
Porém, ainda que partilhando de tal primazia do esse, e nele reconhecendo a fundamentação da ontologia e epistemologia agostinanas expostas neste ponto do De libero arbitrio, a afirmação do intellegere como excelente e superior ao esse e ao uiuere, não faz com que a atividade da intelecção se converta em matriz do conhecimento, tomando-se a evidência do autoconhecimento da razão sua própria fundamentação? Podemos efetuar uma tentativa responsiva - uma vez mais na esteira da tradição platônica que identifica o bem supremo ao ser, sendo este acessado, no espírito do Banquete, através do impulso amoroso que ascensiona a alma humana até sua esfera de participação - de verificar, nas relações que Agostinho estabelece entre a volição amorosa e o conhecimento, uma analogia quanto ao papel exercido entre esse, uiuere e intelligere. Assim como "menos, Senhor, o ama aquele que, junto com vós, ama outra coisa, que não a ama por vós"156, também é impossível qualquer conhecimento do ser finito de modo verdadeiro, sem que se imediatize sua relação ao ser supremo e absoluto, ao Vere Esse, que presentifica e imediatiza o ser, em qualquer momento ou instante de sua inteleção, tornando-o cognoscível. Somente se pode dizer e pronunciar acerca do ser finito, tendo já por escopo o ser infinito e absoluto, do que decorre ser o conhecimento do Vere Esse a própria instância fundamentadora do conhecimento do esse, ser finito e criado. Somente se ama o ser finito, amando-o no ser absoluto e eterno. Somente se conhece a realidade sensível e finita, na própria presença perene e doadora da realidade infinita e ideal. ${ }^{157}$

Antes, porém, de avançarmos quanto à funcionalidade e ao papel precípuo desempenhados pela atividade de intelecção da realidade sensível, na construção do itinerário ascensional do conhecimento - e adentrarmos, por conseguinte, na exposição do itinerário ascensional propriamente dito - torna-se fundamental ao nosso presente intento, que analisemos a conceituação do ser/esse efetuada por Agostinho no escopo amplo de nosso texto, na tentativa de verificar e minuciar seu alcance; sua especificidade dentro do quadro de referências traditivas presente neste período; e, sobretudo, se se pode justificar tomar tal conceituação como elaborada com fins propositais para uma explicitação das relações Deusser-verdade, o que, tendo em vista o pano-de-fundo de antemão delineado pela discussão acerca da argumentação comprobatória da existência de Deus, permite-nos a antecipação afirmativa, ainda que parcial, da resposta a tal quesito.

\footnotetext{
156 conf. X, 29.

${ }^{157}$ Comentando o pensamento agostiniano expresso na passagem citada na nota anterior, Tillich aduz que "Não existe nenhuma via direta de um amor ao outro, senão que a direção inerente a qualquer um que se ame é a essencial, sempre rumo [...] ao transcendente, ao que sustenta, ao amor como essência das essências, como essência sustentadora. Não podemos amar nada, se não amamos no Incondicionado." - TILLICH, P. Dogmática (Lecciones de Dresde 1925-1927), Madrid: Editorial Trotta, 2013, p. 194.
} 


\section{2) O conceito de ser nos diálogos de Cassicíaco/Milão/Roma}

Como ressaltado anteriormente, a sessão II, iii, $7-\mathrm{v}, 12$ do De libero arbitrio inicia com um pré-ordenamento com vistas à retomada do diálogo, após a culminância da sessão anterior na suspensão do juízo cognitivo efetivada por Evódio. É, pois, no intuito primeiro de responder a tal suspensão judicativa que Agostinho estabelece novas bases para a continuidade do diálogo. Porém, como visto no decurso do texto até então, as novas premissas ou reordenamentos evocados pelas viradas ou rupturas conceituais, igualmente condicionam a expansão conceitual da discussão para além de sua simples continuidade, na finalidade pretendida por Agostinho, qual seja, introduzir um novo postulado ou axioma para que a discussão, então exaurida em suas possibilidades, possa superar seu ponto estanque. Já o início do Livro II atestara tal "virada" conceitual, indicando os caminhos para a disputa que viria, então, a se esgotar nos seus elementos prévios em jogo, preparando-se para nova virada e expansão. Como igualmente fizemos notar, estas retomadas funcionam, estruturalmente, como ocasiões para remissões às inuentio de principio, fazendo com que o diálogo, a cada momento de ruptura, provoque nova retomada, através de reordenamento conceitual, dos elementos em disputa, os quais são reestabelecidos em novas bases que, por sua vez, são dispostas de modo a evidenciar a necessidade da inserção de novos elementos para sua solução, o que invariavelmente acarreta expansões doutrinais e conceituais ao curso da disputatio, ilustrandose uma vez mais o movimento peculiar da escrita reflexiva agostiniana.

Nesse sentido, após reordenar as metas da discussão quanto a 1) provar que Deus existe, para então 2) evidenciar que todo bem nele tem sua origem, finalizando com a 3) consideração acerca do livre-arbítrio como eventual bem, Agostinho efetivamente inicia por enfrentar a suspensão judicativa, asseverando que se deva partir de uma verdade indiscutível, para então localizá-la numa resposta cujo teor de imediaticidade factual é sabiamente por ele preparado na inquirição que lança à Evódio, de tal modo que este, pela absoluta evidência e caráter manifesto dos quais se reveste a resposta, recusa-se sequer a formalizá-la verbalmente, deixando claro que, pela evidência imediata da resposta na própria pergunta, esta sequer merece consideração, pelo que então solicita a Agostinho que se passe adiante, de pronto. Ora - e como também já ressaltado anteriormente - somente uma única postulação poderia, a um só tempo, fazer frente ao nada resultante da suspensão judicativa, bem como revestir-se de certeza tal que, pela ausência da mediação igualmente oriunda do vácuo cognitivo gerado pela suspensão, sua simples postulação resultasse, no imediato de sua manifestação, em verdade indubitável e fundante à possibilidade de emergência de toda outra postulação que possa advir, 
a partir de seu surgimento. E, com efeito, tal postulação se verifica no uso que Agostinho faz de esse, tomando-o como manifestamente indubitável quanto à existência concreta e factual ${ }^{158}$.

Retomando, em suma, nossa tentativa até aqui delineada, afirmamos que, face a um nada de certezas racionais, há um dado bruto verificado de pronto no questionamento do próprio questionador (ou seja: em si mesmo), de cuja concretude, imediaticidade e imponência presencial Agostinho extrai um tudo fundante às demais verdades. Esse tudo, ou fundamento essencial ao soerguimento da construção do discurso em diálogo (e aqui, devido à inserção de novos elementos, já não se trata, pois, de simples retomada, mas de nítida expansão discursiva, podendo-se mesmo qualificá-la como nova construção dialogal), fornece, a partir do esse fundante, toda a expansão nele contida de verdades que ensejam articulação do movimento de presença essente, que se exaurem no apontar à sua própria excelência (superação, conquanto compreendida no sentido de ultrapassagem engendrada ou ensejada pela anterioridade que lhe aponta). Retomemos que esse aponta à uiuere, dos quais se caminha para intellegere. A tríade tem, pois, sentido de fundamentação à (nova) instauração e expansão da discussão, então exaurida em seus termos anteriores e retomada pela pré-ordenação de seus termos novos: o trinômio axial esse-uiuere-intelligere expõe as possibilidades todas a partir das quais se caminhará na demonstração da existência de Deus, ou seja, o perfazimento do itinerário inteleccional na feitura cognitiva da realidade em culminância no summus ens, ou esse supremo e absoluto. Nesse sentido, a própria disposição sequencial dos termos e sua apresentação em consecução indica o propósito, interno à sua composição, de fundamentação e exposição da feitura essente da realidade ante um questionamento por assim dizer vital e/ou essencial, tomando-se o primeiro termo como principial e ensejante dos dois seguintes. Têm-se aqui o delineamento, na retomada com a inserção de novos elementos, de um movimento que o próprio passo retórico e a estruturação do diálogo já o evidenciava, e que, reafirmamos (no âmbito de nossa tentativa de leitura), pode ser tomado como caracterização própria do

\footnotetext{
158 Teremos adiante ocasião de aludir ao uso que Agostinho faz do neologismo essentia, em que conjuga a acepção de essencialização ao matiz de existência, presente no étimo radicial e de origem do termo. " $O$ uso de essência justifica-se pela própria definição, por ser 'o principal o primeiro e o maximamente dito' e, assim sendo, 'nem se diz de algum sujeito nem está em algum sujeito'. Além disso, mantém a ênfase grega do verbo ser, resguardando a noção platônica de participação. [...] A predileção de Agostinho pela palavra essência, que se impõe por seu significado, trazia, por outro lado, o inconveniente do neologismo. Porém, atribuído por Quintiliano a Plauto e por Sêneca a Cícero, é aceito pelo Hiponense não só pela possível precisão do termo, como pela certeza de que não está em detrimento da tradição." - GÓES, P. Essência ou substância? - A dificuldade agostiniana ao falar de Deus in Caminhando, Revista da Faculdade de Teologia da UMESP, Vol. $07, n^{\circ} 02$ [10], 2002, p. 132. Góes cita ainda, junto à fontes acima, Hilário de Poitiers, de cujo De trinitate haure Agostinho, segundo o autor, uma das vertentes para a leitura de Êxodo 3,14. "Quando Agostinho se engaja na polêmica trinitária, já a tradição latina incorporara e precisara o termo substância ao enunciado do dogma e à possível solução das interrogações que suscitava. Ele há de preferir-lhe a palavra essentia,..." - SOUZA NETTO, F.B. Augustinus - Teologia da Trindade: ..., op. cit., p. 26. Cf. GILSON, 1951: 13-22; MARION, J.L. Note sur l'usage de substantia par sain Augustin..., op.cit., p. 153-157.
} 
pensamento agostiniano: a simultaneidade essencial que postula, no início do discurso filosófico, o dado imediato a ser encontrado e demonstrado em seu final. O esse primordial e fundante, na totalidade por assim dizer peticionada ou predisposta pela suspensão judicativa anterior, preenchedor do nada cognitivo gerado no interior da discussão, é o esse ao qual a razão, enquanto expressão ordenada discursivamente, da realidade ordenada ontologicamente e no recolhimento em feitura interna dos sinais externos, é teleologicamente ordenada. Assim, importa verificarmos a amplitude que o uso de esse assume, no contexto de composição do De libero arbitrio e nos textos que lhe são paralelos e contemporâneos, para nos certificarmos de que, a partir do conceito de esse, dá-se ou enseja-se a feitura cognitiva do universo, componente do itinerário de intelecção rumo a Deus, evidenciando que este itinerário compõe a mosaicização do esse primordial no esse final, através da expressividade dos sinais que, na exterioridade dos dados que se manifestam (aparecem, ensejam-se), são recolhidos na interioridade que perpassa e intersecciona, em simultaneidade, o esse primordial - já surgido e exposto perenemente ao exercício intelectivo - ao esse ensejado e manifesto pelo dado anterior. Nesse sentido, a análise de Paula Oliveira e Silva parece-nos fundamental, numa feliz sumarização das relações atinentes aos estatutos de cada um dos elementos em pauta:

\begin{abstract}
A afirmação de que o conhecimento de si está implícito em todo o acto de julgar é ponto de partida para a auto gnose, já em Soliloquiorum e, em De líbero arbitrio, torna-se início do itinerário de mostração da existência de uma noção óptima, identificada com a ideia de Deus, sem a qual Sto. Agostinho esclarece que a razão não pode exercer a sua actividade própria: julgar. A interrogação "cogitare te scis?", que em Soliloquiorum é já uma certeza irrefragável, alcança, em De libero arbitrio, um nível de certeza ainda mais radical: scio me esse - sendo um facto que esta apreensão do ser é inseparável da percepçao da forma específica, no caso, da própria existência como vida racional - scio me esse, uiuere, intellegere. Esta dedução, na sua brevidade, supõe, para Sto. Agostinho, a afirmação do conhecimento implícito que todo o ser humano tem de si mesmo, precisamente quando exerce a actividade que $o$ caracteriza, definindo, por isso, o lugar que tal expressão de ser ocupa na hierarquia ontológica. - OLIVEIRA E SILVA, 2007: 265-266 (grifos nossos).
\end{abstract}

A afirmação da implicitude do conhecimento de si repousa, segundo Oliveira e Silva, na própria antecipação da presença e primordialidade da "apreensão do ser", ensejando o itinerário de perfazimento intelectual da realidade como "mostração ... da ideia de Deus", sendo que a própria atividade da vida racional compreende sua inseparabilidade para com a apreensão do esse conjuntamente ao seu autoconhecimento, o qual, em sua "certeza radical", apreende as relações de decorrência interna à tríade em implicitude de postulado. 


\title{
2.2.1) As tríades conceituais no período inicial.
}

As tríades, ou trinômios conceituais, marcam forte presença nos diálogos do período Cassíciaco/Roma ${ }^{159}$. A partir de tais trinômios, Agostinho estrutura toda a feitura e composição de uma discussão, ou uma sua retomada conjugada às redefinições conceituais e, no exercício de tal funcionalidade discursiva, clarifica-se que suas funções ultrapassam a mera estruturação cursiva do diálogo, para se revelarem como eixos fundamentais às linhas de execução do percurso cognitivo da realidade, como que fornecendo os campos de atuação à ratio e sua visualização, atuando como motes em torno dos quais se exercita a intelecção do universo. Eles delimitam e apontam o sentido de caminhada, feitura ou percurso de conhecimento, fornecendo-lhe antecipadamente o itinerário a ser perquirido, concretizado e sumarizado pela ascensão intelectual da ratio até o absoluto. Claudio Moreschini afirma que

\begin{abstract}
a missão do cristão, portanto, é a de encontrar essas estruturas [triádicas/trinômicas] para subir até a [estrutura] fundamental [Trindade]. Essa concepção é, porém, um método de pesquisa, mais que um resultado a que o escritor chegou: Agostinho, com efeito, repropõe várias tríades em suas obras, ou as entrelaça, sem se limitar a uma só.- MORESCHINI, 2008: 466 (grifo nosso)
\end{abstract}

Observa-se que a caracterização, por parte de Moreschini, da tríade como pressuposto metodológico ao início do itinerário ascensional do conhecimento, reafirma a anterioridade ou, antes, a preeminência - da emergência da percepção de sua fundamentação triádica, o que significa, nos termos de nossa tentativa presente, visualizar o esse enquanto manifestação imediata que se constitui na verdade primeira e fundante da feitura cognitiva da realidade criatural, posto que o uiuere e o intellegere surgem em torno ao ser. O ser se manifesta enquanto a realidade primeira, na sua instituição como dado primordial à intelecção; do que resulta afirmar, à vista de nossa tentativa, a imediação da emergência do intellegere em Agostinho, instituinte por sua vez da temporalidade, a qual (veremos adiante) se revela como o movimento de excelência, interno à estrutura triádica ensejante da realidade e que, por conseguinte, perpassa toda a gradação ou os passos constituintes do percurso de ascensão intelectiva do real, resultando, termo final, no nada ante o qual manifesta-se o ser, sequência esta recorrente em todo o percurso, tornando-o menos evolução ou hierarquização, e mais expansão em abarcamento.

${ }^{159}$ Embora não discrimine o uso por obras, tampouco por período histórico de sua produção, o index do sítio www.augustinus.it lista 108 ocorrências da tríade ora em questão (ser-viver-inteleccionar), as quais, seguramente, ocorrem predominantemente nos diálogos da fase inicial do pensamento de Agostinho. Cf. COUTINHO, Jorge Trilogias agostinianas: tríades e dinâmica ternária em Santo Agostinho in Theologica, Revista da Faculdade de Teologia da Universidade Católica Portuguesa (Braga), 2a. série (47), II, 2012, p. 497-508; e OLIVEIRA E SILVA, 2007: 260-261 e 265-278. 
Anne-Isabelle Bouton-Touboulic situa a tríade axial dentro do influxo traditivo neoplatônico no qual se move Agostinho. Após repassar, alusivamente e à luz da abordagem levada a efeito por P. Hadot [2010: 127-157], a presença da tríade já nos escritos platônicos (Sofista 248e); bem como ressaltando, no tocante a Plotino, que a plenitude do ser ocorre como posse simultânea da tríade pela segunda hipóstase (relembrando ainda que a causalidade da tríade reside no Uno) - do que resulta a estruturação hierárquica de toda a realidade -, BoutonTouboulic nota que "a hierarquia dos seres [em Plotino] corresponde à distinção e à gradação de suas qualidades, as quais são uniformes no ser perfeito" [BOUTON-TOUBOULIC, 2004: $120]^{160}$. A caracterização da hierarquia em Plotino termina com a observação de que esta encontra-se "integrada à doutrina platônica dos degraus do ser, segundo uma lógica de 'compreensão crescente" [2004: 121]. A breve exposição da hierarquização plotiniana da realidade sinaliza para o aspecto central trabalhado por Bouton-Touboulic na apresentação do tema em Agostinho:

\begin{abstract}
A funcionalidade da tríade esse-uiuere-intellegere é levada a efeito por gradação e por implicação, e Agostinho herda este duplo princípio [...] Seu funcionamento oferece suporte à coerência e à unidade da hierarquia fundada sobre esse-uiuere-intellegere, pois ela não resulta de uma justaposição das partes, mas sim de uma combinação destas três determinações, de modo que os degraus superiores 'recapitulam os degraus inferiores' - BOUTON-TOUBOULIC, 2004: 121
\end{abstract}

Ressalte-se que, para a autora, também o movimento interno à ascensão intelectual compõe, em Agostinho, uma expansão do inferior no superior, embora tal expansão ocorra como em Plotino - na espiral de elevação ontológica em que os graus correspondem à "distinção e à gradação das qualidades" dos seres. Contudo, Bouton-Touboulic observa, a seguir e com base em lib. arb. II, iii,7, que esta expansão recapituladora própria de Agostinho "se manifesta em uma das primeiras aparições da tríade nas obras [agostinianas], onde a presença simultânea ao homem destas três propriedades em implicação mútua ocorre com base na evidência do cogito" [2004: 121-122]. Ora, impõe-se de per si a observação quanto à relação de implicação sublinhada por Bouton-Touboulic, no tocante à disposição da tríade ao intelecto humano e, mormente, quanto à sua ocorrência por ocasião do emergir do cogito. Nesse sentido, a intuição do intellegere como que ilumina a percepção da tríade em sua simultaneidade essencial. Para além de uma discordância quanto ao sentido ou vetorialização nossa pesquisa caminha na tentativa do vetor contrário: é a simultaneidade essencial e imediata que possibilita a emergência do inteligir a realidade a partir do esse fundamental - importa-nos,

\footnotetext{
160 “La hiérarchie des êtres correspond à la différenciation et à la gradation de ces qualités qui sont unies dans l'être parfait.". Tal caracterização, ainda que fortuita dentro do conjunto da exposição da autora, permite - mesmo que involuntariamente - a percepção de que Bouton-Touboulic visualiza, já na herança neoplatônica de Agostinho, o primado do ser face aos outros termos da tríade axial.
} 
por ora, o relevo conferido pela autora à relação tríade axial-cogito na imediatez de sua ocorrência mútua, no que convergimos em nossa tentativa exposta anteriormente. De igual modo, e não obstante iniciar seu estudo acerca da percepção cognitiva no De libero arbítrio II, definindo a tríade como essencialmente hierárquica, Gerard O’Daly qualifica entretanto as relações internas aos termos triádicos como evidência de pronto:

\begin{abstract}
A hierarquia existência-vida-inteligência [...] é postulada como série ascensional autoevidente: seres inanimados, bem como animais e homens, existem; animais e homens são seres vivos; o homem tem inteligência [...]. Animais e homens igualmente podem ter percepção com seus sentidos, e ambos possuem sentido interior, o qual coordena, julga e atenta para a atividade ou inatividade dos sentidos externos. Mas somente quando aquilo que os sentidos percebem excede o sentido interno, pode ser chamado de conhecimento. [...] Conhecimento é, por definição, racional... - [O'DALY, 1987: 178 - itálicos nossos]
\end{abstract}

A caracterização da decorrência das relações internas à tríade como serial, bem como o reconhecimento de sua imediaticidade enquanto autoevidência da gradação ao espírito, parecenos atestar que a análise de O’Daly converge, topicamente, à nossa presente tentativa de leitura dos diálogos agostinianos. Note-se igualmente que o caráter de autoevidência aponta para o simul entre sua apresentação (ou seu dar-se) e sua percepção, compondo pois, nos termos de nossa pesquisa, um único e mesmo surgimento. Há que se notar, ainda, que a própria ascensionalidade intelctual, enquanto exercício envolto no ato judicativo em interioridade (sentido interior e razão), pelo qual se julga a superioridade de um grau em relação ao anterior, é manifestamente evidente à própria adjudicação, o que aponta para a imediaticidade do ato judicativo, em sua intelecção ascensional, ante a primordialidade do esse e sua exauriência e excelência na série autoevidente.

Igualmente, a análise de Paula Oliveira e Silva parece-nos caminhar e ratificar tal sentido da tríade, bem como a primordialidade do esse no interior, a partir da qual opera-se sua intelecção no próprio ato de dar-se e presentificar-se ao conhecimento da razão:

Esse, uiuere, intellegere, na gradação importada por Agostinho do neoplatonismo, são
as primeiras certezas incontestáveis descobertas como propriedades indissociáveis do
cogito humano [...] O Hiponense irá desenvolver o dinamismo destas propriedades da
mente humana em De trinitate, insistindo na unidade de uma mesma essência que
subjaz a esta tríplice actividade do espírito. [...] O cogito augustiniano, na dimensão
máxima de desojamento de si, não cria realidade, mas apenas descobre um domínio
de actividade, que se traduz numa anterioridade do ser e do agir sobre a constituição
da própria forma do ser humano e, por conseguinte, do próprio exercício do pensar,
sendo tal anterioridade de conteúdos uma nota característica da natureza da mente.
Por seu turno, essa anterioridade reenvia a mente para a descoberta de uma realidade
suprema que é causa do seu ser e agir específicos. - OLIVEIRA E SILVA, 2007:
260-261.

Constata-se que os trinômios axiais atuam como estruturas pressupostas ao decurso prosseguinte do diálogo, perfazendo uma vez mais o aludido movimento de ensejo do real, 
próprio ao dar-se primordial do esse: do primeiro ao terceiro termo, de forma permanente, dentro do qual este último recebe do primeiro sua postulação e ensejo, ao mesmo tempo que o consuma e engloba. Tal movimento intrínseco revela-se, como sobejamente notamos no decorrer de nossa pesquisa, na atuação em simultaneidade de base, verificada nas relações polares binomiais e/ou nas estruturas trinômicas, as quais Agostinho estabelece como vértices conceituais na feitura do discurso estruturado que, por sua vez, reflete o viés da estruturação feitural do conhecimento da realidade, levada a efeito pela intelecção manifestada pela ratio.

\subsection{2) Amplitude do uso de esse nos diálogos agostinianos: exposições de análises}

Usualmente reservadas aos grandes tratados da fase de maturidade, as análises e pesquisas sistemáticas acerca da ontologia agostiniana e, mais especificamente, sobre o conceito de ser no pensamento de Agostinho, apresentam-no como conjugado ao exame de sua epistemologia e da ética eudaimonística. A seguir, intentamos apresentar análises contemporâneas que, não obstante tão-somente tangenciarem, em alguns autores, o período inicial da reflexão agostiniana, centram-se contudo, em outras pesquisas, nas obras deste período, reconhecendo neste a presença de teorizações e conceituações já explicitadas quando a uma ontologia trabalhada em torno da noção de esse. Iniciaremos pela apresentação de autores contemporâneos, próximos ao nosso âmbito de pesquisa, sobretudo os estudos pós-gilsonianos (em torno à celebrização e discussão da metafísica do Êxodo), para em seguida finalizar com a perspectiva de estudos recentes.

1) Paul Gilbert - Jean-Luc Marion. Em seu tratado de ontologia, Gilbert apresenta a noção de ser trabalhada por Agostinho no De libero arbítrio, no contexto de sua abordagem acerca da hierarquia de atos de ser, caracterizando-a como exemplo de descrição de uma "hierarquia dos entes assumindo uma perspectiva formal, agrupando esses entes em conjuntos cada vez mais universais, mas distantes da realidade feita de singularidades." [GILBERT, 2005: 139-140] Embora condicionada por esta visão de fundo, em que se pretende o contraste entre uma compreensão do ser definido como forma geral ou formalizante, e outra que o conceitua como $a t o$, a exposição de Gilbert ostenta precisão acerca da visão agostiniana em seu período inicial:

Uma tal ordenação dos entes em espécies e em gêneros resulta do trabalho da inteligência que exige uma unidade capaz de englobar tudo o que ela examina. [...(Tal ordenação)] se inspira no Do livre-arbítrio de Santo Agostinho, que ordena o universo falando do gênero mais universal, do ser, passando pela vida e indo na direção da espécie mais determinada, o pensamento. Para pensar, com efeito, é preciso viver e ser; para viver, é preciso ser, mas não é necessário pensar; para ser não é indispensável viver ou pensar." [GILBERT, 2005: 140 - grifos nossos] 
A despeito de certo influxo aristotélico na apresentação, em que a ordenação parece assumir a feição taxonômica da realidade, com a classificação em grupos de semelhança e universalização, Gilbert apresenta o exercício da intelecção da realidade de modo fiel ao intento agostiniano, tal como intentamos apresentá-lo em nossa leitura. Efetivamente, o percurso cognitivo, via intellegere, manifesta a necessidade de abarcamento da realidade, na qual possa "englobar tudo o que ela examina" numa visão unitária e ordenada. Sobretudo, porém, Gilbert parece-nos captar com fidelidade a funcionalidade interna à tríade ser-viverinteleccionar, própria do conceito de ser de Agostinho, pela qual este ultrapassa quaisquer limitações, bem se situa na base de toda especificação e determinação dos seres, não tendo de per si "nenhuma determinação, como um gênero supremo". E, ao explicitar seu posicionamento crítico em relação à conceituação agostiniana, Gilbert faz avançar sua exposição até apresentar uma definição acabada, que em realidade lança mão da definição de ser tornada clássica ao longo da história da metafísica ocidental:

\footnotetext{
Mas se se entende assim o ser como o que não tem nenhuma determinação, como um gênero supremo sem nenhuma especificação, o inteligível mais unificador será o oposto das substâncias concretas, tal como o ens pauperrimum obtido pela subtração de todas as determinações que poderiam precisá-lo. [(GILBERT, idem]
}

Torna-se claro que Gilbert visualiza, no conceito de ser exposto no De libero arbitrio, sua definição como gênero, tomando-o - sobretudo na finalização de sua apresentação - como protótipo da clássica definição do ser como o conceito mais universal e indeterminado de todos (ens pauperrimum), trabalhada por boa parte dos autores do medievo ${ }^{161}$. Ora, precisamente pelo esforço em classificar a conceituação agostiniana como parte das definições "formalizantes" verificadas ao longo da história da metafísica, é que Gilbert terminou por captar com precisão a funcionalidade do esse, no escopo da tríade em questão: o ser como pressuposto necessário - e portanto ensejante - do viver e do entender (“para pensar, é preciso viver e ser; para viver, é preciso ser, mas não é necessário pensar; para ser não é indispensável viver ou pensar"). Em relação de decorrência interna e simultânea, a intelecção atua teleologicamente voltada à captação e percepção do primeiro termo, que lhe condiciona em seu próprio exercício (“o inteligível mais unificador será o oposto das substâncias

\footnotetext{
${ }^{161}$ Cf., entre outros, a definição adotada por Tomás de Aquino na Summa Theologiae, I, 1, 2, q. 13, art. 11. A crítica de Gilbert decorre do fato de retomar, como referencial teórico de base na construção de uma ontologia própria, bem como na leitura da metafísica ocidental ao longo de seu tratado A paciência de ser, a crítica heideggeriana tecida em relação a esta tradição [GILBERT, 2005: 12-29], na qual o pensamento agostiniano é tomado como um dos momentos de perda da ontologia fática do cristianismo primitivo, decaindo-se para a teologização, a qual compõe um dos "esquecimentos" do questionamento do ser - vide ARRIEN, S.J. L'inquiétude de la pensée: l'herméneutique de la vie du jeune Heidegger (1919-1923), Paris: P.U.F., 2014, p. 270-355; MAC DOWELL, J.A.A. A Gênese da Ontologia Fundamental de Martin Heidegger, $2^{\mathrm{a}}$ edição, São Paulo: Loyola, 1993, p. 13-35.
} 
concretas"). Com efeito, a crítica de Gilbert permite-nos uma percepção que, não obstante seu esforço em desautorizar a validade da construção agostiniana ${ }^{162}$, revela-se em verdade como antítese à sua classificação de Agostinho, na esteira de sua herança heideggeriana, enquanto partidário de uma ontologia na qual a consideração dos entes "os empobrece em formas mentais e conduz ao esquecimento da realidade dos existentes" [GILBERT, 2005: 141]. Esta percepção aponta, ainda que involuntariamente, para a primazia do esse, tomado na acepção de existência manifesta de per si e imediata, em relação ao princípio anímico e em relação à inteligibilidade como atuação da ratio. Parece-nos não haver dúvida quanto ao caráter primordial, fundante e autoevidente manifesto pelo ser, na feitura intelectiva do universo, efetivada a partir da tríade que o De libero arbitrio postula como estrutura axial ao início do percurso de ascensão cognitiva da realidade. E, ao contrário da postulação de Gilbert, intentamos evidenciar, em nossa presente pesquisa, que o conceito agostiniano de ser trabalhado nos diálogos do período inicial leva em conta, como dado inalienável, justamente a "brutalidade" da existência manifesta como ser, como existência que é indubitável, imediaticidade ensejante de toda mediação de sua captação intelectiva, terminando por ensejar e compor a essentia do universo, aspecto este captado com precisão por Gilbert (que praticamente transforma Agostinho no criador do conceito de ser matizado como universal e indeterminado), ainda que no contraponto da inclusão de Agostinho em sua crítica à onto(teo)logia ocidental.

Herdeira, tal como a leitura de Gilbert, da intepretação heideggeriana acerca da constituição onto-teo-lógica da metafísica ocidental, a análise de Jean-Luc Marion distancia-se porém desta, ao intentar visualizar nos textos agostinianos, mormente nas Confessiones, e na esteira da fenomenologia de origem husserliana, um pensamento que recua, por assim dizer, ao extrato pré-metafísico do pensamento, com o fito de constituir uma "não-ontologia"163 na qual

\footnotetext{
${ }^{162}$ Em outro texto, Gilbert acentua sua avaliação crítica a respeito da exposição de esse no De libero arbitrio: "significado pobre, mínimo, até mesmo mineral. [...]" - GILBERT, P. "Eu sou aquele que serel" - Deus: da sarça ardente às aventuras da razão in MIES, Françoise (org.) Bíblia e filosofia: as luzes da razão, São Paulo: Loyola, 2012, p. 28-29. Nesse aspecto, a exemplo de Marion [capítulo VII de seu Au lieu de soi: 2008: 389-414, embora seja contrário a Gilbert, vislumbrando o valor da exegese agostiniana precisamente em sua nãometafísica, ou "ontologia sem ser"], Gilbert chega a contradizer a possibilidade de uma "metafísica do Exxodo" na conceituação agostiniana: "Nessa perspectiva, a palavra 'ser' tem um sentido evidentemente muito mais pobre do que aquele proposto em Êxodo 3,14." [Idem, ibidem]. É precisamente na tentativa de confirmar a primordialidade noção de ser, presente nos diálogos de início, que caminha nossa pesquisa, mas no matiz por assim dizer fenomenológico, próximo ao de Marion, ao intentar verificar no construto agostiniano, na imediaticidade da presença do esse, as presenças simultâneas da existentia e da essentia no engendramento da mediação intelectiva da realidade universal.

163 "Nous avons ailleurs tente de lire [...] saint Augustin comme um penseur assez prémétaphysique pour jouer, aujour-d'hui, le role d'um penseur postméthaphysique."- MARION, J.-L. Note sur l'usage de substantia par sain Augustin et sur son appartenance à l'histoire de la métaphysique in DE LIBERA, A. (ed.) Après la métaphysique: Augustin?, Paris: Vrin, 2013, p. 149. Na nota 6, Marion remete ao capítulo VII de Au lieu de soi,
} 
é postulado que Agostinho "não pensa Deus como ser, a fim de não fazer do ser um deus"164. Com efeito, Marion procede através da análise, nas obras agostinianas, de Idipsum e sua relação com a passagem escriturística de Ex 3,14 com a revelação do nome de Deus, para ressaltar que a interpretação celebrizada por Étienne Gilson como “metafísica do Êxodo" (vide o próximo item de nosso estudo, dedicado a Gilson), não encontra sustentação em Agostinho. Após precisar que a tradução agostiniana de to auto por idipsum preserva a apofaticidade de sua revelação, permitindo "de-nominar sem pretender definir" [MARION, 2008: 404-407], Marion estabelece o que propriamente constitui seu sentido, e portanto do (não)ser de Deus:

O ponto essencial encontra-se firmado no estatuto e na função da imutabilidade. Pois, reproduzido em Idipsum, o esse agostiniano se encontra a cargo da imutabilidade. Quando surge para denominar Deus, o esse designa sobretudo o imutável "Esse, nomem est incommutabilitatis" (Sermão 7,7). A diferença entre o imutável e o movente perfaz uma diferença indiretamente ontológica, respectiva aos modos de ser do ente, e organiza os entes em totalidade a partir de uma distinção sobremodo originária: a distinção entre criatura e Criador. [...] Pois, dado que Deus é essência suprema, ou seja, ele é sumamente e, por conseguinte, imutavelmente, ele pois doa o ser às coisas que criou do nada. [...] A hierarquia dos seres [...] se lê e se traduz nos degraus da hierarquia da imutabilidade, muito mais que em termos estritamente ontológicos [...] De maneira que, [...] a eternidade depreende-se do ser de Deus, entre outras propriedades [...] Aeternum determina esse, e não o contrário. A via de santo Agostinho não deixa dúvidas: Êxodo 3,14 não leva ao ipsum esse, nem pois a uma "metafísica do Exxodo", [...] L’idipsum permite pensar a diferença entre Deus e sua criação sem passar por uma diferença ôntica, sem inscrevê-lo no horizonte do ser MARION, 2008: 409- (grifos nossos). ${ }^{165}$

A clareza da escrita de Marion não permite dúvida alguma quanto à sua interpretação não-ontológica de Deus "sem ser", precisamente na medida em que toma a peito a primordialidade da revelação de Deus e sua relação para com a criação. Ao "esvaziar" o ser de

no qual analisa Idipsum em Agostinho, esclarecendo que "un de nos arguments adjacents tenait au sens non ontologique du terme idipsum, inventé par saint Augustiin pour tenir le role de nom (strictement déictique) de Dieu, ..." (idem).

164 “Car même lorsqu'il use parfois de l'ipsum esse, jamais saint Augustin ne s'inquiète de l'être. Il se pourrait qu'il fasse, avec d'ailleurs beaucop d'autres, exception à règle peut-être imprudemment fixée par É. Gilson: 'Il n'y a qu'um Dieu et ce Dieu est l'être, telle est la pierre d'angle de toute philosophie chrétienne.' Car saint Augustin, chrétien par excellence et qui pense, ne pense pás Dieu comme être - afin de ne pas faire de l'être um dieu." - MARION, 2008: 414. Cf. ainda a nota breve acerca do pensamento agostiniano em continuidade à ontoteo-logia metafísica em seu Dieu sans l'être, 3a. éditon, Paris: P.U.F., 2010, p. 109-110.

165 “Le point essentiel réside maintenant dans le statut et la fonction de l'immutabilité. Lorsque l'esse surgit pour dénomer Dieu, il le désigne aussitôt comme l'immuable: 'Esse, nomen est incommutabilitatis'(Sermon 7,7). La différence entre l'immuable et le mouvant devient une différence indirectement ontologique, celle des manières d'être de l'étant, et organise l'étant en totalité à partir d'une distinction, aussi originaire, voire plus originaire la distinction du crée et du Créateur. [...] Car, puisque Dieu est essence suprême, c'est-à-dire qu'il est suprêmement et donc immuablement, il a donné l'être aux choses qu'il a crées du néant, [...] La hiérarchie des étants [...] se lit et se traduit dans les degrés de la hiérarchie de l'immutabilité, plutôt qu'em termes strictement ontologiques. [...] Au lieu que, [...] l'éternité s'ensuive de l'être de Dieu, entre autres propriétés [...] Aeternum détermine esse, et non l'inverse. La démarche de saint Augustin ne fait plus de doute: Exode 3,14 ne conduit pás a l'ipsum esse, ni donc à une 'métaphysique de l'Exode' [...] L'idipsum permet de penser la différence entre Dieu et sa création sans passer par une différence ontique, sans l'inscrire dans l'horizon d'être." 
Deus de sua substancialidade e determinação ${ }^{166}$, Marion em realidade pretende subtrair qualquer possibilidade de determinação e, portanto, identidade e mudança. Deus está para além do ser, na medida em que este constitui uma sua doação, e enquanto evento e presença, encontra-se em mutabilidade e temporalidade ${ }^{167}$. Precisamente a imutabilidade e a eternidade assim o veremos em nosso capítulo 4, itens 4.1, 4.5 e 4.6 - irão compor o cerne da argumentação agostiniana quanto à relação entre a realidade absoluta e transcendente, e a razão que a esta busca e para tal ascende.

2) Étienne Gilson. A possibilidade de se verificar ambas as noções - existencial e essencializante, aludidas na exposição de Gilbert - como conjugadas, e mesmo conexas dentro da amplitude de significação de esse, se fará presente na análise procedida por Gilson, em seu estudo dedicado ao pensamento agostiniano, publicado inicialmente em 1929 e melhor compreendido tendo em vista o pano-de-fundo do debate no qual se insere. Com efeito, à luz da discussão então em voga, decorrente do questionamento acerca da possibilidade de uma autêntica filosofia cristã ${ }^{168}$; bem como acerca das vias de refundamentação da ontologia pósHegel próprias das abordagens fenomenológico-existenciais, Gilson trabalha a presença da metafísica no período medieval, em contraponto aos períodos moderno e contemporâneo, tendo precisamente a polaridade existência/essência como o eixo condutor na análise comparativa entre os construtos metafísicos tornados clássicos. Na consecução desta tarefa, Gilson opera com a pressuposição fundamental - presente nas suas exposições histórico-sistemáticas, bem como nas monografias dedicadas a autores cristãos do medievo - de ser a metafísica inerente ao pensamento cristão, correspondendo aliás à sua aspiração máxima. Nesse sentido, Gilson cunhou e/ou celebrizou expressões referentes a filósofos da fé cristã: metafísica da interioridade (em que retoma e aperfeiçoa a expressão criada por Wilhelm Windelband), e

\footnotetext{
166 "Aussi bien saint Augustin ne maintient-il justement pas substantia comme um concept adéquat pour designer Dieu, mais lui prefere-t-il, malgré as nouveauté, le quase-néologisme d'essentia...”- MARION, J.-L. Note sur l'usage de substantia par sain Augustin et sur son appartenance à l'histoire de la métaphysique, op.cit. , p. 152. Acerca da interpretação marioniana de Agostinho, vide FALQUE, E. Après la métaphysique? Le "poids de la vie" selon Augustin in DE LIBERA, A. (ed.) Après la métaphysique: Augustin?, op.cit., p. 111-128. Uma discussão crítica a respeito é fonecida por Lorenz PUNTEL em seu tratado Ser e Deus: um enfoque sistemático em confronto com M. Heidegger, É. Lévinas e J.-L. Marion, São Leopoldo: Editora Unisinos, p. 357-363.

${ }^{167}$ Também Niceto Blázquez apresenta o conceito de ser no pensamento agostiniano, à luz da imutabilidade: " $E m$ termos absolutos, as substancias criadas não são, mas ao mesmo tempo não se pode dizer que não sejam. Não são na medida em que Deus é. Mas são, na medida mesma em que dele procedem. [...] Toda mudança faz não ser o que antes era, pelo que se infere que somente Deus verdadeiramente é, devido à sua imutabilidade. Neste sentido, ao Sumo Ser opõe-se o não-ser." - BLÁZQUEZ, 2012: 135.

${ }^{168}$ Do debate em torno da autenticidade da filosofia cristã - sobretudo com Émile Bréhier - resulta, entre outros textos e exposições de Gilson, uma série de preleções a respeito, levadas a público por ocasião do convite para pronunciá-las nas Gifford Lectures da Universidade de Abeerden em 1931, e reunidas em L'esprit de la philosophie médiévale, publicado no ano seguinte [GILSON, 2006].
} 
metafísica da conversão ${ }^{169}$, aplicadas a Agostinho; metafísica da mística, referente à Boaventura; e, sobretudo, uma definição ofertada numa notação circunstancial e alusiva que, entretanto, viria a se tornar referência de pleno a todos os desenvolvimentos posteriores acerca da natureza e do alcance do pensamento metafísico cristão: metafísica do Exxodo, referente à passagem escriturística de Ex 3,14, fonte para uma exegese de caráter filosófico presente em todos os autores tardo-medievais que se dedicaram ao construto ontológico ou metafísico ${ }^{170}$. Tais expressões confirmam a centralidade, trazida ao relevo pela análise tornada referencial por Gilson, da aspiração metafísica em praticamente todas as filosofias de inspiração cristã.

Neste contexto, Gilson publica a segunda edição de sua Introdução ao estudo de Santo Agostinho em 1942, com revisões e ampliações já decorrentes da cristalização da noção de uma metafísica cristã inspirada pela exegese do texto de Êxodo 3,14 (além, evidentemente, do avanço promovido pelo debate a respeito) ${ }^{171}$. Neste estudo, Gilson aborda o itinerário da alma para Deus em sua constituição probatória da existência de Deus, situando-se portanto no contexto dos diálogos do período inicial agostiniano. Após a observação inicial de que "as provas agostinianas da existência de Deus se desenvolvem muito mais no plano da essência do que no plano da existência" [2007: 52], Gilson assevera-nos que

Elas [as provas] partem [...] da observação de algumas maneiras de ser das quais se busca a explicação última num ser cujo estatuto ontológico [...] é o único capaz de prover-lhe a razão. [...] Santo Agostinho pensa menos sobre a existência do que sobre o ser, [... (e)] quis sobretudo colocar em evidência a necessidade que se impõe ao pensamento de exprimir o ser bastardo que se oferece para nós na experiência por um supremo Vere Esse, ou seja, por um ser plenamente digno do título de ser. [...] o Vere Esse é o que Agostinho nomeia essentia,... [2007: 52-53 - grifos nossos]

\footnotetext{
${ }^{169}$ GILSON, 2006: 180.

170 "Não se trata naturalmente de sustentar que o texto do Êxodo oferecia aos homens uma definição metafísica de Deus; mas se não há metafísica no Exxodo, há uma metafísica do Exxodo, que se constitui bem cedo entre os Padres da Igreja, cujas diretrizes sobre esse ponto os filósofos da Idade Média apenas seguiram e exploraram." [GILSON, 2006: 67 (n14)]. Um dos mais sugestivos contrapontos à conceituação de Gilson foi fornecido por P. Hadot no seu Dieu comme acte d'être. À propôs des théories d'Étienne Gilson sur la 'métaphysique de l'Exxode' in HADOT, P. Plotin, Porphyre: études néoplatoniciennes, op.cit., p. 117-122 (originalmente publicado em 1980). Também Marion, como já o notamos, discute, no capítulo VII de seu Au lieu de soi, a aplicação da definição gilsoniana a Agostinho, trazendo em seu bojo, a exemplo de Gilbert, a crítica heideggeriana ao esquecimento do ser por parte da onto-teo-logia ocidental, da qual a "metafísica do Êxodo" seria exemplo: MARION, 2008: 389-414. Evocando P. Hadot, Moreschini afirma que a possibilidade de uma metafísica do Exodo, por parte da exegese cristã contemporânea a Agostinho e por ele supremamente partilhada, deu-se pela via do encontro com o pensamento grego: "Mas se os cristãos descobriram no Êxodo a identificação de Deus com o ser absoluto, é justamente porque os gregos tinham feito conhecer essa concepção, observa P. Hadot. Agostinho é provavelmente devedor a Porfírio a esse propósito." [MORESCHINI, 2008: 457].

${ }^{171}$ Uma ampla e plural apresentação do desenvolvimento dos estudos e discussões acerca da exegese de Ex 3,14 foi promovida pelo Centro de Estudos das Religiões do Livro, no âmbito do CNRS parisiense, sob a direção de Alain de Libera e Émilie Zum Brunn, e reunindo contribuições de intérpretes judeus e cristãos, entre os quais Jean-François Courtine, Roland Goetschel, Paul Vignaux, Édouard Wéber, além dos próprios editores: DE LIBERA, A. et ZUM BRUNN, É. (eds.) Celui qui est: interprétations juives et chrétiennes d'Exode 3.14, Paris: Du Cerf, 1986.. Courtine apresenta, ainda, um sumário do tema, no âmbito da discussão relativa à interpretação tomasiana e neotomista, em seu Inuentio analogiae - Métaphysique e t ontothéologie, Paris: Vrin, 2005, p. 271278.
} 
Se resulta claro que Gilson - ao contrário de Gilbert, para o qual Agostinho se move fundamentalmente na acepção da existência - toma as provas agostinianas dentro de uma concepção que pode ser tida por essencialista, contudo parece-nos igualmente clarificado que sua leitura traz, em relevo, que o âmbito no qual são expostas é, máxime sentido, o do ser, ainda que as provas contenham desenvolvimentos ou correlações nos campos do conhecimento e da autoconsciência: o esse, ainda que "essencializante", ostenta preeminência a respeito do intellegere, correspondendo, na verdade, à própria finalidade da prova da existência de Deus. Em torno a esse âmbito fundamental do ser, Gilson esclarece, primeiramente, que o sentido da exposição probatória assenta-se no apontamento do ser enquanto essência dos seres que existem em finitude e mutabilidade. Há, pois, uma primeira caracterização ofertada por Gilson quanto a um dos matizes de esse presente nas demonstrações de Agostinho: o ser, enquanto Vere Esse, é o fundamento (razão) para os seres finitos e mutáveis. Para Gilson, o esse em uso nos textos probatórios dos diálogos agostinianos constitui a essência manifestada na existência. Contudo, tal visão essencializante parece-nos mais matizada e complexa do que uma primeira leitura esquematicamente simplificada possa, eventualmente, ter-nos induzido a tomá-la desta maneira simplificadamente esquemática. Vemos que o próprio esclarecimento de Gilson atesta que os seres mutáveis e finitos (contingentes) não possuem, por evidente, a razão de ser em si, mas se exaurem na excelência que os perpassa e ultrapassa, ou seja, a evidência resulta do fato de ser o próprio esse, em seu movimento de exaurição/exsurgência, e enquanto primordialidade dada no instante de sua insurgência na intelecção, a partir dos seres existentes - numa palavra: esse-uiuere-intelligere - quem irá compor o mosaico do conhecimento da criação, através do itinerário inteleccional culminante no Vere Esse. Ao qualificar, ante a evidência de sua finitude e mutabilidade, como necessária e impositiva (de pronto e de imediato, portanto) a expressão da intelecção do ser criado como "bastardo", Gilson atesta em realidade que o esse primordial, em contínua temporalidade de exaurição e exsurgência no instante de seu intellegere, aponta de per si (devido à sua "ilegitimidade" bastarda) para a sua própria excelência e excedência, ou seja: a existência se propõe (e igualmente impõe, como diz Gilson, à instituição do intellegere) à sua própria culminância no Vere Esse, no instante mesmo em que surge como esse primordial, numa palavra: a inteleção do esse primordial exsurgente, afigura-se o instante de presentificação e surgimento do Vere Esse. Perceber o esse bastardo somente é possível porque se percebe, em simul e no preciso instante da percepção, o Esse legítimo, dada sua prefiguração da eternidade, enquanto verdadeiro ser que fundamenta e expõe a inteleç̧ão do ser criado como "ilegítimo bastardo", em sua intelecção imediata por parte da ratio. O que pretendemos 
ressaltar, em termos diretos, é a possibilidade de se extrair como elementos presentes de forma inequívoca na análise de Gilson - que nos parece indubitavelmente centrada no primado do ser, ressalvando-se sua interpretação essencialista do esse agostiniano nos textos probatórios dos diálogos - igualmente o matiz da imediação e simultaneidade dadas ao intellegere, quando da presentificação e doação do ser à sua intelecção.

Em convergência às posições de Gilson, na acepção plena da metafísica “d'Aquele que e’, Lenka Karfíková afirma, em sua análise do período inicial agostiniano, que "Agostinho encontra (concebe) Deus como princípio único de tudo o que é, e o único a transcender este mundo, mas igualmente próximo aos corações dos homens, e vindo à humanidade em sua encarnação [do Verbo]"172. Embora centrando-se no papel da graça na economia das relações Deus-ser humano, Karfiková acentua, em prosseguimento e com base principalmente no texto dos Soliloquia, a relação entre o Vere Esse enquanto Deus-princípio, e o esse enquanto ser humano-criatura, em seu aspecto fontal: todo conhecimento da verdade resulta, evidentemente, da ação divina enquanto dádiva ao ser humano ${ }^{173}$, com a devida ressalva acerca do efetivo papel da livre escolha humana (liberum arbitrium) no interior de tal economia das relações ${ }^{174}$. Muito embora conclua entendendo haver "certa ambiguidade" no pensamento agostiniano a respeito, Karfíková sumariza com a observação de que "Deus é visto como origem e sustentáculo (garantia) da ordem universal, bem como da compreensão das verdades matemáticas (incluindo sua polaridade verdadeiro-falso)" ${ }^{\prime 175}$. Afigura-se, entrementes, neste passo da análise de Karfíková, a constatação de que a natureza binomial presente nas verdades universais remete, por seu caráter, à fontalidade divina, o que nos parece ratificar, a par desta análise, a presença essencial da simultaneidade no ato cognitivo-judicativo humano.

Outrossim, o prosseguimento da análise de Gilson acerca das provas agostinianas da existência de Deus, permite uma percepção ainda mais aguda acerca da relação entre o esse primordial e o esse final, enquanto consumação do primeiro no segundo:

\footnotetext{
172 "Augustine found God as the only principle of all that is, one which does transcend this world, but is also close to the hearts of men and comes to men in his incarnation." - KARFÍKOVÁ, L. Grace and will according to Augustine, Leiden (Netherlands): Brill, 2012, p. 8. Cf. a reafirmação adensada da conceituação na p. 13: “[The human beatitude is the] understanding of God as the eternal truth and supreme measure of all things".

173 "The beatitude of men [Deum habere] them means 'being with God' [cum Deo esse - De ordine II,7,20], i.e, 'understanding him' [Deum intellegere - De ordine II, 2,4] (...) However, such beatific understanding - in Soliloquies it is the understanding of the truth which lasts independently of individual true things [Soliloquia, I,35,28] and which is God himself [Soliloquia, I,1,3] - can only be found with God's help [Soliloquia, I,1,5]" KARFÍKOVÁ, op.cit., p. 12.

${ }^{174}$ Idem, ibidem, p. 13.

175 "God is regarded as the guarantor and source of the world order, and the understanding of the mathematical truths (including their bipolar true-false nature)" - Idem, ibidem, p. 14.
} 
... toda a economia de suas provas se explica por seu propósito de colocar em evidência a existência desse ser idêntico a si mesmo, perfeitamente imutável, portanto, perfeitamente ser, que chamamos de Deus. Daí se explica a preferência notória, da qual Agostinho é prova, pelos argumentos obtidos a partir da presença da verdade em nós. [GILSON, 2007: 53]

Ao sublinhar a identificação entre as características do ser verdadeiro (essentia) e as da verdade, a análise de Gilson nos possibilita a percepção de que tal identificação situa-se na base da simultaneidade essencial do pensamento agostiniano, recorrente em nossa pesquisa. Com efeito, a manifestação ou surgimento do ser evoca - enseja - ao mesmo tempo (instante) o surgimento da verdade, tratando-se, de fato, de um único surgir instituinte da temporalidade de sua intelecção.

Evidencia-se, em tal análise e como fundamental neste sentido, uma colocação cujo primor estilístico próprio de Gilson evoca, com muita felicidade, o sentido do itinerário agostiniano como decorrente do esse em excelência ao (e no) Vere Esse:

Cada vez que ele tenta novamente uma de suas asceses mentais, Agostinho coloca-se a caminho do Deus do Exxodo, mas todas as rotas o conduzem ao que, para a sua razão, constitui o ser em sua plenitude: a estabilidade na essência, a imutabilidade, enfim essa eternidade que, para ele, não é somente um atributo, mas a substância mesma de Deus: Aeternitas, ipsa Dei substantia est. ${ }^{176}$ [2007: 53 - grifo nosso]

A análise de Gilson deixa claro que a itinerância intelectual, a partir das "asceses mentais", significa dispor-se ao Vere Esse em busca de sua intelecção e ratificação, nos sinais presentes na realidade criatural. Com efeito, “colocar-se a caminho do Deus do Êxodo" traduz, inequivocamente, que o ponto de partida se consuma no de chegada, ou seja: o ser perpassa todo o itinerário, enquanto princípio da intelecção, bem como sua plenificação. O esse primordial institui o percurso de feitura cognitiva da realidade, perpassando-o - tal como intentamos aqui expor, em nossa pesquisa - em cada passo do itinerário, na sua presentificação e doação essenciais, ao mesmo tempo que na intelecção instituinte da temporalidade interna a este movimento. $\mathrm{Na}$ asseveração de Gilson, o trajeto agostiniano é conduzido ao ser pleno enquanto essência, cujas características escapam a qualquer outro ser criado (imutabilidade e eternidade), o que significa reafirmar, uma vez mais, a concepção essencialista do "Deus do Êxodo". Mas qual a acepção trabalhada por Gilson quanto à essência?

$\mathrm{Na}$ introdução de $\mathrm{O}$ ser e a essência, onde trabalha detidamente o significado de esse ao longo da história do pensamento patrístico, Gilson sumariza o panorama apresentado aludindo, entre os autores cristãos, justamente a Agostinho:

\footnotetext{
${ }^{176}$ Enarrationes in Psalmos 101, n. 10, t. 37, c. 1311 (apud GILSON)
} 


\begin{abstract}
Por outro lado, o que é a essência? Este termo deriva do latim essentia, que Sêneca considerava um neologismo indispensável, já que nenhuma outra forma latina era capaz de traduzir exatamente o grego ovoı $\alpha$ [...] Santo Agostinho falava ainda de essentia como de uma palavra estranha à antiga língua, e lhe reconhecia exatamente a mesma função. [...] em bom francês clássico, a essência significa primeiramente "o ser", ou seja, o real, o que é. Tal é o sentido que geralmente apresenta a ovoı $\alpha$ entre os gregos, porque Platão a emprega para designar a substância. O mesmo se dá em Santo Agostinho, para quem dizer que Deus é summa essentia equivale a dizer: Deus é o ser supremo, o que é supremamente. [GILSON, 1951: 19]
\end{abstract}

Observa-se, inobstante a nota relativa à tradição platônica quanto a certa concepção "substancializante" do termo essência ${ }^{177}$, que Gilson tem por certo que, no pensamento agostiniano, essentia reporta ou traduz o matiz de plenificação relativo ao ser enquanto tal. Em paralelo ao que afirmara na passagem citada de sua monografia sobre Agostinho, dizer que Deus é o ser supremo significa que o esse, em sua acepção plena (e, portanto, perfeita), somente se encontra em Deus, o único ser propriamente, do que decorre terem todos os demais entes seu fundamento essente no Vere Esse: só se pode falar que são seres, ou que existem, tendo por pressuposto principial o ser pleno, ainda que não plenamente inteleccionado, ou seja: "colocando-se a caminho do Deus do Êxodo". Em suma, o passo inicial instaurativo e ensejante do itinerário de intelecção do universo é instituído pelo esse em sua disposição ao Esse pleno e verdadeiro (equivalendo à postulação, de imediato, do Deus do Êxodo), instituída (a disposição) na intelecção do esse. O caminho é, pois, a transparência da presença do Esse a cada passo do esse em exauriência e excelência.

Resta-nos ainda uma consideração acerca da análise gilsoniana das provas agostinianas, que acreditamos poder explicitar - mesmo que na contramão ao intento de Gilson - a conjugação dos matizes existencial e essencial, bem como a imediaticidade da presença do ser, presentes na concepção de ser dos escritos iniciais de Agostinho. Na finalização de suas considerações, afirma Gilson que

\begin{abstract}
Orientadas em direção à "essencialidade" de Deus, as provas agostinianas naturalmente deveriam tender seguir uma via mais curta e a buscar no único conteúdo da essência divina a prova de sua perfeita essencialidade. O caminho mais curto uma dialética diferente da que santo Agostinho expôs e que, talvez, ele não gostasse permitiria tal engajamento. Contudo, se não o adotou, Agostinho constituiu a ontologia a partir da qual santo Anselmo e seus sucessores medievais iriam exercer sua dialética para estabelecer a existência de Deus. [2007: 55]
\end{abstract}

Gilson aponta ao que, em seu entendimento, deveria ser a consequência lógica da argumentação probatória agostiniana acerca da existência de Deus: o argumento a simultâneo que, séculos mais tarde, Anselmo de Cantuária iria celebrizar em seu nome, cujo núcleo

177 Cf. MARION, J.-L. Note sur l'usage de substantia par sain Augustin et sur son appartenance à l'histoire de la métaphysique, op.cit., p. 152-153. 
consiste, termos sumários, em deduzir da essência do que se nomeia Deus, sua existência. Gilson pontua que tal dedução lógica seria a mais direta, posto que uma sua consequência, não sendo porém adotada por Agostinho. Aparentemente, Gilson aduz, como única motivação para Agostinho não seguir pelo "caminho mais curto", a prática de uma dialética "que talvez ele não gostasse", reconhecendo entretanto que, não obstante esta hipotética recusa, Agostinho constitui a ontologia de base ao argumento anselmiano, e todo seu histórico de desenvolvimento no Medievo ${ }^{178}$. Porém, verifica-se a possibilidade de outra consideração na aparente recusa agostiniana. Se Agostinho não chega a explicitar, em suas provas, a visualização acerca do Vere Esse enquanto "aquilo a respeito do que o pensamento não pode pensar nada de maior", tal se dá precisamente porque a presença do esse como signo do Vere Esse comporta, de per si - vale dizer: de imediato - a argumentação em sua composição de intelecção. O dado da existência é simultâneo à intelecção de sua essência.

3) Werner Beierwaltes. No contexto de sua pesquisa acerca das aproximações entre a tradição platônica e o idealismo moderno, Beierwaltes principia por elucidar como, em seu entendimento, a impostação assim chamada (desde Kant) onto-teo-lógica, compreendida como originária no pensamento cristão, terminou por fornecer a estruturação necessária a que o pensamento grego clássico das correntes platônica e aristotélica tivesse sua veiculação assegurada. Assim, no primeiro capítulo de seu Platonismo e Idealismo, após tratar da exegese filosófica de Êxodo 3,14, dentro de um panorama da questão pela era patrística (onde se detém explicitadamente no influxo do neoplatonismo na formação do pensamento cristão patrístico), Beierwaltes dedica-se à interpretação do pensamento neoplatônico efetuada por Agostinho, de modo específico ao papel que nela desempenha o esse característico deste histórico traditivo, e sua consequente construção de elementos ontológicos próprios.

Assim, após iniciar com a afirmação da presença da herança, em Agostinho, da "explicitação do ser como espírito em Plotino; e, em Porfírio, do Uno como ser pensante", Beierwaltes aduz a esta o elemento propriamente dogmático do pensamento cristão, relativo ao ser de Deus enquanto essência trinitária, ante o que "se encontram reunidos os elementos essenciais, filosoficamente falando, a partir dos quais irão se constituir os conceitos de Deus e de ser em santo Agostinho" [BEIERWALTES, 2000: 33]. Situando o pensamento agostiniano na construção da onto-teo-logia do pensamento ocidental em sua raiz cristã, Beierwaltes pontua, como traços essenciais de sua herança neoplatônica, a unidade e a espiritualidade que, em realidade, irão permitir sua junção à metafísica do Exxodo tornada referencial por Gilson: “ $O$

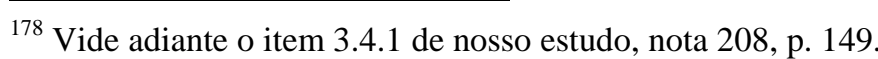


'Ego sum qui sum' assume a seus olhos [Agostinho] um significado central, tal que ele se encontra compreendido a partir desta tradição: ela constitui, em sua visão, um mote à explicitação de Deus como ser (verdadeiro)" (Idem). Desse modo, Beierwaltes visualiza, precisamente na herança da tradição platônica, a possibilidade da interpretação de Ex 3,14 como identificação entre ser e verdade. Dado que, desde o início em suas obras, Agostinho toma o texto escriturístico como referência maior aos seus desenvolvimentos filosóficos e, como salienta Beierwaltes, ao seu intento de visualizar, na fé cristã, os legítimos esforços e as melhores aspirações da filosofia grega antiga, parece-nos provável que sua interpretação, ao pontuar o elemento neoplatônico como essencial ao pensamento metafísico de Agostinho, esteja levando em conta, ainda que não de modo detido num texto ou obra do período, os escritos agostinianos de início, onde o embate com o pensamento grego se traduz em sua assimilação com vistas à sua expansão ou plenificação. Em tal escopo, sua pesquisa e argumentação afiguram-se possuindo plena aplicabilidade ao período inicial da obra agostiniana. Nesse sentido, após referenciar os dois traços traditivos presentes na construção de sua metafísica, Beierwaltes especifica que, para Agostinho, “....ser significa [...] 'eternal', ou seja, imutável, estando permanentemente (mas sem processo temporal), de modo tal que ele, idêntico a si mesmo, seja sem diferenciação interna." (Idem). Ao identificar o ser com o eterno e o verdadeiro, Agostinho estaria aqui dentro da mais genuína tradição platônica, via os pensamentos de Plotino e Porfírio. Entretanto, Beierwaltes salienta, ainda no escopo desta identificação, outra relação de identidade peculiar ao pensamento agostiniano, e preciosa à nossa presente tentativa de apresentação da filosofia de Agostinho: a eternidade do ser de Deus, implicada na relação identitária maior entre veritas essentiae e Vere Esse, manifesta-se, para além da sua intuição em imutabilidade (cuja permanência ilustra, mais uma vez em simul, sua perenidade), aqui na atemporalidade que suprime o caráter processual de sua ocorrência, ou, nos termos de nossa tentativa: na simultaneidade que suprime o tempo cognitivo processual. O esse, em Agostinho, ostenta a imediaticidade e a perenidade, decorrentes da atemporalidade em que se manifesta.

\section{3) A feitura inteleccional da realidade}

$\mathrm{Na}$ continuidade de sua explanação, Evódio deixa claro que a majoração de grau advém da completude, ou inclusividade, dos graus anteriores no posterior, indicando que a realidade mais excelente é aquela que inclui as anteriores em sua essência, correspondendo a uma plenificação, no passo atual da realidade conhecida, dos passos anteriores já perfazidos. Decorre que uma realidade, ou um grau de ser, somente se intelecciona como superior, na 
medida em que estabelece a plenitude do inferior, conjuntivamente a todos os demais já inteleccionados (reconhecendo-se os anteriores como já realizados). Nesse sentido, a gradação advém da completude ostentada e da plenificação perfazida pela realidade ou nível em questão. A título de exemplo, Evódio afirma que “... um cadáver existe. Ninguém, porém, dirá que vive. Ora, o que não vive, muito menos entende." [II, iii, 7], seguindo-se a conclusão, por Agostinho, de que as três perfeições em questão estão presentes no ser humano, ao contrário do cadáver (que só existe) e do animal (que também vive), ressaltando porém a excelência da perfeição presente unicamente no ser humano: " $E$ admitimos, igualmente, que a melhor das três é a que só o homem possui, juntamente com as duas outras, isto é, a inteligência, que supõe nele o existir e o viver." [Idem]. Com efeito, a exclusividade da perfeição advém, por evidente, da excelência da inteligência em relação às outras duas, tornando o ser humano único. Impõe-se notar que a justificativa de Agostinho novamente expõe a simultaneidade de conjunção entre as perfeições, dado que o caráter único do ser humano advém de possuir a inteligência, a qual ostenta conjuntamente as demais, explanando ainda que estas são pressupostas na excelência daquela. É de fato a pressuposição de que a mais excelente contém as excedidas, que encontramos na base da gradação das perfeições. O caráter conjuntivo e includente, por sua vez, atesta que a excelência de uma realidade repousa na copresença, ou conjunção, ou mesmo con-scientia, de todas as excedidas na excelente atual (ou perfazida). No prosseguimento do diálogo, Agostinho irá expor mais e mais a aplicação da excelência inclusiva, na exposição da feitura itinerante da intelecção da realidade criatural.

Resta notar, ainda, que Agostinho finaliza a postulação da tríade axial ao decurso da disputatio (e fundamento da exposição ascensional que irá ter início na seção imediatamente seguinte), com a notação de Evódio a respeito de sua assertividade quanto ao caráter indubitável da certeza advinda do trinômio: "Assim é, sem dúvida." [Idem], asserção sem dúvida remissiva à suspensão judicativa que propusera na seção anterior: em resposta à incertitude total, agora dispõe-se de certeza indubitável.

\subsection{1) Sentidos exteriores e sentido interior}

a) Exterioridade. A sequência pós-trinômio fundamental tem início com a inquirição prontamente dirigida a Evódio por Agostinho, acerca de mais uma aparente evidência: "Ag. Dize-me, agora, se sabes com certeza que possuis os tão bem conhecidos sentidos corporais: a vista, o ouvido, o olfato, o gosto e o tato? Ev. Sim, eu os conheço, com certeza."

A pergunta de Agostinho é formulada retomando os termos da inquirição póssuspensão judicativo-cognitiva que Evódio efetuara: "sabes com certeza que...?" O núcleo da 
questão repousa no requerer, a Evódio, certificação de um conhecimento tido, geralmente, por inequívoco, mas acerca do qual se requer, por ora e a quem ousou questionar o princípio da existência (Evódio), ofereça certificação de evidência tida por assentimento praticamente unânime: “... que possuis os tão bem conhecidos sentidos corporais”. O acento retórico de sagacidade, mesmo irônico, que perpassa a formulação da pergunta tem objetivo elucidativo: após o assentimento, por parte de quem suspendeu o juízo cognitivo in totum, da certeza primordial de seu ser (tendo antes colocado em suspenso a certeza cognitiva referente ao Ser supremo) - certeza esta, recordemos, cuja indubitabilidade imediata era tal, que Evódio mal disfarçara seu traço irônico desdenhoso ante sua postulação, óbvia e evidente [II, iii, 7: "É melhor passares logo adiante...”] - em simul à certeza de que vive e, portanto, intelige esta primeira verdade de que é e vive, Agostinho "devolve" o traço irônico evodiano com igual ironia, iniciando por questionar, agora que há certeza primordial, algo que é, de igual modo, manifestamente evidente e, por isso mesmo, de domínio público ou comum: a certeza da sensação ("utrum illos vulgatissimos corporis sensus"). Ao postular inquirições sobre evidências manifestas, Agostinho aponta ao exterior, vale dizer, à alteridade que imediatiza o sentido interno. Em certo aspecto, Agostinho postula a exterioridade que, de per si e de imediato (sem mediação da temporalidade lógica), expõe a interioridade. O caráter abrupto e impositivo da certeza desta verdade é inteligido, interiormente, pela imediaticidade da exterioridade. A indubitabilidade é tal que, na própria inquirição, Agostinho articula a questão em termos de posse (Evódio tem a certeza de sua exterioridade corporal em si mesmo, portanto). Em suma, a evidência da exterioridade corporal advém da possibilidade de se falar acerca da mesma, já na instância da interioridade.

Entendemos que o prosseguimento do diálogo ratifica nossa tentativa. É possível observar a ocorrência - a rigor, uma vez mais recorrência, posto que já verificada anteriormente - de movimento peculiar ao pensamento agostiniano (que alcançará sua feição definitiva quando da cristalização de sua presença nos grandes tratados da maturidade): trata-se da atemporalidade própria da simultaneidade essente à relação entre o ser, viver e inteleccionar. No exercício de sua intelecção, o esse, instado pela exterioridade através dos sentidos, institui a temporalidade inerente ao ato de separar ou distinguir, componente da feitura analítica da realidade. Precisemos que a análise que distingue ou separa não constitui decorrência da alteridade ontológica, mas institui justamente a temporalidade inerente à disposição decomponente e hierarquizante da realidade. Não se interpõe, à maneira de um intervalo ou inserção, menos ainda como queda, mas a atemporalidade permite a percorrência da sequência temporal. Nesse sentido peculiar, hierarquização vem a ser a concatenação e 
separação, necessária à distinção e análise. Ora, a temporalidade é percorrida e completada a todo instante de ruptura, no qual o surgimento de novo grau ou passo do conhecimento enseja a completude, ou perfeiciona e plenifica o todo anterior, exaurindo-o em sua temporalidade própria; e, relembrando a elucidação de Lorenzo Mammì, enquanto instante de atemporalidade, comporta em simul (interpretação pessoal do texto de Mammì) toda a realidade passada, presente e futura, vale dizer: a atemporalidade é garantia da feitura em completude, ou plenificação, da realidade.

Assim, a conjuntividade (ou o perfazimento de totalidade) inerente a determinado nível de conhecimento, confere-lhe o estatuto de superioridade na hierarquia ascensional, dado que sua posição corresponde à atualização e perfazimento do todo percorrido até então, e não um status isolado e estanque em relação aos passos inferiores. Em termos ilustrativos, a hierarquização exposta por Agostinho ostenta, em nossa tentativa de leitura, menos a imagem de escada (onde o degrau superior é justaposto acima ao inferior, sem qualquer relação entre ambos), que de uma bolsa ou balão que se enche e expande, no qual todas as partes previamente ensejadas e dispostas - guardam relação entre si, a maior incluindo a menor e dela dependente. Da certeza dos sentidos externos e corporais, cada um deles correlacionados a um âmbito de sensação, Agostinho faz ver a Evódio que há percepções que ultrapassam a singularidade de um único sentido exterior, englobando dois ou mais sentidos em seu âmbito. A percepção que ultrapassa a distinção e inicia uma amplitude da percepção do real como um todo, é ocasião para que Agostinho questione se tal percepção advém da singularidade de um dos sentidos exteriores, ao que de pronto Evódio aponta para o domínio do sentido interior.

b) Interioridade. Elucida-se, a partir desta sinalização ao âmbito da interioridade, que esta perfaz excelência em relação à distinção e singularidade que tornam a sensação exterior múltipla por sua própria constituição e essência. A interioridade é a excelência da singularidade e da distinção temporais, ensejante da totalidade atemporal em simultaneidade: uma percepção comum pode ser atestada por várias sensações ao mesmo tempo, e se perfaz enquanto tal (percepção), justamente por conter a superação da singularidade, vale dizer: a simultaneidade é a feitura do real que escapa à temporalidade da distinção, é um "furto" ao tempo e à sequência processual. A simultaneidade permite pensar e perceber a totalidade sem a temporalidade. A totalidade, como já anteriormente visto, ostenta nos textos dos diálogos agostinianos, sua fundamentação epistemológica na simultaneidade essencial. Enquanto instituinte da temporalidade própria ao singular e ao distintivo (mensurável, articulável, estruturável, etc.), a interioridade é o âmbito do instante atemporal, apoiado na evidência advinda do esse relativo ao novo passo do conhecimento. Têm-se, pois, que todo passo da 
ascensão intelectual é instituído no âmbito de uma atemporalidade por assim dizer permanente, no qual se instancia a interioridade. A interioridade atemporal, enquanto âmbito de intelecção do esse, termina por feiturar a "costura" de cada um dos pontos ou graus do conhecimento ascensional, na medida em que sua instituição, a partir da atemporalidade que lhe é inerente, é recorrente e reiterada temporalmente em cada um dos passos do conhecimento intelectual ascensional.

c) Racionalidade. No âmbito da interioridade, a razão se instancia como excelência do sentido interior e, por conseguinte, da totalidade dos sentidos corporais exteriores e da percepção interior. Ratificando o movimento que expusemos até então, a exaurição do percurso percorrido até o momento enseja sua ultrapassagem, ou sua excelência, na qual se dará a manifestação de um novo dado ou elemento de conhecimento, ou ainda uma notitia. Agostinho descreve a conversão dos elementos conhecidos para objetos de ciência, o que se dá somente no âmbito da racionalidade. Seja como for, o elemento ou notitia ostenta a primazia no estabelecimento de um novo grau ascensional a ser percorrido, um novo passo do conhecimento em que sua intelecção, própria à sua funcionalidade correspondente a um novo esse primordial deste novo passo, termina por perfazer e feiturar o conhecimento da totalidade anterior. A temporalidade de percurso, ensejada ao ato pelo excellere próprio a cada manifestação essente, exaure-se ante a totalidade perfazida pela nova manifestação. O esse de cada novo grau do conhecimento assume, pois, a temporalidade anterior, e cada novo instante, em sua pertinente atemporalidade, insurge-se em nova intelecção, por sua vez instituinte de nova temporalidade. Essa recorrência constante entre os passos da ascensão do conhecimento constitui fio contínuo que mapeia todo o itinerário intelectual da realidade. Neste sentido único, é possível afirmar que o movimento temporal da gradação interna ao percurso cognitivo, é guiado e instituído pela atemporalidade perene à instituição de cada novo grau de conhecimento, que a cada passo assume o tempo percorrido.

Agostinho introduz a racionalidade a partir de sua devida qualificação: o saber e a ciência, únicos no ser humano, nela têm sua fundamentação. Neste trecho basilar, expõe a articulação peculiar entre os âmbitos fundamentais da exterioridade, interioridade e racionalidade. Há, por certo, entre os três âmbitos, a relação de inclusividade a que nos referimos no início desta seção, em que a exterioridade remete à interioridade (o que, por evidente e à luz da temporalidade inerente ao movimento de excedência/excelência a que nos referimos, torna esta igualmente remissiva àquela, compondo certa simultaneidade transitiva), e ambas remetem à racionalidade, que totaliza e perfeiciona a comunicação efetuada pelos sentidos exteriores e sentido interior. Ressaltemos, uma vez mais (e pela importância cada vez 
mais evidente, à medida que o itinerário se desenvolve), que a excelência de um grau ou passo do conhecimento é remissivo ao todo percorrido até então, totalizando e consumando-o, a partir de sua exaurição (que apontara para as novas possibilidades e determinações, a partir mesmo de suas limitações excedidas ou "excelencionadas") e instituição de novo (notitia) âmbito essente a ser cognido. A importância dessa observação é melhor compreendida quando percebemos que cada novo passo ou grau de conhecimento, soma e perfeiciona, em conjunção, todos os anteriores. Isto mostra a organicidade do percurso ascensional que Agostinho expõe neste trecho, o que justifica tomá-lo, ilustrativamente, como parábola (e não como escada ou reta vertical), ou mosaico: a interdependência dos graus ascensionados faz com que não ostentem superioridade excludente (e portanto seletiva e ética), mas sim includente e orgânica. Com efeito, a racionalidade ultrapassa e contém, não somente o sentido interior, mas igualmente este $e$ os exteriores. Exterior e interior perfazem a razão, e a ciência é visualizada como reconhecimento (conjunção) do todo conhecido até então (exterior e interior). Assim, a relação entre os três âmbitos de conhecimento se dá, menos por articulação e justaposição, e mais por adensamento e plenificação de um nível no seguinte: a racionalidade consuma a percepção essente, e de modo unitário, entre a exterioridade e a interioridade. Este telos interno ao percurso inteleccional da ascensão cognitiva, em si mesmo já prefigura - talvez pudéssemos afirmar: enseja ou condiciona - a manifestação ou presentificação final, que em realidade consuma todo o universo na convergência teleológica na qual toda ação se plenifica e se perfaz no verbo divino, na consumação com a qual Agostinho pontua, em finalização, o itinerário do De quantitate animae - o telos da multiplicidade em totalidade, de toda a alteridade e exterioridade, para o qual o itinerário converge e no qual se consuma, cuja absolutidade, presente em toda a presentificação pontuada (e permeante) ao longo do percurso, perfaz-se na recomposição da atemporalidade própria à ratificação do instante, que igualmente pontuara e "costurara" todo o itinerário. Por seu turno, a recomposição plenifica toda a temporalidade anterior que foi assumida pela ratio, consumando o absoluto permeante das manifestações e intelecções pontuais, no absoluto final.

Pontuamos que a atuação própria da razão, na estruturação e feitura do percurso cognitivo, ocorre tanto com relação à totalidade do percurso, quanto em relação aos passos do conhecimento tomados isoladamente. No que respeita ao primeiro aspecto, Agostinho especifica o papel atuante da ratio valendo-se dos momentos performativos que compõem o que podemos intitular como a racionalidade percursional do itinerário de ascensão cogntiva: comprehendere e intellegere. No tocante ao segundo aspecto, ocorre a especificação do ato ratificador que "costura" passo-a-passo toda a feitura cognitiva ascensional da realidade, 
especificado em referretur - rursus - offert et renuntiat. Na sequência de nossa tentativa de exposição, vamos nos deter, por ora, no primeiro aspecto, retornando ao segundo aspecto logo adiante. Ressaltemos, entretanto, que ambos os aspectos evidentemente ocorrem não de forma delimitada ou separada, ao contrário: a funcionalidade da ratio abrange a racionalidade do percurso todo, no instante mesmo em que ratifica os passos singulares do itinerário, de modo simultâneo entre as especificações acima. As respectivas tentativas de nossa exposição acerca de cada um dos aspectos possibilitarão melhor visualização a respeito.

d) Ciência. Dissemos nos parágrafos anteriores que a ciência é, essencialmente, conjunção e recolhimento do conteúdo comunicado pelos sentidos, ou pela intuição concretizada no instante do intellegere. Mas Agostinho explicita que todo conteúdo conhecido pelos sentidos somente compõe percepção, quando esgotado em si, ou seja, exauridos em sua temporalidade inerente e atuante, e excedido rumo a novo âmbito, que por sua vez somente se atualiza ou se perfaz, tendo por referencial o conteúdo que acaba de ultrapassar. Nesse sentido, cabe-nos verificar o sentido de ciência propriamente, dentro do escopo que perfaz o conteúdo único da razão.

A primeira qualificação que Agostinho nos fornece a respeito da ciência, de sua atuação e sua funcionalidade, corresponde, como já aludimos, à especificidade do ato e conteúdo racional. Ao exemplificar com base na percepção do campo de atuação próprio a cada sentido externo, bem como do termo próprio ao sentido interior, Agostinho visa ressaltar a peculiaridade da faculdade humana: a racionalidade compõe a distinção humana por excelência, e Agostinho especifica sua atuação: o saber distintivo e singular, ou a ciência da singularidade no contexto de uma multiplicidade, perfaz o campo único da razão, cuja atuação contempla o conteúdo sabido, vale dizer: cientificado. Nesse sentido, ciência é, essencialmente, discernimento e consequente determinação das relações e articulações entre as singularidades, internamente ao múltiplo. Mas a própria escolha do termo evidencia a prioridade e, sobretudo, o papel condicionante exercido pela multiplicidade face à estruturação interna dos singulares: scientia, que compartilha seu étimo radicial sci com outros termos cujos matizes atestam a penetração na singularidade: scire, utilizado em nosso texto. Evidencia-se que, após a instituição de um todo composto, a penetração e o discernimento de sua articulação interna quanto aos seres que se lhe somam em sua feitura, numa palavra: a composição de sua estrutura, e consequente temporalidade lógica, situam-se no âmbito de scire, ou seja, a ciência estrutura as internalidades temporais, na composição das sequências cujas feituras se consumam na totalidade, a qual, do ponto de vista da racionalidade, compõe um múltiplo 
essencial, discernido na estruturação interna de suas partes. Em suma, ciência é saber a distinção que enseja o tempo, é somá-la e abarcá-la: comprehendere .

Mas parece-nos haver outras nuanças ou matizes presentes na conceituação de scientia em nosso texto. O exemplo da relação visão-olhos, trabalhado por Agostinho para ressaltar que esta ligação de condicionamento escapa à percepção dos animais, atesta que a ratio humana, no conhecimento que se faz sabedoria/scientia, e ao distinguir singularidades e determinações, intenta e penetra, no ato mesmo de distinguir e determinar, a essência de cada ser ou manifestação, universalmente compreendida. Ao compreender que as cores pertencem unicamente ao sentido da visão, a razão recolhe o elemento essencial a tal percepção, cujo conteúdo é comunicado ao âmbito da interioridade, para somar à conjunção de todo o conteúdo sabido e cientificado. Esta essência captada pela comunicação entre os sentidos exteriores, interior e a racionalidade, é sabida, por evidente, não ser o próprio sentido, mas sim sua consumação identitária: ao ver, eu tenho, por comunicação perceptiva, a scientia de que a visão é a essência do ato executado pelo olho, mas este não é a essência da visão.

Efetivamente, o olho se perfaz e se consuma, quanto à sua identidade essencial, na visão enquanto ato realizado e consumado. Mas, se a evidência inconteste a respeito da impossibilidade da recíproca ser verdadeira, impede-nos de visualizar o simul entre ambos os vetores, permite-nos entretanto algo tão precioso quanto: a razão, em seu conteúdo cientificador, atesta a presença da essência na existência, tratando de levar à conjunção a disparidade e a distinção. Talvez possamos tentar a leitura de que este ato único da razão de efetuar conjunção, face à distinção dos singulares dentro da multiplicidade sensível como totalidade (conjunto), e enquanto efetivação unívoca da racionalidade, possa ser visto como conjugação, aduzindo-se o matiz da atuação, ou ato essencializante, atento aos próximos passos da ascensão do conhecimento em que, logo mais, Agostinho irá tecer considerações acerca das funções de iudicare e moderare, próprias e, na verdade, essenciais quanto à funcionalidade e atuação da razão. Importa, neste momento, verificarmos e constatarmos todos os elementos e consequências presentes neste poder estatuinte da razão. De fato, é possível visualizar que a cientificação do conteúdo recebido pelos sentidos, efetuada pela razão que traz, além da relação essência-existência como comunitária (e não distintiva e hierárquica), a comunicação entre os sentidos e a razão. E, ao receber a comunicação, a razão discerne e/ou distingue e determina as singularidades, ao mesmo tempo que estabelece sua dependência com relação ao esse permeante da realidade. Por conseguinte, a comunicação vetorial assume papel preponderante na obtenção do conhecimento em vias de sua cientificação ou ratificação. Este papel, porém, não se esgota em sua mera função transitiva, como se sua importância estivesse 
restrita à funcionalidade de apoio para a veiculação dos conteúdos conhecidos. De fato, o papel e a funcionalidade da referência e comunicação dos sentidos, sua veiculação e apresentação ostenta âmbito próprio, cuja importância de sua significação compõe item à parte.

e) Referência/Comunicação

A comunicação das percepções à razão perfaz, em primeiro lugar, uma intentio de consumatio e superação, não propriamente de si com relação a um nível superior, e sim da temporalidade interna à sua própria feição ${ }^{179}$. Esta consumação, efetivada pela movimentação temporal interna (e, a bem da verdade, em sua decorrência) aos sentidos exteriores e interior, totalizando a perceptividade de ambas as fontes e a compondo em âmbito próprio, aponta, preliminarmente e neste contexto prévio dos diálogos (em comparação aos tratados de maturidade), para outro sentido do tempo: condição para a excelência da singularidade em sua liberdade. Com efeito, o telos ensejante e aspirante à consumação e à excelência é ato singular, e somente em sua liberdade volitiva pode ser feiturado em sua finalidade criatural, e portanto querer (amar) sua essência primordial em sua essência eternal. Entretanto, a necessidade de prosseguir na análise do diálogo impede-nos de continuar, neste momento, no adensamento próprio desta consideração acerca deste segundo aspecto no sentido do tempo nos escritos iniciais. Ao final das considerações analíticas a respeito da apresentação do itinerário ascensional no livro II, retomaremos a tentativa de aprofundamento a respeito. Notemos somente que, de fato, Agostinho pontua o movimento da percepção à consumação referenciando, ou comunicando, o conteúdo percebido pelos sentidos, externa e internamente. Até este ponto do diálogo, Agostinho não se preocupa em vincular, de modo estrito, esta referência/comunicação à "faculdade desconhecida" que atuaria como intermediária entre a percepção sensorial e a razão; ou a esta própria. Essa ausência preliminar de precisão ou vinculação acerca do estatuto originário e de posse acerca da referência da multiplicidade sensorial, não nos parece despropositada. Agostinho se preocupa, de fato e em primeiro plano, com a recapitulação do momento perceptivo, mais propriamente com seu conteúdo (que, nos grandes tratados, estará predisposto à feitura da memória em eternidade, tal como nas Confessiones e no De trinitate) de modo referencial, ou seja, de maneira a ter os dados em presença perene, em sua totalidade. O conteúdo percebido afigura-se, deste modo, em balizamento permanente, no tempo mesmo (próprio) desua própria feitura. A referência suprime a perda temporal.

\footnotetext{
179 Vide toda a segunda parte do ensaio de Giraud [2013: 237ss], intitulada "O agir do sentido - referre" (sobretudo os parágrafos 43 e 44), fundamental ao tópico em questão.
} 
Numa densa passagem do parágrafo 43 da segunda parte de seu Augustin, les signes et la manifestation, Giraud estabelece a estruturação e o movimento da inquirição agostiniana precisamente em torno da noção de referre, clarificando sua relação para com a multiplicidade e a temporalidade:

Fé, esperança e caridade formam pois uma tríade ativa, que faz do sentir não o termo inacessível de uma busca, mas o ter-se próprio do fenômeno, o qual se abre assim aos avanços do ego e de seu desejar. Este avanço, pelo ego emanado posto que Deus o dotou do poder de unir, se diz, pois, em Agostinho, de várias maneiras: como aquilo em que se crê, como o que se ama, e como o que se espera. Mas há uma palavra que congrega todos estes aspectos, e expressa de modo unitário $\mathrm{o}$ ato de visar seu objeto através do sensível e da mutabilidade que caracterizam a conduta humana. Esta palavara é um verbo: referre. Nomeia-se aqui, com este simples termo, aquilo que para nós vem a constituir o centro e o eixo de todo o pensamento agostiniano, ou seja, igualmente de toda a sua interpretação e hermenêutica. [...] Este verbo é muito comum em latim, desde a época clássica. [...] os autores cristãos anteriores a Agostinho usam-no copiosamente. A palavra aparece, outrossim, na Escritura tal como traduzida por Jerönimo. [...] A novidade não está, pois, no emprego de um verbo já tornado corrente em latim, mas na constatação de que, em Agostinho, este uso perfaz caráter sistemático. O que entende Agostinho por este verbo: referre? [...] Num estágio preliminar da pesquisa, é possível pontuar a distinção de quatro usos principais [...] Alguns destes usos podem tomar lugar no escopo de um conceito maior da especulação agostiniana. $\mathrm{O}$ primeiro trata da confessio, levando-se em a instância fundante da palavra. O segundo pertence à doutrina da illuminatio, e traz ao relevo o problema do conhecimento. O terceiro diz respeito à actio, inserindo-se no horizonte da ética. O quarto uso de referre, enfim, presta-se à definição de dilectio, e fornecenos uma compreensão da caridade. - GIRAUD, 2013: 255-257 (grifos nossos) ${ }^{180}$.

Observamos que Giraud toma pelo ato de referir, ou o referenciar, o eixo principal da estrutura cognitiva de todo agir humano, validando-o como o ato intencional e conducente da excelência do conhecimento humano, na medida mesma em que constitui a atitude básica, tal qual intentamos visualizar no uso de referre na passagem ora analisada do De libero arbitrio, de visar (intencionalmente) o esse ou essência do dado conhecido e manifestado (fenômeno), na própria sensibilidade e na multiplicidade que a caracterizam. Notemos, enfim, que os quatros usos associados por Giraud à presença de referre nos textos agostinianos, perfaz o

180 "Foi, espérance et charité forment ainsi une tríade active, qui fait du sens non le terme inaccessible d'une quête, mais la teneur même du phénomene, lequel se dêclot ainsi aux avance de l'ego et de son désir. Cette avance, émanant de l'ego parce que Dieu lui a donné de pouvoir l'accomplir, se dit donc pour Augustin de multiples façons: comme ce qu'on croit, comm ce qu'on aime, et comm ce qu'on espere. Mais il est un mot qui rassemble tous ces aspects et dit de manière unitaire l'acte de viser son objet à travers le sensible et la mutabilité qui caractérisent la vie de la criature humaine. Ce mot est um verbe: referre. Voici nommé, avec ce simple terme, ce qui constitue selon nous le centre et le pivot de toute la pensée augustinienne, c'est-à-dire aussi de toute son herméneutique. [...] Ce verbe est três courant em latin, et ce, dês l'époque classique. [...] les auteus chrétiens antérieurs à Augustin em usent aussi volontiers. Le mot apparaît em outre dans l'Écriture telle que la traduit Jérome. [...] La nouveauté ne tient donc pás à l'emploi d'um verbe déjà courant em latin, mais dans le constat que, chez Augustin, cet usage fait systéme. Qu'entend Augustin pat ce verbe: referre? [...] À um stade préliminaire de la recherche, on peut d'abord distinguer quatre usages principaux [...] Chacun de ces usages peut être placé sous l'égide d'um concept majeur de la spéculation augustinenne. Le premier a trait à la confessio, il rend compte de l'adresse qui fonde la parole. Le second appartient à la doctrine de l'illuminatio, et releve du problème de la connaissance. Le troisième se dit selon l'actio, et s'inscrit donc dans l'horizon de l'ethique. Le quatrième usage de referre, enfin, sert à definir la dilectio, et offre une compréhension de la charité." 
espectro de toda a conduta humana, em sua antecipação cognitiva (confessio enquanto ato de credere) e fundante da expressão e comunicação; em sua presença perene ante o absoluto e eterno, pelo qual é perenemente iluminada; como ato volitivo fundante da ética (em Agostinho, sempre com caráter eudaimonístico); e do amor enquanto alvo de realização plena e bem maior, desejado e querido. Nesse sentido, a referência - ato fundante da linguagem evidencia-se como estrutura antecipatória do conhecer, bem como impulsionadora da busca pelo conhecido, ao mesmo tempo que enseja, face ao ser que se manifesta e se dá a conhecer, o referenciar do intellegere ao esse dado, tornando-se a atitude volitivo-cognitiva axial ao empenho humano de conhecimento e realização. 


\section{3 - RAZÃo COMO GUIA E JUIZ: PONTO DE PARTIDA INSTITUINTE E PERFAZIMENTO DO TODO (lib. arb. II, vi, 13 - vii, 19)}

\section{1) Interioridade e temporalidade}

Após a exposição relativa ao âmbito definidor de cada um dos elementos componentes da feitura cognitiva da realidade, dispostos (uma vez mais de forma trinomial, estruturante da sequência cursiva do diálogo) quanto à exterioridade, interioridade e racionalidade, Agostinho novamente como que recensiona a discussão de forma recursiva ao princípio de retomada do diálogo. Vimos anteriormente que tal movimento afigura-se como elemento próprio à retórica dialogal presente no De libero arbitrio, e tais momentos atuam como pontuações de "virada" ou adensamentos próprios à estruturação da disputa em questão, mas ostentando, sobretudo, a recorrência perene ao dado de início, que permeia - e mesmo condiciona - a continuidade do diálogo. Neste ponto de nosso texto, é possível verificar que a recorrência, e sua consequente "virada" no interior do diálogo, preparam um adensamento relativo ao transitus entre os passos ou degraus ascensionais do conhecimento humano, com a finalidade de precisar em que se constitui a excelência própria à feitura cognitiva da realidade criatural, ou, lançando mão de terminologia convencional, qual o significado específico da superioridade estabelecida entre os degraus cognitivos conhecidos, compondo a hierarquização do todo conhecido, numa palavra: o que efetivamente caracteriza o sentido de hierarquização que marca toda a feitura ascensional da realidade conhecida. Porém, um passo antes de trabalhar especificamente os elementos que conferem o sentido próprio da superioridade hierárquica (quais sejam: a excelência que se institui a partir da funcionalidade; e a atuação moderadora e judicativa da razão), Agostinho detém-se na funcionalidade do sentido interior, com o intuito de esmiuçar seu estatuto no interim da ascensão intelectual. Tratar-se-ia, em atenta observação, de uma superação não científica, já que esta comporta a autorreferencialidade e autopercepção, inerentes à racionalidade e inexistentes no sentido interior. Constata-se um âmbito de interioridade sem racionalidade. Em realidade, este passo do diálogo visa uma definição de base, ao mesmo tempo que uma contrastação de alcance estrutural, relativas à interioridade e à racionalidade. De fato, esta não se confunde com a primeira, algo que uma primeira leitura de nosso texto poderia sugerir tratar-se de âmbito intermediário entre a exterioridade e a racionalidade. 
Agostinho parece-nos, entretanto, querer dizer algo além a respeito. Ao insistir na questão acerca da eventual autopercepção do sentido interior, ele parece insistir na independência e autonomia deste em relação à racionalidade, sabendo que, mesmo não compondo seu repertório de conhecimento em nível científico, não deixa contudo de ostentar poder de adjudicação e moderação, referentes ao conteúdo percebido pelos sentidos exteriores. Agostinho parece sinalizar para a constituição do sentido interior como instância primeira da afirmação do verdadeiro, ou seja, da manifestação e expressividade do ser. Ao argumentar por exclusão - ou pela negação de aproximação - no que respeita à determinação da causa de sua superioridade (anteposição) em relação aos sentidos exteriores (ilustrada com o exemplo da "compreensão da sabedoria"; bem como da hipótese da "inclusão" dos animais ao grupo dos "humanos", caso se definisse o sentido interior como elemento da racionalidade), Agostinho parece sinalizar a um campo peculiar do sentido interior

\subsection{1) Sentido interior enquanto âmbito da temporalidade}

Se Agostinho acautela-se enfatizando que o conteúdo do sentido interior, a despeito de sua inclusividade quanto à percepção, em conjunto, da sensação e do próprio sentido que sente, não o torna próximo da racionalidade (precisamente devido ao fato desta compor scientia) é com o fito de evidenciar, tanto quanto possível, a diferença essencial entre seus âmbitos de atuação cognitiva e, sobretudo, a instância em que ambos se dão, no tocante à temporalidade. Dado que a cientificação do conhecimento advinda de sua ratificação o torna atemporal, clarifica-se que em todas as outras instâncias em que ocorre a compreensão do conteúdo percebido, tal se dá em temporalidade e mensuração. Tentemos aproximação e adensamento do texto em continuidade.

O questionamento acerca do alcance da atuação funcional e do estatuto do sentido interior, no plano geral do conhecimento humano, é centrado por Agostinho no problema concernente à sua eventual autopercepção:

Mas, de outra monta, já não resulta claro se esta vida [interior], que percebe, em sua atuação sensível/sensibilidade, as coisas temporais, percebe igualmente a si mesma; a menos que, interrogando-se interiormente, observe-se que tudo aquilo que tem vida foge da morte, a qual, sendo o contrário da vida, faz com que seja necessário que a vida, percebendo a si mesma, fuja do seu contrário [a morte]. - II, iv, 10 $\mathbf{1 0}^{181}$

A articulação do questionamento fora iniciada levando-se em conta a familiaridade e o campo comum de atuação entre os sentidos exteriores e o sentido interior. Da comunicação

\footnotetext{
${ }^{181}$ Sed utrum et se ipsam haec vita sentiat, quae se corporalia sentire sentit, non ita clarum est, nisi quod se quisque intus interrogans invenit omnem rem viventem fugere mortem; quae cum sit vitae contraria, necesse est ut vita etiam se ipsam sentiat, quae contrarium suum fugit.
} 
entre as percepções físicas e interiores, ressalta o contraste intencionado por Agostinho quando da colocação da questão a respeito da autopercepção do interior. Tal contraste permite que visualizemos a especificidade do questionamento: a diferenciação entre a exterioridade e a percepção interior é pontuada no movimento de inclusividade e recuo, para se perceber e se incluir. Compõe, portanto, o movimento de perfazimento de um totum em que a atividade perceptiva se inclui nas percepções. A dúvida de Agostinho, no tocante ao sentido interior, localiza-se precisamente na eventual posse, por parte deste, da autoinclusividade. Por seu turno, a pergunta pelo "si mesma" sinaliza o simul atemporal no qual a ratio se dá: a autoinclusividade ou autopercepção corroboram e ratificam (redundantemente) a totalidade, que não somente escapa à feitura temporal da realidade, mas a esta preside. A atemporalidade é a predisposição do totum que fundamenta a instituição da temporalidade, o que se consuma na racionalidade consciente, embora não se encontre restrita a esta.

De fato, a temporalidade em que se constitui o âmbito de atuação do sentido interior, se dá na ausência de consciência. Esta é instituída primordialmente no âmbito da racionalidade, e todo instante ratificador compõe scire e, por conseguinte, consciência; a qual, por seu turno, institui-se atemporalmente. Já no âmbito do sentido interior, sua atuação constitui sequência em feitura e mensuração, na conjunção perene dos dados conhecidos, porém não cientificados (o que comporia scientia). Decorre, pois, ser o sentido interior o âmbito da temporalidade em que se dá a feitura cognitiva do real, a qual não resulta em conscientia (própria à razão), mas em vivência temporal. Nesse sentido, é possível afirmar que a constituição da temporalidade sensível é o âmbito funcional da intencionalidade, a qual não se identifca à conscientia (embora não a contraste, ou lhe seja estranha); ao passo que a instituição da scientia, sempre anterior a todo passo, ou consciência, é sempre atemporal. Assim, a relação entre o sentido interior e a razão é, precisamente, a observada entre a temporalidade e a atemporalidade, não em termos dialéticos (Agostinho não estabelece postulados antitéticos, tampouco fundamenta seu fio argumentativo numa dinâmica de superações de teses), mas em relação ontológica ${ }^{182}$, na qual o ser se verifica em sua presença máxima, constatando-se e se ratificando no seu dar-se e em suas manifestações componentes das alteridades que se lhe perfazem in totum. Observamos que, em seu estudo a respeito do papel da intencionalidade do campo que toma como psicologia (do conhecimento) agostiniana, Carla Di Martino postula a influência aristotélica nas definições trabalhadas por Agostinho quanto ao sentido interior, o qual toma

\footnotetext{
${ }^{182}$ Cf. VAZ, H.C.L. A metafisica da interioridade - Santo Agostinho, op.cit., p. 81-83.
} 
como correspondente ao que Aristóteles conceitua como sentido comum em seu De anima ${ }^{183}$. Igualmente, Vincent Giraud especifica, como já citado anteriormente, que a intencionalidade nos textos agostinianos, carrega viés essencialmente diverso do matiz preponderantemente assumido na contemporaneidade, máxime a acepção trabalhada na fenomenologia husserliana, ainda que não lhe seja estranho ou mesmo oposto ${ }^{184}$.

Ao questionar Evódio quanto às razões pelas quais considera o sentido interior como excellerens face aos sentidos exteriores, Agostinho visualiza tal excelência de modo que termina por apresentar, indiretamente, sua conceituação acerca da superioridade entre estes. De fato, o passo superior (no caso, o senso interior) é, necessariamente, preposto ao seu imediatamente inferior, do que resulta, evidentemente, a remissão ao todo percorrido até aquele momento. Ao lançar mão de praeponere, Agostinho clarifica que a superioridade (hierárquica, por conseguinte) vem a ser sua anterioridade ou predisposição ontológica e cognitiva, pois sua postulação possibilita (e predispõe) a feituração intelectual do conteúdo abarcado até o momento. Predispor pode ser tido, no contexto do De libero arbitrio II, por antevisão face à atuação funcional.

\subsection{2) Interioridade como instância primeira de afirmação do ser}

O senso interior prepõe-se como primeira instância de afirmação do ser, bem como o reconhecimento de sua feitura em temporalidade. $O$ afirmar (instituir) e feiturar respectivamente: iudicare e moderare - são efetivados pelo sentido interior, ante os sentidos exteriores, mediante o sentido da feitura do todo, ou de seu telos interno (o que somente é possível mediante a percepção - ou dado - prévia do todo), vale dizer, de sua relação com o

\footnotetext{
${ }^{183}$ DI MARTINO, C. Il ruolo della intentio nell'evoluzione della psicologia di Agostino: dal De Libero Arbitrio al De Trinitate in Revue des Études Agostiniennes, $\mathrm{n}^{\circ} 46$ (2000), p. 174ss. A autora observa que o De libero arbítrio compõe o único texto no qual Agostinho conceitua o senso interior enquanto passível ou não de autoconsciência, sendo que nas obras posteriores (ou ainda contemporâneas, citando o De quantitate animae entre estas), o problema se amplia quanto à autoconsciência da percepção em geral, não mais restrito ao sentido interior. 184 "Par là se trouve rejuint le concept qui fait pièce à celui de signification, à savoir celui de manifestation. $L$ 'intentio augustinienne, em son sens le plus radical comme intendere ad (ou in) Deum relevant du 'fecisti nos ad te' n'est pas l'intentionalité de la phénomenologie husserlienene comme acte de conscience. Elle se situe 'avant'et 'en amont' d'elle, exprimant la destination dont est porteur le ad herméneutique avant même que l'ego ne mette en oeuvre l'intentio de l'esprit comme acte concret de visée d'um objet ou d'um sens. On dóit donc parler, dans le cas d'Augustin, d'une 'Archi-intentionalité'. La manifestation est la fin à laquelle se refere l'intention et l'horizon sur lequel se découpe toute signification..." - GIRAUD, 2013: 352-353 (o grifo por nós adotado na citação encontra-se ressaltado em itálico no original). Vide igualmente BERMON, 2001: 52-53 (embora Bermon qualifique o passo intencional como próximo, na herança aristotélica, da fenomenologia de Husserl: "Aristote, ainsi que Husserl après lui, s'efforcent em effet de montrer comment le sens commun, ou ce que l'on peut appeler en des termes contemporains, l'intersensorialité, trouve son fundement même dans l'um des cinq sens, à savoir, le toucher. [...] En bref, Augustin souligne le fait qu'en vertu d'un certain 'sens interieur' l'ame sent qu'elle sent par chacun de sés cinq sens. Aristote, et Husserl après lui, précisent quant à eux qu'elle ne pourrait sentir qu'elle sent ni sentir les communs, si elle n'etait douée du sens du toucher. Par quoi il existe un enracinement du 'sens commun' ou du 'sens intérieur' dans le toucher." - BERMON, 2001: 52-53.
} 
Vere Esse. De fato, iudicare e moderare equivalem, neste passo, a observar a relação do conteúdo percebido face à sua feitura final, ou seja, seu esse previamente relacionado ao Vere Esse. Daí ser evidenciado que todo passo cognitivo - todo julgamento e moderação - equivale à visualização do temporal em sua relação com - e remissão ao - atemporal, à relação entre o esse e o Vere Esse. Parte-se do dado final para se julgar o atual. O atemporal está situado de modo permanente, à base de toda afirmação e moderação - julgar e feiturar; instituir e perfazer; eterno e temporal - sobre a realidade. Nesse sentido, toda a dinâmica do conhecimento humano, no De libero arbitrio II, é postulada e esclarecida como a atemporalidade que institui a medida e o tempo, os quais, afinal, são exauridos permanentemente - nulificados ou "nadificados" - a cada afirmação do real. O tempo somente existe enquanto não se predica sobre o real (predicação que, no "instante que prefigura a eternidade", instancia-se, evidentemente, no âmbito da manifestação e doação do esse ao seu intellegere, como tentamos expor na seção anterior). Toda afirmação ou juízo acerca de um dado real, assenta-se sobre uma relação entre este (o dado, ou a percepção) e sua destinação/finalização, vale dizer: toda predicação situa-se teleologicamente, não porque atinja, após sua percepção concreta, a captação da totalidade e do Vere Esse na qual se insere, mas precisamente este, atemporalmente e de forma perene, institui a teleologia inerente à percepção dos seres e sua temporalidade.

\subsection{3) Interioridade e consciência}

A ressalva feita por Agostinho no final do trecho citado (II, iv, 10), quanto à única possibilidade de que o sentido interior perceba a si próprio, sinaliza para a concepção de consciência com a qual trabalha neste ponto do desenvolvimento do De libero arbitrio. Com efeito, o texto indica dois aspectos que poderiam perfazer, à vista do caráter inconcluso acerca de sua autopercepção, a certeza de que o sentido interior a tem, ostentando pois a consciência própria de si: a) o recolhimento inquiridor (intus interrogans), atitude de moto próprio cujo escopo intenta (interrogans), por seu próprio movimento (intus, recuo para colher e reunir), a realização essente da sensação, ou o seu ser respectivo; o que nos parece confirmado pelo fato de, proporcionado pelo recuo, o senso interior identificar-se enquanto existência que, contrária à morte (ameaça comum a todo ser vivo: omnen rem viventem fugere mortem), está viva e, portanto b) percebe e sabe, de si, que é (necesse est ut vita etiam se ipsam sentiat), ou seja, sabe de si na medida em que sabe do ser próprio, cuja realidade é atestada - uma vez mais no movimento de simultaneidade próprio ao ato de recuo essente à intelecção e movimento de excelência efetuado pela inteligência (intus-legere) - pela percepção, ao mesmo tempo, do ser 
e de sua possibilidade negativa. Recuo para saber da existência: o movimento resulta virtualmente idêntico à postulação da certeza primeira, por parte de Agostinho, relativa ao trinômio ser-viver-entender pós-suspensão judicativa evodiana. Em certo sentido, a similaridade entre tais movimentos, ou mesmo uma virtual identidade entre ambos, parece intencionar, por parte de Agostinho, uma como que resposta à suspensão cética de Evódio, quanto ao que corresponderia a uma autêntica e verdadeira inquirição acerca da realidade, a qual não trataria de suspender o iudicare acerca da realidade e de seus dados/notitias, mas efetuaria o recuo para colher, em seu âmbito de visão, toda a realidade que lhe é diante do olhar, ou que lhe é (e será) ofertada pelos sentidos (vide adiante capítulo 3, item 3.5). Vimos, há pouco, que é precisamente este o movimento que Agostinho associa ao exercício e uso da ratio. Tal identidade de movimentos afigura-se-nos de todo fundamental, posto clarificar, em corroboração ao anteriormente por nós tentado, sobremaneira a correlação entre a percepção do esse, enquanto dado primordial e certeza primeira, e o saber a respeito, numa palavra: o esse fundamenta a consciência, mormente quando no recuo para atestar a existência, numa palavra: autoconsciência. Agostinho parece-nos fazer implicar a autoconsciência no saber da existência ou do ser. A consciência resulta, pois, como constatação do ser, o saber do que é voltado (recuo ou recolhimento: intus interrogans) a si enquanto existência. Nesse sentido, em termos sumários, nossa tentativa caminha para a assertividade da consciência enquanto afirmação primeira do ser, bem como deixando explícita a diferença entre a consciência e a racionalidade. Porém, como veremos adiante, a possibilidade de compor scientia acerca da realidade in totum, pertence exclusivamente à ratio, visto sua autoconsciência principiar pelo abarcamento, a partir de si própria, da realidade como totalidade percebida tanto exterior e temporalmente (corporalia), quanto interior e atemporalmente (intus interrogans). Por ora, podemos tãosomente afirmar, grosso modo, que o excellere, por parte do senso interior em relação aos sentidos interiores, perfaz uma superação não científica, resultando, por assim dizer, numa interioridade sem racionalidade [“... non ad sciendum, nam hoc rationis est, ...”- II, iv, 10] ${ }^{185}$.

\footnotetext{
${ }^{185}$ Embora nossa tentativa seja de fundo divergente, as análises judiciosas de Bermon acerca do sentido interior neste trecho do lib. arb. II parecem-nos próximas: "L'analyse augustinienne du sens intérieur est originale dans la tradition philosophique. Le nom même qu'Augustin donne au príncipe qui permet de sentir les communs et d'unifier le champ du sensible revele l'originalité de sa pensée. Em effet, Augustin n'appelle pás ce príncipe le 'sens commun', comme la distinction entre le propre et le commun de la senstion l'invitait à Le faire; [...] Le fait qu'Augustin ait pense ce que la tradition appelle le 'sens commun' comme um sens 'interior' explique sans doute qu'il n'entreprenne pás de 'constitution' du sens intérieur à partir des cinqu sens, et notamment à partir du sens du toucher. Sur ce point, la pensée d'Augustin se démarque de la traditon aristotélicienne. [...] La critique du pouvoir des sens produite par Augustin montre par conséquent qu'aucun des cinq sens n'est capable ni de perceboir les autres sens, ni de se percevoir soi-même. Ce qui permet à l'ame de percevoir quélle perçoit est encore un sens. Ce sens permet une 'aperception' sensible mais il ne produit lui-même aucun savoir. [...] La
} 


\subsection{4) Senso interior e moderação-juízo}

Agostinho faz prosseguir o diálogo, no sentido de elucidar a natureza da excelência do senso interior em relação aos sentidos exteriores. Como já o fizemos notar, após pontuar, em retomada dos pontos principiais, o estágio do debate até então, ele solicita a Evódio que estabeleça relação de pertença entre o conteúdo percebido pelos sentidos exteriores, os próprios sentidos, e a tríade axial de princípio (II, v, 11), para então pedir-lhe que se detenha no sentido interior:

Ag. E, no que tange àquele sentido interior, que anteriormente vimos como sendo inferior à razão, e até nos é comum com as bestas, teria dúvida em antepô-lo a este sentido através do qual percebemos os corpos, e que antes já disseste que deveria ser preposto ao próprio corpo? [...] De fato, não poderás dizer que este sentido interior deva ser classificado naquele gênero [...] ao qual pertencem os seres inteligentes, [...] já que este sentido interior também se encontra nas bestas... [II, v, 12] ${ }^{186}$

Se por um lado se preocupa em acentuar a ausência de inteligência no exercício do senso interior, Agostinho enfatiza, por outro, sua anterioridade e preposicionamento ontológico e epistêmico em relação à exterioridade, vale dizer: a ausência de percorrência temporal em seu exercício. Tal advém, em realidade, da natureza essente e da funcionalidade própria ao sentido interior: ele atua, como vimos, em recolhimento de inquirição, ou seja, no âmbito interrogativo. Já a ratio, como veremos, atua na esfera da constatação e feitura do todo, compondo scire em conjunto de toda a realidade, ou seja: consciência, cujo ato perfaz a identificação essente de cada ser em sua relação imediatizada pela predicação em relação ao Vere Esse enquanto fundamento de todo ser, vale dizer: intus-legere. Se o senso interior efetua sua excelência em moderare et iudicare a realidade corporal através do ato em intus rogare, a ratio por sua vez se efetiva, instante a instante, em intus-legere. E, ao situar a atuação do senso interior no recuo face à exterioridade, instanciando-o portanto em atemporalidade, Agostinho qualifica-o como instância primeira de ordenação prévia e configurativa da realidade sensível (praeponere), pela qual o sentido de recolhimento da exterioridade, em interiorização, configura disposição prévia à intelecção deste mesmo exterior ${ }^{187}$. Assim, no dispor previamente a efetivação da intelecção da realidade, a interioridade atua como âmbito primeiro em que se afirma, de modo atemporal,

sciene de la vie ne vient pás de la sensation. Elle ne vient pás non plus su sens intérieur mais de la raison. BERMON, 2001: 52-53.

${ }^{186}$ Quid? Illum sensum interiorem, quem quidem infra rationem et adhoc nobis communem cum bestiis superius indagavimus, dubitabisne huic sensui praeponere, quo corpus attingimus et quem iam ipsi corpori praeponendum esse dixisti? [...] Non enim poteris dicere hunc sensum interiorem iam in eo genere trium illorum esse ponendum quod etiam intellegit [...] iste enim sensus inest et bestiis...

${ }^{187}$ Vide BERMON, 2001: 51-52. Cf. ainda KREMER, Patrick J. The "psychological” proof for the existence of God developed by Saint Augustine, op.cit., p. 12; TILLICH, P. História do Pensamento Cristão, op.cit., p. 125126. 
tanto o esse em sua notitia dada ante o nada da exauriência anterior, quanto sua imediação como intelecção do significado dado.

3.1.5) Recuo e avanço atemporal (prae-ponentia/potentia): busca interior e leitura inquiridora (intus-rogans/legens)

$\mathrm{Na}$ medida em que se pre-posiciona ante o esse, imediatizando-o com vistas à sua afirmação primordial, por parte de sua intelecção, enquanto certeza de fundamento (vide nossas tentativas anteriores de leitura quanto à tríade ser-viver-inteleccionar), a interioridade resulta como pré-disposição à feitura intelectual da realidade sensível e interiorizada, o que termina por qualificá-la como o instante primeiro do direcionamento e da adjudicação dos seres criados em sua relação com o Ser supremo, noutras palavras: o senso interior dispõe à moderação e ao juízo do real, instituindo a temporalidade inerente à sua feitura e intelecção. Anteriormente, numa definição que podemos qualificar como preliminar, Agostinho postulara que unicamente a razão pode julgar acerca do eventual caráter de scientia dos objetos, os quais lhe são direcionados e apresentados com vistas ao seu exame [“... nisi de his quae sibi examinanda offerentur." - II, iii, 9]. Por sua vez, e com vistas a tal exame, a ratio igualmente se antecipa à temporalidade da intelecção ofertada pela predisposição da interioridade, posicionando-se ao exercício próprio de cientificação, de forma perene e incondicional (“...ipsa ratio [...] et se ipsam distet agnoscit seque illis praepotentiorem esse confirmat, ..." - Idem). Ora, ao lançar mão de praeponere para qualificar a funcionalidade da interioridade, bem como praepotentior para a racionalidade, Agostinho deixa claro, uma vez mais, que o âmbito de atuação de ambas, dada sua antecipação e/ou anterioridade de postulação, se dá na ausência de mensuração, antepondo-se à temporalidade (ensejada no instante mesmo de sua atuação - vide pontuações anteriores acerca de intellegere e esse), bem como no recuo em busca (intus rogare - interioridade); e na intentio em avanço de perfazimento intelectual da realidade (intus-legere racionalidade). Clarifica-se, pois, que a inquirição e a intelecção ostentam pressuposição, atemporal e incondicionalmente, face ao movimento de exauriência dos seres conhecidos. Tal predisposição, pressuposição e incondicionalidade resultam, ou melhor: repousam na única instância possível no espectro geral do conhecimento até aqui delineado: a do instante do ser em sua manifestação. Enquanto manifestação ou surgimento (tal como um exsurgir), o esse pressupõe a atemporalidade que lhe é própria de sua relação e direcionamento ao Vere Esse; bem como predispõe e institui a temporalidade de sua exauriência, fazendo com que a pressuposição atue como necessária ao conhecimento, com o fito de configurar o âmbito de sua intelecção. Por sua vez, a instância (ou: instantaneidade, por assim dizer) ou o âmbito do 
instante atemporal ("prefigurativo do eterno" - Mammì) torna as relações entre a interioridade e a racionalidade como de decorrência, nas quais a simultaneidade essencial à funcionalidade de ambas faz com que a atuação da racionalidade, no âmbito da instantaneidade do esse, se dê como que em vetor retrocedente: a consciência, atinente de modo único à ratio, perfaz a atuação desta em todos os âmbitos que lhe são pressupostos ou anteriores, de maneira tal que, ao julgar e moderar a corporeidade, os sentidos exteriores estejam antecipando - o que, na instantaneidade/simultaneidade essencial da intelecção, equivale a dizer que esteja se dando de modo imediato - a funcionalidade da ratio, com seus próprios atributos e/ou funcionalidade, o que implica afirmar que, na verdade, trata-se da ratio atuando na imediação dos sentidos exteriores, fornecendo-lhes os meios de atuação. De igual modo, o sentido interior, ao adjudicar e moderar os sentidos exteriores, o faz com o instrumental ambientado e "fornecido" pela racionalidade. Este movimento geral - que em sua amplitude e abarcamento, compõe a exauriência do esse em seu perfazimento da realidade criatural - ocorre numa presentificação imediata entre seus âmbitos internos, quais sejam: exterioridade, interioridade, racionalidade, na decorrência direta dos termos da tríade inicial com a qual Agostinho redirecionara e ampliara a disputatio a novos rumos e conquistas conceituais. É pois num "presente eterno", por assim dizer, que se dá a presença da consciência na interioridade ${ }^{188}$, o que evidencia a diferença do ser humano em relação aos outros seres animados, os quais não possuem racionalidade, tampouco consciência: nestes, a interioridade atua enquanto modo de sobrevivência (vide citação em II, v, 12) e vivificação; no ser humano o senso interior constitui prefiguração e preparo à ratio, em intus-rogare, na busca que se lança à scientia em conjunto a todo o anteriormente vivenciado, numa palavra: con-scientia. Este duplo aspecto inerente à manifestação e doação do ser, bem como à sua exaurição, ocorrendo nos âmbitos da interioridade (enquanto busca interior - intus-rogare) e da racionalidade-intelectualidade (como intelecção da realidade universal em recolhimento dos signos da relação Vere Esse-esse, ou Esse major-esse minor, Ser supremo e ser criado: intus-legere), encontra sua feitura e concretude, vale dizer: sua mensuração e temporalidade, na funcionalidade em exercício própria (inerente) aos dois âmbitos: as funções de direcionamento-feituração e adjudicaçãoafirmação da realidade em sua ipseidade e essência, respectivamente: moderare e iudicare.

188 “..., um decidido 'recolher-se' a uma presença sempre presente, à contemplação de um objeto intemporal. [...] aqui, [trata-se de um] recolhimento. E voltada a alma ao 'interior', está posta a condição para um avançar em sentido positivo na linha 'epistemológica' [...] a passagem à interioridade é um abandono dos quadro cosmológicos, da multiplicidade espacio-temporal, mas não é uma fuga mística." - VAZ, H.C.L. A metafísica da interioridade - Santo Agostinho, op.cit., p. 83. 


\section{2) Adjudicação-afirmação da realidade: a feituração no dizer e instituir a realidade}

\subsection{1) Pares conceituais e relações binomiais}

A inserção do par moderare e iudicare neste ponto da disputatio atesta, uma vez mais, o método de Agostinho, ou bem a estrutura de seu desenvolvimento dialogal. A condução deste desenvolvimento opera com base em pares conceituais, dentre os quais alguns compõem relações binomiais e/ou polaridades entre si, mas todos perfazendo as simultaneidades de base que configuram o todo do pensamento agostiniano expresso em nosso texto. Com efeito, no livro II tivemos inicialmente o eixo binomial credere-intellegere, a partir do qual deu-se a retomada, após a suspensão de juízo cognitivo efetuada por Evódio, do diálogo em novas bases. Destas, a tríade fundamental esse-uiuere-intellegere (que, como vimos, Agostinho propositadamente recepciona junto ao neoplatonismo, com o fito de compor instrumental que lhe propiciasse justificar o ser conjuntamente à sua intelecção na realidade universal, vale dizer: a metafísica do Exxodo, junto à ascensão intelectual da tradição platônica) possibilitará seu próprio desdobramento através da profusão de relações binomiais: esse-intellegere; exterioridade-interioridade (sensus exteriores-sensus interior); interioridade sensivel racionalidade (sensus-ratio); intus-rogare e intus-legere. Observa-se que alguns destes pares não ostentam polarizações entre si (esse-intellegere; interioridade sensível -racionalidade), outros atuam como binômios polares (exterioridade-interioridade), ao passo que outros apresentam complementariedade interna (intus-rogare e intus-legere). Todos, entretanto, atuam e/ou funcionam em simultaneidade essente, ou seja, atuam espacio-temporalmente em conjunto. A simultaneidade de base afigura-se, aqui, como amálgama ou liame perpassante por tais binômios, os quais efetuam o molde da feitura intelectual da ascensão anímica, no todo anteposto e prefigurado ao abarcamento pelo itinerário ascensional.

\subsection{2) Feiturar e afirmar: cronometrar-contemplar (dizer-instituir)}

Esta característica (simultaneidade de base) inerente aos pares conceituais irá se mostrar ainda mais evidente no par moderare-iudicare, que Agostinho apresenta na imediata continuidade de nosso texto. Antes de nos determos no momento preciso de seu surgimento no texto, importa retomarmos que Agostinho está, nesta altura do diálogo, a solicitar que Evódio forneça as razões pelas quais, na sequência de excellere entre conteúdo e percepção, bem como entre sentidos externos e sentido interior, a este antepõe (praeponere) e o qualifica como melhor (melius) que aqueles. Agostinho finaliza sua solicitação, ainda, tratando de agudizá-la em suas hipóteses, com vistas a impedir eventuais respostas dúbias por parte de Evódio: 
Se me disser que este [sentido interior] sente aqueles [exteriores], não creio que tenha encontrado uma regra pela qual se possa estabelecer que todo o que percebe é melhor que aquilo por ele percebido, dado que nos veríamos forçados a admitir igualmente que todo ser inteligente é melhor que aquilo por ele inteleccionado. Mas isto é falso, pois todo homem entende a sabedoria, e nem por isso é melhor que a própria sabedoria. [II, v, 12] $]^{189}$

A ressalva com a qual Agostinho esmiuça - e dificulta - o teor da resposta que espera ouvir de Evódio, como que trai seu intento "secreto" ou subreptício: trata-se - sentido interior de uma realidade diferente, tanto dos sentidos exteriores (razão pela qual não the cabe a aplicação do raciocínio baseado na relação de pertença: "o que contém é superior ao conteúdo"), quanto da racionalidade (à qual se poderia, a princípio, aplicar a regra aludida por Agostinho, precisamente por se tratar do próprio exemplo utilizado: a sabedoria, enquanto razão, contém e, na verdade, se identifica ao seu conteúdo). Em consequência, sua colocação terá necessariamente de ostentar esta "intermediação" entre exterioridade e racionalidade, decorrendo pois que as "razões" de ambas não cabem neste âmbito intermédio. Ora, a evidência, e mesmo certa redundância, de tal definição e esmiuçamento é tal, que podemos nos perguntar: porque Agostinho faz disso uma questão tão incisiva a Evódio, tratando de inserir até mesmo ressalvas, com o fito de evitar erros que deviam ser comuns em tais discussões? E, afinal, porque insiste Agostinho na demarcação de uma área intermédia entre exterioridade e racionalidade, quando poderia reduzí-la a esta última, pura e simplesmente?

Podemos tentar vislumbrar as respostas nos próprios exemplos pelos quais Agostinho, em verdade, termina por balizar a resposta de Evódio. De um lado, a evidente excelência em relação aos sentidos exteriores; por outro, a exclusão de sua igualdade à racionalidade, apelando à própria identidade desta. Observemos que a exemplificação pela qual Agostinho exclui a hipótese da relação de pertença, apoia-se em situação única e inexcedível: a sabedoria (sapientia). Trata-se da única situação em que o sentido interior, ou interioridade, não pode pretender a excelência pela relação de contenção, posto apontar para a única realidade à qual o ser humano é inferior. De fato, é unicamente a sabedoria que excede, ou perfaz excelência, em relação à interioridade.

Agostinho, na realidade, quer especificar o elemento propriamente humano, em relação à interioridade e racionalidade. Ao passo que o senso interior é compartilhado pelos animais, a ratio compete unicamente ao ser humano. Nota-se que o esforço, e mesmo insistência, em demarcar a região intermédia correspondente ao senso interior, visa evidenciar, em termos

\footnotetext{
${ }^{189}$ Si enim dixeris quia ille istum sentit, non te credo inuenturum regulam qua fidere possimus omne sentiens melius esse quam id quod ab eo sentitur, ne fortassis ex hoc etiam cogamur dicere omen intellegens melius esse quam id quod ab eo intellegitur. Hoc enim falsum est, quia homo intellegit sapientiam et non est melior quam ipsa sapientia.
} 
comprobatórios, a excelência ou superioridade do elemento anímico face ao corporal, ou da atemporalidade interior (em sua amplitude máxima) frente à corporeidade temporal. Agostinho visa, sobretudo, estabelecer verdades decorrentes da primordialidade do esse em sua excelência de uiuere. ${ }^{190}$ É precisamente a captação do movimento de superação que nos parece constituir o alvo das análises agostinianas neste passo, cujas recorrências, e até mesmo as redundâncias estrategicamente elencadas, visam ilustrar a percorrência da realidade via intelecção humana, feiturada sob o signo da exauriência de cada aspecto ou surgimento de um esse (imediatizado pelo Vere Esse) e efetivada na atuação permanente da ratio, cuja presentificação, por todo o percurso do itinerário, é pontuada sob o excellere efetuado em cada passo, sem exceção, como que compondo um movimento de recorrência em que ela (ratio) presentifica-se a todo instante na atuação dos demais sentidos e instâncias, os quais a utilizam em sua funcionalidade, embora não a componham ou façam parte de sua instância. De fato, a vivência do ser, na concretude de sua feituração e afirmação, pode ser percebida em todo ser vivo, animais e ser humano. Mas o elemento especificamente humano face às demais criaturas, qual seja, a ratio, na medida em que se mostra voltada para o Vere Esse eterno e absoluto enquanto seu fundamento, está em excelência para com a própria atemporalidade, embora tenha esta por pressuposto necessário, ao passo que a interioridade, enquanto região intermédia excedente aos sentidos, mas não alçada à racionalidade, afigura-se no recolhimento e plenificação da temporalidade.

\subsection{3) Hierarquização e feituração inteleccional da realidade}

Talvez possamos entender o sentido da hierarquização verificada entre sentido exterior - senso interior - racionalidade, realizada na atuação funcional do juízo e da moderação de uma instância em relação à outra, como um recuo perpassante do todo, perfazido pela ratio na feituração da realidade criatural, no instante de presentificação dos diversos sentidos, num presente único, atemporal. Iudicare e moderare se revestem, ou melhor, compõem atuação permanente de cientificar-se da (scire) realidade em sua vivência instantânea, e imediatizada precisamente enquanto todos os dados anteriores estão reportados - presentificados em seu todo, ou enquanto totalidade - ao nível imediatamente seguinte. Julgar e moderar são o presente atemporal e perene da excelência do esse em relação ao tempo e ao limite e finitude do ente. Notamos pois que, na concretude da feituração inteleccional da realidade, o excellere de cada nível ontológico é efetivado mediante uma recursividade (uma excelência prévia: “..., quam sensum interiorem vocamus praecellentem sensibus corporis,..." - II, iii, 9) que aponta para um duplo movimento, por sua vez realizado em simultaneidade decorrente da

${ }^{190}$ Cf. BERMON, 2001: 54-73. 
simultaneidade maior verificada entre a manifestação e a intelecção primordiais: a) a corporalidade e os sentidos exteriores como que remetem e presentificam, em prospecção, seus dados à interioridade, que por sua vez presentifica seus dados à racionalidade por imediato e instante ( "... ipsa ratio quae ministros suos et ea quae suggerunt discernit invicem et item quid inter haec et se ipsam distet agnoscit seque illis praepotentiorem esse confirmat,..." - Idem), a qual, por seu turno, b) atua em retrospecção (o que Agostinho qualifica como anteposição do sentido superior ao inferior: “...dubitabisne huic sensui praeponere, quo corpus attingimus...”II, v, 12) ou ainda introjeção, presentificando-se desde o início do percurso, através de cada passo ascensionado ou ascendido, em excellere. Esta presentificação simultânea e atemporal tem por instrumento, ou imediação, precisamente as funções de julgar e moderar a realidade. Se tais funções se efetuam e se concretizam, de modo permanente, pelo passo seguinte em relação ao anterior, este trata, por seu turno, de recursar e projetar toda sua exauriência ao passo seguinte ou "superior", igualmente valendo-se das mesmas funções.

Da tentativa que acabamos de expor, resulta a implicação de que iudicare-moderare qualifica-se como a medida de cada passo da ascencionalidade inerente ao percurso cognitivo, posto que o movimento de superação ocorre à medida do julgamento e condução para a completude, com o consequente esgotamento (exaurição) do conteúdo inferior pelo superior. Tal medida, no momento mesmo em que se performa e atua como tal, implica em sua própria ausência de medida interna; bem como, atuando na feitura temporal, implica em sua própria atemporalidade. Julgar e moderar implicam, pois, que se dão e atuam em atemporalidade e em infinitude, o que equivale a dizer que sua imediaticidade é assegurada e necessária, visto fornecer a medida para a mediação, temporalidade e finitude. Igualmente, o binômio impõe ainda o seu reconhecimento como um conhecer sem scientia explicitada, noutros termos: uma cognitio inconsciente, visto a postulação de Agostinho acenar neste sentido.

\subsection{4) Sentido interior e julgamento-moderação}

Verifiquemos, em nosso presente passo, a sequência da exposição da discussão, no momento preciso em que Agostinho postula o binômio no âmbito do sentido interior. Em resposta ao pedido de Agostinho acerca das razões pelas quais antepõe o sentido interior aos exteriores, Evódio apresenta então sua justificativa baseado, precisamente, no binômio conceitual em questão:

Porque reconheço que este [sentido interior] atua como moderador e juiz daquele (sentido exterior). Como vimos, se este [exterior] incorre em falta no exercício de seu ofício, aquele [interior] aponta e cobra o que lhe falta, como se faz a um ministro. Assim como o sentido da visão não sabe se vê ou não vê; e, não sabendo, não pode 
julgar acerca do que falta ou que completa, mas sim aquele sentido interior é que adverte e move o animal a abrir o olho e preencher o que ele [interior] constatou faltar. Ademais, ninguém põe em dúvida que o que julga é melhor que o julgado. [II, $\mathbf{v}, \mathbf{1 2}]^{191}$

É possível ressaltar, de início, que a resposta de Evódio acusa um paralelo de contraste, decorrente do esmiuçamento e da delimitação do campo responsivo que, de modo estratégico, Agostinho praticamente impusera a Evódio, autor da suspensão judicativa passos atrás na discussão. Assim como o conduzira à afirmação da preeminência do esse enquanto certeza primeira e indubitável, rompendo assim com a suspensão do juízo cognitivo, uma vez mais Agostinho leva seu interlocutor a contradizer sua posição cética inicial, através da postulação afirmativa quanto à possibilidade do conhecimento humano, fazendo com que Evódio afirme o juízo e a moderação como inerentes à cada passo do conhecimento humano. O objetivo da sequência e análise agostinianas parece-nos ser o de responder, de modo claro, à epóche estoica, partilhada entre outros por Cícero, de quem aparentemente herda Agostinho o binômio iudicantem et moderatorem, transpondo-o porém de seu uso restrito ao direito público e civil, para reaplica-lo à esfera do conhecimento humano, com o fito de restituir-lhe o alcance genuíno $^{192}$. O binômio ostenta a possibilidade de se ajuizar, de modo categórico, o conhecimento da realidade tal qual nos é apresentada pelos sentidos: julgar e moderar correspondem, de fato, ao atestamento e dicção da realidade, atestá-la e afirma-la ou dizê-la, numa palavra: reconhecê-la, chancelando-a no julgamento e na modulação, ou ainda: na afirmação e feituração, em cada dado ou notitia apresentados pela percepção, os quais compõem a presentificação do esse indicativo de um determinado nível de conhecimento. Neste preciso sentido que O'Daly estabelece relação biunívoca entre a percepção dos sentidos e a atividade judicativa que lhe é simultânea:

Os objetos da percepção, na medida em que são percebidos, são discriminados: a centralização envolvida na percepção (a intentio sentiendi) é uma atividade judicativa [...] No caso das cores, por exemplo, não meramente as sentimos com os olhos, nós as distinguimos, categorizamos, queiramos ou não nós as explicitamos como "verde", "cinza" ou "amarelo". Para ilustrar este ponto, Agostinho lança mão da metáfora da luz. [O’DALY, 1987: 88-89]

\footnotetext{
${ }^{191}$ Quia moderatorem et iudicem quendam huius illum esse cognosco. Nam et si quid huic in officio suo abfuerit, ille tamquam debitum a ministro flagitat, sicut paulo ante disputatum est. Non enim se videre aut non videre sensus oculi videt, et quia non videt, non potest quid sibi desit aut quid satis sit iudicare, sed ille interior, quo admonetur et anima bestiae aperire oculum clausum et quod deesse sentit implere. Nulli autem dubium est eum qui iudicat eo de quo iudicat esse meliorem.

${ }_{192}$ Aldo Cassi faz remontar à experiência de oratória de Agostinho, a origem do uso da conceituação centrada em iudicare, tomando o referencial agostiniano para tal uso na acepção clássica de hierarquia judicativa, ou função judicativa hierarquizante - CASSI, A. La Giustizia in Sant'Agostino, Milano: FrancoAngeli, 2013, p. 23-25 e 3739.
} 
Importa ainda notar, no âmbito de tal funcionalidade interna, que as atuações adjudicativa e moderadora ocorrem em simultaneidade essencial ao âmbito próprio da interioridade, bem como à atuação da ratio neste e em outros âmbitos (exterioridade e corporeidade). A simultaneidade inerente ao exercício das funções revela, por seu turno, que o excellere constitutivo da gradação ou hierarquização dos níveis de conhecimento da realidade, é efetuado, de modo pleno, na atemporalidade essencial em que se dá o âmbito da interioridade, atestando que o movimento ascensional, executado e perfazido através da funcionalidade adjucativa e moderadora da ratio, em sua anteposição e presentificação perpassante por todo o itinerário (desde o seu início), ocorre na instituição da simultaneidade essencial fundante anteriormente aludida, entre o esse e seu intellegere, instituindo, de per si, a temporalidade da feitura do percurso inteleccional efetuado na ascensão anímica. Assim, as funções adjudicativa e moderadora, ao mesmo tempo em que ostentam a afirmação e feituração da realidade, igualmente a apresenta em sua linguagem instaurativa e sua instituição temporal, numa palavra: a ratio, ao julgar e moderar a feituração cognitiva da realidade, termina por dizê-la, descrevê-la, apresentá-la e instituí-la ${ }^{193}$.

De igual modo, observamos que a exemplificação adotada por Evódio aponta para o fato de que as funções judicativa e moderadora exercidas no excellere interno à ascensionalidade do conhecimento, envolvem o senso prévio de totalidade e completude: “... [o sentido exterior] não pode julgar acerca do que lhe falta ou completa, mas sim aquele sentido interior...". É a partir da totalidade, vale dizer: do esse enquanto totum e uno, que a funcionalidade adjudicativa e moderadora da ratio passa a efetivar o excellere interno à intelecção da realidade, evidenciando-se como o senso primordial ensejante de sua própria feitura e intelecção. Será, pois, precisamente a partir do esse - na imediatez de sua presentificação em relação com o Vere Esse - enquanto primeira certeza, cuja presença manifesta e dado evidente perfazem um sentido de totalidade enquanto impossibilidade de qualquer falha, falta ou ausência, que a sua intelecção possibilitará o vetor da exauriência, a qual irá perpassar a itinerância da feitura intelectual da realidade.

Outrossim, a maneira como Evódio qualifica a apresentação de suas razões chama-nos igualmente a atenção. Ele afirma reconhecer (cognosco), e não inteligir ou compreender, a

\footnotetext{
193 "Den Argumentationsrahmen des zweiten Buchs bildt deshalb ein zahlentheoretischer Gottesbeweis, der die Rangfolge der Trias Sein, Leben und Denken durch den Grundsatz rechtfertigt, Urteilsfahiges stehe über von ihm Beurteilbarem. [...] Lebenwesen seien gegenüber [...] der als ihr moderator und iudex (De libero arbitrio II, 5,12) der Selbsterhaltung des Lebenwesens diene (II, 4,10)." HORN, C. Augustins Philosophie der Zahlen in Revue des Études Augustiniennes 40 (1994), p. Horn analisa ainda a numeralidade e seu sentido em outros diálogos do período inicial, entre os quais De ordine e De quantitate animae. Vide ainda KREMER, Patrick J. The "psychological" proof for the existence of God developed by Saint Augustine, op.cit., p.12-13.
} 
funcionalidade adjudicativa e moderadora presente na interioridade. A escolha de cognoscere parece-nos apontar, como decorrência da peculiaridade do conteúdo conhecido, para a especificidade das funções e, sobretudo, de seu papel na economia geral do processo de ascensão intelectual em pauta neste início de sua apresentação. Ao descrever uma atuação e funcionalidade interna ao percurso inteleccional, Evódio lança mão de uma das possibilidades de qualificação do ato intelectivo, cuja definição evidencia discernimento e captação de sequência temporal, numa palavra: movimento, dinâmica e funcionamento, implicando em composição de partes. Aqui, precisamente, resulta clarificada a questão anterior acerca da eventual autopercepção do sentido interior, no sentido de sua negação. Posto que a percepção das funções de julgar e de moderar, exercidas pelo sentido interno, são captadas por ato cognitivo que supõe, em si, que tal percepção seja externa a ambas, de modo a possibilitar a captação de seu movimento e de sua composição entre si, torna-se evidente que tal captação perfaz conhecimento externo ao âmbito em que tais funções se dão, configurando-se numa instância que as abarque, juntamente com o conhecimento de ambas, numa palavra: a racionalidade ${ }^{194}$.

No prosseguimento, Agostinho aponta para o caráter homogêneo e uniforme da argumentação evodiana, evidenciando a perfeita continuidade de sua aplicação no que respeita aos sentidos exteriores, com a observação de que

Não é necessário prosseguir no exame dos demais sentidos externos, pois me parece
que atentaste ao que quis dizer, ou seja, que aquele sentido interior julga os sentidos
exteriores, ao aprovar sua integridade e reclamar aquilo que devem, ao modo como os
mesmos sentidos exteriores/corporais julgam estes mesmos corpos em suas sensações,
aceitando a suavidade e recusando quando contrário. [II, v, 12] ${ }^{195}$

Notemos que Agostinho faz ressaltar a natureza da função judicativa, e em que consiste o julgamento dos sentidos entre si: na percepção da inteireza e da completude de sua atuação e funcionalidade, decorrendo o mesmo com relação ao conteúdo percebido. Assim, o ato judicativo pressupõe a posse prévia, por parte do sentido que julga, da finalidade do resultado e do conteúdo ao qual o sentido julgado deverá chegar, evidenciando que o iudicare próprio à racionalidade, e perpassante em cada um dos níveis ascensionados (julgados) até então, presentifica-se e atua, necessariamente, em anteposição ao exercício e atuação da corporeidade, de cada um dos sentidos exteriores, do sentido interior, e mesmo da interioridade enquanto

\footnotetext{
${ }^{194}$ Vide a discussão de Horn acerca da autorreferencialidade do cogito em Plotino e Agostinho - cf. HORN, 2008: 93-95.

${ }^{195}$ Non necesse est ceteros sensus corporis persequi. Iam enim, ut opinor, animaduertis quid uelim dicere, ita scillecet sensum illum interiorem de istis corporis sensibus iudicare, cum eorum et integritatem probat et debitum flagitat, quem ad modum et ipsi corporis sensus de corporibus iudicant, adsumentes in eis lenem tactum reicientesque contrarium.
} 
âmbito de recolhimento, "preparação" e apresentação do conteúdo percebido à racionalidade. Pode-se dizer, nesse sentido, que julgar e moderar cumprem anteposições instituídas e perfazidas pela intelecção originária, em sua racionalidade atemporal, através das quais, quando da instituição da temporalidade própria à exauriência do esse no movimento de excellere constituinte da ascensionalidade cognitiva, atuam na interioridade e na temporalidade inerente ao movimento do itinerário ascensional. Igualmente, notamos que o julgamento está para a integridade, tal qual a moderação está para a equidade ou equilíbrio: os sentidos julgam a sensação corporal, quanto à sua inteireza e integridade finalista, de igual modo ao julgamento a que serão submetidos pelo sentido interior. Nesse sentido, a consecução das funções aponta para sua finalidade: integridade e igualdade correspondem à perfeição ou ausência de faltas, desníveis e distorções na ocorrência da feitura da realidade, dada a conhecer (e ser julgada) pela ratio, nas imediações corporal, perceptivas e interiorizadas.

\title{
3.3) Ratio: instância suprema de juízo e moderação da realidade conhecida
}

Se o caráter homogêneo e coerente da argumentação evodiana pareceu a Agostinho justificar a dispensa da continuidade em exemplificação, ou da verificação de sua aplicabilidade quanto aos sentidos exteriores em relação às sensações corporais, com muito maior evidência será a razão dispensada de tal "exercício":

\begin{abstract}
Se bem que nem isso me parece necessário investigar: se ela julga aquele sentido. De fato, quem afirma, a não ser a própria razão, nas coisas que lhe são inferiores, isto é, os corpos, os sentidos corporais e o sentido interior, de que maneira um é melhor do que outro e como ela mesma é mais poderosa de todos? E não poderia fazer isso, se ela não julgasse sobre eles. [II, vi, 13] ${ }^{196}$
\end{abstract}

Detenhamo-nos no trecho final, em que Agostinho questiona, e praticamente responde ao mesmo tempo, acerca da possibilidade de outro nível ou instância, fora a racionalidade, exercer julgamento acerca da realidade sensível e interior. A resposta, como que já embutida na pergunta, aponta para a totalidade do conteúdo conhecido e de antemão posto à sua presença, o que equivale a postular sua superioridade enquanto anterioridade (praestantior), bem como seu caráter presencial irrenunciável (renuntiat). A ratio exerce suas funções e atua, de maneira anterior e totalizante, no sentido de todo o conteúdo da realidade lhe estar previamente submetido e avalizado, ante o qual ela (razão) como que irá delegar atividades para todos os níveis que se encontram por ela abarcados (ou seja, toda a realidade), para que,

\footnotetext{
${ }^{196}$ Iam enim non quaero utrum eant meliorem illo esse dubites, quia non dubito id te iudicare; quamquam ne id quidem iam quaerendum putem, utrum de isto sensu iudicet ratio. Namque in his ipsis quae infra eam sunt, id est in corporibus et in sensibus corporis et isto interiore sensu, quo modo sit aliud alio melius et quam sit illis ipsa praestantior, quae tandem nisi ipsa renuntiat? Quod profecto nullo modo posset, nisi de his ipsa iudicaret.
} 
com o instrumental que lhe é inerente, e através do qual perpassa toda a estratificação da realidade inteleccionada, bem como todo o processo de excellere feiturado a partir da exauriência do esse primordial em cada passo do percurso intelectual, ela paute, conduza em equalização (moderare), e sobretudo afirme e institua em adjudicação (iudicare), toda a realidade inteleccionada e ascensionada rumo ao absoluto e eterno.

A qualificação da racionalidade como anterioridade totalizante e instância suprema perpassante de todo o processo ascensional do conhecimento humano, perfazendo a consumação temporal da intelecção instituída primordialmente (e instanciada, como por várias vezes aqui ressaltamos, recursivamente e prospectivamente, pela própria ratio), presta-se ao intento prosseguinte de Agostinho, no sentido de caminhar para a argumentação demonstrativa da existência de Deus, enquanto única realidade superior à razão humana, constituindo-se na sessão de continuidade da discussão com Evódio, e perfazendo o núcleo por assim dizer concreto da argumentação ora apresentada, em que irá se verificar, passo a passo, todo o movimento de excelência do esse, em sua dinâmica de exauriência e superação, até concluir pela afirmação judicativa de Deus enquanto Vere Esse, ser absoluto e supremo. Antes, porém, de contiuarmos no passo expositivo do livro II do De libero arbitrio, convém pontuarmos um paralelo, com relação à atuação judicativa e moderadora da ratio, explicitado junto ao livro VI do De musica, diálogo praticamente contemporâneo ao nosso texto de base, e igualmente representativo do período inicial da filosofia agostiniana. Na apreciação desta passagem, Louis Ucciani nota que

Na classificação e sucessão de ritmos, Agostinho coloca a razão ao cimo (do processo cognitivo) [...], conferindo-lhe dessa forma, primazia em relação aos sentidos [...] Ela [razão] separou todos estes ritmos psicológicos dos ritmos corporais, e reconheceu que ela própria não poderia nem observar todas as coisas, nem as distinguir, tampouco nomeá-las convenientemente, sem possuir, de per si, certos ritmos, e então apreciá-los à maneira de um juiz. [UCCIANI, 1998: 69]

No prosseguimento de sua análise, Ucciani explicita seu ponto-de-vista de que a função e/ou atuação adjudicativa e coordenadora da ratio radica, instância última e fontal, em Deus: "Este sobrepor(-se) da razão que se efetua na triagem e classificação dos diferentes ritmos, encontra sua referência na esfera divina." [1998: 69]. Em complementação, Ucciani coloca que a atuação racional se perfaz a partir de um domínio harmônico sobre todas as outras harmonias, estabelecendo um remontar ao inferior, através da "ordem eterna", onipresente no universo (Idem).

Na continuidade do diálogo, Agostinho conclui a argumentação relativa à superioridade da ratio, retomando a classificação atinente à tríade com a qual dera início à resposta ante a suspensão judicativa evodiana, e apresentando o elenco das etapas percorridas até então: 
$\boldsymbol{A g}$. Assim, pois, em precedência à natureza, que apensas é sem viver nem compreender (como acontece com os corpos sem vida), está aquela outra natureza que não somente é, mas igualmente vive, embora sem inteligência (como ocorre com os animais); e, um passo ainda atrás, temos a preceder esta última, aquela que simultaneamente é, vive e intelecciona, a qual é a mente racional humana [II, vi,13] ${ }^{197}$

Observamos que Agostinho procede à sumarização do movimento exposto, apresentando a superioridade entre os níveis ou instâncias, em termos de precedência e anterioridade, o que por evidente supõe prefiguração, como também antecipação. Na recapitulação, cada um dos elementos da tríade é reapresentado em vista de sua limitação ou esgotamento face aos demais: ressalva-se que a natureza apenas existe, sem vida e sem inteligência, como também o viver se apresenta sem a inteligência, ao passo que esta finaliza a composição triádica da realidade, contendo-a em sua totalidade, com a notação explicitada de Agostinho acerca da simultaneidade com que a inteligência perfaz e consuma, em si, as instâncias do real compostas no trinômio axial, clarificando que a precedência ostentada por esta última diz respeito ao perfazimento e à sumarização da realidade inteleccionada em seu polo final, permitindo-nos a percepção de que a ratio, em seu ato intelectivo, antecipa o percurso das diferentes etapas de gradação, em sua excelência própria e na precedência temporal, vale dizer: na atemporalidade com que se institui enquanto precedência e prefiguração do todo consumado em eternidade. Tais explanações serão repostas e esmiuçadas por ocasião das sessões II, viii e xi, quando Agostinho discorrer acerca da imutabilidade das verdades numéricas e da sabedoria.

Impõe-se, ademais, observar o sentido de retroação com que Agostinho descreve a precedência da razão humana, face ao conjunto da realidade por ela sumarizado intelectualmente: ao repassar as etapas decorrentes do trinômio fundante, a excelência do esse primordial resulta no perfazimento do real, dado simultaneamente à intelecção da mente que, em seu ato instituinte intelectivo, precede a essência da totalidade perfazida em cada uma de suas partes. Se o esse primordial enseja, em seu excellere próprio e volitivo (aspecto que será examinado ao final - item 4.3), a feitura intelectual da realidade passo-a-passo, quando do esgotamento e/ou exauriência de cada um dos níveis ontológicos, a ratio já obtivera, em precedência, o todo essente e consumado em sua captação da realidade à luz da atemporalidade interna que a fundamenta, e a situa permanentemente no passo antecedente (rursus hanc praecedat) quanto ao aspecto temporal, bem como precedente em relação ao espacial, mas cuja

\footnotetext{
${ }^{197}$ Aug. Cum ergo eam naturam quae tantum est neque vivit neque intellegit, sicut est corpus exanime, praecedat ea natura quae non tantum est, sed etiam vivit neque intellegit, sicuti est anima bestiarum, et rursus hanc praecedat e aquae simul et est et vivit et intellegit, sicut in homine mens rationalis.
} 
completude (sentido do todo, ou totalidade) permitem-lhe a captação conjunta e num mesmo tempo, noutros termos: imediata e simultânea (aequae simul). Nesse sentido, a precedência da racionalidade, oriunda desta atemporalidade própria em que atua, não somente coaduna-se ao exercício de suas funções de moderação e adjudicação da realidade, as quais intentamos descrever na seção anterior; como ilustra, de modo categórico, que a intelecção perpassante do itinerário ascensional tem sua consecução efetiva, tão-somente após ser instituída no instante mesmo desta simultaneidade em que atua.

A importância de observarmos a coadunação das funções judicativa e moderadora da ratio, junto à precedência com que instaura o curso de sua intelecção, reside em que a continuidade da argumentação agostiniana rumo à concretização de sua finalidade probatória, encontra sua fundamentação precisamente na precedência com que a razão se dispõe ao totum real, bem como em sua natureza atemporal, através das quais se poderá estabelecer a percepção da magnitude e absolutidade próprias do ser de que se espera provar a existência. De fato, as características inerentes e/ou essentes à ratio, permitirão delinear o que está em jogo provar, e Agostinho trata de preparar esta como que transição final - em que esgota a descrição ou sumário da realidade estratificada até a razão - para a argumentação decisiva e propriamente dita acerca da existência de Deus, conduzindo e finalizando o itinerário anterior, consumado na ratio, de modo tal que os termos em que esta se define, terminam por definir os termos do que se pretende evidenciar o que lhe esteja acima, vale dizer: que lhe preceda e supere. Podemos dizer que da apresentação da racionalidade enquanto cimo da realidade criatural, Agostinho evidencia os termos de definição da realidade divina que a precede e, sobretudo, a ela move e sustenta. A condição para se provar a realidade divina reside em que se defina o que, sendo a culminância da esfera do esse, de per si permita visualizar sua própria excedência e, até mesmo, enseje e manifeste sua excelência na esfera que lhe preceda e supere, ou se se quiser, que a transcenda (que será, afinal, o termo com que Agostinho explicitará a verdade enquanto realidade divina - vide adiante II, xi, 31 - item 4.5). O esgotamento e a exauriência da realidade criatural, ensejada pelo esse primordial e consumada na preeminência de atuação da ratio, apontam para a precedência da realidade superior com a qual a própria ratio - movendose na atemporalidade e totalidade que escapam a si própria, mais ainda ao que lhe está sujeito instaura e institui a intelecção que feitura cognitivamente a realidade temporal, fragmentada e instável.

Assim é, de modo que Agostinho conduz a retomada do elenco sumarizado na ratio, rumo à inquirição acerca de sua própria limitação, com o fito de averiguar se estamos, de fato, no ponto culminante da realidade, do qual nada mais lhe seja superior: “... entre os elementos 
que constituem nossa natureza como humana, pode-se postular algum outro mais preeminente?" [II, vi, 13] ${ }^{198}$. Novamente observamos que a preeminência ou preponência (ou ainda a excelência maior) de algo além do já elencado, dá-se em termos de precedência e antecipação, o que nos possibilita a percepção de que a esfera da excelência e excedência ontológicas, se por um lado ostenta o sentido ascendente quando de sua intelecção acerca da realidade sensível (gradualmente elevada até a esfera da ratio), por outro apresenta a prefiguração antecedente e totalizante quando de sua predisposição por parte da ratio, em sua instantaneidade constituinte de cada ato intelectivo que gradua o ser, em sua excelência de superação e perfazimento da realidade conhecida. Superar é prepor e preceder, na antecipação proporcionada pela atuação da racionalidade humana, toda a esfera da realidade em sua estratificação gradual dos seres, para feiturá-la instante a instante, na temporalidade de seu percurso intelectual.

Mas a preparação para o estabelecimento da inquirição de caráter probatório acerca do que eventualmente preceda e ostente preeminência sobre a ratio (lhe preceda em excelência), é ainda mais agudizada por Agostinho, ao qualificá-la com adjetivações que visam estabelecê-la, definitvamente, como termo máximo da realidade conhecida até o momento:

É evidente que possuímos corpo, como também uma alma que o anima e lhe é causa de desenvolver-se vegetativamente. [...] Temos, além disso, um terceiro elemento, que vem a ser como a cabeça ou o olho de nossa alma. [...] Peço-te, pois, que veja se é possível encontrar na natureza humana alguma outra coisa mais sublime que a razão. [Idem] ${ }^{199}$

A articulação da inquirição que Agostinho lança a Evódio, uma vez mais carrega o intento subreptício de condicionar a resposta, pelas precondições da questão, como que impondo de antemão o teor responsivo, ao limitar o alcance de seus termos ante a questão formulada (que praticamente define, antecipadamente, o ser que se provará superior em relação à razão, a partir da definição desta, numa palavra: Deus é definido a par da excelência com que se exaure a razão em sua própria definição): haverá algo que esteja além do que é, manifestamente, a cabeça e a visão da realidade como um todo? Se atingimos o cimo e a culminância, pela qual se está no topo da realidade conhecida (e pela qual esta é visualizada seu totum), seria possível encontrar algo além do limite máximo conhecido? Ver algo além da própria visão?

198 ... in his quibus natura nostra completur in homines simus, aliquid invenire posse praestantius quam hoc quod...?

${ }^{199}$ Num et corpus nos habere manifestum est et vitam quandam qua ipsum corpus animatur atque vegetatur, [...], et tertium quiddam quase animae nostrae caput aut oculum [...] Quare vide, obsecro, utrum aliquid invenire possis quod sit in natura ominis ratione sublimius. 
A esperada (e preparada) resposta negativa de Evódio (II, vi, 13) fornece, enfim, a senha estrategicamente aguardada por Agostinho, para lançar o fundamento da demonstração da existência de Deus. Por seu turno, a condensação do sentido argumentativo probatório é de tal modo direta, concisa, que afirmamos ser difícil, mesmo impossível, exagerar a importância da qual se reveste sua formulação e seu posicionamento, os quais, repetimos, estrategicamente preparados por Agostinho, tanto como finalização da sequência argumentativa baseada no maximum-minimum observado na natureza, quanto na simultaneidade colhida nas polaridades precedência-excedência/excelência e instantaneidade/imediaticidade-fugacidade com a qual conduzira o diálogo até sua culminância no estabelecimento da ratio como portadora de ambas as finalizações ${ }^{200}$. Importa observar, como prévia à sua formalização e apresentação, que a concisão de sua disposição, fundamentada na simultaneidade observada entre a definição pela maximização auto-evidente, e a necessária postulação de seu caráter essente, emerge justamente do núcleo atinente à relação primordial Vere Esse e esse, pelo qual a excelência deste possibilita a imediata e instantânea postulação daquele.

\section{4) A pergunta por Deus enquanto fundamentação prévia da argumentação probatória}

Ante a culminância atingida, a inquirição encontra-se como que condicionada e previamente definida em sua formulação e postulação, de modo que a argumentação probatória igualmente seguirá o balizamento, já predisposto e mesmo vislumbrado, na pergunta que a instaura: “Ag. Que dizer, pois, se fosse possível encontrar algo, do qual não somente não pudesses duvidar de sua existência, mas também [não pudesse duvidar] de sua preeminência em relação à nossa própria razão? Duvidarias, fosse o que fosse, ser Deus?" [II, vi, 14] ${ }^{201}$.

Ao mesmo tempo em que introduz novo campo de inquirição, avançando rumo à consecução plena da proposta originária da disputatio, a questão é apresentada por Agostinho em termos de convergência de toda a discussão até o momento, precisamente com o intuito de

\footnotetext{
200 Victorino Capanaga [Introducción in El libre albedrío, 5a . edición, Madrid: B.A.C., 2009 (reimpressión), p.282] define a articulação agostiniana sucintamente como "dialética dos graus e da subordinação entre eles", ressoando a ampla categorização do itinerário demonstrativo, como um todo, em termos de uma dialética agostiniana dos graus de ser, acerca da qual uma pesquisa de caráter dissertativo, como o nosso presente estudo, não comporta uma abordagem explicitada e detida. Pontuamos somente que intentamos uma leitura acentuando a prevalência da imediaticidade e da simultaneidade na feitura interna à intelecção ascensional, mais que sua dialeticidade intragradual. [Em relação à presença da dialética nos diálogos agostinianos, enquanto disciplina, método de ensino e norma de julgamento em relação às demais atividades racionais, vide DOUCET, 2004: 64-68; para sua utillização no De ordine II (cuja abordagem consistirá no tema de nosso capítulo...), em que assume a caracterização de distinção, antíteses, harmonização dos contrários e congruência universal, vide BOUTONTOUBOULIC, 2004: 256-260.] Remetemos, enfim, para as considerações acerca do caráter hierarquizante interno da tríade estrutural esse-uiuere-intelligere, ocasião em que nossa tentativa igualmente buscou o mesmo acento, bem como procuramos maior aprofundamento quanto ao sentido ascensional decorrente do trinômio de base.

${ }^{201}$ Aug. Quid si aliquid invenire potuerimus quod non soblum esse non dubites, sed etiam ipsa nostra ratione praestantius? Dubitabisne illud quidquid est deum dicere?
} 
remir o todo conhecido à fontalidade de seu ser. Se a suspensão judicativa do conhecimento humano por Evódio levou Agostinho a partir do esse indubitável como verdade primeira e fundamentadora de todo o decurso prosseguinte; se seu excellere interno conduz ao movimento de excedência interna às etapas ou níveis da realidade, cuja estratificação é inteleccionada pela ratio em sua anteposição e preeminência ante a realidade temporalmente instituída; e se esta (razão) mostrou-se, ao final da argumentação, constituir o cimo da realidade conhecida, sendo ela própria quem perfaz e consuma a totalidade do real em sua intelecção e antecipação instituinte, então o prosseguimento da discussão evidencia-se estabelecido a partir da própria consumação anterior: há algo superior ao elemento máximo e excelente da realidade criatural? Se esta culmina e se consuma na ratio, o que porventura a esta exceder, evidentemente não pertencendo à esfera criatural, necessariamente será a realidade divina? ${ }^{202}$ Antes, porém, de prosseguirmos na continuidade do diálogo com a resposta de Evódio, importa ainda elucidarmos dois aspectos da formulação da questão agostiniana, que se apresentam como confirmatórios do caráter remissivo e de culminância com que se reveste a inquirição, ao mesmo tempo que desempenham funcionalidade estratégica para a conceituação pretendida por Agostinho no direcionamento da questão a Evódio, visando obter a única resposta possível ante tais pressupostos.

Observa-se que a postulação sobre Deus, pontuada por Agostinho ao término da formulação da pergunta decisiva e central, é efetuada à maneira de um ato final concludente (inclusivo, portanto) da série ensejada até o momento, na verdade um salto proporcionado pelo esgotamento da percorrência efetuada na esfera criatural, cuja própria culminância leva, pela excelência de sua essência, à passagem imediata para a inquirição acerca do que lhe excede e supera. A excelência/excedência em questão é evidenciada, tanto em seu caráter retroativo (para com as etapas e graus excedidos e superados até a ratio) quanto prospectivo (apontando para o ato/movimento final da pergunta, que postula a inquirição sobre Deus) ${ }^{203}$, precisamente

${ }^{202}$ Vide KREMER, Patrick J. The "psychological" proof for the existence of God developed by Saint Augustine, Chicago: Loyola University, 1948, p. 13-14; PLAMONDON, Paul La preuve augustinienne de l'existence de Dieu, Faculté de Philosophie de l’Université de Ottawa, 1957, p. 04-06.

${ }^{203} \mathrm{O}$ sentido da gradação ascensional é elucidado por sua culminância na ratio, clarificando-se que o movimento essencial, o qual a partir da exaurição do grau ontológico enseja sua excedência, indica a necessidade de se postular um maximum que, por antecipação, ultrapasse a própria percepção de seu movimento interno, vale dizer: enseja a postulação imediata da excelência em relação à ordem criatural, tanto em sua totalidade dos entes, quanto em sua racionalidade perceptiva: "Do sensus interior, órgão superior aos sentidos [físicos], o qual também os animais possuem, salta-se à nova esfera da razão, para proclamar sua excelência e dignidade. [...] Estas escaladas the preparam para dar o grande salto da transcendência." - CAPÁNAGA, V. nota 18 [II, 6,13] in El libre albedrío (tradução castelhana de Evaristo Seijas, do diálogo agostiniano), 5a . edición, Madrid: B.A.C., 2009 (reimpressión), p. 282. Por seu turno, Gilson deixa entrever, em sua análise da itinerância ascensional-gradual, certo aspecto crítico quanto a repousar a ênfase da argumentação probatória no caráter essencialmente hierarquizante da estruturação do real: "Incontestavelmente, esse método [exposição agostiniana da gradação 
pela articulação do núcleo inquiridor em torno aos dois motes conducentes de todo o percurso efetuado pela intelecção da realidade criatural até então: existência e preeminência; ou, na conceituação que intentamos ressaltar ao longo de nossa leitura até o momento: esse e excellere (aqui, validado pelo emprego de praestantius, o que intentamos elucidar, coerentemente à nossa tentativa geral, como a excedência/excelência ensejada por antecipação e atemporalmente, no ínterim da relação Vere Esse - esse, embora tal ensejamento venha a ser explicitado posteriormente, com a própria explicitude desta relação na seção seguinte). Com efeito, o grau e a extensão da certitude a ser obtida na prova a que se lança Agostinho, são ancorados justamente no par em questão, cuja certeza do primeiro possibilitou o início do percurso intelectivo pós-suspensão judicativa, bem como o fundamentou em seu todo; ao passo que a certeza do segundo, permeando (a exemplo da certeza relativa ao esse) toda a feitura do percurso ascensional do conhecimento sensível até a ratio, possibilitou sua culminância exatamente por apontar à sua própria excedência e excelência. Ambos - esse e excellere constituirão o par conceitual em torno do qual será definido o que supera a razão (o que será evidenciado, assim o veremos, pela primeira resposta evodiana), na precisa identidade entre ambos no Vere Esse ou ser divino: em Deus, preeminência e excelência coincidem em sua essência, fazendo com que nada lhe seja preeminente ou lhe exceda. De fato, aquilo que na ordem criatural, pela própria determinação temporal e sua finitude, é dado em simultaneidade e imediaticidade (o esse criatural cujo estatuto ou grau ontológico, na ordenação hierárquica, enseja sua própria superação ou excellere, cuja intelecção é antecipada e preeminente através da ratio), em Deus é dado de modo unívoco e idêntico entre si, eternamente. Em realidade, a simultaneidade e imediaticidade/instantaneidade verificadas pela intelecção da realidade criatural, são possibilitados pela presença essencial do ser divino, cuja identificação (ser e essência), permite à ratio exercer as funções judicativa e moderadora de toda a ordem do esse.

Assim, a pergunta lançada por Agostinho não somente conclui o percurso até então culminante na ratio, como também insta (pelo seu núcleo definidor e termo final) Evódio a defrontar-se, irremediavelmente, com a definição do ser divino como possibilidade da afirmação de sua existência. Evódio percebe que a estruturação da inquirição lhe conduz à afirmação, mas veremos que sua prudência judicativa uma vez mais fornece ocasião para a explicitação do intento agostiniano contido na formulação da pergunta.

ontológica] deixa uma certa impressão de delonga e de sinuosidade, mas os numerosos intermediários que se interpõem entre seu ponto de partida e seu ponto de chegada são indispensáveis apenas ao espírito que se tornou mestre nisso. [...] Toda verdade, qualquer que seja, poderia então servir como ponto de partida à prova e, mais do que qualquer outra, a primeira de todas que é a de que eu sou. Com efeito, uma vez que a dúvida e também o erro nos aparecem atestando a existência do pensamento que duvida, podem atestar não menos evidentemente e imediatamente a existência de Deus." - GILSON, 2007: 45 (grifos nossos). 
3.4.1) "Aquele a quem nada é superior": definição (de Deus) como antecipação probatória

A resposta de Evódio é tecida seguindo a estruturação da perquirição anterior de Agostinho: atentando para a gradação ensejada pelo excellere de todo ente, bem como para a definição de Deus como seu termo:

$\boldsymbol{E} \boldsymbol{v}$. Não diria de imediato, caso pudesse descobrir algo como sendo superior ao mais excelente em minha natureza, que seja Deus. Não me apraz chamar de Deus aquilo a que minha razão é inferior, mas sim aquele a quem nada é superior. [II, vi,14] $]^{204}$

Ao perceber que Agostinho articula a questão de maneira a conduzi-lo à asserção de seu termo final, Evódio procura defender-se utilizando, por assim dizer, as mesmas "armas": não somente "aceita" a estruturação conducente da inquirição, mas trata de, a partir dela mesma, refinar o que se pretende nela como afirmativo, direcionando-a para uma prévia definição cujos termos, se já estão implicitados na formulação da inquirição agostiniana, adquirem agora a real amplitude que termina, afinal, por oferecer o que Agostinho intentava ouvir, embora com a devida "correção" do interlocutor: Deus como ser superior e preeminente em absoluto. Como observamos, Agostinho fizera reunir, nos termos da questão, as noções centrais de esse e excellere (em sua acepção de preeminência), componentes da tessitura da itinerância ascensional do conhecimento, perfazendo-se da realidade sensível até a ratio, que julga e modera toda a realidade conhecida. Ora, se a formulação agostiniana encontra-se fundamentada no vetor ascensional, no qual a ratio culmina em si mesma a gradação ontológica da realidade cognoscível, sua estruturação só poderia seguir o sentido vetorial no qual se ampara: postular um ser acima da razão enquanto termo ascensional da realidade criatural, implica em postular o ser divino, por evidente superior à realidade criatural. A implicação contida na inquirição de Agostinho, possibilitada pela vetorialização permeante da intelecção ascencional, igualmente é evidenciada com base na retomada da certeza inerente ao esse enquanto dado primordial, presente em toda certificação com que a ratio adjudica e modera a realidade conhecida. Dado que o excellere de cada ente, ou nível hierárquico da realidade ensejante da excelência ontológica de cada grau, ou escala de ser, na medida em que lhe exaure ou esgota sua presença/densidade ontológica ${ }^{205}$, traz em simul a antecipação com que se predispõe o passo anterior do conhecimento ao posterior (imediatizando-o à intelecção

\footnotetext{
${ }^{204}$ Ev. Non continuo, si quid melius quam id quod in mea natura optimum est inuenire potuero, deum esse dixerim. Non enim mihi placet deum appellare quo mea ratio est inferior, sed quo est nullus superior.

${ }^{205}$ Em seu ensaio sobre Agostinho, Marion estabelece (em perfeita ressonância de seu referencial maior ancorado em uma fenomenologia da saturação do aparecer, ou do evento saturado) que a evidência da verdade, pela qual o fenômeno aparece e se presentifica, também se reveste, nos textos agostinianos, de saturação ou ex-cesso (e, portanto, se exaure ou esgota) - MARION, 2008: 166-170.
} 
através da preeminência da ratio), será precisamente esta noção - excellere - que irá se tornar epicêntrica, neste ponto da disputatio, a ambas as argumentaões (inquiridora e responsiva), convergindo-as para se tornar a matriz conceitual da definição prévia do ser divino a que já nos referimos anteriormente, e a partir da qual irá se desenvolver o itinerário probatório agostiniano, contrapontuado pelas intervenções evodianas, mas evidenciando de pronto, neste momento do diálogo, a inversão do sentido argumentativo e de suas implicações: se na formulação inquiridora agostiniana, como já repetido antes, a verticalização ascensional da vetorialização condiciona a estrutura da questão, para que necessariamente se parta do inferior ao superior, no responso evodiano o sentido vetorial como que se inverte: não se estabelecerá a divindade no ser perante o qual a razão seja imediatamente inferior, mas no ser cuja excelência seja tal, que nada lhe seja superior, estabelecendo, na decorrência em simul, que toda a realidade conhecida lhe seja inferior.

Observe-se que Evódio inicia sua resposta interpondo a ressalva da impossibilidade de se postular a divindade no fio contínuo do vetor ascensional: não será o ser imediatamente superior à natureza conhecida e culminada na ratio que, de pronto (continuo), virá a ser reconhecido como divino (... deum esse dixerim), dado que, assim fosse, a ordem criatural como que estaria condicionando o reconhecimento da essência do ser divino, com base em sua feituração e graus de excelência, numa palavra: não é a continuidade sequencial e hierarquizante da realidade criatural, baseada em sua excelência interna e na finitude própria dos entes nela situados, que estabelece a postulação imediata (ou seja, na sequência imediatamente superior), do ser supremo, posto que haveria então - e aqui parece residir a razão implícita da ressalva evodiana - a possibilidade, a se seguir o fio contínuo hierarquizante, de se postular outro que lhe seja superior, e mais outro, etc, o que simplesmente impossibilitaria a postulação pretendida por Agostinho. É por estar assentada na imediaticidade e simultaneidade inerentes à intelecção do fio contínuo hierarquizante da ordem criatural, que a pergunta de Agostinho caminha da excelência ontológica interna da realidade conhecida, para o passo que imediatamente lhe transcenda: atingindo-se a culminância desta (ratio), não se impõe, ao mesmo tempo, a postulação de que o que lhe ultrapassa seja, de pronto, reconhecido como divino (tal como, na itinerância ascensional da intelecção da ordem criatural, a ratio imediatamente postulava o passo superior ao mesmo tempo da excelência do inferior)?

A imediaticidade e o simul com que a ratio, a cada passo em que adjudica e monitora a realidade conhecida, procede à feituração intelectual da ordem criatural, se por um lado constituem-se (como já o indicamos anteriormente em nosso presente estudo) numa espécie de 
"furto" à temporalidade que lhe é inerente ${ }^{206}$, por outro se encontram fundamentadas precisamente na postulação do ser cuja excelência é tal que, em sua preeminência e superioridade, constitui-se ele próprio no juiz e moderador do universo, de modo a estabelecer, a partir de si, a medida para o que seja a superioridade e preeminência a ser percebida e estabelecida gradativamente, na ordem que lhe seja imediatamente inferior, vale dizer: a racionalidade que intelecciona e estabelece a ordem e gradação hierárquica da realidade criatural, somente adjudica e modera cada passo do conhecimento, precisamente pela percepção do ser divino em sua própria atuação e fontalidade, ou seja, somente o maximum absoluto, eterno e imutável pode servir como fundamento e referência da medida para a gradação de tudo o que lhe seja inferior. As adjetivações com que Agostinho irá caracterizar o ser divino (bem como a presença destas características na atuação perceptiva da ratio) no prosseguimento do diálogo, parece-nos confirmar tal possibilidade de leitura:

\begin{abstract}
$\boldsymbol{A g}$. Precisamente isto, e ele mesmo é quem deu à tua razão este sentir tão piedoso e verdadeiro a seu respeito. Mas, pergunto-te, se não encontrasses como sendo superior à nossa razão, nada que não fosse eterno e imutável, duvidarias dizer que se trata de Deus? Os corpos são mutáveis, tu bem o sabes, como também é evidente que a própria vida que anima o corpo, devido a várias afetações, é mutável; e a própria razão, devido a algumas vezes se esforçar para chegar à verdade, outras não, às vezes atingindo-a, outras não, se mostra como mutável. Daí que, se sem o auxílio de nenhum órgão corporal, nem do tato, nem do gosto, nem do olfato, nem dos ouvidos, nem dos olhos, nem de algum outro sentido que lhe seja inferior, mas de per si ela $\lceil r a z a \tilde{a} o\rceil$ discerne algo de eterno e imutável, faz-se necessário que, ao mesmo tempo, se reconheça como lhe sendo inferior, e que esse ser seja Deus (Idem - grifo nosso) ${ }^{207}$.
\end{abstract}

O reconhecimento inicial da correção e acerto com que Evódio lhe respondera não se faz sem acompanhar de uma asseveração que, em realidade, atua como prelúdio à descrição das características, e sobretudo ao termo final da resposta com que Agostinho contempla a brilhante intervenção de seu interlocutor: o pronunciar-se da razão, em sua atuação perceptiva

\footnotetext{
206 Em sua análise interpretativa acerca da compreensão, entre os autores tardo-medievais, da temporalidade e da espacialidade, bem como sobre as suas conceituações diversas a respeito, Márcia Sá Schuback expõe a importância da noção de simultaneidade no pensamento agostiniano, explicitando-a como traço constituinte essencial em sua construção ao longo das diversas fases, sobretudo para a percepção da totalidade enquanto prévia ilimitação do absoluto, evidenciando-se ainda seu papel quanto à intuição da eternidade como superação da sucessividade temporal aliada à sequencia espacial; bem como fundamento da constituição da própria percepção do tempo. Retendo a definição boeciana de eternidade ("aeternitas est interminabilis vitae tota simul et perfecta possessio" - De consolatione philosophiae, V, 6), Schuback a faz remontar ao seu escopo agostiniano, para ressaltar a importância da simultaneidade enquanto percepção conjunta da eternidade e totalidade - SCHUBACK, M.S.C. Para ler os medievais: ensaio de hermenêutica imaginativa, Petrópolis: Vozes, 2000, p. 79-82 e 88-96.

${ }^{207}$ Aug. Ita plane, nam ipse huic tuae rationi dedit tam de se pie vereque sentire. Sed, quaeso te, si non inveneris esse aliquid supra nostram rationem nisi quod aeternum atque incommutabile est, dubitabisne hunc deum dicere? Nam et corpora mutabilia esse cognoscis et ipsam vitam qua corpus animatur per adfectus vários mutabilitate non carece manifestum est et ipsa ratio, cum modo ad verum pervenire nititur modo non mititur et aliquando pervenit aliquando non pervenit, mutabilis profecto esse convincitur. Quae si nullo adhibito corporis instrumento neque per tactum neque per gustatum neque per olfactum neque per aures neque per oculos neque per ullum sensum se inferiorem, sed per se ipsam cernit aeternum aliquid et incommutabile, simul et se ipsam inferiorem et illum oportet deum suum esse fateatur.
} 
da permanência e atemporalidade (o que certamente inclui, entre outras, suas funções de percepção, adjudicação e moderação/condução da realidade, que vimos nas seções anteriores), fundamenta-se na presencialidade, que lhe vem a ser própria e dirigida (per se ipsam), do ser divino junto a ela. É Deus mesmo quem enseja e possibilita à ratio o sentir piedoso e verdadeiro a seu respeito, assim como (ao final da resposta) lhe imediatiza e possibilita a percepção (ou discernimento - cernit) de algum ser na condição de eterno e imutável. Entre a observação inicial e a conclusão argumentativa, Agostinho demonstra a Evódio que, tal qual este o fizera na intervenção anterior, também ele sabe manejar com precisão o "armamento adversário" para revertê-lo a seu favor: agora é sua vez (Agostinho) de "aceitar" os termos do interlocutor para avançar no intento dialogal, fazendo ver que, se de fato não convém atribuir o qualificativo divino, necessariamente, ao ser definido como imediatamente sequente à ratio na graduação ontológica hierarquizante, e sim ao ser cuja magnitude lhe faça ser considerado o maximum ante o minimum, a qualificação divina poderá então ser postulada e estabelecida quando identificarmos as características componentes desta qualificação, a par de sua absolutidade e magnitude ${ }^{208}$.

Agostinho lista duas substantivações que, tomadas como atributos da divindade, revelam-se, outrossim, como maximizações e absolutizações daquilo com o qual a ratio, até então, atuara na intelecção do itinerário: eternidade e imutabilidade. Vimos que as noções

\footnotetext{
${ }^{208}$ A proximidade da postulação evodiana - quo est nullo superior - com o argumento único de Anselmo de Cantuária no Proslogium II - id quo nihil maius cogitari possit - possibilitou ter sido, por vezes, interpretada como uma primeira formulação deste: "A expressão id quo maius cogitari nequit, deriva presumivelmente de santo Agostinho de Hipona (354-430), que no diálogo O livre-arbítrio, leva Evódio a dizer: 'Admitirei plenamente que seja Deus, se for estabelecido que não existe nada que lhe seja superior (II, 6,14)" - TOMATIS, F. $\boldsymbol{O}$ argumento ontológico: a existência de Deus de Anselmo a Schelling, São Paulo: Paulus, 2003, p. 13. Tomatis alude ainda à formulação agostiniana do De doctrina christiana I, 7,7 (id quo nihil sit melius atque sublimius illa cogitatio conetur attingere), bem como à possível origem da conceituação em Cícero (De natura deorum II, 7). Com relação à influência do pensamento agostiniano na formulação de Anselmo, Maria Leonor Xavier faz observar o fio contínuo entre ambos, a partir da metafísica do Exxodo: "Cabe [...] perguntar: qual a postura de Santo Anselmo a respeito da metafísica do Exxodo? [...] Ora, uma teologia da essência suprema privilegia naturalmente a essência entre as possíveis acepçoes do ser em Deus. Santo Anselmo deve, pois, inscrever-se na linhagem de Santo Agostinho, quanto à prevalência de uma metafísica da essência na determinação do ser divino. Com base na correlação dos termos essentia-esse-ens, Anselmo afirma a inter-permutabilidade dos nomes divinos summa essentia - summe esse - summe ens." - XAVIER, Maria L.L.O. Razão e Ser: três questões de ontologia em Santo Anselmo, Porto: Fundação Calouste Gulbenkian/Ministério da Ciência e Tecnologia, 1999, p. 509-510. Vide ainda MARTINES, P. R. O "argumento único" do Proslogium de Anselmo de Cantuária, Porto Alegre: Edipurs, 1997, p. 54-55; STREFLING, S. R. O argumento ontológico de Santo Anselmo, Porto Alegre: Edipucrs, 1997, p. 24-25. Vale lembrar, por fim, que Boaventura irá herdar a argumentação anselmiana, refundamentando-a na conjugação com a doutrina da iluminatio agostiniana: a máxima boaventuriana Se Deus é Deus, Deus é clarifica que, se se toma por Deus a realidade que é vislumbra e pensada como infinita, imutável, eterna, necessária, atual, autônoma, e sobretudo, luz criadora e sustentadora do cosmos, então a existência que é pensada é na verdade a iluminação da realidade, captada e apreendida através dos vestígios ontológicos impressos em todo ente: "si Deus est, Deus est; sid antecedens est adeo verum, quod non potest cogitari non esse; ergo Deum esse verum indubitabile" - De mysterio trinitatis, q.1, a.1, 29; Itinerarium mentis in Deum, V, 3; vide FALQUE, E. Saint Bonaventure et l'entrée de Dieu em théologie, Paris: Vrin, 2000, p. 65-71; GILSON, E. La philosophie de saint Bonaventure, $3^{\mathrm{a}}$. édition, Paris: Vrin, 2006, p. 108-112.
} 
basilares à gradação ontológica, e através das quais se possibilita a intelecção ascensional da realidade conhecida, repousam na essência (esse) e na excelência (excellere), que, na dinâmica de superação intragradual, assentam-se justamente na temporalidade e na mutabilidade de graduação ou nível de ser, culminando na própria ratio. Por sua vez, em seu exercício intelectivo, a ratio resulta (como vimos nas seções anteriores 3.1.6 e 3.2.3, nas quais intentamos a análise semântico-funcional de praeponere aplicada à razão, quando de sua adjudicação e moderação dos dados antepostos em percepção), como fundamentada na atemporalidade e na imediaticidade, pelas quais estabelece e executa (julga e modera) sua preeminência (e, portanto, sua prerrogativa ou sua petição por antecipação face ao dado temporal) ante os demais níveis da realidade, evidenciando-se e constituindo-se no grau máximo até então da hierarquia ontológica. Ora, se a ratio culmina o itinerário ascensional da realidade conhecida, precisamente por sua preeminência ancorada num "furto" da mutabillidade e da temporalidade inerentes à dinâmica, clarifica-se que sua superioridade advém justamente de tais características. Estas, por seu turno, precisamente por não poderem ser tidas por essenciais à ratio enquanto tal, uma vez que, não obstante o perfazimento de atuação e os tais "furtos", seu exercício evidencia a presença de mutabilidade e fugacidade, como ilustram os exemplos empregados hábil e estrategicamente por Agostinho, dado que lança mão do aspecto volitivo presente na atuação racional (o qual será examinado adiante - II, ix).

Outrossim, Agostinho igualmente alude à sua independência quanto aos sentidos exteriores e interior, os quais em tese poderiam ser os responsáveis pela ocasional inércia e imprecisão da ratio, indicando que seu âmbito de atuação institui-se na presença relacional de algo que lhe permite discerní-lo ou percebê-lo, no próprio ato preemintente e prerrogativo de instituição e feitura da realidade cognoscível, vale dizer, na insurgência inteleccional do esse exsurgente em cada grau ascensionado, em sua imediação e atemporalidade (além da simultaneidade) face ao absoluto e eternidade justamente presentes neste instante de sua atuação-adjudicação-moderação.

3.4.2) “... per se ipsam cernit, ... simul et se ipsam oportet fateatur” - Presença divina na atuação racional.

Ao finalizar a devolução a Evódio de sua inquirição, agora assumindo a postulação de absolutidade por este firmada em sua resposta anterior, Agostinho estabelece a argumentação concludente com a elucidação e indicação fundamentais do âmbito independente de atuação da razão (nullo adhibito), com relação a quaisquer âmbitos que lhe sejam inferiores, quer no 
âmbito da exterioridade (corporis instrumento...), quer no da interioridade (neque per ullum sensum se inferiorem). A importância de tal elucidação e, sobretudo, da ênfase em sua indicação, para o passo estratégico agostiniano ensaiado neste ponto do diálogo, revela-se no construto da sentença com que arremata a intervenção, o qual aponta para aspecto inalienável da atuação racional: a polarização essencial composta pelos atos perceptivo, ou de discernimento (cernit), e o ato predicativo ou, mais especificamente neste ponto: declarativo ou de reconhecimento (fateatur).

A sequência com que se estrutura a argumentação concludente, bem como sua concatenação verbal, indicam que a polaridade entre percepção/discernimento e aquiescência/reconhecimento (ou ainda: declaração/manifestação) é estabelecida (tal como ressaltamos ao longo de nossa presente tentativa de leitura) na simultaneidade fundamental a todo ato judicativo-conducente com que a ratio institui a intelecção ascensional da realidade. Se ambos estão situados na presencialidade indicativa de ação própria, diferenciam-se, contudo, quanto ao sentido de tal ação: ao passo que a primeira é apresentada como resultante de um agir como sujeito próprio ante a realidade discernida (voz ativa do presente do indicativo: cernit), a segunda advém de um agir em sujeição própria (fateatur), ante a imposição de evidência à qual se deve necessariamente aquiescer ou consentir (oportet). Observa-se, pois, que a atividade da ratio comporta o ato judicativo culminante (de saber-se, enquanto tal, sujeita ao reconhecimento da divindade) em duplo aspecto, respectivo ao 1) discernimento ativo da realidade eterna e imutável (cernit aeternum aliquid et incommutabile), a qual impõe, ao mesmo tempo, necessariamente um reconhecimento atual (presente), que implica no 2) assentimento declarativo que se impõe ante esta realidade, quanto ao seu caráter divino (deum suum esse fateatur). Tal duplicidade assenta, de fato, na simultaneidade essencial do próprio ato em questão: $o$ ato indicativo do discernimento da presença da realidade absoluta (eternidade e imutabilidade), se dá ao mesmo tempo (simul) da indicação do reconhecimento manifesto de sua divindade, como também de sua inferioridade ante a mesma, aliado à evidência de sua inferioridade ante a mesma ${ }^{209}$. Evidencia-se, assim, que o agir da ratio comporta, em sua manifestação, o polo do discernimento da realidade eterna e imutável, em simultaneidade essencial ao do reconhecimento de sua divindade, bem como de sua relação com tal (lhe é superior).

Atentemos ainda para outro aspecto presente na estruturação concludente de Agostinho. Ao finalizar a argumentação com o assentimento imposto à ratio pela realidade superior por

${ }^{209}$ Cf. KREMER, Patrick J. The "psychological" proof for the existence of God developed by Saint Augustine, op.cit., p. 14-15. 
ela discernida, Agostinho faz uso de vocábulo cuja noção de raiz denota a necessidade da explicitação de um tipo de reconhecimento da realidade discernida que enseje, ao mesmo tempo, o reconhecimento de si na relação ontológica para com este discernimento, de monta tal que a explicitude seja, necessariamente, vertida justamente neste aspecto relacional: fateor, que acentua a necessidade com que a ratio, longe de se reconhecer inferior opondo-se ou tensionando-se dialeticamente perante a realidade discernida, torna assente, manifesta, declara, confessa sua inferioridade ante o eterno e o imutável. Ao lançar mão de termo cujo étimo de raiz compõe, assim como fatum, a noção de pronunciar, dizer, vaticinar, propugnar (ou ainda prognosticar $)^{210}$, Agostinho faz ver que o reconhecimento implica, ou comporta necessariamente, o aspecto relacional entre reconhecedora e reconhecida (ratio e realidade eterna e imutável), no qual a razão, ao declarar-se inferior, o faz reconhecendo que a superioridade manifesta lhe inclui, em conjunto com a natureza até então conhecida, do que resulta ser ela própria voltada, no sentido hierarquizante que permeia a gradação ontológica, a essa mesma realidade que acaba por discernir, confessando-lhe pois sua sujeição no reconhecimento de que ela própria se exaure e enseja seu excellere, sua consumação e realização final, nesta realidade que lhe excede e supera. A ratio, pois, pronuncia e propugna, em seu assentimento confessional de reconhecimento, sua própria excelência em culminância e realização essente no eterno e imutável.

Por fim, tentemos ainda uma elucidação quanto ao modo como Agostinho, em decorrência da ênfase anteriormente aludida, quanto à independência de atuação da ratio, termina por descrever o exercício racional componente da polaridade discernimento ativoassentimento declarativo. Após ressalvar, através da constatação de lapsos de mutabilidade em sua atuação, que a razão evidentemente não ostenta a condição de realidade absoluta e, portanto, não pode ser considerada a culminância da realidade conhecida, Agostinho passa a elucidar, então, como a própria percepção de tal noção - absolutidade - por meio do discernimento do eterno e imutável, atesta de per si como a razão nestes se encontra, por assim dizer, "imersa", balizada, fundamentada. Na finalização, Agostinho ressalta uma vez mais o moto independente da ratio, em termo tal que faz resultar o ato racional culminante, em sua polaridade constitutiva e a par da simultaneidade inerente a este, como efetuado na imediatez do dado percebido, mais: deste decorrente, em sua atemporalidade. Efetivamente, a razão

\footnotetext{
${ }^{210}$ Santiago Munguía lista, como núcleo radicial para fateor e fatum, o étimo for (que ele faz notar como inusual, de possível derivação do grego $ф \varepsilon \mu \mathrm{l}$ - phémi), com conjugações fari e fatus sum, e do qual é vertida ampla série de derivações e/ou composições (entre as quais confiteor, cujo sentido essencial reside no ato confessional em seus aspectos de assentimento voluntário a algo conhecido, bem como explicitação pública de um reconhecimento interno) - MUNGUÍA, S. S. Diccionario por Raíces del Latín y de las voces derivadas, Bilbao: Universidad de Deusto, 2007, item 1.206 (verbetes citados, p. 254-255).
} 
atesta sua independência ao discernir, de per si, o eterno e imutável. Mas, sobretudo, ostenta a imediação de tal percepção e discernimento, ao efetuá-los em si mesma (ipsam) $)^{211}$. A independência essencial da ratio, em seu agir próprio e em sua funcionalidade orgânica para com o todo da realidade cognoscível, além de clarificada sobremaneira no binômio iudicaremoderare, cristaliza-se e culmina na feitura inteleccional da realidade conhecida via polaridade discernimento-assentimento, através da qual é elucidada sua fundamentação atemporal e sua simultaneidade essente, características que lhe conduzem, per se ipsam (cujo acento pronominal demonstrativo clarifica o agir no sentido da imediação própria da evidência), no ato mesmo de sua postulação, a reconhecer-se como fundamentada no absoluto em sua eternidade e imutabilidade (das quais a atemporalidade/imediaticidade e a simultaneidade como que prefiguram e compõem tipos, no decorrer da atuação da ratio).

O construto argumentativo de Agostinho resulta, enfim, estrategicamente certeiro: “Ev. De minha parte, reconhecerei abertamente ser Deus aquele acerca do qual nada conste como lhe sendo superior" ${ }^{212}$. Ante a exposição agostiniana, Evódio trata de assumir o desafio proposto, não sem antes repisar as bases em que o aceita: insistindo no nihil superius (adjetivo de qualificação, e não um comparativo, tal como maius ou melius, o primeiro dos quais, como vimos anteriormente, vindo a ser utilizado séculos mais tarde por Anselmo de Cantuária ${ }^{213}$ ), Evódio evidencia sua preocupação em resguardar a absolutidade do ser divino, que o torna incomparável e subtraído a quaisquer tipos de mensurações ou aproximações. Note-se porém que a resposta evodiana se faz enfatizar do caráter de clarificação e assentimento, com o qual Agostinho descrevera a atuação racional em seu binômio discernimento-reconhecimento, ante o eterno e imutável. Ao assumir a mesma atitude (fatebor), por assim dizer, ostentada pela ratio (incluindo a explicitude da inteireiza do assentimento - plane), Evódio intenta fazer ver que tais características - eternidade e imutabilidade - evidenciam a magnitude absoluta do ser superior, e que é por este caminho - o assentimento ante o absoluto - que unicamente deve

\footnotetext{
211 Acerca do uso em Agostinho de ipse, seu histórico traditivo e heranças conceituais, bem como ainda as variações e correlatos no interior de sua amplitude lexical, vide o fundamental ensaio de Dominique DOUCET Enquête pour une étude d' "Idipsum" et de ses enjeux dans l'oeuvre d'Augustin in CARON, M. (dir.) Saint Augustín - Les Cahiers d'Histoire de la Philosophie, Paris: Éditions du Cerf, 2009, p. 159-187, tratando, entre outros, da acepção relativa à identidade própria e imediação essencial respectivos do ser em relação ao (se) conhecer, na qual apresenta a correlação com a latinização do nome próprio de Deus na passagem de Ex 3,14 (Ego sum qui sum). Como já aludido anteriormente, Marion, no ensaio dedicado a Agostinho, reserva o capítulo final justamente voltado para tal relação ("Idipsum ou o nome de Deus"), no qual aborda o matiz de atração reservado à tradução do termo latino - MARION, 2008: 389-414 (sobremaneira importante, ao nosso propósito, as p. 398404). Sob o influxo de Marion, Giraud, em seu ensaio (como que em continuação da leitura fenomenológica de Marion), igualmente trata do "fundamento da nomeação" relativo ao nome divino, intitulando o capítulo respectivo por "O archi-nome: idipsum" - GIRAUD, 2013: 214-222.

${ }^{212}$ Ev. Hun plane fatebor deum quo nihil superius esse constiterit.

${ }^{213}$ Vide nota 208 (p. 150). Cf. MARTINES, P. R. O “argumento único” do Proslogion, op.cit., p. 57-58.
} 
caminhar a disputatio, e é somente nestas condições que aceita prosseguir no desafio agostiniano.

Importa observarmos a conjunção das duas "balizas", ou definições de base, condicionantes do prosseguimento do diálogo. Ao estabelecer que o reconhecimento da divindade caberá unicamente ao ser que ostentar eternidade e imutabilidade (Agostinho), bem como magnitude absoluta, tal que nada lhe seja superior (Evódio), a estratégia agostiniana revela seu objetivo de fundo: dada a identificação de ambas as bases (eternidade e imutabilidade são atributos exclusivos do absoluto), a argumentação probatória tratará, na verdade, de expor as decorrências internas à postulação, o que já foi estabelecido de antemão e aceito primordialmente por ambos: Deus é reconhecido como tal, no discernimento e assentimento confessional ao absoluto, através do eterno e imutável presentes no ato racional. Evidencia-se que o que se pretende provar já se encontra, certo modo, estabelecido e aceito tacitamente por ambos, dado ser patente que a razão, per se ipsam, adentra (imerge, por assim dizer) e se exercita, em sua imediaticidade/atemporalidade, e em sua simultaneidade, no prelúdio da eternidade e imutabilidade.

Ao concluir esta seção preparatória, Agostinho ressalta o que lhe parece certo a partir deste momento do diálogo: a inexorabilidade da percepção/discernimento da presença divina, do absoluto dado à ratio:

Ag. Pois bem. Me será o bastante demonstrar que existe este ser, do qual ou tu reconhecerás ser Deus, ou, se houver outro superior, concordarás então que este é Deus. Do que, quer exista algo superior, quer não exista, será evidente que Deus existe, quando eu conseguir demonstrar, com a ajuda dele mesmo, o que prometi, qual seja, a existência de um ser superior à razão. ${ }^{214}$

Parece-nos suficientemente elucidado, em nossa tentativa, o que anteriormente mencionamos a respeito da estratégia de Agostinho: dado que, acima da razão, há o eterno e imutável (discernidos no próprio ato racional), restará, de modo irretorquível, demonstrada a existência de um ser superior à razão, cujas características, assentadas em tais substantivações tornadas seus atributos, impõem seja explicitamente confessado e assentido como Deus. A prova, em realidade, está previamente estabelecida e delineada, ainda que a prudência renitente de Evódio o leve a não se dar por vencido, mesmo ante a inexorabilidade da estratégia agostiniana: "Demonstra, pois, o que prometeste." 215.

\footnotetext{
${ }^{214}$ Aug. Bene habet. Num mihi satis erit ostendere esse aliquid huius modi quod aut fateberis deum esse, aut si aliquid supra est, eum ipsum deum esse concedes. Quare siue supra sit aliquid siue non sit, manifestum erit deum esse, cum ego, quod promisi, esse supra ratiotem eodem ipso adiuvante mostrauero.

${ }_{215}^{215}$ Ev. Demonstra ergo quod polliceris.
} 


\title{
3.5) Singularidade e aspecto público nas sensações
}

A demonstração levada a efeito por Agostinho tem início, na seção compreendida entre os itens 15 a 19 do capítulo 7 , com uma espécie de recapitulação preambular quanto ao espectro do conhecimento sensível, exposta porém com base na singularidade e na generalidade das sensações e percepções, tanto no tocante aos sentidos, quanto no que respeita ao objeto conhecido. Assim, a inquirição inicial leva em conta os sentidos físicos:

\begin{abstract}
Ag. [...] Primeiramente, pergunto-te se meus sentidos corporais são os mesmos que os teus, ou se, pelo contrário, os meus são tão-somente meus, e os teus unicamente teus. Porque, se assim não fosse, eu não poderia ver com meus olhos coisa alguma que tu não visses também.

Ev. Concordo inteiramente: conquanto sejam do mesmo gênero, sem dúvida cada um de nós tem seus próprios sentidos: visão, audição, ou qualquer dos restantes. De fato, um homem pode não somente ver, mas também ouvir o que o outro não vê nem ouve; bem como pode perceber, por qualquer outro sentido, algo que outro homem não percebe. Donde se evidencia que os teus sentidos são somente teus, e os meus não são senão meus. [II, vii, 15] $]^{216}$
\end{abstract}

A concordância de plano entre ambos os interlocutores ressalta de pronto numa primeira leitura. Não sem propósito, Agostinho intenta mostrar o quão pacífico se apresenta a consideração acerca da individualidade dos sentidos corpóreos, em seu caráter inalienável de instância originária do conhecimento sensível. A ausência de discussão a respeito visa apontar para a real origem dos problemas relativos à intelecção da realidade (tendo em vista, aqui, o ceticismo acadêmico), a qual evidentemente não está situada no âmbito da percepção individual, posto que ninguém haverá de negar que percebe as coisas pelos próprios sentidos, e não por outros. O prosseguimento imediato do diálogo, em que se inclui o sentido interior e a própria razão, parece-nos confirmar o intento agostiniano de "limpar terreno" rumo à real localização do nascedouro dos problemas, bem como estabelecer postulados cuja certitude tenha sido de antemão consentida entre ambos os interlocutores, os quais virão a ser utilizados em sequências posteriores da disputatio.

Uma vez estabelecido, pacífica e inequivocamente, o caráter inalienável e condicionante da individualidade da percepção primordial cognoscente, relativa aos sentidos exteriores ou corpóreos, Agostinho se volta então ao outro polo do conhecimento sensível: os objetos dados à percepção dos sentidos corporais:

\footnotetext{
${ }^{216}$ Aug. [...] prius quaero utrum sensus corporis meus idem sit qui tuus an uero meus non sit nisi meus et tuus non sit nisi tuus. Quod si non ita esset, non possem poer oculos meos uidere aliquid quod tu non uideres. - Ev. Concedo prorsus, quanuis eiusdem generis, tamen singulus nos habere sensus, uidendi uel audiendi uel quoslibet alios ceterorum. Non enim solum uidere sed etiam audire potest aliquis hominum quod alius non audiat, et aliud aliquid quolibet alio sensu quisquam sentire quod alius non sentiat. Unde manifestum est et tuum non nisi tuum et meum sensum non esse nisi meum.
} 
Ag. Podemos, por conseguinte, muitos de nós juntos e ao mesmo tempo ver um único objeto, embora possuindo cada um os seus próprios sentidos. Perrmitem-nos eles ver, juntamente e ao mesmo tempo, um único objeto. Assim, ainda que meus sentidos sejam uns, e outros os teus, pode acontecer que o objeto de nossa visão não seja distinto para ti do que é para mim mesmo, mas um único objeto esteja presente a nós dois, e que o vejamos igualmente e ao mesmo tempo.

Ev. Isso é bem evidente. (II, vii, 16 Paulus - grifos nossos) $)^{217}$

Se o início da explanação deu-se pelo ressalto da obviedade quanto ao aspecto inapelavelmente individual da percepção sensível, o passo contínuo atenta para o que, grosso modo, podemos chamar de objetividade presente no conhecimento dos dados sensíveis. Aqui, não se trata mais, certamente, de se fazer notar a evidência manifesta quanto à percepção conjunta unívoca de um mesmo objeto, mas de ressaltar sua possibilidade diante da multiplicidade de sentidos individuais, na presença de um mesmo objeto. Se a individualidade relativa aos sentidos exteriores é evidente e indiscutível, igualmente o pode ser o aspecto público da percepção relativa ao objeto, ainda que Agostinho trata de manter o devido cuidado quanto ao alcance de tal publicidade: sua ocorrência é possível em algumas situações (Possumus [...] possit).

Mais importante, porém, que o voltar-se da atenção para o polo "objetivo" da intelecção da realidade, é a maneira como Agostinho a procede: imediata guinada para a possibilidade de uma percepção conjunta, que se configure generalizada ou pública em seu conteúdo e em seu tempo ${ }^{218}$. Tão clara e inequívoca quanto a percepção individual pelos sentidos próprios de cada pessoa, é a percepção pública de um dado cognscível, percebido por vários sentidos, de modo idêntico a si mesmo, de forma unívoca e, sobretudo, num único tempo. $\mathrm{O}$ constraste cuidadosamente articulado do primeiro construto frasal acentua o aspecto publico que se manifesta inequívoco ante a multiplicidade (Possumus [...] videre unum aliquid multi simul). A despeito de se dar à vista da multiplicidade (multi), sua univocidade permanece inalterada (unum), o que bem poderia soar óbvia trivialidade, tal qual o fora o passo anterior relativo à individualidade perceptiva dos sentidos individuais de cada um, não fosse a instância à qual Agostinho reporta tal univocidade: a simultaneidade em que se dá a percepção do público em multiplicidade. Atestada pela tríplice presença, neste passo, de simul em sua função

\footnotetext{
217 Aug. Possumus ergo videre unum aliquid multi simul, cum sint sensus nostri nobis singulis singuli, quibus omnibus illud unum sentimus quod simul videmus, ut quamvis aluis sensus meus sit et alius tuus, possit tamen fieri ut id quod videmus non sit aliud meum aliud tuum, sed unum illud praesto sit utrique nostrum et simul ab utroque videnatur. - Ev. Manifestissimum est.

${ }^{218}$ Patrick Kremer visualiza a articulação agostiniana, neste ponto, como uma composição por analogia: The "psychological”proof..., op.cit., p. 15.
} 
adverbial $^{219}$, a univocidade perceptiva se dá (assim o ratificaremos nos passos imediatamente seguintes do diálogo) em simultaneidade essente e própria do ato inteleccional primordial, já na percepção dos sentidos físicos, aqui exemplificada pela visão. Ao remontar a generalidade perceptiva à simultaneidade de sua ocorrência em multiplicidade, Agostinho parece indicar que a primeira é como que "garantida" ou fundamentada pela temporalidade única em que se dá a perceber, o que bem podemos visualizar, uma vez mais (e em confirmação de nossa tentativa de leitura na presente pesquisa), como atemporalidade inerente ao ato perceptivo, no instante de sua receptividade da publicidade, imponente ante a multiplicidade de "receptores", vale dizer, de sentidos individuais aos quais é manifestada a univocidade de algo percebido (unum aliquid), atemporalidade esta que, tal como referimos na análise imediatamente anterior ao início da demonstração, configura-se como prototípica da eternidade, justamente porque nela erradicada e, a rigor, uma sua manifestação, "furtiva" à temporalidade inerente à realidade conhecida, atestada pela sucessividade do ato cognoscente e à qual Agostinho escapa remindo a intelecção, em sua fontalidade e manifestação primeira (sentidos físicos), do princípio de sucessão temporal para instanciá-lo na simultaneidade atemporal, ou temporalidade única e total $^{220}$.

Outrossim, a imediatez com que efetua a guinada para o polo objetivo, aliada à simultaneidade em que situa o ato perceptivo primordial da universalidade, por parte dos sentidos físicos, perfazem uma primeira exposição da presenca do absoluto e eterno, na própria intelecção da realidade iniciada pelos dados sensíveis. Efetivamente, após indicar como absolutidade e eternidade as características da divindade que haveriam de se reconhecer como atestados inequívocos da presença (e existência) de Deus, Agostinho trata de iniciar precisamente pela evidência da presença de tais características no ato inteleccional em seu

\footnotetext{
${ }^{219}$ A despeito de toda a herança neoplatonica (mormente de Plotino) quanto à conceituação da simultaneidade essente e inerente à cognoscibilidade humna, o largo uso de simul em conjunção adverbial (tal qual praesto, logo adiante tornado advérbio no construto final da presente intervenção agostiniana), reflete o influxo da matização filosófica do vocabulário latino em voga à época, notadamente de herança ciceroniana. Vide a respeito: FOLEY, M.P. Cicero, Augustine and the Philosophical Roots of the Cassiciacum Dialogues in Revue des Études Augustiniennes, vol. 45, Paris, 1999, p. 51-77 (sobretudo 71-75, enfatizado no De ordine).

${ }^{220}$ Intitulando um subitem do capítulo reservado à análise da temporalidade em Agostinho, como "A crítica de Santo Agostinho ao principio de sucessividade e o privilégio da simultaneidade", Márcia Schuback faz notar, no ensaio acerca da hermenêutica dos textos medievais anteriormente aludido, que "... [A eternidade] não se deixa apreender pela representação temporal imediata, de base linear e sucessiva, voltada para a medição do tempo. O tempo sucessivo e linear não pode medir a eternidade." - SCHUBACK, M.S.C Para ler os medievais, op. cit., p. 88-89 (ressalto em negrito da autora). Por sua vez, Moacyr Novaes, após asseverar que "com base no imperativo de se subtrair à vicissitude temporal, Agostinho conduzirá o exame do tempo combinando [...], a dificuldade de compreensão do que é passageiro [...] e [...] a consciência de que tais dificuldades só podem ser explicadas [...] justamente em razão também da temporalidade...”, assinala que “... em Agostinho, a [...] solução se dá apenas mediante a presença da eternidade no homem interior", fazendo notar, entretanto, que "... será preciso levar em conta a importância da sucessividade e não simultaneidade, pelas quais o tempo já não pode ser reduzido ao espaço" - NOVAES, 2007: 258-259 (grifo nosso).
} 
exercício elementar (percepção sensível). A presencialidade que se dá a conhecer e se impõe, em sua unicidade (e, portanto, sinal da imutabilidade) e em simul (sinal, pois, da eternidade), à multiplicidade, é ressaltada pelo dar-se de pronto, de algo conhecido: "Que um único objeto, porém, esteja presente a nós dois...”, o qual se presentifica (praesto sit), e cuja composição em locução adverbial ilustra a perenidade e anterioridade com que a universalidade do dado conhecido se manifesta à percepção sensorial, bem como aponta para a receptividade permeante do ato intelectivo, ante a imponência do dado que se dá conhecer: “..., e que o vejamos igualmente e ao mesmo tempo.", uma vez mais posto à evidência através do uso da passiva (videatur).

A centralidade da disposição ao conhecimento, ou do presentificar-se à percepção, com que Agostinho reveste a conceituação do ato primeiro e elementar do conhecimento humano, no nível dos sentidos exteriores, leva-nos ainda a um maior detimento em seu termo focal. Impóe-se notar, pois, que, ao fazer uso de praesto para o ressalto da presentificação de um objeto à percepção, Agostinho está situando o dar-se objetivo precisamente na anterioridade do excellere permeante da dinâmica ascensional ou gradual ontológica inteleccionada pela ratio. Com efeito, a antecipação presencial do passo seguinte na escala gradual, ensejada pela exaurição do esse em seu nível atual, permite, a um só tempo, a percepção da atemporalidade inerente à presencialidade do esse, em seu ensejar a excelência componente da dinâmica da percorrência gradual dos níveis ontológicos da realidade conhecida; bem como da atualidade com a qual o esse dispõe-se (poderíamos perfeitamente dizer: impõe-se) ao conhecimento, vale dizer: presencia-se enquanto ato primeiro que enseja a dinâmica do real, dispondo e levando ao conhecimento, justamente no dispor-se de si mesmo em ato de excedência do passo gradual em que se situa num dado instante. Composto em locução com esse, a função adverbial de praesto, com a qual Agostinho elucida a univocidade do dado conhecido ante múltiplos perceptores, ilustra-nos não só a primordialidade do esse em relação à consecução (temporal, portanto) de seu conhecimento por parte do processo intelectivo, mas principalmente a fundamentação deste naquela $^{221}$. A processualidade do conhecimento, biunivocamente estabelecida pela gradação hierárquica da realidade conhecida, encontra-se assim disposta pela unicidade própria com a qual o esse (o algo conhecido, neste ponto do nosso texto) se excede ${ }^{222}$ ou se "excelencia",

\footnotetext{
${ }^{221}$ Cf. SCHUBACK, M.S.C. Para ler os medievais, op.cit., p. 82-83.

${ }^{222}$ Cabe lembrar que, tanto em seu particípio presente, quanto em seu frequente uso adverbial, praesto traduz precisamente o preeminente, excedente e/ou excelente, notando-se ainda que seu étimo possibilita ampla gama de matizes que envolvem, no núcleo semântico de excelência/excedência, as noções de realização plena, satisfação enquanto ato concludente de algo anteriormente proposto (tal qual o pagamento antecipadamente ajustado), garantia de efetivação, etc. - cf. verbetes respectivos, além do Thesaurus, em COÊLHO DA SILVAMONTAGNER 2009; MUNGUÍA 2008; SARAIVA 2007.
} 
presentificando-se (praesto sit) e conduzindo, em seu dispor-se unívoco ou universal na atemporalidade "furtiva" da simultaneidade, à temporalidade da percepção sensível.

\title{
3.6) Identidade e imutabilidade pontuadas no conhecimento sensível
}

Estabelecida em concórdia plena a individualidade dos sentidos físicos, e elucidada a publicidade dos objetos cuja presencialidade se disponha simultânea e univocamente à multiplicidade, a continuidade do diálogo reclama, no passo agostiniano, a verificação de como ambos os aspectos se estruturam no âmbito geral das possibilidades de conhecimento proporcionadas por todos os sentidos. Assim, se a visão e a audição possibilitam a universalidade percebida ante a multiplicidade receptora, não se pode assegurar o mesmo quanto às sensações olfativa, gustativa e táctil:

\begin{abstract}
Ag. Agora, convém também notar, em relação aos demais sentidos corporais, que no que se refere à questão presente não dizemos que eles se comportam de maneira totalmente semelhante à dos dois sentidos referidos: o da vista e o do ouvido; nem de maneira totalmente diferente. Com efeito, podemos, eu e tu, encher nossas narinas com o mesmo ar, ou perceber pelo odor a qualidade deste ar. E do mesmo modo, um e outro podemos degustar um mesmo mel ou qualquer outro alimento ou bebida, ainda que esse mel seja único e que nossos sentidos nos pertençam a cada um em particular. [...] E quanto ao alimento, ainda que um único em sua totalidade seja absorvido por um e outro de nós, ele não pode, entretanto, ser absorvido totalmente por mim, nem totalmente por ti; [...] Não te parece que se possa comparar o sentido do tato ao dos olhos e dos ouvidos, do ponto-de-vista que ora tratamos? Pois não somente podemos nós dois perceber pelo tato um mesmo corpo, mas que poderás também tocar a mesma parte que eu tiver tocado. [...]

Ev. [...] Vejo [...] uma diferença nisto: simultaneamente, isto é, num só e mesmo tempo é que podemos um e outro ver e ouvir totalmente uma só e mesma coisa. Ao passo que, quanto ao tato, não podemos certamente um e outro tocar no mesmo objeto por inteiro, ao mesmo tempo, apensas em partes distintas. [II, vii, 17-18 Paulus grifo nosso $]^{223}$
\end{abstract}

Observamos que Agostinho como que retoma a obviedade da descrição relativa à individualidade do exercício perceptivo por parte dos sentidos próprios de cada pessoa, relacionando-a porém, num primeiro momento, com o conteúdo percebido pelo olfato e pelo paladar, objetivando evidenciar, por assim dizer, o privilégio da visão e da audição, no tocante à universalidade percebida; e, num segundo momento, especificar a atuação do tato, que Agostinho, uma vez mais, articula habilmente de modo a "cavar" a resposta que deseja ouvir,

\footnotetext{
${ }^{223}$ Aug. Iam etiam de ceteris sensibus corporis licet animaduertas quod dicimus, neque omnino illos, quod ad hanc rem adtinet, ita se habere, ut illos duos oculorum et aurium, neque omnino non ita. Nam quia ex uno aere et ego et tu possomuns implere spiramentum et eius acris adflectionenm odore sentire, et item quia ex uno melle vel quolibet alio cibo seu potu ambo gustare possumus et eius adfectionem sapore sentire, quamvis ille unus sit, nostri autem sint sensus singuli, [...] Et cibus quamvis unus et totus ab utroque absumatur, non tamen et a me totus et a te totus absumi potest, [...] Num censes tangendi sensum comparandum esse oculorum et aurium sensibus in ea re de qua nunc agitur? Qua non solum corpus unum ambo possumus sentire tangendo, se ditam eandem partem tu quoque poteris tangere quam ego tetigero, [...] Ev. [...] in hoc video esse dissimilem, quod simul, id est uno tempore, et uidere aliquid unum totum ambo possumus et audire, tangere autem possumus quidem totum aliquid ambo uno tempore, sed partivus singulis, ...
} 
por parte de Evódio, ao traçar um paralelo sabidamente impróprio entre o âmbito de atuação do tato e os da visão e audição. Evódio não demora em apontar a diferença entre eles, e a importância de sua resposta reside precisamente na clarificação pontual e definidora com que a efetua, quanto à fundamentação da univocidade recepcionada pela visão e audição: a univocidade (vale dizer: a unicidade identitária do objeto universalmente conhecido) se dá unicamente na simultaneidade, numa palavra: na preeminência inerente ao dado que se dispõe ser conhecido, em sua excelência primordial (antecipatória), furtando-se e superpondo-se à temporalidade processual e sucessiva própria da multiplicidade e limitação sensorial. A simultaneidade inere à universalidade, atuando como uma espécie de iniciação ofertada e dada à multiplicidade transitória, em que, a um só tempo e instância - vale dizer: no instante atemporal propriamente, cuja presencialidade faz com que a imediaticidade/instantaneidade se torne vislumbre da eternidade - a excelência em antecipação da universalidade se converta em prefiguração da temporalidade processual do conhecimento.

Ante a lúcida e (uma vez mais, estrategicamente "preparada" pela inquirição agostiniana) resposta de Evódio, Agostinho pode, então, arrematar e cristalizar o teor nela contido:

\begin{abstract}
Ag. Respondeste com toda precisão. Mas, de todas estas coisas que sentimos, umas são as que sentimos conjuntamente, e outras as que sentimos cada um em particular. Ademais, percebemos, cada um, nossas próprias sensações, e de modo tão exclusivo, que eu não percebo tuas sensações, nem tu percebe as minhas. Atenta, pois, no que respeita às coisas que percebemos pelos sentidos do corpo (ou seja, as corporais), que as que não podemos sentir juntos, mas tão-somente cada um em particular, são aquelas que terminamos por fazê-las nossas, que podemos transformá-las e convertêlas em nossa própria substancia. [...] Quanto, porém, às outras coisas sensíveis, as quais apesar de sentirmos, não as transformamos por esta sensação em nossa própria substância, podemos senti-las conjuntamente, seja de forma simultânea, seja sucessivamente, e de modo tal que tu sintas o todo ou a parte, que eu também sinto. [...] É evidente, portanto, que aquelas coisas que não transformamos, e que, não obstante, percebemos pelos sentidos do corpo, não pertencem à natureza de nossos sentidos, e por isso mesmo nos são comuns, porque nem se transformam nem se convertem em algo próprio privativo nosso. [II, viii, 19 B.A.C. $]^{224}$
\end{abstract}

O contraste trabalhado por Agostinho tem por base a verificação de uma "prévia", ou sinal presente, da segunda característica intentada como provada e assentida, no escopo probatório a que se propusera/lançara. No passo final anterior ao início da demonstração atual,

\footnotetext{
${ }^{224}$ Aug. Vigilantissime respondisti. Sed oportet te etiam illud uidere: cum horum omnium quae sentimus alia sint quae ambo alia quae singuli sentiamus, ipsos uero sensus nostros suos quisque singuli sentiamus, ut neque ego sentiam sensum tuum neque tu meum, quid de his rebus quae sentiuntur a nobis per corporis sensus, id est quid de corporalibus rebus non possumus sentire ambo, sed singuli, nisi quod ita fit nostrum ut hoc in nos vertere et commutare possimus? [...] Nam cetera sensibilia, quae quamvis sentiamus, non tamen ea sentiendo in nostrum corpus corrupta mutamus, possumus ea sive uno tempore sive singulis vicissim temporibus ambo sentire, sic ut vel totum vel pars ipsa quam sentio abs te etiam sentiatur. [...] Manifestum est ergo ea quae non commutamus et tamen sentimus corporis sensibus, et non pertinere ad naturam sensuum nostrorum et propterea magis nobis esse communia, quia in nostrum proprium et quasi privatum non vertuntur atque mutantur.
} 
Agostinho determinara que a divindade haveria de ser reconhecida pelos atributos da absolutidade e eternidade, com os quais, de pronto, evidencia-se ou presentifica-se/manifestase como superior a qualquer outro ser (antes, sendo precisamente a fundamentação da presença e medida da gradação ontológica inteleccionada pela ratio). Assim como, no trecho anterior, a simultaneidade prefigurara a eternidade, num "roubo" à sucessão temporal com que se efetua cada passo cognitivo, a percepção da inalterabilidade dos objetos conhecidos, por assim dizer imunes à sucessividade e mutabilidade processual da dinâmica temporal inerentes às percepções dos sentidos físicos, atua como primeira manifestação da imutabilidade que sinaliza à absolutidade. Ao passo que, na atuação dos sentidos exteriores que assimilam o objeto conhecido, sua transformação "na substância mesma" do perceptor os torna restritos à individualidade, limitação e mutabilidade, os objetos universais, simultâneos e atinentes à visão e audição, fazem com que a simultaneidade e a imutabilidade convertam-se no ponto de partida da imediação presencial das características buscadas como demonstração da presença da divindade dada a se conhecer e, por conseguinte, estabelecida e reconhecida como $\operatorname{provada}^{225}$. Clarifica-se, pois, que Agostinho estabelece certa hierarquização entre os sentidos físicos, posto que já na instância primordial e ensejante do processo cognitivo - sensação física e exterior - manifesta-se a excelência permeante e conducente de toda a posterior (temporal) dinâmica processual cognitiva, relativa à gradação ontológica. Entretanto, se a presença da estruturação hierárquica perfaz resultado inequívoco já nesta primeira instância intelectiva, seu sentido sinaliza (ou mesmo funda), entretanto, para além de sua verticalização segmentária e estratificante. Ao reconhecer o privilégio dos sentidos da visão e audição, evidencia-se, num primeiro momento, outro aspecto intentado por Agostinho como ilustrativo e sinalizador da infinitude, atributo essencial da divindade: a ilimitação apoiada na, por assim dizer, "imaterialidade" do conteúdo inteleccionado (vista e som), os quais superam a limitação dos sentidos físicos na própria sensação. De fato, a visualização ${ }^{226}$ e a audição ocorrem "imaterialmente", ou melhor, sem a assimilação que as altera essencialmente, transmutando-as no ser que as percebe, tal como nas sensações gustativa e olfativa, cabendo ainda observar, no tocante ao tato, que sua como que "posição intermediária" entre as sensações de assimilação individualizante, e as de recepção universalizante, corrobora e ilustra perfeitamente a gradação com que Agostinho pretende, com o aparato estrutural da hierarquização, elucidar, enfim,

\footnotetext{
${ }^{225}$ Cf. PLAMONDON, P. La preuve augustinienne de l'existence de Dieu, op.cit., p. 07.

226 "Ver, querer ver, poder ver, são para Agostinho a substância mesma da consciência. Assim como exalta o sentido da visão acima dos demais, assim também o ato espiritual da visão se resolve no ato do conhecimento. A razão (ratio) é como, nesse sentido, aspectus, olhar, cuja força subjetiva é impassível até que se ofereça o objeto ao qual irá se aplicar. Somente quando o objeto se revela de forma livre, chega a razão à visão e, por consequência, ao saber." - VON BALTHASAR, H.U. Gloria: una estética teológica, op.cit., p. 98.
} 
questão vital onipresente nas correntes filosóficas gregas, herdada por Agostinho no seio da tradição neoplatônica (na qual a questão articulara-se de modo dialético), qual seja: a percepção da unicidade e da imutabilidade, em sua relação com a fragmentação e a fugacidade, com a evidente inclusão do problema da temporalidade, articulação esta que restará, afinal, tópico seminal no decorrer de toda a obra agostiniana, possibilitando desenvolvimentos fundamentais vários, incluindo os construtos estritamente teológicos, sobretudo nos textos intermédios (Confessiones), e nos grandes tratados da maturidade (com o evidente relevo ostentado pelo De trinitate $)^{227}$; e convertendo-se, nos itinerários intelectivos ascensionais da realidade deste período inicial de sua obra, em autêntica plataforma para toda a estrutura de seu construto filosófico, posto que a convergência e culminância do percurso inteleccional, na verdade evidenciada como existência de Deus, tem início (assim o vemos neste passo), pela percepção do eterno e absoluto em seus, por assim dizer, vestígios iniciais.

A consideração da longa explanação agostiniana, no passo atual de nosso texto, requer ainda que nos detenhamos em torno a outro aspecto, cuja importância se depreende a partir da conclusão de Agostinho:

Ag. Portanto, é preciso entender como sendo coisa própria e de ordem privada o que pertence a cada um de nós em particular, e assim somente cada um percebe em si mesmo, como pertencente propriamente à sua natureza. E, por sua vez, é preciso entender como coisa comum e de ordem pública o que, sem nenhuma alteração nem mudança, é percebido por todos.

Ev. Assim acontece. [II, vii, 19 Paulus $]^{228}$

Ao explicitar a dimensão pública como a percepção da imutabilidade (nulla sui corruptione atque commutatione sentitur) por parte da multiplicidade em seu todo (omnibus sentientibus), Agostinho procede a uma equação sobremaneira fundamental para o decurso posterior do diálogo: a percepção da universalidade equivale à percepção da imutabilidade através da totalidade. Ao conjugar os aspectos relativos à percepção e ao ser percebido, Agostinho faz ver que o caráter universal do conhecimento, que escapa à fragmentação e às

\footnotetext{
${ }^{227}$ Temática axial no interior do pensamento agostiniano em todas as suas fases, por evidente que a questão da temporalidade ensejou bibliografia imensurável a respeito, da qual intentamos tão-somente pontuar, em consonância ao que já notamos a respeito; e para além das obras referenciais de ZUM BRUNN [1984], GUITTON [2004 (1933)], COURCELLE [1968], e GILSON [2007 (1946)], os textos igualmente mencionados de DOUCET [2004: 88-94], MAMMİ [2002: 57-59 e 61], NOVAES [2007: 253-285], SOUZA NETTO [2002: 14-22] e SCHUBACK [2000: 79-111]; e ainda os trrabalhos de BLÁZQUEZ [2012: 142-145]; PIC [2009: 245-259]; BOCHET [2009: 519-549]; PUENTE, F. R., e BARACAT Jr., J. (orgs.) Tratados sobre o tempo: Aristóteles, Plotino e Agostinho, Belo Horizonte: Editora UFMG, 2014, p. 101-105; além do capítulo dedicado a Agostinho no tratado de José REIS Sobre o tempo, Porto: Edições Afrontamento, 2008, p. 151-224 (sobretudo, para nossa pesquisa, as p. 159-172);

${ }^{228}$ Aug. Proprium ergo et quase privatum intellegendum est quod unus quisque nostrum sibi est et quod in se solus sentit quod ad suam naturam proprie pertinet; commune autem et quase publicum, quod ab omnibus sentientibus nulla sui corruptione atque commutatione sentitur. - Ev. Ita est.
} 
mutações inerentes à multiplicidade, se dá unicamente quando, grosso modo, ambos os polos (sentidos exteriores e algo sentido) ostentam, em suas próprias totalidades, a ausência de mudanças e a manutenção da univocidade identitária do ser conhecido. Com efeito, se a um dos polos faltar sua inteireza no ato cognitivo, haverá a consequente impossibilidade de se perceber a imutabilidade enquanto expressão de completude ou totalidade que não sofrera degeneração ou corrupção; do que resultará a ausência da percepção do universal, o qual somente se presentifica à intelecção quando todo o objeto (ou seja, em sua integridade e totalidade: nulla corruptione ... commutatione) se dá a perceber a toda a multiplicidade (omnibus sentientibus). Mais: Agostinho estabelecera, no início da exposição ora finalizada, que “... simultaneamente, isto é, num só e mesmo tempo é que podemos um e outro ver e ouvir totalmente uma só e mesma coisa." [II, vii, 18 Paulus]. A elucidação decorre de imediato: a universalidade faz-se presente na ausência de passo temporal entre as totalidades respectivas ao ser que se presentifica à percepção, e à percepção que atualiza a excelência do ser percebido (sentitur). Numa palavra: a simultaneidade parece-nos resultar, de forma inequívoca, como primordialidade fundamental à percepção da imutabilidade, permitindo-nos fixar que a atemporalidade inteleccionada no simul inerente à percepção da totalidade na multiplicidade, antecipa e se torna preeminente (praesto) da percepção da eternidade e absolutidade. 


\title{
IV - DEUS: VERDADE ETERNA E ABSOLUTA (lib. arb. II, viii, 20 - xii, 34)
}

\section{1) Numeralidade e razão}

Esgotado o âmbito dos sentidos exteriores, ou mesmo o primeiro nível do conhecimento humano, relacionado às percepções dos dados sensíveis; bem como nele evidenciada a presença da universalidade na percepção de um todo imutável ante a multiplicidade, através do simul de sua ocorrência entre o dado conhecido e os sentidos conhecedores, com a decorrente elucidação da atuação de ambas como vislumbres do eterno e absoluto - tal é a equação com que Agostinho inicia a demonstração da existência de algo acima da razão, acerca do qual nada se possa pensar como lhe sendo superior. Importa verificar, no interior da sequência gradual anteriormente fixada entre as instâncias componentes e atuantes do processo cognitivo, o âmbito da interioridade, instância superior aos sentidos corporais e composta, sobretudo, pela razão, até então o nível reconhecido como maximamente superior, dentro do espectro cognitivo.

\begin{abstract}
Ag. Continuemos! Atende agora, e dize-me, se há alguma coisa que possa ser objeto comum de visão a todos os seres capazes de raciocinar. Todavia, que a veja, cada um, com sua própria razão e espírito. Alguma coisa visível a todos, e que estando à disposição geral, entretanto não sofre alteração pelo uso dos que dela se servem à vontade, o que não acontece com o alimento e a bebida. Mas que permanecem inalteráveis em sua integridade, seja ela vista ou não. Em tua opinião, talvez nada exista com tais propriedades?

Ev. Ao contrário. Eu vejo muitas coisas dessa natureza. Basta lembrar a razão e a verdade dos números. Apresentam-se elas a todos os que raciocinam, de tal forma que aqueles que fazem cálculos, cada um baseado em sua própria razão e inteligência, esforçam-se para adquiri-la. [II, viii, 20 Paulus $]^{229}$
\end{abstract}

O prosseguimento de Agostinho parece retomar, num primeiro momento, as inquirições anteriores a respeito do âmbito de atuação dos sentidos da visão e audição (os quais privilegiara em função da universalidade de suas percepções), voltando-se agora para o campo de atuação da razão : “... se há alguma coisa que possa ser objeto comum de visão a todos os seres capazes de raciocinar." Novamente, a presença do totus em simul, prefigurativos do absoluto e eterno. Agostinho explicita o paralelo de base (que, em verdade, termina por se mostrar como passo anterior ensejante do posterior, em perfeita percorrência dinâmica do

\footnotetext{
${ }^{229}$ Ag. Age, nunc attende, et dic mihi utrum inueniatur aliquid quod omnes ratiotinantes sua quisque ratione atque mente communiter videant, cum illud quod videtur praesto sit omnibus nec in usum eorum quibus praesto est commutetur quase cibus aut potio, sed incorruptum integrunque permaneat, sive illi vidant sive non videant. An forte nihil huiusmodi esse arbitraris? - Ev. Immo multa esse vídeo, e quibus unum commemorati satis est: quod ratio et veritas numeri omnibus ratiotinantibus praesto est, ut omnis eam computator sua quisque ratione et intellegentia conetur adprehendere.
} 
itinerário ascensional) entre visão e razão, chegando até mesmo à convergí-las entre si: "Todavia, que a veja, cada um, com sua própria razão e espírito.” A convergência almeja, evidentemente, incluir a razão no escopo da análise dos âmbitos cognitivos em que se desenvolve a inquirição entre Agostinho e Evódio, à luz porém dos parâmetros alçados como referenciais no exame crítico dos sentidos corporais: precisamente a percepção da imutabilidade inerente à visão do todo, simultânea a todos: algo “... visível a todos [...] à disposição geral”, mas “... que não sofre alteração" ao ser percebido pela razão, tal qual a visão. A convergência, entretanto, cede espaço à especifidade do âmbito racional, pois a coisa conhecida deve permanecer "inalterável em sua integridade (totalidade), seja ela vista ou não". Embora divisem e atinjam a universalidade e a imutabilidade, as percepções da visão e da razão apresentam alcances diferenciados em suas atuações, posto que a superioridade do ato racional localiza-se, como anteriormente já o expusera Agostinho, na preeminência/excelência que o torna antecipatório, bem como adjudicativo e conducente, da dinâmica temporal do processo intectivo, no qual a fragmentação e sucessão dizem respeito, entre outros aspectos, à finitude da corporalidade e materialidade.

\subsection{1) Ratio et Veritas}

A resposta de Evódio evoca a percepção do número em sua "razão e verdade", vale dizer: evidência e certeza. O acento em tais características é ilustrado pela referência à universalidade do resultado numérico, na totalidade dos que dele fazem uso, tornando-a, em função disso, meta perquirida e buscada pelos que "se esforçam em alcançá-la", aos quais " $a$ todos, e de igual modo, ela própria se mostra e se dispõe ao ensejo de si" [II, viii, 20] $]^{230}$. Efetivamente, em sua operacionalidade e resultado, os números dispõem-se à percepção unicamente em sua inteireza e imaterialidade (imunes a quaisquer alterações ou defasagens) as quais compõem a racionalidade veraz com que Evódio contempla a inquirição que lhe dirige Agostinho.

Notemos que, longe de se delinear como mera justaposição de conceitos, a resposta evodiana apresenta-se como uma única realidade, composta porém por dois termos que, a rigor, não poderiam compor conceituação unívoca, tanto pela diferenciação essencial entre si, quanto pelos diferentes níveis de gradação ontológica em que, ao menos em tese, encontram-se situados. Ainda que sua culminância e excelência máxima, a ratio permanece circunscrita, neste passo do diálogo, ao âmbito do humano enquanto realidade limitada, mutável e temporal, ao passo que a veritas perfaz atributo até então inédito na disputatio, presumivelmente

230 ... ipsa aequaliter se omnibus praebeat valentibus eam capere ... 
pertencendo à realidade divina que se intenta provar como existente. Ao torná-las composição única, Agostinho parece sinalizar, para além de prévia identificação fundamental entre ambas (que, afinal, restará concretizada ao término da argumentação demonstrativa: o fundamento da razão é a verdade enquanto ser divino), rumo a uma atuação em sinergia: em sua essência, a numeralidade é ratificada por sua veracidade (certeza evidente), tanto quanto sua veracidade é atestada e reconhecida pela razoabilidade com que se reveste e se apresenta aos que a buscam e se dispõem à sua conquista. A funcionalidade sinérgica de ambas, em composição única, será elucidada e detidamente exposta em todo seu alcance, no final do itinerário probatório apresentado por Agostinho. $O$ fato, porém, de se iniciar a verificação do âmbito de atuação da razão, tomando-se a numeralidade como exemplo e justificando-a, para tanto, como portadora dos requisitos elencados na inquirição a Evódio com base na racionalidade enquanto veracidade, permite-nos a percepção de que Agostinho introduz a noção de verdade, precisamente no âmbito do grau ontológico máximo da realidade criatural, objetivando mostarnos que, longe de se encontrar situada unicamente no final do itinerário inteleccional, a verdade, enquanto meta a ser atingida, faz-se presente na própria preeminência pela qual a racioalidade adjudica e modera, atemporalmente, todo o processo temporal da consecução de conhecimento humano, o que restará plenamente elucidado, como notamos, ao término da argumentação agostiniana. Por ora, retenhamos a composição sinérgica entre ambas como fundamentação da numeralidade em sua excelência e evidência.

\subsection{2) Iluminação e ratificação}

Ante a precisão e a completude da resposta evodiana, Agostinho anima-se a aprofundála perscrutando a origem da percepção e entendimento da numeralidade:

Ag. Muito bem! Vejo, ademais, que como homem que não desconhece tais matérias, ocorreu-lhe de pronto a resposta. Porém, se alguém te dissesse que estes números têm sido impressos em nossa alma, não em virtude de sua natureza específica, mas sim como efeitos próprios das coisas percebidas pelos sentidos externos, e que são, portanto, como certas imagens das coisas sensíveis, o que responderias? Ou tu também assim pensas?

Ev. De modo algum penso assim. Porque, mesmo concedendo que os números são percebidos pelos sentidos, não se segue que seja possível perceber também pelos sentidos, a razão da divisão e adição de tais números. É pela luz da mente que não admitimos o resultado daquele que, seja quem for, se nos apresenta, em função de uma operação de somar ou dividir, uma soma falsa ou equivocada. [II, viii, 21 $B A C]^{231}$

\footnotetext{
${ }^{231}$ Ag. Recte sane. Sed uideo te tamquam non rudem harum rerum cito inuenisse quod diceres. Tamen, si tibi aliquis diceret numeros istos non ex aliqua sua natura, sed ex his rebus quas corporis sensu attingimus impressos esse animo nostro quase quasdam imagines quorunque visibilium, quid responderes? An tu quoque id putas? Ev. Nullo modo id putaverim. Non enim si sensu corporis percepi numeros, idcirco etiam rarionem partitionis numerorum vel copulationis sensu corporis percipere potui. Hac enim luce mentis refello eum quisquis vel in addendo vel in retrabendo dum computat falsam summam renuntiaverit.
} 
O intento de Agostinho em clarificar a natureza essencial da numeralidade, bem como o seu estatuto no processo cognitivo, enquanto ilustração da superioridade da interioridade em relação à exterioridade, transparece na singeleza com que questiona Evódio, explicitando-lhe os elementos e conceituações em jogo de maneira a permitir a articulação sucinta e direta da quaestio, deixando entrever que tenha em mente, na sua estruturação, possivelmente algumas das teorias do conhecimento das correntes helenísticas, cuja ressonância se verifica, entre outros pontos, à teoria estoica da origem do ato representativo-imaginativo no conteúdo percebido pelos sentidos físicos, em que se o define como phantasia kataléptica. ${ }^{232}$ Assim, a pergunta agostiniana agudiza o problema quanto à possibilidade da racionalidade inerente à (e fundamentadora da) numeralidade, em sua origem, situar-se no domínio dos sentidos corporais, o que implicaria, a rigor e para além do assentimento ao probabilismo da escola acadêmica, capitulação face ao seu materialismo. Noutros termos, Agostinho intenta estabelecer, com a explicitude concisa e articuladora da questão, igualmente em termos explícitos e definitvos, a refutação do materialismo, precisamente em sua "base de ataque", qual seja, a origem das evidências e certezas das operações matemáticas, à qual encontra-se vinculado o estatuto da independência e superioridade do âmbito da razão (em sua imutabilidade e ilimitação), face ao campo do sensível transitório e fragmentado.

Evódio contempla a concisão e agudeza da inquirição agostiniana, com idêntica disposição de espírito. Após o rechaço de pronto, ao modo de interjeição de recusa; e mesmo admitindo a origem sensível corpórea dos números, prontamente se recusa a ponderar sobre a hipótese de que a racionalidade das operações aritméticas tenha a mesma origem, expondo para tanto, não propriamente uma argumentação elaborada como justificativa, mas sim introduzindo um elemento inédito no decurso demonstrativo iniciado por Agostinho: a iluminação interior (intelectual - luce mentis), da qual extrai a fundamentação de sua resposta, lançando mão

\footnotetext{
${ }^{232}$ No escopo da epistemologia estoica, a phantasia kataléptica ostenta, termos sumarizantes, a primazia do sensível enquanto fonte exclusiva das representações, tanto impressivas quanto imaginativas, rejeitando-se por conseguinte qualquer possibilidade de elucidação originária da mente ou do interior do ser humano. Jean-Baptiste Gourinat observa, no tocante à escola estoica helenística, que "segundo Zenão, a representação (phantasia) é uma impressão na alma, o que Cleanto toma ao pé da letra, [...] A representação é a maneira pela qual as coisas externas se manifestam na alma, modificando-a. [...] Apesar do que sugerem metáforas e etimologia, phantasia não é necessariamente visual (ela pode se produzir pelos cinco sentidos) [...] Mesmo assim, se certas representações não resultam diretamente de impressões produzidas pelos objetos externos, não há ideia inata...". Por outro lado, no que respeita ao estoicismo imperial, Jonathan Barnes aponta para a divergência de base entre Epicteto e Crisipo, com o primeiro defendendo uma presumível "epistemologia natural" e a teoria das "prenoções" (a qual eventualmente sinalizaria proximidade a um inatismo intelectivo), ao passo que o segundo mantém-se fiel aos cânones céticos dos acadêmicos - GOURINAT, J.-B. e BARNES, J. (orgs.) Ler os estoicos, São Paulo: Loyola, 2013, p. 38-39 e 165-168, respectivamente. Adiante, quando de nossa tentativa de análise e interpretação do De quantitate animae, teremos ocasião de atentarmos mais detidamente às doutrinas estoicas, notadamente a da phantasia kataléptica.
} 
novamente do mesmo aparato conceitual com que se lhe depara a inquirição lançada. Nesta, Agostinho retomara, como vimos, a observação acerca do alcance totalizante, e por assim dizer universal, do sentido da visão (conjuntamente à audição), para introduzir o questionamento acerca da razão, aludindo então àqueles que, pelo raciocínio, "veem de modo comum a todos, cada um com sua razão, e mente" [II, viii, 20] $]^{233}$. Assim, a visão da razão e da mente atua com fundamento na luz essente e que lhes pré-excede toda a veracidade das certezas vistas, de forma que a primazia a que nos referimos antes, reconhecida por Agostinho à visão, e metaforicamente aplicada à ratio em sua intelecção da realidade, possibilita o entendimento de que a luz permeia a captação e percepção da verdade em sua totalidade (toda a sua excelência e preeminência) $)^{234}$.

Atentemos para determinado matiz presente no alcance da metáfora da luz, no contexto da aplicação ora dirigida à racionalidade. A luz intelectual, na intervenção evodiana deste passo do texto, não atua em elucidação dialética ou abstraente da realidade estratificada ontologicamente, mas sim em iluminação intuitiva e imediata, na antecipação e preeminência com a qual ratifica (ratio et veritas), institui e modela (iudicem et moderatem das sessões anteriores de nosso texto) cada passo do itinerário ascensional do conhecimento. Esta nos parece a razão pela qual Evódio apresenta a lux mentis sem qualquer desenvolvimento prévio, ou argumentação justificadora anterior, ao contrário: sua imediata postulação faz supor que a luz intelectual instancia-se, não ao final do processo, nem propriamente ou tão-somente em seu início (embora perfaça ponto de partida, pela presença na sensação corporal), mas sim por todo o percurso inteleccional pelo qual a mente ascende até Deus. Mais: a imediatez permite inferir que componha metaforização precisamente da totalidade, bem como da simultaneidade e imediaticidade/instantaneidade pelas quais a ratio, em sua presentificação e ensejo da realidade cognoscível, no instante mesmo em que se dispõe aos que a buscam, permite o vislumbrar-se (videantur) das características pré-requisitadas (imutabilidade/absolutidade e eternidade) como probatórias (ratificantes) da existência da divindade.

A continuação da intervenção evodiana parece-nos confirmar nossa tentativa acima:

\footnotetext{
233 “... omnes ratiocinantes sua quisque ratione atque mente communiter videant, ...".

234 "Assim, a multiplicidade entre o sagrado e o profano é unificada na luz única e singular, a qual transcende todo aspecto múltiplo e, em decorrência, atua preponderantemente na alma mais na amplitude de sua visão luminosa, subjetiva (interior), do que em direção aos muitos objetos externos, sendo uma luz que ilumina tanto mais, quanto mais consegue purificar-se das escórias do múltiplo e da rejeição mundana e material, avançando rumo à sua própria essência luminosa." - VON BALTHASAR, H.U. Gloria: una estética teológica, volume 2, Madrid: Ediciones Encuentro, 1986, p. 100. Vide GONZÁLEZ, O. La iluminación agostiniana..., op.cit.; SCHUMACHER, L. Divine Illumination - The History and Future of Augustine's Theory of Knowledge, Oxford: Wiley-Blackwell (John Wiley and Sons Ltd), 2011, p. 58-65.
} 
Ev. E, de tudo o que atinjo com meus sentidos corporais, assim o céu como a terra, bem como quaisquer outros corpos que neles sinto, não sei quanto haverão de permanecer no futuro. Sei, porém, que certamente sete e três são dez, não somente agora, mas sempre, e sei que jamais sete e três deixaram de ser dez, e nunca deixarão de sê-lo. Logo, esta é uma verdade inalterável dos números, que eu disse ser comum a mim e a todo ser que faz uso da razão [II, viii, 21]. ${ }^{235}$

Evódio tece sua exemplificação com base na funcionalidade dos sentidos exteriores e da razão, para ilustrar que o contraste entre a corporalidade e a racionalidade assenta, sobremaneira, na atemporalidade e na imutabilidade da percepção racional, ao contrário da incerteza dos dados alcançados pela corporalidade (ainda que estes digam respeito ao céu e à terra!), dada a fugacidade e mutabilidade que lhe são próprias. Ao contrário, a certeza apresentada pela verdade da racionalidade numérica é infinita e imutável, características inerentes ao dado conhecido, e à disposição de todos que raciocinam. Tais aspectos, percebidos e iluminados pela ratio em sua intelecção da realidade, dão-se a perceber (dispõem-se) na excelência intragradual da dinâmica de ascensão inteleccional (praesto sit). Porém, a iluminação por certo não se dá ao modo da própria verdade da certeza aritmética, ou mesmo da evidência geométrica: sei que $7+3=10$ em virtude de: 1) postular os números; 2) operar a conjunção entre ambos; e 3) obter uma soma como resultante destes passos. De igual modo, o número se apresenta à minha percepção através do exercício de meus sentidos, pelos quais se dá a captação da numeralidade geométrica resultante da disposição e concatenação dos objetos dados (dispostos) a perceber. A iluminação, porém, com que minha mente intelecciona a racionalidade perpassante da realidade em sua totalidade, exercendo sua preeminência e excelência ensejante (via juízo e moderação) do próprio ato inteleccional da estratificação gradual $^{236}$, não supõe operação alguma anterior, constituindo ato sem mediações e instituinte da totalidade essente de uma verdade, pelo qual esta é intuida como inerente à racionalidade disposta e que se presentifica à sua recepção. A iluminação da intelecção enseja a si própria ao dispor-se, na excelência e preeminência que lhe são próprias, à busca dos que a almejam e, à sua luz, dispõem-se igualmente à sua posse e feitura intelectual da realidade ${ }^{237}$.

\footnotetext{
${ }^{235}$ Ev. Et quicquid sensu corporis tango, ueluti est hoc caelum et haec terra et quaecumque in eis alia corpora sentio, quandiu futura sint nescio. Septem autem et tria decem sunt et non solum nunc sed etiam semper neque ullo modo aliquando septem et tria non fuerunt decem aut aliquando septem et tria non erunt decem. Hanc ergo incorruptibilem numeri veritatem dixi mihi et cuilibet ratiocinanti esse communem.

236 “... per se ipsam cernit, ... simul et se ipsam” - II, vi, 14; cf. item 3.2.4 de nossa pesquisa.

${ }^{237}$ Embora não haja evidentemente uma teoria da numeralidade explicitada neste ponto (cf. entretanto HORN, C. Augustins Philosophie der Zahlen, op.cit.), é possível afrmar a presença de uma visão intuicionista embrionária acerca da essência do número na geometria da realidade dada aos sentidos, mas sobretudo da aritmética inerente à racionalidade matemática, em contraste com ambas as acepções presentes, p.ex., no sistema de Aristóteles, cuja lógica e matemática calcadas na abstração constituem exemplo do que foi tido como visão intelectualista da operação lógico-matemática, a qual terminou por influenciar grande parte do desenvolvimento histórico de ambas as ciências - cf. JAIRO JOSÉ DA SILVA, Filosofias da matemática, São Paulo: Editora Unesp, 2007, p. 43-49
} 
Por sua vez, Agostinho não somente partilha dos pressupostos evodianos quanto à iluminação intelectual das verdades eternas e imutáveis, como trata ainda de corrigi-los quanto à origem da própria numeralidade:

\begin{abstract}
Ag. Não tenho nada a opor às tuas respostas tão verdadeiras e tão certas. Porém, facilmente verás também que os próprios números não são percebidos pelos sentidos, se refletir no fato de que cada número assim é chamado, em virtude das ocasiões (vezes) que contém a unidade. Por exemplo: se contém duas vezes a unidade, chamase dois; se contém três, chama-se três; e se contém dez vezes, chamar-se-á dez; e qualquer número, sem exceção, recebe o nome pelas vezes que contém a unidade [...] Assim, todo aquele que tem verdadeira noção da unidade, se dá conta que esta não pode ser percebida pelos sentidos corporais. [II, viii, $22 B A C]^{238}$
\end{abstract}

Agostinho fundamenta sua correção trazendo à tona a noção de unidade, e definindo a numeralidade como a soma das ocorrências desta. Chamando a atenção de Evódio para a impossibilidade de que a noção de número seja extraída da percepção sensorial corpórea (“... numeros non per corporis sensus adtractos esse..."), Agostinho aponta para a indivisibilidade da noção de unum, com o que remonta, uma vez mais, à totalidade percebida pela visão e audição, característica-mor da verdade proporcionada pela ratio e alusiva à imutabilidade inerente ao caráter absoluto da divindade. Com efeito, igualmente o lapso temporal é pressuposto como superado ou transposto, dado que a soma das ocorrências compõe exatamente a numeralidade enquanto uma unidade de várias unidades num tempo único, tal que seja intuída como um todo de unidades, cuja soma constitua novo todo de unidades, etc. A sucessividade da repetição (“... si bis...”) é, pois, suprimida pela captação como totalidades de unidades (“... si ter tria, et si decies [...] decem.”). A disponibilidade e a presentificação, por igual e de pronto (pública), do unum e sua ocorrência na supressão temporal, tal qual em simul de unidades enquanto novo unum, e na decorrência mesma de tal simultaneidade (que, traço essente da atemporalidade raciocinante, igualmente alude e prefigura a eternidade característica da divindade), são atestadas pela ausência de interposições e operações intelectivas para sua obtenção. Ela é dada, gratuitamente disponibilizada, sem pré-requisitos.

Mas, se a primazia da noção da unidade resulta clara e indiscutível ${ }^{239}$, porque assevera Agostinho que sua percepção não pode ocorrer no domínio dos sentidos corporais, âmbito por

(relativo a Aristóteles); KNEALE, W. e KNEALE, Martha $\boldsymbol{O}$ desenvolvimento da lógica, $2^{\text {a }}$ edição, Lisboa: Fundação Calouste Gulbenkian, 1980, p. 63-83.

${ }^{238}$ Aug. Non resisto tibi verissima et certissima respondenti. Sed ipsos quoque numeros non per corporis sensus adtractos esse facile videbis, si cogitaueris quemlibet numerum tot uocari quotiens unum habuerit; uerbi gratia, si bis habuerit unum duo vocantur, si ter tria, et si decies unum habent tunc uocantur decem et quilibet omnino numerus quotiens habet unum [...] Unum vero quisquis verissime cogitat profecto invenit corporis sensibus non posse sentiri.

${ }^{239}$ Cf. TRELENBERG, J. Das Prinzip “Enheit” beim frühen Augustinus, Tübingen: Mohr Siebeck, 2004, p. 37 40, em que o conceito de unidade é analisado especificamente em seu papel central para a conceituação de 
excelência da multiplicidade? Precisamente pelo fato desta não poder dispor-se à unidade, senão pelo ensejo de sua excelência por parte da racionalidade, cuja precedência e preeminência conduzem sua instituição em unidade, percebendo-a pela via da iluminação da ratio et veritas. A unidade presente na multiplicidade dos dados percebidos, não se dá a perceber senão em sua superação e antecipação excelente pela racionalidade, a qual capta a totalidade do múltiplo enquanto una. A ilustração exemplificadora adotada por Agostinho parece confirmar a interpretação de tais características, ao fazer notar que, mesmo na percepção de um único objeto, os sentidos o percebem e captam não enquanto uma unidade, e sim na diversidade de suas características próprias:

\begin{abstract}
Ag. Todo objeto atingido por um de nossos sentidos, seja ele qual for, não é constituído pela unidade, mas sim pela pluralidade que o forma. Com efeito, por ser um corpo, por aí mesmo, possui inúmeras partes. [...] um corpúsculo, por exemplo, por menor que seja possui, sem dúvida, ao menos uma parte à direita e outra à esquerda, [...] Se bem que não se possa enumerar nele tal infinidade de partes, senão quando as distinguimos pelo conceito da mesma unidade. [... - Paulus] Como eu sei que o corpo não é a unidade? Se não soubesse o que é a unidade, não poderia distinguir muitas e diversas partes em um mesmo corpo. Mas por onde quer que eu possa ver a unidade, certamente não a verei pelos sentidos corporais, já que por eles não conheço senão os corpos, e da verdadeira e pura unidade, convencidos estamos de que não é corpo. Além disso, se não percebemos a unidade pelos sentidos do corpo, tampouco por eles perceberemos número algum daqueles que intuímos pela inteligência. [II, viii, 22 B.A.C. $]^{240}$.
\end{abstract}

Ao ressaltar que a recepção sensorial de um objeto não comporta sua percepção de unidade, Agostinho, ante uma aparente contradição com o que nos é atestado pelo conteúdo dos sentidos corporais, deseja fazer ver, em realidade, que até mesmo o domínio da corporalidade é permeado, em sua sensibilidade e receptividade perceptiva, pela iluminação intelectual, posto que, mesmo quando temos por certo que nossos sentidos perceberam um único objeto, o que de fato ocorre é a percepção de várias partes deste objeto, unidas e percebidas enquanto tal. Um corpo, ainda que minúsculo, é um composto de múltiplas partes, as quais são percebidas ao voltar-me para o objeto (esquerda, direita; superior, inferior; anterior, posterior); e se o percebo, não como soma de partes justapostas, mas como algo, certamente tal ocorre pela percepção da unidade, devido a intuirmos intelectualmente (intellegentia cernimus), por si e na enumeração componente da realidade, ainda que a

ordenação e hierarquização da realidade esteticamente conhecida, baseado sobretudo no De libero arbitrio e no De uera religione.

${ }^{240}$ Aug. Quidquid enim tali sensu attingitur, iam non unum sed multa esse conuincitur; corpus est enim et ideo habet innumerabiles partes; [...] quantulumcumque illud corpusculum sit, habet certe aliam partem dexteram aliam sinistram, [...] in quo tamen non possent tam multa numerari nisi illius unius cognitione discreta. [...] Ubi ergo noui quod non est corpus unum? Unum enim si non nossem, multa in corpore numerare non possem. Ubicumque autem unum noverim, non utique per corporis sensum novi, quia per corporis sensum non novi nisi corpus, quod vere pureque unum non esse convincimus. Porro si unum non percepimus corporis sensu, nullum numerum eo sensu percepimus, eorum dumtaxat numerorum quos intellegentia cernimus. 
sucessividade de ocorrências da unidade componha uma sequência infinita, a qual percebo, uma vez mais, pela unidade que me é presentificada e disposta pela lux mentis.

\subsection{3) Numeralidade e imutabilidade}

Outrossim, a própria sucessividade interna à numeralidade fornece a Agostinho um topos privilegiado para ampliar a exposição da iluminação racional enquanto percepção das características da divindade que se presentificam à ratio, em seu próprio exercício de superação e preeminência da realidade conhecida:

Ag. Ademais, seguindo a ordem dos números, vemos que depois do um vem o dois, o qual, comparado com o um, é o dobro, e que o dobro de dois não segue imediatamente ao dois, senão que entre este e o quatro, que é o dobro de dois, interpõe-se o três. E esta relação, em razão de uma lei segura e imutável, é constante através de todos os outros números. [...] Pois bem. Por meio de qual faculdade interna percebemos a imutabilidade, firmeza e inalterabilidade desta lei, que vemos cumprida em toda a sérire de números? [...] Como chegamos a conhecer isto que se realiza em todos eles, ou por meio de que imaginação, ou imagem, vemos esta verdade tão certa dos números, com tal segurança através da série indefinida dos mesmos, senão por meio da luz interior, a qual é desconhecida pelos sentidos corpóreos? [II, viii, 23 $B A C]^{241}$

Agostinho faz observar que a racionalidade que inere à numeralidade compõe sequência ordenada, a qual perfaz justamente a possibilidade de sua percepção enquanto todo ${ }^{242}$. Mas não é, evidentemente, sobre a noção de ordem que recai a observação central de nosso trecho, muito embora a ordenação da realidade desempenhe, no pensamento agostiniano como um todo, traço essencial de sua apresentação da realidade como obra divina, por óbvio no $D e$ ordine. Ao notar que a progressão geométrica verificada a partir do dobro do um, não equivale à sequência ordinária da numeralidade; e que, portanto, a ordem natural dos números - em cuja sucessividade poderia se pensar estar circunscrito o domínio completo da racionalidade numérica, e cuja percepção poderia se tomar por atinente à sensibilidade corpórea (mas que, como visto anteriormente, já de per si não se possibilita captar e perceber pelos sentidos corporais) - não comporta a apresentação à percepção da indiscutível e imutável lei da progressão geométrica (certissima et incommutabili lege), Agostinho torna evidente que a percepção desta verdade (cuja certitude e inalterabilidade a fazem assumir, pela atuação judicativa da ratio, caráter de lei) ocorre unicamente pela idêntica disposição anterior:

\footnotetext{
241 Aug. Deinde quoniam tentes ordines numerorum post unum duo uidemus, qui numerus ad unum collatus duplus inuenitur, duplus duorum non consequenter adiungitur, sed interposito ternario quaternarius sequitur qui duplus est duorum. Et haec ratio per omnes ceteros numeros certissima et incommutabili lege pertenditur, [...] Hoc ergo quod per onmes numeros esse immobile firmum incorruptumque conspicimus, unde conspicimmus? [...] Unde ergo novimus per omnes hoc esse, aut qua fantasia uel fantasmate tam certa ueritas numeri per innumerabilia tam fidenter nisi in luce interiore conspicitur, quam corporalis sensus ignorat? A respeito da imaginação, ver adiante em nosso estudo o item 5.2 do capítulo 5, respectivo ao De quantitate animae, quando da análise do ato imaginativo e seu papel no contexto da ascensão intelectual aí descrita.

${ }^{242}$ Cf. TRELENBERG, J. Das Prinzip “Einheit”..., op.cit., p. 40-43.
} 
precedência para com a atuação dos sentidos corporais, ao mesmo tempo ensejante de sua excedência. Tal disposição, já apresentada como a lux mentis no passo anterior de sua intervenção, é uma vez mais trazida à disputatio por Agostinho em sua definição como um conspicere, pelo qual vemos a sucessividade da multiplicidade numérica, interiormente e em sua totalidade, ao modo de uma contemplação a partir de um ponto privilegiado e equidistante de todas as partes da multiplicidade vista ${ }^{243}$. Igualmente, a reapresentação ou redefinição da iluminação intelectual comporta, nesta variante, além do evidente matiz do ato de ver, igualmente a acepção da espacialidade da visão: vejo a partir de posição em que a iluminação alcance o todo do múltiplo, tornando-o um; o que se traduz, na exemplificação de Agostinho, na percepção de uma lei, cuja solidez a torna inalterável (firmum incorruptumque), e que constatamos ser todo o prosseguimento da sequência dos números, em sua totalidade, por ela perpassado (pertenditur), não obstante a impossibilidade de se captar a infinitude de partes desta mesma totalidade (“...innumerabiles enim sunt.”).

$\mathrm{O}$ intento agostiniano resulta explicitado afinal, voltando-se novamente à lux mentis, não sem antes aludir, possivelmente e uma vez mais, às teorias naturalistas da atividade intelectual, valendo-se mesmo de sua terminologia específica: na percepção da lei imutável, pela qual contemplo a totalidade da numeralidade (ainda que imensurável na multiplicidade dos números que a compõem); bem como no ato imaginativo que a compõe ${ }^{244}$; e ainda na constatação de que a totalidade das possibilidades encontra-se seguramente permeada pela lei certíssima (“... innumerabilia tam fidenter...”), onipresente, no influxo da luz interior pela qual tudo é contemplado em sua totalidade e imutabilidade (“... nisi in luce interiore conspicitur,...").

Agostinho conclui a digressão acerca da razão e verdade inerentes à numeralidade, e contempladas pela iluminação intelectual, observando que "é certo que muitas outras verdades podem ser encontradas, e que se apresentam, por assim dizer, pública e universalmente a todos os que refletem. E cada um, em seu espírito e sua razão, e não com os sentidos

\footnotetext{
${ }^{243} \mathrm{O}$ uso de conspicere não se mostra frequente no período patrístico, preferindo-se videre na maioria das vezes, ou mesmo comprehendere, para verter ambos os matizes nele presentes. Jerônimo apresenta-o uma única vez em sua revisão dos manuscritos da Vetus Latina, porém no texto que se tornou seminal a toda a theologia naturalis desenvolvida na história cristã: "Invisibilia enim ipsius, a creatura mundi, per ea qua facta sunt, intellecta, conspiciuntur: sempiterna quoque ejus virtus, et divinitas: ita ut sint inexcusabiles." - Romanos 1,20 (Biblia Sacra iuxta Vulgatam Clementinam, duodecima editio, Madrid: B.A.C., 2005).

$\frac{144}{244}$ ide adiante, em nossa pesquisa, acerca da funcionalidade e alcance do ato imaginativo descrito no $D e$ quantitate animae.
} 
corporais, deixam-nas invioláveis e imutáveis" [II, viii, 24 Paulus adaptada] ${ }^{245}$, ratificando por fim a impossibilidade de situar, na sensibilidade corporal, a origem das verdades que se dão a perceber à intelecção da realidade, fazendo-se notar e ver, por igual e por todos aqueles em que a disposição a contemplá-las, pela própria luz interior da razão, se faça utilizada e presente (“...communiter et tamquam publice praesto sunt ratiocinantibus et ab eis uideantur mente..." $)^{246}$.

\section{2) Sabedoria natural e Bem supremo}

Após discorrer a respeito da numerabilidade, sua razão e verdade manifestadas na luz interior e intelectual posta à disposição de todos o que se dispõem a buscá-la, Agostinho conduz o diálogo para um segundo momento, dentro do escopo de sua demonstração da existência daquele ser "a quem nada é superior", em que se voltará para a sabedoria. Se a exposição, centrada na lei certíssima e inalterável da razão numérica presente na percepção do todo, fez valer os atributos da imutabiblidade e da unidade, a sabedoria irá se deter noutro aspecto da racionalidade humana, que irá permitir trazer à tona outra disposição comum a todos os homens, portanto como condição perene da humanidade. Enquanto a consideração da numeralidade evocava a imutabilidade da razão, com a decorrente igualdade de sua presentificação aos humanos, a sabedoria evidenciará, grosso modo, a igualdade da humanidade em sua necessidade de buscá-la, ainda que nem todos se disponham à ratio et veritas que lhe fundamentam.

\subsection{1) Sabedoria e busca por felicidade}

Ag. [...] Diga-me, por favor, o que te parece devermos pensar acerca da sabedoria mesma. Crês tu que cada um dos homens sábios tem sua sabedoria própria, distinta da sabedoria dos demais? Ou que há uma somente, acessível a todos, por igual, e cada um é tanto mais sábio quanto mais dela participa?

Ev. Não sei de que sabedoria falas, porque vejo a diversidade de opiniões dos homens acerca do que consiste falar ou agir sabiamente. Pois aos que seguem a carreira militar, parece-lhes que agem sabiamente; os que a menosprezam e põem todo seu empenho no trabalhar e cultivar os campos, elogiam preferencialmente esta ocupação, colocando-a como o marco da sabedoria; os que são hábeis em descobrir meios de ganhar dinheiro, se consideram sábios por isto; os que depreciam e passam ao largo de tudo isto, bem como a todas as coisas temporais, e se entregam plenamente à

\footnotetext{
245 Quapropter, cum multa alia possint occurrere quae communiter et tamquam publice praesto sunt ratiocinantibus et abi eis uidentur mente atque ratione singulorum quorumque cernentium eaque inuiolata et incommutabilia maneant, ...

246 "Manter que a essência é número, ideia que o velho Platão tomou dos pitagóricos e que Plotino integra em seu sistema - Agostinho mesmo celebra que seus amigos o considerem continuador de Pitágoras [De ordine 2,53] no deve ser entendido como uma quantificação o matematização do ser, posto que a unidade que os números e as relações numéricas refletem está acima de toda quantidade e é o valor pleno em sentido absoluto. Por isso Agostinho aplica juízos de valor superior a figuras numéricas da geometria que se extendem no espaço, e às do ritmo musical que se extendem no tempo, hierarquizando-as segundo as visões, que para ele são evidentemente distintas." - VON BALTHASAR, H.U. Gloria: uma estética teológica, op.cit., p. 118-119.
} 
investigação da verdade para conhecerem a si mesmos e conhecer a Deus, estimam que esta é a ocupação mais importante da sabedoria; os que não desejam se entregar à busca e contemplação da verdade, mas tão-somente aos cuidados e deveres mais penosos, com a finalidade de serem úteis à humanidade, e se ocupam da direção e governo justos das atividades e tarefas humanas, têm-se a si mesmos por sábios; e há os que fazem uma coisa e outra, e dedicam parte da vida à contemplação da verdade, outra parte aos serviços e trabalhos que creem serem devidos à sociedade, parece-lhes que são eles a carregar a palma da sabedoria. [II, ix, $25 B A C]^{247}$.

A questão é postulada por Agostinho de forma semelhante à que ensejara a exposição a respeito da numeralidade: a possibilidade de se verificar a existência de ocorrências singulares ou individualizadas, acerca de algo presumidamente universal ou comum a todos. Tal como questionara acerca da existência de verdades universais, acessíveis de igual modo a todos, ou em acessos singulares em função da razão individual de cada ser humano, assim também Agostinho lança a Evódio a inquirição acerca do caráter eventualmente universal da sabedoria. Notemos que Agostinho parece seguir como que um roteiro, tomando por objetos de questionamento conceituações e definições cuja posse ou noção, num primeiro momento, todos acreditam possuir, bem como se reconhece constituírem alvos unânimes da humanidade. Como a verdade e a razão na quaestio anterior, assim a sabedoria no passo atual do diálogo, porém com o responso "invertido" de Evódio: se, ante a inquirição acerca da existência de eventuais razões e verdades universais, ou de acessos individuais e únicos a uma verdade tida por universal, respondera pela postulação da numeralidade como exemplo de verdades que se presentificam enquanto universais, de igual modo a todos; agora expõe sua dificuldade em verificar uma única sabedoria que esteja de posse e seja universal e uniformemente exercida por todos. De fato, a pluralidade de conceitos acerca do que seja ser sábio é manifesta: há tantas "sabedorias" quantas são as funções, atividades, tarefas e opções de vida exercidas na sociedade.

Entretanto, o próprio responso evodiano ostenta pressupostos que o "traem" em sua apresentação crítica acerca da sabedoria e da diversidade de acepções a respeito do ser sábio. Nos exemplos listados, Evódio pontua que todas as pessoas creem possuir a sabedoria, em

\footnotetext{
${ }^{247}$ Aug. [...] quase te, quid de ipsa sapientia putas existimandum? Singulas quasque suas arbitraris singulos quosque homines habere sapientias? an uero uma praesto est communiter omnibus, cuius quanto magis quisque fit particeps tanto est sapientior? - Ev. Quam dicas sapientiam nondum scio, uideo quippe uarie uideri hominibus quid Fiat dicaturue sapienter. Nam et qui militant sapienter sibi facere uidentur, et qui contempta milita colendo agro curam atque operam inpendunt, hoc potius laudant tribuuntque sapientiae, et qui astuti sunt ad excogitandos modos conquirendae pecuniae uidentur sibi esse sapientes, et qui haec omnia neglegunt uel abiciunt et quaeque sunt hius modi temporalia et totum studium suum ad inuestigationem conferunt ueritatis ut semet ipsos deumque cognoscant, magnum hoc esse sapientiae múnus iudicant; et qui huic otio quaerendi et contemplandi ueri nolunt se dare, sed potius laboriosissimis curis et officis agunt ut hominibus consulant, et in rerum humanarum iuste moderandarum, et gubernandarum actione uersantur, sapientes se esse arbitrantur, et qui utrumque horum agunt et partim uiuunt in contemplatione ueritatis, partim in laboribus officiosis quos humanae societati deberi putant, sibi palman sapientiae uidentur tenere.
} 
virtude de sua escolha quanto à tarefa e/ou função na sociedade; as quais, por sua vez, advêm da crença, igualmente partilhada por todos, de se procurar fazer o melhor para si e/ou para a sociedade. A exemplificação apresenta todos os seus componentes como resultado de uma deliberação ou escolha fundamental, em função da qual todas as pessoas vivem, em sua relação consigo mesmas e/ou com a sociedade, ou ainda com Deus, tendo por pressuposto que tal escolha e sua consequência constituem a própria sapiência vital. Assim, os exemplos trabalhados por Evódio apresentam a sabedoria como o moto próprio inerente a todas as deliberações e atividades humanas, resultando na conduta humana por excelência, ainda que expressa em multiplicidade por vezes contraditória entre si. Ora, ao listar exemplos díspares e mesmo conflitantes, Evódio parece querer compor um quadro completo dos vários "tipos de sabedoria" então em voga, nos quais a descrição aponta claramente para os diversos grupos sociais, correntes de pensamento da época, ensinamentos religiosos, etc., incluindo até mesmo o grupo reunido em torno de Agostinho (do qual ele próprio faz parte), cuja descrição compõe o contexto histórico de sua estada em Cassicíaco, cenário de alguns dos diálogos do período inicial do pensamento agostiniano ${ }^{248}$, ostentando inclusive, termos equivalentes, o conteúdo do mote conducente celebrizado na abertura do livro II dos Soliloquia (“... semet ipsos deumque cognoscant, ...”). A completude do quadro termina por apresentar algo cujo sentido, se não contradiz em termos estritos o posicionamento evodiano anterior, traz em sua descrição um elemento, do qual Agostinho saberá explorar todo seu alcance e possibilidades para sua intervenção posterior, e certamente insuspeitado por Evódio: a universalidade da busca pela sabedoria, tida por bem supremo, acerca da qual iremos expor logo adiante. Antes, compete observarmos, ainda e brevemente, outro aspecto correlato ao que ora expomos e presente, igualmente de maneira involuntária por assim dizer, no quadro traçado (o qual também haverá de ser sabiamente transposto à argumentação própria agostiniana): o empenho vital decorrente da deliberação exercida pelos componentes dos diversos exemplos mencionados, fazendo ver que, independentemente de sua eventual universalidade ou plurivalência, a sabedoria compõe a

\footnotetext{
${ }^{248}$ Embora não componha o cenário estrito do livro II do De libero arbitrio (c. 390-391 d.C.), o período de Cassicíaco e sua ambiência (c. 386-388) fornecem, sem dúvida, o pano-de-fundo refletido no diálogo. A questão acerca da historicidade dos diálogos certamente não incide de modo direto em nossa pesquisa, embora possa, se situada no escopo do contexto histórico do período (como ainda do desenvolvimento eclesiástico do cristianismo), fornecer elementos preciosos para a compreensão de sua estruturação e de conceituações expostas. Em seu artigo a respeito, Goulven Madec, asseverando que “... le problème de l'historicité engage l'interpretation globale des Dialogues”, afirma conclusivamente que estes “... son historiques: leur conformité au genre litteráire n'est que relative et ne fait, du reste, pas obstacle à cette conviction; car les entretiens philosophiques sont les actes de l'otium; [...] les Dialogues doivent être lus em fonction de la remarquable continuité qui apparaît dans la conception qu'Augustin s'est fait de la philosophia, depuis sa première lecture de l'Hortensius. C'est toujours l'amour de la Sagesse en soi qui l'anime, autrement dit l'amour du Christ." - MADEC, G. L'historicité des Dialogues de Cassiciacum in Revue des Études Augustiniennes, vol. 32, 1986, p. 207-231.
} 
atitude fundamental, pela qual as pessoas deliberam acerca do que entendem ser o procedimento e modo de vida sábios, e em função dos quais suas vidas são traçadas em sua inteireza, ou seja, a sabedoria é a livre decisão que condiciona e molda a vivência em sua totalidade, constituindo-se pois na congruência total entre deliberação e ação, entre disposição de vida e seu exercício efetivo, numa palavra: a instância fundante da ética, sociabilidade e vida religiosa. E, como já o notamos, será precisamente tal convergência que irá permitir a Agostinho a exposição derradeira e definitiva acerca da realidade que, superior à ratio, ostenta as prerrogativas da universalidade e imutabilidade alusivas aos aspectos reconhecidos como probatórios da existência da divindade.

\title{
4.2.2) Eudaimonismo e sapiência (empenho vital)
}

Ante o desafio do quadro exposto, e percebendo-lhe as pressuposições de cunho universalizante e das quais, aos menos aparentemente, Evódio não se dera conta, Agostinho trata de assumí-las como o ensejo fundamental da exposição decisiva acerca da universalidade da sabedoria, em sua vivência pela multiplicidade dos "sábios", articulando-os em torno da atitude de busca da felicidade e de sua concretização, enquanto o empenho vital que anima todo ser humano, o qual se traduz na atitude sapiencial universalmente vivenciada, vertida nas deliberações e escolhas que todos tomam para si, ética, social e religiosamente. A resposta de Agostinho principia justamente pelo postulado central a tal articulação, cuja apresentação como interrogação intenta evidenciar a Evódio o quanto sua descrição, embora pretendesse expressar a contradição da multiplicidade, retém em sua base a pressuposição fundamental da universalidade, tão clara que Agostinho o questiona na forma de chamado a uma certeza manifesta:

\begin{abstract}
Ag. Acaso, em tua opinião, será a sabedoria outra coisa a não ser a verdade, na qual se contempla e se posssui o sumo Bem, ao qual, sem dúvida alguma, todos desejamos chegar? Com efeito, todos aqueles de quem acabas de citar as opiniões divergentes, na busca da sabedoria, desejam o bem e fogem do mal. Mas a razão da divergência de seus sentimentos encontra-se nas diversas acepções que têm do bem. [II, ix, 26] ${ }^{249}$.
\end{abstract}

O chamado aos pressupostos "velados" do quadro exposto é posto de pronto, ao modo de clarificar algo cuja aceitação é sabidamente universal: o que Evódio expôs outra coisa não é que a busca de todo homem pela realização pessoal, na posse e vivência do Bem. Mas a dupla identificação (resultante da articulação dos pressupostos na descrição de Evódio) que Agostinho faz preceder ao postulado central de seu início responsivo, reclama de imediato sua

\footnotetext{
${ }^{249}$ Aug. Num aliam putas esse sapientiam nisi uieritatem in qua cernitur et tenetur summum bonum? Nam ille omnes, quos commemorasti diuersa sectantes, bonum adpetunt et malum fugiunt; sed propterea diuersa sectantur quod aliud alii uidentur bonum.
} 
notação: o summum bonum, cuja contemplação e posse são desejadas por todo ser humano, é a instância onde se dá e se presentifica a verdade, por sua vez feita (identificada à) sapiência vital. O alcance da identificação procedida por Agostinho dificilmente poderia ser exagerado ou supervalorizado: a verdade (que já aparecera como o âmbito da certificação e ratificação da numeralidade, na intervenção de Evódio a respeito - vide II, viii, 20) constitui o âmbito de manifestação da relação do ser humano com o que o realiza, numa palavra: o ponto de convergência da absolutidade e eternidade junto ao transitório e temporal, precisamente na sapiência vital do ser humano. Na verdade enquanto sapiência, a culminância da ascensão cognitiva da realidade se encontra não somente em sua dinâmica de concreção e feitura intelectual da realidade, mas também, e maximamente, em sua convergência como atitude de empenho vital para o início e finalização da realização pessoal, vale dizer: Bem supremo. A identificação entre Bem supremo, verdade e sabedoria certamente já está dada, até mesmo esclarecida, mas ainda não é o passo para se explicitá-la em todas as suas nuanças e alcance. Mais adiante haverá a ocasião para tais desenvolvimentos e explanações. Detenhamo-nos ainda no postulado central de Agostinho, voltando-nos para sua importância enquanto início da intervenção (que, por sua vez, se revelará como autêntica sumarização do percurso disputado com Evódio).

A imediata identificação entre sabedoria e verdade é seguida pela atitude propiciatória para a vivência da felicidade, deixando em evidência o pano-de-fundo eudaimonista assumido por Agostinho, como o fundamento ético para o desenvolvimento ora apresentado no diálogo, justificado aqui precisamente pela visão universal do agir humano que lhe é intrínseca, e apresentando-se sobremaneira adequado ao seu intento de evidenciar a universalidade da vivência ética da humanidade, vertida na busca da felicidade enquanto atitude primordial do ser humano, sendo mesmo a expressão maior da condição humana em sua necessidade de busca e desejo ${ }^{250}$. A sequência dos três aspectos envolvidos demanda maior atenção. Primeiramente, Agostinho faz ver que a verdade, longe de se constituir e/ou se encerrar numa disputa infindável entre debatedores, tornando-se como que inalcançável e motivo de contradições várias - o próprio quadro, afinal, delineado por Evódio - vem a ser, não o objeto próprio de cada um dos que a buscam, mas a própria atitude de busca que se dispõe a alcançála - preeminência/excelência da ratio, e na justa medida em que é identificada à sabedoria com

\footnotetext{
${ }^{250}$ Com vistas à caracterização do eudaimonismo fundamental da filosofia agostiniana, sobretudo em sua ética e moral, mas também nas categorizações metafísicas, vide COSTA, M. R. N. Introdução ao pensamento éticopolítico de Santo Agostinho, São Paulo: Loyola, 2009 [notadamente, para nosso estudo, o capítulo 1 - $O$ eudaimonismo antropológico de Santo Agostinho, p. 19-50 (sobretudo 20-26)]. Cf. ainda BRACHTENDORF, 2008: 14-15.
} 
que todo ser humano se empenha em sua concretização e realização. Verdade é a sapiência com que se a busca, na medida em que sabe como e onde buscá-la. Este primeiro aspecto diz respeito, pois, à sapiência enquanto atitude de disposição e empenho vital - a preeminência mesma da ratio, em sua excelência da realidade conhecida, pela qual intelecciona a realidade, culminando o percurso de intelecção na posse do que se vislumbrou ao início. O segundo aspecto se relaciona ao como buscar a verdade: esta não é gozada ou usufruída ao modo de um bem transitório, ou mesmo de algo que, prestado seu serviço e esgotada sua finalidade, termina por ser descartado, numa palavra: não se procura a verdade como se procura um bem cuja posse se dê pelos sentidos corporais. Antes, a verdade presentifica-se a ser intuída e discernida, ou mesmo contemplada, para que se possa saboreá-la e vivenciá-la como tal, requerendo, pois, não um aprendizado ou uma ciência cuja verdade esteja atrelada e condicionada pela fugacidade de seu objeto, tal como a agricultura ou a estratégia de milícias, ou ainda o negócio. Antes, a verdade se presentifica pela contemplação proporcionada pela altivez e excelência da ratio, cuja visão e captação do todo ao um tempo único, a faz notar e se faz notar (o conspicere da intervenção anterior), presentifica ao mesmo tempo que se presentifica, culmina em excelência o que enseja em preeminência. Com a observação já aludida do passo anterior, afigura-se-nos perfeitamente legítima a equivalência, neste ponto preciso, entre a verdade conspicitur à luz intelectual da ratio (II, viii, 23)], e a sabedoria cernitur na própria verdade, atentando-se, evidente e cautelosamente, para as respectivas preponderâncias (ou acentos semânticos) quanto às possíveis matizações contemplativa (conspicere) e volitiva (cernere) presentes na equivalência intentada, ambas perfazendo traços essenciais da sapiência enquanto empenho vital para a posse do Bem supremo, objetivo máximo da vida feliz, como veremos no passo seguinte. Por fim, o terceiro aspecto remete à finalidade a que se propõe a atitude sapiencial, qual seja: a conquista do Bem supremo enquanto realização própria para a qual tende, e na qual se consuma todo o empenho vital assumido pela sabedoria, via ratio e (nesta própria) à luz intelectual que feitura o próprio caminho até a posse e gozo final, do que contemplara e propusera no início.

Voltemo-nos, mais detidamente, para este momento de posse aqui pontuado por Agostinho. Ao descrevê-lo como um tenere, Agostinho certamente intenta bem mais que uma caracterização do momento culminante e consumador da vivência da verdade, em termos unicamente de posse ou obtenção pura e simples de algo do qual me assenhoreei como proprietário (o que, de resto, remeteria à vivência dos sentidos corporais). Se é inegável a presença de tal matização, o acento parece-nos, outrossim, na conjunção entre as acepções relativas a manter-se firme, bem como a mover-se rumo a algo, ou caminhar no rumo de, visto 
que a posse do summum bonum sinaliza, em sentido forte, para uma atitude de empenho vital na entrega plena a algo que me possui, o qual sempre busquei, para o qual sempre tendi e caminhei, ao qual me agarro por inteiro e no qual me mantenho firme e permanentemente. A inflexão decorrente de tais acepções, em sua conjunção, além de preservar a explicitude do aspecto volitivo inerente (e essente) ao empenho vital vivenciado na sapiência da verdade, ressoa - na medida mesma desta preservação - todo o escopo desenvolvido por Agostinho até o momento, atinente ao exercício da ratio em suas funções essenciais de juízo e moderação, às quais nos dedicamos anteriormente; e, à vista do passo atual da disputatio, igualmente resulta na definição axial do ato racional como deliberação conducente da atitude sapiencial, vivida na verdade e voltada para o Bem enquanto sua realização (vida feliz).

A continuidade do passo agostiniano, neste momento da disputa, ilustra em sentido confirmatório nossa tentativa acima:

\begin{abstract}
Ag. Erra, pois, qualquer que desejou o que não deveria desejar, se bem que não o desejaria caso não lhe parecesse bem. Antes, é impossível errar aquele que nada deseja, ou aquele que desejou o que deveria desejar. Assim, na medida em que todos os homens desejam a vida feliz, não erram. Ao contrário, aquele que, mesmo declarando e proclamando que não deseja outra coisa senão a vida feliz, erra na medida em que não se mantém no caminho que conduz à felicidade. De fato, o erro está em seguirmos outro caminho, que não leva para onde queremos chegar. [...] Logo, tal como se constata que todos nós queremos ser felizes, também se constata que queremos ser sábios, já que ninguém sem sabedoria é feliz, posto que ninguém tem a felicidade sem ter o sumo bem, o qual está nesta verdade que, pela contemplação e tenacidade com que se a tem, a chamamos de sabedoria. [II, ix, 26 grifos nossos] $]^{251}$.
\end{abstract}

O aspecto volitivo envolvido na busca do summum bonum é então explicitado na justificativa fornecida por Agostinho para os erros (os quais, por implícito, fazem entender a diversidade e a contradição dos múltiplos tipos de sabedoria listados por Evódio) cometidos por muitos que, partindo da busca do bem supremo vivenciada por todo ser humano, desviamse por caminhos que, em realidade, terminam por afastá-los da meta universal humana. Porém, a explicitação agostiniana é sintetizada numa sentença composta em adágio ou máxima: assim como ninguém deseja o erro, assim também ninguém erra sem desejo. A sentença proverbial reflete, assim o entendemos, ponto axial em torno a partir do qual Agostinho estabelece desenvolvimento fundamental a respeito da relação identitária entre desejo (appetitus), sabedoria (sapientia) e felicidade (beatitudo). Com efeito, a vida feliz consiste em ser sábio,

\footnotetext{
251 Aug. In quantum igitur omnes homines adpetunt uitam beatam, non errant; in quantum autem quisque non eam tenet uitae uiam quae ducit ad beatitudinem, cum se fateatur et profiteatur nolle nisi ad beatitudinem peruenire, in tantm errat. Error est enim cum sequitur aliquid quod non ad id ducit quo uolumus peruenire. [...] Ut ergo constat nos beatos esse uelle, ita nos constat esse uelle sapientes, quia nemo sine sapientia beatus est. Nemo enim beatus est nisi summo bono, quo in ea ueritate quam sapientiam vuocamus cernitur et tenetur.
} 
conquanto se esteja disposto a tanto. Entretanto, a possibilidade de erro advém, não no disporse ao caminho, mas na falta de disposição a nele se manter. Por seu turno, a tenência/tenacidade com que se mantém na dinâmica do caminho, advém precisamente da deliberação, via contemplação (conspicere/cernere) na - e pela - ratio em sua lux mentis, em prosseguir no caminho iluminado. Configura-se assim, a um só tempo, uma primeira sumarização de Agostinho, neste passo do texto, com vistas à definição da verdade enquanto sumo Bem (vale dizer: enquanto a exposição probatória da divindade): o dispor-se ao caminho é precisamente a primordialidade onde a razão e a vontade convergem na atitude sapiencial, enquanto verdade essencial, de busca pela felicidade, cuja realização se dá justamente enquanto manutenção da disposição em agarrar-se (e manter-se com tenacidade/em tenência) ao (e no) caminho correto. Somente há erro, sapiencialmente falando, em não dispor-se a caminhar, o que, dada a convergência entre sabedoria e felicidade, equivale a indispor-se ante o caminho da contemplação e discernimento (via lux mentis). O erro resulta, pois, de uma nãodisposição à racionalidade que ilumina o caminho.

\subsection{3) Notio impressa}

É certo que, tal como expostas até o momento, a síntese e a convergência agostinianas resultam, inescapavelmente, em argumentação circular: pela atitude sapiencial e pelo (feliz) desejo de felicidade, disponho-me ao caminho que me levará à sabedoria e à vida feliz. A circularidade repousa na presença da via ou caminho entre conhecer e saber acerca de algo, cujo desejo de tê-lo (portanto, já conhecido e sabido) me impulsiona e conduz para percorrer tal caminho. Porém, longe de tentar se livrar do círculo entre pressupostos, Agostinho não só o explicita, como trata de validá-lo enquanto sentido mesmo da atitude sapiencial, transpondo-o ao âmbito fundamental já amplamente abordado no curso da disputa (antecipação e preeminência racional):

Ag. Desse modo, assim como antes de sermos felizes possuímos impressa em nossa mente a noção de felicidade, visto ser por ela, com efeito, que sabemos com firmeza, sem nenhuma hesitação, afirmamos que queremos ser felizes; assim também, antes de sermos sábios, nós temos impressa em nossa mente a noção de sabedoria. [Idem] ${ }^{252}$.

Eis que o raciocínio circular evidencia-se como a atuação por excelência da mente, em sua dinâmica inteleccional da totalidade, na precisa medida em que mostra seu fundamento na atemporalidade atinente à instantaneidade da ratio, instaurativa e ensejante da processualidade temporal, ilustrando uma vez mais a estrutura atemporal e universalizante da racionalidade,

${ }^{252}$ Aug. Sicut ergo antequam beati simus mentibus tamen nostris impressa est notio beatitatis per han enim scimus fidenteque et sine ulla dubitatione dicimus beatos nos esse uelle, ita etiam priusquam sapientes simus, sapientiae notionem in mente habemus impressam, ... 
pela qual todo ato intelectivo, justamente enquanto primordialidade ensejante da ação de excelência e excedência das estratificações, discerne e contempla a finalidade a que se propõe conhecer. Nesse sentido, a circularidade perfaz, tal como ilustrado neste passo da disputatio, a solução agostiniana ${ }^{253}$ para o problema das relações entre a temporalidade/fugacidade da realidade sensível, em sua multiplicidade e transitoriedade, refletidas na intelecção processual e temporal da realidade estratificada ontologicamente; e a atemporalidade e imutabilidade da verdade, na qual repousa a sabedoria discernida primordialmente pela ratio, atitude fundamental pela qual a ratio se lança à busca da sabedoria mesma, identificada com o próprio Bem supremo, e cuja tenacidade em nele se manter, após tê-lo contemplado e discernido, constitui o próprio exercício de garantia de posse (tenere, tenência/tenacidade) da felicidade. A pressuposição circular manifesta-se como condição de antecipação e predeterminação da realidade conhecida, permitindo-me a visualização ou discernimento ensejante de seu percurso, ao mesmo tempo que possibilita lançar-me à sua percorrência ${ }^{254}$.

Porém, o que permite que a ratio, em sua circularidade estrutural, possa estar em condição de antecipação e predeterminação da realidade a ser conhecida? A resposta de Agostinho lança mão de uma conceituação cuja origem remete a um contexto essencialmente oposto àquele no qual intenta inserir e trabalhar seu desenvolvimento ${ }^{255}$ : a noção acerca de algo que ainda está para ser conhecido, mas que já se encontra, porém, impressa na mente humana. Tanto quanto salientar a origem atemporal da noção, presentificada à mente humana e relativa ao que se aspira conhecer, Agostinho intenta chamar a atenção para o modo como a noção se faz presente à racionalidade; e, sobretudo, para o caráter de delineamento da

253 Ressalte-se que, como se verifica ao longo do desenvolvimento de seu pensamento, a circularidade pressuposicional se estabelece como plataforma estrutural e alicerçante dos grandes eixos com os quais Agostiinho desenvolve seu pensamento, já nos diálogos, pelos textos fundamentais do período interemediário, até as grandes obras da maturidade. Tais pontos axiais incluem, além de conspicere/cernere que atentamos por ora, a confessio que é manifestada e realizada na entrega conducente e na atitude ouvinte à presença de Deus: confesso porque invoco; invoco porque creio - "Que eu vos procure, Senhor, invocando-vos; e que vos invoque, crendo em Vós [...] Senhor, invoca-vos a fé que me destes" [conf. I, 1; vide I, 5]; o cognoscere expresso, uma vez mais, em conf. X, I: "Que eu te conheça, ó conhecedor de mim, que eu te conheça, tal como sou conhecido por ti. Ó virtude da minha alma, entra nela e molda-a a ti, para que a tenhas e possuas sem mancha nem ruga". A circularidade se evidencia, em suma, como constituindo o liame perpassante de todo o pensamento metafísico e antropológico agostiniano.

${ }^{254}$ Acerca da circularidade essencial da alma, considerada no contexto amplo de sua origem divina (enquanto criada por Deus, mas também no escopo estritamente teológico da discussão a respeito de sua essência como imago Dei), a tese de Daniel Napier oferece-nos um exaustivo quadro referencial, bem como da abordagem maior da antropologia presente nos diálogos do período inicial, no qual situa "a alma circular" agostiniana como herdeira direta da formulação plotiniana da processão e retorno da alma ao uno, bem como da atemporalidade essencial das almas individuais, em razão de sua origem no Uno - NAPIER, D. A. From the Circular Soul to the Cracked Self: a genetic historiography of Augustine's anthropology from Cassiciacum to the Confessions, tese de doutorado, Universidade Livre de Amsterdam, 2010, p. 41-56.

255 Vide nossa remissão ao contexto estoico acerca da origem das noções e representações, sensíveis e imaginárias, na nota 32 , p. 28. Acerca do influxo estoico neste preciso contexto da produção agostiniana, vide NAPIER, D.A. From the Circular Soul to the Cracked Self..., op. cit., p. 98-100. 
identidade e da imagem que fundamenta a expressão permanente, via ato volitivo, da relação da mente com a realidade que lhe circunscreve. Num termo: a impressão é a identificação do ser humano enquanto ser no qual habita a suprema realidade. Nesse sentido, ela o torna mediante a volição deste em dispor-se à sua presença, bem como em caminhar para a sua presença máxima e plena - a sua expressão máxima. Vale notar, aqui, a observação de Paula Olliveira e Souza a respeito da conceituação de noção impressa agostiniana:

[...] o espírito humano depara-se com um grêmio de realidades irrefragável e
indissociável do seu ser, inerente à sua forma específica enquanto mens rationalis. Tal
recheio é constituído pelo conjunto das verdades eternas, iidentificadas pelo
Hiponense como notiones impressae. Estas, por seu turno, apresentam-se já, no
interior da mente, como o resultado de um esfor;o analítico, cujo alicerce é a
evidência inconcussa de verdades mais siimples, redutíveis aos elementos essenciais
do cogito humano, a saber, a certeza acerca da própria existência como vida
racional.- OLIVEIRA E SILVA, 2007: 260 .

Com efeito, a conceituação de noção impressa na mente permite a Agostinho preservar duas características que lhe são fundamentais à estratégia de delineamentos prefigurais, com a qual estrutura sua argumentação, tecida pelo fio contínuo com o qual alinhavou, inbrincados e ajustados entre si, tempo e eternidade, mudança e absolutidade: 1) Antecipação do saber. Ao postular a existência de um conhecimento enquanto noção, Agostinho faz ver que a incipiência pela qual se antecipa, no caráter de elemento primordial (ou de prefiguração nocional priusquam), porém explícita, da completude do saber, perfaz o ponto de partida e o próprio fundamento para qualquer atitude de busca da sabedoria, numa palavra: só o saber me move a saber, fazendo com que a sapiência vivida e obtida seja muito mais a relação entre o princípio do saber, delineado (noção) em minha própria identidade (mente), que me leva à consumação do saber (sabedoria), perfeitamente contemplada à luz mesma da minha mente (lux mentis). A instância na qual se delineia a sabedoria vem a ser a mesma que a ilumina e identifica. Na mente, impressão e iluminação se dão, conjuntamente, no saber que se dispõe a ser perfeito e consumado enquanto posse do bem superior. Nesse sentido, pode-se afirmar que a relação entre a noção e a consumação da sabedoria não ocorre em termos dialéticos, visto não haver espaço para um não-saber na concepção agostiniana do conhecimento humano, não cabendo um instante sequer para qualquer lapso de ausência, sem solução alguma em sua continuidade.

De fato, é impossível, em qualquer tempo, não saber. 2) Imutabilidade do saber. Ao caracterizá-la como impressão, Agostinho faz notar a inalterabilidade e a permanência da noção, à maneira de um traço delineado que, na condição de fundamento, não somente permanece seguro e inamovível, mas sustenta seu próprio relevo e expansão, quando de sua iluminação. 
A conceituação ora adotada permite ainda uma elucidação quanto à sua originariedade. Ao tomá-lo por notio impressa, Agostinho especifica que o saber incipiente e primordial da humanidade não perfaz uma realidade conceitual e/ou formal, à vista da qual são moldadas as demais realidades que lhe sucederão na ordem temporal do conhecimento, numa palavra: a notio distancia-se tanto mais de uma imago - um eidos - quanto mais próxima e correlata se verifica de uma notitia, de uma nota, o que nos sugere estar Agostinho equidistante tanto da tradição platônica, em sua postulação das formas enquanto arquetípicas na intelecção da realidade sensível; quanto das escolas estoicas, na sua definição da representação enquanto de origem sensível (embora o paralelo seja vislumbrado, aqui, quanto ao aspecto impressivo pelo qual ambas - notio agostiniana e phantasia estoica - se dão e se configuram na mente). Se permite se dispensar de discorrer acerca da origem do traço impresso do saber presente em nossa mente, prefigurativo da sabedoria a ser alcançada, é porque, talvez, Agostinho a tem por suposta, mesmo evidente: a noção impressa em nossa mente é justamente a própria verdade presente, imediata e perene, em nós mesmos, antecipando e predeterminando, a bem da verdade, toda sua dinâmica inteleccional, mostrando-se como a realidade suprema a ser alcançada, não para ser então conhecida, mas sim consumada e possuída. A notio impressa não se configura como uma implicitude que aguarda a iluminação para que seja explicitada; tampouco se poderia definí-la como latência ou potência, prestes a ser atualizada ou determinada. Ao contrário, ela é quem, pelo traço em relevo (notório e destacado), fortemente marcado na mente, predetermina e atualiza a presença da ratio no ato inteleccional pelo qual a realidade sensível e temporal é conhecida.

Mas Agostinho ainda tem algo a expor a respeito, e seu prosseguimento no passo dialogal nos permitirá maior esclarecimento acerca do matiz com que trabalha e reveste, finalizando-a, a conceituação fundamental à sua articulação argumentativa:

Ag. Logo, estamos agora de acordo sobre a natureza da sabedoria. Talvez as tuas palavras não puderam exprimir essa definição, mas se teu espírito não o tivesse percebido de algum modo, ignorarias totalmente que queres ser sábio, e que tens a obrigação de o querer. [II, ix, 27 Paulus $]^{256}$.

A um só tempo, Agostinho aponta para 1) a presença inalienável e explícita (em relevo, impressa) da noção de sabedoria, tal que Evódio não poderia não saber a respeito, embora não tenha podido expressá-las. A observação acerca da verbalização (diríamos: predicação), por evidente apresenta importância decisiva, na medida em que permite visualizarmos o entendimento de Agostinho acerca do conhecimento humano enquanto saber e empenho vitais:

\footnotetext{
${ }^{256}$ Aug. Quare si iam constat inter nos quae sit sapientia, quam fortasse uerbis explicare nos poteras nam si eam nullo modo animo cerneres, nullo modo scires et uelle te esse sapientem et uelle debere, ...
} 
não se trata de uma ciência, ou de um conceito, mas sim de uma vivência, cuja presença dispensa a processualidade e sucessividade de sua explicitação ou determinação conceitual, tornando irrelevante sua articulação verbal. Noutros termos, Agostinho entende o dispor-se ao saber como inerente a todo ser humano, quer consiga explicitar e verbalizar sua busca (comunicá-la), quer mantenha sua disposição fora das palavras ${ }^{257}$; 2) a percepção clara o suficiente para que Evódio saiba que tem de ser sábio, noutros termos: que se entregue a consumar o que tem por início em si; e 3) que igualmente o querer e o saber se fundam na correlação interna, diríamos: simultaneidade essencial característica do pensamento agostiniano, entre vontade e intelecção, ato volitivo e manifesto deliberativo. A finalização de Agostinho acerca da disposição do saber à posse da sabedoria, trazendo à tona o papel da vontade e do juízo deliberativo, além da livre-decisão, no escopo da intelecção humana, demanda que nos detenhamos na relação das três componentes entre si, como no âmbito maior das relações razão-vontade.

\section{3) Sapientia et uoluntas: aspectos volitivo e deliberativo do saber humano}

À luz de nossa exposição anterior quanto à verificação do estatuto dos atos judicativo e coordenativo na atuação da ratio; e ante a convergência operada no passo atual de nosso texto, insere-se o questionamento acerca do aspecto deliberativo, bem como do ato volitivo (e da vontade enquanto moto próprio anímico) no pensamento agostiniano. Por certo que uma exposição de fôlego acerca de tais aspectos, tanto histórica quanto ao estado atual dos estudos, ultrapassa de todo os limites de nossa pesquisa (o que, necessário fosse, haveria de se tomar por eixo o Livro I do De libero arbitrio). Atendo-nos ao âmbito estrito de nosso estudo, intentaremos, neste espaço, breves pontuações que nos permitam situar a articulação entre a sapiência e a vontade, neste momento preciso da discussão, com vistas à proximidade de sua sumarização na definição de verdade enquanto a realidade máxima e absoluta, identificando-se

\footnotetext{
${ }^{257}$ O paralelo elucidativo para com a fenomenologia de corte husserliano soa plausível e, mesmo, historicamente constatado na origem desta: ao iniciar suas Lições sobre a consciência íntima do tempo, Husserl toma por mote o questionamento acerca do tempo celebrizado por Agostinho em Confessiones XI, cuja inquirição aponta, no contexto das possibilidades oferecidas por uma tentativa de leitura fenomenológica do texto agostiniano, precisamente para a experiência antepredicativa da linguagem e da estrutura do conhecimento humano - cf. HUSSERL, E. Expérience et jugement, 4a. édition, Paris: P.U.F., 2011 (1939), p. 120-123; ID. Manuscrits de Bernau sur la conscience du temps (1917-1918), Grenoble: Éditons J.Millon, 2010. Vide ainda VON HERRMANN, F.-W. Begegnungen mit Augustinus in den Phänomenologien von Edmund Husserl, Max Scheler und Martin Heidegger in FISCHER, Norbert (dir.) Augustinus - Spuren und Spiegelungen seines Denken, Band 2: Von Descartes bis in die Gegenwart, Hamburg: Felix Meiner Verlag, 2009, p. 253-264; DEPRAZ, N. Saint Augustin et la méthode de la réduction in CARON, M. (dir.) Saint Augustin - Les Cahiers d'Histoire de la Philosophie, Paris: Éditions du Cerf, 2009, p. 551-571; FALQUE, E. Après la métaphysique? Le "poids de la vie" selon Augustin in DE LIBERA, A. (ed.) Après la métaphysique: Augustin?, op.cit., p. 115-119; ARRIEN, S.-J. L'inquiétude de la pensée: l'hermeneutique de la vie du jeune Heidegger (1919-1923), Paris: P.U.F., 2014, p. 292-316 ("Heidegger et Augustin: le soi en question").
} 
à divindade. Com efeito, o passo do diálogo em que ora nos detemos, evoca algumas das questões fundamentais relativas ao estatuto da uoluntas no quadro geral do conhecimento humano; sua relação estrita com a ratio; e seu papel na itinerância ascensional da realidade. $\mathrm{O}$ elenco de tais inquirições assumiu, historicamente, a forma do "tratado" sobre o livre-arbítrio enquanto instância autônoma no interior da psicologia e/ou antropologia agostinianas, muito embora a ênfase preponderante, ao longo do desenvolvimento do pensamento agostiniano, tenha recaído sobre as relações entre a livre vontade, o pecado e o problema do mal, as quais têm ensejado posições que se estabeleceram como referenciais, até mesmo para as pesquisas acerca da filosofia cristã em geral do período tardo-medieval, desenvolvendo-se os estudos, majoritariamente, no plano da apologética e da teodiceia, bem mais que nos terrenos epistemológico e ontológico (nos quais intentamos situar nossa pesquisa). Assim, em sua Introdução ao estudo de Santo Agostinho, Gilson esclarece que o livre-arbítrio se dá, na inquirição agostiniana, em decorrência de sua metafísica própria, vale dizer: da doutrina acerca do ser supremo, no caso o Deus criador cuja atuação perfaz suma providência aos humanos, desembocando evidentemente na questão da presença do mal:

\begin{abstract}
Se a palavra 'Deus' tem um sentido, só pode significar um ser perfeito, autor responsável de todas as coisas. Ora, dizer que há um mal no homem é admitir a imperfeição do universo. [...] O problema depende essencialmente da metafísica, pois a vontade humana é apenas um fragmento da ordem universal. Para resolvê-lo é preciso partir da consideração do ser. [GILSON, 2007: 271 - grifo nosso]
\end{abstract}

Se Deus, sendo o bem supremo, perfeito e imutável, nada poderia criar que contivesse algum traço de maldade, como explicar a presença do mal na criação ${ }^{258}$ A partir, pois, da teodiceia e da metafísica, a impostação da questão do mal seguirá o preciso contorno da sua caracterização como a possibilidade de não se escolher o bem supremo, ou seja, de não se decidir pelo caminho de Deus (de não se atingir e/ou realizar aquilo para o qual o telos essencial a toda criatura nos impele, devido a uma escolha livre em instância primordial e

\footnotetext{
258 Toda a articulação prévia à demonstração da existência de Deus, no livro II do De libero arbitrio, tem como pressuposta a discussão em torno da providência divina no curso da humanidade: “Ag. Por outro lado, se o homem carecesse do livre-arbítrio da vontade, como poderia existir esse bem, que consiste em manifestar a justiça, condenando os pecados e premiando as boas ações? [...] Ora, era preciso que a justiça estivesse presente no castigo e na recompensa, porque aí está um dos bens cuja fonte é Deus - Ev. Eu já admito que Deus nos concedeu a vontade livre. Mas não te parece, pergunto-te, que se ela nos foi dada para fazermos o bem, não deveria poder levar-nos a pecar." [lib. arb. II, i, 3-2,4]. Tentamos levar em conta, precisamente, a necessidade do esclarecimento da natureza epistemológica da livre vontade deliberativa, exposta no ínterim da demonstração em pauta, tal como intentamos por todo o curso de nossa pesquisa até o momento.
} 
incondicional). Tal exposição da doutrina agostiniana acerca do livre-arbítrio vem a ser, em realidade, o substrato a partir do qual vários estudos contemporâneos têm sido realizados ${ }^{259}$.

Por seu turno, Horn explicita, em sua apresentação esquemática a respeito [2002: 237244], que alguns autores têm considerado a ocorrência de duas fases na filosofia da vontade de Agostinho: a primeira fase corresponderia precisamente à dos diálogos do período inicial, nos quais Agostinho define a voluntas como sendo a tendência à realização essencial e feitura de determinado propósito ou ser ("tendência para a ação", no dizer de Horn, o que bem podemos entender, sentido último, pelo caráter teleológico de todo ato deliberativo humano, tal qual exposto no passo ora em questão de nossa disputatio), restando idêntica, nesta acepção, ao livre poder de decisão, ao qual nada condiciona ou determina, antes é exercido em total liberdade de decisão volitiva, ou seja, o querer é instaurado e havido de per-si, instanciado de forma plena $^{260}$, não sendo decorrente ou dedutível de causa alguma, sendo por isso um liberum arbitrium, uma escolha ou decisão livre em seu exercício pleno ${ }^{261}$. Numa palavra, e valendonos novamente da classificação de Horn, podemos definir a decisão volitiva nesta fase como poder dispor (dispositio) de livre decisão, no ato deliberativo expressivo de sua tendência almejante própria (uoluntas) ${ }^{262}$. Numa segunda etapa, já nas obras de maturidade, Agostinho passa a considerar a vontade como cativa e dividida, em decorrência sobretudo da queda original no pecado. A doutrina da livre vontade, ou poder de decisão livre, passa então a gravitar em torno da doutrina da graça, perante a qual a dimensão volitiva é restaurada e exercida em liberdade pelo ser humano, mediante a qual a voluntas almeja o bem, não de forma particularizada, mas sim na integralidade da destinação à eternidade. Dão mostras de tal

\footnotetext{
${ }^{259}$ Cf. OLIVEIRA E SILVA, 2007: 80-92 e 104-119; MARION, 2008: 222-260; BOUTON-TOUBOULIC, 2004 : 291-317; DOUCET, 2004: 129-135; NOVAES, 2007: 292-301; MICHON, 2009: 308-311; MADEC, 1990: 1134.

260 “Ora, ninguém pode viver com segurança no meio de bens que pode vir a perder contra a sua vontade. A verdade e a sabedoria ninguém as pode perder contra a própria vontade. Pois ninguém pode ficar separado delas por distâncias de lugar. O que se pode entender por ficar separado da verdade e da sabedoria será o amor dos bens inferiores. Aliás, ninguém quer alguma coisa sem de fato o querer. Logo, nós possuímos na verdade um bem do qual todos podemos gozar igualmente e em comum. Nesse gozo não existe estreiteza alguma, nem defeito nenhum. A Verdade acolhe todos aqueles que a amam, sem suscitar qualquer inveja." - lib. arb. II, xiv, 37.

261 "Ag.: Ainda que ele (o Ser supremo) tivesse esse poder, ele não forçaria a mente a submeter-se às paixões. Ev.: Não há ninguém que deixe de admitir essa afirmação, sem hesitação alguma. - Ag.: Logo, só me resta concluir: se, de um lado, tudo o que é igual ou superior à mente que exerce seu natural senhorio e acha-se dotada de virtude, não pode fazer dela escrava da paixão, por causa da justiça; por outro lado, tudo o que lhe é inferior tampouco o pode, por causa dessa mesma inferioridade, como demonstram as constatações precedentes. Portanto, não há nenhuma outra realidade que torne a mente cúmplice da paixão, a não ser a própria vontade e o livre-arbítrio." - lib. arb. I, xi, 21. Cf. BERMON, E. A teoria das paixões em santo Agostinho in BESNIER, B.; MOREAU, P-F.; e RENAULT, L. (orgs.) As paixões antigas e medievais, São Paulo: Loyola, 2008, p. 202206.

${ }^{262}$ HORN, 2002: 237-239.
} 
acepção os textos do livro VIII das Confessiones $^{263}$. A queda levou à divisão da voluntas, não mais unitária em sua tendência teleológica e deliberação de arbítrio, mas fraturada em seu exercício de livre querer ${ }^{264}$.

Ante tal quadro, e à luz de nossas tentativas expostas, podemos de modo esquemático afirmar que nesta primeira fase do pensamento agostiniano, especificamente no contexto próprio do De libero arbitrio, a teorização acerca da uoluntas, muito embora originada no contexto da disputa doutrinária em torno do alcance da responsabilidade humana face à providência divina (assumindo, ainda que secundariamente, certa herança grega das correntes do helenismo pós-aristotélico) $)^{265}$ - que, mais tarde, eclodirá no contexto da controvérsia pelagiana em torno da responsabilidade humana - está como que condicionada pelas inflexões ontológicas e antropológicas, situando-se no escopo de uma visão integral do ser humano face a realidade cósmica e divina. O liberum arbitrium recebe, assim, estatuto ontológico nessa primeira fase, o qual irá incidir sobre desenvolvimentos posteriores de Agostinho, doutrina da graça inclusa. É nessa acepção primeira, nesse desenvolvimento primordial e, por assim dizer, fundante de suas posteriores concepções, que intentamos localizar, ainda que à maneira de vislumbre, as possibilidades de uma leitura unitária da filosofia da vontade agostiniana, entendendo então o livre-arbítrio não essencialmente no pano-de-fundo apologético e/ou teológico - que será afinal a vertente de leitura preponderante no decorrer histórico do agostinianismo - mas, primeiramente e de modo perene, no escopo de sua elucidação acerca de uma teoria global nos em seus aspectos cosmológico e, sobretudo, epistemológico, levando em conta a exposição de nossa tentativa até o momento, acerca da ontologia e epistemologia, a qual, se se permite o molde neoplatônico da identidade essencial entre ambas, deste se distancia quando remonta o eixo ontológico e epistêmico ao ato volitivo fundante por excelência.

Em nossa apresentação da intelecção ascensional da realidade levada a efeito no livro II do De libero arbitrio, intentamos ilustrar que, nos traços epistemológicos presentes no texto, as

\footnotetext{
263 “Com efeito, não só o ir até ao céu, mas também o atingi-lo, não são mais que o querer ir, mas um querer forte e total, não uma vontade tíbia que anda e desanda daqui para ali, que lutra entre si, erguendo-se num lado e caindo no outro. [...] Fiz, portanto, muitos movimentos, quando o querer não era o mesmo que o poder. Não fiz o que incomparavelmente desejava muito mais, apesar de o poder fazer logo que quisesse, porque para o querer basta querer sinceramente." - conf. VIII, viii, 20.

${ }^{264}$ Horn trata mais detalhadamente da teoria da cisão da vontade em Agostinho, em seu ensaio Fraqueza da vontade e vontade cindida - A teoria agostiniana da ação em Confessiones VIII in HORN, 2008: 107-131 (para nosso estudo, especialmente 121-124).

265 “... [Agostinho] por um lado segue a Paulo, na medida em que assume um conflito fundamental entre a boa vontade existente e a sua realização. Por outro lado, ele segue aos neoplatônicos [... (ao ligar)] a noção de um princípio primeiro, absolutamente digno de afirmação (a saber, Deus), com uma teoria do desejo natural de todas as coisas de volta à sua origem divina." - HORN, C. Fraqueza da vontade e vontade cindida..., op.cit., p. 116-117.
} 
noções de direcionamento/feitura (moderare) e adjudicação/deliberação (iudicare) assumem o papel de atualização e de condução do movimento cognitivo, desde o ato instituinte proporcionado pelo dado sensível, até sua estatuição como juízo e norma. Anteriormente, no livro I, Agostinho apresentara o escopo teológico inicial acerca da vontade e do livre-arbítrio em relação ao mal, seu conhecimento e sua prática responsável. Tal escopo compõe o mote para a explicitação da função da ratio humana em sua ascensão espiritual/racional, como exposto no Livro II. Nesse sentido, podemos entender que o pano-de-fundo composto pela discussão acerca da responsabilidade da deliberação humana em relação ao mal, indica que a voluntas, no instante do liberum arbitrium, constitui a instância originária e ensejante do ato intelectual, e sua função não perfaz o ponto de chegada, ou mesmo um ato que possa ser instituído de forma autônoma, ou ainda situar-se acima da atualidade intelectual. Para uma melhor visualização de tal articulação entre os momentos, por assim dizer, fundantes da ascensão espiritual, em cuja primordialidade está situada a volição livre e decisiva do ato adjudicativo humano, voltemos ao movimento da ratio em sua feitura do real. Retomemos a linearidade axial do percurso: 1) das percepções sensíveis para 2) a intuição do sentido interior; e deste para 3) a certitude da razão, instância superior do ser humano. A especificação do itinerário parte do conhecimento da exterioridade fornecido pelos sentidos físicos ${ }^{266}$, e dirigese para o reconhecimento do sentido interior ${ }^{267}$, o qual se sobrepõe àqueles na medida mesma e no tempo mesmo - em que os supõe (simultaneidade fundamental, sobremaneira ressaltada em nossa tentativa). Do sentido interior, partilhado pelos seres vivos, avança-se à razão, presente tão-somente no ser humano e seu traço próprio e distintivo, a qual fundamenta, reconhece e ratifica todos os elementos de conhecimento adquiridos pelos sentidos físicos e interior $^{268}$. Finalmente, a ascensão do conhecimento atinge sua culminância ao reconhecer como única realidade superior à razão o ser do qual, além de eterno, imutável e verdadeiro ${ }^{269}$, provou-se nada existir que lhe seja superior ${ }^{270}$. No decorrer de nossa exposição, intentamos mostrar que, em cada nível do conhecimento em ascensão, o passo seguinte está em realidade suposto - e na verdade o contém e perfaz, fundamentando-o - no anterior, de maneira que a etapa ou passo posterior do conhecimento, necessária e permanentemente, ratifica e valida o

\footnotetext{
${ }^{266}$ lib. arb. II, iii, 8

${ }^{267}$ Idem, ibidem.

${ }^{268}$ Idem, II, iii,9.

269 "Não é também em conformidade com a verdade que emitimos juízos sobre a nossa própria mente, sem que ninguém possa proferir, de modo algum, juízos a respeito da verdade ela mesma? [...] a medida conforme a qual a mente humana deve compreender é a medida mesma com que consegue aplicar-se e unir-se à verdade imutável. Assim, pois, se a verdade não é nem inferior, nem igual a nossa mente, segue-se que ela só pode ser superior e mais excelente do que ela." - lib. arb. II, viii, 12.

${ }^{270}$ lib. arb. II, vi, 14.
} 
passo anterior, caracterizando a razão em suas funções de condução e perfazimento (moderare) e instituição/instauração (iudicare) da eternidade/verdade na realidade sensível/temporal. Nesse sentido, a condução e o juízo são dispostas e instituídas na anterioridade imediatizada e explicitada do ato cognitivo: a veracidade de qualquer conhecimento é atestado em seu início e em realidade lhe fundamenta o ato ou movimento de conhecer - conquanto expressa o desejo e a vontade - presentificar-se da verdade - de instituição do eterno e absoluto, efetuando-se pela disposição em alcançar a sapiência, cuja instância localiza-se na verdade eterna e imutável. $^{271}$

\subsection{1) Vontade e juízo deliberativo}

Como demonstrado quando da abordagem dos sentidos da visão e audição, e igualmente pela exposição acerca da sapiência, assim como não se reconhece uma composição musical senão em seu caráter composto e (per)feito, no sentido de perfazida em sua totalidade, assim o conhecimento humano em si mesmo: somente se dá a partir de sua configuração em totalidade $^{272}$. O movimento de condução/moderação da razão finaliza o dado conhecido, no sentido que lhe revela o escopo teleológico que o ordena à eternidade, à totalidade, à imutabilidade e ao absoluto, que em realidade o fundamentam. Precisamente aqui convergem, dentro do que intitulamos, por vezes, como simultaneidade essencial à racionalidade humana, as funcionalidades respectivas ao ato deliberativo e à predisposição da volição, enquanto fundamento ao julgamento e à ação, ou seja: a fundamentação da epistemologia e da ética repousam, instância última, na simultaneidade essencial ao espírito, entre desejar o que devo desejar, querer o que devo querer, dirigir-me ao meu telos. A função judicativa (julgar ou deliberar) da razão atua face à excelência com a qual a iluminação interior/intelectual reveste o dado conhecido, cuja ascensão permite vivenciar a deliberação cognitiva enquanto querer a realização cuja finalidade lhe é evidenciada, em primeira instância, pela lux mentis, sendo vivenciada volitivamente, na ratificação efetuada passo-a-passo, no próprio perfazimento do saber rumo à culminância e à consumação em Deus ${ }^{273}$. Em certo sentido, pode-se qualificar todo ato de fé e de conhecimento como volitivo, na medida em que a confiança e a cognição compõem, respectivamente, expressões do desejo e de abertura do espírito à busca de sabedoria, o que pode ser exemplificado, por analogia, no exercício do ato amoroso enquanto

\footnotetext{
271 "Para Agostinho, [...] a percepção é sempre uma síntese de forma inteligível e experiência sensível que pressupõe um ato de vontade individual. [...] é também possivel reconhecer, no ato de vontade que constitui as percepções a cada instante, uma figura ou uma imitação do ato divino que constitui o mundo a partir da eternidade."- MAMMİ, L. STILLAE TEMPORIS - Interpretação de uma passagem das Confissões, XI, 2 , op.cit., p. 61.

${ }^{272}$ Cf. ord. I, ii, 4.

${ }^{273}$ Vide an. quant. xxxv, 79; lib. arb. II, xvii, 45; imm. an. viii, 14. Cf. GILSON, 2007: 47 e 49.
} 
componente de ambas as disposições da alma ${ }^{274}$. Relembremos a asseveração de James Wetzel: “Aberto é o que um desejo finito por sabedoria infinita tem de ser" [WETZEL, 2011: 90-91]. E se por Deus se toma o que é vislumbrado como aquilo que unicamente supera a razão, e pensado como infinito e imutável, então o ser que é pensado é dado e se manifesta, em verdade, à luz da realidade captada e apreendida no movimento de condução e adjudicação, simultâneo ao querer e desejar que fundamentam a interioridade do conhecimento, a culminar nesse mesmo ser, percebido e "ratificado" (adjudicado) volitivamente. O juízo predicativo, ontológica e verdadeiramente, é a clarificação das percepções judicativas, na resultante da disposição e empenho do desejo vital pela verdade, instância do eterno e absoluto $^{275}$.

Assim, a deliberação da vontade humana em realizar-se desejando se alçar ao summum bonum, através da feitura cognitiva da realidade, e portanto contemplar e realizar o querer aquilo para o qual foi o ser humano criado (vontade almejante), termina por elucidar a natureza do ato volitivo; o qual compõe, essencialmente, simul ao ato adjucativo, posto que ambos convergem na realização teleológica da humanidade, conhecida através da ascensão cognitiva, na qual se antecipa de maneira volitiva, direcionada e adjudicativamente, o telos desejado (porque conhecido) e inteleccionado (porque almejado). Tal elucidação revela a ascensão da alma humana, em termos intelectuais, menos como subordinação impositiva de um saber que se supõe superior - e portanto dominaria os extratos inferiores ou camadas subordinadas, e consequentemente quem nesses níveis estivesse - e muito mais como a composição de um saber que se dispõe e, sobretudo, deseja/almeja a sabedoria enquanto bem supremo. Numa palavra: a ação, levada a efeito a partir da livre deliberação, concretiza a dispositio fundamental e primordial do meu querer a finalidade que minha ratio modera e adjudica ${ }^{276}$. Na

\footnotetext{
274 “L'amour ne constitue pas une volonté comme les autres, seulement spécifiée par un objectif et une modalité particuliers, mais la seule valentior voluntas, la seule volonté vraiment forte, en fait la seule volonté pouvant vouloir effectivement ce qu'elle sait devoir vouloir" [MARION, 2008: 251].

${ }^{275}$ Giovanni Casertano alude, em artigo acerca da noção de verdade nos diálogos platônicos tardios tradicionalmente vista como ancorada, de modo restrito e excludente, no aspecto racional, ao que se costuma associar igualmente a herança agostiniana de tal tradição - à presença, nesta, das acepções referentes ao logos e ao pathos, fazendo com que a racionalidade e a afetividade componham, ambas, o poder de convencimento da palavra que se estabelece como verdadeira - CASERTANO, G. A verdade platônica entre lógica e páthos in Anais de Filosofia Clássica, Volume 02, número 04, 2008, p. 1-18.; cf. ainda ID. Paradigmas da verdade em Platão, São Paulo: Loyola, 2010.

276 "Num primeiro momento, Agostinho apresenta o livre-arbítrio ou a vontade livre, como a faculdade que o espírito possui de se determinar a agir, lançar-se a viver, [...] A razão não se posiciona em oposição à vontade, como a parte teórica da alma, dado que ela própria é uma potência ativa, conhecedora. [...] A vontade é a faculdade de fazer prevalecer um desejo [superior] sobre outro [inferior], por um consentimento que vem a ser, por sua vez, aversão elou conversão em relação ao bem desejado. [...] Nesse sentido, Agostinho afirma que nossa liberdade consiste em 'nos submetermos à esta Verdade perdida pela vontade pervertida (De libero arbítrio II, 13,27)." - MICHON, C. Le libre arbitre in CARON, M. (dir.) Saint Augustin - Les Cahiers d'Histoire de la Philosophie, Paris: Éditions du Cerf, 2009, p. 309.
} 
ética deliberativa agostiniana, volição e ratificação virtualmente convergem, a partir de seu simul originário e fundante $\mathrm{e}^{277}$.

\title{
4.4) Sabedoria e universalidade
}

A continuidade do diálogo parece voltar dois passos atrás, quando da inquirição a Evódio sobre a sabedoria humana. Porém, Agostinho retoma a questão municiando-a com as devidas asseverações/observações e pontuações advindas do que foi discutido acerca da verdade numérica, bem como sobre a própria multiplicidade dos que se dizem sábios:

\begin{abstract}
Ag. Pois bem. Quero que me digas se julgas que a sabedoria, assim como as razões e as verdades dos números, se oferece como uma coisa comum a todos os que usufruem da razão; ou, pelo contrário, assim como há tantas inteligências humanas quanto homens, de modo que eu não vejo nada da tua inteligência, nem tu da minha - assim também pensas que há tantas sabedorias, quantos sábios possam haver.

Ev. Se o sumo bem é único para todos, é necessário que igualmente o seja a verdade, na qual aquele é percebido e possuído, ou seja, que a sabedoria seja única, e comum a todos.

Ag. Acaso tens dúvida de que o sumo bem, seja qual for, é único para todos?

Ev. Sim, eu tenho dúvidas. Vejo que alguns homens se comprazem em algumas coisas, outros se alegram em outras, como se fosse o bem supremo. [II, ix, 27 $B A C]^{278}$.
\end{abstract}

Notamos que Evódio parece repor a dúvida que manifestara acerca da definição da sabedoria, voltada desta vez para a natureza do sumo bem: a contraditoriedade verificada entre os que professam, em sua multiplicidade, possuírem e usufruírem do sumo bem. Entretanto, num primeiro momento, ele respondera afirmativamente à repropositura da questão acerca da sabedoria, em que Agostinho traça um paralelo entre esta e a racionalidade numérica, especificando porém que sua inquirição, desta vez, está voltada para a possibilidade de se concluir pela universalidade da sabedoria, não mais com base em sua definição ou natureza

\footnotetext{
277 "Para conhecer o conteúdo [do De libero arbitrio] convém aludir à estrutura do espírito, concebida como um regnum mentis, um reino no qual a sabedoria tem seu direito de governo, ainda que, de fato, nem sempre o consiga. Sua lei fundamental é a da ordem [...] A lei eterna, como voz da sabedoria de Deus, proclama esta lei por todo o reino, para que o homem viva sempre na ordem. Neste reino há um castelo [... (arx)], com ius proprium imperiumque, com seu direito próprio e seu império, cujo controle está nas mãos da mens rationalis et sapiens, a mente racional e sábia, que é a excelência e o aspecto superior do homem, ao qual tudo deve submeterse: o poderoso deve dirigir o débil, o forte deve dirigir o fraco, a virtude deve dirigir as afeições ou paixões, que hão de seguir os ditames da mente racional ou da boa vontade, pela qual apetecemos viver reta e honestamente, $e$ atingir a sabedoria." - CAPÁNAGA, V. Introducción in El libre albedrío, op.cit., p. 197 (grifo nosso). Vide ainda o artigo de Olivier BOULNOIS Augustin, la faiblesse et la volonté in DE LIBERA, A (ed.) Après la métaphysique: Augustin?, Paris: 2013, p. 51-77 (especificamente, acerca da "ética e metafísica da vontade", as p. 53-59)

${ }^{278}$ Aug. Volo iam dicas mihi utrum etiam sapientiam sicut numeri rationem et ueritatem omnibus ratiocinantibus communem se praebere arbitreris, an, quoniam tot sunt mentes hominus quot homines sunt, unde nec ego de tua mente aliquid cerno nec tu de mea, tot etiam putes esse sapientias quot potuerunt esse sapientes. - Ev. Si summum bonum omnibus unum est, oporte etiam ueritatem in qua cernitur et tenetur, id est sapientiam, omnibus unam esse communem. - Aug. Dubitas autem summum bonum, quicquid illud est, omnibus hominibus unum esse? - Ev. Dubito sane, quod diuersos diuersis rebus gaudere uideo tamquam summis bonis suis.
} 
própria, mas através da verificação da sua autodisponibilidade à todos quantos a observam e se identificam a ela, e dela partilham a presença (omnibus ratiocinantibus communem se praebere arbitreris); bem como ainda no tocante à sua incomunicabilidade entre os homens, na hipótese contrária (nec ego de tua mente aliquid cerno nec tu de mea). Cumpre notar que Agostinho, uma vez mais, toma a termo a antecipação com que a sapiência se oferece aos homens, valendo-se novamente de verbalização ancorada em predisposição ativa (praebere), pela qual se reafirma a iniciativa e atividade próprias da racionalidade e da sabedoria, frente à receptividade humana em seu uso da razão e volição. É a sabedoria que se presentifica e se oferece ao ser humano, cabendo-lhe saber que a deve observar (arbitrare), desejar e, finalmente, buscá-la e possuí-la. Ressalta-se que, na concepção agostiniana, a verdade racional nunca se presta a ser tão-somente observada de forma indiferente, mas sua predisposição (ou mesmo: sua anteposição) e presença evocam uma tomada de posição por parte do ser humano, que sabe dever querê-la. Ante a preeminência e excelência da verdade e da sabedoria, a razão e a vontade do homem dão-se, ao mesmo tempo, em impulso rumo à sua conquista e consumação.

Agostinho termina sua inquirição aludindo à eventual possibilidade de que a sabedoria, uma vez múltipla, igualmente não se preste a ser unanimente vivenciada pelos homens, o que faz surgir um novo elemento na discussão: a comunicabilidade da verdade como verificação de sua universalidade. Se as sabedorias são múltiplas, igualmente o são suas percepções e vivências por parte dos homens, de maneira que uma dada sabedoria é percebida e discernida unicamente pelo que dela tem posse, o que leva à inevitável conclusão de que as sabedorias são múltiplas, na mesma medida em que o são os respectivos discernimentos a respeito. Mas Evódio, habilmente, faz ver a Agostinho que sua dúvida não reside propriamente na univocidade e universalidade da sabedoria, posto que esta já fora definida no decorrer do diálogo como una, via racionalidade numérica. Sua dúvida - que consiste, a bem ver, num esmiuçamento da anterior que postulara a Agostinho - reside exatamente lá onde se localiza - e para onde tudo conflui - o objeto final da conduta e empenho humanos: o bem supremo. Sua resposta a Agostinho não se inicia pela sabedoria, mas sim pelo acento da dúvida acerca da unicidade do sumo bem (“ $\underline{\mathrm{S} i}$ summum bonum omnibus unum est...."), para então, e em decorrência do estabelecido nos passos anteriores, afirmar que a verdade e a sabedoria igualmente ostentam unicidade, somente na hipótese afirmativa quanto ao sumo bem. A questão, em suma, reside em saber se a natureza do sumo bem é una, tal qual a sabedoria e verdade que a ele conduzem, de modo a se poder obter, na afirmação de um, a validade e, ainda mais, a própria postulação dos outros: uma vez definido o que seja o bem supremo, sua 
unicidade e universalidade, de imediato presentificam-se a verdade e sabedoria que the são inerentes, e a ele conduzem. Nesse sentido, a convergência de fundo entre sumo bem, verdade e sabedoria permitem-nos afirmá-la como plano de sustentação e estrutura fundamental da simultaneidade essencial à intelecção humana, observada e acentuada nos passos anteriores, dado que na dinâmica do contemplar e buscar, do conhecer e agir (respectivamente, os domínios epistemológico e ético), a par da ascensionalidade cognitiva da realidade (e nela inscrita), significam, no interior do pensamento agostiniano, virtualmente uma só disposição de espírito, simultaneamente dada em dois aspectos, diversos mas convergentes entre si.

Agostinho prontifica-se ao desafio da resposta a Evódio, reconhecendo que sua dúvida, pelo fato de residir, instância última, na convergência de fundo entre as três realidades então discutidas (bem supremo - verdade - sabedoria), demanda longa e completa recapitulação, em esforço de sumarização:

Ag. [...] Esta é uma questão importante e exigirá, talvez, uma ampla exposição argumentativa. Suponhamos que haja tantos bens supremos, quantas são as distintas coisas que os vários homens desejam como bens supremos. Seguir-se-á, pois, que a sabedoria não seja única, comum a todos, pelo fato de que também são muitas e diversas as coisas que nela vemos? [...] Bem, são muitas e diversas as coisas que os homens veem à luz do sol, e as escolhem para se deleitar, e sem dúvida a luz do sol é única [...] Do mesmo modo, são muitos e diversos os bens, entre os quais cada um escolhe o que lhe agrada, e em vê-los e possuí-los para usufrur é que consiste, real e verdadeiramente para ele, o sumo bem, e, apesar disso, pode ocorrer que a luz mesma da sabedoria, mediante a qual estas coisas podem ser vistas e possuídas, seja única e comum a todos os sábios.

Ev. Reconheço que assim possa ser, e nada há que impeça que uma mesma sabedoria seja comum a todos, ainda que sejam muitos e diversos os bens supremos. Mas desejaria saber se de fato é assim, porque saber que isso possa ser assim, não significa aceitar já que o seja. [Idem - BAC adaptada] $]^{279}$

Agostinho traz à baila novamente a analogia da luz, para evocar o caráter unívoco da sabedoria, aplicando o raciocínio analógico à posse e usufruto do bem supremo: ao deleite da iluminação, pelo sol, da multiplicidade à sua volta, os homens permitem-se escolher dentre os vários objetos vistos, aqueles mediante os quais haverão de se satisfazer em sua posse e usufruto, não se seguindo, porém, que a multiplicidade de escolha invalide a unicidade da vista e da luz que a permite. Por seu turno, Evódio concede a possibilidade de validar o conteúdo da analogia à posse e usufruto do bem supremo, porém não mais que isso, sendo então a sua vez

\footnotetext{
${ }^{279}$ Aug. [...] quoniam magna quaestio est et longum sermonem forte desiderat, putemos omnino tot summa bona esse quot sunt ipae res diuersae quae a diuersis tamquam summa bona adpentuntur. Num ideo sequitur ut etiam ipsa sapientia non sit uma communis omnibus, quia ea bona quae in illa cernunt, et eligunt homines multa et diuersa sunt? [...] Sicut ergo ista multa et diuersa sunt quae in luce solis homines uident et eligunt ad freundum, lux tamen ipsa una, [...] etiam si multa sunt bona eaque diuersa, e quibus eligat quisque quod uolet idque uidendo et tenendo ad fruendum summum sibi bonum recte uereque constituat, fieri tamen potest ut lux ipsa sapientiae, in qua haec uideri et teneri possunt, omnibus sapientibus sit uma communis. - Ev. Fateor fieri possse nec inpedire aliquid ut non sit omnibus communis una sapientia, etiam si multa et diuersa sint summa bona. Sed uellem scire an ita sit. Quod enim concedimus fieri posse tu ita sit, non contnuo ita esse concedimus.
} 
de lançar à disputatio um outro adágio: da possibilidade de ser, não se segue que há o ser (“Quod enim concedimus fieri posse ut ita sit, non continuo ita esse concedimus.").

$\mathrm{Na}$ realidade, a funcionalidade do adágio evodiano se presta, neste passo dialogal, à repropor novamente uma suspensão de juízo, quanto à possibilidade de se constatar a existência de algo essencialmente pressuposto e concluído por analogia (como, antes, o fora pela auctoritas): ainda que se reconheça e se admita a possibilidade de sua existência, qualquer ser, para ser reconhecido como existente, não deve permanecer na mera possibilidade, mas deve-se buscar saber de sua existência para além de sua mera possibilidade ("Sed vellem scire an ita sit."). Numa palavra: a dúvida evodiana, aqui reproposta novamente em forma de suspensão do juízo cognitivo, evoca novamente a necessidade da certeza do ser. Tanto que, no imediato passo de finalização da sessão argumentativa, Agostinho faz notar de pronto, com sagacidade, esta primeira demanda, por assim dizer, inerente à dúvida evodiana, para então assim o veremos - iniciar nova estratégia argumentativa a partir justamente deste primeiro elemento: "Entrementes, sabemos que existe a sabedoria, mas não se ela é única e comum a todos, ou se tem cada sábio a sua sabedoria, como cada um tem sua alma e sua mente." [Idem $]^{280}$. Novamente, Agostinho lança como pedra fundamental uma espécie de certeza provisória interna à lógica da explicitação (interim), tratando de se assegurar do consentimento e certeza igualmente provisória de Evódio (Ita est).

Ato contínuo, Agostinho lança-se a trazer à atenção de Evódio a evidência de uma certeza dada e manifesta:

\footnotetext{
Ag. Agora bem: de onde obtemos o que já sabemos, ou seja: que existe a sabedoria, que existem sábios, e que todos os homens desejam ser felizes? Porque eu não me atreveria a por em dúvida que tu o vê, e que é verdadeiro. Tu vê essa verdade, tal como vê o teu pensamento - que eu ignoro por completo enquanto não mo comunica - ou a vê de modo que entenda que eu também posso vê-la, ainda que não me digas nada a respeito?

Ev. Certamente que a vejo. Eu não duvido que também é vista por ti, até mesmo contra minha vontade

Ag. Por conseguinte, a verdade que ambos vemos como sendo uma somente, e cada um com sua própria mente, acaso não é comum a ambos?

Ev. Manifestamente que sim. [II, $\mathbf{x}, \mathbf{2 8}]^{281}$.
}

\footnotetext{
${ }^{280}$ Aug. Tenemus interim esse sapientiam; sed utrum sit communis uma omnibus an singuli sapientes suas habeant sicut animas uel mentes suas, hoc nondum tenemus.

281 Aug. Quid? Hoc quod tenemus uel esse sapientiam uel sapientes et beatos esse omnes homines uelle, ubi uidemus? Nam hoc te uidere et verum esse nullo modo utique dubitaverim. Hoc ergo uerum sic uides ut cogitationem tuam, quam si mihi non enunties, ego prorsus ignoro? an ita, ut intellegas et a me uideri posse hoc uerum, tametsi mihi abs te non dicatur? - Ev. Immo ut abs te quoque, etiam me invito, uideri posse non dubitem. - Aug. Quod ergo unum verum uidemus ambo singulis mentibus, nonne utrique nostrum commune est? - Ev. Manifestissime.
} 
Tal como o fora a primeira certeza em sua imediatez e evidência, por ocasião da primeira suspensão judicativa de Evódio, assim Agostinho faz soar a certeza de fundamentação deste final de percurso rumo à demonstração da existência da realidade eterna e absoluta. Ele inicia por sinalizar para a certeza primeira, fundamental enquanto evidência manifesta, da existência das certezas deduzidas no interior da discussão até aquele instante: tanto quanto tem a certeza do que pensa em si mesmo, Evódio tem certeza da existência da sabedoria, de homens sábios, e do desejo unânime entre os homens de atingir a felicidade. Trata-se, ainda que de modo indireto, de aludir à preeminência ostentada pelo existir no interior da tríade esseuiuere-intelligere com que Agostinho iniciara sua exposição comprobatória até aqui, e que atuara como a certeza primordial por ocasião da incerteza total de Evódio. Igualmente, o passo argumentativo agostiniano parte da certeza evidentemente manifesta do ser, tal que possa ser visto (“... ubi uidemos? [...] uideri posse non dubitem”), acentuando-se, como por ocasião da certeza primordial, sua imediaticidade através da analogia com a visão. Porém, se quando da primeira certeza pós-suspensão judicativa, Agostinho fizera Evódio concluir pela impossibilidade da dúvida quanto à sua própria existência, desta vez o conduz para a manifesta certeza, não somente da existência de algo visto por ambos, mas da univocidade e/ou comunitariedade da visão (vista igualmente por diferentes). Se a primeira certeza postulava-se como imediatamente correlata ao intellegere individual, a certeza atual posta-se como correlacionada, em sua identidade própria e em sua univocidade, às intelecções comuns a várias pessoas. A primeira certeza era voltada para a verdade do ser, ao passo que a segunda se volta para a universalidade da certeza. O que está em jogo agora, não mais diz respeito a se encontrar algo que se tenha na conta de certeza indiscutível, mas sim em estabelecer que esta (certeza indubitável, e portanto, a verdade) seja única e a mesma, na percepção de várias mentes. Se se buscou, antes, obter a existência da certeza indubitável (sendo que a existência mesma é esta própria certeza), agora procura-se obter a universalidade da certeza (sendo que a comunitariedade se configura como o critério para sua obtenção).

Detenhamo-nos na articulação nuclear da argumentação agostiniana: há uma verdade, vista como una por ambos os receptores/perceptores de sua presença (unum uerum uidemus ambo singulis mentibus), e como tal, é comum a ambos (nonne utrique nostrum commune est). Cabe inquirir a razão pela qual se evidencia sua dedução de universalidade a partir de sua comunitariedade, noutros termos: a percepção em comum de uma mesma verdade pode fundamentar sua postulação como unívoca, tal que se possa tê-la como universal? Seguramente, esta razão não incide tão-somente sobre a univocidade própria da coisa percebida, pois ambos os receptores poderiam ter visões divergentes a respeito. De igual modo, 
não reside tão-somente na univocidade própria da visão percebida, pois da mesma forma poderia haver ilusão e erro quanto a se ver algo diferente do que realmente é, ainda que dois ou mais receptores estejam enganados da mesma forma quanto a suas percepções. Resta que a evidência da universalidade de uma verdade comunitariamente percebida, repousa conjuntamente na visão ou olhar comum dos perceptores, acerca de uma visão dada a ambos de um modo único. Observe-se que ambos os elementos, ainda que ostentando unicidade própria, não asseguram a validação de universalidade à verdade vista, ou seja, não somente a verdade (ainda que unívoca), tampouco somente a visão (ainda que unívoca), respondem de per si pelo estabelecimento da universalidade do juízo efetuado, mas sim a comunitariedade da visão em sua totalidade, tal que se torne bem comum, comunidade, pública. É pois a visão comum, em sua totalidade e unicidade, que evidencia como universal uma verdade vista pela totalidade de vários como sendo única. A continuidade da exposição agostiniana parece-nos sinalizar neste sentido:

Ag. Igualmente não negarás, que devemos nos dedicar à sabedoria, e me concederás que também isto é uma verdade.

Ev. Não tenho dúvida alguma a respeito.

Ag. Ademais, podemos negar que esta verdade é única e comum à visão de todos os que a conhecem, não obstante cada qual vê-la, não com a tua mente, nem com a minha, nem com nenhuma outra, senão com a sua própria, posto que o objeto que se vê está igualmente à disposição da visão de todos os que a olham?

Ev. De modo algum. [Idem $-B A C]^{282}$.

Agostinho retoma os postulados que firmara por ocasião das exposições acerca da verdade numérica, da sabedoria, e do desejo de todos pela felicidade, numa espécie de inquirição sumária e sintética de todo o exposto até o momento: a busca em comum da sabedoria é uma verdade concordemente (Agostiinho extrai, para tanto, o concedere prévio de Evódio) reconhecida, tal que se estabeleça como postulado axiomático: a verdade existe enquanto única e comum (unum esse [...] esse commune). Este ponto axial - em cujos termos Agostinho faz condensar todas as acepções e alusões em relação à possibilidade de se vislumbrar o eterno e o absoluto a partir das noções de totalidade/imutabilidade, bem como de simultaneidade - como que se auto-estabelece na comunitariedade de sua vivência: a verdade é universal, enquanto única em si, e comum a todos que a contemplam e discernem em sua presentificação; bem como na doação (preponência) de si à tal percepção (id quod conspicitur omnibus conspicientibus communiter praesto si). Com efeito, a partir dos exemplos elencados por Agostinho, é possível perceber que a universalidade de uma verdade, em sua unicidade e

\footnotetext{
${ }^{282}$ Aug. - Item credo te non negare studendum esse sapientiae atque hoc uerum esse concedere. - Ev. Prorsus non dubito. - Aug. Hoc item uerum et unun esse et omnibus qui hoc sciunt ad uidendum esse commune, quamuis ununs quisque id nec mea nec tua nec cuiusquem alterius, sed sua mente conspiciat, com id quod conspicitur omnibus conspicientibus communiter preasto sit, numquid negare potetimus? - Ev. Nullo modo.
} 
imutabilidade, advém justamente neste tornar-se bem comum a todos, na medida em que todos a ela se voltam:

\begin{abstract}
Ag. Não concederás também, como sendo uma das maiores verdades, que deve se considerar como correto que as coisas inferiores estejam submetidas às superiores, que as iguais devam estar no mesmo plano que suas iguais, e que a cada um deva ser dado [sua medida proporcional], e que esta verdade é comum tanto a mim, como a ti, bem como a todos os que a veem?

Ev. Concordo. [II, $\mathbf{x}, \mathbf{2 8} B A C$ adaptada $]^{283}$
\end{abstract}

A chamada de Agostinho às verdades comumente aceitas soa, a um primeiro contato com sua apresentação, como um apelo ao senso comum partilhado pelos que se dispõem à busca da sabedoria, enquanto bem supremo da felicidade. De fato, como notamos no início, Agostinho conclama à comunitariedade da vivência acerca do verdadeiro e justo, como aspecto confirmatório e ilustrativo da universalidade da verdade, e bem poderíamos ratificá-la como uma legitimação de um senso comum, não fosse sua cautela em assegurar que, a par de se tornar bem comum, e no tempo mesmo em que se torna tal, a verdade é percebida, contemplada e discernida, tanto a um quanto a outro, enquanto tais, ou seja: não há um senso comum impondo-se ao assentimento e intelecção individuais, ao contrário: a verdade se presta ao discernimento e contemplação, tanto de um quanto de outro, e em comum a todos (tam mihi quam tibi atque omnibus id uidentibus praesto esse communiter), evidenciando-se como bem público em sua vivência comum a todos, não se impondo sem a percepção, mas ratificada pelo discernimento de cada um; o qual, sendo o mesmo em todos, fundamenta saber de todos, noutros termos: bem público, comum, universal.

Após lançar vários exemplos análogos ao utilizado neste passo - todos submetidos à concórdia e assentimento de Evódio - Agostinho permite-se então, finalmente, a conclusão quanto à universalidade da verdade, una e comum, universal e imutável, por todos percebida enquanto tal:

Ag. Já não me perguntarei mais sobre este ponto, pois basta que tenhas já visto e admitido comigo, como certíssimo, que tais verdades existem à maneira de normas e luzes das virtudes, e que são verdadeiras e imutáveis, prestando-se em sua totalidade, ou cada uma em si, a serem contempladas em comum indistintamente por todos os que são capazes de contemplá-las, cada um com sua própria razão e inteligência. [...] E o que tens a dizer sobre aquele que vive de modo justo? Poderia viver com justiça se não tivesse visto quais são as coisas inferiores, as quais deve subordinar às superiores; quais são as iguais, entre si unidas; e quais são as que se deva dar a cada um como suas próprias [proporcionais]?

Ev. Não poderia.

Ag. [...] Portanto, é manifesto e evidente que todas aquelas coisas que intitulamos como normas e luzes pertencem à sabedoria, posto que é certo que quanto mais

\footnotetext{
${ }^{283}$ Aug. Item iuste esse uidendum, deteriora melioribus esse subdenda et paria paribus comparanda et própria suis quibusque tribuenda nonne fateberis esse uerissimun et tam mihi quam tibi atque omnibus id uidentibus praesto esse communiter? - Ev. Adsentior.
} 
alguém ajusta sua vida a elas, vivendo segundo as mesmas, tanto mais sabiamente vive e age, de modo que todo o que age sabiamente, não pode dizer-se, razoavelmente, que esteja alheio à sabedoria. [II, x, $29 B A C]^{284}$.

A sumarização de Agostinho ressoa todos os postulados acerca da ratio e da sapiência, com os quais entabulara o diálogo e conduzira Evódio até a admissão de sua universalidade, para, com admirável coerência aplicativa no tocante às conotações éticas e epistemológicas, preparar a validação final da verdade, em sua universalidade e imutabilidade, como a realidade superior, identificando-se-a coma aquela acerca da qual nada de superior poderá ser pensado. Notemos que o sumário conclusivo reitera, aplicando-a ao homem que age racionalmente em sua atitude sábia de desejar e buscar o bem supremo, todas as características com que a ratio atua, disponibiliza-se e ilumina a conduta humana, enquanto sua realidade superior: 1) a visão antecipatória da realidade adjudicada, em sua totalidade, a cada passo de sua estruturação interna (“... nisi uident quae inferiora quibus potioribus subdat et quae paria sibimet copulet...”); 2) a simultaneidade de sua percepção, quer como uma totalidade, quer de modo isolado relativo a cada uma das leis e normas, pelo que se depreende que a percepção de uma equivale à percepção do todo (“...siue singula siue omnia communiter adesse ad contemplandum..."); 3) a confluência entre os aspectos volitivo e intelectivo no agir humano, na busca do bem supremo enquanto felicidade, perfazendo-se ambos na perspectiva eudaimonística da ética agostiniana.

Porém, o aspecto mais importante da sumarização procedida reside, seguramente, nas duas sentenças proverbiais com as quais Agostinho respectivamente inicia e conclui o passo de recapitulação e síntese da discussão percorrida (e preparando-a para sua conclusão final): as verdades estabelecidas compõem a medida e a luz do agir sábio e virtuoso (“... istas tamquam regulas et quaedam lumina uirtutum...”), de modo que toda ação sábia é, necessariamente, feita à luz da verdade imutável e comum a todos (“... onme autem quod sapienter fit non potest recte dici a sapientia esse separatum.”), clarificando-se pois que, independentemente da concórdia quanto à intelecção de seu alcance ou objeto; ou de sua explicitação em palavras; ou mesmo quanto ao se reconhecer como tal, a sabedoria se evidencia menos pelo discurso explícito, e mais pela ação que a esclarece como presente em toda atitude humana que a deseja e a

\footnotetext{
${ }^{284}$ Aug. Iam huius modi plura non quaeram. Satis est enim quod istas tamquam regulas et quaedam lumina virtutum et uera et incommutabilia et siue singula siue omnia communiter adesse ad contemplandum eis qui haec ualent sua quisque ratione ac mente conspicere, pariter mecum uides certissimunque esse concedis. [...] Quid? Ille qui iuste uiuit, possetne ita uiuere nisi uidente quae inferiora quibus potioribus subdat et quae paria sibimet copulet et quae propira suis quibusque distribuat? - Ev. Non posset. [...] Aug. Manifestissimum est igitur omnes has quas regulas diximus et lumina uirtutum ad sapientiam pertinere, quandoquidem quanto magis quisque ad agendam uitam eis utitur et secundum haec agi tuitam, tanto magis uiuit facitque sapienter; omne autem quod sapienter fit non potest recte dici a sapientia esse separatum.
} 
persegue, ainda que disso não se dê conta. A posse e vivência da sabedoria - e, portanto, do bem supremo, a ela identificado - independem, assim, de sua explicitação e concordância na totalidade dos homens (contemplando, portanto, a dificuldade reiteradamente colocada por Evódio ao apresentar os quadros de multiplicidades contraditórias de "ação sábia"), pois é justamente em seu todo que a humanidade manifesta, a par de cada atitude virtuosa e sábia, sua vivência comum da busca pela felicidade via sapiência, numa palavra: a sabedoria é bem comum e público a todos, visto todos a quererem e agirem segundo ela.

\title{
4.5) Sabedoria e imutabilidade
}

Agostinho ainda encontrou espaço, na finalização do sumário com que encerrara a sessão anterior, para aludir à comparação entre a imutabilidade das verdades numéricas, e a da sabedoria em sua vivência comunitária e ética, lembrando a Evódio que todas elas - verdades e leis matemáticas e sapienciais - foram submetidas à sua apreciação (II, x, 29). Mas a propensão à integração já manifestada por Evódio em outros passos do diálogo, leva-o novamente a trazer à disputa uma questão, que bem poderia se intitular como "de/pela ordem" (ou categorial):

\begin{abstract}
Ev. Não posso ter dúvidas a respeito [de todo o exposto na sumarização agostiniana]. Mas desejaria saber ao certo se ambas as coisas, a sabedoria e o número, pertencem a um mesmo gênero [...] ou se uma procede da outra, ou se existe na outra, como por exemplo: se o número procede da sabedoria, ou existe na sabedoria. [...]

Ag. Fazes menção de um fato que também a mim, chama muito a atenção. Quando considero em mim mesmo a verdade imutável dos números [...] sinto-me transposto para bem longe do corpóreo. [...] O mesmo me ocorre quando também penso na sabedoria, com a maior atenção e intensidade que me é possível. [...] Porém, é indubitável que são uma só e mesma coisa [...] Pelo fato de julgarmos, com muita facilidade, os corpos como coisas que estão ordenadas em uma categoria inferior à nossa, e porque vemos igualmente, neste grau inferior a nós, os números aos quais estão [os corpos] sujeitos, então os consideramos [números] como de menor valor que a sabedoria. Mas quando começamos a olhar para as alturas, deparamo-nos igualmente com eles, os números, os quais transcendem nosso espírito e permanecem imutáveis na mesma verdade. [II, xi, 30-31 $B A C]^{285}$.
\end{abstract}

Se consente que a exposição agostiniana foi de tal modo pertinente, mesmo irrefutável, de modo que não lhe restou sequer a possibilidade da dúvida, nem por isso Evódio se sente impedido de fazer notar a Agostinho que a analogia central com que fundamenta sua

${ }^{285}$ Ev. Dubitare non possum. Sed peruellem scire utrum uno aliquo genere contineantur haec duo, sapientia scillicet et numerus, [...] an alterum existat ab altero aut alterum in altero consistat ueluti numerous a sapientia uel in sapientia. [...] Aug. Rem dicis quam ego quoque mirari soleo. Nam cum incommutabilem ueritatem numerorum mecum ipse considero [...] longe removeor a corpore. [...] Hoc mihi accidit etiam cum de sapientia, quantum ualeo, uigilantissime atque intentissime cogito. [...] Sed nimirum illud est, quod uma quaedam ea demque res est. [...] itaque quoniam de corporibus facile iudicamus tamquam de rebus quae infra nos ordinatae sunt, quibus inpressos numeros cernimus, putamus etiam ipsos numeros infra nos esse et eos propterea uilius habemus. Sed cum coeperimus tamquam sursum uersus recurrere, inuenimus eos etiam nostras mentes transcendere atque incommutabiles in ipsa manere veritate. 
argumentação pode, ao menos em tese, abrir flanco ao questionamento quanto à pertinência de seu uso nesta investigação, ou ainda, levar à se inquirir se a passagem de um "tipo" de saber, ou razão, a outro permite que se aplique a ambos a mesma base argumentativa, os mesmos raciocínios, de modo a tratá-los por igual, ou tê-los na conta de um único gênero de saber; ou seja, se sua ordenação ou, mais propriamente, sua categorização tem por base o mesmo saber originário, comum a ambos (genere), de maneira a permitir que o raciocínio analógico ostente validade e sustentação. Evódio observa que, comumente - ou seja, justamente no âmbito de verificação da universalidade da busca pela sabedoria - há muitos matemáticos e pessoas que trabalham bem com os números, ao mesmo tempo em que se conhece bem poucos sábios, o que indica a preciosidade maior da sabedoria frente à numeralidade, fato cuja analogia de base presente na argumentação de Agostinho, ao incluí-las no âmbito único da racionalidade amparada em leis verdadeiras e imutáveis, torna incompreensível. De fato, aos olhos de Evódio, a habilidade e o "manejo" com os números são muito mais comuns que o uso e prática da sabedoria, o que torna esta última especial, digna de maior honraria bem mais que a numeralidade.

Porém, justamente nas observações "de campo", com as quais Evódio justifica sua inquirição acerca da relação entre os "tipos" de saberes em pauta, esconde-se um aspecto que, mais uma vez, não passará desapercebido a Agostinho: trata-se da identificação entre acessibilidade (ou facilidade) e comunitariedade, fazendo com que o fato da numerabilidade se verificar como de fácil utilização por um grande número de pessoas (de modo a se tomá-la por um bem comum a todos) pareça, aos olhos de Evódio, contradizer a defesa agostiniana da comunitariedade como o aspecto ratificador da universalidade da sabedoria, ao modo como Agostinho estabelecera no passo anterior. Com efeito, se a verdade se apresenta universalmente a todos que se dispõem à sua presentificação via racionalidade; e se toda ação sábia evidencia a presença da sabedoria; e se, afinal, suas regras e normas são, a exemplo dos números, verdadeiras e imutáveis, por que, no fim das contas, a numeralidade é vulgarizada, ao passo que a sabedoria é rara, a ponto de merecer até mesmo a veneração? Noutros termos: se a sabedoria é tornada bem comum, enquanto universal, porque a comunidade não a vive e pratica como tal?

Precisamente a identificação entre acessibilidade e comunitariedade, ou, termos amplos, entre o vulgar e o comunitário, possibilita a Agostinho expor, no responso, característica que se evidenciará como essencial, por ocasião de sua finalização da argumentação probatória da verdade enquanto realidade suprema (II, xii): a presencialidade permeante, ou inerência, da ratio em toda a estratificação gradual da realidade, ante a qual, em qualquer ponto que venha a 
se situar, ou ainda para qualquer direção que se volte, o homem a tenha à sua disposição, em sua presentificação da verdade imutável e una, na preeminência e excelência com que antecipa toda a dinâmica inteleccional da realidade, fazendo com que a atitude sábia - mesmo por parte de homens que, não obstante ainda não terem alcançado a sabedoria, estão em sua busca (mesmo nas diversas acepções ilustradas pelas descrições de Evódio) - se faça sempre acompanhar da sabedoria já presente e, em realidade, fundamentando-a. Ao iniciar o responso pela identificação de ambas quanto à sublimidade e elevação a que conduzem, face à realidade sensível e corporal, Agostinho intenta manter em evidência o ponto pacífico e indiscutível (posto que já estabelecido nos passos anteriores), relativo à natureza incorpórea de ambos os tipos de saberes, com o que evidencia uma primeira identificação cujo alcance, para além da incorporeidade (e em sua decorrência), envolve o enlevo espiritual por elas proporcionado, com o que se tem uma primeira mostra da congenitalidade da sabedoria e dos números.

Mas a resposta agostiniana se concentrará, a par mesmo da incorporeidade ressaltada em seu início, no fato de que ambas se evidenciam como uma única sabedoria precisamente por partilharem da antecipação e excelência da ratio, na contemplação e no discernimento pelos quais, a partir da percepção do todo em sua imutabilidade, os homens atingem a sabedoria, de que tanto a numeralidade, quanto a atitude sábia e/ou sapiência, evidenciam-se como exemplos notórios e comuns. Sobretudo, a numeralidade, ao perpassar toda a realidade conhecida (corporal e interior), permite que se a tome por presença da totalidade imutável na própria multiplicidade em mudança, disponibilizando a sabedoria a todos os que se lançam a buscá-la (enquanto bem comum) para a conquista da felicidade (tomando-a, pois, pelo bem supremo), fazendo com que todos tenham a ela acesso e, até mesmo, a facilidade de sua presença à disposição, em praticamente todas as situações ou ocorrências. Se, por lapso, negligenciarmos os números enquanto expressão da sabedoria verdadeira e imutável (posto que permeante até mesmo das realidades mais ínfimas), basta que, à luz da contemplação e do discernimento proporcionados pela atitude sábia de buscar a sabedoria e, portanto, voltar-se à totalidade antecipadora presentificada pela ratio, voltemo-nos para a sublimidade de sua imutabilidade e totalidade, vale dizer: para o alto, onde a própria norma e regra da numeralidade brilha e ilumina, pela verdade de que é expressão, nossas mentes em seu exercício intelectivo, nas quais habita a verdade maior, e cuja presença e relação para com nossa intelecção constituirá o próximo passo, finalizador e consumador, do itinerário probatório com o qual Agostinho propusera demontrar a existência de realidade superior à mente, e acerca da qual nada de superior pode ser pensado. 


\section{6) Ascendência e transcendência}

Outrossim, a presença permanente da numeralidade, por toda a realidade conhecida, aponta para a imutabilidade que lhe é inerente, a qual, presentificando-se à intelecção do todo real, possibilita aos seres humanos contemplarem, neles próprios, a verdade imutável e una, experienciada na sabedoria e no uso dos números, pelos quais são ascensionados por equiparação a estes. Porém, a descrição que nos é oferecida por Agostinho acerca do modo como a verdade, a partir da numeralidade, vem a ser contemplada e discernida em sua imutabilidade e unicidade, impõe-nos maior detimento quanto à relação que se estabelece, por imediato, entre a disponibilidade e autopresentificação da verdade a nós, no tempo mesmo em que, transportando-nos a ela, ultrapassa-nos enquanto primordialidade, numa palavra: revelase, a um só tempo, como pretérita, presente e futura realidade máxima; bem como, no tempo mesmo em que perpassa toda a realidade conhecida, e ainda como presente em nossa própria percepção, mostra-se como estando (desde sempre) um passo além do nosso, a cada passo mesmo que consigamos dar em sua direção, ou seja: ela será sempre o passo ulterior ao nosso, ainda que tenhamos atingido nosso passo máximo. Ela nos ultrapassa desde sempre.

A imagem traçada por Agostinho parece-nos próxima de uma sincronização (tentamonos, aqui e uma vez mais: simultaneidade), apoiada em duas verbalizações sugestivas e/ou tomadas a partir da espacialidade temporal: no tempo, ou instante mesmo (imediaticidade ou atemporalidade com que a ratio se prepõe, em preeminência e excelência, a toda a realidade, aqui via numeralidade perpassante) que principia a voltar-se para empreender sua ascendência, a intelecção se vê (desde sempre, ou atemporalmente) ante a transcendência que lhe é imediatizada - e à qual é transposta - pelos números, numa palavra: pela própria sabedoria que lhe move, em sua atitude sábia, a consumar-se nela, e enfim, nela superar-se e transcender-se (configurada, portanto, uma vez mais a circularidade a que aludimos duas seções atrás). Talvez possamos traçar a proporcionalidade direta, em simul, entre o ato volitivo principial de querer ver o supremo, atitude primordial pela qual nos lançamos ao empreendimento da trajetória de ascensão (“...coeperimus tamquam sursum versus recurrere,...”), e a imediata presença com que nos deparamos dos números, no ultrapasso permanente em relação ao nosso passo inteleccional/ascencional (“..., invenimus eos etiam nostras mentes transcendere...”), numa palavra: para cada passo da ascendência (ou, se quisermos retomar o fio contínuo perposto no início da exposição: excedência/excelência), haverá o imediato ultrapasso da transcendência (que, em verdade, arbitra e conduz o passo anterior da ascendência, revelando-se afinal o próprio fundamento do iudicare et moderare com que a ratio enseja e perfaz o itinerário ascensional). O passo-em-ascendência atua, pois, em sincronia com o ultrapasso-em- 
transcendência, no tempo único de sua ocorrência e de modo diretamente proporcional, na visão imediatizada pela atitude sábia e primordial, que deseja e se alça à busca da sabedoria. Se, ao permearem toda a realidade que nos é inferior, mostram-se estarem à nossa disposição, os números imediatamente se mostram acima de nossas mentes, quando a eles nos voltamos como tais, depurados da inferioridade com que se encontram imiscuídos no interim da realidade sensível e corporal, estando não em trânsito de ascensão (tal como está a mente humana), mas na sua ultrapassagem já posta, não ascensionada, mas sim transcendida. A transcendência dos números, enquanto fundados na verdade, é unicamente percebida pelo espírito que, em ascendência, percebe-a na própria inerência e permanência na realidade material até a espiritual; e, enquanto termo de culminância da trajetória da mens em sua intelecção da realidade, constitui-se no telos cuja presença, para além do próprio itinerário, permite que a intelecção em ascendência possa contemplá-la e discerní-la como a realidade que permanentemente a ultrapassa e finaliza, mesmo que esteja permeando o trânsito e transposição da sensibilidade corpórea para a interior, e desta para a ratio, instância que lhe toca e culmina. Com efeito, há uma ascendência intelectual que transita pelas estratificações da realidade como um todo, tão-somente por haver uma transcendência que lhe fornece o empuxo, meio e o fim mesmo do itinerário. Em simul, somente no tempo mesmo em que se pode verificar a dinâmica de excelência intragradual com que a ratio enseja toda a ascensionalidade, é que se pode conceber (concernir, discernir e contemplar) haver uma realidade que, análoga à superioridade com que cada passo termina por realizar e suceder ao anterior, é estabelecida como aquela da qual nada se possa pensar como excendendo-a ou superando-a, pois ela mesma é quem deu o sentido de superação de todos os graus até aqui percorridos e perfazidos em sua intelecção pela ratio em exercício.

A asseveração com que Agostinho finaliza o passo último antes de culminar a exposição probatória da verdade imutável como a realidade excelente e transcendente - divina, portanto - ilustra-nos sobremaneira, pela espacialidade inerente à comparação, o papel fundante da atitude sábia da busca da sabedoria, como o bem supremo (e, portanto, da vida feliz), enquanto ato decisivo e volitivo:

Ag. Do mesmo modo como no fogo percebe-se a luz e o calor, que são por assim dizer consubstanciais, sem poderem ser separados um do outro, contudo, o calor atinge somente os objetos que se colocam perto dele. A luz, entretanto, difunde-se também nos lugares mais distantes e espaçados. De igual maneira, o poder da inteligência, inerente à sabedoria, inflama com seu calor os seres mais próximos a ela, como são as almas racionais. Quanto aos seres mais afastados, como os corpos, esses 
não são tão atingidos pelo calor da sabedoria, também se inundados pela luz dos números. [II, xi, 32 Paulus] $]^{286}$

Ao condicionar, via ilustração, a "conquista" da sabedoria à atitude de se posicionar em sua proximidade, Agostinho clarifica a capital funcionalidade desempenhada pelo ato primordial de se lançar à sua busca, explicitando que a receptividade decorrente dispõe as almas movidas pela ratio ao poder da inteligência, própria da sabedoria, fazendo-nos ver que, para se atingi-la, o aproximar-se, vale dizer: o querer voltar-se a ela e dispondo-se a principiar (coepere) o caminho de sua percorrência ascensional até atingi-la, constitui o princípio de sua posse e conquista. Nesse sentido, Agostinho pode ressaltar que, não obstante a proximidade imediata da numeralidade estar à vista e à disposição de todos, em todas as estratificações e níveis da realidade - sensível, interior e racional - o inverso, lamentavelmente, não se permite ocorrer: nem todos se postam à disposição da imutabilidade e veracidade ostentada pela numeralidade, através da qual imediatiza-se, à todos quantos assim o queiram ver e buscar, a sabedoria eterna e imutável: "[...]; finalmente, se é possível ver uma mesma realidade sob nome duplo, o que é evidente, de qualquer maneira, é que [a sabedoria, como o número], é verdadeira e imutavelmente verdadeira." [Idem $]^{287}$.

\section{7) Verdade: una, imutável, superior, excelsa e eterna}

Agostinho finaliza, pois, sua exposição probatória ao tornar remissiva a verdade, todas as decorrências dos postulados que estabelecera passo-a-passo com Evódio, com a evidente inclusão de definições e conceituações relativas que, na realidade, já efetuara em relação à própria verdade. Assim, após estabelecer a fundamental congruência entre verdade - sabedoria - bem supremo - felicidade, na qual conflui todo o construto ontológico agostiniano à sua ética eudaimonística de base, Agostinho inicia pelas características que, ao longo da exposição, postulara como alusivas à eternidade e absolutidade, por sua vez atributos "daquele a quem nada de superior pode ser pensado":

Ag. Em consequência, não poderás negar que existe a verdade imutável, a qual contém em si todas as coisas que são imutavelmente verdadeiras [...];

que, de modo maravilhoso, como uma luz secreta e pública ao mesmo tempo, se prontifica e se oferece, por igual, a todos os que são capazes de ver as verdades imutáveis; [...]

Essa verdade, de que há muito tempo estamos a discorrer, e na qual, sendo una, vemos tantas coisas, pensas ser mais excelente que nossa mente, igual ou inferior? Se fosse inferior, não julgaríamos segundo ela, mas sim a julgaríamos, como julgamos os

\footnotetext{
${ }^{286}$ Sed quem ad modum in uno igne consubstantialis, ut ita dicam, sentitur fulgor et calor nec separati ab inuicem possunt, calor tamen ad ea peruenit quae prope admouentur, fulgor uero etiam longius latiusque difunditur, sic intellegentiae potentia quae inest sapientiae proprinquiora feruescunt, sicuti sunt animae rationales, ea uero quae remotiora sunt sicuti corpora non adtingit calore apeindi, sed perfundit lumine numerorum.

287 "an utrumque nomen unius rei possit ostendi, illud certe manifestum est utrumque ueruim esse et incommutabiliter uerum."
} 
corpos, que são inferiores à razão, e acerca dos quais dizemos, frequentemente, não somente que são ou não tal e qual modo, senão que deveriam ser ou não de outra maneira. O mesmo seja dito a respeito de nossa alma, pois não somente reconhecermos ser nossa alma de tal maneira, mas muitas vezes dizemos também que deveria ser de outra maneira. [...]

E julgamos acerca destas realidades, segundo aquelas normas interiores de verdade que nos são comuns, sem que, a seu respeito, jamais venhamos a emitir juízo algum. Nesse sentido, quando alguém diz que as coisas eternas são superiores às temporais, ou que sete e três são dez, ninguém afirma que assim deve ser, ao contrário: limitando-se a constatar que de fato é assim, não se arvora a corrigir como um censor, mas sim alegra-se unicamente como um descobridor. [II, xii, 33-34 $B A C]^{288}$.

A anteprévia finalização com que Agostinho asseverara acerca da imutabilidade da sabedoria e dos números, através da analogia da luz e do calor, permitiu-lhe passar para o passo conclusivo das decorrências estabelecidas nas realidades demonstradas pelos exemplos. Assim, se a indiscutível certeza acerca da verdade imutável relativa à numeralidade (II, viii, 20-22), mostra-se congênita à da sabedoria com a qual todas as pessoas julgam as realidades (II, x, 28-29); ambas, por seu turno, comuns a todos os seres humanos, cuja busca pela felicidade consubstanciada num bem comum - sabedoria - igualmente perfaz a condição humana em si (II, ix, 27), torna-se, pois, imperioso concluir pela existência da verdade imutável e uma, presentificando-se em toda certeza indiscutivelmente verdadeira e imutável, que nela está contida (incommutabilem veritatem, haec omnia quae incommutabiliter vera sunt continentem). $\mathrm{O}$ traço de herança platônica assume, como vimos no decorrer da exposição agostiniana, não somente a realidade inteligível que fundamenta e conforma as contingências mutáveis à sua imutabilidade, porém ostenta presentificação própria ("praesto sit", em suas variações ao longo da peça probatória) pela qual dispõe-se igualmente a todos os que se dispõem, ato volitivo primordialmente ensejado, a contemplá-la e discerni-la, à luz de sua própria presença impressa - presença imediata - e notada intelectualmente pelos homens. Retenhamos que o passo conclusivo ora em curso, é dado por Agostinho imediatamente após haver estabelecido, por assim dizer, a relação fundamental entre ascendência e transcendência, na qual - assim o intentamos notar - o passo da primeira, necessária e perenemente, é ensejado e trilhado à luz do ultrapasso da segunda, cuja presença imediata ao ato primordial de dispor-se à ascensionalidade, pela busca da sabedoria, a torna a realidade permanentemente à vista, instituinte e conducente do próprio itinerário (funções judicativa e moderadora da ratio).

\footnotetext{
288 Aug. Quaproper nullo modo negaueris esse incommutabilem veritatem, haec omnia quae incommutabiliter uera sunt continentem, [...] omnibus incommutabilia uera cernentibus tamquam miris modis secretum et publicum lúmen praesto esse ac se praebere communiter. [...] ueritatem de qua iam diu loquiimur et in qua tam multa conspicimus, excellentiorem putas esse quam mens nostra est na aequalem mentibus nostris na etiam inferiorem? Sed si esset inferior, non secundum illam, sed de illa iudicaremus, sicut iudicamus de corporibus quia infra sunt [...] Et iudicamus haec secundum illas interiores regulas veritatis quas communiter cernimus, de ipsis uero nullo modo quis iudicat. Cum enim quis dixerit aeterna temporalibus esse potiora aut septem et tria decem esse, nemo dicit ita esse debuuisse, sed tantum ita esse congnoscens non examinator corrigit, sed tantum laetatur inuentor.
} 
A sumarização remissiva com a qual Agostinho caminha, torna-se mais clara no segundo momento de sua presente articulação. Ao inquirir Evódio acerca do estatuto hierárquico da verdade, Agostinho - fazendo notar que dela já se falou e discerniu-se por quase todo o diálogo (loquimur et in qua tam multa conspicimus), reconhecendo pois tratar-se aqui de sumário conclusivo - retoma a noção de excelência com a qual iniciara toda a exposição acerca da dinâmica ascensional ensejada pela ratio, e pela qual, por evidente, a esta se reconhecia como superior a todas as outras realidades por ela julgadas e conduzidas. Com efeito, se se busca provar a existência de uma realidade eterna e imutável, tal que nada lhe seja superior; sendo a ratio a realidade até então postulada como a mais excelente, a pergunta soa por óbvia a tais construtos da disputatio: a verdade é excelente/excedente em relação à ratio? Igualmente, a resposta já se tem por conhecida, entrementes, por todas as digressões a respeito da verdade feitas nos passos imediatamente anteriores: a verdade é a própria medida pela qual se permite à ratio o julgamento da realidade que lhe é inferior, bem como a própria medida - enquanto limite - da excelência e excedência da ratio em relação a si própria, pois que somente à luz da imutabilidade da verdade é que se clarifica sua mutabilidade e limitação. E, tal como as realidades que por ela são adjudicadas e conduzidas em sua excelência e superação, a própria ratio é como que exercitada e ajustada pelas normas interiores de verdade, as quais não se prestam aos juízos, nem demandam serem conduzidas, pois precisamente elas é que o fazem. Ante as luzes da verdade, não ocorre postar inquirição ou juízo, mas tão-somente a constatação do ser assim, como ainda não se deduz a verdade, apenas se a vê postada à nossa frente.

É precisamente nesta acepção que Agostinho deseja finalizar a conclusão acerca da verdade enquanto manifestamente superior à ratio e, enquanto a própria medida da excelência e superioridade; do julgamente e condução operadas pela ratio frente a toda a realidade conhecida; bem como ainda a via mesma de se ratificar o ser, por ser a própria presença do ser - eis que se depara provada sua realidade de ser acerca do qual nada de superior pode se provar:

\begin{abstract}
Ag. Aqueles que mantém seu olhar voltado para ela [luz da verdade], alegram-se, pois são iluminados. E ficam cegos os que se recusam olhar em sua direção. [...] Ora, a medida conforme a qual a mente humana deve compreender é a medida mesma com que consegue aplicar-se e unir-se à verdade imutável. Assim, pois, se a verdade não é nem inferior, nem igual a nossa mente, segue-se que ela só pode ser superior e mais excelente do que ela. [II, xii, 34 Paulus $]^{289}$.
\end{abstract}

\footnotetext{
${ }^{289}$ Aug. [...] sed integra et incorrupta et conversos laetificet lumine et aversos puniat caecitate. [...] Tantum autem mens debet intellegere quantum propius admoueri atque inherere potuerit incommutabili ueritati. Quare si nec inferior nec aequalis est, resta ut sit superior atque excellentior.
} 
Ao finalizar a argumentação, Agostinho clarifica que a realidade que emerge como evidenciada, a qual anteiormente prometera demonstrar como superior à ratio, vem a ser a própria possibilidade pela qual se julga e verifica a excelência de um ser em relação a outro, ou um passo da ascensão em relação a outro. A superioridade da verdade em relação à razão não se mostra como uma superposição ou um estamento estanque justaposto por sobre a racionalidade, mas, antes, presentifica-se à razão enquanto a própria instituição do sentido de atuação desta, ao fornecer-lhe a medida para estabelecer o juízo e a moderação de toda a realidade, vale dizer: o modo pelo qual a razão institui, afirma, modera e conduz a feitura intelectual da realidade, tornando evidente que, enquanto remissiva ao absoluto e imutável, ela radica no ser absoluto e eterno, imeditatizando pois a relação de identidade entre o Vere Esse e a verdade, numa palavra: Deus é a verdade. Já na seção seguinte, Agostinho consuma a apresentação descritiva do itinerário ascensional, em termos de realização da felicidade humana:

\begin{abstract}
Ag. Prometi demonstrar-te, se te recordas, que havia algo que era muito mais sublime que nosso espírito e que nossa razão. Aqui está: a própria verdade. Abrace-a se puderes, alegra-te dela. "Seja o Senhor tua delícia e ele te dará o que pede o teu coração" (Salmo 36,4). Porque, que outra coisa pode você pedir, senão ser feliz? E quem é mais feliz que aquele que goza da firme, imutável e excelentíssima verdade? [II, xiii, $35-B . A . C.]^{290}$
\end{abstract}

\title{
4.8) Paralelo: De vera religione
}

Dos textos paralelos ao De libero arbitrio, seguramente o De vera religione é o que, tanto cronológica quanto conceitualmente, mais se lhe aproxima, sobretudo pela exposição de vários de seus temas em comum, de forma abreviada e mais acessível que o árido e desafiador cenário que uma disputatio impunha ao desenvolvimento do Livro II de nosso diálogo, cerne de nossa pesquisa. Assim, a título de uma aproximação ratificadora, observemos alguns dos traços apresentados no pequeno tratado, já analisados em nossa exposição do diálogo, os quais certamente permitirão contribuir à mesma.

Agostinho identifica a busca interior com a quietude e o recolher-se face à multiplicidade corpórea, vale dizer: do limitado e transitório. O caráter múltiplo se lhe afigura como exposição da limitação e conseqüente transitoriedade da matéria, e o deter-se no corpóreo, enquanto termo da busca, configura verdadeira capitulação da alma interior, sede da razão eterna, face à fugacidade da realidade corporal. O múltiplo é a própria raiz da inquietude,

\footnotetext{
${ }^{290}$ Aug. Promiseram autem, si meministi, me tibi demonstraturum esse alquid quod sit nostra mente atque ratione sublimius. Ecce tibi est ipsa ueritas: amplectere illam si potes et fruere illa et delectare in domino et dabit tibi petitiones cordis tui [Ps 36,4]. Quid enim petis amplius quam ut beatus sis? Et quid beatius eo qui fruitur inconcussa et incommutabili et excellentissima ueritate?
} 
e como tal a antítese da quietude que alcança o simples, o Uno ${ }^{291}$. Vê-se que, para Agostinho, a busca pela sabedoria é conduzida, em termo e êxito, na absoluta simplicidade do coração, contrária à sedução da multiplicidade corpórea que se esvai no efêmero, posto que quebradiço e limitado (múltiplo), temporal e passageiro. Ao contrário, o Uno recolhe-se à simplicidade da alma que, contrastando à busca exterior que se esfacela na fugacidade que intenta alcançar o princípio subjacente nela própria, toma todo o coração livre no eterno e imutável, ilimitado e infinito $^{292}$. Assim, a simplicidade da alma, vale dizer: a interioridade tomada em sua intimidade primeira, vem a ser, no imediato primordial dado a si [e anterior, portanto, a qualquer busca exterior], o elemento que funda a reflexão e o pensar, e a filosofia verdadeira em sua busca pelo eterno na sabedoria e felicidade imutáveis. Trata-se de verdadeira libertação ao pensamento que busca, bem como à alma em sua inquietude e necessitada do repouso no Absoluto e Infinito ${ }^{293}$. Mas, ainda mais decisivo: trata-se de contrastação vital para com a sabedoria que julga encontrar, autonomamente, a felicidade principial fora do absoluto divino e eterno, noutros termos: que julga poder alçar-se ao amor à sabedoria, à filosofia, com a sutileza dos raciocínios e elucubrações que encobrem a falsidade dos entes tomados em si mesmos, como objetos da vã curiosidade que se lança ao questionar e perquirir, sem ancorar-se no absoluto que está no fundamento imediato e íntimo de toda a realidade, a começar pelo próprio inquiridor e "buscador", vale dizer: pelo filósofo. A simplicidade de coração contrasta, em Agostinho, com o refinamento das especulações vazias e estéreis daqueles que "se perderam em vãos arrazoados", cujo "coração insensato ficou nas trevas" ${ }^{294}$.

Nesse sentido, a atitude de recolhimento ante a imponência presencial, ou a presença que se impõe à intimidade daquele que busca, assume caráter imperativo e metodológico. $\mathrm{E}$ como tal, compõe um caminho de transposição dos limites aos quais a alma encontra-se presa e necessitando, por sua própria intimidade (que se lança, na interioridade, à sua própria superação para plenificar-se na culminância do encontro e diálogo com o eterno), transcender a si mesma na própria origem e fonte da razão que a movimenta em sua busca ${ }^{295}$. Eis o ponto

\footnotetext{
${ }^{291}$ uera rel. xxxv, 65, tradução de Nair de Assis Oliveira, $2^{\text {a }}$ edição, São Paulo: Paulus, 2007, pp. 90-91.

${ }^{292}$ Idem, ibidem: "É por certo o Uno que nós procuramos. Não há nada mais simples do que ele. Procuremo-lo, pois, em toda simplicidade de coração. [...] Não se trata do repouso da ociosidade, mas do repouso do pensamento, libertado do espaço e do tempo.”. Cf. VAZ, H.C.L. A Metafísica da Interioridade - Santo Agostinho, op.cit.., p. $81 \mathrm{ss}$

${ }^{293}$ Idem, ibidem .

${ }^{294} \mathrm{Rm} \mathrm{1,21}$ in $\boldsymbol{B J}, 1^{a}$ edição revista, São Paulo: Paulinas, 1985. A $2^{\text {a }}$ edição, de 2002, mantém inalterada tal tradução.

${ }^{295}$ uera rel. xxxix, 72 (Paulus): "Não saias de ti, mas volta para dentro de ti mesmo, a Verdade habita no coração do homem. E se não encontras senão a tua natureza sujeita a mudanças, vai além de ti mesmo. Em te ultrapassando, porém não te esqueças que transcendes tua alma que raciocina. Portanto, dirige-te à fonte da própria luz da razão."
} 
fulcral no itinerário interior agostiniano: o que me valida e, por assim dizer, autentica e legitima (assumindo portanto evidente caráter ético, sempre tendo em mente o eudaimonismo agostiniano) o movimento de busca, dentro do recolhimento e repouso na intimidade, é a própria interioridade enquanto ato (atitude ou disposição) essencialmente através da ratio, ou seja, enquanto o ser próprio que se supera à mutilação e instabilidade do mundo sensível e corpóreo, limitado e temporal, para se deter no eterno e absoluto, ilimitado e infinito. A interioridade, enquanto locus Dei, se autorreconhece em sua essência no ato racional. Importante verificar que não é a ratio que legitima, de per si, o ato pelo qual a interioridade se transcende face à corporeidade que a situa no mundo transitório da materialidade, mas sim seu próprio constituir-se em manifestação primeva do absoluto e eterno que corrobora e autentica a razão no ato de superação, vale dizer: transcendência, face à realidade material e temporal. Nesse sentido, Agostinho pode falar acerca da busca da verdade como uma constatação do já dado anteriormente, ao que a ratio, em sua interioridade como movimento de busca e recolhimento à sua fonte primeva e autenticadora, como que suspende o refletir e inquirir típicos da atitude exteriorizada, para ver as coisas em si mesmas, já dadas, faticamente presentes na intimidade que perfaz a primordialidade na qual a verdade se apresenta e se dá. ${ }^{296}$

\footnotetext{
${ }^{296}$ uera rel. xxxix, 73: "Não é o ato de reflexão que cria as verdades. Ele somente as constata. Portanto, antes de serem constatadas, elas já permaneciam em si, e uma vez constatadas essas verdades nos renovam." (p. 100).
} 


\section{5 - ITINERÁRIO ASCENSIONAL NOS DIÁLOGOS PARALELOS}

\section{5) $\underline{\text { De ordine }}$}

\section{1) Primeira discussão: introdução $(\mathrm{I}, \mathrm{i}, 1)$}

Agostinho inicia o diálogo expondo três pares a partir dos quais se estabelecerá a discussão, que indicam o alcance da ordenação da realidade, ou mais propriamente como esta se efetiva e se dá a perceber ao conhecimento, a partir da amplitude ou nível ontológico do real: Seguimento/Entendimento (consequi ac tenere), referindo-se à ordem das coisas e seres [ou seja, ordenação dos entes singulares (ordinem rerum)]; Visão/Explicação (vel videre vel pandere), igualmente relativa à ordenação do universo (já ampliando, por conseguinte, o alcance da ordenação da realidade, extensiva neste ponto ao universo como um todo, e sugerindo, pela escolha dos termos, a contemplatio como atitude mestra ou sua correlata); e Guia/Governo [(coercetur ac regitur) sugerindo-se consecução teleológica a presidir o curso dos fatos, os quais dão-se e ordenam-se, portanto, enquanto história com moral e juris próprias.] Os pares intentam dar conta da plenitude da realidade ontológica em sua relação cognitiva com o ser humano, demarcando-o em função da estruturação seqüencial da ordem presente no universo. O caráter de plenitude é atestado pela presença da nota ético-teológica inerente ao ordenamento da realidade, evidenciando-se mesmo como uma percepção da identidade entre o bem e a ordem do mundo. Ao falar do governo do universo, Agostinho expõe o único âmbito ou locus no qual se poderia colocar um tal questionamento acerca do mal. A correção do curso seqüencial da história condiciona a feitura da realidade em seu ordenamento teleológico, cuja correta percepção assegura a autoinserção e realização própria nesta mesma ordem, ao mesmo tempo que enseja a questão do mal presente no mundo, equacionando-a como desordem do real. O estatuto ontológico da ordenação do real, conjugado à sua percepção, são igualmente ressaltados na nota relativa ao êxito de tal percepção, e sobretudo à sua comunicação ou compartilhamento, quando Agostinho classifica a ambos como "coisas divinas", tanto quanto "obscuras" (diuinis obscurisque rebus). A medida para tal classificação - divino e misterioso - é dada pelo anseio de ouvir e aprender, por parte das inteligências de fôlego, bem como pelos ouvidos atentos e sensíveis à dor e às fragilidades desta vida, acerca da contradição manifesta entre ordem e mal. Agostinho deixa claro, pois, que a percepção da ordem identifica-se, aqui, à valoração ética da realidade. Pode-se dizer que a ordinem rerum situa-se na base do que poderia ser entendido como um senso ordenativo de 
justiça, uma ordo juris. Igualmente, a ordenação da realidade é por Agostinho identificada à providência divina: "como pode ser que, ao mesmo tempo em que Deus cuida das coisas humanas, haja tanta perversidade nas coisas humanas, ..."297. Na realidade, Agostinho faz ver que é a percepção da ordenação presente na realidade que leva ao questionamento acerca do mal, o que de per si clarifica uma primeira definição deste: ruptura ou perversão do ordenamento ontológico do real. Agostinho arremata este primeiro momento da interlocução fazendo incidir, como no De libero arbitrio, o questionamento sobre o pressuposto teológico, equacionando-o em duas hipóteses: 1) alheamento da providência divina infinita e eterna, em relação à ordem criatural limitada; ou, mais drástica e impiamente cogitado: 2) deliberação divina na desordem humana e dos seres em geral $(\mathrm{I}, \mathrm{i}, 1)$.

De imediato, porém, trata Agostinho de excogitar tais hipóteses, esvaziando-as em sua própria inconsistência, através do chamado à racionalidade inerente à realidade, a qual ultrapassa a limitação dos entes e situa-se além de qualquer deliberação e possibilidade humana $(\mathrm{I}, \mathrm{i}, 2)^{298}$; bem como fazendo notar, ainda, o caráter misterioso - vale dizer: divino - de tal racionalidade ordenadora, identificando por conseguinte, e num único passo, a ratio e à ordo (secretissimo maiestatis arbitrio $)^{299}$. Longe de significar ou reduzir a ordenação racional a qualquer ato misterioso divino, e com isso resolver toda a investigação filosófica no pressuposto teológico, trata-se de trazer este último à percepção imanente da racionalidade permeante do universo, numa palavra: Agostinho refina qualquer possível divisão entre a religião e filosofia, fazendo-nos ver que a abordagem da primeira deve sempre partir e ter por base o passo racional, que se admira e maravilha ante a ordenação dada ao universo pela providência divina, ou seja, é a filosofia que conduz primeiramente o olhar ao divino propósito presente e governante da realidade universal $(\mathrm{I}, \mathrm{i}, 2)$.

$\mathrm{Na}$ precisa finalidade de delimitar e localizar a origem do questionamento acerca da providência divina, na contrastação entre a ordenação divina e a inobservância humana da mesma, Agostinho caminha no diálogo fazendo-nos ver, em primeiro lugar, que tal deficiência de percepção advém da falta de instrução, o que remonta, instância última, à incapacidade de retenção do todo; o que é confirmado, em segundo lugar, pela identificação entre percepção da ordem e percepção do todo: "Não é diferente o que ocorre a homens menos instruídos que, incapazes de abranger e considerar com sua débil mente a adequação e harmonia globais das

\footnotetext{
297 "quam quomodo fiat ut et Deus humana curet, et tanta in humanis rebus perversitas"

298 "Sed quis tam caecus est mente, ut quidquam in movendis corporibus rationis quod praeter humanam dispositionem ac voluntatem est, divinae potentiae moderationique dare dubitet?"

299 “... aut vero per universam naturam, quod in singulis quibusque rebus nihil arte humana satagente ordinatum miramur, alienare a secretissimo maiestatis arbitrio ullis nugis vanae opinionis audebimus"
} 
coisas, [...] acham que existe uma grande feiúra nas coisas." ${ }^{300}$. Clarifica-se, por conseguinte, que a conceituação agostiniana de ordem, neste texto, só pode ser situada na percepção e no alcance do todo, que se apresenta simultâneo à ordem ou disposição ordenada da realidade, conferindo-lhe em verdade seu estatuto ontológico, ou mesmo epistemológico, visto que o todo (ou a totalidade ordenada) somente é acessado pelo conhecimento, quando de sua percepção da ordem cosmológica, numa palavra: a ordenação ontológica presentifica e manifesta a totalidade do real ao espírito humano (Idem). Tal conceituação, ao início do Livro II, atua em corroboração ao que Agostinho já expusera no início do Livro I, quando da narrativa acerca do fascínio exercido nele pela disputa entre galos: "Por que o espectáculo em si nos atraía, mesmo prescindindo de tais considerações? Que há dentro de nós, separado dos sentidos, que pergunta tantas coisas, e quem é escravizado pelo mesmo convite dos sentidos?” (I, viii, 25). Observamos que o "espetáculo", aqui no sentido do todo ou totalidade vista em seu conjunto pelos sentidos, possibilita o próprio exercício do filosofar, configurando a possiblidade da busca de sentido à realidade através do inquirir o dado em si, em sua manifestação por inteiro, em sua totalidade. O parcial ou inordenado não configura totalidade, e a fragmentação não manifesta a necessidade de busca de sentido, por não configurar um todo que conclama significação e interpela a intelecção à sua penetração e entendimento do signo dado. Fragmento não sinaliza, não compõe significancia, não é signo. $\mathrm{O}$ todo, de per si, configurado aos sentidos pelo distanciamento que permite ver-sem em sua totalidade, leva à pergunta pelo sentido, a partir da totalidade ordenada.

A falta de instrução - causadora da incapacidade de retenção da visão do todo - não se afigura, entretanto, de per si como suficiente para explicar a inobservância da ordenação racional da realidade. Agostinho caminha à raiz de tal deficiência: "A maior causa deste erro é que o homem não se conhece a si mesmo", matizando o socratismo do diagnóstico na precisa acepção da sua interioridade ${ }^{301}$, entendida como retenção/recolhimento, e sobretudo manutenção em si mesmo (seipso retinendi) ${ }^{302}$, face à fuga na dispersão causada pela multiplicidade perceptiva dos sentidos empíricos, quando não recolhidos pela visão unificada

\footnotetext{
300 "Nihil enim aliud minus eruditis hominibus accidit, qui universam rerum coaptationem atque concentum imbecilla mente complecti et considerare non valentes, si quid eos offenderit, quia suae cogitationi magnum est, magnam putant rebus inhaerere foeditatem"

301 "Cuius erroris maxima causa est, quod homo sibi ipse est incognitus. Qui tamen ut se noscat, magna opus habet consuetudine recedendi a sensibus, et animum in seipsum colligendi atque in seipso retinendi". Em sua análise, já tornada referencial, da receptividade e transmutação do lema socrático ao longo das eras, Gilson intitula precisamente de socratismo cristão a aproximação promovida historicamente pela filosofia cristã junto à tradição platônica, em sua raiz délfica - GILSON, 2006b: 279.

${ }_{302}$ Dominique Doucet [2004: 29] toma o De ordine por exemplar, dentro do esquema que qualifica como basilar para os desenvolvimentos intelectuais registrados nos diálogos de início, centrado na tríade evento-intelecçãomanutenção.
} 
radicada na interioridade. Percebe-se, pois, o caráter atemporal ostentado pela interioridade, pois sua instância vem a ser precisamente a da ausência da divisão na multiplicidade, cuja tessitura sequencial enseja a temporalidade. Nesse sentido, a interioridade vem a ser presença eterna, manutenção perene. E, após reconhecer que esta necessita de exercício e purificação [prescritos em dupla recomendação: a) purificação do conhecido até então, e b) no exercitar a razão no conhecimento por adquirir] $]^{303}$, Agostinho articula o papel da percepção racional da ordenação racional, com o exercício de sua retenção in totum na interioridade, fazendo convergir a epistemologia teleológica que delineara até então, junto a uma estética do uno, cujo matiz remonta evidentemente a Plotino ${ }^{304}$ : “Assim, o espírito, a partir de sua interioridade, entende o que seja a beleza do universo, que certamente assim se denomina a partir do termo uno." (I, ii, 3) ${ }^{305}$. Clarifica-se que a noção agostiniana de uno cristaliza-se, no presente texto, a partir de sua função catalizadora do conhecimento das ordenações estratificadas de acordo com os diversos níveis da realidade, numa grande e única ordenação racional presente (e imanente) à realidade, tornando-a ornata e bela ${ }^{306}$. A partir da elucidação de sua função de catálise do conhecimento dos sentidos, a unificação interior conceitua univocamente a ordo cognoscendi junto à ordo rerum, radicando-as enquanto beleza universal (Idem). Tal enraizamento atua com base nas funções que ocupam, dentro da exposição agostiniana de uma estética ontológica neste texto, o signo e a linguagem; e, sobretudo, na relação inerente a ambos, tornando-a imanente à ordem presente na realidade ${ }^{307}$.

À luz desta conceituação - cujo teor plotiniano evidentemente tem por raiz os desenvolvimentos platônicos acerca do belo ${ }^{308}$ - pode-se entender que o uno está situado, no

\footnotetext{
303 "Quod ii tantum assequuntur, qui plagas quasdam opinionum, quas vitae quotidianae cursus infligit, aut solitudine inurunt, aut liberalibus medicant disciplinis."

304 Cf. BEIERWALTES, Werner Das Eine als Norm des Lebens. Zum methaphysischen Grund neuplatonischer Lebensform in KOBUSCH, Theo; ERLER, Michael (Her.) Metaphysik und Religion: zur signatur des Spätantiken Denkens, Munique/Leipzig: K.G. Saur Verlag GmbH, 2002, p. 121-151; O'DALY, G. The Presence of the One in Plotinus in ID. Plotino e il Neoplatonismo in Oriente e in Occidente (Problemi Attuali di Scienza e di Cultura, Quaderno no 198), Roma, 1974, p. 156-169. Vide ainda FATTAL, Michel Plotin face à Platon suivi de Plotin chez Augustin et Farâbî, Paris: L'Harmattan, 2007.

305 "Ita enim animus sibi redditus, quae sit pulchritudo universitatis intellegit; quae profecto ab uno cognominata est."

306 "Agostinho - influenciado pelo neoplatonismo a ele acessível, o dos Platonicorum libri, que tinha aceito elementos de neopitagorismo - abraça a concepção neoplatônica do ser. É a unidade, com efeito, segundo Plotino, que permite ao real ser e ser pensado [...] Essa mesma concepção de Deus como Um é retomada por Agostinho [...] O um neoplatônico e o Deus do crente são o princípio do ser, do bem, do belo..." [MORESCHINI, 2008: 455].

${ }^{307}$ Cf. GONZÁLEZ, Alfonso R. Signo y lenguaje en San Agustín, Bogotá: UNB, 1992, p. 88.

308 Presente nos vários momentos da constituição dos diálogos platônicos, tal conceituação cristaliza-se nos diálogos intermediários e/ou tardios, como p. ex. no Filebo. Para uma elucidação crítica quanto aos pressupostos interpretativos não restritos ao pitagorismo, vide RACHID, Rodolfo A bela ordem incorpórea no Filebo de Platão in Trans/Form/Ação, Revista Eletrônica de Filosofia/UNESP, Marília, Volume 35, n 2, Maio/Agosto de 2012, p. 3-29 (especialmente p. 6-7).
} 
presente texto, como noção primordial em relação aos dados sensíveis conhecidos e nele catalizados, fazendo-se a própria possibilidade de captação da ordem única e presente a toda a realidade múltipla, unificando-a pois em percurso e finalidade, numa palavra: perfazendo-lhe sentido e fim. A percepção do uno, advinda unicamente a partir do recolhimento em interioridade do conhecimento sensível e múltiplo, atua primordialmente ao elenco unificado de dados sensíveis múltiplos, ao mesmo tempo que lhe confere sentido e unidade ${ }^{309}$. Não se afigura suficiente a postulação do uno como condição apriorística do conhecimento da ordenação do real, mas sim sua própria atualidade e perfazimento, posto que, enquanto ato, não se constitui sequencialmente, portanto temporalmente, mas sim atemporalmente, na própria simultaneidade de sua atuação como possibilidade e atualidade de, respectivamente, catalizar e unificar. Outrossim, o locus ocupado pela interioridade, bem como a atualidade própria do uno, permitem-nos tentativa de visualizá-los (locus e atualidade) como a instituição própria e única do conhecimento humano, visto que a percepção da ordenação ontológica da realidade encontra-se radicada em ambos; os quais, por sua vez, articulam-se numa estética teoteleológica, fio estrutural que costura, no pensamento agostiniano, a ética e a epistemologia num plano unívoco e autocondicionante ${ }^{310}$.

O desenvolvimento da interlocução torna claro que a conceituação é desenvolvida e entendida no viés da totalidade, evidenciando-se que, para Agostinho, esta acepção possibilita a perfeita compreensão da relação unidade/multiplicidade, como se verifica na analogia da circunferência com o espírito humano, após a qual define, de modo capital, que "sua natureza [do espírito] o impele a buscar em toda parte a unidade do centro, e a multiplicidade de coisas não lhe permite encontrá-la, ${ }^{\text {311 }}$. O todo somente pode ser percebido, ou mesmo visto, a partir da unidade conferida pela interioridade, o que equivale a dizer, reversamente, que a unidade somente se configura a partir do todo (da totalidade), quando de seu recolhimento junto ao interior do espírito humano. A dedicatória a Zenóbio parece confirmar tal acepção do uno (enquanto todo-em-recolhimento), pelas recorrências, na seqüência do texto, às noções de totalidade e/ou conceituações análogas:

\footnotetext{
309 "Idcircoque illam videre non licet animae quae in multa procedit, sectaturque aviditate pauperiem, quam nescit sola segregatione multitudinis posse vitari." [I, ii, 3]

${ }^{310}$ A articulação do construto ético-epistemológico junto à estética do uno em interioridade, será alcançada em sua plenitude nos grandes tratados de maturidade, com a evidente inclusão das Confessiones. Nestas, Agostinho irá elencar a memória junto à interioridade, como espaço constituinte do conhecimento inteligível em eternidade. Cf. COUTINHO, Gracielle N. A construção do conhecimento sensivel em A Trindade de Santo Agostinho in Kinesis, Revista de Filosofia da UNESP, Volume IV, nº 07, Julho/2012, p. 1-16.

311 “...eum natura sua cogit ubique unum quaerere, et multitudo invenire non sinit." [I, $\mathbf{i i}, \mathbf{3}]$
} 


\begin{abstract}
"Mas você, meu caro Zenóbio, certamente compreende o sentido do que eu disse acima e qual é a causa do desvio dos espíritos e de que modo todas as coisas se harmonizam para formar a unidade e são perfeitas [...] Pois conheço [...] seu espírito amante da beleza em todos os seus aspectos, [...] Creia-me, você conseguirá estas coisas aplicando-se à instrução [...] $\underline{\text { Tudo }}$ isso, como se processa e a ordem que o exige [...] acredito que esse livro [...] lhe ensinará suficientemente tudo isso...” [I, ii, 4 - grifo em negrito itálico nosso $]^{312}$
\end{abstract}

$\mathrm{O}$ texto permite, igualmente, a elucidação do entendimento agostiniano quanto a harmonia e perfeição: trata-se de formar (recolher na interioridade) unidade de percepções, perfazendo a totalidade do ordenamento universal visto a partir de sua captação racional.

Não se nos afigura meramente ocasional a lembrança com a qual Agostinho começa a discussão. Afinal, o De ordine iniciara com sua asseveração acerca da raridade, entre a humanidade, quanto à percepção da ordenação presente na realidade. Agostinho chega mesmo, como já o notamos, a colocar que tal percepção é reservada às "grandes inteligências", dignas de "coisas tão divinas e obscuras". À luz da cena prosaica da irregularidade da água nos canais de escoamento, ressalta-se que a percepção da ordenação racional do mundo faz-se presente no fato imediato e nos detalhes da existência, nos acontecimentos comuns e cotidianos que nos cercam a todo instante. A percepção da ordem universal não se encontra, pois, reservada a iniciados, mas pode ocorrer a qualquer pessoa, em qualquer circunstância e momento. Com efeito, a regularidade e a ordem inerentes ao real estão manifestadas em todos os momentos da vivência cotidiana, como faz notar Doucet: "Se inicia de maneira acidental, ele [De ordine] responde a uma inquirição central acerca da verdade, sinal da presença e da atividade da razão na existência humana." ${ }^{313}$. Porém, Agostinho precisa que tal percepção, ainda que à mercê do comum humano, somente lhe ocorreu quando de seu exercício habitual de recolhimento em interioridade: “... estava acordado e revolvia calado o que me vinha à mente não sei de onde..." 314 . O exercício de recolhimento em interioridade permite a Agostinho o estar desperto para que, a seguir, sua atenção esteja voltada à percepção do entorno de realidade que o cerca: "Portanto, como disse, eu estava acordado, quando o ruído da água, que fluía ao longo por trás dos locais dos banhos, chegou-me aos ouvidos e prendeu-me a atenção mais fortemente do que o usual." (I, iii, 6) ${ }^{315}$. O relato detalha que a atenção é revolvida pelo inusual, permitindo inferir que a atenção mantém-se voltada à ordem de maneira

\footnotetext{
${ }^{312}$ Sed et haec quae dixi qualia sint, et quae causa exstet erroris animarum, quoque modo et in unum congruant atque perfecta sint cuncta [...] mi Zenobi [...] Sic enim mihi notum est ingenium tuum et, pulchritudinis omnimodae amator animus [...] Assequeris ergo ista, mihi crede, cum eruditioni operam dederis [...] Quod totum cuiusmodi sit, et quem flagitet ordinem [...] hi te libri satis, ut opinor, edocebunt

313 "S'il commence de manière accidentelle, il répond à une quête de la vérité, signe de la présence et de l'activité de la raison en l'existence humaine." [DOUCET, 2004: 31]

314 “... cum evigilassem de more, mecumque ipse tacitus agitarem quae in mentem nescio unde veniebant"

315 ". ergo, ut dixi, vigilabam; cum ecce aquae sonus pone balneas quae praeterfluebat, eduxit me in aures, et animadversus est solito attentius."
} 
regular e habitual, sendo deslocada por algo que rompa a ordenação e curso regular dos fenômenos. Têm-se, por conseguinte, que a intencionalidade habitual da inteligência e da mente, constituída e vivenciada temporalmente pela regularidade da ordenação entitativa do universo, é rompida quando da irrupção de seu desordenamento, ocasionando ruptura da intentio e instituindo a attentio na alma, suspensa em surpresa e admiração ante a ruptura. A epistemologia agostiniana do De ordine denota, neste início de discussão, sua herança direta da tradição platônica ao identificar, uma vez mais, a ordo cognoscendi à ordo rerum, com a decorrente relação condicional da primeira para com a segunda, mas inserindo-lhe o par intencionalidade/atenção como seu elemento de concretude e intermediação entre a eternidade da ordem racional e a temporalidade da ordem dos seres contingentes, em analogia com a alma e seu conhecimento. Intencionalidade e atenção correspondem a atitudes anímicas de decorrência direta da ordem universal e sua manifestação na mutabilidade, finitude e temporalidade.

No prosseguimento da discussão, a interrogação de Agostinho pela causa da mutabilidade faz observar que a conceituação de ordenação universal permite inferir, ou mesmo deduzir, a noção de causalidade: "Qual lhes parece ser a causa da alternância deste ruído?"316. A explicação oferecida por Licêncio corrobora tal relação de contraponto, ao explicar a ruptura da ordenação regular dos fenômenos por um nexo causal observado regularmente. A causa que rompe a ordem natural compõe, ela própria, sequência ordenada, permitindo-nos deduzir que mesmo um fenômeno de desordem e rompimento segue certa ordenação interna em sua ocorrência.

Após fazer notar, novamente, a imbricação entre admiração e interioridade -a esta estabelecendo como condição para a insurgência daquela ${ }^{317}$ - Agostinho igualmente reafirma a relação condicional entre o espanto e a ruptura da ordenação habitual e/ou usual: "De onde retruquei - costuma originar-se a admiração ou qual é a mãe desse vício, senão de uma coisa insólita fora da ordem evidente das causas?” (I, iii, 7) ${ }^{318}$, ressaltando que a atenção devotada à ordenação habitual, ou por ela estabelecida e vivenciada, constitui como que a condição natural da inteligência, sua consonância à ordem ontológica do mundo, do que resulta constituir o direcionamento da atenção à ruptura da ordenação um verdadeiro "roubo" epistemológico, autêntico "vício", ao mesmo tempo que qualifica a ruptura da ordem natural como "insólita" (Idem). Desvirtuamento da atenção e caráter inusual fático: eis o que significa, à luz do quadro

\footnotetext{
316 "Quidnam vobis, inquam, videtur esse causae quod sic alternat hic sonus?"

317 "É lógico que você não se admirava disso - continuei a falar - pois você no seu íntimo estava entretido com a sua Caliope." (I, iii, 8)
} 
epistemológico desenhado no De ordine até este ponto, a intercorrência do binômio intencionalidade/atenção a que aludimos anteriormente. Por seu turno, a resposta de Licêncio trata de expor certa questão já implícita em sua fala anterior, quando da explicação da alteração no som intermitente da água: sendo a ruptura da ordem um fenômeno cuja causa reside em outra ocorrência ordenada e regular, haverá porventura algo fora da ordem no curso natural dos fenômenos e das coisas?

Antes da interlocução caminhar para a abordagem explícita desta questão, a partir de I, iv, 11, duas outras intervenções de Licêncio trazem-nos espécie de elucidação a que procede Agostinho, quanto ao caráter e, sobremodo, à vivência única proporcionada pelo exercício do filosofar. 1) Após a reconhecida rispidez com que lhe respondera, externando sua impaciência e irritação com o seu envolvimento pela poesia e seus devaneios, Agostinho ouve de Licêncio que “... já comecei a acreditar em você (Agostinho), que diariamente prova que a filosofia é nosso verdadeiro e inabalável lugar de habitação." (I, iii, 9). Tal reconhecimento, por parte de um amante da poesia, de que a filosofia é a verdadeira e incontornável situação/habitação humana (vera et inconcussa nostra habitatio), ou a vivência em que há e se dá a sabedoria e conhecimento verdadeiro da realidade, é ressaltada com precisão, dado proceder de alguém que relutava ao seu exercício. Com efeito, Agostinho exalta a filosofia ante o que lhe parece arroubos e fugas causados pela ausência da vivência e do exercício da racionalidade, posto que precisamente o exercício da ratio permite a percepção da ordenação ontológica da realidade, pela qual se observa e têm-se a majestade da presença divina na realidade. 2) Este caráter divino da sabedoria filosófica - aqui, manifestada e exercitada na observação do ordo entis através do ordo cognoscendi - aparece clarificado na resposta que Licêncio oferta a Trigécio, quando este lhe ironiza uma sua resposta: "Deixe disso - replicou ele (Licêncio) - para que esta sua astúcia ou algo de bajulação não me afaste nem me arrebate de não sei que coisa divina que começou a manifestar-se a mim e à qual me dedico com ardente desejo." (I, iv, 10). A fala seguinte e imediata de Agostinho traz elucidação plena quanto ao caráter divino da habitatio da sabedoria filosófica, à qual se tem acesso através de dedicação voluntariosa e ardorosa, por sua vez impulsionadora para se colocar à condução divina rumo a "fixar $a$ morada" (Idem). De fato, é de início e despertamento que Agostinho trata neste trânsito do diálogo. Antes de adentrar na difícil questão acerca do eventual nexo entre ordenação e causalidade, e se esta compõe como que variação daquela, Agostinho faz ver qual a causa suprema da condução e ordem racional que nos permitem a "interpretação dos sinais", bem como o "sublime" experimentado pelos espíritos que se entregam à morada da sabedoria e verdade. E eis que Agostinho arremata o início propedêutico do diálogo identificando esta com 
aqueles: “... aquele outro sublime e verdadeiro [...] É a própria Verdade: os seus vaticinadores são todos aqueles que possam ser sábios." (Idem) ${ }^{319}$, não sem antes colocar o devido acento na atitude primordial pela qual se alcança o sublime desejo de sabedoria: “... cultivando com base na piedade, sufoquemos com nossos pés o pernicioso fogo das negras paixões." ${ }^{20}$, epitomizando assim a consumação da filosofia grega (enquanto exercício espiritual de sabedoria verdadeira) na atitude de entrega confiante e volitiva à Verdade, para que esta lhe conduza e se dê a conhecer e manifestar.

Incisivamente, Agostinho lança a questão a Licêncio definindo de pronto os termos em pauta:

"Responda-me à seguinte pergunta: por que lhe parece que esta água não flua assim casualmente, mas conforme à ordem? [...] que aquelas folhas caíssem, como você diz, de modo que ocorresse o que estávamos, admirando, como afinal pensar que seja pela ordem das coisas e não por casualidade?" $(\mathbf{I}, \mathbf{i v}, \mathbf{1 1})^{321}$

Na resposta, Licêncio parece evocar uma causalidade geral pela qual se põe a natureza em curso, advertindo a Agostinho que as seriações por assim dizer intermediárias - as que são responsáveis por "perguntas enfadonhas" (ou típicas de um "questionador pernicioso" odiosus percontator) - não podem ser objeto de compreensão por sua parte, posto que compõem "causas inumeráveis e obscuras" (caeterisque innumerabilibus atque obscurioribus causis). Tal evocação de uma possível causalidade geral deixa entrever, novamente, a necessidade da percepção do todo, muito mais importante e decisivo que as intermediações infindas e imperceptíveis; bem como evidencia que, em sua fala, Licêncio qualifica, e identifica uma vez mais, a causalidade como um princípio de ordenação e seriação inerente aos fenômenos naturais. Contudo, uma intervenção de Trigécio faz acrescentar um elemento por assim dizer corroborante à preponderância da totalidade causal evocada por Licêncio, em realidade já preparada pela fala deste. Ao tentar fazer frente à objeção de Agostinho, que retrucara resposta de Licêncio quanto à fertilidade das árvores (causa da produção das folhas por estas), Trigécio apela a "tantas outras coisas" (quanta sunt alia - I, v, 12) que poderiam ser classificadas e compor um elenco de causas da presença das árvores ali, e não unicamente a sua fertilidade. O conhecimento deste elenco pode, como observara Licêncio anteriormente, ser obscuro e até mesmo irrelevante, mas não é ignorado em seu todo e - elemento próprio da resposta - compõe-se de causas concomitantes entre si, as quais concorrem para a utilidade e

\footnotetext{
319 “alius profecto est, alius ille altus veridicus, atque ipsa (quid enim verbis ambiam?) Veritas: cuius vates sunt quicumque possunt esse sapientes"

320 "freti pietate cultores, vestigiis nostris ignem perniciosum fumosarum cupiditatum opprimamus".

321 "Hoc ipsum, inquam, mihi responde, primo unde tibi videatur aqua ista non temere sic sed ordine influere [...] Quod vero illa, ut dicis, folia sic inciderunt, ut hoc quod admirati sumus eveniret, quo tandem rerum ordine ac non potius casu factum putabimus?"
} 
importância de tais recursos aos homens. Outrossim, lançando mão precisamente desta obscuridade da multiplicidade infinda, como também de sua irrelevância, a reação de Licêncio repõe, uma vez mais, o questionamento acerca da causalidade inerente aos fenômenos corriqueiros: "Ele [Agostinho], então, que nos ensine se há algo sem uma causa que o preceda." (I, v, 12). E, para finalizar a introdução da questão fundamental, Licêncio assevera que tal questionamento compõe o "âmago da filosofia" (media philosophia docet - I, v, 13), seguindo-se a ponderação de Agostinho no sentido de fazer notar que, mesmo aqueles que estão bem distantes de tais questões profundas, podem instruir algo "quando se ligam como que por vínculos de perguntas ao grupo" (Idem). Tais colocações intentam ilustrar o nascedouro da filosofia, bem como a importância de seu exercício, ambos ligados, respectivamente, ao detalhe prosaico do cotidiano, e à compreensão e visão do todo da realidade fenomênica.

Após tais intervenções acerca da importância do questionamento fundamental sobre a ordem das causas no universo, bem como a respeito da relação entre tais questões e o próprio exercício do filosofar - com efeito, este tem origem naquele - o mesmo tem prosseguimento já na finalização da fala introdutória de Agostinho: "Por acaso você não percebe que aquelas mesmas folhas [...] podem resistir um pouco ao curso das águas que se precipitam e lembram aos homens a ordem das coisas, [...] ?" (Idem). Afinal, pode um obstáculo à ordem (por assim dizer) natural das coisas constituir, ele próprio, também o resultado de uma ordem, ou possuir uma causa ordenada?

A magnitude e densidade contidas na resposta de Licêncio pedem-nos análise detida e mais ampla. Primeiramente identifica e/ou remete a ordenação universal com/ao agir divino na realidade: “Quem o negará, ó grande Deus, que administrais tudo com ordem? Como tudo se mantém! Com que sucessões invariáveis tudo é impelido aos seus desenlaces!" (I, v, 14). Os três tópicos conceituais aqui relacionados - administrar/ordenar a realidade; manutenção da realidade; e sucessão teleológica da realidade - tratam de fazer a cosmologia depender da teologia, fazendo ver que a presença e atuação de Deus são manifestas e se dão a conhecer ao ser humano na realidade mundana, cotidiana e factual, que nos cerca. Mas também a utilização de tais conceitos básicos elucida-nos a herança agostiniana da epistemologia das Enéadas, onde percebemos que ordenação, manutenção e finalização da realidade sensível remetem à presença do Uno neste mundo, formando uma cosmologia na qual os três tópicos estão em correspondência respectiva à origem, presença atual e fim do universo ${ }^{322}$.

${ }^{322}$ Cf. Enéada V, 1 ss 
À luz deste trinômio fundamental interposto em seu início, o prosseguimento da resposta caminha para clarificar o sentido de sua percepção por parte do ser humano. Se na primeira parte Licêncio tratou de estabelecer a cosmologia junto à ontologia/teologia, a continuidade de sua fala aponta para a epistemologia decorrente da tríade acima, fazendo-nos ver que a sucessão temporal dos fatos, acontecimentos e coisas está, por um lado, em relação de decorrência para com a origem divina do universo; por outro, aponta para sua finalização como percepção de uma totalidade causal, remetente do presente percebido ao destinatário maior que culmina o curso dos eventos; para concluir, numa palavra, que o sentido da história é dado presentemente ao ser humano, por sua percepção da relação de decorrência entre cosmologia e ontologia do uno, esta por sua vez tornada, por Agostinho, elemento da teologia criacional cristã. Na exposição de Licêncio, a história emerge como sentido ontoteleológico do curso temporal vivenciado e percebido pelo ser humano, sendo que um fato reveste-se de sentido histórico na medida em que é percebido como parte do todo. Ressalte-se que esta percepção não tem necessidade de captar, ou dispor de todos os seus elementos internos para que se integralize e/ou se perfaça; antes, talvez se dê precisamente o contrário: o todo, ou a percepção da ordenação universal da realidade, permite ver o sentido e significado até dos mais prosaicos acontecimentos, mesmo que não venhamos a nos dar conta de tais: "Quantas coisas terão ocorrido até que discutíssemos tais coisas! Quantas coisas se fazem para que vos encontremos!", o que inclui até mesmo as palavras e sua eventual intencionalidade: "Finalmente, também as suas mesmas palavras, talvez sem intenção da sua parte (pois ninguém tem domínio sobre o que lhe vem à mente), não sei como elas mesmas, dando voltas de cá para lá, me ensinam o que lhe deva responder." 323 (I, v, 14). Licêncio esclarece, afinal, que não há relação de condicionamento entre uma explicitação intencional ou formalizada (assim como entre o entendimento conceitual), e a percepção do Uno advindo da totalidade percebida na ordenação do real. Com efeito, este não depende daquela, tampouco a pressupõe.

Mas o passo seguinte na argumentação exposta por Licêncio cuida de traçar nítida linha demarcatória entre causalidade e sentido, ou ainda entre nexo causal e senso histórico. Exemplificando com a hipótese de um adivinho que vaticina o registro de suas discussões, Licêncio argui que este jamais poderia chegar a termo em suas profecias, se não remontasse cada elo da sucessão de nexos causais que ensejou o momento que ora vivenciam. Assim, no quadro da ilustração de Licêncio, o adivinho caldeu que predissesse a discussão teria

323 “Quanta et quam multa facta sunt ut haec loqueremur! [...] Postremo tuus etiam ipse sermo, te fortasse id non agente (non enim cuiquam in potestate est quid veniat in mentem), sic nescio quomodo circumagitur, ut me ipse doceat quid tibi debeam respondere." 
necessariamente, sob pena de compor um registro falho ou lacunar - e portanto sem nexo ou sentido - que dar conta dos fatos e coisas insignificantes, cuja posição na sequência temporal não pode ser prescindida, visto formarem elos cuja ausência romperia a própria sucessão de nexos causais: “... o que quer que seja o esvoaçar das folhas no campo, o que quer que faça em casa esse desprezível animalzinho, certamente isto é tão necessário na ordem das coisas como estes escritos." Evidencia-se, neste passo argumentativo, que Licêncio tem presente, na conta de explicação factível dos acontecimentos, a ideia de fluxo contínuo e intermitente compondo sucessão temporal histórica, ou seja, a história é composta pela crônica factual do suceder dos eventos, numa linha sem solução de continuidade, o que supõe impossibilidade de ocorrência de vácuos na linearidade causal: "Pelo que peço que ninguém me pergunte por que ocorre cada coisa. Basta-me saber que nada se faz, nada se produz, sem que alguma causa o tenha feito e produzido." ${ }^{324}$. Torna-se claro que, para Licêncio, o sentido do fio contínuo histórico está em seu todo resoluto e finalizado, e não em cada elo ou segmento da linha de nexos isolados, que por si só seriam, por vezes, totalmente insignificantes, mas adquirem sentido histórico no seu todo (per)feito. Numa palavra: não são os fatos que fazem a história, mas sim esta, em sua totalidade perfazida e composta univocamente, é que faz vir à tona o nexo causal a ser atribuído a cada fato isolado e em si, o que equivale a dizer que, no curso histórico em sua totalidade, a insignificância individualizada simplesmente não existe.

Agostinho, entretanto, atento e ávido pela conclusão do jovem entusiasmado, parece não se deter nesta visão da história como fluxo contínuo e linear, cujo sentido é revelado ou clarificado em seu final. Após questionar a respeito da ética intrínseca à ordenação universal, Agostinho avança para o questionamento no terreno ontológico, mais incisivamente acerca de possível contradição no âmago da disposição ontológica dos seres em ordem entitativa, inquirindo acerca da possibilidade de algo se dar, não propriamente fora da ordem, mas em sua contradição. A resposta de Licêncio acentua a coerência argumentativa - vale dizer: a força com que pautara até então suas intervenções. Em consonância ao que dissera, ele responde enfaticamente que nada pode ser contrário à ordem universal, pois tal hipótese assenta-se necessariamente numa impossibilidade, qual seja, a de que algo possa se dar fora da ordenação real, o que de pronto se mostra absurdo, pois implicaria em algo não causado, noutras palavras: algo sem ser, pois a ordem (nexos causais/causalidade) “ocupa o todo e se mantém no todo",325 (I, vi, 15), ou seja, a totalidade do ser é ordem, nada lhe podendo ser fora de si, nada ocorrendo

\footnotetext{
324 “Quare iam, rogo, nemo ex me quaerat cur quidque fiat. Satis est nihil fieri, nihil gigni quod non aliqua causa genuerit ac moverit."

325 "...totum occupavit, totum obtinuit?"
} 
fora da sequência temporal componente da totalidade, do que resulta que tudo o que podemos conhecer situa-se nesta totalidade. Mais: até mesmo a aparência de contradição, vale dizer: o erro, encontra-se inserido na ordenação universal, pois não há erro sem causa, ainda que tal série de causas "erráticas" venha a se situar na ordem universal. Assim, as séries de causas intermediárias ou secundárias, ainda que algumas aparentem irrelevância, situam-se inexoravelmente na totalidade causal e universal, evidenciando-se que tal relação - séries causais intermediárias (paralelas ou convergentes entre si) e totalidade - representa uma variação, de cunho propriamente agostiniana, ao problema arquetípico platônico da relação uno/múltiplo ${ }^{326}$. Tal vigor de coerência, exposto com ardor e nitidez, não passa desapercebido a Agostinho, maravilhado ante a exposição feita pelo jovem que, pouco tempo antes, não acreditava fosse capaz de filosofia.

\subsection{2) Segunda discussão: definição preliminar de ordem}

O início da segunda discussão (I, ix, 27), já no dia seguinte, fornece em realidade uma primeira definição de ordem, dada pelo próprio Agostinho no contexto de sua exortação ao prosseguimento da interlocução, bem como no espírito de louvor contemplativo e reverencial à ordenação universal, como que hipostasiando-a: "a ordem é aquilo que, se a conservarmos em nossa vida, nos leva a Deus" "327. A postulação como via intermédia entre o ser humano e Deus clarifica o significado teleológico de tal definição, elucidando-a como perfazimento temporal do percurso a ser feito para se alcançar a divindade. Têm-se, pois, a partir desta definição preliminar de ordem, o início propriamente do coração do diálogo, cuja importância, de per si evidente no conjunto dos diálogos de início, assume caráter de fundamento perene dentro do escopo de toda a obra agostiniana, como ressalta Claudio Moreschini na ressonância de outros autores $^{328}$.

Mas um matiz torna-se, a par de seu locus na definição, determinante para a caracterização presente da ordem: esta é algo predisposto e dado ao ser humano, e sua conservação compõe tarefa vigilante deste. Trata-se pois de um meio ou caminho já disposto ao ser humano, requerendo-lhe observância diligente e obediente. Assim, Agostinho pauta a realização e consecução do caminho para se chegar a Deus, pela conservação da ordenação

\footnotetext{
326 “... no intuito de identificar o que nela (conceituação agostiniana de ordem/ordenação) há de próprio, cabe destacar dois aspectos, intensamente vividos por Agostinho: a experiência da desordem e a exigência de resposta para a questão essencial de toda a metafísica, a saber, a da relação entre o Uno e o múltiplo." - OLIVEIRA E SILVA, 2007: 15.

327 "Ordo est quem si tenuerimus in vita, perducet ad Deum" [I, ix, 27]

328 "'́́ significativo o fato de que Agostinho tenha dedicado uma obra específica a esse problema. A ordem deriva de Deus e está presente por toda parte; [...] Segundo [Jean] Pepin, a ideia principal sobre a qual se baseia todo o pensamento de Agostinho é a noção de 'ordem', ...” [MORESCHINI, 2008: 463]
} 
como meio de vida humana. Viver - cuja culminância de realização consiste no conhecimento e comunhão com o Deus Criador da ordem - consiste, nesse sentido, em coadunar-se à ordem predisposta à existência, e que em realidade lhe condiciona o direcionamento e feitura de atos. E, ao mencionar a possibilidade, na continuidade da definição ora discutida, de não se chegar a Deus pela inobservância da ordem cósmica, Agostinho emenda de pronto que "supomos $e$ esperamos que haveremos de chegar (a Deus)...", clarificando o escopo teleológico da ordenação universal ora definida, tecido no contexto criacional e providencial.

O cuidado para com a observância da ordem estende-se, na continuidade da fala agostiniana, até mesmo para o detalhe do registro escrito do diálogo, quando Agostinho, ao lamentar a ausência de outras pessoas, ressalta que estas "irão ler nossos escritos porque nos propusemos não perder as palavras elaboradas sobre estas questões e, como que as amarrando com uma corda, fixar por escrito as mesmas questões que poderiam escapar da memória", terminando por fornecer, obliquamente, uma como que teoria da escrita na qual esta passa a ser expressão da ordenação do logos discursivo em registro memorial, apontando de quebra à memória histórica como feitura ordenada das vivências temporais. Vislumbra-se, nestas protodefinições da gramática enquanto registro histórico, a atividade humana como recriadora da ordem que governa o universo, atividade divina por excelência e que o homem, no contexto da ontologia teocêntrica registrada no Gênesis, herda por mandato de Deus ${ }^{329}$.

\subsection{3) Definição de ordem segundo Licêncio}

Licêncio, instado por Agostinho com uma invocação emendada à fala exortativa com que iniciara este segundo ciclo de discussões, fornece então sua definição: “A ordem é aquilo pelo qual são feitas todas as coisas que Deus estabeleceu” ${ }^{330}$ (I, x, 28). Igualmente ancorada e tecida em escopo teleológico, esta definição guarda entretanto diferença fulcral para com a agostiniana, exposta pouco antes: se a primeira dizia respeito à atividade da ratio, através da observância diligente, para se realizar no chegar até Deus, a segunda está voltada, primordialmente, à feitura e constituição dos entes por parte de Deus. Nesse sentido, podemos dizer que a definição agostiniana volta-se à ordo cognoscendi (et agendi), por parte da ratio; ao passo que Licêncio caminha para a ordo rerum em seu estatuto ontológico criatural. Pode-se mesmo dizer que ambas assentam-se na verticalidade perpassante da totalidade criatural dada primordialmente ao conhecimento humano, sendo que a definição agostiniana perfaz o

\footnotetext{
${ }^{329}$ Cf. as narrativas da criação em Gênesis 1 e 2, nas quais se reserva ao homem a função de nomear e, portanto, ordenar a criação que lhe é apresentada pelo Criador. Cf. NOVAES, 2007: 30, em notação alusiva a tal atividade humana (no contexto porém do que intitula como uma "ontologia da significação").

330 "Ordo est, inquit, per quem aguntur omnia quae Deus constituit."
} 
movimento vertical na ascensio mentis rumo a Deus, ao passo que a proposição de Licêncio faz cursar a verticalidade cognitiva em descenso, de Deus ao mundo. Ambas convergem, porém, na instrumentalidade e no caráter intermediário da ordem universal, tornada meio de atuação divino e humano, em realidade espaço de encontro entre as esferas divina e humana, noutras palavras: região de confluência e contato entre a divindade e humanidade. Clarifica-se, pois, que a ordenação compõe: a) uma região já dada de antemão à sensibilidade e compreensão humanas; b) intermédia entre Deus e o ser humano; c) índice de graduação da atuação e da presença divinas quanto à realidade conhecida; e d) instrumental pelo qual o homem conhece a atuação divina e chega até Deus.

\section{2) As disciplinas liberais e ascensão da ratio a Deus (II, i, 1 - xvi, 44)}

Ao iniciar o Livro II do De ordine com uma espécie de balanço, ou avaliação propositiva, acerca das duas primeiras discussões sobre a noção e o conceito de ordem registradas no Livro I, Agostinho pretende uma vez mais antepor (ou mesmo pressupor) o escopo teleológico da discussão norteante do diálogo: a percepção humana - e portanto racional - da providência divina no curso da história, aceita inicialmente nos "mistérios da fé". Nesse sentido, ele reinicia propriamente a interlocução qualificando as discussões ocorridas no Livro I, numa avaliação geral que é (dada a forma da convicção em que é exposta), ela própria, uma percepção da ordenação divina no governo da realidade humana: “... parece-me que o fato de tanto tempo ter sido empregado no discurso com que eu tentatava afastá-los daquela leviandade não aconteceu fora de ordem e do beneplácito de Deus", para logo em seguida relembrar a definição instrumental de Licêncio a respeito da ordem universal ("aquilo pelo qual Deus faz todas as coisas”). Agostinho parece identificar ambos os campos de atuação divina: a ordem é a boa disposição e/ou estabelecimento das coisas e fatos em curso na realidade humana e mundana. Assim, a ordem é boa e, na mais fiel tradição platônica, pode-se afirmar ser a ética a correta percepção e avaliação da ontologia subjacente à boa ordenação da realidade pelo Criador ${ }^{331}$. O bem é a feitura e o perfazimento das atitudes em observância da ordem presente e permanente na realidade criatural, que lhe possibilita mesmo sua apresentação como totalidade orgânica ${ }^{332}$.

Ora, precisamente a correlação entre ética e ontologia, nesta retomada da definição fornecida por Licêncio no Livro I, permitirá que Agostinho faça avançar a questão para a

\footnotetext{
331 "O Deus de Agostinho, criador e supremo ordenador, tem as características do demiurgo e da ideia do Bem, de Platão." (MORESCHINI, 2007: 463) Vide, contudo, a crítica tornada célebre por Gilson a tal identificação, e mesmo à verificação, no pensamento antigo, da ideia monoteísta da divindade: GILSON, 2006: 54-67.

${ }^{332}$ Cf. MORESCHINI, Idem.
} 
necessidade de se equacionar, de modo preciso e claro, a relação entre o Criador a ordenação da criação, objetivando a clareza da distinção entre ambos (ante o perigo de se incursionar nas heresias de cunho panteísta): “Como Deus faz todas as coisas com ordem? (...) Ele age com ordem estando dentro da ordem ou, porventura, estando ele fora da ordem, todas as demais coisas são governadas por ele?". Porém, se o modo como Agostinho equaciona a relação Deus/ordem termina por revelar o real intento de tocar na difícil questão acerca da transcendência divina do Criador em relação à ordem enquanto tal - tomada em si na acepção criatural - e se esta lhe condiciona de alguma forma, a resposta oferecida por Licêncio proporciona o equacionamento da relação entre a ética ontológica pressuposta à ordenação divina, permeando-a em realidade; e o problema do mal presente nesta mesma ordem universal, em si mesma boa. O mote inicial de sua resposta fornece nova definição, embora oblíqua, da ordem, ao estabelecer a necessidade de ordenação a partir da diferença, a qual enseja a formalização de relação ontológica, ou seja, a disposição de coisas que, diferentes entre si, necessitam de ajustamento em harmonia e ordenação, pois a igualdade supõe a desnecessidade de se harmonizar e ordenar entes diferentes, posto que não há diferenciação. Por conseguinte, há ordenação somente entre seres, coisas e fatos que, a partir de sua distinção ôntica, ensejam a composição da totalidade unívoca, a qual ocorre somente em ordenação teleológica. Necessitam contudo ordenarem-se para a composição da totalidade: "Não há ordem onde tudo é bom. Porque há entre as coisas uma grande igualdade que não requer ordem., 333

Clarifica-se, pois, neste ponto do De ordine, a impostação de um estatuto ontológico da ordem, anterior à relação ser/ente, cujo escopo último, por seu turno, evidentemente remonta ao plano Criador/realidade criatural. Dá-se que, em igualdade ôntica, as partes ou seres não se ajustam entre si, pois estão de pronto já igualados na medida perfeita do ser. A necessidade de ordenação decorre - assim resta evidenciado - a partir da diferenciação que se revela, afinal, como degradação do ser, ou decréscimo no ser (ou mesmo, e ainda: descenso no ser). Note-se, em decorrência da necessidade de se deter e precisar tal ponto do diálogo, que a diferença entitativa, ilustrada pelo descenso ontológico, em si não compõe perda ou degeneração, mas separação e distensão, pelo que, na finalidade de permanecer e dispor-se em uno, a alma necessita perceber as coisas e os seres separados e distendidos na totalidade da realidade dada ao conhecimento, a qual somente é composta e se apresenta como tal a partir do ajuste e da

\footnotetext{
${ }^{333}$ Moreschini [2008: 463] precisa que, na conceituação agostiniana de ordem, “de uma parte não há nada fora do mundo, que é o tudo; de outra, dentro do mundo não há nada que fuja à ordem. [...] onde tudo é bom, não há distinção e não é necessária a ordem."
} 
harmonia das de-gradações e dissensões do ser nos entes, evidenciando-se que o totum e o esse possibilitam a percepção da ordem, a qual por sua vez remete a estes como seu telos intrínseco e constitutivo. Por conseguinte, somente se pode falar e perceber em graduação/gradação nos seres - e, consequentemente, ordenação a partir da diferença entitativa - tendo em vista primeiramente, e sobretudo perenemente, a totalidade anteposta a qualquer ato de distinção e junção, ou diferenciação e união, efetuado pela ratio. Esta somente se exercita - e Agostinho o elucidará logo adiante - a partir da percepção do totum essente à realidade percebida, mormente - assim o veremos - na simultaneidade temporal em que se dá sua atividade dialética. Em suma, no arremate do ponto de partida da retomada da discussão no início do Livro II: a presentificação à percepção humana da ordem, da totalidade e do ser é perfazida em simultaneidade. A fala seguinte de Licêncio permite tal arremate, ao clarificar que totalidade compõe a percepção ética do bem e mal, conjuntamente a tudo que existe: "Pois, quando dizemos 'tudo o que existe', certamente não nos referimos somente às coisas boas. Donde se deduz que todas as coisas que Deus administra são governadas com ordem.".

Deparamo-nos, de súbito, com uma definição da razão em II, xi, 30: “A razão é o movimento da mente capaz de distinguir e estabelecer conexão entre as coisas que se conhecem. ${ }^{2334}$. A proximidade para com o estatuto ontológico da ordem, a que aludimos anteriormente, ressalta imediata: em simultaneidade à percepção da totalidade ordenada da realidade criatural, a razão constitui-se no ato que diferencia e une, noutras palavras: efetiva a diferença ontológica cognitivamente, em ajustamento e harmonização das partes na composição da totalidade universal. Ressalta imediato, neste ponto, o paralelo com a conceituação da racionalidade ofertada no Livro II do De libero arbitrio, em termos praticamente convergentes: a razão ostenta a percepção do todo, em simul à sua distinção e percepção da singularidade, constituindo-se no momento/instante da simultaneidade de base que permeia toda sua atividade e que, na tentativa que ora efetuamos em nossa pesquisa, intentamos evidenciar como traço essencial peculiar ao pensamento agostiniano. De fato, a racionalidade apresentada nos textos iniciais atua sempre a partir da totalidade que, instituindose como dado primeiro, exaure-se temporalmente a cada passo do conhecimento, de maneira que o passo seguinte conjunciona o todo no imediato de sua exsurgência, bem como no instante de sua insurgência cogitativa, das quais decorrem a temporalidade como feitura. A racionalidade é o fio de conduto concretizante/"feitural" de tal percurso, à medida que fundamenta os passos graduais do conhecimento, permitindo a "costura" dos passos na

334 "Ratio est mentis motio, ea quae discuntur distinguendi et connectendi potens" 
totalidade teleológica que, partida do esse primordial, consuma-se na presentificação do Vere Esse final e no qual a multiplicidade, passo-a-passo instituindo-se temporalmente à luz da atemporalidade, é mosaicizada e eternizada na manifestação do verbo (ato divino eterno).

A razão é primeiramente ato, "movimento da mente". Tal caracterização supõe que o entendimento humano é exercido e possui como espaço de ocorrência a multiplicidade e a diferença entitativa, dado que na igualdade não há movimento. Mas se a razão diferencia, é justamente para unir. Observemos que a atividade de distinção e união compõe autêntico binômio conceitual cuja constituição acena - ou mesmo repousa - na simultaneidade da atuação bipolar. Com efeito, o movimento de separar e unir constitui atuação anímica de consecução, supondo simultaneamente o perfazimento de um todo, ou totalidade, dado de antemão e de forma perene à racionalidade, como telos ou meta à qual esta tende; e em meio à diferenciação do todo na multiplicidade atestada, de pronto e de imediato, pelos sentidos. Assim, totalidade/unidade percebida e diferenciação em multiplicidade correspondem aos polos do binômio conceitual acima exposto, cuja simultaneidade da imediatez com que se dão ao conhecimento vem a ser condição necessária para o movimento ou exercício da razão, constituindo-se em atividade de perfazimento da realidade enquanto totalidade, meio predisposto para se chegar a Deus.

Agostinho, porém, precisa logo em seguida que tal atividade é para poucos, "porque para aquele que está disperso nos [...] sentidos é difícil voltar-se a si mesmo.". Observa-se, vez mais, que o recolhimento na interioridade, ou a visão em univocidade que enseja a totalidade, constitui princípio de atividade da ratio, a qual somente é exercitada na simultaneidade do conhecer o ser sendo ${ }^{335}$.

\section{3) Percurso de gradação dos seres}

Situamo-nos enfim no percurso de graduação expresso pelas artes liberais, a ser efetuado pela ratio em seu itinerário para atingir e contemplar a perfeição e Deus. Agostinho passa à caracterização e definição do próprio esforço da atividade pela qual a razão procedeu e perfez as artes da gramática e da retórica, descrito inicialmente como tendo sido efetuado "através de definições, divisões e sínteses" (II, xiii, 38). Observemos que a tríade da atividade principia pelas definições, que antecedem as atividades de perfazimento e consecução efetuadas pela ratio na composição do conhecimento. Poder-se-ia dizer que, no âmbito da tradição platônica esposada por Agostinho, a ideia e a essência universal antecedem seu

\footnotetext{
${ }^{335}$ Cf. a interpretação de Werner Beierwaltes a respeito do conceito de ser no pensamento de Agostinho BEIERWALTES, 2000: 33.
} 
exemplar empírico, ou a forma inteligível predispõe a representação sensível. Porém, se resulta indiscutível ser congênere ao neoplatonismo em sua origem e feição, parece-nos igualmente haver diferenciação fundamental na apresentação final a que procede Agostinho no tocante à racionalidade: a atividade de princípio efetuada na visualização e concepção da totalidade expresso pela definitio - enseja e acompanha a atividade-fim efetuada na divisão e reunião ou síntese. Numa palavra: as operações componentes do ato de intelecção dão-se ao mesmo tempo, dado que a eternidade da verdade racional movimentada pela atividade do entendimento predispõe-se desde o seu princípio instaurativo, permeando-o e lhe sendo até mesmo fundamento perene e simultâneo à sua consecução.

\section{A) As disciplinas da palavra/comunicação [incursão horizontalizante (II, xii, 35 - xiii, 38)]}

- Gramática - Agostinho descreve o surgimento e a formação da gramática como ensejados, basicamente, pela necessidade funcional da racionalidade ser partilhada e comunicada, ou seja, pela funcionalidade da nomeação das coisas e seres pela razão, cuja onipresença conclama à união entre as partes sob seu signo; o que equivale à coordenação, entre as partes equivalentes, e sua ampliação numa totalidade que permita sua visualização e composição, posto que a fala se expressa somente a partir da delimitação. Ora, comunicar a ordenação da multiplicidade equivale a compor e justapor, numa palavra: sequenciar e numerar, o que origina a morfologia e fonética. Assim, pode-se falar que a gramática perfaz como que a primeira superação da dicotomização entre a miríade sensível e a unidade racional, na horizontalidade da comunicação entre iguais, ou seja, entre a humanidade.

- Literatura - Agostinho assevera que a numeração e a métrica da comunicação, ensejadas pela necessidade de se delimitar ordenadamente as possibilidades de expressão ornada, conduzem por sua vez à sistematização do partilhado, ou seja, à memória da vivência e da fala discursiva, o que equivale a dizer que a literatura compõe a disciplina do repertório histórico do vivido e comunicado.

- Dialética - Ato decorrente e contínuo, Agostinho passa à conceituação da disciplina resultante desta atividade motriz da racionalidade, meio de consecução de todas as outras artes e ciências: "Pois como podia passar a outras construções se antes não distinguisse, notasse e classificasse seus próprios instrumentos e meios e passasse adiante para produzir a disciplina das disciplinas, que se chama dialética?" "336 (II, xiii, 38). Para além da reiteração da herança platônica evidenciada em tal qualificação, é possível a percepção do esforço agostiniano no

\footnotetext{
336 “Quando ergo transiret ad alia fabricanda, nisi ipsa sua prius quasi quaedam machinamenta et instrumenta distingueret, notaret, digereret proderetque ipsam disciplinam disciplinarum, quam dialecticam vocant?"
} 
ressalto do caráter de decorrência deste instrumental-mor da razão, em relação às percepções simultâneas contidas no ato primordial da razão (definição, divisão e síntese). A dialética somente é postulada e se forma, enquanto disciplina, a partir da atividade primordialmente efetuada pela razão ao voltar-se a si mesma, traço característico e constituinte, por sua vez, da interioridade enquanto espaço fundamental à sua atuação (da ratio). Assim, temos que o exercício da razão compõe-se de ato primordial, através do qual se enseja a constituição das artes e disciplinas produtivas do conhecimento humano, dentre as quais a dialética enquanto exórdio às demais artes: "Esta (a dialética) proporciona a metodologia para ensinar e aprender ${ }^{337}$ (Idem). Têm-se pois que, na percepção da ordenação da realidade criatural, a razão dispõe-se em ato primordial (tríade definição/divisão/síntese) e consecução sequencial (dialética), momentos relativos ao que antecede e ao que movimenta a percepção do real, respectivamente.

Ressalte-se ainda (em paralelo a esta postulação dos momentos constituintes da percepção, por parte da razão, da ordem perpassante e conducente de toda a realidade) que Agostinho identifica, nas duas menções à tríade operadora da razão feitas nesta passagem, o momento da definição com o ato de notar o esse levado adiante pelo entendimento humano, ou seja, a percepção do esse (ou a consecução da definição do ser das coisas, seres e fatos) equivale, na epistemologia agostiniana exposta na passagem ora detida, ao momento da notitia dada ao intelecto, à novidade que se dá e se mostra à ratio. E, analogamente, ao momento da síntese colocado na primeira menção à tríade cognitiva, vemos a postulação da atividade classificatória efetuada pelo intelecto, do que decorre ser a atividade de união já uma ordenação em classes (realidade ordenada no todo). Em seu ensaio acerca da funcionalidade da dialética, tal qual herança da tradição platônica, no pensamento agostiniano, Uhle a apresenta precisamente na condição de ambiência conducente e/ou perpassante da execução da intelecção em cogitatio (tal como vimos no De libero arbitrio II), na precisa acepção de instrumental portanto, em aspecto estritamente técnico - disposto à intelecção da realidade [UHLE, 2012: 26-29].

\section{B) As disciplinas da visão/contemplação [percurso verticalizante (II, xiv, 39 - xv, 42)]}

Somente a partir da caracterização do ato racional, e sobretudo da nomeação e definiç̧ão da dialética enquanto sua instrumentação principal, é que Agostinho passa, em II, xiv, 39ss, à descrever a gradação ascensional efetuada através das demais disciplinas liberais. Ele inicia ressaltando o caráter de decorrência deste percurso: "Daí, a razão quis elevar-se à beatíssima

\footnotetext{
337 "Haec docet docere haec docet discere"
} 
contemplação das mesmas coisas divinas. ${ }^{\text {338 }}$. O desejo beatífico resulta decorrente (Hinc) da atuação racional até então levada a efeito, ao mesmo tempo que a esta impele na ascensão à contemplação divina. Note-se que o desejo advém da ratio, ou melhor, é a própria ratio que deseja. Este querer racional afigura-se, no contexto peculiar da descrição que ora temos, como consequente e resultante ato de realização a ser efetuado após o exercício nas artes liberais até então trabalhadas, quais sejam, as artes discursivas ou da palavra (dialética inclusa), rumo à sua própria consecução e finalização. Resta, por conseguinte, que a elevação a) constitui-se na efetividade de uma aspiração/busca do intelecto, resultando num impulso motor da ratio, ou seja, potência e ato; b) decorre dos exercícios nas artes da palavra, dentre as quais a dialética, cuja atuação resultara, por seu turno, de um voltar-se da ratio para si própria, ou seja, um ato prefigurativo da interioridade; e c) almeja contemplar, ou seja, deseja visualizar o todo. Nesse sentido, a ascensão desejada pela razão configura uma busca pela efetividade da predisposição contida em si mesma, ou seja, abarcar a totalidade através da qual ela (razão) já percebe a realidade ordenada através de seus exercícios de nomeação (gramática) do real. Assim, podemos afirmar que o desejo racional por ver a totalidade da realidade situa-se, ontológica e temporalmente, em momento anterior à própria efetivação ou perfazimento da visão do todo, atuando pois como espécie de posse antecipada, mapeamento de itinerário, do objeto a ser alcançado pela visão (beatífica). Em suma, o desejo vem a ser, em nosso texto, a antecipação e a prefiguração impulsiva da razão, modo de projeção à qual se lança a ratio após delineado seu objeto pela voluntas. Precisemos pois em que consiste a elevação à contemplação, em si (como resta exposto por ora) um ato volitivo.

Para que se a compreenda em toda sua exposição e feitura, Agostinho cuida de justificar a gradação a ser levada a efeito pela razão: trata-se de recurso adotado com o fito de que a razão, uma vez alçada/ascensionada, não venha a "cair" ${ }^{339}$. A ideia subjacente à ilustração adotada é a de suporte à permanência na altura alçada, tal qual degraus de uma escada que igualmente proporcionam apoio ao vetor ascensional, e suporte à sua manutenção. Nesse sentido, a gradação constitui-se em instrumental adotado pela razão para a consecução de desejo já delineado em seu objeto e impulso, porém não ainda concretizado.

A contemplação visa as "coisas divinas" (rerum divinarum). Agostinho coaduna, neste passo, a ascensão intelectual (cujo itinerário constitui-se na ordenação gradual das ciências e artes liberais, herdada da tradição platônica como um de seus tópicos exemplares) com a herança da doutrina cristã acerca da visão beatífica. De igual modo, dá-se a identificação entre

\footnotetext{
338 "Hinc se illa ratio ad ipsarum rerum divinarum beatissimam contemplationem rapere voluit." 339 "caderet"
} 
a visão da totalidade ontológica e a "contemplação beatíssima". Esta, juntamente com seu objeto ("coisas divinas"), compõe a meta do desejo racional de se elevar dos elementos sensíveis. Assim, a predisposição da razão ao alvo, o qual deseja alcançar e atingir através da elevação por gradação, sugere que esta (a razão) irá se conceituar como tal, em conformidade ao que de antemão está posto e desejado.

A ilustração da verticalidade oferece ainda outro flanco de exploração. Agostinho esclarece que a razão, ao buscar a gradação, movimentou-se "segundo a ordem com base no que já havia conseguido" 340 (Idem). Se, como foi explicitado anteriormente em nosso estudo, a própria percepção da ordenação é possibilitada pela captação da totalidade anteposta ao intelecto; e se, como acabamos de expor, esta configura objeto do desejo (contemplação) racional, tendo por finalidade a visão beatífica, temos pois que a totalidade predisposta ao senso e noção de ordem, situa-se no princípio do ato intelectivo pelo qual proceder-se-á ao itinerário ascensional da razão, bem como em seu final, numa palavra: perpassa-o (permeando a ordenação gradativa das artes liberais a ser percorrida pelo intelecto) e fundamenta-o. Do que decorre ser a ascensão intelectual, numa primeira acepção, a concretização e feitura da intersecção entre o inteligível e o sensível. Ora, a verticalidade compõe, nesse aspecto, precisamente a junção entre a multiplicidade sensível e a unidade inteligível, bem como entre a contemplação beatíssima e a totalidade ordenada; e ainda entre a visão das coisas divinas do Criador, e a sustentação oferecida à intelecção da mesma (visão), pela concretude ordenada das ciências criaturais. Verticalidade vem a ser, em suma, junção e feitura, elo de harmonização e união entre as expressões da realidade criatural e o Criador.

$\mathrm{O}$ desejo não se exaure em postular a contemplação beatíssima como seu propósito final. Ele necessita de beleza em seu perfazimento e percurso. Agostinho perfilha o Belo junto à visão beatífica como objeto do desejo racional, tornando-o em verdade uma de suas expressões. A beleza ostenta igualmente a característica de junção entre a concretude ordenada da realidade criatural, e as "coisas divinas" contempladas. Mas a beleza desejada racionalmente possui traço único, diferencial de toda outra expressão desejável, respectivo ao modo de sua aquisição ou percepção. Trata-se do Belo imediato. O texto trata de minuciar até mesmo o ato intelectivo próprio de tal conquista ou captação, qual seja, a intuição, do que decorre diretamente sua imediaticidade intelectual, anterior à mediação sensível. Agostinho trata, porém, de esmiuçar a aquisição do belo, por assim dizer, rumo à contemplação beatíssima, expondo sua contradição fundamental em relação à situação humana enquanto ser

340 “... viam per suas possessiones ordinemque molita est." 
em trânsito intermédio entre a multiplicidade sensível e a unidade inteligível: "Desejava aquela beleza que só ela (razão) podia intuir [...]. Mas os sentidos a impediam.”341 (Idem)

A explicitação da contradição fundamental da situação humana constitui-se em ocasião para Agostinho expor o refinamento de sua originalidade conceitual acerca das tentativas de se equacionar e solucionar questão incontornável aos círculos da tradição platônica: conflito entre limitação sensível e infinitude inteligível. Como que milimetrando o uso de cada termo, Agostinho inicia afirmando que os sentidos tornam-se esmiuçados (paululum aciem torsit) pela ratio, o que equivale a dizer (ou mesmo pode ser traduzido) que os sentidos são como que exauridos ou levados a termo pela razão, em sua especificidade de atuação ${ }^{342}$. Dito de outra feita, pode-se colocar que a razão aponta para a insuficiência dos sentidos, quando estes pretendem fixar ou deter a racionalidade, fazendo-lhes ver que a aspiração ao todo portada pelos sentidos revela-lhes a aspiração à totalidade e à união que possuem em sua própria atuação. Exaurir e esgotar equivalem, certo sentido, em nivelar para igualar e/ou ordenar.

- Música - Agostinho ilustra o conflito inicial entre os sentidos e a razão, tomando a percepção do contraste entre o som ambientado e vivenciado pela audição, e seu significado. Perceber a diferença entre som e significado é, num certo sentido, perceber a diferenciação entre o particular e o todo. Como que agudizando ainda a percepção desta diferença, Agostinho a enfatiza qualificando-a como decorrente do "poderosíssimo poder de discernimento"343 exercido pela razão, ressaltando através do superlativo que a captação da totalidade é exercida na concretude da sensibilidade, guiada pela racionalidade em seu exercício próprio de definir, discernir e unir. Como que corroborando este aspecto concreto da percepção, Agostinho esmiuça a descrição tipológica da sonoridade percebida, na tríade vocalização-sopro-percussão (Idem).

Porém, a continuidade do percurso ascensional efetuado pela razão via artes liberais se perfaz com a asseveração de Agostinho acerca da necessidade permanente, por parte do entendimento, de que a sensibilidade se dê a conhecer através da beleza, cuja essência reside na ordenação harmoniosa de seus conteúdos e partes. Por seu turno, tal harmonização repousa na medida temporal, através da qual são compostas escalas de variações dentro de certas medidas prévias, resultando no todo harmonioso e ornado. Assim lemos: "Mas a razão notou que isto (a percepção sonora do trecho anterior) seria uma matéria de pouco valor se os sons não fossem

\footnotetext{
341 "Desiderabat enim pulchritudinem, quam sola et simplex posset sine istis oculis intueri; impediebatur a sensibus"

342 "Itaque in eos ipsos paululum aciem torsit, qui veritatem sese habere clamantes, festinantem ad alia pergere importuno strepitu revocabant" [II, 14,39].

343 "potentissima secernendi"
} 
ornados com certa medida de tempos e com uma variedade combinada de acentos agudos e graves. ${ }^{344}$ (II, xiv, 40). A ornamentação - traço característico fundamental à descrição que ora tomamos - elucida-se como essencial à estética da harmonia esboçada aqui por Agostinho, cuja expressão "variedade combinada" (moderate varietate) bem pode ser tomada como lapidar de sua teoria da sensibilidade harmoniosa. Por seu turno, a ornamentação (figurarentur) descrita em nosso texto evidencia que, para Agostinho, a atividade de figurar ou compor elementos harmoniosos possui como nota preponderante - e mesmo essencial - a percepção de que as partes da multiplicidade captada sensivelmente tendem ao todo ordenado e figurado/ornado pelo senso do belo racional.

Entretanto, no quadro da epistemologia agostiniana em questão, a sensibilidade, embora autônoma e atuando como espécie de sistema nervoso central de todo o conhecimento humano (na medida em que atua como fonte primeira e unívoca da captação dos dados exteriores), não possui estatuto próprio de origem enquanto espaço independente de percepção e entendimento. Agostinho ressalta-nos que a razão "reconheceu que as bases para tudo isso (percepção da ornamentação sonora em métrica e escala temporal) estavam na gramática, onde havia dado os nomes de pés e acentos, quanto tratou das sílabas com cuidadosa consideração" "345 (Idem). A passagem claramente situa a estética como tendo matriz junto ao ato de nomear/considerar efetuado pela verbalização e discursividade, o que, noutros termos, equivale a remontar a sensibilidade temporal da medida junto à percepção da totalidade ontológica (consideração/nomeação). A percepção sonora harmoniosa, pela qual se capta a escala temporal métrica componente da musicalidade, remete, instância última, ao ato de consideração da multiplicidade em totalidade, do qual resulta a nomeação e classificação da tonalidade sonora das sílabas e palavras, como se verifica da continuidade da explanação agostiniana: “... ela (razão) procurou dispor e ordenar aqueles pés e acentos em certas ordens...", clarificando-se que resultou necessário à razão harmonizar - vale dizer: colocar dentro da ordem - as tônicas verbais presentes nas falas estruturadas, vindo ainda a "compactar articulações". Configura-se, a partir do texto, que o ato da disposição e ordenação - atitudes prévias e primordiais - se lança como fundamental à percepção estética do entendimento e da racionalidade, os quais têm por base a percepção da totalidade "compactada e articulada".

Mas Agostinho reserva ainda outra função à estética, mais precisamente à percepção da sensibilidade harmoniosa do belo, ou estética. Ele nos faz entender que, com o fito de não ferir

\footnotetext{
344 "Videbat autem hanc materiam esse vilissimam, nisi certa dimensione temporum et acuminis gravitatisque moderata varietate soni figurarentur"

345 "Recognovit hinc esse illa semina quae in grammatica, cum syllabas diligenti consideratione versaret, pedes et accentus vocaverat".
} 
a suscetibilidade da percepção (iudicium), a razão "estabeleceu uma medida de onde se podia reverter, voltar, dando-lhe, por isso, o nome de verso" (modum statuit unde reverteretur et ab eo ipso versum vocavit - II, xiv, 40). A incisiva funcionalidade que Agostinho denota à atividade racional, coadunada e coordenada ao senso estético da beleza harmoniosa, não deixa a menor dúvida quanto à necessidade de que a medida se torne autorrecorrente e reversível (por assim dizer, a partir do texto). Jamais se poderia exagerar a importância deste trecho ímpar, de resto evidentemente fundamental às teorias epistemológica e estética agostinianas. Agostinho estabelece, ou elucida, a necessidade da reversibilidade perene na percepção estética coordenada pela racionalidade. Com efeito, a sensibilidade estética se efetiva (se adjudica iudicium) na percepção do todo, por sua vez dado recorrente e condicionante de todo e qualquer ato racional de medida sensível a compor harmonização da multiplicidade concreta. Assim, a versificação afigura-se como a atuação de autorrecorrência da percepção totalizante da sensibilidade, por sua vez condicionando todo e qualquer ajustamento e harmonização efetuado pelo "gosto estético" (juízo racional). Resulta, pois e enfim, que a reversibilidade termina por constituir-se e apresentar-se de forma simultânea à composição métrica racionalmente coordenada, o que, um vez mais, pontua o eixo da simultaneidade a dar sustentação ao quadro epistemológico agostiniano.

A notação quanto à reversibilidade se coloca, de per si, como conducente à numeralidade essencial e presente em toda a fluência da sensibilidade concreta. Agostinho reconhece que, para além da métrica, o que resulta como aparente disformidade e ultrapassagem da medida estabelecida, a rítmica igualmente flui com "pés razoavelmente ordenados". Ato contínuo, Agostinho postula que, neste grau da ascensão intelectual via artes liberais, a razão, através da métrica harmoniosa e da rítmica, reconhece em ambas a constituição do domínio do número ou cadência. E, uma vez mais, no despojamento de uma descrição cuja amplitude ultrapassa a pormenorização e o detalhamento em tópicos seletivos, deparamo-nos com preciosidades incontornáveis. Ao estabelecer a numeralidade como fio contínuo perpassante da sensibilidade estética das artes até então estudadas, Agostinho trata de estabelecer relação de decorrência entre domínio e completude, ou entre dominar e perfazer. Ora, à luz de tal junção, vislumbra-se que, na teoria agostiniana de uma estética geral do conhecimento humano, o ato de domínio equivale ao perfazimento da realidade em ordenação e harmonização. O domínio constitui-se no momento primeiro de ordenação da totalidade em harmonia e beleza sensível. Dominar, pois, é sustentar e permitir o perfazimento do todo (e não abarcá-lo ou possuí-lo). Tal é o caráter de fundamentação desta dominação, que Agostinho nele reconhece reflexo divino: a razão, no perfazimento cognitivo da realidade (perficere) 
“investigou, pois, com suma diligência a sua natureza e descobriu que havia números divinos e eternos,..."346 (II, xiv, 41). E, na sequência expositiva do regnare exercido pela numeralidade perene e perpassante da concretude sensível, eis que Agostinho lapida expressão conceitual, de concisa densidade e verdadeira epítome do desenvolvimento até então apresentado, tornandose por isso absolutamente basilar: “... aquilo que a mente percebe está sempre presente e se aprova como imortal, ...”347 (Idem). A força da incisão presente na sentença não deixa margem a dúvida alguma: a perceptividade racional perfaz perenidade e simultaneidade ao exercício do conhecimento e do entendimento humanos, lhe sendo anterior enquanto totalidade ordenada tornada ponto de partida para a razão realizar seu exercício de superação e elevação da sensibilidade "quebrada" (desunida) para a conexão perfeita nas artes e disciplinas liberais. A perenidade perceptiva é atesta pelo prosseguimento de Agostinho na exposição, ao notar a fugacidade do dado sensível que, enquanto tal - e contrariamente ao percebido pela razão "perde-se no passado e deixa sua impressão na memória".

- Geometria - Na trilha intelectual de ascensão através das artes liberais, Agostinho qualifica sua continuidade como avanço, ao situá-la no âmbito do sentido visual, mais especificamente como exercício potencial de amplitude da visão: "Depois, avançando no poder de visão dos olhos e percorrendo a terra e o céu, ...” ${ }^{348}$ (II, xv, 42). Novamente, a descrição do nascedouro/feitura de uma disciplina tem como seu princípio ativo estabelecido, a apresentação de um sentido possível da noção do todo. Observa-se que o potencial visual relaciona-se diretamente à amplitude alcançada pelos olhos, cujo escopo abrange toda a realidade criada ("percorrendo a terra e o céu”), ou seja, a totalidade da multiplicidade é unificada/dominada no olhar sensível, agudizado (como colocara Agostinho no trecho imediatamente anterior - xiv, 39) o sentido da visão através do exercício de seu poder máximo. Por conseguinte, a visão do todo proporciona (e, sobretudo, predispõe) a visão do belo, e a beleza equivale, uma vez mais, ao sentido da totalidade. Mais: somente a partir do sentido visual do todo é que a razão vem a ser preenchida e realizada. A consecução deste preenchimento/realização é trazida por Agostinho na concretude da metrificação do dado sensível: “... na beleza as figuras (agradavam à razão), nas figuras as medidas e nas medidas os números, ...". Com efeito, o que agrada (efetiva e realiza) a razão não se situa em si mesmo, mas para além do sensível, tal qual fosse o dado concreto refinado até atingir sua essência suprassensível. A sequência figura - medida - número, de evidente herança pitagórica via

\footnotetext{
346 "perficere: inspexit diligentissime cuiusmodi essent; reperiebat divinos et sempiternos, ..."

347 "Et quoniam illud quod mens videt semper est praesens et immortale approbatur"

348 "Hinc est profecta in oculorum opes et terram coelumque collustrans,..."
} 
tradição platônica, ilustra perfeitamente - e em realidade a efetua - a via de ascensão perfazida pela razão, o que indica ser a geometria como que a disciplina antonomásica e modelar do itinerário de elevação racional até as "coisas divinas", evidenciando em sua exposição a sobredita carga traditiva pitagórico-platônica, mas assentando-se num traço peculiar à epistemologia agostiniana quando contrastada com esta sua matriz histórico-filosófica: parte-se necessariamente da totalidade como condição pressuposta à meta já apresentada e visualizada, para alcancá-la através do perfazimento da elevação racional via artes liberais, culminando em contemplação beatífica. Se na tradição platônica o itinerário tem por início uma reminiscência não totalizada da essência ou forma ideal, cujo valor de impulso é posto em atividade pelo dado sensível, no trajeto agostiniano temos que uma totalidade é de pronto explicitada, visualizada e considerada/compreendida enquanto ponto de partida da ordenação universal, a qual por sua vez compõe e ordena a sequência a ser perfazida/perfeita pela razão até a contemplação.

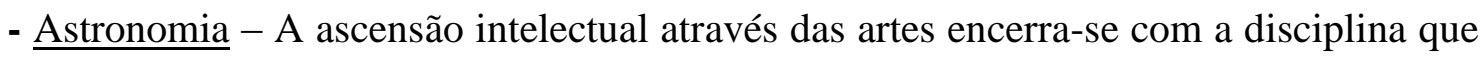
Agostinho qualifica como "grandioso espetáculo" para os espíritos religiosos. Se, partindo da visão do todo da realidade sensível e concretamente múltipla, a razão pôde catalogar e coordenar a feitura de figuras em medidas, e estas em números, para sistematizá-las enquanto disciplina das medidas dos seres neste mundo, qual seja: geometria, o mesmo olhar racional busca elencar os dados que alçam a atenção da razão ao céu. Invariavelmente, parte-se da terra para o céu. Agostinho frisa que a razão teve sua atenção voltada para o céu, devido ao movimento deste, que a "convidava a refletir (considerar) com diligência" (diligenter considerandum invitabat), ressaltando em seguida a peculiaridade que lhe alçou o olhar atento: “... ali (no céu) dominavam aquela medida e ritmos (números) através das regularíssimas alternâncias dos tempos (...) cursos invariáveis e definidos dos astros (...) espaços de tempo ordenados ..." (grifos nossos). Nota-se que o movimento possui características que, a princípio e essencialmente, lhe são antitéticas: regularidade (exatidão), imutabilidade e ordenança. O que significa, pois, afirmar que o movimento ressoa e é cursado com base em aspectos que, por essência, negam a mudança? Talvez possamos, a partir de tais oposições e conexões através de antíteses, visualizar que a medida e o número instanciam-se como funções de consumação e realização da multiplicidade sensível na inteligibilidade com a qual fora criada. A ordenação que outra coisa não é senão a composição ou feitura da realidade sensível na totalidade una através da medida e do número - é o meio de superação da dicotomização entre sensível e inteligível. Em suma, a astronomia talvez venha a ser, enquanto essencialmente contemplativa, como que um prelúdio sensível à visão da perfeição beatífica, posto que o poder visual dos 
olhos, situado entre a sensibilidade e a racionalidade, foi refinado e agudizado até sua completa superação e fusão.

Talvez pudéssemos traçar o paralelo comparativo entre as duas disciplinas, com a ilustração de que a disciplina da terra é constituída pela atividade de feitura e perfazimento da realidade múltipla sensível em unidade harmoniosa e teleologicamente ordenada, através da razão, lançando mão do instrumental métrico e rítmico, no refinamento e na ultrapassagem do sensível rumo à sua essência, da figura ao número; e a disciplina do ceu, por sua vez, institui-se enquanto arte da contemplação por excelência, da constatação dos regularíssimos e invariáveis cursos dos corpos celestes, que são dados ao entendimento humano para percepção do traço de infinitude e eternidade que se faz presente a toda a realidade criatural, na forma de uma apresentação já per-feita ou totalizada num "grandioso espetáculo"349.

\section{C) Perenidade e culminância: essência numérica e número fundamental}

No término da descrição do percurso de elevação racional até a contemplação divina, Agostinho conclui, em tom sumarizante, que as "harmoniosas correlações das partes (...) sobressaíam (...) naquelas medidas" (II, xv, 43), o que lhe conduziu à contemplação do todo composto pela essência perpassante das artes liberais: "Considerando e refletindo em si mesma (razão) tudo isso, contemplava-o (o todo, ou totalidade essencial das disciplinas)...", fazendo com que a razão, compreendendo a superioridade do número e da métrica sobre as coisas sensíveis, se erguesse e se fortificasse ${ }^{350}$ (Idem). Tais asseverações ressoam como vislumbre à finalização e conclusão essencialmente pitagóricas levadas a efeito por Agostinho: a razão "percebeu que (...) todo o seu poder estava na força dos números (...) e começou a conjecturar que ela mesma talvez fosse aquele número pelo qual todas as coisas eram numeradas com cadência." ${ }^{351}$. A identificação postulada resulta de evidente concepção ontológica herdada da tradição neopitagórica: a alma (racionalidade) identifica-se ao seu exercício, o qual atesta sua identificação com a imaterialidade, inteligibilidade, imutabilidade e eternidade. De fato, a razão atesta ser congênere - e mesmo identificar-se com - à numeralidade essencial que permite 1) por um lado (e a exemplo das disciplinas discursivas e da palavra), juntar e ordenar a multiplicidade da sensibilidade, conferindo e atestando-lhe identidade ontológica ao inserir-lhe na totalidade universal, bem como - e sobretudo - a (co)relação entre o inteligível e o sensível,

\footnotetext{
349 Relembremos que, no projeto posterior da Enciclopédia, Agostinho deixa de incluir a astronomia, possivelmente ancorado no juízo depreciativo que, ao longo das eras, foi-se aplicando mais e mais à esta disciplina, no seio da Igreja.

350 "quae tamen in illis dimensionibus manifestius eminebant quas in seipsa cogitando atque volvendo intuebatur verissimas"

351 “...et suspicari coepit seipsam fortasse numerum esse eum ipsum quo cuncta numerarentur...”
} 
iniciando pela comunicação entre tais estatutos ou registros ontológicos (disciplinas e artes da palavra e discurso), e culminando em sua superação, não propriamente sob o signo do despojamento e da obsolescência, mas sim pela ótica do perfazimento através do avanço em plenificação na ordenação do real em totalidade racional; e 2) noutro viés, perpassar e agudizar, como se expressa Agostinho, os sentidos e a concretude da realidade por eles percebida, pela perenidade da percepção racional que fundamenta e ordena (institui ontologicamente) a própria sensibilidade, posto que a numeralidade "completa tudo" (totumque - II, xiv, 41), numa palavra: culmina a percepção fragmentada e mutável fornecida pelos sentidos, na plenificação dos números, na perenidade e simultaneidade da harmonização métrica com que se identifica e se reconhece na razão.

\section{2) De quantitate animae}

Texto emblemático do período de Cassicíaco, e sobremaneira ilustrativo da preocupação agostiniana em assimilar os conteúdos das tradições gregas - enquanto instrumental de pensamento com o fito de penetrar e inteleccionar o dado da fé fundamentada, o diálogo De quantitate animae traz uma das exposições mais elaboradas e amplas do itinerário da ascensão anímica para Deus. Ao tratarem propriamente da grandeza da alma, Agostinho e Evódio terminam por realizar um sumário da atuação anímica em relação ao dado sensível, à imaginação e à ascensão do conhecimento humano da esfera múltipla e sensível, para a realidade espiritual infinita e eterna. O espectro/lastro temático amplo, e explicitude das abordagens relativas às correntes gregas, impõe-nos a delimitação de nossa tentativa de leitura, rigorosamente, à 1) atuação do ato imaginativo, em vias de sua funcionalidade no 2) quadro geral da itinerância ascensional da alma humana, expondo a esta como consumação da amplitude de atuação anímica. Ademais, a par da ilustração quanto à assimilação da filosofia no interior do exercício da fé cristã, e em precisa decorrência da riqueza com que "mapeia" o percurso inteleccional da ascensão anímica, o texto do De quantitate animae possibilita-nos, igualmente, nítido contraste entre o "espírito" que move a ascensão agostiniana, em relação aos paralelos herdados das tradições gregas. Efetivamente, o duplo registro da atividade perceptiva anímica, entre o sensível e inteligível, é visualizado - assim o intentamos expor, em nossa leitura - como itinerância de perfazimento compreensivo da realidade conhecida, em uma como que "mosaicização" da intelecção do universo, em que o vislumbre de identidade entre o ponto inicial e a convergência final permitem entendê-la como feitura intelectual do já conhecido pela fé, sem níveis de excludência nem regiões de exceção - contraste maior para com os percursos descritos nas correntes gregas. 


\title{
5.2.1) Ato de imaginar
}

Para delinear a especificidade da alma em relação aos seres corpóreos, e no intuito de expor sua natureza no tocante à sua amplificação e/ou ilimitação ${ }^{352}$, Agostinho inicia por descrever a Evódio a feitura de figuras geométricas em crescente amplitude, como o ponto, a reta, o triângulo e o quadrado. $\mathrm{O}$ acento na descrição da ampliação intenta ilustrar como toma forma e desenvolvimento o conceito de expansão, ou espacialidade crescente, porém não (ainda) explicitada como infinita ${ }^{353}$. Nesta exposição - que se apresenta em seu início como primordial ou mesmo fundante, ratificando-se enquanto tal ao longo do tratado - ressalta-se um movimento do pensamento que será evidenciado como a) sua atuação própria e perene, compondo b) seu traço constitutivo estrutural; bem como, e enfim, c) o fundamento permanente da simultaneidade verificada entre sua perenidade presencial ao corpo e sua superação da corporalidade: $\mathrm{o}$ ato de imaginar. Assim o texto o expõe:

\begin{abstract}
Ag. Como explicar então que a alma, ligada ao pequeno espaço do corpo, é capaz de representar (exprimi imagines) imagens imensas, muito maiores que o corpo, [...] ? Que imensa profundidade e amplitude, que imensidade de coisas pode estar contida na alma? [...] Ev - Já não sei o que dizer, nem consigo explicar o que tais noções produzem no meu entendimento. [...] Ag. - Então, já não parecde que a alma é semelhante ao vento? $\boldsymbol{E} \boldsymbol{v}$. - De modo algum, pois o ar, cujo movimento chamamos vento, poderia encher apenas este espaço visível, enquanto a alma pode representar inúmeros espaços e um universo tão grande coisas, que nem podemos imaginar um espaço capaz de conter tudo isso. [an. quant. $\mathbf{v}, 9$ - Vozes $]^{354}$.
\end{abstract}

A) Caracterizações do ato imaginativo: tradição platônica, escola aristotélica e neoplatonismo

Na exposição levada a efeito no De quantitate animae, imaginari assume de início caracterizações herdadas, via neoplatonismo plotiniano, das construções platônica e aristotélica. A sequiência delineada em v, 9 carrega remissões alusivas aos conceitos expressos por $\phi \alpha v \tau \alpha \sigma \iota \alpha$ - phantasia em ambas as escolas. Nestas - sobretudo nos textos platônicos - a operação de formar imagens incumbe-se de demonstrar que o espírito matemático/geômetra opera a partir do não-sensível, ou incorpóreo.

Platão aponta, de maneira uniforme em vários textos, para a atuação imaginativa como inexoravelmente ligada à opinião. Sofista 264a-b, passagem antonomásica da definição

\footnotetext{
352 an. quant. iii, $4 \mathrm{ss}$

${ }^{353}$ an. quant. $\mathrm{v}, 7 \mathrm{ss}$

${ }^{354}$ Aug. Cur ergo, cum tam parvo spatio sit anima quam corpus est eius, tam magnae in ea possunt exprimi imagines, ...? [...] quanta et quam multa memoria nostra contineat, quae utique anima continentur [...]?- Ev. Non invenio quid respondeam, nec satis explicare possum, quantum me ista moveant [...] - Aug. Non ergo iam tibi tale aliquid videtur, qualis ventus est?- Ev. Nullo modo: nam etiamsi aer iste cuius quasi fluctum ventum esse probabiliter creditur, universum istum mundum possit implere, innumerabiles tales tantosque mundos secum anima imaginari potest, quas imagines quo spatio contineat suspicari non possum.
} 
platônica, apresenta a imaginação como "estado de espírito" caracterizado pela "mistura de sensação e opinião" ${ }^{\text {355. }}$. Entretanto, a sequência do texto apresenta a imaginação como "congênita à racionalidade" 356 , permitindo que se conclua pela alternância, ou mudança aleatória, entre falsidade e veracidade.

Se, no decorrer da história, a tradição platônica acerca da atividade anímica a fez contrapor-se de forma sistêmica ao sensível//corpóreo ${ }^{357}$, a posição de Aristóteles foi tomada, não em contraposição formal, mas como alternativa de desenvolvimento à de seu antigo mestre. Historicamente, a doutrina aristotélica definiu-se como a postulação da imaginação enquanto região intermediária entre o sensível e o inteligível/racional. Se Platão tratou de afiançar em conjunto phantasia e aisthesis à doxa, Aristóteles irá situar a primeira, conjuntamente à segunda, não mais como fiança da opinião, porém como vetor da sensibilidade à racionalidade. Outrossim, a sensação - e mesmo a sensibilidade, enquanto dispositio da alma à notitia do dado sensível, por sua vez componente do segundo grau ascensional que Agostinho irá expor ao final do De quantitate animae - ensejará a doxa, a qual traz atrelada em seu bojo, por assim dizer, a phantasia, jamais alçada, na acepção aristotélica, para além do circuito do sensível. Será porém a phantasia que, por seu livre exercício (ou o livre pulsar anímico), tratará de evidenciar, no âmbito da herança platônica, o movimento fundamental da alma como contrastante para com a fluidez e parcialidade da fragmentação dos sentidos, trazendo em seu transfundo a essência pela qual seu movimento é explicado e posteriormente delineado (com o fito de se direcionar, no desenvolvimento platônico, à Ideia e sua instância ${ }^{358}$, ao passo que, no pensamento aristotélico, atua como base elementar à intelecção abstraente).

A exposição da atitude imaginativa por parte de Aristóteles ocorre nas sequencias explicitadas com o fito de se articular, satisfatoriamente, uma crítica que funcione como alternativa à definição de phantasia no interior da psicologia ancorada na teoria das formas dos platônicos, na qual o princípio anímico não subsista de forma independente do corpo, antes the

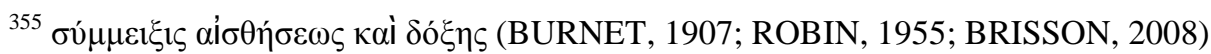

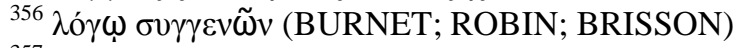

${ }^{357}$ Vide o item b de nossa Introdução, p. 21-27. Cf. ainda CASERTANO, G. Paradigmas da verdade em Platão, São Paulo: Loyola, 2010 (italiano: 2007), sobretudo, quanto ao contexto de nosso presente estudo, o capítulo 7 (p. 155ss, ainda que indevidamente sumário e abreviado); e de Elisabetta CATANNEI Entes matemáticos e metafísica, São Paulo: Loyola, 2005 (italiano: 1996), cujo capítulo 1 corresponde de maneira direta ao presente ponto de nosso texto (p. 21ss).

${ }_{358}$ Cf. o texto áureo da alegoria da caverna na República, VI, 514a-517. Para uma aproximação com outros textos platônicos descritivos da ascensão do conhecimento racional - notadamente o Banquete em 211-212 - vide LIMA VAZ, Henrique C. A ascensão dialética no Banquete de Platão in Escritos de Filosofia VIII - Platonica, São Paulo: Loyola, 2011, p. 49-67 (texto originalmente publicado em 1959), sobretudo p. 57-59.
} 
seja a forma essencial ${ }^{359}$. No interior desta pretensão, as tentativas caminham no sentido de penetrar nas atividades anímicas, com o propósito de clarificar sua suplantação em relação ao sensível, porém de maneira tal que lhe deva a atividade principial e fundamental, pela qual a potencialidade se manifesta em ato. Aristóteles apresenta a imaginação como ato intelectual compondo momento intermediário entre a percepção e o entendimento, elo preciso da sensibilidade para com a racionalidade:

[...] a imaginação é algo diverso tanto da percepção sensível como do raciocínio; mas a imaginação não ocorre sem percepção sensível e tampouco sem a imaginação ocorrem suposições. [De Anima, III, 3, 427b15] $]^{360}$

Em contraste com o fio estrutural (neo)platônico de suas especulações, o pensamento plotiniano ostenta uma caracterização do ato imaginativo essencialmente aristotélica. A exemplo da definição verificada acima no De anima, os textos das Enéadas a respeito trazem usos diversos de Phantasia, phantastikón e phantasmata, nos quais é possível compor um quadro cuja preocupação axial encontra-se na demarcação e visualização do campo de atuação da alma, o qual de per si ilustra sua essência e origem espiritual, eterna e ilimitada; ao mesmo tempo que sinaliza sua condição atual, na qual todo ato anímico necessariamente parte da sensibilidade impressiva e noticiante, em transição à realidade inteligível depurada do amálgama formado pela corporalidade. Para Plotino, a atuação em imaginação da alma coaduna-se - explica-se, mais propriamente - perfeitamente à dupla itinerância da alma, que verificamos nos primeiros capítulos de nossa pesquisa, a respeito das tradições pitagórica e platônica. Enquanto reminiscente de sua congenitalidade à esfera espiritual e inteligível, e alusivo portanto, de maneira originária, ao movimento de processão da alma em relação ao Uno, o ato imaginativo ocorre, por sua vez, precisamente no exercício anímico de natureza espiritual, remetendo por conseguinte, de maneira teleológica, à necessidade da alma de retornar à sua origem una e espiritual, ilimitada e eterna.

\footnotetext{
359 Cf. De Anima, III, 3, 431b2-10. Aristóteles compôs o tratado na fase ateniense tardia, quando de sua permanência derradeira na cidade com a instalação do Liceu. Na maturação definitiva de sua obra em tal período, Aristóteles teria elaborado seu pensamento em alternativa ao dos platônicos, após vinte anos de frequentação da Academia e um "início platônico" de sua filosofia. Tal é a tese de Werner Jaeger em seu clássico trabalho sobre o Estagirita - JAEGER, W. Aristoteles, tradução de José Gaos, México: Fondo de Cultura Económica, $1^{\text {a }}$ edição, 1946 (terceira reimpressão: 1995), p. 58-60. Vide ainda p. 380-381, onde Jaeger aduz o fato de que Aristóteles reúne, no tratado sobre psicologia, a investigação acerca da sensibilidade e do movimento como revelador de "uma persistente atitude fisiológica", em contraste com os "adeptos das formas". Em uma extensa nota da introdução que elaborou à sua própria tradução do De Anima, Maria Cecília Gomes dos Reis expõe um breve panorama da discussão científica acerca da proposta de Jaeger e sua resultante para o entendimento da contrastação do Estagirita para com Platão - DOS REIS, M.C.G. Introdução ao De Anima, São Paulo: Editora 34, 2006 ( $1^{\text {a }}$ reimpressão: 2007), p. 33-34.

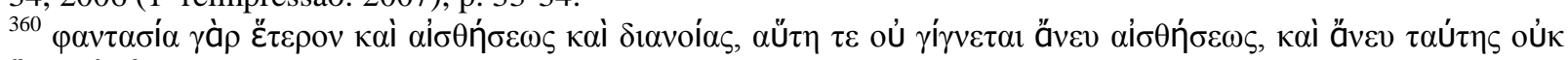

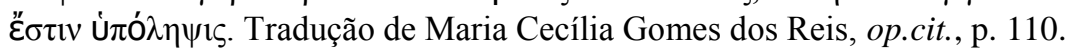


Tal esquematização da condição de atuação anímica, resultante das movimentações originária e teleológica próprias da alma humana, perfaz-se numa região intermédia entre as realidades sensível e inteligível (o que evidentemente permitiu o uso plotiniano "sob medida" da teoria aristotélica da imaginação), ilustrando dessa maneira a qualificação que se estabeleceu como referencial nos estudos dedicados à psicologia plotiniana: a "natureza anfíbia da alma no pensamento plotiniano",361.

\section{B) Representação cataléptica no pensamento estoico}

Se as referências aos pensamentos platônico e, sobretudo, aristotélico impõem-se de per si através da herança plotiniana de Agostinho, será contudo a escola estoica que lhe fornecerá, ainda que em contraponto, mote decisivo para seu desenvolvimento da atividade imaginativa como ato primordial e fundante da alma em relação à sua própria expansionalidade e transcendência. Frequentemente tomados na conta de empiristas, os estoicos apresentam, segundo Rachel Gazolla, uma "teoria do conhecimento complexa e muito específica", na qual o "estatuto do sensivel", ao contrário da simplificação na qual são os estoicos no mais das vezes classificados, é "cuidadosamente pensado" [GAZOLLA, 1999: 115]. De modo convergente, Roberto Bolzani Filho acentua a nota de originalidade de tal epistemologia, face aos construtos até então excludentes entre si, mormente a tradição platônica e a escola aristotélica:

\footnotetext{
${ }^{361}$ Études Platoniciennes, publicação anual dirigida por Jean-François Pradeau, dedicou um número de seu volume de 2006 precisamente a esta temática: LAVAUD, L. (ed.) Études Platoniciennes III - L'âme amphibie: études sur l'âme selon Plotin, Paris: Les Belles Lettres, 2006. Loraine Oliveira descreve, em termos praticamente idênticos, o papel da imaginação em Plotino, apresentando-o igualmente como decorrência da essência anímica humana (potencialidade de conhecimento, acentuando o matiz aristotélico presente na teoria do conhecimento plotiniana), porém em sua pluralidade ativa, na relação direta com as partes da alma: “... dentre as faculdades cognitivas, a imaginação parece ser a única a possuir a mesma natureza anfibólica da Alma. [...] uma parte da imaginação está voltada para o sensível, e outra parte para o inteligível, correspondente cada uma a determinada parte ou função da alma." - OLIVEIRA, L. Entre o sensivel e o inteligivel: o estatuto intermediário da imaginação em Plotino in MARQUES, M.P. (org.) Teorias da imagem na Antiguidade, São Paulo: Paulus, 2012, p. 289. Outros estudos, porém, expõem o papel da imaginação plotiniana, a par da intelecção e do estritamente racional, de modo diverso à estratificação sensível-imaginável-inteligível. Nesse sentido, Laurent Lavaud situa o próprio ato dianoético como intermediário da polaridade sensibilidade/racionalidade, com o pensamento especulativo composto pela atuação da percepção sensível e da dianoia em conjunto, respectivamente as instâncias da sensibilidade, e da sucessão discursiva a partir desta - LAVAUD, L. La diánoia médiatrice entre le sensible et l'intelligible in ID. (ed.) Études Platoniciennes III, Paris, 2006, p. 29-31. Para Stéfan Leclercq, a importância do exercício da phantasia no interior do sistema plotiniano não se configura propriamente no terreno gnosiológico, e sim naquilo que classifica, tomando-a enquanto função vital (e mesmo teleológica) da alma, como "potência do não-saber", na acepção mística que caracteriza, segundo o autor, a visão do Uno em êxtase - cf. LECLERCQ, S. Plotin et l'expression de l'image, Mons: Sils Maria/Paris: Vrin, 2005, p. 51-55. Cf. ainda, para uma leitura crítica quanto às interpretações apoiadas num esquematismo dualistacompartimental "corpo-alma" de Plotino, o artigo de Andrés SANTA MARIA Observaciones sobre el dualismo 'cuerpo-alma' en Plotino in HYPNOS - Da Alma, Ano 10/nº 14, São Paulo: Editora da PUC-SP Educ, 2005, p. 103-125. Por fim, remetemos ao item c de nossa Introdução, onde procuramos apresentar um quadro sintético da teoria do conhecimento em Plotino, visando situar, em seu ínterim, o locus preciso da descrição plotiniana da ascensão intelectual da alma, da realidade sensível em retorno à realidade inteligível/espiritual, e ao Uno.
} 
Intelectualismo empirista ou empirismo intelectualista, como quer que a rotulemos, a teoria estoica do conhecimento será, por isso, algo bastante original, se comparada à tradição platônico aristotélica. Pois a sensibilidade, agora, não mais é vista como um obstáculo ao pensamento e ao conhecimento, à maneira platônica, ou como uma instância positiva, mas ainda precária, que, à maneira aristotélica, um trabalho de universalização viria necessariamente enformar. Isso tem como resultado que o dado imediato da sensação, logicizado pela cosmologia estoica, já seja "lugar" de verdade. Daí, um conceito técnico de representação - em verdade, algo inédito - fazer-se necessário, para dar ao sensível o direito de deter o critério de verdade. [BOLZANI, 2013: 125-126]

Ora, é precisamente essa complexidade teorética que funcionará como esteio preparatório e indutor à teoria imaginativa agostiniana, na medida em que se furta à estratificação ou redução das esferas da atividade da imaginação, vindo a deter-se entre os âmbitos sensível e racional, compondo, a partir da exclusão/rejeição mútua entre ambos, a atuação intermediária que viabiliza o trânsito anímico no ínterim da polarização ${ }^{362}$. Gazolla esquematiza a apresentação da teoria representativa estoica em quatro pontos: 1) representação propriamente $(\phi \alpha \nu \tau \alpha \sigma \curlywedge \alpha)$, a qual poderíamos (ainda que Gazolla não se valha do termo) qualificar como sensível; 2) compreensão ( $\kappa \alpha \tau \alpha \lambda \varepsilon \Psi 1 \sigma)$; 3) representação compreensiva ( $\phi \alpha \nu \tau \alpha \sigma \iota \alpha \kappa \alpha \tau \alpha \lambda \varepsilon \pi \tau \iota \kappa \varepsilon)$, vértice conceitual na apresentação da teoria representativa, porquanto possibilita a interseccionalidade racionalizada entre a afecção anímica provocada por algo na alma, e sua compreensão enquanto atividade de "participação do logos humano no logos cósmico", à maneira de inserção dentro de um movimento global e universal, com o qual deve a alma coadunar-se [GAZOLLA, 1999: 115]; e 4) o assentimento ( $\sigma v v \kappa \alpha \tau \alpha \tau \varepsilon \sigma 1 \sigma)$, momento culminante do juízo cognitivo, no qual afirma-se o compreendido enquanto assentimento de inserção na ordem cósmica (note-se que o assentimento não é voluntário, mas a culminância evidente - e portanto lógica - do conteúdo representado junto ao ato representativo) ${ }^{363}$. Neste quadro, o assentimento é o ato final da alma, sem evidentemente comportar ou fundamentar-se na volição, posto que, enquanto o ato de assentir às verdades representadas, desta não somente não tem necessidade, mas sim exercita-se enquanto momento compreensivo e finalizador, ratificador, das representações que se inseriram na alma através de sua atividade cataléptica $(\text { idem })^{364}$. Como teremos ocasião de verificar adiante, na teoria agostiniana a representação

\footnotetext{
${ }^{362}$ Bolzani aduz que "a representação, $\phi \alpha v \tau \alpha \sigma ı \alpha$, 'ponto de partida do conhecimento no ser vivo' [...] (AM VII, 163), concebida com tal estatuto e importância, expressa uma valorização provavelmente inédita da sensação ( $\left.\alpha \_\theta \eta \sigma i \varsigma\right)$, fundamentada no que terá sido talvez a primeira elaboração deliberada e completa de uma metafísica do realismo." [BOLZANI, 2013: 124]

${ }_{363}$ Vide igualmente, para uma exposição da impressão cataléptica nas várias correntes estoicas: HANKINSON, R.J. Epistemologia estoica in INWOOD, Brad (org.) Os Estoicos, São Paulo: Odysseus, 2006, p. 65-93 (cf. especialmente, para nosso estudo, p. 66-72).

364 "Aquilo que cabe voluntariamente ao intelecto, seu ato de assentimento a representações, se torna necessário

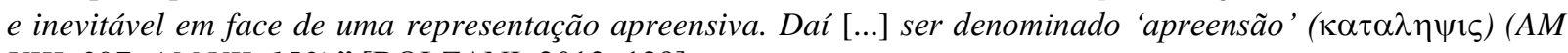
VIII, 397; AM VII, 153)." [BOLZANI, 2013: 129]
} 
comporta a volição como moto fundante/atuante, não para consignar em ratificação os atos e conteúdos representados, mas sim para atuar como vetor conducente na expansionalidade anímica que situa-se para além da determinabilidade sem entretanto dissolvê-la.

Com frequência é verificada, nos estudos agostinianos, a associação entre memória e imaginação, via de regra supondo-se a primeira uma como que instância depositária da segunda, ou ainda o seu repertório de sedimentação. Assim, em uma obra do século XIX, Jean Félix Nourisson aponta, com base no livro X das Confessiones, para uma visão de culminância do processo cognitivo no qual a sedimentação, tendo as imagens sensíveis como ponto de partida, ocorre a partir do uso especulativo destas, onde a recorrência ao elemento sensível de maneira incorpórea ou não-sensível, via memória, é possibilitada unicamente pelo imaginar que, em seu ato racional, instaura e institui a atualização do potencial memorial como culminância em recolhedura das notícias e dados compreendidos ${ }^{365}$ [NOURISSON, 1866: 155156]. Nesse sentido, enquanto "fiel depositária" do ato imaginativo em sua amplificação e perfazimento do real, a memória permite o mapeamento preciso da atuação imaginativa como amplificação em (ou rumo à) feitura do real em consumação contemplativa. Nas obras de maturidade - sobretudo no livro $\mathrm{X}$ das Confessiones a que já aludimos - Agostinho tratará de minuciar o papel da memória enquanto arcabouço perene do vivencial, transponente da temporalidade na medida mesma em que lhe aponta a superação. Evidentemente não é aqui o espaço para avançarmos em tal exposição (que exigiria, ademais, a análise dos aludidos textos de maturidade como fundamentação), mas o somente pontuá-la, neste momento de nosso estudo, tem por finalidade possibilitar o vislumbre das propostas principiais que Agostinho perfilha nos Diálogos de início e que, em nosso texto de base, apontam para o ato imaginativo como vetor volitivo da ratio para seu perfazimento de culminância no itinerário ascensional que perfaz rumo a Deus, no qual a completude ou consummatio se elucida como atualização na temporalidade, da eternidade professada (ou confessada) no ato primordial e instaurativo de fé.

Agostinho conduz a discussão através do instrumental da geometria, fazendo ver a Evódio que a figuração geométrica compõe exercício racional cuja elucidação aponta para a função ou atividade imaginativa do intelecto. Com efeito, se para a obtenção da imagem de um triângulo ou de um quadrado, torna-se necessário um speculum proporcional à espacialidade por aqueles ocupada, como explicar que a mente consiga formar imagens imensamente superiores à sua própria espacialidade? Por conseguinte, será a atividade imaginária que formará o eixo em torno do qual Agostinho se ocupará a fim de esmiuçar a natureza da alma,

\footnotetext{
${ }^{365}$ Note-se a pronta remissão à impressão cataléptica dos estoicos.
} 
no intuito de clarificar seu contraste essencial para com a matéria, bem como fazer culminar a atividade intelectiva - ou anímica por excelência, na medida em que, no pensamento agostiniano, a intelecção revela-se como a atividade constitutiva da identidade essencial da alma - na instância ontologicamente primordial que lhe acompanha e na verdade fundamenta seu múltiplo exercitar-se racional: a memória. Antes, porém, de voltarmos à abordagem da memória, detenhamo-nos na atuação imaginativa da alma, para entendermos como sua caracterização enquanto atividade de superação de delimitação ou determinação figurante, evoca ou traz presente a infinitude originária à qual a alma se reporta e na qual está situada de forma permanente, essencial e mesmo ontologicamente instanciada.

Ante a funcionalidade ora descrita da imaginação ou ato imaginativo no interior do pensamento agostiniano, resulta-nos clarificada, em nosso entendimento, sua distinção e, sobretudo, sua figuração própria para com os paralelos funcionais da phantasia no interior dos pensamentos platônico e aristotélico, bem como para com a phantasia cathaleptiké das correntes estóicas. Se, no que tange à tradição platônica, a phantasia pareceu de alguma maneira sempre atrelada à doxa, ou conhecimento impressivo/sensível; se, no que diz respeito ao sistema aristotélico, a phantasia ocupa o intermédio motor da sensibilidade material para o entendimento conceitual (do que herda Agostinho, certamente, o matiz da ambivalência mediadora); e se, na finalização do escopo comparativo, a impressão cataléptica estoica funcionará como mote inspirador para se pensar um contraponto antisensualista, então podemos ter por esclarecido que, na acepção agostiniana, a imaginação ocupa a função de colhedura do dado sensível, não intermediando seu transporte a um intelecto passivo, porém afigurando sua própria delimitação na medida mesma em que se mostra como ato de compor e perfazer a imagem, ou alteridade entitativa, da notitia dada à alma. A imaginação é ato principial ancorado na voluntas e presentificado na confessio (diferença capital em relação ao estatuto que ocupa na antropologia aristotélica e no pensamento estoico). Mas, efetivamente, a função primordial e fundante que a imaginatio desempenha na filosofia de Agostinho se dá a perceber quando, através de sua ocorrência como ato instituinte, a ratio procede a feitura do real em sua presença ante o absoluto e eterno, afigurando-se como Imago Dei precisamente porque amplificadora da realidade em sua totalidade e atemporalidade, per-feicionando-a na primordialidade da confessio e na culminância da contemplatio. A imaginatio vem a ser, pois, a própria amplitude da alma em ato instituinte. É o que a ascensionalidade anímica, exposta por Agostinho na culminância de seu tratado, ilustra e realiza. 


\subsection{2) Ascensão da alma para Deus}

No início do capítulo xxvi, Agostinho estabelece uma discussão acerca da relação conducente entre razão e ciência (conhecimento), aparentemente com o objetivo de clarificar a qual delas cabe a anterioridade ou prioridade na relação e, portanto, a fundamentação do saber humano. Mas a qualificação e/ou delimitação do campo de atuação da ratio, especificadas por Agostinho com a adjetivação de firmeza, faz com que a resposta de Evódio seja inevitavelmente ambígua: primeiro o assentimento de pronto, por este, à identificação de ciência com conhecimento ratificado pela razão; segundo, a asseveração de Agostinho de que, em realidade, os animais igualmente possuem conhecimento sem entretanto a ratificação da ratio, ao que Evódio responde hesitante e de modo ambíguo, citando o caso do cão de Ulisses; e, em terceiro, a agudização da questão com a pergunta de Agostinho acerca da preferência entre ambas baseada no caráter teleológico que porventura venham a ostentar. Observemos detidamente tal equacionamento.

A) A propositura inicia pela antecipação, em forma de interrogação mediadora por parte de Agostinho, do "critério de avaliação" entre ciência e razão: a causalidade final ou teleológica ostenta prioridade ou preponderância sobre as demais, posto que finaliza ou perfeiciona o conhecimento e, portanto, a ciência rumo ao saber pleno. Logo a seguir, Agostinho arremata, pois, tendo já a resposta confirmatória sobre a primazia do teleológico sobre a mediação (ou da causa final sobre a formal), com a formulação da questão mestra (xxvi, $50^{366}$ ): a ciência antepõe-se de forma conducente à razão, ou dá-se o contrário?

Inicialmente admitindo certa simultaneidade na relação conducente, para depois afirmar a prioridade da ciência, Evódio rapidamente caminha, após a objeção de Agostinho, para a afirmação do conhecimento inato ou inserto/inserido (xxvi, 50). Agostinho então faz ver que uma tal afirmação conduz a um contra-senso acerca do que até então fora dito, ao que Evódio reafirma seu posicionamento, chamando inclusive Agostinho à concordância factual de que a razão, sem dispor de dado algum (aliquid) antes (prius), jamais poderia atingir tal finalidade (ad summam pervenire - xxvi, 51). Observa-se, aqui, que o vocabulário do qual Agostinho lança mão como que prepara ou conduz à exposição da ascensionalidade potencial (ou expansional) da ratio rumo ao pleno e absoluto, que será afinal a culminância do tratado. Atingir a plenitude ou completude representa o próprio ato instituinte da ratio em seu posicionar-se ante a factualidade da scientia e do dado experiencial. Outrossim, igualmente observa-se que Agostinho rejeita a via inatista para a origem do conhecimento científico,

\footnotetext{
366 "per scientiam pervenimus ad rationem, an per rationem ad scientiam?” Observe-se que pervenimus aduz o matiz teleológico de culminância ou finalidade, e que se traduz com maior precisão por "atinge-se a razão".
} 
evidenciando-se que a interioridade não compõe forma de apriorismo epistêmico, mas o aspecto fontal para a contemplatio sumária, ou consumatio que terá ocasião na exposição da ascensionalidade da alma para Deus.

B) Agostinho decide então caminhar na interlocução introduzindo nova distinção: razão e raciocínio (rationem et ratiocinationem - xxvii, 52). E logo traz seu intento: razão é a visão maior (amplitude visual) da mente (mentis aspectus: "o olhar da mente", Vozes), raciocínio é o inquirir da razão (rationis inquisitio: "exercício da inteligência", Vozes - xxvii, 53). A distinção se revela fundamental para clarificar o que foi discutido até então, bem como será o mote para conduzir o diálogo doravante. Da correta percepção acerca do papel de ambos razão e raciocínio - advém, enfim, que ciência é a concretização da inquirição racional, ao passo que razão a (per)feição geral, ou visualização ampla, do conhecimento adquirido. E Agostinho finaliza esta seção fazendo ver a Evódio que, se de fato os animais possuem ciência, seriam então melhores que o homem, que por vezes não chega à ciência, o que causa a imediata rejeição de Evódio, ao que Agostinho prepara então a postulação intermediária acerca do papel da graça divina na condução da inquirição racional - e da ciência - rumo ao summus rationis proporcionado pelo aspectus rationis (xxvii, 54-56). Notamos que o fato de Agostinho pontuar o papel da graça, nesta altura da discussão, como vetor para se atingir a culminância da ciência na razão plena, clarifica que o itinerário anímico é muito mais "assunção que ascensão" ${ }^{367}$, e que o empuxo é vertical de cima para baixo, e não o contrário. Como também nos traz à luz diferença fundamental para com a processão plotiniana de retorno da alma ao Uno, ou ainda para com a ascensão anímica rumo ao Mundo das Ideias exposta no livro VI da República. Embora não possamos aqui aprofundar o sentido da passagem, voltaremos a ela mais tarde, quando da exposição dos graus de ascensionalidade anímica para o Absoluto, a qual, segundo Agostinho, seria impossível sem a assunção da Imago Dei (xxvii. 55).

3) A interlocução prossegue com a retomada da questão acerca da presencialidade corpórea da alma, ou com a identificação de sua extensão com a corporalidade, não sem antes repassar a defesa do estatuto do sensível anteriormente feita por Evódio, com Agostinho explicitando onde este se equivocara: sensação somente poderá receber o qualificativo de ciência, quando notificada e entendida pela alma, ou seja, quando não oculta racionalmente à alma, ou por esta entendida. Somente quando visualizada racionalmente, poderá a sensação receber o estatuto científico por assim dizer. Neste breve apanhado em conclusão, Agostinho traz à luz uma definição mestra acerca do conhecimento racional: tanto sensação quanto

\footnotetext{
${ }^{367}$ Definição proferida pelo Prof. Moacyr Novaes em aula do dia 31.03.2011.
} 
ciência formam conhecimento, pelo fato de ambos não serem ocultos à alma, ou seja, a con(s)ciência é comum à sensação e à ciência, esta porém como que ratificada, enquanto tal, pelo olhar racional $(\mathrm{xxx}, 58)$.

4) Na retomada da questão acerca da extensão anímica, clarifica-se o sentido propedêutico da discussão até então travada acerca do estatuto do sensível (xxx, 59-61). Sendo claro que a sensação somente poderá ser levada na conta de ciência quando da ratificação pela razão de sua notificação à alma, Agostinho traz à luz que a potencialidade de conhecimento por parte dos sentidos advém pois não da extensão corporal que porventura tenha a alma em sua união/identificação com a corporalidade, mas sim da atuação própria da alma, qual seja, o ato imaginativo (cf. v ,9).

Os capítulos xxxi e xxxii aduzem exemplos de imaterialidade anímica, ou se se quiser: de translucidez acerca da inequação, não apenas da alma racional por assim dizer com o corpo, mas quiçá até mesmo do princípio anímico com este. Quando determinadas partes de um animal, lagartas pequenas por exemplo, sofrem cortes ou perdas de pedaços, não ocorreu o efeito correspondente na alma, pois esta não sofreu perda de suas faculdades ou mesmo de sua atuação. Dá-se pois que a alma, em sua imaterialidade ou expansionalidade de superação em relação ao corpo, evidentemente não se restringe ou limita-se a este.

5) Enfim, a consumação e culminância do percurso da atividade racional da alma $(x x x i i i)^{368}$. Os itinerários ascensionais do espírito compõem temática já bastante conhecida nas tradições filosóficas gregas, platônica e plotiniana as mais célebres. Ainda que compartilhe tópicos fundamentais destes percursos, Agostinho intenta mostrar a magnitude e superioridade libertária da alma em relação às limitações do universo corporal, suas seduções e caducidades. Trata-se de uma perene expansão pela qual a alma gradativamente se liberta do mínimo rumo ao máximo, da limitação de atuação à grandiosidade da visão e contemplação do eterno e verdadeiro, pela qual, no entendimento e compreensão das verdades até então unicamente cridas, o sensível e corpóreo serão, pela verdade da ressurreição, igualmente ascensionados/assuntos na infinitude e libertação da eternidade. A gradação estabelecida por Agostinho decorre da pergunta de Evódio acerca do poder da alma. Na resposta direta, a exposição agostiniana compõe um mosaico do universo conhecido, percursionado então pela razão, intentando ilustrar que a potencia da alma abarca cada parte do todo em sua respectiva destinação e finalidade, culminando a alma em seu repouso (vale dizer: sua realização e finalização) "sabático", ou gozo divino. Atentemos à descrição da gradação percursional.

\footnotetext{
${ }^{368}$ Cf. a apresentação precisa de tal percurso em OLIVEIRA E SILVA, 2007: 137-139.
} 
5.1) Primeiro grau: vivificação e organização. Em seu primeiro nível de atuação, a alma dá vida e unifica num todo orgânico a corporalidade na qual se encontra. Trata-se pois de, a exemplo da atuação do Espírito na criação (Gn 1.2), vivificar e unificar para um sentido de ordem e finalidade, a matéria corpórea em si mesma morta e desagregada. A organicidade vivencial decorre, assim, da atividade anímica racional, de uma ratio que se verifica, em verdade, comum a todo ser vivo. A vida é, pois, o substrato do universo criado enquanto dado à existência pelo Criador, o selo de origem enquanto resulta, pela presencialidade da alma, em organicidade e unificação.

5.2) Segundo grau: ambientação e seleção. No segundo grau, a alma sobrepõe-se ao sensível, à medida em que não se restringe a vivificá-lo e animá-lo, mas sim em exercer sua atividade de escolha e decisão em relação à multiplicidade do sensível, não se limitando a um ou outro aspecto da realidade material, porém a todos percebendo e identificando (a exemplo do ser humano em Gênesis 2: identificando e nomeando as espécies).

5.3) Terceiro grau: culturalidade. Nesta etapa, observamos que a alma supera a ambientação junto à corporeidade e ao sensível, para estabelecer sua esfera própria de atuação, enquanto intencionalidade primordial em relação ao vivido e sedimentado em memória, ou seja, ao cultivado. O cultivo, ou cultura, de liberdade de atuação configurada em artes, técnicas, realizações várias e inumeráveis, representa a atividade própria da alma e o momento de superação em relação a todas as outras espécies animadas.

5.4) Quarto grau: purificação. Podemos afirmar que o quarto grau corresponde à etapa intermediária na ascensão anímica rumo a Deus. Até então, a atividade da alma relacionava-se, de alguma forma, ao mundo sensível e à corporalidade, e inevitavelmente sofria, em algum momento, sua influência ou interferência. Já a partir deste nível, anseia a alma por purificar-se e/ou libertar-se de tudo que possa implicar em qualquer forma de dependência do sensível, ou por ele afetado de alguma maneira. A alma descobre seu tesouro interno, muito mais precioso e digno da busca anímica que os bens deste mundo.

5.5) Quinto grau: vontade livre. Agostinho clarifica de forma direta em que se constitui este estágio: vontade livre em relação ao sensível. Pois o querer não implica necessariamente em posse e garantia do almejado, ao passo que, uma vez atingido este grau, a alma humana, livre e soberanamente, deseja unicamente o que não lhe perturba a liberdade e isenção de ânimo plenos, o que significa dizer que não mais encontra-se limitada, de maneira alguma.

5.6) Sexto grau: razão livre. Se até então a razão, como que voltada para outrem, não se manifestava serena e livremente na sua exercitação rumo ao Princípio Criador, eis agora o momento em que se alça a si mesma, em sua inteireza livre e soberana com relação ao limite e 
alteridade. Nada mais há que se volte a razão, em sua potencialidade e liberalidade, que the seja condicionante ou limitante, ao contrário: acima encontra-se a alma de tudo o criado, e por isso mesmo numa liberalidade plena e serena. Acima dela, nenhuma limitação criatural, somente o Criador. A criação restaurada e recapitulada está na amplitude (quantitate) da alma.

5.7) Sétimo grau: morada de Deus, habitação da razão. A contemplatio repousa a alma no descanso e gozo divino da adoração e louvor verdadeiro. Por que explicita Agostinho que esse grau - máximo da expansionalidade anímica - consuma o itinerário ascencional tendo por termo adoração e louvor? Adorar - e consequentemente louvar ou engrandecer - significa rendição plena ante o absoluto, reconhecimento de que unicamente digno de louvor é o que não está situado em nenhum dos graus ascensionados, mas acima da alma, posto que, além de Criador, é ilimitado e infinito.

Antecipemos a exposição de xxxv, 79, em que o próprio Agostinho nos oferece interpretação ou aplicação pedagógica da ascensionalidade anímica. O retorno à explanação acerca da ascensão da alma vem imediatamente após Agostinho deter-se na culminância da adoração a Deus. Como se, em repouso e serenidade contemplativa, na entrega desejosa ao Absoluto e Eterno, a alma pudesse retomar a visão do todo (aspectus mentis - a visão que retoma em feição plena) já mosaicizado e ascensionado (ou percursionado), e então pudesse entender (ratio) a realidade em sua grandeza e quantificação, no próprio agir da alma. E eis que Agostinho sumariza, temporal e espacialmente, o percurso resolvendo-o na simultaneidade dos atos de percurso ou gradação, para pontuar que “... pode ser que a alma realize a um só tempo todos estes atos" ${ }^{369}$. Esta simultaneidade de base, essencial e fundante, condição para o exercício de todo ato cognitivo e perpassante da intelecção ascensional feiturada e sumarizada no esse absoluto, é sobremodo ilustrada pela perfeição geométrica da figura circular ${ }^{370}$.

6) Em xxxiv. 78, Agostinho oferece uma definição lapidar que, à maneira de mote conclusivo, arremata a interlocução até este ponto e aponta com precisão para o objetivo maior da recém efetuada exposição sobre a libertação em graduação (atentemos que não se trata de uma hierarquia gradual pela qual, de um nível/grau superior, se dispensasse os inferiores, ou deles se abrisse mão, ou ainda os rejeitasse - estaríamos próximos da tradição platônica, neoplatonismo incluso) da alma: (re)conciliar sua grandiosidade em adoração (remissão/rendição) a Deus, na magnitude da liberdade (expansionalidade ilimitada, ou

\footnotetext{
369 “... et fieri potest ut haec omnia simul agat, ..."

370 "Chega-se ao fim dessa pesquisa mediante a procura do belo (A quantidade da alma 35,79). É um exemplo disso a figura do círculo, que é introduzida e ilustrada no tratado sobre a A quantidade da alma: ela é mais bela do que as outras por sua forma; [...] é a mais igual a si mesma, e a figura que possui a mais perfeita igualdade deve ser preferida..." [MORESCHINI, 2008: 465]
} 
ilimitude) - da qual a alma "se fez digna", ou seja, sua feitura e propriedade - o que sumariza a "verdadeira, perfeita e única religião" ${ }^{, 71}$. Tendo tal mote por luz é que podemos entender que, após a exposição acerca da graduação anímica, Agostinho pontue a adoração como atividade suprema e máxima da alma: a alma não encontra termo (feitura plena, ou per-feição final) senão na assunção/remissão ao seu Criador, da qual na verdade é Imago, ou seja, lhe reflete e expõe (cf. xxxiv. 78: “... acreditamos ser o mesmo Deus quem age por nosso intermédio.”).

Observa-se que a intervenção acerca da religiosidade verdadeira e perfeita compõe a terceira interrupção ou digressão, que Agostinho interpõe quando da exposição de linearidades ou percursos cumpridos pela alma racional. Na primeira (xxviii. 55), ele pontua que sem a graça divina, mediante a qual reforma-se à imagem de Deus, jamais poderá a alma alçar-se à superioridade sobre o bruto sensível, e expandir-se e ampliar-se rumo ao absoluto. A segunda intervenção (xxxiii. 76) dá-se ao cabo do percurso ascensional da alma (quando, no molde da tradição platônica, a corporeidade valor algum assume), quando Agostinho, após a exposição do grau máximo e supremo a que atinge a alma, trata pois de assumir igualmente a assunção do corpo em ressurreição. A terceira digressão (xxxiv. 78) pontua, enfim, a adoração verdadeira como o cimo da atividade anímica, mas que simultaneamente perfaz marco primordial de instauração do crer, motivo axial do entendimento, conquanto êmulo da voluntas.

\subsection{3) Conclusão tópica}

$\mathrm{Na}$ descrição que levamos a efeito da ascensão anímica, intentamos ilustrar sua decorrência direta da atividade instaurativa e primordial da alma racional: o ato imaginativo, pelo qual a alma se exercita e se realiza em sua vocatio teleológica, pelo que se lança à amplificação (quantitate) da (per) feição do real, abarcando a expansionalidade em amplitude, não porém em si mesma (posto que, inobstante sua amplitude ou potencialidade à expansão, jamais romperá sua limitação criatural), mas unicamente face a Deus, em seu louvor e adoração (rendição - remissão da totalidade face ao absoluto). Nesse sentido, podemos afirmar que o itinerário ascensional é consumado no exercício da itinerância expansional, por sua vez possibilitado unicamente pela instauração da imaginação em ato. A quantitate da alma, sua amplitude em ato (ou amplificação), tem por fim precisamente a feitura do real na ascensionalidade à qual foi chamada e movida.

\footnotetext{
371 "Haec est vera, haec perfecta, haec sola religio, per quam Deo reconciliari pertinet ad animae, de qua quaerimus, magnitudinem, qua se libertate dignam facit".
} 


\section{CONCLUSÃo}

\section{a) Ontologia das descrições ascensionais dos diálogos de Agostinho}

1) Ser e conhecimento na ascensão dialética de tradição platônica e no itinerário inteleccional agostiniano

Escapa ao objetivo da tentativa presente em nossa pesquisa, traçar um comparativo de fôlego entre as descrições ascensionais verificadas na tradição platônica, e as constantes nos diálogos (e também nos textos de maturidade) de Agostinho. Recordamos que o intento de nossa apresentação, nos capítulos iniciais, a respeito do conduto pitagórico-platônico e do pensamento neoplatônico, foi o de clarificar traços essenciais componentes da herança traditiva na qual Agostinho irá se mover de início, e a partir dos quais estabelecerá o contraponto de seus desenvolvimentos próprios, na relação de consumação que intenta ofertar (e justificar) entre pensamento grego e intelecção cristã. Precisamente no alcance deste contraponto - cujo delineamento tivemos oportunidade de traçar, em vários pontos de nossa tentativa, sobretudo nas descrições diretas das ascensões intelectuais - convém, a título de visualização sumária e conclusiva, pontuarmos de forma conjunta alguns tópicos que se mostraram convergentes, como também outros que se revelaram de nítido contraste, entre as duas filosofias.

Verificamos, na Introdução, que a ascensão anímica apresentada por Platão em textos como o Banquete e a República, encontra-se assentada no idela maior de formação educativa do ser humano, por ele visualizado na conduta e ação do filósofo. O sentido ascensionalidade intelectiva é essencialmente pedagógico, efetivado através da dialética, ciência mediadora por excelência do conhecimento da realidade. O caráter mediativo e instrumental da ascensão anímica no pensamento platônico, permite sua identificação, sem mais, com a própria dialética, posto que a instrumentalidade com a qual esta opera, afigura-se como decorrência direta da estratificação gradual com que a realidade é definida no registro platônico entre o sensível e o inteligível. Em suma, a ascensão é, numa palavra única e que lhe define mormente, a própria dialética. A diferenciação essencial e perpassante da ascenscionalidade agostiniana e a de tradição platônica (como, sentido lato, de toda a estruturação filosófica do pensamento de ambas as correntes), bem pode residir no conceito de amor de que se valem como moto próprio à consecução e efetivação do percurso intelectual: enquanto para Platão e toda a tradição ligada a seu nome, o eros enquanto desejo que aspira e move ao ser, constitui-se no núcleo fundamental da condição de aspirante à posse da sabedoria (que lhe realiza o desejo pelo belo, dando sentido ao descarte do inferior pelo superior), formando-o pedagogicamente mais e mais 
rumo à perfeição da contemplação e posse do belo que o forma (cf. interpretação heideggeriana da alegoria da caverna), para Agostinho o ágape reverencial visualiza o itinerário de feitura inteleccional da realidade criatural, enquanto signo e resplendor da beleza que o possui e o conduz, no início, à sua própria consumação e plenificação do universo. No matiz de eros enquanto desejo de aperfeiçoamento próprio e autorrealização no belo, Platão postula um sentido propedêutico e metodológico do registro sensível da realidade, fornecendo-lhe estatuto de instrumento transitório das formas evanscentes, as quais permitem alçar o desejo pela forma eterna. O desejo é, pois, o êmulo transitório, mas necessário e inescapável, para o trânsito do efêmero ao eterno, que permitirá dar sentido ao descarte do êmulo: enquanto ausente o eterno, o transitório de encarrega de manter o desejo vivo rumo ao seu fim. O estatuto do desejo é essencialmente diverso em Agostinho. Distante da condição erótica do aspirante à posse da sabedoria em Platão, a voluntas deliberativa em Agostinho atua em consonância à presença primordial, fundante e perene, do Vere Esse a lhe mover para, através dos sinais presentes na realidade inteleccionada, perfazer-se o sentido como um todo em mosaico que resplandece a beleza, não em descarte, mas em consumação restaurativa no Verbo que ostenta, em cada uma das criaturas, sua presença (ainda que proporcional ao estatuto do ser de cada um) enquanto Imago Dei, em todos os seres criados. Em Platão, o desejo se consome e cessa ante a contemplação de belo, inacessível no princípio, imponente e dissolutivo ao final. No pensamento agostiniano, a vontade deliberativa se consuma, no perfazimento e feitura intelectual, que se estabelece em mosaico ante a presença perene, em simul e atemporal, do ser que restaura e sustenta a todos. O eros platônico lança-se à sua realização, precisamente por não ter o objeto que deseja, tampouco conhece, mas busca a partir do que o registro sensível lhe indica. O ágape agostiniano é movido pelo ser que ama, pressupondo um seu conhecimento principial, para feitura intelectualmente a realidade à luz do sumo Bem já conhecido, mas não ratificado e "feiturado" em sua mosaicização da criação. Ressalte-se, enfim, que a ascensão platônica é, em sua essência e propósito ultimo, um métido para elevação e superação dos seres entre si (o que leva à exclusão do inferior, não integrado à perfeição superior), ao passo que a ascensão agostiniana assume a feitura em abarcamento de toda a realidade, na imediação da exauriência que integra e antecipa o posterior pelo anterior, compondo em mosaico toda a realidade em feitura intelectual.

\section{b) Simultaneidade e imediaticidade nos escritos agostinianos de início}

A simultaneidade essencial aos construtos cognitivos - diríamos epistemológicos, em uma análise extemporânea e à luz dos quadros atuais de leitura filosófica - dos escritos iniciais 
de Agostinho, restou-nos suficientemente esclarecida e fundamentada pela leitura que intentamos proceder com base no De ordine, De quantitate animae e, sobretudo, De libero arbitrio, bem como incidências posteriores (mas ainda no período inicial, em seu término) no De vera religione. Com efeito, ela se situa e se faz presente, de pronto, na estrutura triádica fundamental à metafísica, herdada da tradição neoplatônica e que Agostinho reconceitua tendo em vista o aparato doutrinário de fé, sobretudo a definição trinitária da divindade (que, por evidente, culminará nas obras de maturidade, mormente o De trinitate); perfaz característica central das exposições dos itinerários de ascensão, permeando-o como um fio de orientação construtora, pelo qual o conhecimento se perfaz mais como amplitude do que elevação; e, sobretudo, permite equacionar a relação entre a ontologia e a epistemologia de maneira a não ostentar primazia entre ambos com base na temporalidade nadificante/in nihilo, mas sim à luz do esse ex nihilo, atemporal e eterno. Nesse sentido, pareceu-nos essencial a possibilidade de se aproximar o que entendemos ser a conceituação do ser operada por Agostinho nos textos iniciais, das noções de manifestação e presentificação (além do possível matiz de surgimento presente na primeira), as quais evocam, para além dos termos paralelos e/ou aproximativos evento e exposição, o motu próprio de urgir a feitura da realidade. Com efeito, o ser não (somente) se dá, ou (não somente) se manifesta, ou ainda (não somente) se apresenta ou se expõe, mas sobretudo, o ser urge-se (esse), na eternidade e atemporalmente, no instante (ao mesmo tempo - simul) de sua intelecção, instituindo-se a temporalidade da feitura cognitiva através do surgimento dos sinais componentes da imediação da linguagem, essente à realidade criatural. $\mathrm{E}$ - dado por demais precioso à nossa tentativa de leitura e análise interpretativa - o matiz da urgência (ou do urgir a) da feitura cognitiva da realidade, em consonância (simultaneidade) ao seu estabelecimento ontológico (ou: à sua feitura ontológica), nos instala em região de imediação ontológica, posto que manifestar e/ou presentificar evoca a imediaticidade que - assim intencionamos, igualmente, evidenciar em nossa tentativa - é tão característica do trato agostiniano para com o ser e a interioridade.

Resultou-nos, assim, que o itinerário ascensional exposto por Agostinho, em suas variações do tema essencial, teve por base fundante a simultaneidade inerente ao trinômio axial esse-uiuere-intelligere, no De libero arbitrio, e perpassante passo-a-passo em sua feitura de abarcamento da realidade em mosaico da realidade criatural, consumado, segundo o De quantitate animae, na 1) visão beatífica em ressurgimento (ressurreição) da realidade fragmentada em temporalidade, mosaicizada na atuação atemporal de cada passo da ratio em inteleccionar o real, na juris e no moderare cada dado conhecido e/ou feiturado cognitivamente; e 2) finalmente consumada em eternidade no Vere Esse. 
A tentativa de visualização do construto ontológico e epistemológico agostiniano, baseado na simultaneidade essencial ao esse e ao seu intellegere, permite-nos a captação do que nos parece resultar na principal diferença das exposições da ascensionalidade cognitiva humana, em Agostinho, para com as construções matriciais da tradição platônica e do neoplatonismo de Plotino e Porfírio: a igualdade dos seres humanos enquanto entes criaturais, à luz da esseidade participativa que lhes é própria, face ao Ser supremo (Vere Esse), do qual e no qual - têm seu ser e existência. De fato, a postulação da simultaneidade essencial do esse junto ao intellegere (que, em realidade, é antecedida pelo simul recorrente entre credere e intellegere, o qual, em certo sentido, se afigura como prévio ao trinômio axial, dado que o credere pode ser visto como primeiro assentimento à presentificação do ser, já na acepção da fé corroborada pela concepção da metafísica do Êxodo conceituada por Gilson) traduz ou verte uma atemporalidade cuja resultante compõe a feitura cognitiva em composição igualitária, quanto ao estatuto de ser participativo, a partir do Esse supremo, e acessado a todos, posto que imeditizado a todo passo efetuado pela intelecção de cada grau ou nível de ser conhecido. A simultaneidade aponta à feitura crescente em abarcamento do conjunto ou totalidade da realidade criatural, tal qual no De ordine; à consumação em inclusão plenificante e imediata, de todos os seres, como no De quantitate animae. Nesse sentido, a feitura cognitiva, através da ascensão intelectual, resulta em plenificação do conhecido, numa "hiperbolização" desenhada pela simultaneidade inerente ao ser e ao conhecer, que faz com que o alvo dado no início convirja e se plenifique no final, vale dizer: o ser a ser atingido e culminado ao final do percurso, dado em primordialidade, já foi manifestado no instante mesmo em que inteligimos a realidade; decorrendo a feitura da alteridade relacional pela qual se itinera a realidade, da primordialidade à consumação, em hipérbole temporal, assegurando a igualdade entre os diferentes (garantidas pela simultaneidade). Se nos construtos de toda a tradição platônica, a alteridade como que se esvaece para dar lugar à realização no Uno (ou no Mundo das Formas), perdido desde o primórdio e ao qual se aspira ao retorno, a feitura cogntiva resultante evidentemente terá a verticalidade excludente e de superposição entre seus seres, graduados de acordo com o nível de intelecção do Uno em que se encontram. No itinerário agostiniano, o nível de conhecimento do princípio já se assegura no primórdio do ato intelectivo, caminhando-se para sua consumação em comunhão, via assunção, entre os seres finitos e temporais, na eternidade que presidiu sua intelecção, doada já no princípio do percurso.

A simultaneidade é a feitura do real que escapa à temporalidade da distinção, é um "furto" ao tempo e à sequência processual. A simultaneidade permite pensar e perceber a totalidade sem a temporalidade. Na tentativa de adensarmos mais a respeito, podemos dizer 
que a simultaneidade é um experimento da superação do tempo, ou antes: do experimentar a atemporalidade, a ilimitação e, mesmo, um vislumbre da eternidade. Como tal, ela é instante e, a cada novo passo do conhecimento, permite que a totalidade ensejante do instante em intellegere, atemporal, instituia nova temporalidade do passo cognitivo seguinte, na composição do itinerário ascensional do conhecimento.

Em suma, a simultaneidade de base e inerente ao trinômio axial, perfaz e assegura a feitura cognitiva do itinerário ascensional, rompendo pois com a noção da causalidade (e, portanto, com a sequência temporal e imponente da gradação e estratificação da realidade), na atemporalidade e na imediação de seu dado, ambas verificadas a cada instante do esse em sua intelecção, instante recorrente a cada novo passo de conhecimento da realidade, instituinte por sua vez da temporalidade que, por seu turno e novamente, irá se exaurir em nada, a partir do qual, novamente, irá se doar e presentificar o esse. Passo-a-passo, instante a instante, o conhecimento humano é ascensionado (plenificado de imediato) pela remissão ao Esse pleno ou verdadeiro, medida de todo ser criado que lhe participa a essentia. E, finalmente, não há graus de mediação do conhecimento, que justificam a constituição de uma hierarquização dos níveis de acesso ao ser, de acordo com os níveis de conhecimentos obtidos pelos seres humanos em sua linguagem mais ou menos penetrante e elevada. Não há elites hierarquizadas ensejantes de éticas seletivas, baseadas nos graus de conhecimento da realidade superior. A ética eudaimonística da imediação e da simultaneidade, a ética da atemporalidade, é uma ética da igualdade e da horizontalidade.

\section{c) Temporalidade e atemporalidade nos escritos iniciais}

Em decorrência direta da verificação da simultaneidade nos escritos iniciais de Agostinho, deparamos-nos, no desenvolvimento de nossa pesquisa, com a questão da temporalidade própria da feitura do itinerário ascensional do conhecimento humano. Se não chega a se instaurar como tópico explicitamente postulado por Agostinho neste período - ao menos nos textos de base ora trabalhados em nosso estudo -, a temporalidade impõe sua presença, ora como inerência à eventual mensuração e quantificação dos atos anímicos e/ou intelectivos, ora como autêntico desafio à relação interna entre a exterioridade das percepções anímicas, e a interioridade de sua cognitio e, sobretudo, sua certificação pela ratio (scientia). Entretanto - e englobando a ambos - tais aspectos com que emergem de outra consideração presente nas obras de início de Agostinho, relativa ao item que acabamos de assinalar, a qual se revelou fundamental à nossa presente tentativa de leitura dos diálogos agostinianos: a simultaneidade instituinte do conhecimento humano. 
Em suas apresentações mais elaboradas - e mesmo sistematizadas, como no De ordine - a ascensão intelectual constitui-se, essencialmente, na temporalidade da vivência humana, a par (e como uma sua decorrência, face à alteridade, implicando pois na história e na ação) da atemporalidade do instante intelectivo da manifestação do esse, fazendo com que a intelecção da realidade, instituída momento a momento por uma notitia que surja após a exaurição da anterior, se constitua da soma destes (momentos) em sequencia e numeração, o que faz com que o simul entre a eternidade do instante inteleccional, e a temporalidade da comprehensio "costurada" passo-a-passo pela ratio atemporal, instaure-se enquanto questão a ser contemplada, ainda que não ao modo de tratativa direta, tal como exposto por Agostinho nos diálogos aqui analisados, mas seguramente no interior de vários desenvolvimentos observados nas apresentações da ascensionalidade anímica. Mas esta instauração, mesmo não sendo articulada com o fito de se converter em tópico elencado no interior de uma disputatio em curso nos diálogos, enseja uma clara tomada de posição que resulta em uma inequívoca doutrina das relações entre tempo e eternidade nos diálogos do período inicial agostiniano, a qual ostenta pontos comuns às apresentações dos três itinerários. Um destes pontos, fundamental a todo o construto agostiniano, diz respeito à natureza das sobreditas relações entre temporalidade e eternidade. Agostinho certamente não as trata enquanto dialéticas. Embora trilhando, desde o início de sua adesão adulta à fé cristã, o percurso da tradição platônica no que diz respeito ao instrumental teórico para se pensar uma escola de pensamento autenticamente cristã, Agostinho não se posiciona, em momento algum, como partidário da dialética platônica enquanto método estrutural para a explicação da realidade e sua dinâmica de conhecimento na feitura intelectual do todo da realidade. Pelo motivo, simples em sua postulação, complexo em seu desenvolvimento e alcance, de que o absoluto encontra-se, desde o princípio e sempre, perenemente perpassando a investigação filosófica. A sabedoria final encontra-se dada já no princípio.

Acreditamos que nossa tentativa de análise do itinerário da ascensão do conhecimento, nos textos agostinianos de início, possibilitou-nos visualizar duas áreas em que Agostinho procura, de modo permanente, situar sua origem e fundamentação: a relação inextrincável e essencial entre a atemporalidade ingênita da sapiência e a sua vertência na feitura da realidade temporal e concreta - atemporalidade/temporalidade; e a relação entre Ser criador e entes criados, apresentada nos diálogos de forma a evidenciar sua como que inversão em relação a uma de suas fontes traditivas, no caso a platônica: não os seres participam do Ser supremo, mas o Vere Esse se apresenta como fundamento e presença doadora de sentido em cada manifestação do esse enquanto notitia inteligida. Assim, temos duas grandes frentes ou 
questões em torno das quais se estruturam a ontologia e a epistemologia agostinianas do período inicial: temporalidade e feituração inteleccional da realidade. A cada uma delas, Agostinho irá se dedicar de forma direta e sistemática, tendo por referencial permanente as bases lançadas neste período dos diálogos, as quais engendram uma filosofia do tempo (Confessiones XI); uma filosofia da história (De civitate Dei); e uma filosofia da linguagem (De magistro). Tal engendramento, contudo, não nos parece que deva ser visto como aprofundamento ou expansão de tais temáticas, que estariam embrionárias nos diálogos. As preocupações moventes e, sobretudo, o público almejado explicam, em boa parte, as finalidades diversas em que tais tópicos são tratados. No período inicial, a proposta de assimilar depurativamente a filosofia grega, enquanto convergência da sabedoria pagã à consumação da revelação cristã, expõe a finalidade dos diálogos: evidenciar a fundamentação racional da fé cristã, como que apologeticamente, com o fito de provar a superioridade do cristianismo face à sapiência greco-romana. Parte-se, por assim dizer, desta para se consumar na sabedoria da palavra revelada de Deus (teologia), o que por evidente exclui a divisão explicitada entre ambas. No período dos grandes tratados, a maturidade da vivência cristã expressa, entre outros fatores, pela experiência do episcopado de Agostinho - faz com que a vetorialização seja como que invertida: parte-se do artigo do credo para intentar maior penetração e melhor exposição de sua verdade, com o aparato proporcionado pela filosofia 


\section{REFERÊNCIAS BIBLIOGRÁFICAS}

\section{$\underline{\text { I - Bibliografia Específica }}$}

\section{1 - AGOSTINHO DE HIPONA}

\section{1) Obras de Agostinho}

(Edição crítica)

Texto latino da Opera Omnia, estabelecido segundo o CSEL (Brepols, 1948), disponibilizado em www.augustinus.it, juntamente com a tradução em alemão, francês, espanhol [Biblioteca de Autores Cristianos - BAC] e italiano [Nuova Biblioteca Agostiniana - NBA, Città Nuova Editrice].

\subsection{1) Edições bilíngues}

Obras Completas de San Agustín, edição bilíngue latim-castelhano em 41 volumes, promovida pela Federación Agustiniana Española, com coordenação de tradução, introduções e notas de Victorino CAPANAGA, $5^{\text {a }}$ edição, Madrid: Biblioteca de Autores Cristianos (B.A.C.), 2008-2013 (reimpressão).

Confessiones, edição bilíngue latim-português, com tradução de Arnaldo do Espírito Santo, João Beato e Maria Cristina C.M.S. Pimentel, $2^{\mathrm{a}}$ edição, Lisboa: Imprensa Nacional Casa da Moeda, 2004.

De Trinitate, edição bilíngue latim-português, com coordenação da tradução de Arnaldo do Espírito Santo, Lisboa: Paulinas, 2007.

El libre albedrío, tradução de Evaristo SEIJAS, volume III, B.A.C., Madrid, 1951 (edição crítica com o texto latino e tradução castelhana).

Il “De libero arbítrio" di S. Agostino, edição bilíngue latim-italiano, com ensaio introdutório, tradução e comentário de Franco DE CAPITANI, Milano: Vita e Pensiero, 1987.

La grandezza dell'anima, edição bilíngue latim-italiano, tradução de Riccardo FERRI, Palermo: Officina di Studi Medievale, 2004.

\subsection{2) Edições em português}

A Grandeza da Alma, tradução de Frei Agustinho Belmonte, São Paulo: Paulus, 2008 (Coleção Patrística - vol. 24).

A Ordem, tradução de Agustinho Belmonte, São Paulo: Paulus, 2008.

A Trindade, tradução de Agustinho Belmonte, $3^{\mathrm{a}}$ edição, São Paulo: Paulus, 2005.

Confissães, tradução de J. Oliveira Santos, S.J., e A. Ambrósio de Pina, S.J., São Paulo: Abril Cultural, 1973 (Coleção Os Pensadores). 
1993.

Confissões, tradução de Maria Luiza Jardim Amarante, $5^{\text {a }}$ edição, São Paulo: Paulus,

Contra os Acadêmicos, tradução de Agustinho Belmonte, São Paulo: Paulus, 2008.

O Livre-Arbítrio, tradução e notas de Nair de Assis Oliveira, $4^{\text {a }}$ edição, São Paulo: Paulus, 2004.

O Mestre, tradução de Agustinho Belmonte, São Paulo: Paulus, 2008.

Sobre a potencialidade da Alma, tradução de Aloysio Jansen de Faria, revisão de Frei Graciano González, 2a edição, Petrópolis: Vozes, 2005.

\subsection{3) Edições em italiano}

Il Libero Arbitrio, edição com ensaio introdutório de Rita MELILLO (com base na tradução de Franco De Capitani, 1987), Roma: Città Nuova Editrice, 2011.

\section{2) Estudos sobre Agostinho}

ANDRADE, Marcelo P. O Autoconhecimento da mens no Livro X do De Trinitate de Santo Agostinho, Dissertação de Mestrado, São Paulo: PUC-SP, 2007.

BERMON, Emmanuel. Le cogito dans la pensée de Saint Augustin, Paris: Vrin, 2001.

A teoria das paixões em santo Agostinho in BESNIER, B.; MOREAU, P-F.; e RENAULT, L. (orgs.) As paixões antigas e medievais, São Paulo: Loyola, 2008, pp. 199-226

BIOLO, Salvino. L'Autoconscienza in S. Agostino, Roma: Editrice Pontificia Università Gregoriana, 2000.

BLÁZQUEZ, Niceto. Filosofía de san Agustín, Madrid: Biblioteca de Autores Cristianos (B.A.C), 2012.

BOCHET, Isabelle. Variations contemporaines sur um thème augustinien: l'énigme du temps in CARON, M. (dir.) Saint Augustin - Les Cahiers d'Histoire de la Philosophie, Paris: Éditions du Cerf, 2009, p. 519-549.

BOULNOIS, Oliver. Augustin, la faiblesse et la volonté in DE LIBERA, A. (ed.) Après la métaphysique: Augustin? - Actes du coloque inaugural de l'Institut d'Études Médiévales de l'Institut Catholique de Paris, 25 juin 2010, Paris: Vrin, 2013, p. 51-77.

BOUTON-TOUBOULIC, Anne-Isabelle. L'ordre caché - La notion d'ordre chez saint Augustin, Paris: Institut d'Etudes Augustiniennes, 2004.

BOYER, Charles. Christianisme et néo-platonisme dans la formation de Saint Augustin, Paris: Beauchesne, 1920.

BRACHTENDORF, Johannes. “Confissões” de Agostinho, tradução de Milton Camargo Mota, São Paulo: Loyola, 2008 (original: Darmstadt: Wissenschaftliche Buchgesellschaft, 2005). 
Les valeurs d'ordo et leur réception chez saint Augustin in Revue des Études Augustiniennes, Vol. 45 (1999), p. 295-334.

L'approche philosophique de l'oeuvre d'Augustin au miroir de la Revue des Études Augustiniennes in REAgP, 50 (2004a), p. 330-332.

BROWN, Peter. Santo Agostinho: uma biografia, tradução de Vera Ribeiro, 7a. edição, Rio de Janeiro: Record, 2012 (original: Augustine of Hippo, 1967, 2000).

CARON, Maxence. Être, Principe et Trinité in ID. (dir.) Saint Augustin - Les Cahiers d'Histoire de la Philosophie, Paris: Éditions du Cerf, 2009, p. 591-636.

. La Trinité - Saint Augustin, Paris: Ellipses Édition Marketing, 2004.

CARY, Phillip. Outward Signs: the powerlessness of external things in Augustine's thought, New York: Oxford University Press, 2008.

CASSI, Aldo A. La Giustizia in Sant'Agostino - Itinerari agostiniani del quartus fluvius dell'Eden, Milano: Edizioni FrancoAngeli, 2013.

CAYRÉ, Fulbert. La contemplation augustinienne, Paris: Desclée de Brouwer, 1954.

Dieu présent dans la vie de l'esprit, Paris: Desclée de Brouwer, 1951.

COSTA, Marcos Roberto N. Introdução ao pensamento ético-político de Santo Agostinho, São Paulo, Loyola, 2009.

A influência do neoplatonismo na conversão de Santo Agostinho in Cultura e Fé, Revista do Instituto de Desenvolvimento Cultural - Faculdade IDC, Porto Alegre, vol. 124, Ano 32, Janeiro-Março - 2009, p. 42-63.

Conhecimento, ciência e verdade em Santo Agostinho in DE BONI, L. A. (org.) A ciência e a organização dos saberes na Idade Média, Porto Alegre: Edipurs, 2000, p. 39-55.

COURCELLE, Pierre. Recherches sur les Confessions de Saint Augustine, $2^{\text {a }}$ edition, Paris: Editions de Boccard, 1968.

COUTINHO, Jorge. Trilogias agostinianas: triades e dinâmica ternária em Santo Agostinho in Theologica, Revista da Faculdade de Teologia da Universidade Católica Portuguesa (Braga), 2a. série (47), II, 2012, p. 497-508.

DE LIBERA, Alain. Augustin et la question du sujet in ID. (ed.) Après la métaphysique: Augustin? - Actes du coloque inaugural de l'Institut d'Études Médiévales de l'Institut Catholique de Paris, 25 juin 2010, Paris: Vrin, 2013, p. 13-41.

DE MARGERIE, Bertrand. Introduction à l'histoire de l'exégese - III: Saint Augustin, Paris: Éditions du Cerf, 2009 (réimpressión $-1^{\text {a }}$ édition: 1983). 
DEPRAZ, Natalie. Saint Augustin et la méthode de la réduction in CARON, M. (dir.) Saint Augustin - Les Cahiers d'Histoire de la Philosophie, Paris: Éditions du Cerf, 2009, p. 551-571.

DI MARTINO, Carla Il ruolo della intentio nell'evoluzione della psicologia di Agostino: dal De Libero Arbitrio al De Trinitate in Revue des Études Agostiniennes, no 46 (2000), p. 173-198.

DOUCET, Dominique. Augustin: l'experience du Verbe, Paris: Librairie Philosophique J.Vrin, 2004.

Enquête pour une etude d" "Idipsum" et de ses enjeux dans l'oeuvre d'Augustin in CARON, M. (dir.) Saint Augustín - Les Cahiers d'Histoire de la Philosophie, Paris: Éditions du Cerf, 2009, p. 159-187.

DULAEY, M. L'apprentissage de l'exégèse biblique par Augustin - Première partie: dans les années 386-389 in Revue des Études Augustiniennes, nº 48 (2002), p. 267-295.

FALQUE, Emmanuel. Après la métaphysique? Le "poids de la vie" selon Augustin in DE LIBERA, A. (ed.) Après la métaphysique: Augustin? - Actes du coloque inaugural de l'Institut d'Études Médiévales de l'Institut Catholique de Paris, 25 juin 2010, Paris: Vrin, 2013, p. 111-128.

FARAGO, F. Lire saint Augustin, Paris: Ellipses Édition Marketing, 2008.

FERRARO, Giuseppe. Lo Spirito e Cristo nel commento al Quarto Vangelo e nel Trattato trinitario di Sant'Agostino, Città del Vaticano: Libreria Editrice Vaticana, 1997.

FISCHER, Norbert (dir.) Augustinus - Spuren und Spiegelungen seines Denken, Band 1: Von den Anfängen bis zur Reformation; Band 2: Von Descartes bis in die Gegenwart, Hamburg: Felix Meiner Verlag, 2009.

FITZGERALD, Allan D. (dir.) Diccionario de San Agustín, Madrid: Editorial Monte Carmelo, 2008.

FOLEY, M.P. Cicero, Augustine and the Philosophical Roots of the Cassiciacum Dialogues in Revue des Études Augustiniennes, vol. 45, Paris, 1999, p. 51-77.

GERBER, Chad T. The spirit of Augustine's early theology: contextualizing Augustine's pneumatology, Surrey: Ashgate Publishing Limited, 2012.

GILSON, Étienne. Introdução ao estudo de Santo Agostinho, tradução de Cristiane N. A. Ayoub, São Paulo: Paulus/Discurso Editorial, 2007 (original: Librairie Philosophique J. Vrin, Paris, 1943).

GIRAUD, Vincent. Augustin, les signes et la manifestation, Paris: Presses Universitaires de France, 2013. 
GÓES, Paulo. Essência ou substância? - A dificuldade agostiniana ao falar de Deus in Caminhando, Revista da Faculdade de Teologia da Universidade Metodista de São Paulo UMESP, Vol. 07, nº 02 [10], 2002, p. 120-136.

GONZÁLEZ, Alfonso Rincón. Signo y lenguaje en San Agustín, Bogotá: Centro Editorial/UNC, 1992.

GUARDINI, Romano. La conversión de Aurelio Agustín, traducción de Roberto H. Bernet, Bilbao: Desclée de Brouwer, 2013 (original: Die Bekehrung Dies Aurelius Augustinus, MatthiasGrünewald-Verlag, Mainz/Ferdinand Schönigh, Paderborn, 4. Auflage, 1989).

HARRISON, Carol. Rethinking Augustine's early theology: an argument for continuity, Oxford University Press, 2008.

HORN, Christoph. Agostinho: conhecimento, linguagem e ética, seleção de textos, introdução, tradução e edição de Roberto H. Pich, Porto Alegre: Edipucrs, 2008.

Agostinho - Filosofia antiga na interpretacão cristã in ERLER, M. e GRAESER, A. (orgs.) Filósofos da Antiguidade - II: Do Helenismo até a Antiguidade Tardia, Coleção História da Filosofia, tradução de Nélio Schneider, São Leopoldo: Editora Unisinos, 2002, p. 228-252.

Augustins Philosophie der Zahlen in Revue des Études Augustiniennes, $\mathrm{n}^{\circ} 40$ (1994), p. 389-415.

KANY, Roland. Augustins Trinitätsdenken, Tübingen: Mohr Siebeck, 2007.

KARFÍKOVÁ, Lenka. Grace and will according to Augustine, Leiden (Netherlands): Brill, 2012 (disponibilizado parcialmente em www.books.google.com - acesso em 21.08.2013).

KREMER, Patrick J. The "psychological" proof for the existence of God developed by Saint Augustine, Chicago: Loyola University, 1948 [ebook (pdf) gratuito em www.ecommons.luc.edu - acesso em 28.06.2013]

LANCEL, Serge. Saint Augustin, Paris: Fayard, 1999.

MADEC, Goulven. “De libero arbitrio” di Agostino d'Ippona, Palermo: Augustinus, 1990.

L'historicité des Dialogues de Cassiciacum in Revue des Études Augustiniennes, vol. 32,1986, p. 207-231

MAMMI, Lorenzo. STILLAE TEMPORIS - Interpretação de uma passagem das Confissões, XI, 2 in PALACIOS, Pelayo M. (org.) Tempo e Razão - 1.600 anos das Confissões de Agostinho, São Paulo: Loyola, 2002, p. 55-61.

MARION, Jean-Luc. Au lieu de soi - L'approche de Saint Augustin, Paris: Presses Universitaires de France, 2008. 
Note sur l'usage de substantia par sain Augustin e $\mathbf{t}$ sur son appartenance à 1'histoire de la métaphysique in DE LIBERA, A. (ed.) Après la métaphysique: Augustin? Actes du coloque inaugural de l'Institut d'Études Médiévales de l'Institut Catholique de Paris, 25 juin 2010, Paris: Vrin, 2013, p. 147-165.

MARROU, Henri-Irénée. Saint Augustin et l'augustinisme, Paris: Éditions du Seuil, 2003 (obra originalmente publicada em 1955).

MARTINS, Maria M. Santo Agostinho no pensamento de J.-L. Marion: uma leitura de “Dieu sans l'Être" in Artigos LusoSofia, Covilhã: Universidade da Beira Interior, 2008, 53 p. (www.lusosofia.net - acesso em 24.09.2012)

MATTHEWS, Gareth. Santo Agostinho - A vida e as idéias de um filósofo adiante de seu tempo, Rio de Janeiro: Jorge Zahar Editor, 2007 (original: ).

MICHON, Cyrille. Le libre arbitre in CARON, M. (dir.) Saint Augustin - Les Cahiers d'Histoire de la Philosophie, Paris: Éditions du Cerf, 2009.

MORIONES, Francisco. Teología de San Agustín, Madrid: Biblioteca de Autores Cristianos (B.A.C.), 2011.

NADEAU, Ch. Le vocabulaire de saint Augustin, Paris: Ellipses Édition Marketing, 2009.

NAPIER, Daniel A. From the Circular Soul to the Cracked Self: a genetic historiography of Augustine's anthropology from Cassiciacum to the Confessions, tese de doutorado, Universidade Livre de Amsterdam, 2010 [disponibilizado em - acesso em - ebook (pdf.) gratuito].

NOURISSON, Jean Félix. La philosophie de Saint Augustin, Paris: Didier et Cie. LibrairesÉditeurs, 2a ${ }^{\mathrm{a}}$. édition, 1866 [disponibilizado em www.books.google.com - acesso em 01.05.2011 - ebook Google (pdf.) gratuito].

NOVAES Filho, Moacyr Ayres. A Razão em exercício - Estudos sobre a filosofia de Agostinho, São Paulo: Discurso Editorial, 2007.

Linguagem e Verdade nas Confissões in PALACIOS, Pelayo M. (org.) Tempo e $\overline{R a z \tilde{a} o}$ - 1.600 anos das Confissões de Agostinho, São Paulo: Loyola, 2002, p. 29-54.

NUNES, Mariciane M. Livre-arbitrio e ação moral em Agostinho - Um estudo a partir do De libero arbitrio, Dissertação de mestrado, Faculdade de Filosofia da Pontifícia Universidade Católica do Rio Grande do Sul, 2009 (Disponibilizada em www.pucrs.edu.br/teses).

O'DALY, Gerard. Augustinu's Philosophy of Mind, Los Angeles/Berkeley: University of California Press, 1987.

OLIVEIRA, Manfredo A. o Ocidente enquanto encontro entre a metafisica da natureza e a metafisica da liberdade: o exemplo de Agostinho in FELTES, H. P. e ZILLES, U. (orgs.) Filosofia: diálogo de horizontes, Caxias do Sul: Educs/Porto Alegre: Edipucrs, 2001, p. 221-235 
OLIVEIRA E SILVA, Paula. Ordem e Ser - Ontologia da relação em Santo Agostinho, Centro de Filosofia da Universidade de Lisboa, 2007.

O binómio vontade-ser em De Libero Arbitrio de Santo Agostinho in Philosophien, vol. 5, Lisboa, 1995, p. 19-34.

PÉPIN, Jean. A propos de la doctrine de la conversion: Augustin et Porphyre sur le degré d'être in KOBUSCH, Theo; ERLER, Michael (Her.) Metaphysik und Religion: zur signatur des Spätantiken Denkens, Munique/Leipzig: K.G. Saur Verlag GmbH, 2002, p. 153-166.

PEREIRA DE MATOS, Manuel Alberto. Interpretação trinitária do Pai-Nosso: o Espírito Santo e espírito de filiação à luz do De Trinitate e de outros escritos de Santo Agostinho, Viseu: Universidade Católica Editora (edição do Instituto Superior de Teologia), 2004.

PIC, Augustin. Le temps selon saint Augustin: lecture du livre XI dês Confessions in CARON, M. (dir.) Saint Augustín - Les Cahiers d'Histoire de la Philosophie, Paris: Éditions du Cerf, 2009, p. 245-259.

PLAMONDON, Paul. La preuve augustinienne de l'existence de Dieu, Faculté de Philosophie de l'Université de Ottawa, 1957 [ebook (pdf) gratuito disponibilizado em www.ruor.uottawa.ca/fr - acesso em 28.06.2013]

RATZINGER, Joseph. Pueblo y casa de Dios en la doctrina de San Agustín sobre la iglesia, traducción de Antonio Murcia Santos, Madrid: Ediciones Encuentro, 2012 (original: Libreria Editrice Vaticana, 2012 - Tese doutoral do autor datada de 1954, com nova edição em 1992).

Originalité et tradition dans le concept augustinien de "confessio" in CARON, M. (dir.) Saint Augustín - Les Cahiers d'Histoire de la Philosophie, Paris: Éditions du Cerf, 2009, p. 9-36 (publicado originalmente em 1957).

SILVA, Manuel M. o problema da fundação de uma terceira navegação em Agostinho e a suprassunção da segunda navegação platônica in Síntese, Revista de Filosofia da F.A.J.E de Belo Horizonte/MG, Vol. 32, no 102 (2005), p. 39-59.

SMALBRUGGE, Matthias. La nature trinitaire de l'intelligence augustinenne de la foi, Amsterdam: Éditions Rodopi, 1988.

SOUZA NETTO, Francisco Benjamin de. Augustinus - Teologia da Trindade: conceitos, imagens, analogias in DE BONI, Luis Alberto (org.) Lógica e linguagem na Idade Média, Porto Alegre: Edipucrs, 1995, p. 25-45.

Tempo e Memória no pensamento de Agostinho in PALACIOS, Pelayo M. (org.) Tempo e Razão - 1.600 anos das Confissões de Agostinho, São Paulo: Loyola, 2002, p. 9-28.

Estado atual dos estudos agostinianos in Boletim do Centro de Pensamento Antigo, Campinas: Unicamp, no. 02, julho/dezembro de 1996, p. 35-46.

TAURISANO, Ricardo R. $\boldsymbol{O}$ De libero arbítrio de Agostinho de Hipona, Dissertação de mestrado em Letras Clássicas, FFLCH-USP, 2007 (www.teses.usp.br/teses/disponiveis; www.fflch.usp.br/df/cepame/textos/teses). 
Retórica no De Libero Arbitrio de Agostino de Hipona in Teoliterária - Revista Brasileira de Literaturas e Teologias, Associação Latino-Americana de Literatura e Teologia, volume I, $\mathrm{n}^{\mathrm{o}} 2,2^{\circ}$ semestre de 2011, p. 35-67.

TRAPÈ, A. San Agustín in DI BERARDINO, A. PATROLOGIA - vol. III: La edad de oro de la literatura patrística latina, Madrid: B.A.C., 1981 (5ª impresión: mayo de 2007), p. 405553.

TRELENBERG, Jörg. Das Prinzip “Einheit” beim frühen Augustinus, Tübingen: Mohr Siebeck, 2004.

UCCIANI, Louis. Saint Augustin ou le livre du moi, Paris: Éditions Kimé, 1998.

UHLE, Tobias. Augustin und die Dialektik, Tübingen: Mohr Siebeck, 2012.

WETZEL, James. Compreender Agostinho, tradução de Caesar Souza, Petrópolis: Vozes, 2011 (original: Augustine: A Guide for the Perplexed, Continuum International Publishing Group, 2010).

VAZ, Henrique C. de Lima. A metafísica da interioridade - Santo Agostinho in ID. Ontologia e História - Escritos de Filosofia VI, $2^{\text {a }}$ edição, São Paulo: Loyola, 2001.

VELÁSQUEZ, Óscar. La iluminación agustiniana como explicación de los contenidos de la mente: Agustín em Casiciaco in Teología y Vida, Vol. XLVIII, 2-3, Pontificia Universidad Católica de Chile, Santiago, 2007, p. 215-227.

VIGINI, Giuliano Santo Agostinho: a aventura da graça e da caridade, tradução de Antonio Efro Feltrin, Paulinas: 2012 (original: Edizioni San Paolo, Cinisello Balsamo, 2006)

ZUM BRUNN, E. Le dilemme de l'être et du néant chez Saint Augustin - Des premier dialogues aux 'Confessions', $2^{\text {a }}$ editon avec additons de l'auteur, John Benjamins Publishing, 1984.

\section{2 - PERÍODO PRÉ-SOCRÁTICO}

\section{1) Textos, Fragmentos e Doxografias}

\subsection{1) Edições bilíngues}

KIRK, G.S.; RAVEN, J.E. Os Filósofos Pré-Socráticos, seleção de textos bilíngue em grego e português, com tradução de Carlos A. L. Fonseca, Beatriz R. Barbosa e Maria A. Pegado, $2^{a}$ edição, Lisboa: Fundação Calouste Gulbenkian, 1982.

\subsection{3) Edições em português}

BORNHEIM, G. (seleção, organização e tradução) Os Filósofos Pré-Socráticos, 15a edição, São Paulo: Cultrix, 2010. 
SOUZA, José Cavalcante de (seleção de textos e supervisão da tradução). Os Pré-Socráticos: fragmentos, doxografia e comentários, São Paulo: Abril Cultural, 1973; $2^{\mathrm{a}}$ edição, 1978 (Os Pensadores).

\section{2) Tradicãa Pitagórica}

BECHTLE, G. Pitágoras: entre ciência e vida in Erler, M. e Graeser, A. (orgs.) Filósofos da Antiguidade: dos primórdios ao período clássico, São Leopoldo, Editora Unisinos, 2002.

BRISSON, Luc. Archytas de Tarente in Périllié, J.-L. (org.) Platon et les Pythagoriciens: hiérarchie des savoirs et des pratiques, Bruxelles: Ousia/Paris: Vrin, 2008.

BURKERT, Walter. Lore and science in ancient Pythagoreanism, Harvard University Press, 1972.

CORNELLI, Gabriele. Em busca do Pitagorismo: o pitagorismo como categoria historiográfica, Tese de Doutorado em Filosofia, São Paulo: FFLCH - USP, 2010 (www.usp.br/df/site/posgraduacao/teses-2010).

Caminho de duas mãos: trocas filosóficas entre pitagorismo e platonismo in Boletim do Centro de Pensamento Antigo, Piracicaba: Unimep, vol. 15, 2003, p. 43-54.

HUFFMANN, C. Philolaus of Croton: Pythagorean and Presocratic. A commentary on the fragments and testimonia with interpretative essays, Cambridge University Press, 1993.

Archytas of Tarentum: Pythagorean, Philosopher and Mathematician King, Cambridge University Press, 2005.

The pythagorean conception of the soul from Pythagoras to Philolaus in Frede, Dorothea and Reis, Burkhard (eds.) Body and Soul in the Ancient Philosophy, Berlin: Walter de Gruyter GmbH \& Co., 2009.

KAHN, C. H. Pitágoras e os Pitagóricos: uma breve história, tradução de Luís Carlos Borges, São Paulo: Loyola, 2007 (original: Pythagoras and the Pythagoreans: a brief history, Indianapolis: Hackett Publishing Company, 2001).

MATTÉI, J-F. Pitágoras e os pitagóricos, tradução de Constança Marcondes César, São Paulo: Paulus, $2^{\text {a }}$ edição, 2007.

O'MEARA, Dominic J. Pythagoras Revived: mathematics and philosophy in Late Antiquity, Oxford University Press (Clarendon Press), 1989 (Reprinted 1997).

\section{3) Pré-Socráticos em geral}

BURNET, J. A aurora da filosofia grega, Tradução de Vera Ribeiro, Rio de Janeiro: Contraponto/PUC-RJ, 2006 (original: Early Greek Philosophy, 4ª ed., St. Andrews, 1930).

CASERTANO, G. Os pré-socráticos, tradução de Maria da Graça Gomes de Pina, São Paulo: Loyola, 2011. 
CORNFORD, F. M. Antes e depois de Sócrates, tradução de Valter Lellis Siqueira, São Paulo: Martins Fontes, 2001.

GOMPERZ, T. Os Pensadores da Grécia - História da Filosofia Antiga/Tomo I: filosofia pré-socrática, tradução de José Ignacio Coelho Mendes Neto, São Paulo: Ícone Editora, 2011.

JAEGER, W. La teologia de los primeros filosofos griegos, traducción de José Gaos, México: Fondo de Cultura Económica, 1952 (tercera reimpresión: 1992).

REALE, G. Corpo, Alma e Saúde: o conceito de homem de Homero a Platão, tradução de Marcelo Perine, São Paulo: Paulus, 2002.

História da Filosofia Antiga, volume I, tradução de Marcelo Perine, São Paulo: Loyola, 1993.

SPINELLI, Miguel. Filósofos pré-socráticos: primeiros mestres da filosofia e da ciência grega, $3^{\mathrm{a}}$ edição, Porto Alegre: Edipurs, 2012.

\section{3 - PLATÃo}

\section{1) Obras de Platão}

a) Francês

Oeuvres Complètes par Léon ROBIN, Paris: Gallimard, 1953-1955.

Platon - Oeuvres Complètes sous la direction de Luc BRISSON, Paris: Flammarion, 2008 (tradução em volume único, com comentários e notas, através de equipe dirigida por Brisson).

b) Português

O Banquete, tradução, introdução e notas de José Cavalcante de Souza, $4^{\text {a }}$ edição, São Paulo: Difel, 1986 ( $1^{\text {a }}$ edição: 1966).

Fédon - Sofista - Político, tradução de Jorge Paleikat e João Cruz Costa, São Paulo: Abril Cultural, 1972. (Coleção Os Pensadores)

A República, tradução de Anna Lia Amaral de Almeida Prado (com revisão técnica e introdução de Roberto Bolzani Filho), São Paulo: Martins Fontes, 2006 (2 ${ }^{\mathrm{a}}$ tiragem: 2009).

\section{2) Estudos}

ALBERT, Karl. Platonismo: caminho e essência do filosofar ocidental, tradução de Enio P. Giachini, São Paulo: Loyola, 2011 (original: Platonismus - Weg und Wesen abendländischen Philosophierens, WBG, Darmstadt, 2008).

BEIERWALTES, Werner. Platonisme et Idéalisme, traduit par Marie-Christine ChalliolGillet, J-F. Courtine et Pascal David, Paris: Vrin, 2000 (original: Vittorio Klostermann, Frankfurt am Main, 1972). 
BRISSON, Luc. Leituras de Platão, tradução de Sonia Maria Maciel, Porto Alegre: Edipucrs, 2003 (original: Vrin, Paris, 2000).

Platon pour notre temps in Oeuvres Complètes, Paris: Flammarion, 2008, p. IX-XXI.

e Fronterotta, Francesco (orgs.). Platão: Leituras, tradução de João Carlos Nogueira (revisão técnica de Marcelo Perine), São Paulo: Loyola, 2011 (original: Lire Platon, P.U.F., 2006).

et Pradeau, Jean-François. Dictionaire Platon, Paris: Ellipses, 2007.

CASERTANO, Giovanni. Uma introdução à República de Platão, São Paulo: Paulus, 2011.

CHARRUE, Jean-Michel. Illusion de la dialectique et dialectique de l'illusion: Platon et Plotin, Paris: Les Belles Lettres, 2003.

DI CAPUA, Luigi. Platão ou sobre o conhecimento in Simon, S. (org.) Filosofia e conhecimento: das formas platônicas ao naturalismo, Brasília: Editora Unb, 2003, p. 23-46.

DIXSAUT, Monique. Platon, Paris: Vrin, 2003.

; CASTEL-BOUCHOUCHI, Anissa; KÉVORKIAN, Gilles (dir.). Lectures de Platon,

Paris: Ellipses Édition, 2013.

GOLDSCHMIDT, Victor. A Religião de Platão, tradução de Oswaldo Porchat Pereira, São Paulo: Difusão Europeia do Livro, 1963 (original: Presses Universitaires de France, 1949).

Os diálogos de Platão: estrutura e método dialético, tradução de Dion Davi Macedo, São Paulo: Loyola, 2002 (original: Presses Universitaires de France, 1947).

MACEDO, Dion Davi. Do elogio à verdade: um estudo sobre a noção de eros como intermediário no Banquete de Platão, Porto Alegre: Edipucrs, 2001.

PAVIANI, Jaime. Filosofia e Método em Platão, Porto Alegre: Edipucrs, 2001.

A gênese da dialética em Platão in ID. e Bombassaro, L.C. (orgs.) Filosofia, Lógica e Existência, Caxias do Sul: Educs, 1997, p. 97-104.

PRADEAU, J.-F. (coord.) Platon: les formes intelligibles, Paris: P.U.F., 2001.

Platon, l'imitation de la philosophie, Paris: Aubier, 2009.

RACHID, Rodolfo. A bela ordem incorpórea no Filebo de Platão in Trans/Form/Ação, Revista Eletrônica de Filosofia/UNESP, Marília, Volume 35, $\mathrm{n}^{\circ}$ 2, Maio/Agosto de 2012, p. 329

REIS, Maria Dulce. Por uma nova interpretação das doutrinas escritas: a filosofia de Platão é triádica in Kriterion, Belo Horizonte: UFMG, nº 116, Dez/2007, p. 379-398. 
SZLEZÁK, Thomas Alexander. Platão e a escritura da filosofia, tradução de Milton Camargo Mota, São Paulo: Loyola, 2009 (original: Plato und die Schriftlichkeit der Philosophie. Interpretationen zu den frühen und mittleren Dialogen, Berlin: Walter de Gruyter GmbH \& Co., 1985)

TRABATTONI, Franco. Scrivere nell'anima: verità, dialettica e persuasione in Platone, Firenze: La Nuova Italia Editrice, 1993 (edizione digitale a cura di Simona Chiodo www.unimi.it/ateneo/filarete/).

TRINDADE SANTOS, José Gabriel. Para ler Platão - Volume I: A ontoepistemologia dos diálogos socráticos; II: O problema do saber nos diálogos sobre a teoria das formas; III: Alma, cidade, cosmo, São Paulo: Loyola, 2008.

Platão: a construção do conhecimento, São Paulo: Paulus, 2012.

VAZ, Henrique C. de Lima. Contemplação e dialética nos diálogos platônicos, tradução do latim de Juvenal Savian Filho, São Paulo: Loyola, 2012 (tese doutoral do autor datada de 1952, defendida no ano seguinte).

A ascensão dialética no Banquete de Platão in ID. Escritos de Filosofia VIII Platonica, São Paulo: Loyola, 2011, p. $49-67$ (texto originalmente publicado em 1959).

XAVIER, Dennys Garcia; e CORNELLI, Gabriele (orgs.). A República de Platão: outros olhares, São Paulo: Loyola, 2011.

\section{4 - ARISTÓTELES}

De Anima ( $\Pi \varepsilon \rho \imath \Psi v \chi \eta \varsigma)$, apresentação, tradução e notas de Maria Cecília GOMES DOS REIS, São Paulo: Editora 34, 2006 (1ª reimpressão: 2007).

\section{1) Estudos}

ANGIONI, Lucas. As noções aristotélicas de substância e essência, Campinas: Editora da Unicamp, 2008.

HERNÁNDEZ, José Alberto Ross. Dios, eternidad y movimiento en Aristóteles, Navarra (Espanha): Ediciones Universidad de Navarra, 2007.

\section{5 - PLOTINO E NEOPLATONISMO}

\section{1) Fontes}

\subsection{1) Plotino}

a) Edições Vernaculares

Ennéades, texte établi et traduit par EMILE BREHIER, vol. I-VI, Paris: Les Belles Lettres, 1924-1938. 
Enéadas, introdução, tradução e notas de JESÚS IGAL, Madrid, 1982 (vol. I - Enéadas I a IV), 1998 (V a VII) e 2008 (VIII e IX - $3^{a}$ reimpression).

Enéada II - A organização do cosmo, introdução, tradução do texto grego e notas de João LUPI, Petrópolis: Vozes/Bragança Paulista: Edusf, 2010.

\subsection{2) Porfírio}

Vida de Plotino, tradução de J. IGAL, Madrid, 1982 (3ª reimpressão: 2008).

\section{2) Estudos}

BAL, Gabriela. Silêncio e Contemplação: uma introdução a Plotino, São Paulo: Paulus, 2007.

BEZERRA, Cícero C. Compreender Plotino e Proclo, Petrópolis: Vozes, 2006.

e BAUCHWITZ, Oscar F. (orgs.). Neoplatonismo: tradição e contemporaneidade, São Paulo: Hedra, 2013.

BRANDÃO, Bernardo G.S.L. A experiência mistica intelectual na filosofia de Plotino in HYPNOS, Revista de Filosofia Antiga Greco-Romana da Pontifícia Universidade Católica de São Paulo, Número 21, $2^{\circ}$ semestre 2008, p. 245-260.

A contemplação mistica do Um em Plotino in Sapere Aude, Revista de Filosofia da Pontifícia Universidade Católica de Minas Gerais, Belo Horizonte, volume 1, $\mathrm{n}^{\mathbf{0}} 2$, setembro/2010, p. 07-19.

BRÉHIER, Émile. La philosophie de Plotin, 3ème édition, Paris: Vrin, 1961.

BRISSON, L. Logos et logoi chez Plotin - Leur nature et leur rôle in Les Cahiers Philosophiques de Strasbourg - Tome 8: Plotin, Université Marc Bloch de Strasbourg, 1999.

CASTELLAN, Arielle. Plotin: l'ascension intérieure, Paris: Michel Houdiard Éditeur, 2007.

CHIARADONNA, Riccardo. Connaissance des intelligibles et degrés de la substance Plotin et Aristote in Études Platoniciennes III - L'âme amphibie: études sur l'âme selon Plotin, Paris: Les Belles Lettres, 2006, p. 57-85 (Publication annuelle de la Societé d'Études Platoniciennes).

D'ANCONA, C. Plotin in GOULET, R. (dir.). Dictionnaire des Philosophes Antiques, Volume V-a, Paris: CNRS Editons, 2012, p. 885-1068.

DUFOUR, Richard. Plotin et les stoïciens in Études Platoniciennes III, Paris, 2006, p. 177194.

FATTAL, Michel. Logos et image chez Plotin, Paris: L'Harmattan, 1998.

Plotin face à Platon suivi de Plotin chez Augustin et Farâbî, Paris: L'Harmattan, 2007. 
GANDILLAC, Maurice de. Plotin, Paris: Ellipses, 1999.

HADOT, Pierre. Plotin ou la simplicité du regard, Paris: Gallimard, 1997.

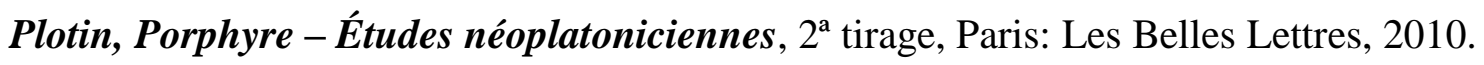

LACROSSE, Joachim. La philosophie de Plotin, Paris: P.U.F., 2003.

LAVAUD, Laurent. La diánoia médiatrice entre le sensible et l'intelligible in Études Platoniciennes III, Paris, 2006, p. 29-55.

O'DALY, G. The Presence of the One in Plotinus in ID. Plotino e il Neoplatonismo in Oriente $\boldsymbol{e}$ in Occidente (Problemi Attuali di Scienza e di Cultura, Quaderno no 198), Roma, 1974, p. 156-169.

O’MEARA, Dominic J. Structures hiérarchiques dans la pensée de Plotin, Leiden: E.J. Brill, 1975.

Plotino: o regresso da alma ao lar in ERLER, M. e GRAESER, A. (orgs.) Filósofos da Antiguidade - II: Do Helenismo até a Antiguidade Tardia, Coleção História da Filosofia, tradução de Nélio Schneider, São Leopoldo: Editora Unisinos, 2002, p. 215-227.

OLIVEIRA, Loraine. Entre o sensivel e o inteligivel: o estatuto intermediário da imaginação em Plotino in MARQUES, M.P. (org.) Teorias da imagem na Antiguidade, São Paulo: Paulus, 2012, p. 287-307.

PANERO, Alain. Introduction aux Ennéades: l'ontologie subversive de Plotin, Paris: L'Harmattan, 2005.

PHILONENKO, Alexis. Leçons Plotiniennes, Paris: Les Belles Lettres, 2003.

PIGLER, Agnès. Le vocabulaire de Plotin, Paris: Ellipses, 2003.

La réception plotinienne de la notion stö̈cienne de la sympathie universelle in Revue de Philosophie Ancienne, Tome XIX, n 1, Bruxelles: Éditions Ousia, 2001, p. 45-78.

SANTA MARIA, Andrés. Observaciones sobre el dualismo 'cuerpo-alma' en Plotino in HYPNOS - Da Alma, Ano 10/n ${ }^{\circ} 14$, Revista do Departamento e Programa de Estudos PósGraduados da PUC-SP, São Paulo: Educ, 2005, p. 103-125.

SZLEZÁK, Thomas A. Platão e Aristóteles na doutrina do Nous de Plotino, tradução de Monika Ottermann, São Paulo: Paulus, 2010.

TAORMINA, Daniela P. Jamblique critique de Plotin et de Porphyre: quatre études, Paris: Vrin, 1999.

TRIBOLET, Serge. Plotin et Lacan: la question du sujet, Paris: Beauchesne, 2008.

ULlmANN, Reinholdo A. Plotino: um estudo das Enéadas, $2^{\text {a }}$ edição, Porto Alegre: Edipucrs, 2008. 
Plotino e os gnósticos in BOMBASSARO, Luiz C. e PAVIANI, Jayme (orgs.) Filosofia, Lógica e Existência, Caxias do Sul: Educs, 1997, p. 367-385.

A estrutura do saber em Plotino in DE BONI, Luiz Alberto (org.) A ciência e a organização dos saberes na Idade Média, Porto Alegre: Edipucrs, 2000, p. 11-28.

Plotino - a relação entre o Uno e o Mundo in FELTES, Heloísa Pedroso M. F. e ZILLES, Urbano (orgs.) Filosofia: diálogo de horizontes - Festschrift em homenagem a Jayme Paviani, Caxias do Sul: Educs/Porto Alegre: Edipucrs, 2001, p. 289-297.

\section{6 - AUTORES TARDO-MEDIEVAIS}

\section{1) Anselmo de Cantuária}

. Obras Completas de San Anselmo - volumes I e II, edição bilíngue com a tradução castelhana por Julian Alameda, e o texto latino da edição crítica de Schmidt, Madrid: B.A.C., 1953 (reimpressão do final de 2008 como edição comemorativa do nono centenário da morte de Anselmo)

\section{2) Boaventura de Bagnoregio}

Obras - volume I, edição bilíngue com tradução em castelhana dirigida e anotada (com introduções) por Leon Amoros, Bernardo Aperribay e Miguel Oromi, Madrid: B.A.C., 2010 (reimpressão, pela série BAC Thesaurus, da $3^{\mathrm{a}}$. edição de 1968).

Itinerário da mente para Deus, $3^{\mathrm{a}}$ edição bilíngue latim-português com tradução, introdução e notas de António Soares Pinheiro, Faculdade de Filosofia de Braga, Portugal, 1986.

\section{$\underline{\text { II - Bibliografia Geral }}$}

ARRIEN, Sophie-Jan. L'inquiétude de la pensée: l'hermeneutique de la vie du jeune Heidegger (1919-1923), Paris: Presses Universitaires de France, 2014.

BERGER, Klaus. As Formas Literárias do Novo Testamento, tradução de Fredericus Antonius Stein, São Paulo: Loyola, 1998 (original: Formgeschichte des Neuen Testaments, Heildelberg: Quelle \& Meyer, 1984).

BOLZANI Filho, Roberto. Acadêmicos versus Pirrônicos, São Paulo: Alameda Casa Editorial, 2013.

. A epokhé cética e seus pressupostos in Discurso $n^{\circ} 27$, Revista do Departamento de Filosofia da USP, 1996, p. 37-60.

BOROBIO, Dionisio. Historia y teologia comparada de los sacramentos, Salamanca: Ediciones Sígueme, 2012. 
BOROS, Ladislau. O homem bom e seu Deus, tradução de Jesus Hortal e Arnaldo Bruxel, São Paulo: Loyola, 1978 (original: Der Gute Mensch und Sein Gott, Freiburg-im-Breisgau, Walter-Verlag, 1971)

CAMPENHAUSEN, Hans Von. Los Padres de la Iglesia II - Los Padres Latinos, traducción de V. A. Martínez de Lapera, Madrid: Ediciones Cristiandad, 2001 (original: Lateinische Kirchenväter, Stuttgart: W. Kohlhammer Verlag, 1995)

CATTANEI, E. Entes matemáticos $\boldsymbol{e}$ metafísica, tradução de Fernando S. Moreira (revisão técnica de Marcelo Perine), São Paulo: Loyola, 2005.

COURTINE, Jean-François. Inuentio analogiae - Métaphysique et ontothéologie, Paris: Vrin, 2005.

DE LIBERA, Alain. A filosofia medieval, tradução de Nicolás N. Campanário e Yvone Maria de C. T. da Silva, São Paulo: Loyola, 1998 (original: Presses Universitaires de France, 1993).

et ZUM BRUNN, É. (eds.). Celui qui est: interprétations juives et chrétiennes d'Exode 3.14, Centre d'Estudes des Religions du Livre (CNRS), Paris: Du Cerf, 1986.

DE LUBAC, Henri. Sur les chemins de Dieu, Aubier, Éditions Montaigne, 1956 (Caps. I a III, p. 19ss).

A Escritura na Tradição, tradução das Monjas Beneditinas da abadia de Santa Maria, São Paulo: Edições Paulinas, 1970 (original: Paris: Éditions Aubier-Montaigne, 1966).

DIAS DA SILVA, Cássio Murilo (com a colaboração de especialistas). Metodologia de Exegese Bíblica, São Paulo: Paulinas, 2000.

ERLER, Michael e GRAESER, A. (orgs.). Filósofos da Antiguidade - II: Do Helenismo até a Antiguidade Tardia, São Leopoldo: Editora Unisinos, 2002.

FALQUE, Emmanuel. Saint Bonaventure et l'entrée de Dieu em théologie, Paris: Vrin, 2000.

FORTE, Bruno. La eternidad en el tiempo, Salamanca: Ediciones Sigueme, 2000 [original: Ciniselo Balsamo (Milano): Edizioni Pauline, 1993].

GADAMER, Hans-Georg. Hermenêutica em retrospectiva, tradução de Marco Antônio Casanova, Petrópolis: Vozes, 2009 (original: Hermeneutik im rüblick, Tübingen: J.C.B. Mohr, 1995).

GANOCZY, A. Il Creatore Trinitario - Teologia della Trinitá e sinergia. Queriniana: Brescia, 2003, p. 61-72.

GAZOLLA, Rachel. O ofício do filósofo estóico, São Paulo: Loyola, 1999.

GIANNOTTI, José Arthur. Lições de Filosofia Primeira, São Paulo: Companhia das Letras, 2011.

GILBERT, Paul. Introdução à teologia medieval, tradução de Dion D. Macedo, São Paulo: Loyola, 1999 (original: Edizioni Piemme Spa, Casale Monferrato (AL), Itália, 1992). 
A paciência de Ser - Metafísica, tradução de Nicolás N. Campanário, São Paulo: Loyola, 2005 (original: Éditions Culture et Vérité, Bruxelles, Bélgica, 1996)

"Eu sou aquele que serei" - Deus: da sarça ardente às aventuras da razão in $\overline{\mathrm{MIES}}$, Françoise (org.) Bíblia e filosofia: as luzes da razão, São Paulo: Loyola, 2012, p. 2350 .

GILSON, E. El Ser y la esencia, version castellana de Leandro de Sesma, Buenos Aires: Ediciones Desclée, De Brouwer, 1951 (original: L'Être et L'essence, Paris: Vrin, 1948)

. La Philosophie au Moyen Age, 2a édition revue et augmentée, Paris, Payot, 1947.

O Espírito da Filosofia Medieval, tradução de Eduardo Brandão, São Paulo: Martins Fontes: 2006.

e BOEHNER, Ph. História da Filosofia Cristã - Desde as origens até Nicolau de Cusa, tradução de Raimundo Vier, $4^{a}$ edição, Petrópolis: Vozes, 1988.

La philosophie de saint Bonaventure, $3^{\mathrm{a}}$. édition, Paris: Vrin, 2006 (Reimpressão da edição de 1953. $1^{\text {a }}$ edição: 1923).

GONZAleZ, Justo L. Uma História do Pensamento Cristão - volume 2: De Agostinho às vésperas da Reforma, traduzida a partir da segunda edição inglesa de 1987, São Paulo: Cultura Cristã, 2004, p. 15-54.

GOURINAT, Jean-Baptiste; e BARNES, Jonathan. Ler os estoicos, tradução de Paula S.R.C. Silva, São Paulo: Loyola, 2013 (original: Presses Universitaires de France, 2009).

GRABMANN, Martín. Historia de la Teología Católica, Madrid: Espasa-Calpe, 1946.

HADOT, Pierre. O que é a filosofia antiga?, tradução de Dion Davi Macedo, São Paulo: Loyola, 1999 (original: Éditions Gallimard, Paris, 1995).

Elogio da filosofia antiga, tradução de Flávio Fontenelle Loque e Loraine Oliveira, São Paulo: Loyola, 2012 (original: Éditions Allia, Paris, 1998).

HALL, Christopher Alan. Lendo as Escrituras com os Pais da Igreja, tradução de Rubens Castilho, Viçosa: Ultimato Editora, 2000.

JAEGER, Werner. Paideia: los ideales de la cultura griega, traducción de Joaquín Xirau (libros I y II) e Wenceslao Roces (III y IV), $1^{\text {a }}$ edición en un solo volumen, México: Fondo de Cultura Económica, 1957.

JASPERS, Karl. Les Grands Philosophes: 2. Platon - Saint Augustin, 2a édition, Paris: Librairie Plon, 2009 (original: Die Grossen Philosophen)

KELLY, J.N.D. Early Christian Doctrines, $5^{\text {a }}$ edition (revised), San Francisco: Harper \& Row, Publishers, 1978. 
LAFONT, G. História teológica da Igreja Católica: itinerário e formas da teologia, tradução de Mariana N.R. Echalar, São Paulo: Paulinas, 2000 (original: Éditions Du Cerf, Paris, 1994).

LOHSE, B. A fé cristã através dos tempos, tradução de Silvio Schneider, $2^{\mathrm{a}}$ edição, São Leopoldo: Sinodal, 1981 (original: Epochen der Dogmengeschichte, Stuttgart: Kreuz-Verlag, 1963)

LOSSKY, Vladimir. Teología mística de la Iglesia de Oriente, Barcelona: Herder, 2009.

MARION, Jean-Luc. Dieu sans l'être, $3^{\mathrm{a}}$. éditon, Paris: 2010.

MARTINS, Paulo. Elegia romana: construção e efeito, São Paulo: Humanitas, 2009.

MIES, Françoise (org.). Bíblia e filosofia: as luzes da razão, São Paulo: Loyola, 2012.

MOLTMANN, Jürgen. Trindade e o Reino de Deus: uma contribuição para a teologia, tradução de Ivo Martinazzo (revisão de Enio P. Giachni), Petrópolis: Vozes, 2000.

MORESCHINI, Claudio. História da Filosofia Patrística, São Paulo: Loyola, 2008.

e Norelli, E. PATRología - Manual de literatura cristiana antigua griega y latina, traducción de José M. H. Blanco, Salamanca: Sígueme, 2009 (original: Morcelliana, Brescia, 1999).

MOSCA, Lineide L. S. (org.). Retóricas de ontem e de hoje, $3^{\text {a }}$ edição, São Paulo: Humanitas, 2004.

MÜLLER, Gerhard L. Dogmática: teoría y práctica de la teología, traducción de Marciano Villanueva, Barcelona: Herder, 2009 (original: Katholische Dogmatik, Verlag Herder, Freiburg im Breisgau, 2007).

NASCIMENTO, Carlos Arthur R. Tomás de Aquino entre Agostinho e Aristóteles in PALACIOS, Pelayo M. (org.) Tempo e Razão - 1.600 anos das Confissões de Agostinho, São Paulo: Loyola, 2002, p. 63-73.

NÉDONCELLE, Maurice. Existe uma Filosofia Cristã? São Paulo: Flamboyant, 1958 (capítulos II e III, p. 27-53).

PEREIRA, M. A. Quintiliano Gramático - O papel do mestre de Gramática na Institutio oratoria, $2^{\mathrm{a}}$ edição, São Paulo: Humanitas, 2006.

PRADEAU, Jean-François (org.). História da Filosofia, tradução de James Bastos Arêas e Noéli Correia de Melo Sobrinho, Petrópolis: Vozes/Rio de Janeiro: Editora PUC-Rio, 2011 (original: Éditions du Seuil, 2009).

PUENTE, Fernando R.; e BARACAT Júnior, José (orgs.). Tratados sobre o tempo: Aristóteles, Plotino e Agostinho, Belo Horizonte: Editora UFMG, 2014.

PUNTEL, Lorenz B. Ser e Deus: um enfoque sistemático em confronto com M. Heidegger, É. Lévinas e J.-L. Marion, tradução de Nélio Schneider, São Leopoldo: Editora Unisinos, 2011 (original: Verlag Mohr Siebeck GmbH \& Co., München-Augsburg, 2010). 
RAHNER, Karl; e VILLER, Marcel. Ascetica e mistica nella Patristica: um compendio della spiritualità cristiana antica, traduzione di Carlos Danna, Brescia: Queriniana, 1991 (original: Aszese und Mystik in der Väterzeit, Freiburg im Breisgau, Verlag Herder, 1939/1989)

RODOLPHO, Melina. Écfrase e evidência nas letras latinas: doutrina e práxis, São Paulo: Humanitas, 2012.

SARANYANA, Josep-Ignasi. A Filosofia Medieval - Das origens patrísticas à escolástica barroca, tradução de Fernando Salles, São Paulo: I.B.F.C.R.L, 2006 (original: EUNSA, Navarra, 2003)

SAYÉS, José Antonio. Teología de la fe, $2^{\mathrm{a}}$ edición revisada, Madrid: San Pablo, 2004.

SCHUBACK, Marcia Sá Cavalcante. Para ler os medievais: ensaio de hermenêutica imaginativa, Petrópolis: Vozes, 2000.

SPINELLI, Miguel. Questões fundamentais da filosofia grega, São Paulo: Loyola, 2006.

TILLICH, Paul Teologia Sistemática, tradução de Getúlio Bertelli, São Leopoldo: Sinodal/São Paulo: Paulinas, s/d (1984); $2^{\mathrm{a}}$ edição revista, São Leopoldo: Sinodal, 2005 (original: Systematic Theology - Three volumes in one, The University of Chicago, 1967).

. História do Pensamento Cristão, tradução de Jaci Maraschin, São Paulo: ASTE, 1988, p. 105-131 (original: Harper and Row, Publishers, Inc., New York, 1968).

Dogmática (Lecciones de Dresde 1925-1927), edición e introducción de Werner Schüsler y Erdmann Sturm, traducción de Luciano Elizaincín, revisión de de Pedro Fernández Castelao, Madrid: Editorial Trotta, 2013 (original: Dogmatik-Vorlesung (Dresden 1925-1927), Berlin: Walter de Gruyter GmbH \& Co. KG, 2005).

TILLY, Michael. Introdução à Septuaginta, tradução de Monika Ottermann, São Paulo: Loyola, 2009 (original: Einführung in die Septuaginta, Darmstadt: Wissenschaftliche Buchgesellschaft, 2005).

TOMÁS, Lia. Ouvir o lógos: música e filosofia, São Paulo: Editora Unesp, 2002.

TOMATIS, Francesco. O argumento ontológico: a existência de Deus de Anselmo a Schelling, tradução de Sérgio José Schirato, São Paulo: Paulus, 2003 (original: Città Nuova Editrice, Roma, 1997).

VANZAGO, Luca. Breve história da alma, tradução de Fernando Soares Moreira, São Paulo: Loyola, 2012 (original: Società editrice Il Mulino, Bologna, 2009).

VAZ, Henrique C. de Lima. Experiência mística e filosofia na tradição ocidental, São Paulo: Loyola, 2000.

VON BALTHASAR, Hans Urs. Gloria - Una estetica teológica, volume 2. Madrid: Ediciones Encuentro, 1986, p. 318-334. 


\section{III - Dicionários, Léxicos e Gramáticas}

FONTANIER, J-M. Vocabulário latino da filosofia, tradução de Álvaro Cabral, São Paulo: WMF Martins Fontes, 2007 (original: Éditions Ellipses, Paris).

MUNGUÍA, Santiago S. Diccionario por Raíces del Latín y de las voces derivadas, Bilbao: Universidad de Deusto, 2007.

MURACHCO, Henrique G. Língua grega: visão semântica, lógica, orgânica e funcional vols. 1 e 2, 2a edição, São Paulo: Discurso Editorial/Petrópolis: Vozes, 2002.

SARAIVA, Francisco R. dos Santos. Dicionário Latino-Português, Livraria Garnier.

SILVA, Amós C.; e MONTAGNER, Airto C. Dicionário Latino-Português, Petrópolis: Vozes, 2009.

SOUSA, Francisco Antonio; LELlO, José; e LELLO, Edgar. Novo Dicionáro LatinoPortuguês, Porto: Lello e Lello Editores, 1984. 